\title{
Characterization and evaluation of washability of Alaskan coals: Fifty selected seams from various coal fields: Final technical report, September 30, 1976-February 28, 1986
}

Rao, P.D.

Sep 1986

Alaska Univ., Fairbanks (USA). Mineral Industry Research Lab.

Reproduced and Distributed by:

U.S. DEPARTMENT OF ENERGY

Office of Scientific and Technical Information

P.O. Box 62

Oak Ridge, TN 37831 


\section{DISCLAIMER}

This report was prepared as an account of work sponsored by an agency of the United States Government. Neither the United States Government nor any agency Thereof, nor any of their employees, makes any warranty, express or implied, or assumes any legal liability or responsibility for the accuracy, completeness, or usefulness of any information, apparatus, product, or process disclosed, or represents that its use would not infringe privately owned rights. Reference herein to any specific commercial product, process, or service by trade name, trademark, manufacturer, or otherwise does not necessarily constitute or imply its endorsement, recommendation, or favoring by the United States Government or any agency thereof. The views and opinions of authors expressed herein do not necessarily state or reflect those of the United States Government or any agency thereof. 


\section{DISCLAIMER}

Portions of this document may be illegible in electronic image products. Images are produced from the best available original document. 


\section{DISCLAIMER}

This report was prepared as an account of work sponsored by an agency of the United States Government. Neither the United States Government nor any agency thereof, nor any of their employees, makes any warranty, express or implied, or assumes any legal liability or responsibility for the accuracy, completeness, or usefulness of any information, apparatus, product, or process disclosed, or represents that its use would not infringe privately owned rights. Reference herein to any specific commercial product, process, or service by trade name, trademark, manufacturer, or otherwise does not necessarily constitute or imply its endorsement, recommendation, or favoring by the United States Government or any agency thereof. The views and opinions of authors expressed herein do not necessarily state or reflect those of the United States Government or any agency thereof.

This report has been reproduced directly from the best available copy.

Available from the National Technical Information Service, U. S. Department of Commerce, Springfield, Virginia 22161.

Price: Printed Copy A09

Microfiche A01

Codes are used for pricing all publications. The code is determined by the number of pages in the publication. Information pertaining to the pricing codes can be found in the current issues of the following publications, which are generally available in most libraries: Energy Research Abstracts (ERA); Government Reports Announcements and Index (GRA and I); Scientific and Technical Abstract Reports (STAR); and publication NTIS-PR-360 available from NTIS at the above address. 


\title{
CHARACTERIZATION AND EVALUATION \\ OF WASHABILITY OF ALASKAN COALS \\ Fifty Selected Seams from Various Coal Fields
}

FINAL TECHNICAL REPORT

September 30,1976 to February 28, 1986

\author{
P. Dharma Rao
}

Mineral Industry Research Laboratory

University of Alaska-Fairbanks

Fairbanks, Alaska 99775-1180

September 1986

Contract Nos. DEFG22-83PC-62695

U.S. DEPARTMENT OF ENERGY Assistant Secretary for Fossil Energy Office of Coal Mining Pittsburgh Mining Technology Center Pittsburgh, PA 


\section{THIS PAGE \\ WAS INTENTIONALLY \\ LEFT BLANK}




\section{TABLE OF CONTENTS}

TABLE OF CONTENTS $\ldots \ldots \ldots \ldots \ldots \ldots \ldots \ldots \ldots \ldots \ldots \ldots \ldots$ iii

LIST OF FIGURES $\ldots \ldots \ldots \ldots \ldots \ldots \ldots \ldots \ldots \ldots \ldots \ldots \ldots$

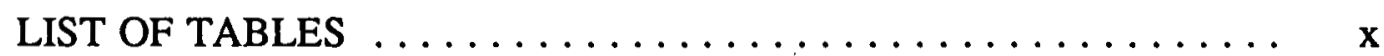

ABSTRACT $\ldots \ldots \ldots \ldots \ldots \ldots \ldots \ldots \ldots \ldots \ldots \ldots \ldots \ldots \ldots \ldots \ldots \ldots$

ACKNOWLEDGMENTS $\ldots \ldots \ldots \ldots \ldots \ldots \ldots \ldots \ldots \ldots \ldots$

INTRODUCTION $\ldots \ldots \ldots \ldots \ldots \ldots \ldots \ldots \ldots \ldots \ldots \ldots \ldots$

COAL FIELDS SAMPLED $\ldots \ldots \ldots \ldots \ldots \ldots \ldots \ldots \ldots \ldots, 5$

NORTHERN ALASKA COAL FIELDS $\ldots \ldots \ldots \ldots \ldots \ldots \ldots, 5$

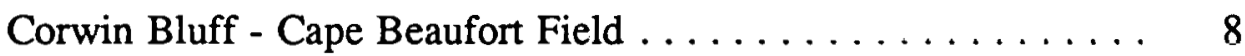

No. 7 coal bed (UA-139)

Kokolik - Utukok River Field . . . . . . . . . . . . . 8

Uncorrelated coal bed (UA-126)

No. 3 coal bed (UA-125)

Kuk - Meade River Fields . . . . . . . . . . . . . . . . . 19

Uncorrelated coal bed (UA-109)

Meade River Field .......................... 19

No. 2 coal bed (UA-110)

Northcentral Alaska Field ...................... 19

Uncorrelated Coal bed (UA-114)

NORTHWEST ALASKA COAL FIELDS $\ldots \ldots \ldots \ldots \ldots \ldots \ldots$

Chicagu Creek ............................ 19

Uncorrelated coal bed (UA-138)

Unalakleet ......................... 21

Uncorrelated coal bed (UA-151)

INTERIOR ALASKA COAL FIELDS $\ldots \ldots \ldots \ldots \ldots \ldots \ldots, 21$

Nenana .......................... 21

No. 2 Seam (UA-105)

Uncorrelated coal bed (UA-141)

Moose Seam (UA-103)

Caribou Seam (UA-104)

Basal Bed (Bed A) (UA-140) 


\section{TABLE OF CONTENTS(Continued)}

No. 1 Seam (UA-129)

No. 3 Seam (UA-130)

No. 4 Seam (UA-119)

No. 6 Seam (UA-100, 101, 102)

Uncorrelated coal bed (UA-120)

Uncorrelated coal bed (UA-132)

Jarvis Creek .......................... 31

Mine Seam (UA-106)

Eagle .......................... 36

Uncorrelated coal bed (UA-121)

Uncorrelated cual bed (UA-124)

Nulato . . . ....................... 36

Uncorrelated coal bed (UA-128)

Tramway Bar ...................... 40

Uncorrelated coal bed (UA-117)

SOUTH CENTRAL ALASKA FIELDS $\ldots \ldots \ldots \ldots \ldots \ldots \ldots, 40$

Beluga ......................... 40

Waterfall Seam (UA-113, 148)

Capps Bed (UA-127)

Green Bed (UA-152)

Yentna ............................. 47

Uncorrelated coal bed (UA-149)

Uncorrelated coal bed (UA-150)

Locality 2 (UA-115,116)

Kenai............................ 53

Cabin Bed (UA-118)

Uncorrelated coal bed (UA-122)

Uncorrelated coal bed (UA-131)

Matanuska .......................... 53

Big Seam (UA-108)

No. 7 A Bed (UA-142)

No. 7 Lower Bed (UA-143)

No. 7 Upper Red (IA-144)

No. 6 Lower Bed (UA-145)

No. 6 Upper Bed (UA-146)

No. 5 Bed (UA-147)

Lower Seam (UA-107)

Broad Pass ............................. 61

Coal Creek Seam (UA-111)

Dunkle Bed (UA-123) 


\section{TABLE OF CONTENTS (Continued)}

SOUTHWEST ALASKA FIELDS $\ldots \ldots \ldots \ldots \ldots \ldots \ldots \ldots 66$

Little Tonzona ...................... 66

Uncorrelated coal bed (UA-112)

ALASKA PENINSULA FIELDS $\ldots \ldots \ldots \ldots \ldots \ldots \ldots \ldots, 68$

Chignik ......................... 68

Uncorrelated coal bed (UA-136)

Herendeen Bay..................... 68

Uncorrelated coal bed (UA-137)

LABORATORY PROCEDURES $\ldots \ldots \ldots \ldots \ldots \ldots \ldots \ldots \ldots \ldots$

INTERPRETATION OF WASHABILITY DATA $\ldots \ldots \ldots \ldots \ldots .79$

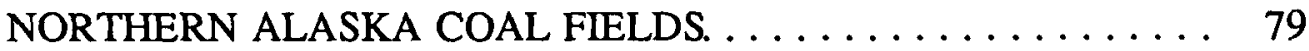

NORTHWEST ALASKA COAL FIELDS $\ldots \ldots \ldots \ldots \ldots \ldots .84$

Chicago Creek ........................ 84

Unalakleet ...................... 84

INTERIOR ALASKA COAL FIELDS $\ldots \ldots \ldots \ldots \ldots \ldots \ldots .85$

Nenana - Healy Creek . . . . . . . . . . . . . . . . . . . 85

Lignite Creek ......................... 85

Moose Seam and Caribou Seam $\ldots \ldots \ldots \ldots \ldots \ldots \ldots .85$

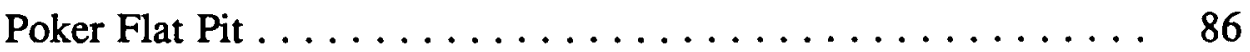

Jarvis Creek . . . . . . . . . . . . . . . . . . . . . 87

Eagle ............................ 87

Nulato $\ldots \ldots \ldots \ldots \ldots \ldots \ldots \ldots \ldots \ldots \ldots \ldots \ldots \ldots$

Tramway Bar $\ldots \ldots \ldots \ldots \ldots \ldots \ldots \ldots \ldots \ldots \ldots \ldots \ldots$

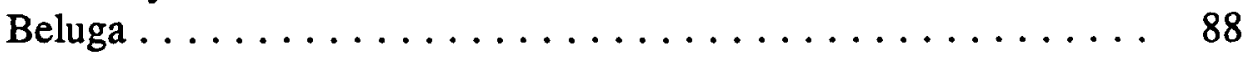

Yentna . . . . . . . . . . . . . . . . . . . . 89

Kenai .............................. 90

Matanuska ........................ 90

Broad Pass . . . . . . . . .

Little Tonzona $\ldots \ldots \ldots \ldots \ldots \ldots \ldots \ldots \ldots \ldots \ldots . \ldots \ldots$

ALASKA PENINSULA $\ldots \ldots \ldots \ldots \ldots \ldots \ldots \ldots \ldots \ldots . \ldots 3$

Chignik $\ldots \ldots \ldots \ldots \ldots \ldots \ldots \ldots \ldots \ldots \ldots \ldots \ldots \ldots \ldots \ldots$ 


\section{TABLE OF CONTENTS(Continued)}

Herendeen Bay . . . . . . . . . . . . . . . 93

CONCLUSIONS $\ldots \ldots \ldots \ldots \ldots \ldots \ldots \ldots \ldots \ldots \ldots \ldots \ldots \ldots$

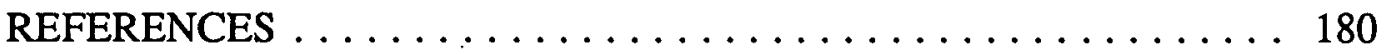

\section{LIST OF FIGURES}

FIGURE NO.

1 Major coal resources in Alaska $\ldots \ldots \ldots \ldots \ldots \ldots \ldots \ldots 6$

2 Generalized stratigraphic correlations rocks of the Northern Alaska field. Wavy lines represent unconformities. Chapman and Sable

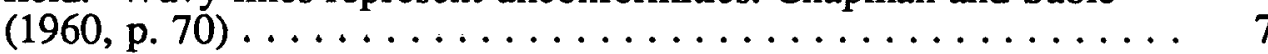

3 Location of sampling site at Cape Beaufort in the Northern Alaska field $\ldots \ldots \ldots \ldots \ldots, \ldots, \ldots, \ldots \ldots \ldots \ldots \ldots \ldots$

4 Aerial view locating U.S. Bureau of Mines trench near Cape Beaufort. Sample UA-139 was sampled from this trench . . . . . . 10

5 A closeup view of UA-139 sampling site $\ldots \ldots \ldots \ldots \ldots \ldots, 10$

6 Geological column showing coal and partings in Bed 7 (UA-139), Cape Beaufort area, Northern Alaska field ............ 11

7 Geological column showing mineable coal beds, Tulugak Creek, Cape Beaufort area, Northern Alaska field ............ 12

8 Location of sampling site on the Kokolik River, Northern Alaska

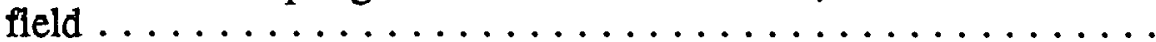

9 Augur sampling of coal seams by U.S. Geological Surveys crews in the National Petroleum Reserves in Alaska. Coal dug by ground squirrels may be seen in the foreground, and is used to locate outcrops hidden under tundra from air............... 14

10 A closeup view of coal outcrop on Kokolik River ......... 14 


\section{LIST OFFIGURES (Continued)}

\section{FIGURE NO.}

11 Geological column showing mineable coal bed on the Kokolik River, Northem Alaska field $\ldots \ldots \ldots \ldots \ldots \ldots \ldots \ldots$

12 Location of sampling site on the Elusive creek, Northern Alaska

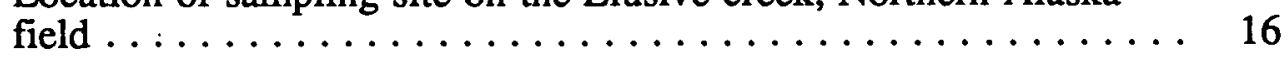

13 Aerial view of coal outcrop on Elusive creek $\ldots \ldots \ldots \ldots \ldots 17$

14 A closeup view of coal outcrop on Elusive Creek. James E. Callahan (left) and Gary Martin, both of U.S.G.S. . . . . . . . 17

15 Geological column showing mineable coal beds on Elusive creek, Northern Alaska field $\ldots \ldots \ldots \ldots \ldots \ldots \ldots \ldots \ldots$

16 Sampling location on the banks of Kuk River, Northern Alaska field. . . 20

17 A closeup view of coal outcrop on Kuk River . . . . . . . 21

18 Sampling location of Meade River, Northern Alaska field ..... 22

19 A closeup view of coal subcrop on Meade River ......... 23

20 Sampling location at Sagwon Bluff, Northern Alaska field ...... 24

21 Location of sampling site at the Chicago Creek coal deposit..... 25

22 Geological section of coal seams at the Chicago Creek coal deposit . . 26

23 Location of sampling site at Unalakleet coal occurrence . . . . . . 27

24 Location of sampling sites in the Nenana field........... 28

25 Geological column showing mineable coal beds on Suntrana and Healy Creeks, Nenana coal field ... . . . . . . . . . . . . . . 29

26 A general view of coal exposures on Upper Lignite Creek. U.A141 was sampled from the seam marked with an arrow ....... 30

27 Geological column showing coal beds on the Upper Lignite Creek, Nenana coal field ......................... 30

28 A mine face of No. 4 Seam $\ldots \ldots \ldots \ldots \ldots \ldots \ldots \ldots \ldots \ldots$

29 Geological column showing mineable coal beds at the Poker Flat Pit, Usibelli coal mine, Nenana coal field ............. 32 


\section{LIST OF FIGURES (Continued)}

FIGURE NO.

30 Outcrop of Basal Bed on Lignite Creek ... . . . . . . . . . 33

31 Outcrop of coal on Marguerite Creek. The outcrop faces Jumbo Dome, Nenana coal field ................... 33

32 Location of sampling site at the Yanert mine, Nenana coal field ... 34

33 Location of sampling site in the Jarvis Creek coal field . . . . . . 35

34 Location of sampling site on Coal Creek in the Eagle coal field ... 37

35 Location of sampling site near Chicken, in the Forty Mile district, Eagle coal field ...................... 38

36 Location of sampling site at the Nulato field . . . . . . . . . . . 39

37 Sampling location of Tramway Bar field . . . . . . . . . . . 41

38 A closeup view of outcrop in Tramway Bar field . . . . . . . . . 42

39 Correlation of Tertiary rocks in the Beluga coal field. (Source: Magoon, Adkison and Egbert, 1976) . . . . . . . . . . . . 43

40 Location of sampling sites in the Capps Basin of the Beluga coal field ..............................444

41 Geological column showing mineable coal beds in the Capps basin, Beluga coal field . . . . . . . . . . . . . . . . . . . 45

42 Capps coal field - cross section $\ldots \ldots \ldots \ldots \ldots \ldots \ldots$

43 A subcrop of the Waterfall seam opened up in benches by Placer Amex for bulk sampling. The lower 30 foot bench and the upper 6 foot bench are distinguishable $\ldots \ldots \ldots \ldots \ldots \ldots \ldots$

44 Location of sampling site at the Lone Ridge mine in the Beluga field . . . 48

45 View of pit dug by Placer Amex, Inc. for obtaining bulk samples for shipment to Japan. Sample UA-152 was obtained from this pit. . .

46 Geological column showing mineable coal beds at Lone Ridge mine, Beluga coal field ... . . . . . . . . . . . . . . 5 5)

47 Location of sampling site on Johnson Creek in the Yentna field . . . 51 


\section{LIST OF FIGURES (Continued)}

FIGURE NO.

48 Geological column showing mineable coal beds exposed along the Johnson Creek, Yentna coal field . . . . . . . . . . . . . 52

49 A closeup view of outcrop on Johnson Creek $\ldots \ldots \ldots \ldots$

50 Location of sampling site on Canyon Creek in the Yentna field. . . 54

51 Geological column showing mineable coal beds exposed along the Canyon Creek, Yentna coal field ................ 55

52 Aerial view of outcrop on Canyon Creek, the sampling site for UA-

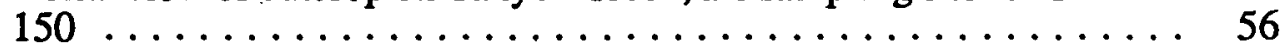

53 A closeup view of the outcrop on Canyon Creek . . . . . . . . . 56

54 Sampling location in the Yentna field .............. 57

55 A closeup view of sampling location at Locality $2 \ldots \ldots \ldots \ldots$

56 Sampling location in the Kenai field ............... 59

57 Geological column showing mineable coal beds near Homer, Kenai coal field (Source: Barnes and Cobb, 1959) . . . . . . . . . . . 60

58 Coal outcrop near Ninilchik, with underclays washed out by wave action, forming a natural cave with coal as resistant roof .......66 61

59 Location of sampling site near Ninilchik, Kenai coal field . . . . . 62

60 Location of sampling site on Happy Creek, Kenai coal field . . . . . 63

61 Location of sampling site in the Lower Matanuska Valley, Matanuska coal field ........................ 64

62 Geological column showing mineable coal beds in the Wishbone Hill District, Matanuska coal field . . . . . . . . . . . . . . 65

63 General view of Evan Jones surface mined pit at the northeast corner of Wishbone Hill. Samples UA-142, 143, 144, 145, 146 and 147 were obtained from this site . . . . . . . . . . . . 66

64 Location of sampling site in the Upper Matanuska Valley, Matanuska coal field ..................... 67

65 View of sampling site at Castle Mountain mine .......... 68 


\section{LIST OF FIGURES (Continued)}

FIGURE NO.

66 Sampling location in the Broad Pass field . . . . . . . . . . . 69

67 View of sampling site on Coal Creek $\ldots \ldots \ldots \ldots \ldots \ldots \ldots$

68 Location of sampling site at the Dunkle mine, Broad Pass coal field. . 71

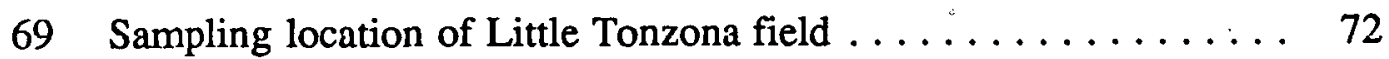

70 Geological column showing coal exposed along the river as well as two drill holes recorded adjacent to the outcrop ........... 73

71 View of coal bed exposed at the bank of Little Tonzona River . . . 74

72 Location of sampling site in the Chignik field .......... 75

73 General view showing the location of Chignik mine....... 76

74 Correlation chart of Cretaceous rocks of Alaska Peninsula .... . . 77

75 Location of sampling site at the Herendeen Bay field........ 78

76 View of coal bed exposed at Coal Point on Herendeen Bay ..... 79

77 Flowsheet for washability characterization $\ldots \ldots \ldots \ldots \ldots .80$

78 Flowsheet for fine coal washability characterization $\ldots \ldots \ldots .81$

79 MIRL Design of round-bottom centrifuge bottle $\ldots \ldots \ldots \ldots .82$

\section{LIST OF TABLES}

TABLE NO.

I Proximate and Ultimate Analyses of Raw Coals . . . . . . 97

II Hardgrove Grindability and Free Swelling Indexes of Raw Coal . . . . . . . . . . . . . . . . . . . . . . . . 104

III Concentration of Major Elements in the Raw Coal Ash $\left(750^{\circ} \mathrm{C}\right)$, Percent . . . . . . . . . . . . . . . 108 


\section{LIST OF TABLES(Continued)}

TABLE NO.

IV Fusibility of Ash of the Raw Coal Samples ......... 112

V Proximate and Ultimate Analysis of Float-Sink Products ... 116

VI Concentration of Major Elements in Ash of 1.60 Specific Gravity Float-Sink Products of Coals Crushed to 65 Mesh Size, Percent . . . . . . . . . . . . . . . 121

VII Fusibility of Ash of 1.60 Specific Gravity Float-Sink Products of Coals Crushed to Minus 65 Mesh Size .... . . 126

VIII Washability Analysis Showing the Effects of Crushing on the Liberation of Ash Forming Impurities and Pyritic Sulfur

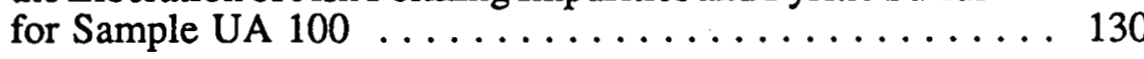

IX Washability Analysis Showing the Effects of Crushing on the Liberation of Ash Forming Impurities and Pyritic Sulfur for Sample UA $101 \ldots \ldots \ldots \ldots \ldots \ldots \ldots \ldots \ldots$

$\mathrm{X}$ Washability Analysis Showing the Effects of Crushing on the Liberation of Ash Forming Impurities and Pyritic Sulfur for Sample UA $102 \ldots \ldots \ldots \ldots \ldots \ldots \ldots \ldots \ldots . \ldots \ldots$

XI - Washability Analysis Showing the Effects of Crushing on the Liberation of Ash Forming Impurities and Pyritic Sulfur for Sample UA $103 \ldots \ldots \ldots \ldots \ldots \ldots \ldots \ldots \ldots \ldots$

XII Washability Analysis Showing the Effects of Crushing on the Liberation of Ash Forming Impurities and Pyritic Sulfur for Sample UA $104 \ldots \ldots \ldots \ldots \ldots \ldots \ldots \ldots \ldots$

XIII Washability Analysis Showing the Effects of Crushing on the Liberation of Ash Forming Impurities and Pyritic Sulfur for Sample UA $105 \ldots \ldots \ldots \ldots \ldots \ldots \ldots \ldots \ldots$

XIV Washability Analysis Showing the Effects of Crushing on the Liberation of Ash Forming Impurities and Pyritic Sulfur for Sample UA $106 \ldots \ldots \ldots \ldots \ldots \ldots \ldots \ldots . \ldots \ldots$

XV Washability Analysis Showing the Effects of Crushing on the Liberation of Ash Forming Impurities and Pyritic Sulfur for Sample UA 107 


\section{LIST OF TABLES (Continued)}

TABLE NO.

XVI Washability Analysis Showing the Effects of Crushing on the Liberation of Ash Forming Impurities and Pyritic Sulfur for Sample UA $108 \ldots \ldots \ldots \ldots \ldots \ldots \ldots \ldots \ldots$

XVII Washability Analysis Showing the Effects of Crushing on the Liberation of Ash Forming Impurities and Pyritic Sulfur for Sample UA $109 \ldots \ldots \ldots \ldots \ldots \ldots$

XVIII Washability Analysis Showing the Effects of Crushing on the Liberation of Ash Forming Impurities and Pyritic Sulfur for Sample UA $110 \ldots \ldots \ldots \ldots \ldots$. . . . . . . . . . 140

XIX Washability Analysis Showing the Effects of Crushing on the Liberation of Ash Forming Impurities and Pyritic Sulfur for Sample UA $111 \ldots \ldots \ldots \ldots \ldots \ldots \ldots \ldots \ldots$

XX Washability Analysis Showing the Effects of Crushing on the Liberation of Ash Forming Impurities and Pyritic Sulfur for Sample UA $112 \ldots \ldots \ldots \ldots \ldots \ldots \ldots . \ldots \ldots$

XXI Washability Analysis Showing the Effects of Crushing on the Liberation of Ash Forming Impurities and Pyritic Sulfur for Sample UA $113 \ldots \ldots \ldots \ldots \ldots \ldots \ldots \ldots \ldots$

XXII Washability Analysis Showing the Effects of Crushing on the Liberation of Ash Forming Impurities and Pyritic Sulfur for Sample UA $114 \ldots \ldots \ldots \ldots \ldots \ldots \ldots \ldots . \ldots \ldots$

XXIII Washability Analysis Showing the Effects of Crushing on the Liberation of Ash Forming Impurities and Pyritic Sulfur for Sample UA $115 \ldots \ldots \ldots \ldots \ldots \ldots \ldots \ldots . \ldots \ldots$

XXIV Washability Analysis Showing the Effects of Crushing on the Liberation of Ash Forming Impurities and Pyritic Sulfur for Sample UA $116 \ldots \ldots \ldots \ldots \ldots \ldots \ldots . \ldots \ldots$

XXV Washability Analysis Showing the Effects of Crushing on the Liberation of Ash Forming Impurities and Pyritic Sulfur for Sample UA 117 . . . . . . . . . . . . . . . . . 147

XXVI Washability Analysis Showing the Effects of Crushing on the Liberation of Ash Forming Impurities and Pyritic Sulfur for Sample UA $118 \ldots \ldots \ldots \ldots \ldots \ldots \ldots \ldots \ldots$ 


\section{LIST OF TABLES (Continued)}

TABLE NO.

XXVII Washability Analysis Showing the Effects of Crushing on the Liberation of Ash Forming Impurities and Pyritic Sulfur for Sample UA 119 . . . . . . . . . . . . . . . . . . . . 149

XXVIII Washability Analysis Showing the Effects of Crushing on the Liberation of Ash Forming Impurities and Pyritic Sulfur for Sample UA $120 \ldots \ldots \ldots \ldots \ldots \ldots \ldots \ldots$

XXIX Washability Analysis Showing the Effects of Crushing on the Liberation of Ash Forming Impurities and Pyritic Sulfur for Sample UA $121 \ldots \ldots \ldots \ldots \ldots \ldots \ldots \ldots \ldots$

XXX Washability Analysis Showing the Effects of Crushing on the Liberation of Ash Forming Impurities and Pyritic Sulfur for Sample UA $122 \ldots \ldots \ldots \ldots \ldots \ldots \ldots \ldots \ldots \ldots$

XXXI Washability Analysis Showing the Effects of Crushing on the Liberation of Ash Forming Impurities and Pyritic Sulfur for Sample UA 123 . . . . . . . . . . . . . . . . . . 153

XXXII Washability Analysis Showing the Effects of Crushing on the Liberation of Ash Forming Impurities and Pyritic Sulfur for Sample UA 124 . . . . . . . . . . . . . . . . . . 154

XXXIII Washability Analysis Showing the Effects of Crushing on the Liberation of Ash Forming Impurities and Pyritic Sulfur for Sample UA $125 \ldots \ldots \ldots \ldots \ldots \ldots \ldots \ldots \ldots$

XXXIV Washability Analysis Showing the Effects of Crushing on the Liberation of Ash Forming Impurities and Pyritic Sulfur for Sample UA $126 \ldots \ldots \ldots \ldots \ldots \ldots \ldots \ldots \ldots$

XXXV Washability Analysis Showing the Effects of Crushing on the Liberation of Ash Forming Impurities and Pyritic Sulfur for Sample UA 127 . . . . . . . . . . . . . . . . . . 157

XXXVI Washability Analysis Showing the Effects of Crushing on the Liberation of Ash Forming Impurities and Pyritic Sulfur for Sample UA $128 \ldots \ldots \ldots \ldots \ldots \ldots \ldots \ldots \ldots$

XXXVII Washability Analysis Showing the Effects of Crushing on the Liberation of Ash Forming Impurities and Pyritic Sulfur for Sample UA 129 . . . . . . . . . . . . . . . . . 159 


\section{LIST OF TABLES (Continued)}

TABLE NO.

XXXVIII Washability Analysis Showing the Effects of Crushing on the Liberation of Ash Forming Impurities and Pyritic Sulfur for Sample UA $130 \ldots \ldots \ldots \ldots \ldots$

XXXIX Washability Analysis Showing the Effects of Crushing on the Liberation of Ash Forming Impurities and Pyritic Sulfur for Sample UA $131 \ldots \ldots \ldots \ldots \ldots \ldots \ldots \ldots$

XL Washability Analysis Shnwing the Fffects of Crushing on the Liberation of Ash Forming Impurities and Pyritic Sulfur for Sample. ITA 132

XII Washability Analysis Showing the Effects of Crushing on the Liberation of Ash Forming Impurities and Pyritic Sulfur for Sample UA 136

XLII Washability Analysis Showing the Effects of Crushing on the Liberation of Ash Forming Impurities and Pyritic Sulfur for Sample UA $137 \ldots \ldots \ldots \ldots \ldots$. . . . . . . . . . 164

XLIII Washability Analysis Showing the Effects of Crushing on the Liberation of Ash Forming Impurities and Pyı ilic Sulfur for Sample UA 138

XLIV Washability Analysis Showing the Effects of Crushing on the Liberation of Ash Forming Impurities and Pyritic Sulfur for Sample UA 139

XLV Washability Analysis Showing the Effects of Crushing on the Liberation of Ash Forming Impurities and Pyritic Sulfur for Sample UA $140 \ldots \ldots \ldots \ldots \ldots \ldots \ldots$

XLVI Washability Analysis Showing the Effects of Crushing on the Liberation of Ash Forming Impurities and Pyritic Sulfur for Sample U^ 141

XLVII Washability Analysis Showing the Effects of Crushing on the Liberation of Ash Forming Impurities and Pyritic Sulfur for Sample UA 142

XLVIII Washability Analysis Showing the Effects of Crushing on the Liberation of Ash Forming Impurities and Pyritic Sulfur for Sample UA 143 


\section{LIST OF TABLES (Continued)}

TABLE NO.

XLIX Washability Analysis Showing the Effects of Crushing on the Liberation of Ash Forming Impurities and Pyritic Sulfur for Sample UA $144 \ldots \ldots \ldots \ldots \ldots \ldots \ldots \ldots \ldots$

L Washability Analysis Showing the Effects of Crushing on the Liberation of Ash Forming Impurities and Pyritic Sulfur for Sample UA $145 \ldots \ldots \ldots \ldots \ldots \ldots \ldots$. . . . . . . . 172

LI Washability Analysis Showing the Effects of Crushing on the Liberation of Ash Forming Impurities and Pyritic Sulfur for Sample UA $146 \ldots \ldots \ldots \ldots \ldots \ldots \ldots \ldots \ldots$

LII Washability Analysis Showing the Effects of Crushing on the Liberation of Ash Forming Impurities and Pyritic Sulfur for Sample UA 147 . . . . . . . . . . . . . . . . . 174

LIII Washability Analysis Showing the Effects of Crushing on the Liberation of Ash Forming Impurities and Pyritic Sulfur for Sample UA $148 \ldots \ldots \ldots \ldots \ldots \ldots \ldots \ldots \ldots \ldots$

LIV Washability Analysis Showing the Effects of Crushing on the Liberation of Ash Forming Impurities and Pyritic Sulfur for Sample UA 149 . . . . . . . . . . . . . . . . . . 176

LV Washability Analysis Showing the Effects of Crushing on the Liberation of Ash Forming Impurities and Pyritic Sulfur for Sample UA $150 \ldots \ldots \ldots \ldots \ldots \ldots \ldots \ldots \ldots \ldots$

LVI Washability Analysis Showing the Effects of Crushing on the Liberation of Ashi Forming Impurities and Pyritic Sulfur for Sample UA $151 \ldots \ldots \ldots \ldots \ldots \ldots \ldots$

LVII Washability Analysis Showing the Effects of Crushing on the Liberation of Ash Forming Impurities and Pyritic Sulfur for Sample UA $152 \ldots \ldots \ldots \ldots \ldots \ldots \ldots . \ldots \ldots$ 


\section{ABSTRACT}

This final report is the result of a study initiated in 1976 to obtain washability data for Alaskan coals, to supplement the efforts of the U.S. Department of Energy in their ongoing studies on washability of U.S. coals. Washability characteristics were determined for fifty coal samples from the Northern Alaska, Chicago Creek, Unalakleet, Nenana, Matanuska, Beluga, Yentna and Herendeen Bay coal fields. The raw coal was crushed to $1-1 / 2$ inches, $3 / 8$ inch, 14 mesh and 65 mesh top sizes, and float-sink separations were made at $1.30,1.40$ and 1.60 specific gravities. A limited number of samples were also crushed to 200 and 325 mesh sizes prior to float-sink testing. Samples crushed to 65 mesh top size were also separated at 1.60 specific gravity and the float and sink products were characterized for proximate and ultimate analyses, ash composition and ash fusibility.

Bituminous coals pulverized to 65 mesh dispersed quite well when dried and mixed in a blender. Subbituminous coals, however, could not be totally dispersed.

Six seams were sampled from the Northern Alaska field. The results showed that No. 7 bed, from Cape Beaufort containing 21.2 percent ash, can be washed to give a product analyzing 11.2 percent ash at 76.2 percent yield. The uncorrelated bed coal from Kokolik River gave a product with 2.55 percent ash, 0.24 percent sulfur at 81.26 percent yield. No. 3 bed coal from Elusive Creek can be washed to give an ultraclean product with less than 2 percent ash and 0.25 percent total sulfur for the sample crushed to $1-1 / 2$ inches top size at 98.7 percent yield.

The results showed that the subbituminous " $B$ " coals from Wainwright and Meade River can be washed to give an ultra clean product containing less than 3.5 percent ash at yields of 91 percent or better. One sample from Sagawon Bluffs in the eastern part of the field was very high in ash which could be reduced significantly, however, the yield would be very low.

The subbituminous "C" coal seam from Chicago Creek field, containing 15.1 percent ash, can be washed to give a product analyzing 8.8 percent ash at 86.7 percent yield.

The high volatile "C" bituminous coal from the Unalakleet field analyzed 11.2 percent ash. Washing will reduce ash to 7.0 percent at 96.0 percent yield.

The results showed that six subbituminous coals from the Nenana coal field, when crushed to minus 14 mesh and floated at specific gravity 1.40 , yielded products ranging in heating values from 10,098 to $11,664 \mathrm{Btu} / \mathrm{lb}$ with 0.15 percent to 0.23 percent sulfur on a moisture free basis, making them among the most environmentally acceptable coals in the United States.

Three subbituminous " $C$ " coal seams were sampled from the Nenana coal field, two of which were from Usibelli Coal Mine. Samples from numbers 1 and 3 seams can be washed at 1.60 specific gravity to give products with 10.9 percent and 9.2 percent ash respectively. Washing coal from Marguerite Creek gave a product with 10.1 percent ash.

Subbituminous "C" No. 4 bed coal, Nenana coal field, could provide a product with 9.6 percent ash and $10,854 \mathrm{Btu} / \mathrm{lb}$ at a 96.8 percent yield when crushed to $1-1 / 2$ inches top size and cleaned at 1.40 specific gravity. 
Two subbituminous "C" coal beds were sampled from the Nenana field. The Basal Bed A raw coal containing 19.5 percent ash, 0.40 percent sulfur can be washed to give a product analyzing 10.2 percent ash at 73.8 percent yield. The uncorrelated bed sampled from the bluffs along Upper Lignite Creek analyzed 12.8 percent ash and can be washed to give a product analyzing 9.4 percent ash at 88.6 percent yield.

High volatile "B" bituminous coal from Yanert Mine, Nenana coal field, gave very low recovery, however, the ash could be reduced from 53.2 to 13.6 percent by crushing to 3 / 8 inch top size and separating at 1.60 specific gravity.

A subbituminous $\mathrm{C}$ coal from the Jarvis Creek coal field yielded 84.9 weight percent of float 1.40 specific gravity product with $11,272 \mathrm{Btu} / \mathrm{b}$ on a moisture free basis and 0.98 percent sulfur after crushing to 14 mesh top size.

The sample from the Eagle field had only 0.05 percent pyritic sulfur. The sample from Coal Creek gave 13.7 percent ash at 82.7 percent yield, and the sample from Chicken gave 18.8 percent ash at 76.1 percent yield.

The sampled high volatile " $A$ " bituminous coal seam from the Nulato coal field was only 12 inches thick and contained more than $60 \%$ ash. However, the 1.60 specific gravity float product gave a free swelling index of 9.6 and a yield of only 19 percent, containing 10 percent ash and 0.97 percent sulfur.

The high volatile subbituminous coal from Tramway Bar coal field was high in ash. Washing the $1-1 / 2$ inches top size coal at 1.60 specific gravity would provide a product with 11.5 percent ash and 0.27 percent sulfur with a calorific value of $11,523 \mathrm{Btu} / \mathrm{lb}$.

The lower 30 feet of the Waterfall Bed from the Beluga coal field gave a float 1.40 specific gravity product with 7.2 percent ash, 0.20 percent sulfur and $11,222 \mathrm{Btu} / \mathrm{lb}$ at 92.7 percent yield.

The top 6 feet of Waterfall seam from the Beluga field contained considerable soft clay that accounted for much of the ash in the raw coal, which averaged 37,0 percent. Washing at 1.40 specific gravity gave a product analyzing 8.0 percent ash.

The Capps bed coal sample from the Beluga field could be upgraded to 7.5 percent upon crushing to $3 / 8$ inch top size and cleaning at 1.40 specific gravity.

The subbituminous " $C$ " coal sampled from Green bed in the Beluga field was quite low in ash; 8.25 percent on a moisture free basis. Washing gave a product analyzing 5.3 percent ash at 98.5 percent yield. All the above results are expressed on a moisture free basis.

Two subbituminous "C" coal beds were sampled from Yentna field.

The coal bed from Johnson Creek gave a product analyzing 7.5 percent at 71.1 percent yield when crushed to 14 mesh top size.

The coal bed from Canyon Creek gave a product analyzing 6.8 percent ash at 63.5 percent yield when crushed to 14 mesh top size.

Lignite from Yentna coal field has less than 5 percent ash in the raw coal and very little 
sulfur, less than 0.15 percent. Washing would not significantly improve the quality of this coal.

The subbituminous " $C$ " coal from Cabin Bed, Kenai coal field, near Homer crushed to $3 / 8$ inch top size, can be washed at 1.40 specific gravity to give a product with 8.3 percent ash, 0.48 percent sulfur, and $1,189 \mathrm{Btu} / \mathrm{lb}$ with a 90.8 percent field.

Two subbituminous coals sampled from Kenai field gave products with acceptable ash. 1.40 specific gravity float product from Ninilchik analyzed 8.16 percent ash whereas the product from Happy Creek analyzed 9.03 percent ash. The total sulfur averaged less than 0.40 percent for both coals.

Six coal beds were sampled from the strip mine pit of the Evan Jones mine in the Matanuska field. These coals are best cleaned to make three products, i.e., a clean coal, middlings and rejects. The seams, by washing the $1-1 / 2$ inch top size material at 1.40 specific gravity, will yield clean coal products ranging in ash content from 4.2 to 8.5 percent with yield ranging from 33.7 to 67.7 . Further washing at 1.60 will yield products analyzing 21.3 to 26.6 percent ash at yields ranging from 56.2 to 92.5 percent.

A high volatile A and a high volatile B bituminous coal from the Premier Mine of the Matanuska coal field yielded 65.7 and 75.3 weight-percent of float 1.40 specific gravity product with heating values of 14,383 and $13,371 \mathrm{Btu} / \mathrm{lb}$ when crushed to 14 mesh top size. The sulfur in these two coals was very low (less than 0.50 percent) and was virtually all organic sulfur, therefore, no sulfur reduction occurred during washing.

Lignite from the Broad Pass coal field showed improvements in the 1.40 specific gravity product after crushing to $3 / 8$ inch top size and gave a product with 10.6 percent ash at a 78.7 percent yield.

Coal from Dunkle bed coal, Broad Pass field, gave a product with 9.0 percent ash at 87.87 percent yield.

The subbituminous " $\mathrm{C}$ " rank sample of Little Tonzona coal bed gave an 8.9 percent ash product with 83.4 percent recovery for coal crushed to $1-1 / 2$ inches top size. The sulfur in this coal is high 1.55 , and with very little pyritic sulfur; therefore, washing will not improve the sulfur content.

Coal from Chignik Bay Coal Mine from the Chignik field contained 36.18 percent ash and could be washed at 1.60 specific gravity to give a product analyzing 11.0 percent ash.

The coal bed from Herendeen Bay field containing 43.6 percent ash and 1.91 percent sulfur can be washed to give a product analyzing 9.9 percent ash and 1.59 percent sulfur at 31.8 percent yield.

\section{ACKNOWLEDGMENTS}

The study was conducted under the sponsorship of the U.S. Department of Energy. The authors are especially grateful to Messrs. Joseph A. Cavallaro and Albert W. Deurbrouck, Pittsburgh Energy Technology Center, formerly with the Pittsburgh Mining Technology Center, U.S. Department of Energy, for their helpful suggestions during the course of the 
investigation, and for their careful review of the final draft report.

Several organizations furnished financial and helicopter support to obtain samples of beds in remote locations. The Alaska Field Operations Center of the U.S. Bureau of Mines provided funds for sampling the Wainwright and Meade River coal beds. The Alaska Division of Geological and Geophysical Surveys was responsible for sampling and transportation of Little Tonzona coal from the field by air. They also furnished helicopter support and camping facilities for the author for sampling the coal bed at Locality 2 in the Yentna field. Beluga Coal Corporation, a subsidiary of Placer U.S. sampled the Waterfall bed in the Beluga field and air lifted the two 55 gallon drums of the sample. Cook Inlet Region, Inc. kindly gave permission to sample the Waterfall and Capps seams. Cooperation of Placer U.S., particularly Benno Patsch, in sampling and transportation is appreciated.

Sampling and transportation of samples from the Sagwon Bluffs was done while working on a project funded by the U.S. Bureau of Mines on the study of the mineral resources of the pipeline corridor. Cooperation of all these organizations is gratefully acknowledged. A field party of the U.S. Geological Survey, Anchorage, under the direction of James F. Callahan, provided lodging, helicopter support, sampling and transportation of samples. Coal Creek Mines, Inc. provided transportation for the Coal Creek sample. Usibelli Coal Co., Mr. Steve Denton in particular, helped in sampling seams. The Alaska Department of Fish and Game provided lodging and helped in the sampling of the Chignik and Herendeen Bay coals. Virgil Vial, operator of the Chicago Creek gold placer mine, provided lodging and backhoe work for exposing the coal seam and transporting coal samples across the tundra. The Mobil Oil Company kindly provided permission to sample seams on Johnson and Canyon Creeks in their lease areas. The authors wish to express special appreciation to the Unalakleet Native corporation for help in sampling, particularly Helga Eakon, general manager of the corporation.

Numerous individuals have helped in collecting the following samples. The bulk of sample sites were located in remote areas. The following are the individuals that were actually involved in sampling the beds: P. D. Rao, Steve Denton. Panl Metz, Mark Robinson, E.N. Wolff, Allen Ahlalook, Edmond Simmons, Cleland Conwell, Bonita Maynard, Benno Patch, Robert Hodel, Ravishankar Rao, Deborah DeLong, Sreenivas Rao, James E. Callahan, Gary Martin, Edward Ellwanger, David R. Maneval and Wu-Ming Chang.

Laboratory investigations were assisted by Edward Ellwanger, Jane Smith, Juliet Cruz, Wu-Ming Chang, John Bennett, Victor Ross, John Hendrick, Robert Fisk, Tina Denton and Christopher Stark. Mitra Vuicich was responsible for most of the laboratory investigations of the fine coal washability part of the project.

Thanks are due to Dr. Donald J. Cook, Dean, School of Mineral Engineering, Dr. Earl H. Beistline, Former Dean, School of Mineral Engineering, and Dr. Ernest N. Wolff, Former Associate Director, Mineral Industry Research Laboratory for their interest and en s...-ragement in these coal investigations. Special thanks are due to Jane Smith for help in the preparation of the manuscript and to Cathy Farmer for typing the manuscript. 


\section{INTRODUCTION}

Alaska has extensive coal deposits (Figure 1). Barnes (1967) estimates identified coal resources at 130 billion tons. Estimates based on oil well drill logs in Cook Inlet (McGee, 1976) and the North Slope (Tailleru and Brogge, 1976; Martin and Callahan, 1978) could place the coal resources of Alaska at several trillion tons, exceeding the resources of the rest of the nation. Alaska, therefore, could possibly supply the energy needs of not only this State but the nation as well.

Alaska can supply coal to lessen the nation's reliance on imported oil and reduce the balance of payments deficit by exporting Alaskan coals to other Pacific Rim belt nations and to the west coast of the United States. This coal would come from the Nenana and Matanuska fields, accessible to the Alaska Railroad, or from the Beluga field, accessible to a deep water port. A beginning has been made by the signing of an agreement by Usibelli Coal Co. with Suneel Alaska Corporation to supply 8 million tons of coal for export to Korea. Shipments commenced in 1985 and will average yearly exports of 880,000 tons. This alone will double current output.

There are three major undesirable substances in coal: sulfur, moisture and ash. Alaskan coals are found in nonmarine formations and this accounts for the low or zero pyritic sulfur content and consequently very low total sulfur. Moisture is the most undesirable of the constituents in Alaska's subbituminous coals and it has been addressed in a separate study by Rao and Wolff (1980). The extent to which ash and sulfur can be reduced depends to a large extent on the form of occurrence and is readily evaluated by standard washability tests. These involve crushing and float-sink separation of coals in organic liquids at varying densities, followed by chemical analysis and evaluation of the densimetric fractions.

Work on this project was started in 1976 with a grant from the U.S. Bureau of Mines and Usibelli Coal Mine. The grant was extended by the U.S. Department of Energy in 4 phases until 1982. The results have been published as four reports by Rao and Wolf (1979, $1980,1982 \mathrm{a}, \mathrm{b})$. By this time washability analyses were completed for 50 samples crushed down to 14 mesh top size. In 1983 the Department of Energy initiated a grant to perform washability studies of the same 50 coals at 65 mesh and finer sizes. This report is a summary of all investigations conducted on washability of Alaskan coals since 1976.

\section{COALFIELDSSAMPLED}

Fifty raw coal channel samples were collected for this study. Samples were obtained from freshly exposed surfaces of outcrops of weathered coal seams exposed by past mining activity. Six hundred pound samples were transported to the Laboratory in heavy duty plastic bags inside burlap gunny sacks. The samples were obtained from all major coal fields and principal coal occurrences.

\section{Northern Alaska Coal Fields}

The great bulk of Alaska's coal resources lie in the Northern Alaska coal field (Figure 1), north of the Brooks Range. Coal bearing Cretaceous rocks are known or inferred to underlie about 58,000 square miles (Barnes, 1967a; Barnes, 1967b). Figure 2 is a generalized facies diagram by Chapman and Sable (1960). They found that the coal beds in the UtukokCorwin region, particularly those of potential economic significance, are confined almost entirely to the Corwin formation. The Cretaceous rocks include sandstone, conglomerate, siltstone, shale and coal. The Corwin formation consists predominantly of marine coal 


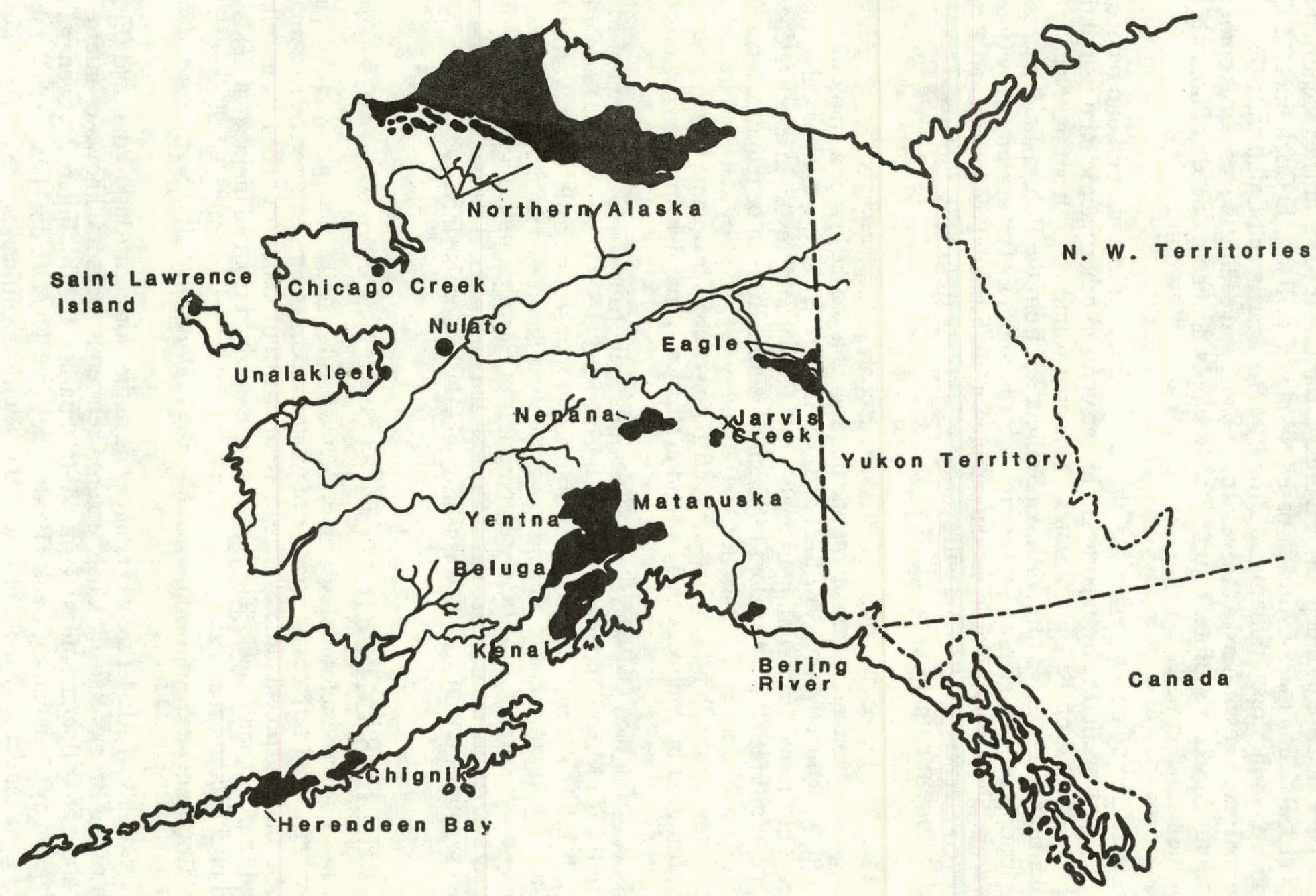

Figure 1. Major coal resources in Alaska. 


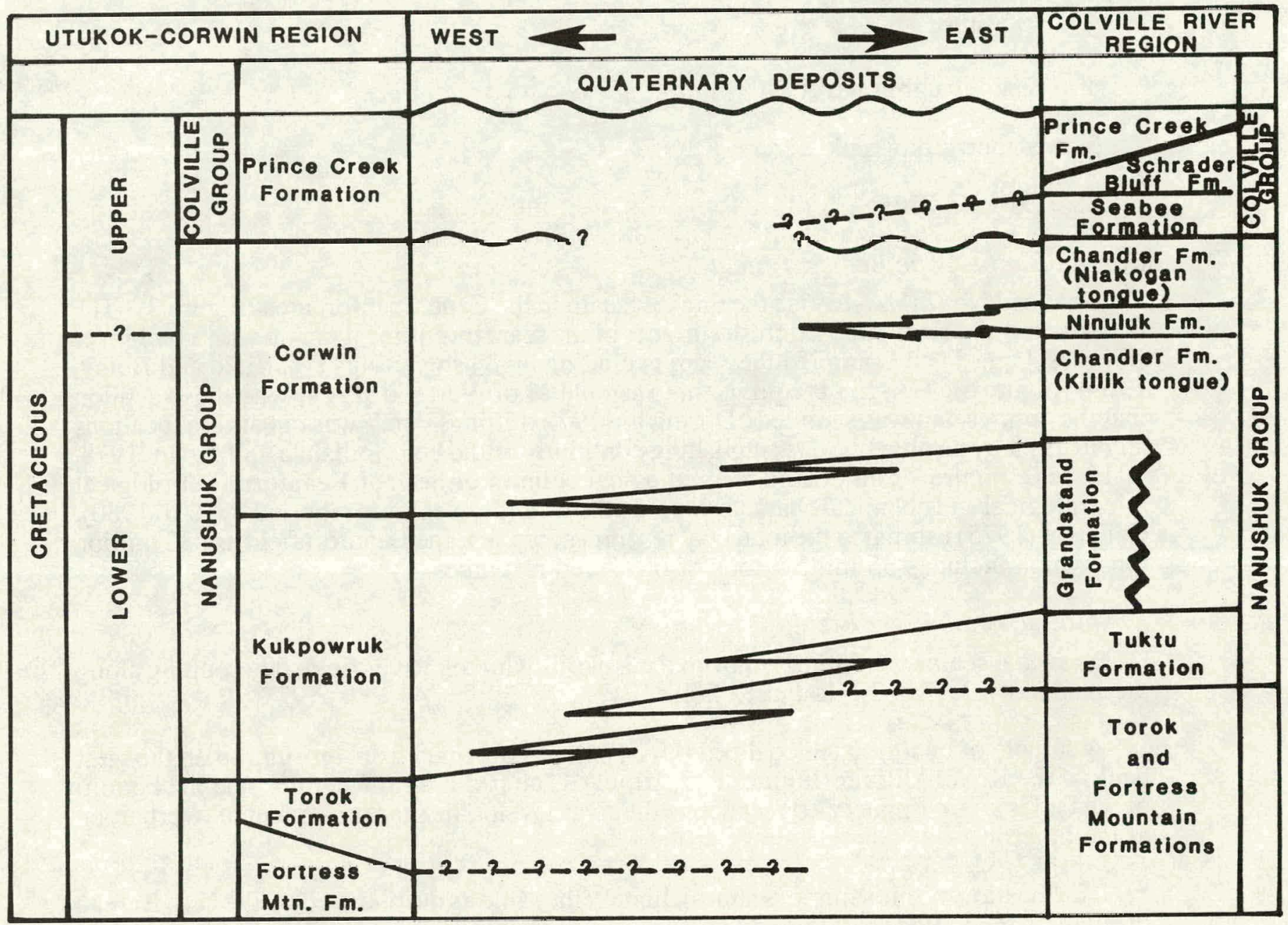

Figure 2. Generalized stratigraphic correlations rocks of the Northern Alaska field. Wavy lines represent unconformities. Chapman and Sable (1960, p. 70). 
bearing rocks that intertongue with the Kukpowruk formation consisting of marine rocks. Based on outcrops along river banks, Barnes (1967a) subdivided the field into six fields.

\section{Corwin Bluff - Cape Beaufort}

2. Kukpowruk River

3. Kokolik - Utukok River

4. Kuk - Kugrua Rivers

5. Meade - Ikpikpuk Rivers

6. Colville River

\section{Corwin Bluff - Cape Beaufort Field}

Coal bed No. 7 (UA-139) is the thickest seam in the Cape Beaufort area (Figure 3). The U.S. Bureau of Mines exposed fresh surfaces of the seam by cutting a trench with a bulldozer (Figures 4 and 5) and sampled the seam excluding high ash partings (Warfield and Boley, 1969) (Figure 6). UA-139 is equivalent to sample 21 of Warfield (1969) with the exception that the entire seam was sampled. During the 1972 drilling, Bed 7 was cut at five locations and in 1973 by an auger hole, establishing continuity of the bed (Callahan and Sloan, 1978, p. 13-15). Figure 7 is a composite geological column of beds at Beaufort. Petrological mineralogical and chemical characteristics of the drill samples were reported by Rao (1980). Callahan (1975) estimated the total coal resources for the Cape Beaufort field as 533 million tons which includes 35 million tons of measured resources.

\section{Kokolik - Utukok River Field}

Two coal seams were sampled from the Kokolik-Utukok River field, outcropping along the banks of Elusive Creek and Kokolik River.

A sample of uncorrelated coal bed (UA-126) was obtained from an outcrop on the west bank of the Kokolik River (Figures 8, 9, 10, 11). The bed is 11.6 feet thick and the bottom of the bed is approximately 10 feet above the river level. The seam has 5 feet of overburden at the outcrop.

The location of this sample is approximately the same as the one used by the U.S. Bureau of Mines in their 1964 sampling and is equivalent to their sample No. 14 (Warfield and Boley, 1969) and sample No. SS-75-55 of Callahan and Sloan (1978, p. 21). Martin and Callahan (1978) estimate hypothetical coal resources of the Nanushuk group in the coastal plain and northernmost part of the foothills of the National Petroleum Reserve in Alaska (NPRA) to be 848 billion tons. The estimate does not include resources west of NPRA, and is based on meager available surface exposures, tracing outcrops with auger holes and seismic record sections.

A sample of coal bed No. 3 was obtained from the west bank of Elusive Creek (UA125) which flows into Utukok River. The bed is 11.5 feet thick and has 6 feet of overburden. The bed dips away from the creek and is 5 feet above river level at the sampling point (Figures $12,13,14,15)$. 


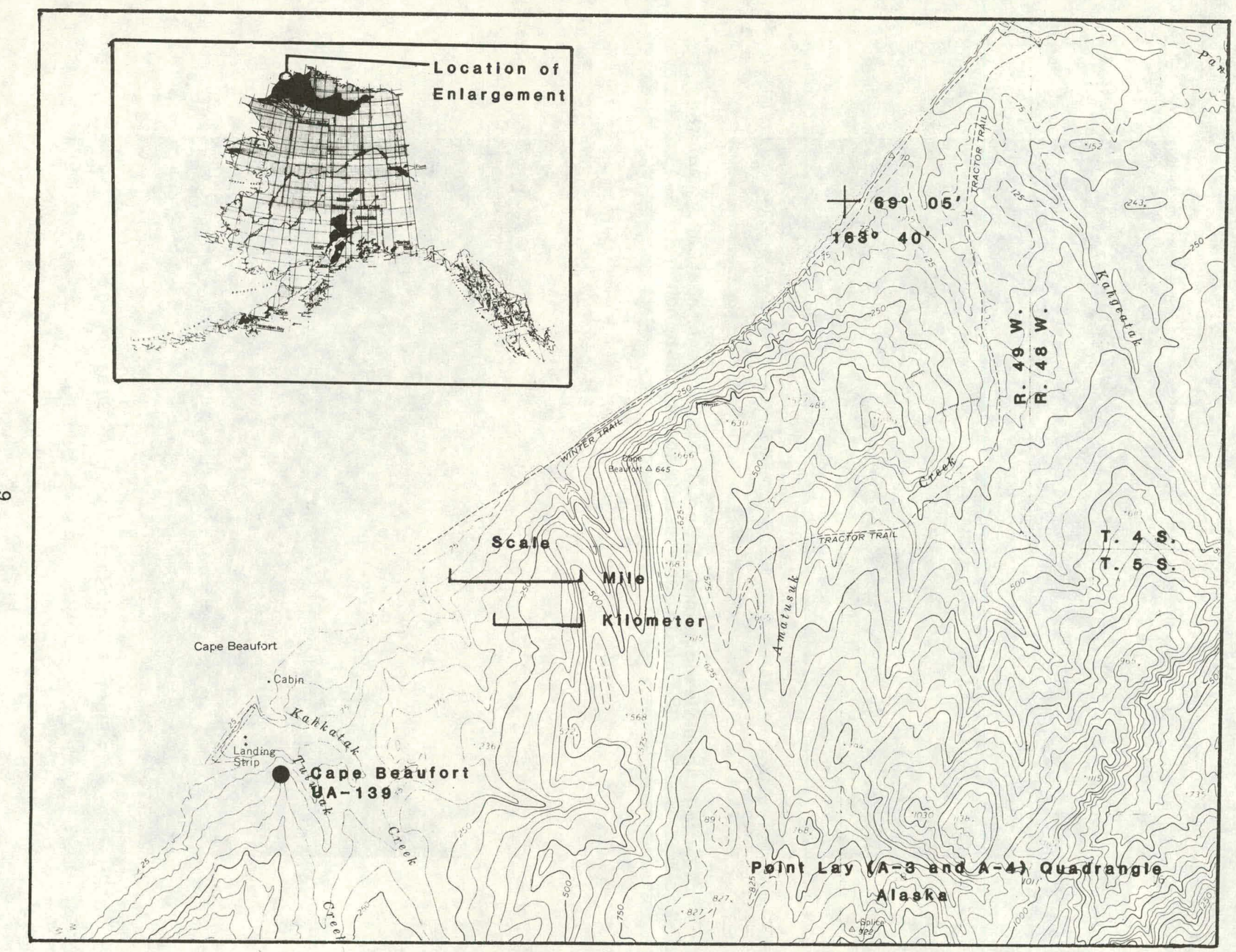

Figure 3. Location of sampling site at Cape Beaufort in the Northern Alaska field. 


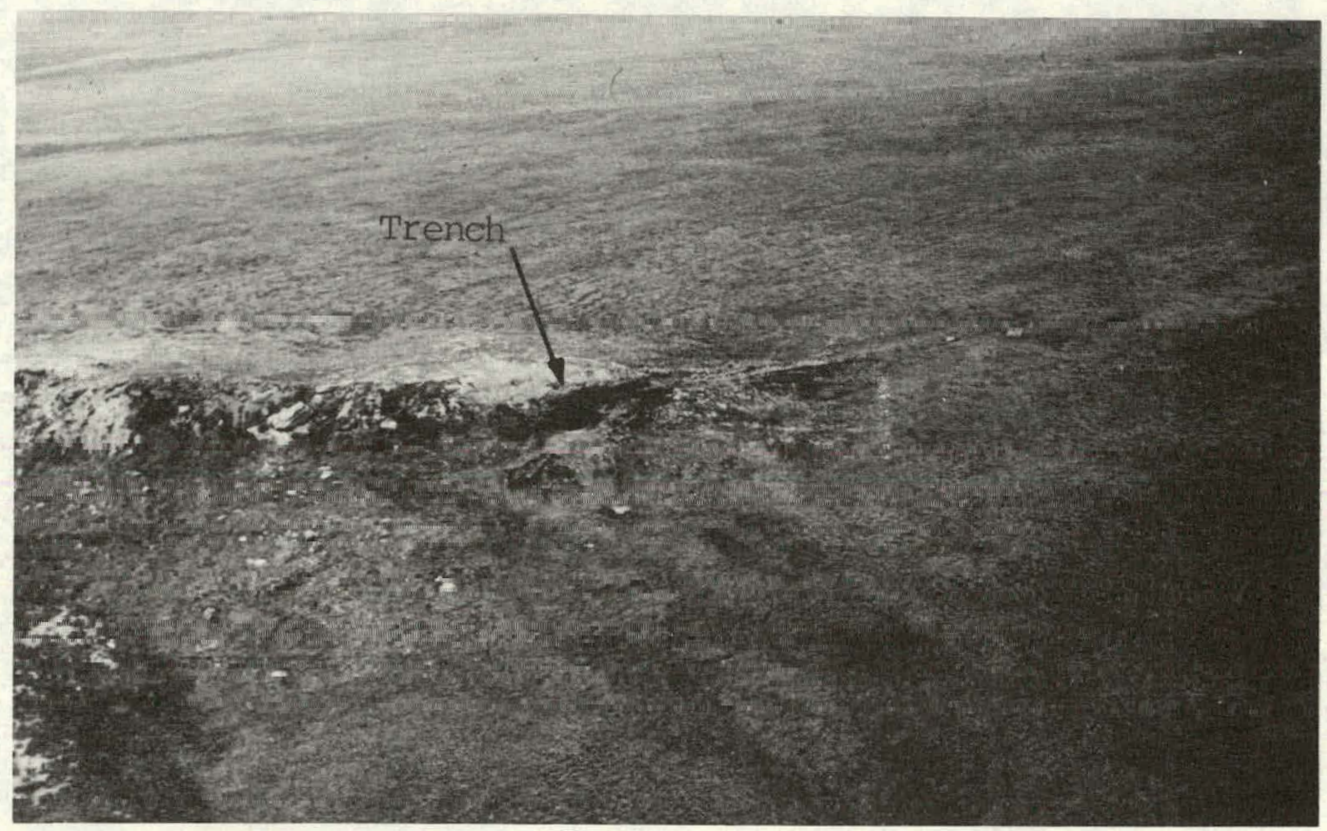

Figure 4. Aerial view locating U.S. Bureau of MInes trench near Cape Beaufort. Sample UA-139 was sampled from this trench.

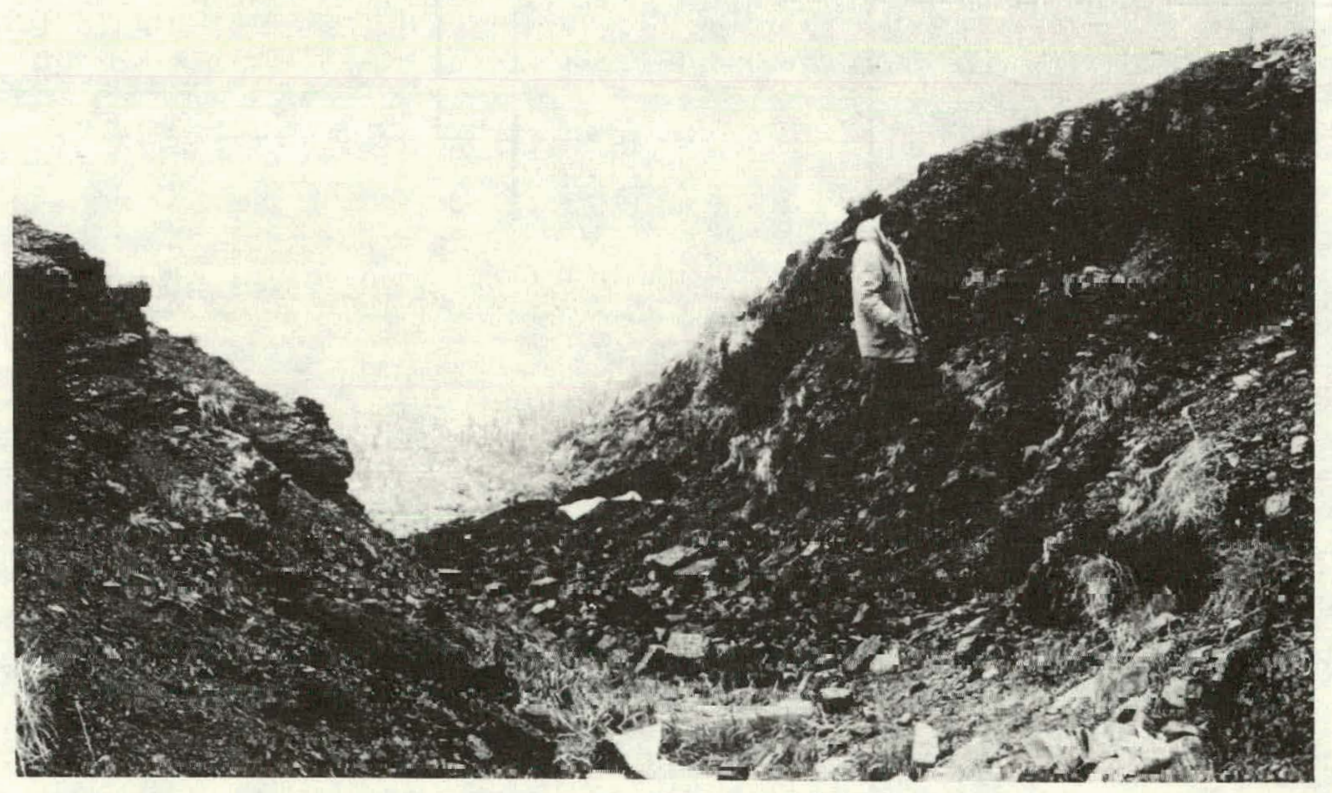

Figure 5. A closeup view of UA-139 sampling site. 


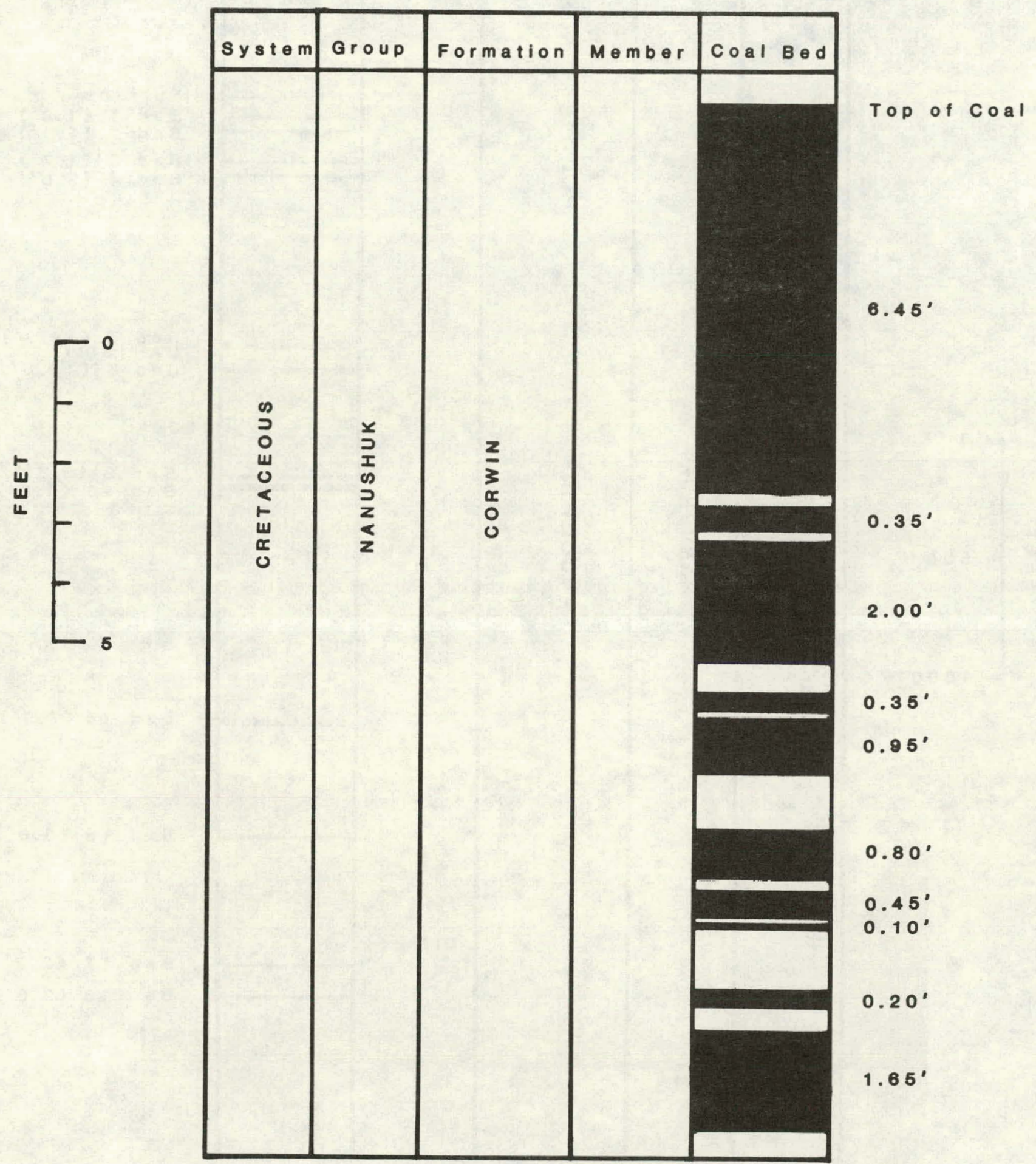

Figure 6. Geological column showing coal and partings in Bed 7 (UA-139), Cape Beaufort area, Northern Alaska field. 


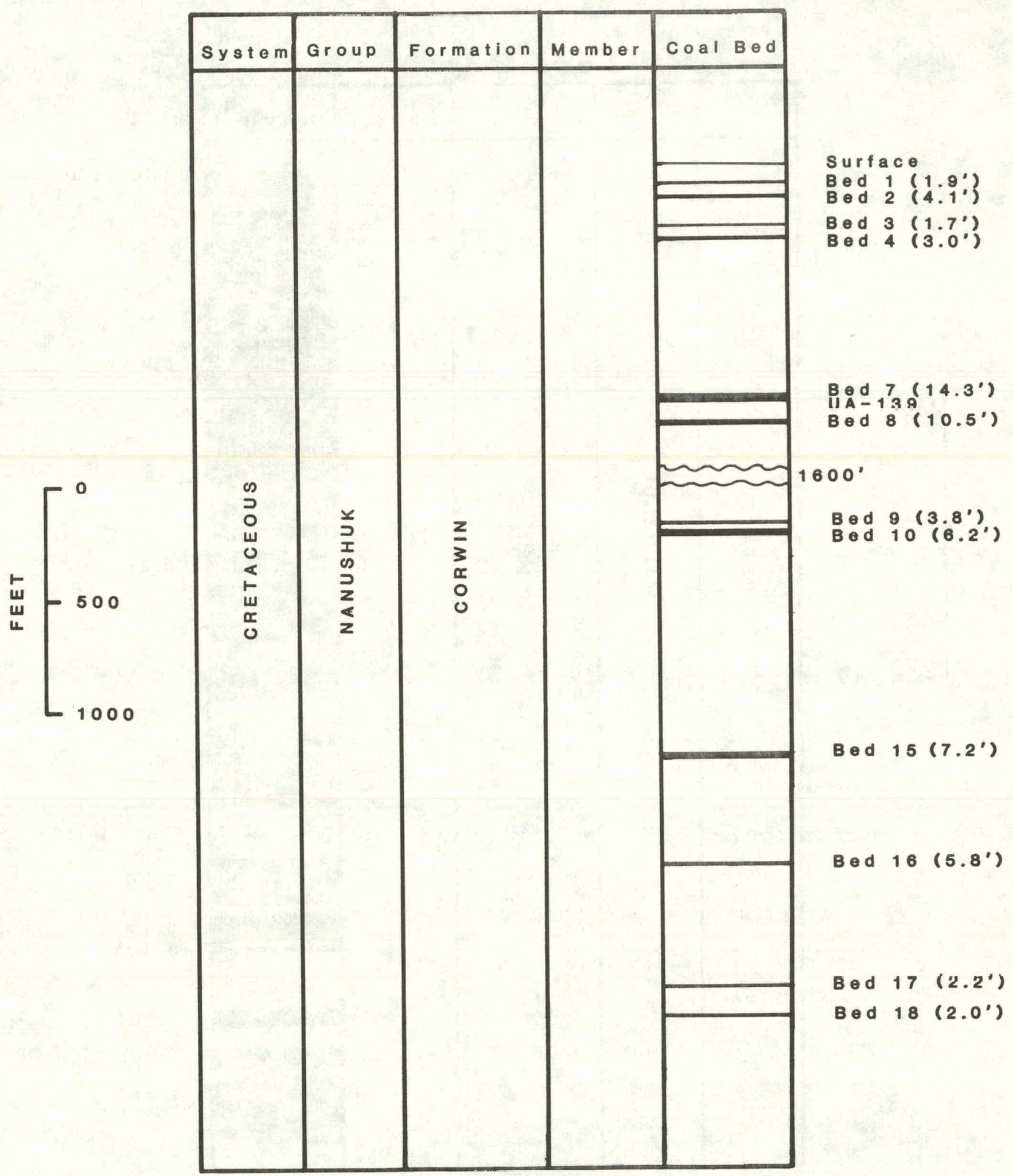

Figure 7. Geological column showing mineable coal beds, Tulugak Creek, Cape Beaufort area, Northern Alaska field. 


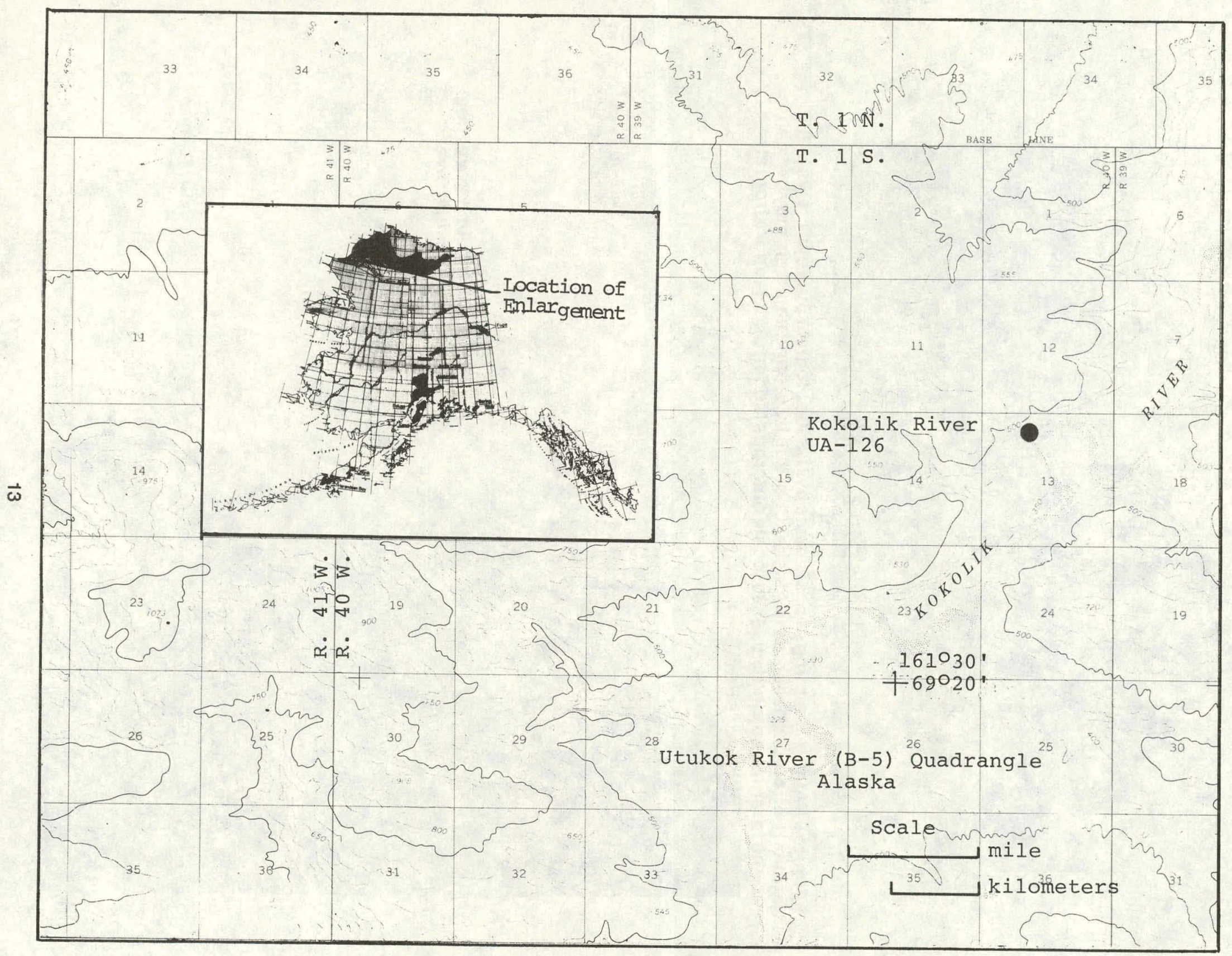

Figure 8. Location of sampling site on the Kokolik River, Northern Alaska field. 


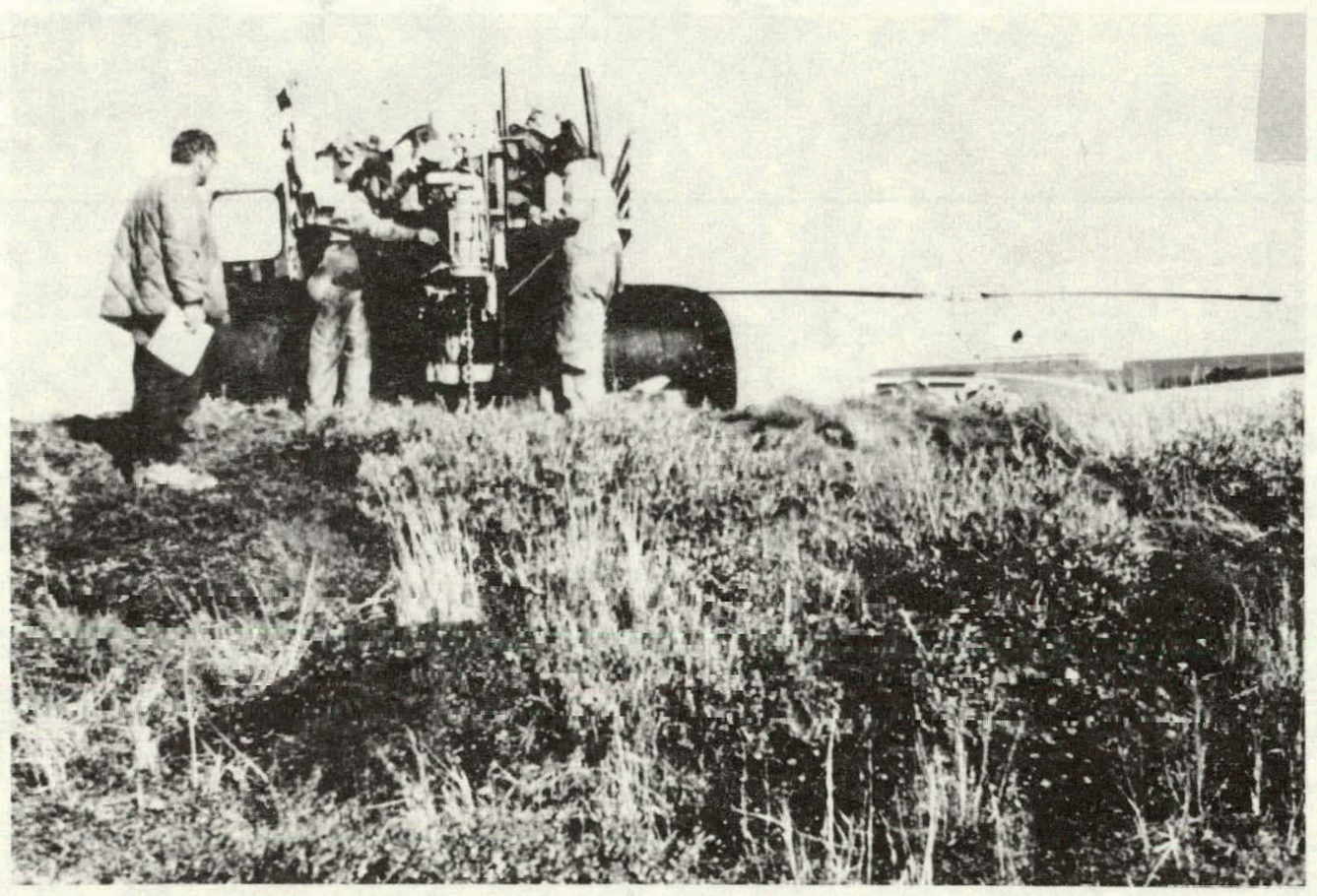

Figure 9. Augur sampling of coal seams by U.S. Geological Surveys crews in the National Petroleum Reserves in Alaska. Coal dug by ground squirrels may be seen in the foreground, and is used to locate outcrops hidden under tund ra from air.

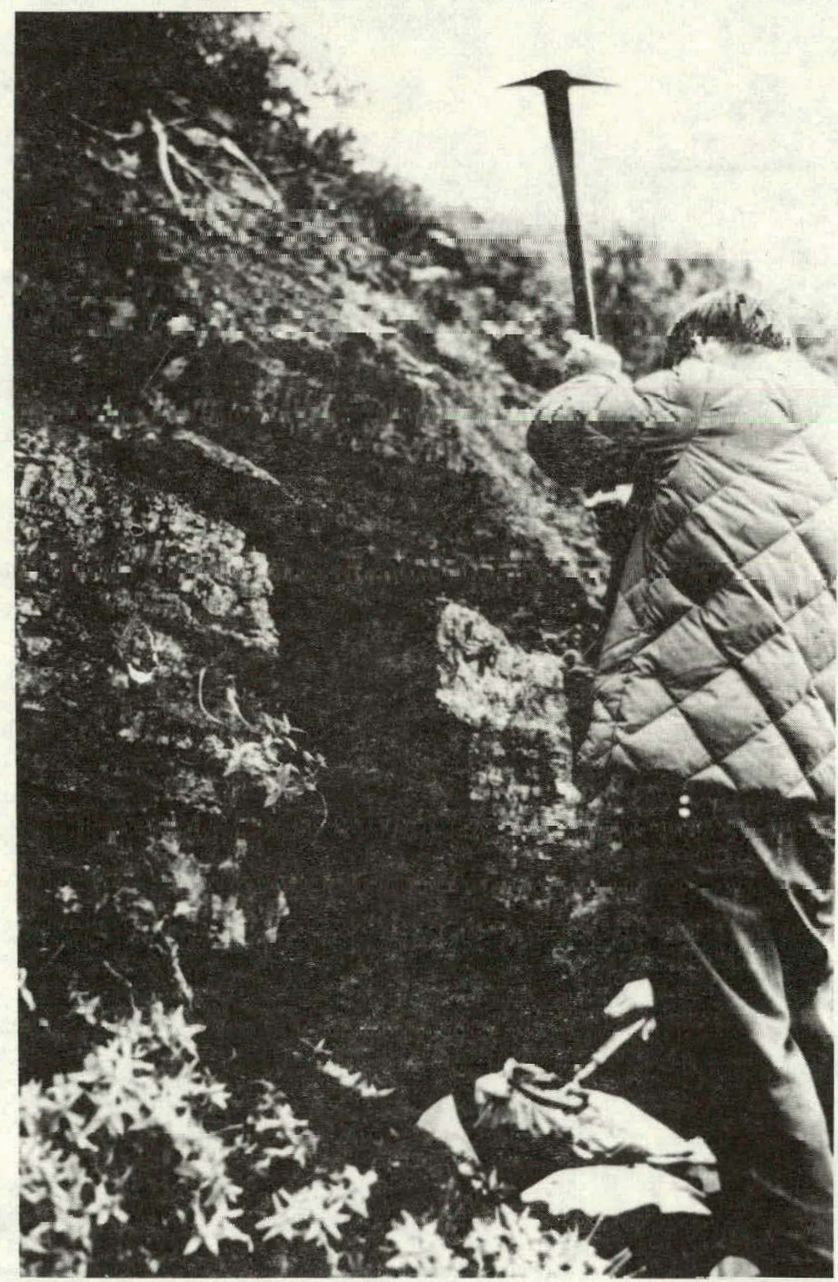

Figure 10. A closeup view of coal outcrop on Kokolik River. 


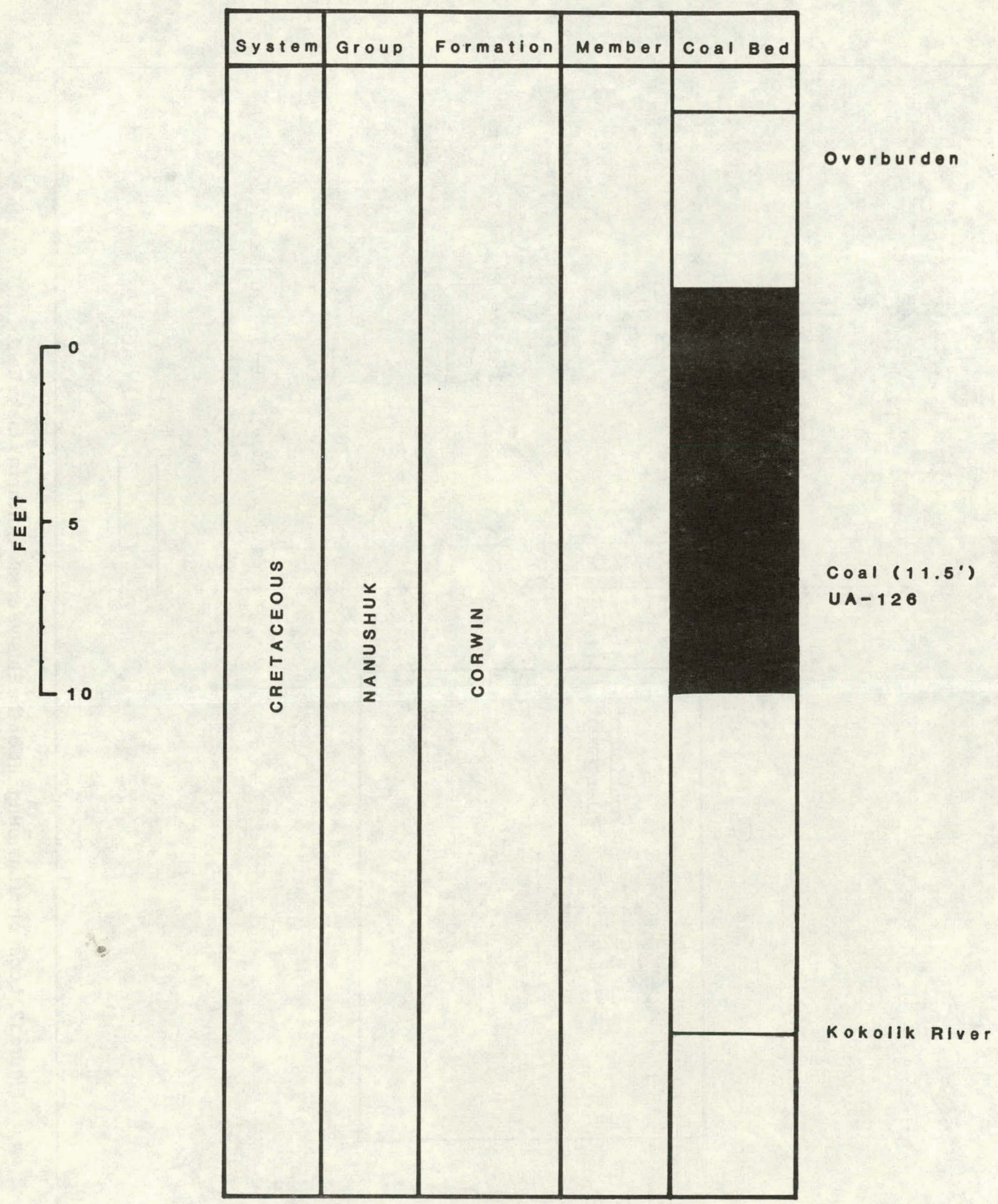

Figure 11. Geological column showing mineable coal bed on the Kokolik River, Northern Alaska field. 


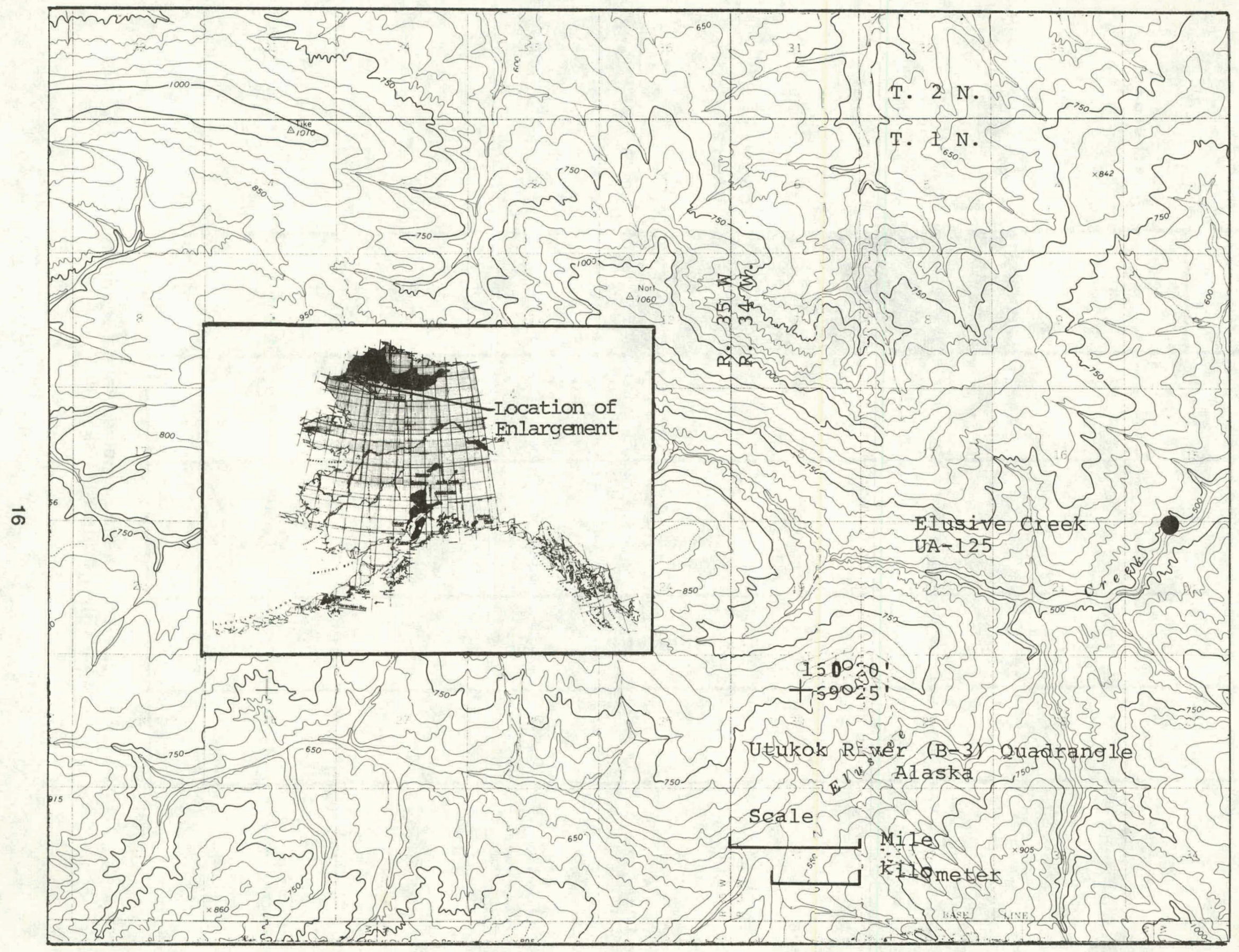

Figure 12. Location of sampling site on the Elusive creek, Norihern Alaska field. 


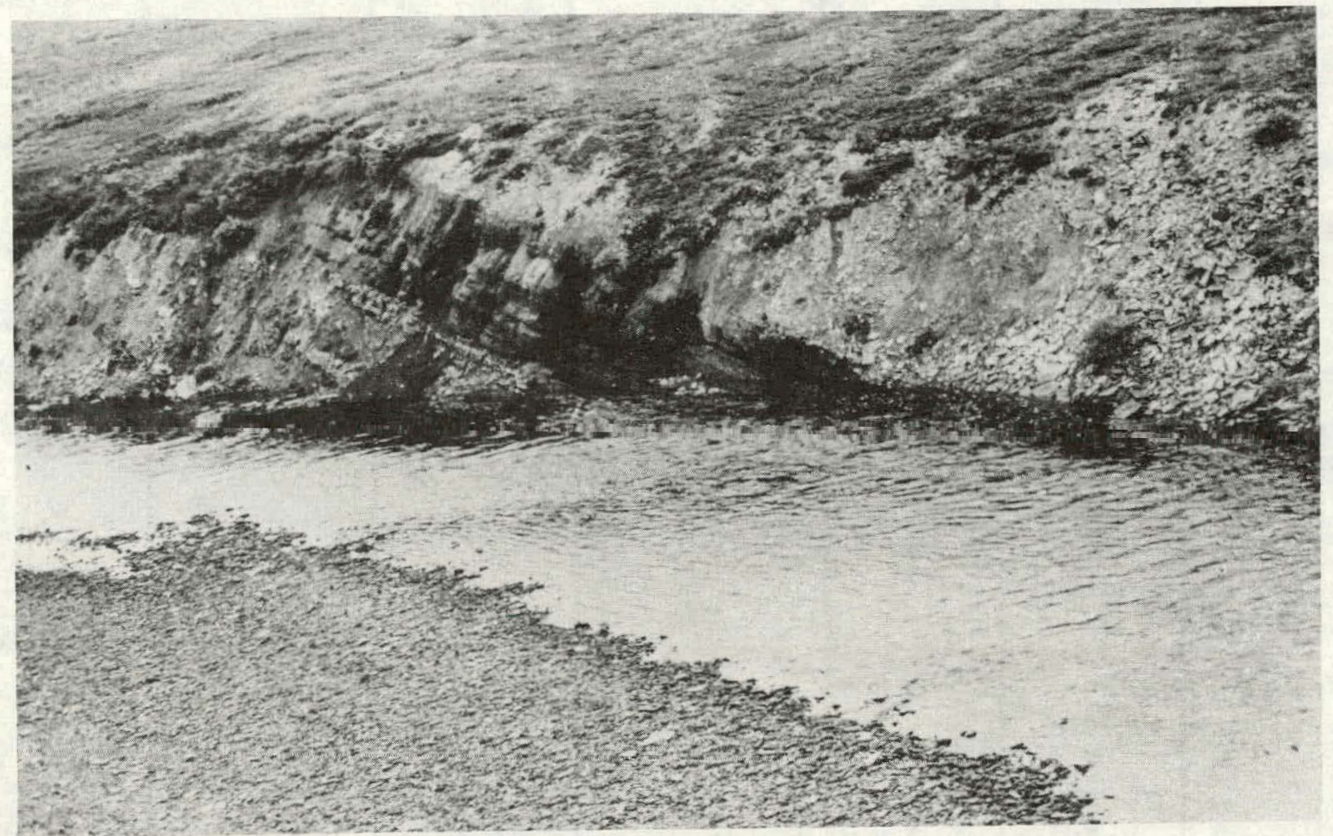

Figure 13. Aerial view of coal outcrop on Elusive creek.

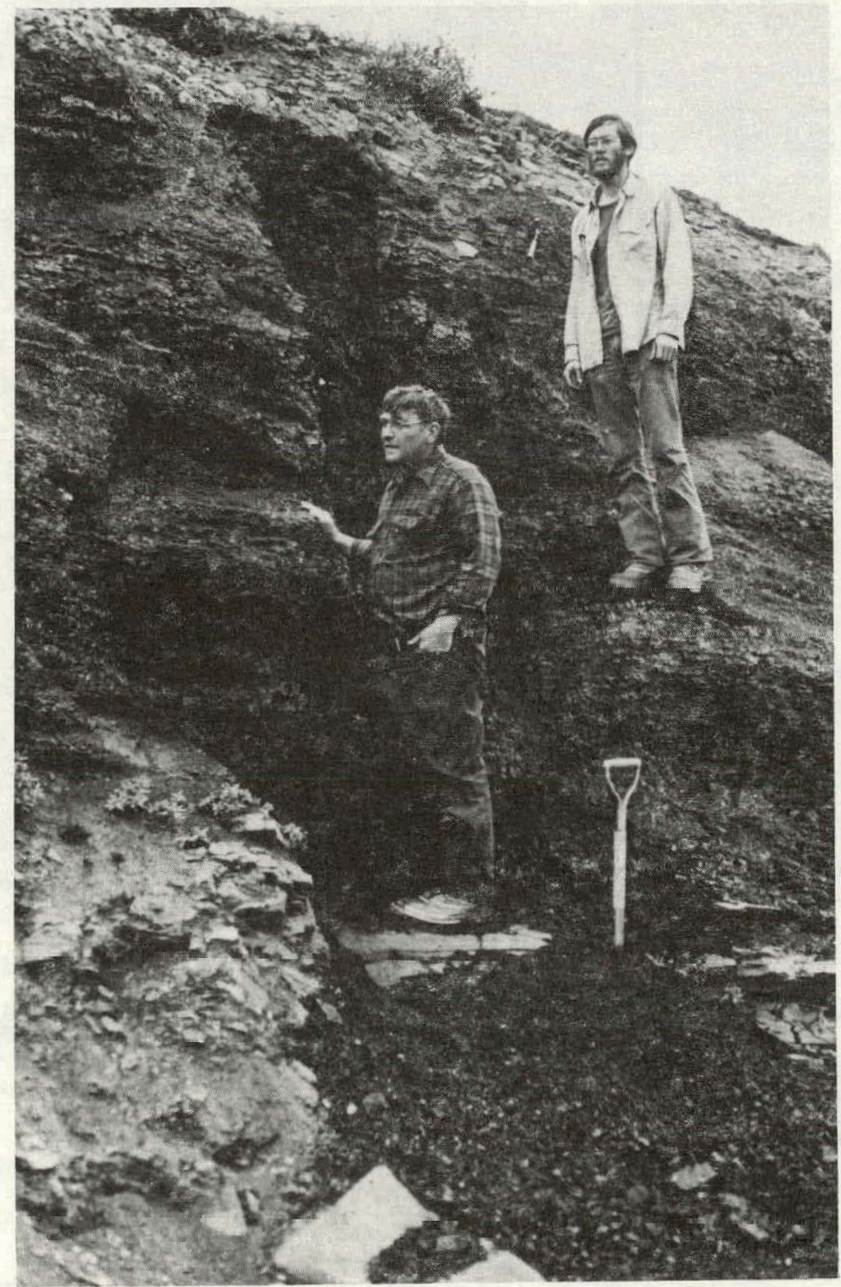

Figure 14. A closeup view of coal outcrop on Elusive Creek. James E. Callahan (left) and Gary Martin, both of U.S.G.S. 


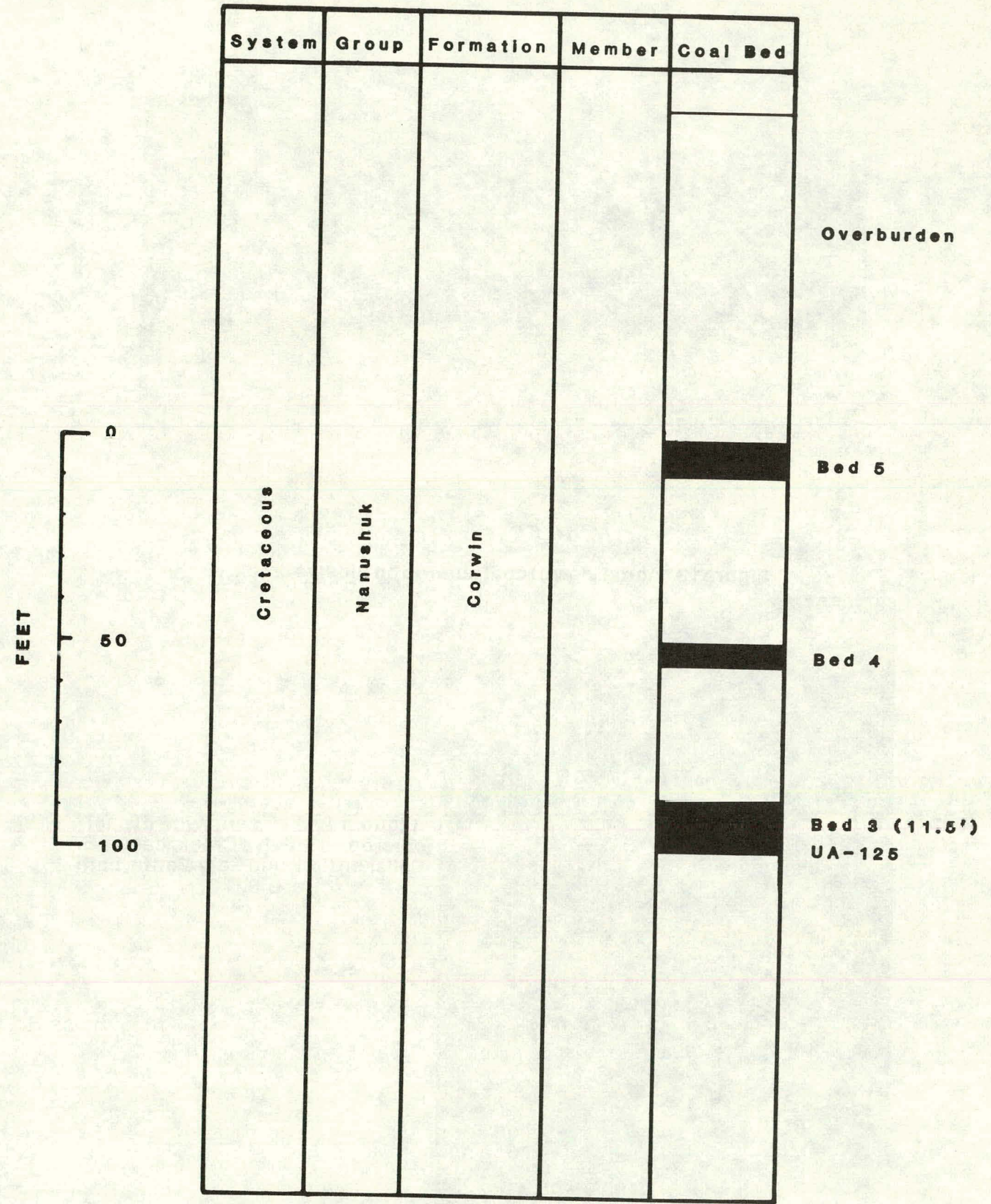

Figure 15. Geological column showing mineable coal beds on Elusive creek, Northern Alaska field. 
This is bed No. 3 of Callahan and Martin (1980). Auger samples of this bed collected by them at a depth of 30 feet or greater had dry, ash-free heating values ranging from 14,381 to $14,777 \mathrm{Btu} / \mathrm{lb}(-\mathrm{P} 7)$. Assuming an equilibrium moisture content of $11.95 \%$, the measured value for the outcrop samples, the ASTM rank of this coal would be between high volatile $\mathrm{B}$ and $\mathrm{C}$.

\section{Kuk - Meade River Fields}

A sample from an uncorrelated coal bed (UA-109) was obtained from an outcrop on the east bank of the Kuk River, about 14 air miles from Wainwright (Figure 16, 17). The bed is 5 feet thick and the bottom of the seam is approximately 4 feet above the river level. The stratigraphic position of this bed has not been definitely established, but according to Barnes (1967a; 1967b), it is believed to be in rocks correlative with the Chandler formation (Figure 2). Coal outcrops have been described and, in fact, some have been mined for a distance of 10 miles along the Kuk River. There are two uncorrelated coal beds exposed at the outcrops with approximately 10 feet of coal. The individual beds range in thickness from two to 6 feet and 10 to 50 feet overburden outcrop along the Kuk River (Tonges and Jolley, 1947). Barnes (1967a; 1967b) estimates indicated resources for the Kuk River (Wainwright) district at 62.6 million tons and inferred resources at 1,395 million tons.

\section{Meade River Field}

A sample of the No. 2 coal bed (UA-110) was collected in the Meade River area. Coal outcrops along the west bank of the Meade River near the village of Atkasook (Figure 18, 19). Coal has been mined during the 1940's and early 1950's in an open trench and underground for shipment to Barrow. The U.S. Bureau of Mines has done extensive drilling in this region and delineated the coal bearing areas for mining purposes (Sanford and Pierce, 1946). Four coal seams have been identified in this locality. The No. 1 bed is 34 inches thick, the No. 2 bed is five to 6 feet and the No. 3 and No. 4 beds are approximately 12 inches and the beds are separated by 1 to 2 feet of clay.

\section{Northcentral Alaska Field}

A sample of Uncorrelated coal bed (UA-114) was collected from an outcrop in the Sagwon bluff area. Rocks in the Sagavanirktok quadrangle (Ferrians, 1971) are part of a thick sequence of submarine volcanic and nonmarine carbonate rocks of Mississippian through Tertiary age. Coal has been reported in Ignek formation of Cretaceous age and Sagavanirktok formation of Tertiary age. The sampled coal outcrop (UA-114) was from the bluffs on the Sagavanirktok River (Keller, et al., 1961) adjacent to the Trans Alaska Pipeline (Figure 20). The sampling location has not been mapped in detail and the age of the formation that the coal occurs has not been determined (Cretaceous to Tertiary).

\section{NORTHWEST ALASKA COAL FIELDS}

\section{Chicago Creek}

Coal was first discovered near Chicago Creek in 1902 by gold prospectors. Mining was done only during winter months. Henshaw (1910) presented a detailed description of the mine workings after his visit to the mine in 1908. He also sampled the coal at nine points. The coal bed measured by Henshaw was 88 feet thick. Mining was done by means of an inclined shaft that followed the outcrop. The Chicago Creek coal has proved an important factor in the development of the Candle Creek placers.

During the 1980 visit by the author, timbers and other evidence of past mining activity 


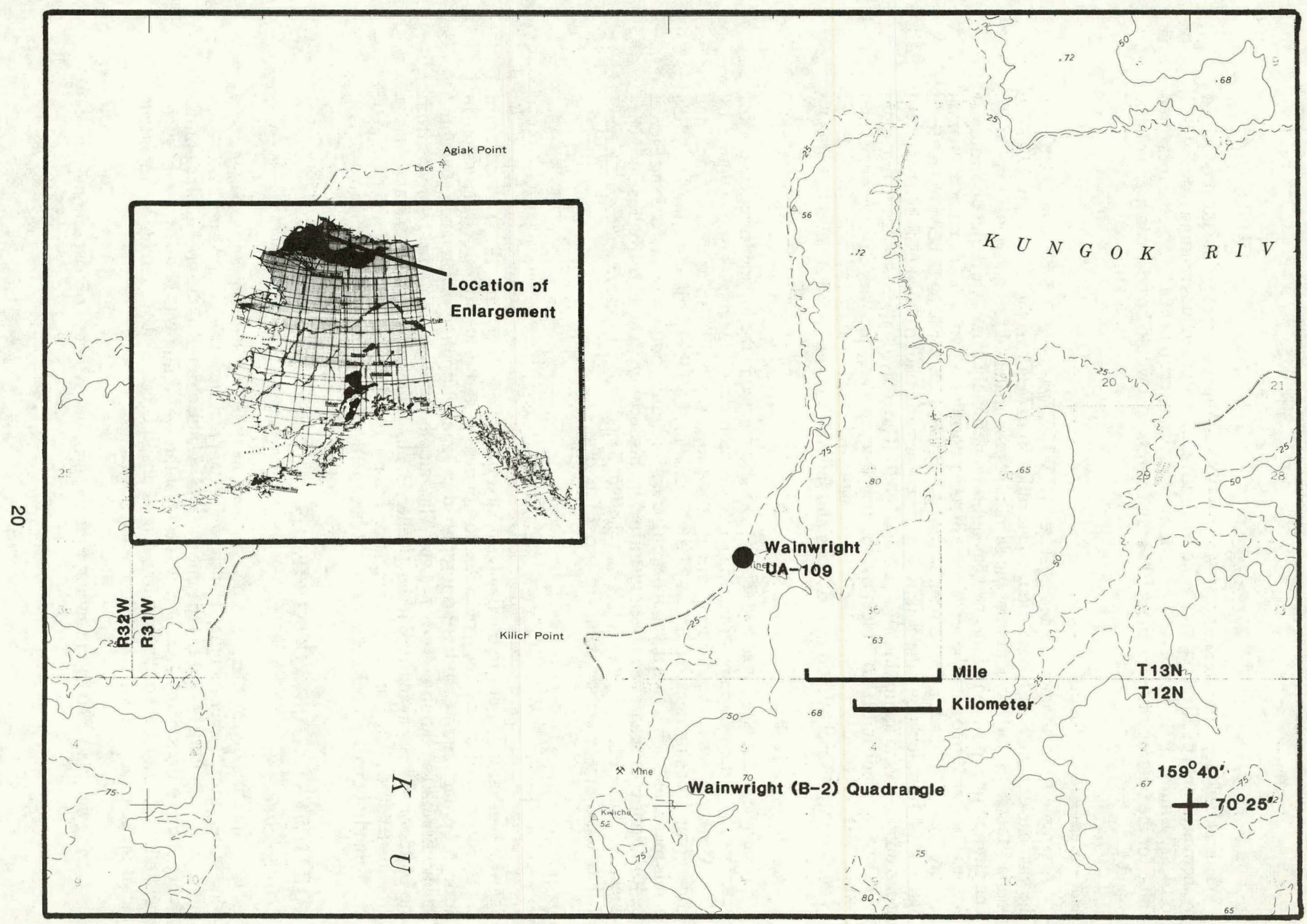

Figure 16. Sampling location on the banks of Kuk River, Northern Alaska field. 


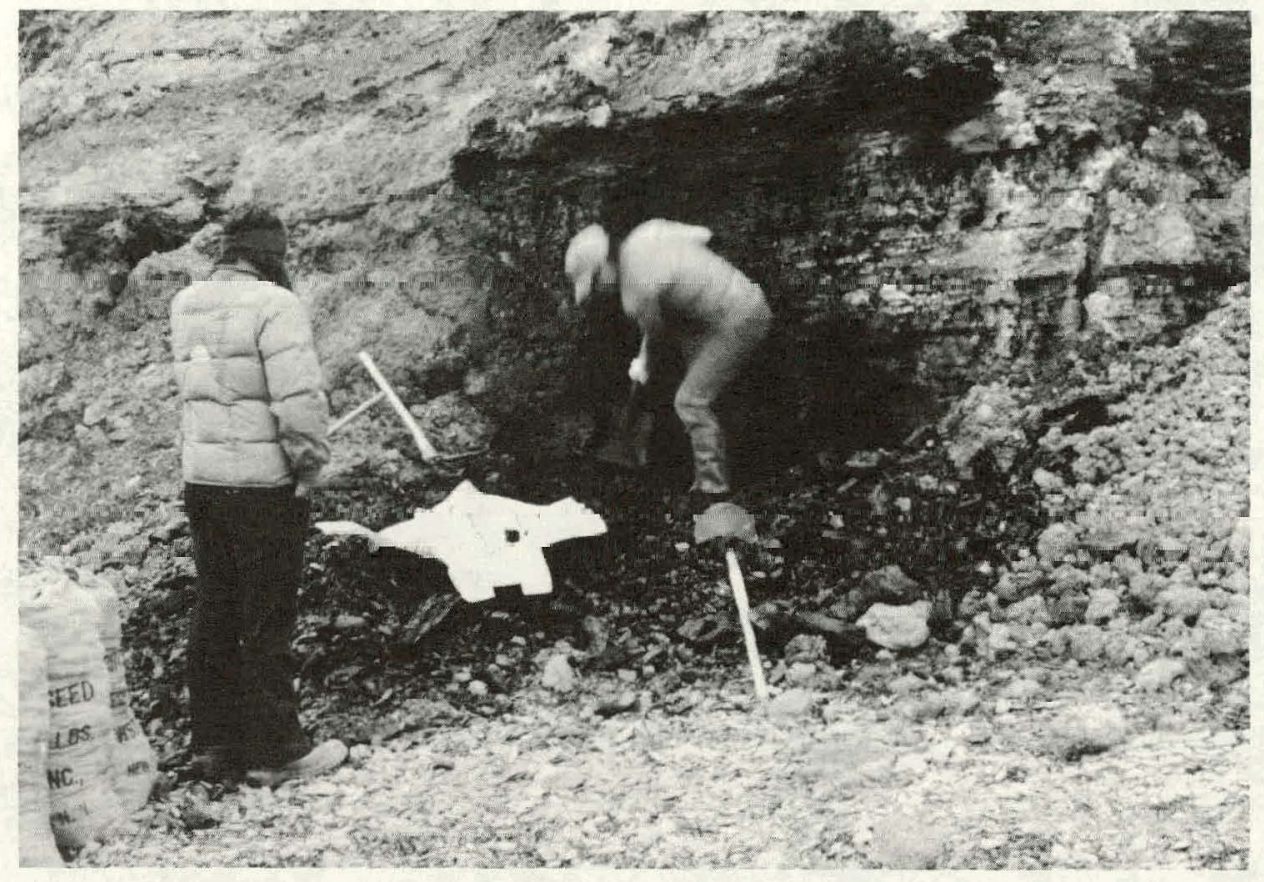

Figure 17. A closeup view of coal outcrop on Kuk River.

was evident. However, he was unable to locate the outcrop or the 88 feet thick coal seam or the shaft used for the past mining activity. Timber, found on the creek level, could be covering the shaft, but the evidence was not conclusive. However, a three foot coal seam was uncovered by digging with a back hoe (Figure 21) and a sample of this seam was collected for the study (UA-138). In 1982, the State of Alaska funded an exploration program carried out by initially by Stevens Exploration Management Corporation (Manning and Stevens, 1982) and completed by Hawley Resource Group Inc. (Retherford, Hinderman and Hawley, 1986). Based on drilling completed thus far, they estimate the potentially mineable identified coal resource at Chicago Creek at 4.7 million tons. Figure 22 is a projection of the steeply dipping coal seams.

\section{Unalakleet}

A sample of uncorrelated coal bed (UA-151) was obtained from an outcrop 8 miles south of Unalakleet on the shore of Norton Sound. This outcrop is on the beach bluff in the vicinity of past mining activity (Figure 23). The age of this outcrop was not investigated. Patton (1973) reported that a written communication from E.B. Leopold in 1966 reported the following: a sample of coal collected from a badly slumped beach bluff 10 miles south of Unalakleet on the shore of Norton Sound contained an abundant pollen flora of Early Tertiary age.

\section{INTERIOR ALASKA COAL FIELDS}

\section{Nenana}

The Nenana coal field is located about 110 miles south of Fairbanks on the Parks Highway 


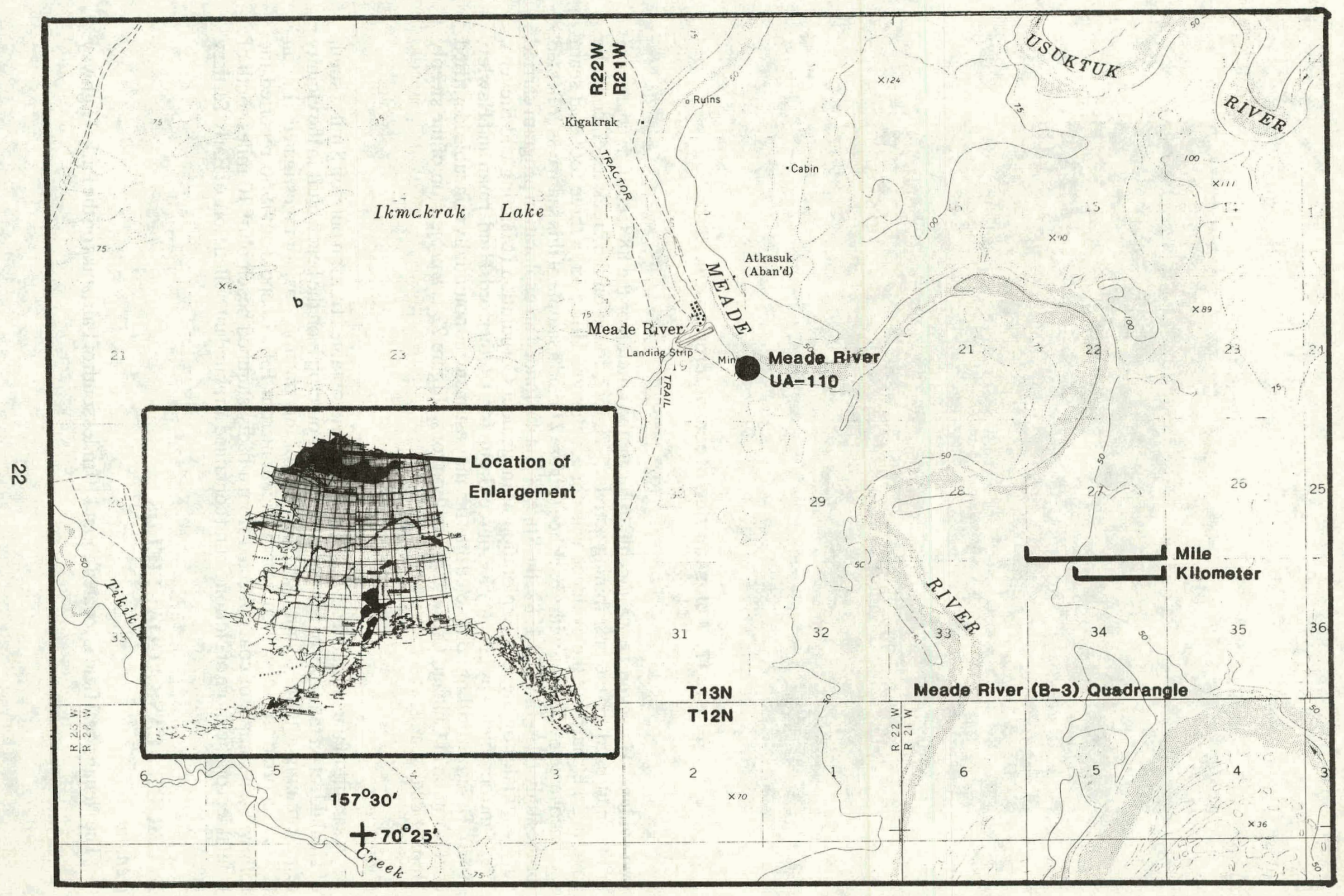

Figure 18. Sampling location of Meade River, Northern Alaska field. 


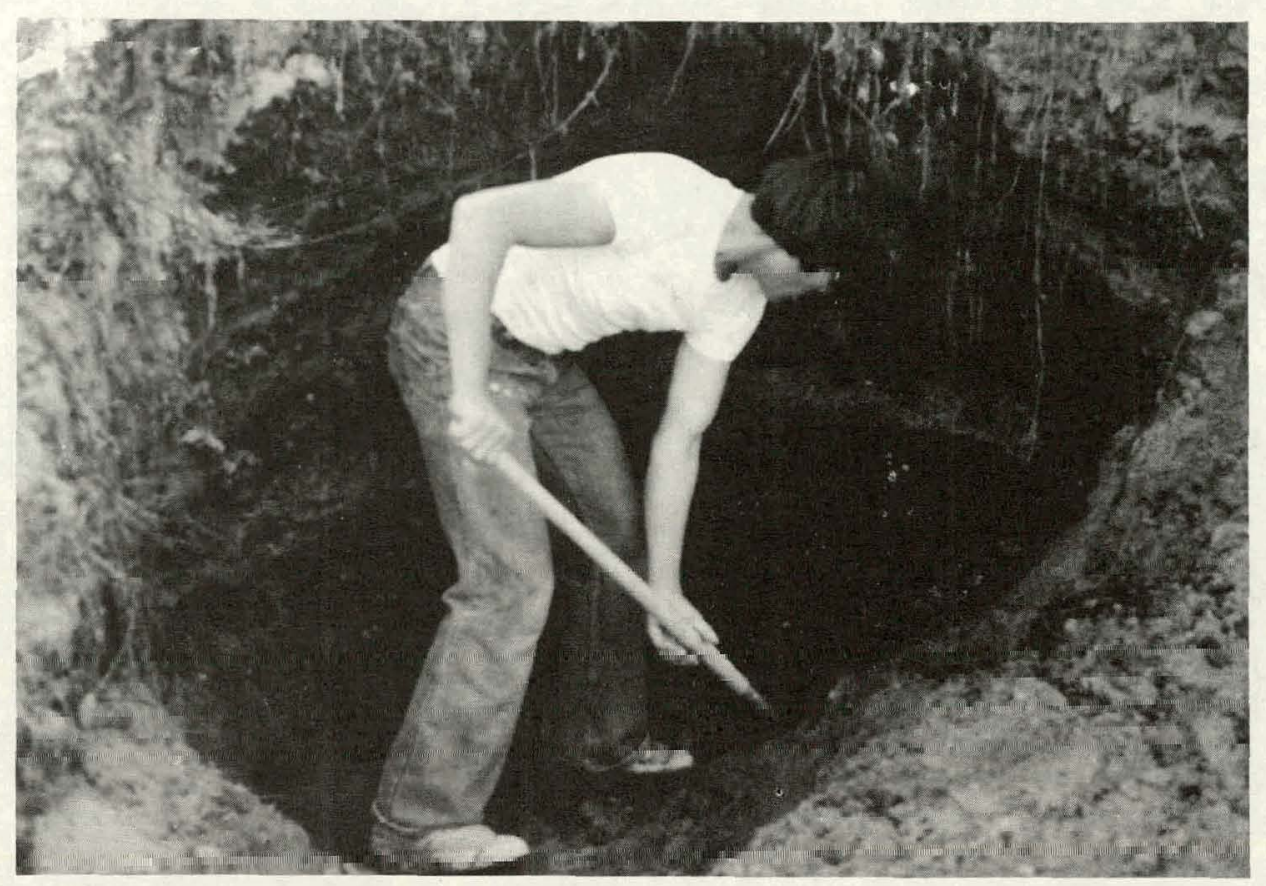

Figure 19. A closeup view of coal subcrop on Meade River.

at Healy. The field extends 80 miles in an east-west direction and is one to thirty miles wide (Wahrhaftig et al., 1951; Wahrhaftig, 1951; Wahrhaftig and Birmon, 1954). The coal bearing formation consists of sandstones, siltstones, claystone, shale and numerous thick coal beds, and is divided into five formations by Wahrhaftig et al. (1969). Thirteen samples were collected from the Nenana field. The location of twelve of these samples is shown in Figure 24.

Barnes (1967a) estimates the original resources of the Nenana field at seven billion tons, of which three billion tons are on Lignite Creek. Accurate estimates of recoverable reserves for individual seams are not available. Total proven reserves in the Lower Lignite Creek area are 80 million tons with a resource potential of 250 million tons (Denton, 1980).

Figure 25 is a generalized geological section showing coal beds exposed at Suntrana and Healy Creeks. No. 2 Seam (UA-105) was sampled in this sequence. Figure 26 is a general view of coal exposed at the headwaters of Upper Lignite Creek. UA-141 was sampled from this location.

Figure 27 is a geological section of seams exposed on Upper Lignite Creek. Moose seam (UA-103) of this section has been correlated to F scam in Гigure above. Caribou (UA-104) and Bear seams, however, have not been correlated to seams in other parts of the coal field.

The Lower Lignite Creek Basin, which extends three miles in an east-west direction and is three miles wide, is the site of the current mining of Usibelli Coal Mine. Mineable coal 


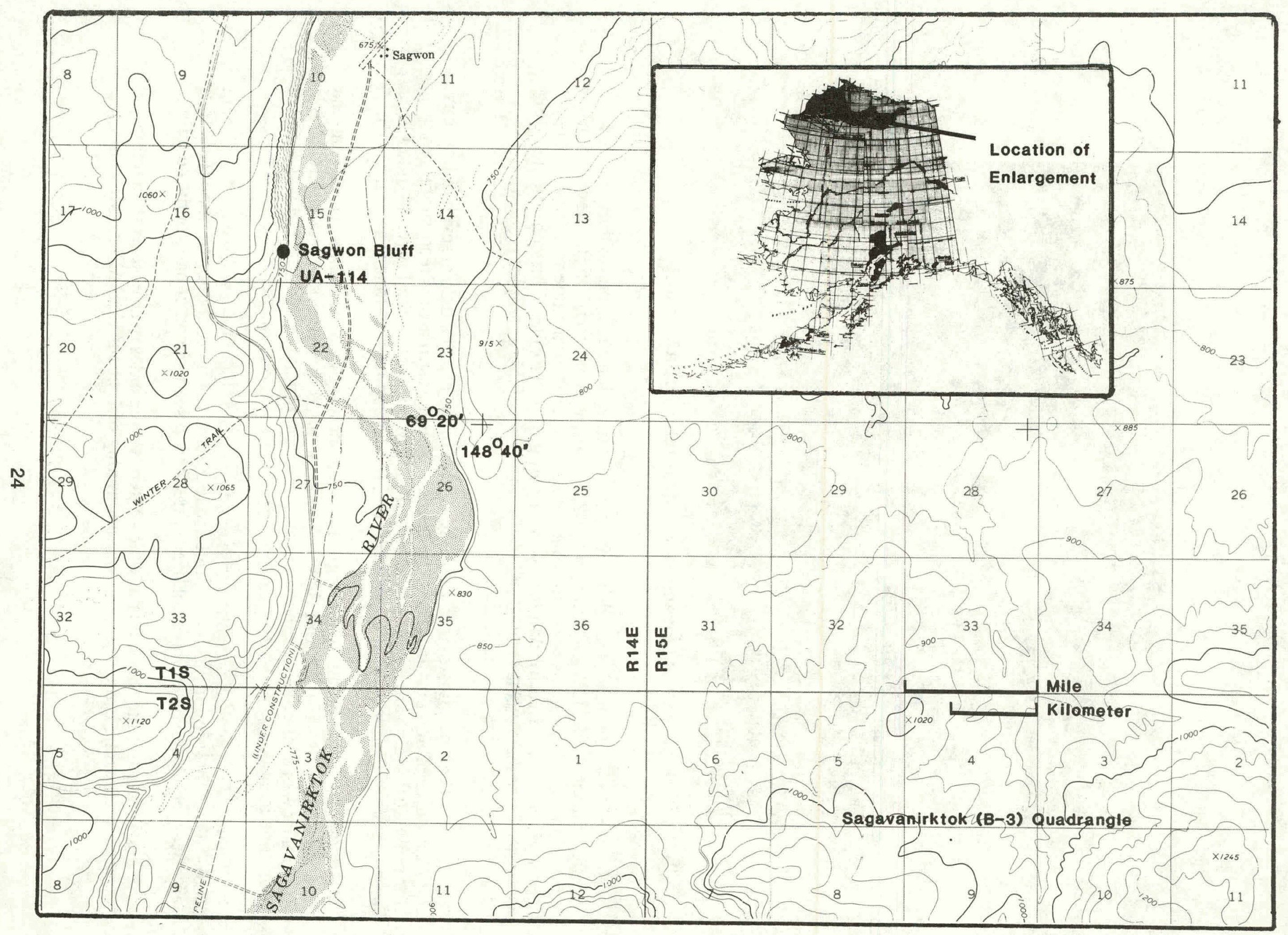

Figure 20. Sampling location at Sag won Bluff, Northern Alaska field. 


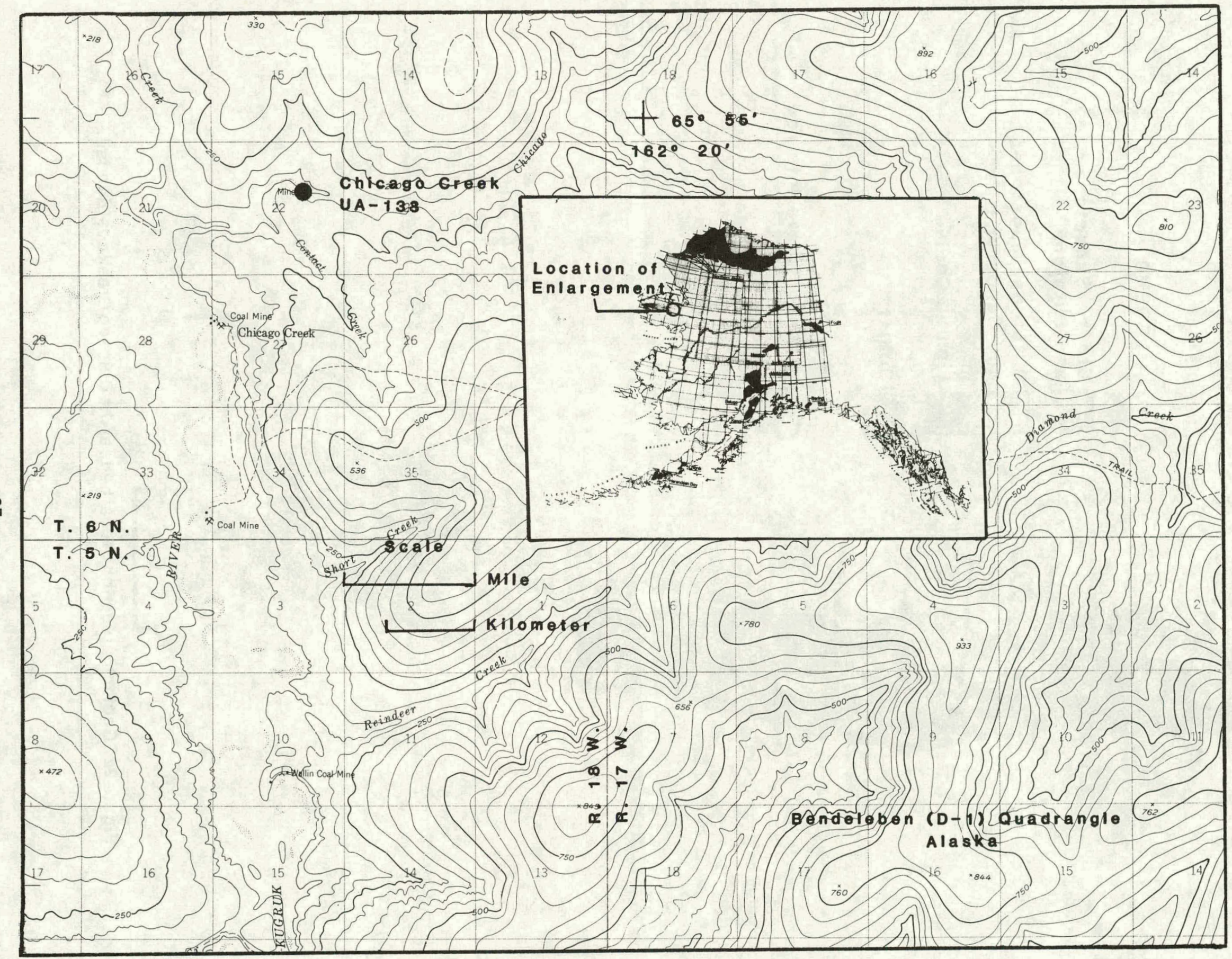

Figure 21. Location of sampling site at the Chicago Creek coal deposit. 


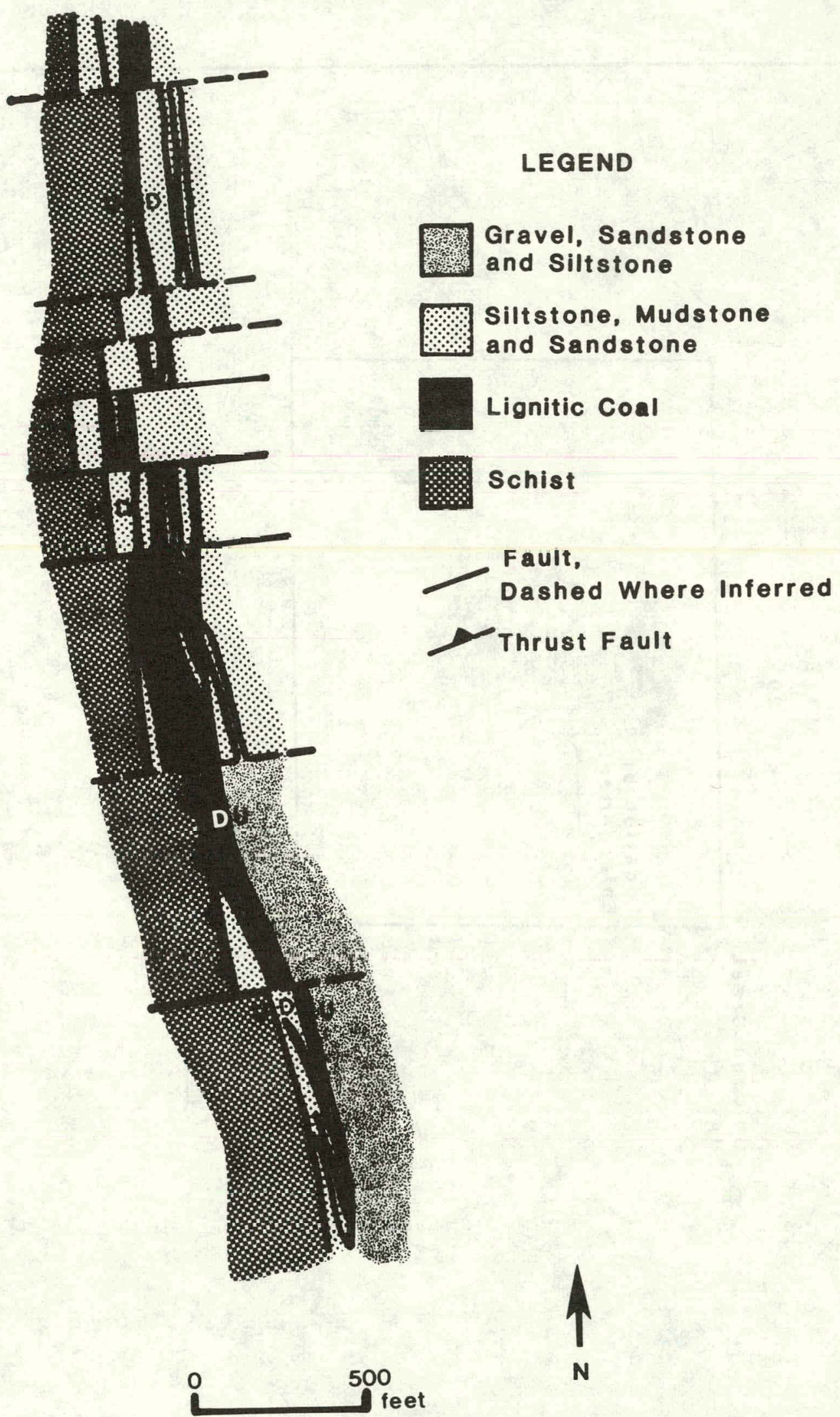

Figure 22. Geological section of coal beds at the Chicago Creek coal deposit. 


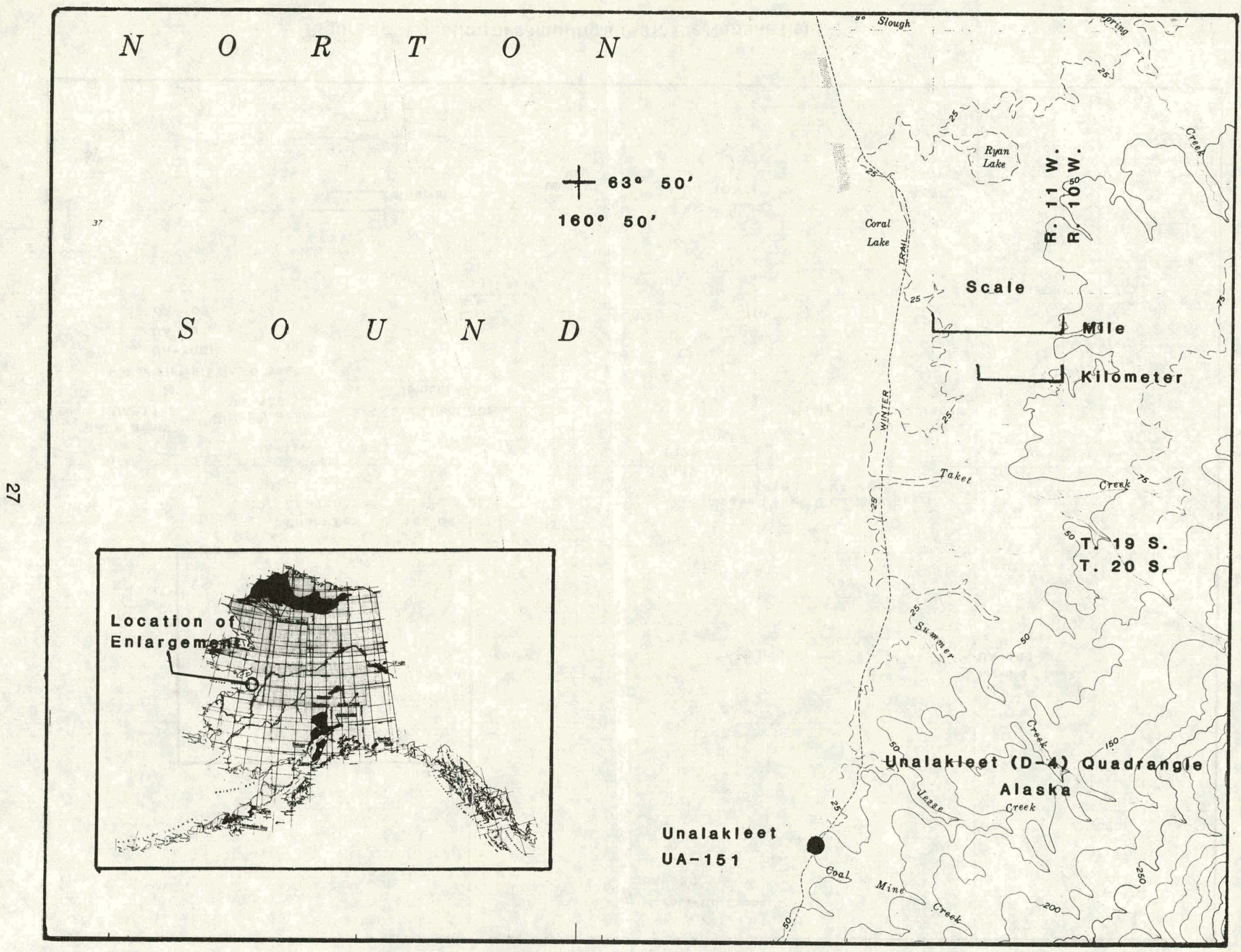

Figure 23. Location of sampling site at Unalakleet coal occurrence. 


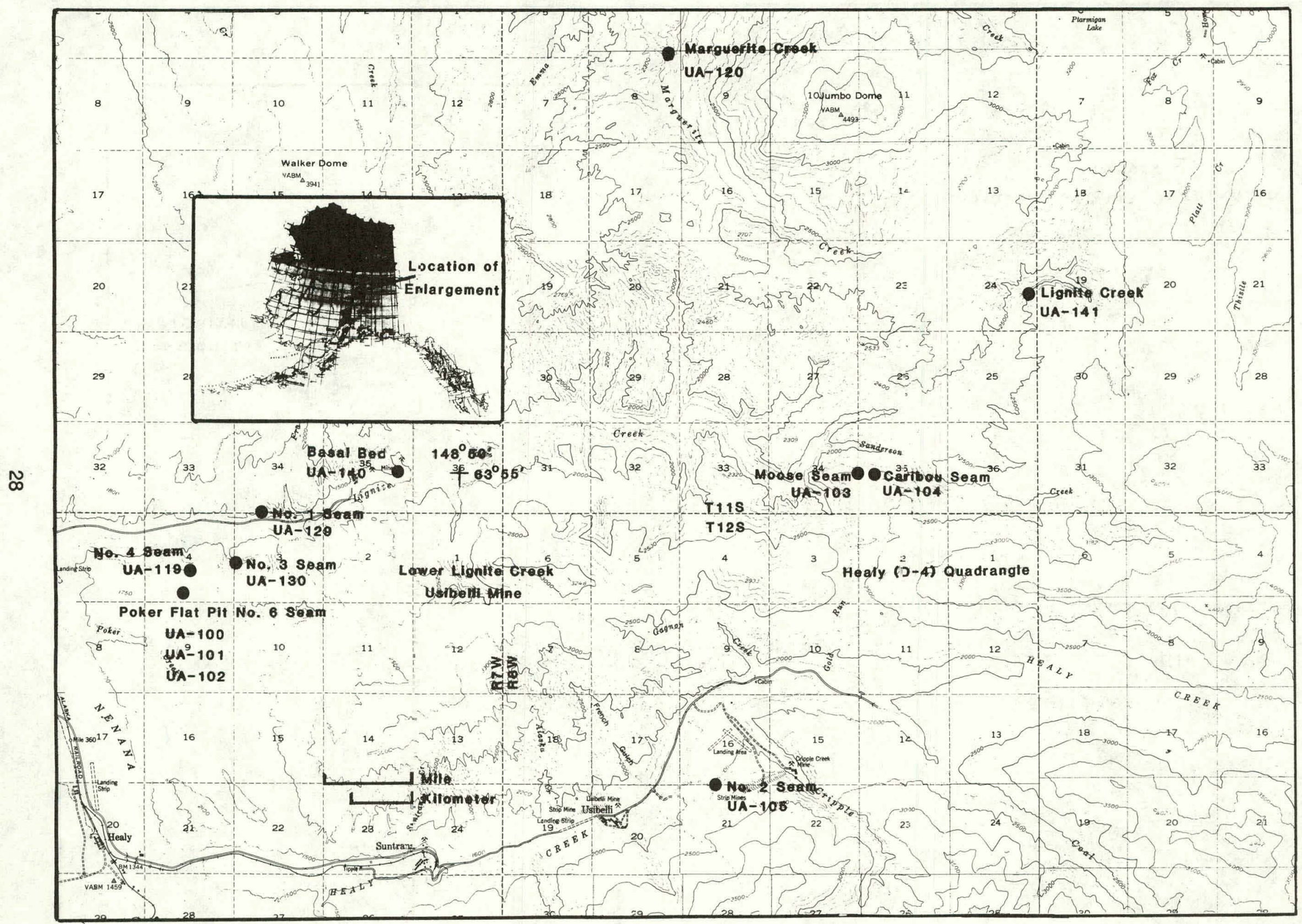

Figure 24. Location of sampling sites in the Nenana field. 


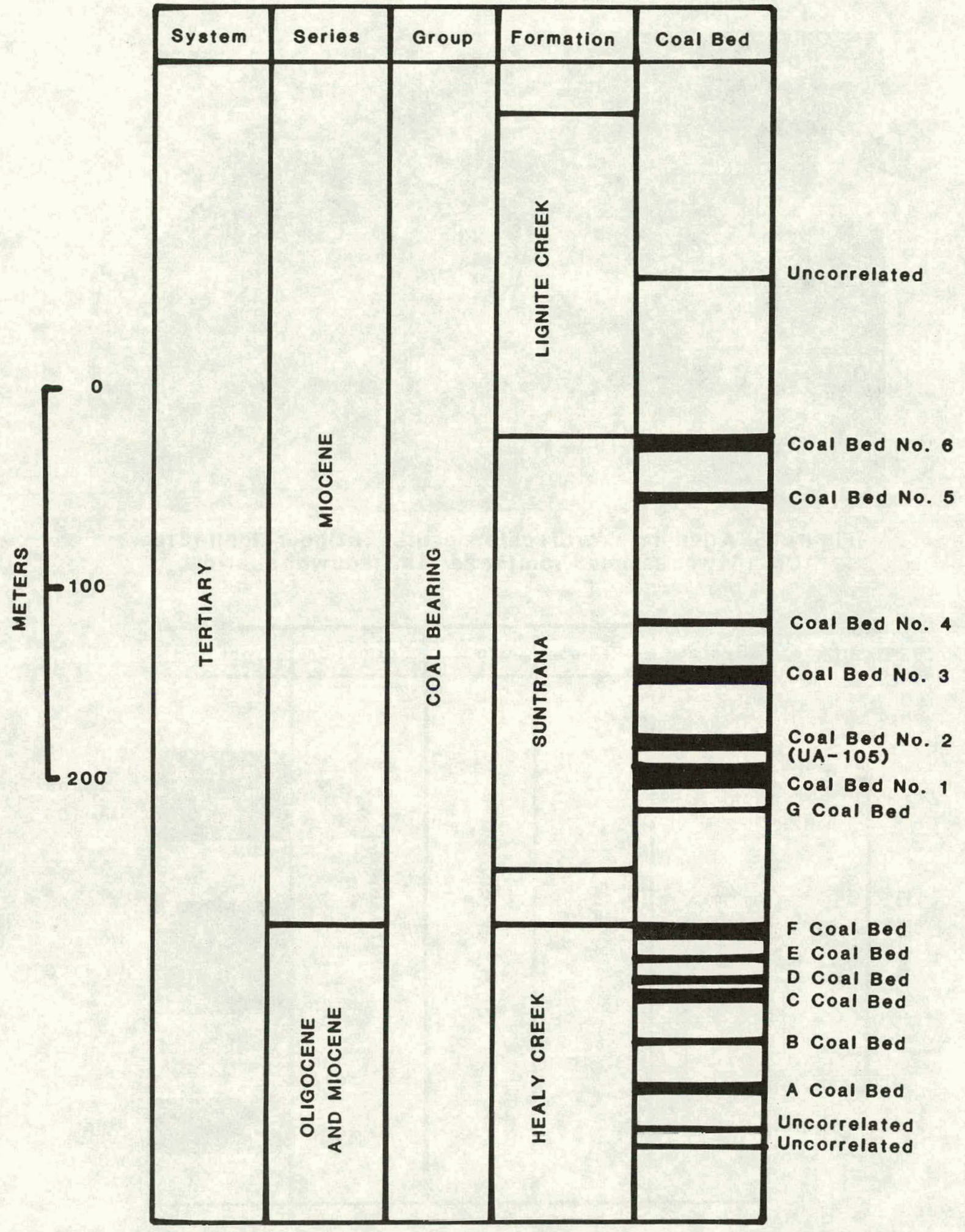

Figure 25. Geological column showing mineable coal beds on Suntrana and Healy Creeks, Nenana coal field. 


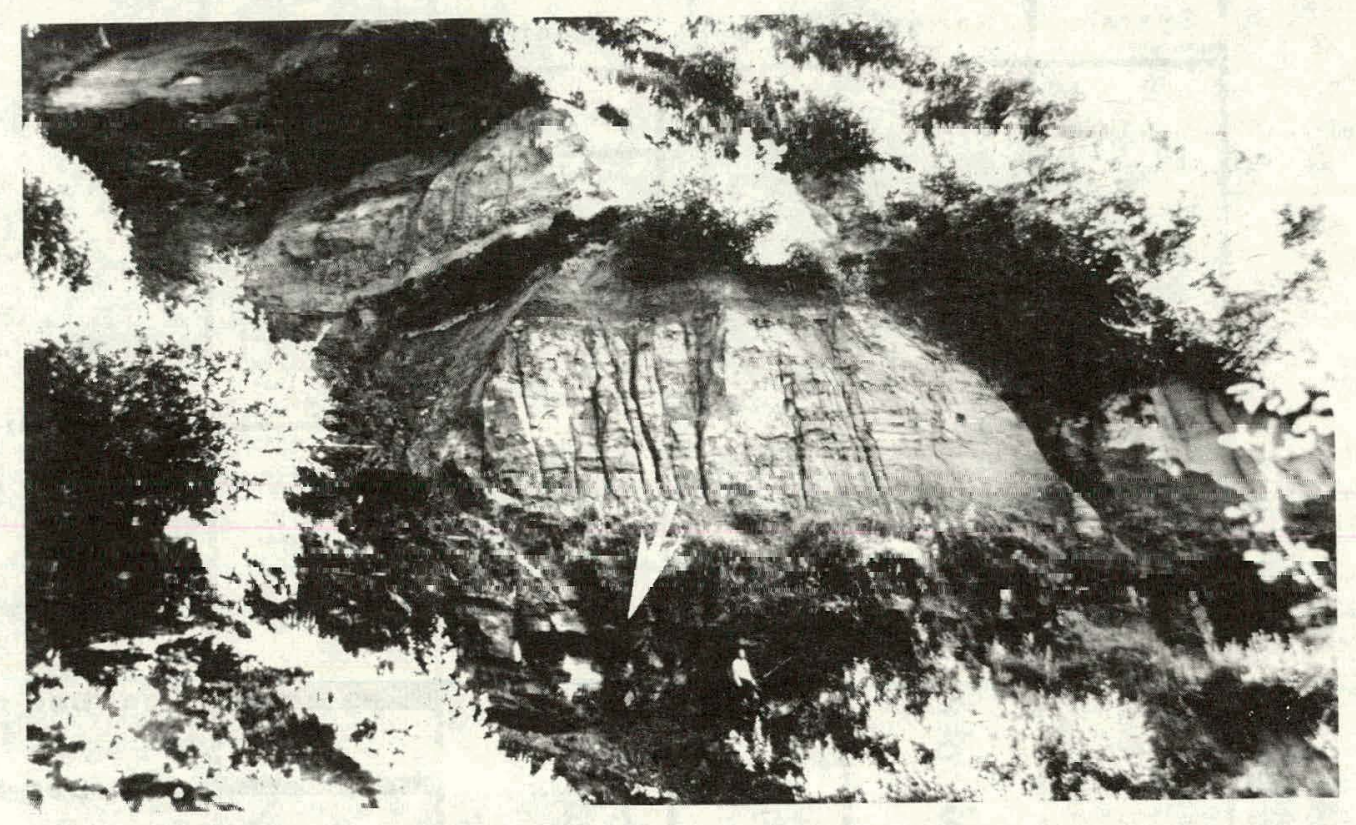

Figure 26. A general view of coal exposures on Upper Lignite Creek. UA- 141 was sampled from the seam marked with an arrow.

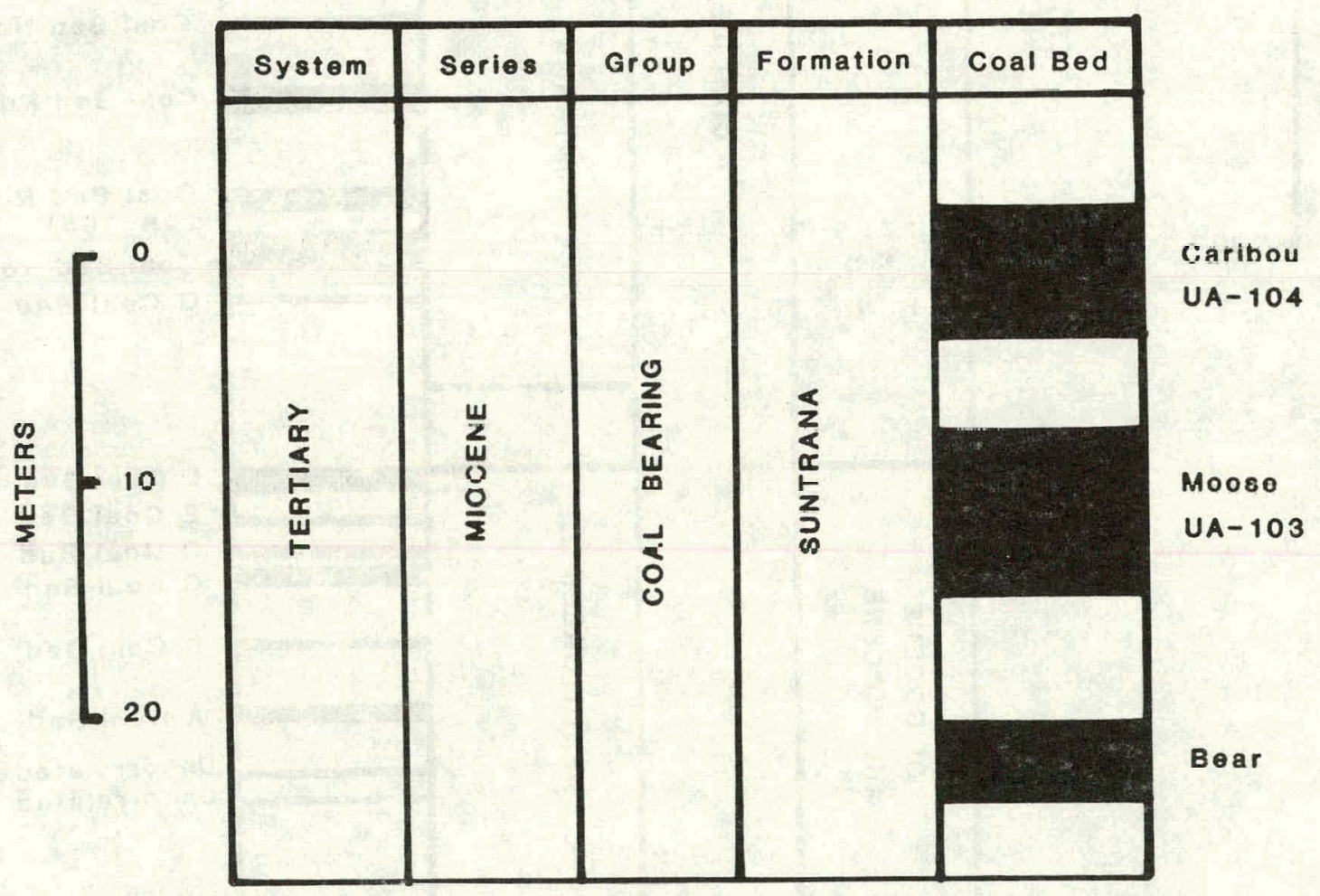

Figure 27. Geological column showing coal beds on the Upper Lignite Creek, Nenana coal field. 
beds are restricted to Suntrana formation. The bulk of the coal resources are contained in seams six (21 feet) (UA-100, 101, 102), four (21 feet) (UA-119, Figure 28), and three (17 feet) (UA-130). No. 2. seam (UA-129) is of poor quality and No. 1 seam has clay and bone parting (Denton, 1980).

Figure 29 is a generalized geological column showing coal beds exposed at Lower Lignite Creek Poker Flat pit of the Usibelli Coal Mine. The south side of Lower Lignite Creek is the location of current mining activity. Sample UA-140 was collected from the north side of Lignite Creek from what is designated by Wahrhaftig (1951) as the Basal bed. It is stratigraphically below No. 1 seam and has not been correlated with other seams in the field. The Basal bed was formerly mined by the Arctic Coal Company. At the sampling location, the seam was 60 feet thick. Wahrhaftig (1951) estimates reserves for the bed at the sampling site to be 0.25 million tons. The full extent of the Basal bed is not known. Sample UA141 was collected from Upper Lignite Creek (Figure 30) from a seam occurring in the Suntrana formation, correlation to other seams on Lower Lignite Creek has not been established. Sample UA-120 is from a 30.5 feet thick seam outcropping on a bluff (Figure 31) along Marguerite Creek west of Jumbo Dome. Although this seam occurs in the Suntrana formation, correlation to other seams along Lignite Creek has not been established. Sample No. UA-132 was collected from the Yanert mine (Figure 32). This seam has not been correlated with other seams in the Nenana field.

\section{Jarvis Creek}

The Jarvis Creek coal field is located about 125 miles southeast of Fairbanks on the north side of the Alaska Range (Figure 33). The coal field is 16 square miles in area and the site

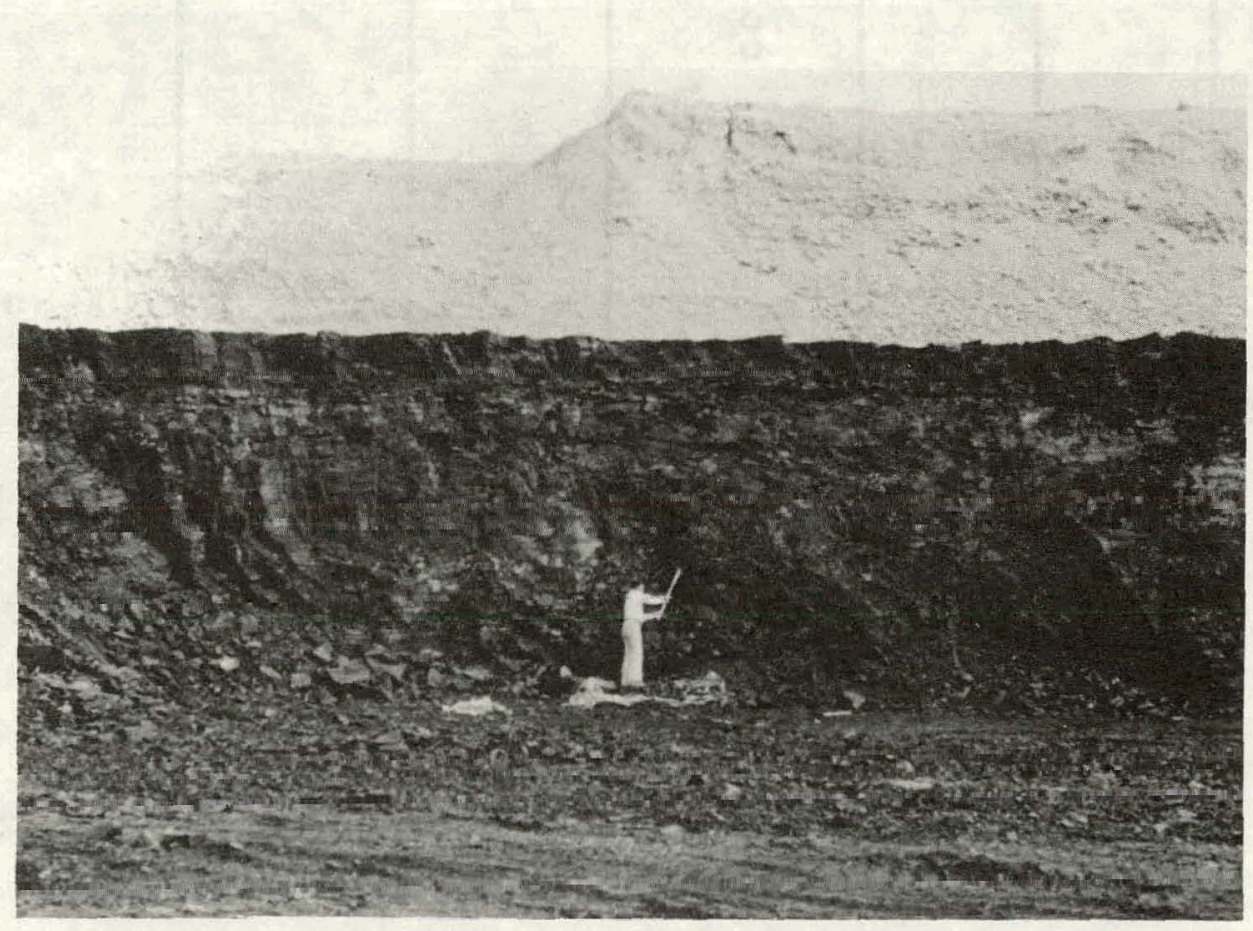

Figure 28. A mine face of No. 4 Seam. 


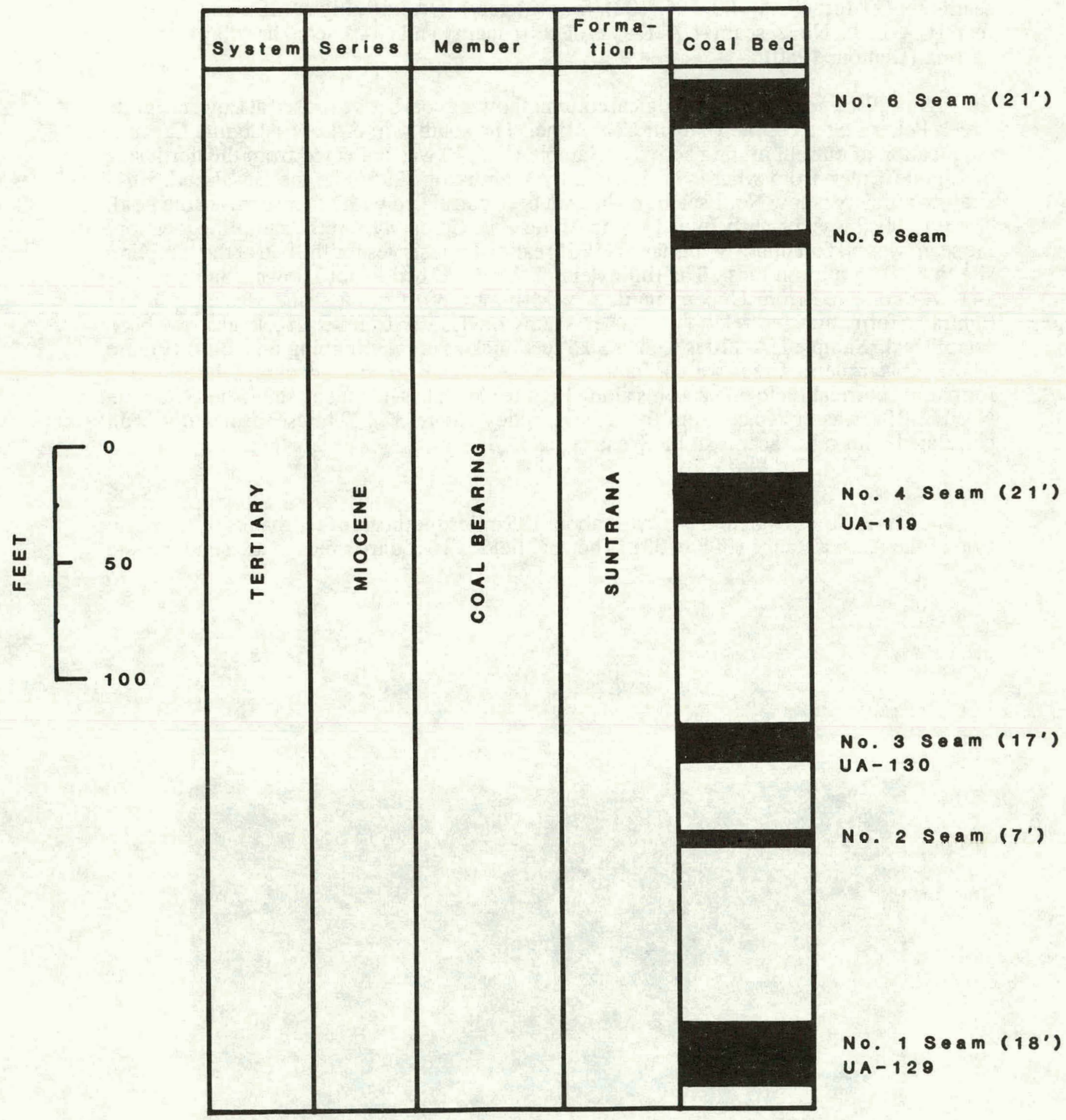

Figure 29. Geological column showing mineable coal beds at the Poker Flat Pit, Usibelli coal mine, Nenana coal field. 


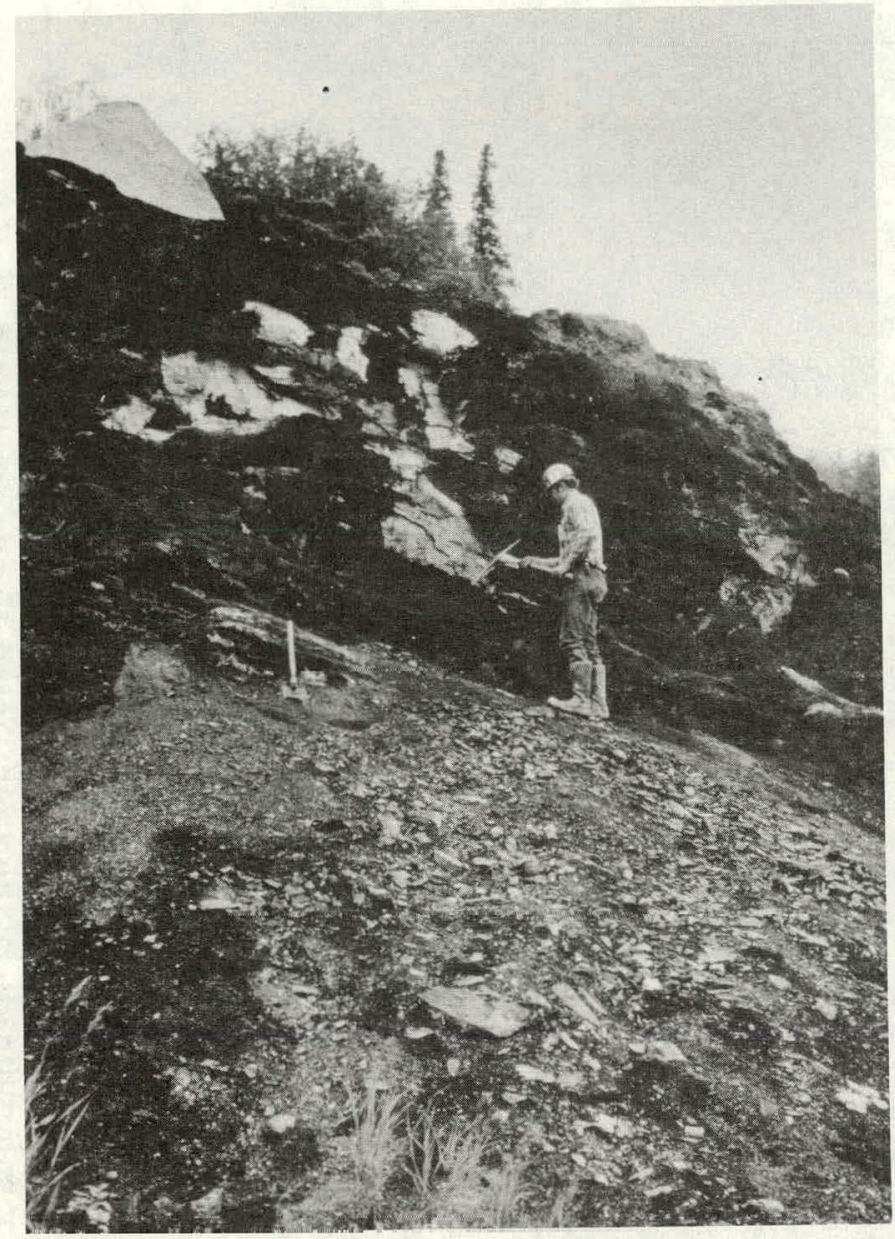

FIgure 30. Outcrop of Basal Bed on LIgnite Creek.
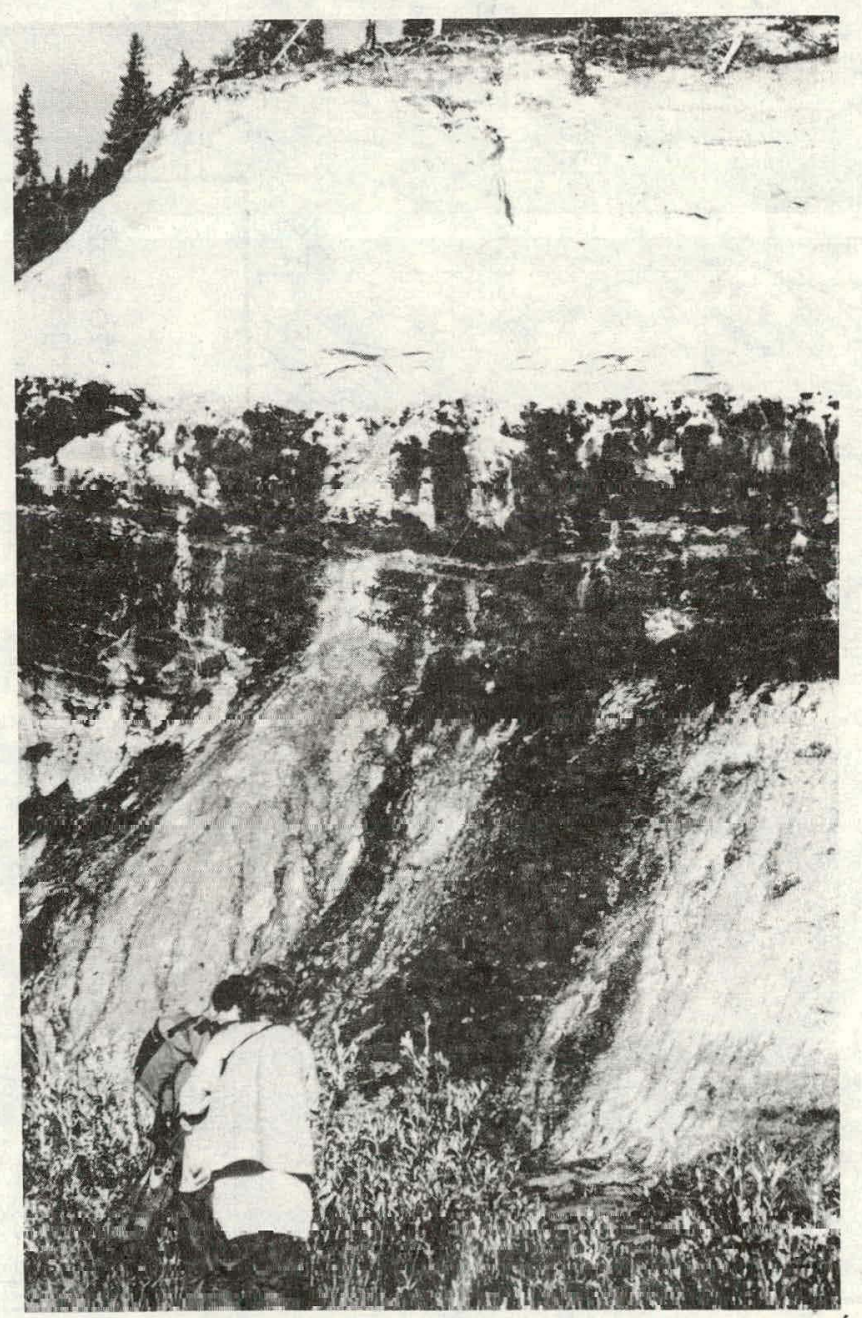


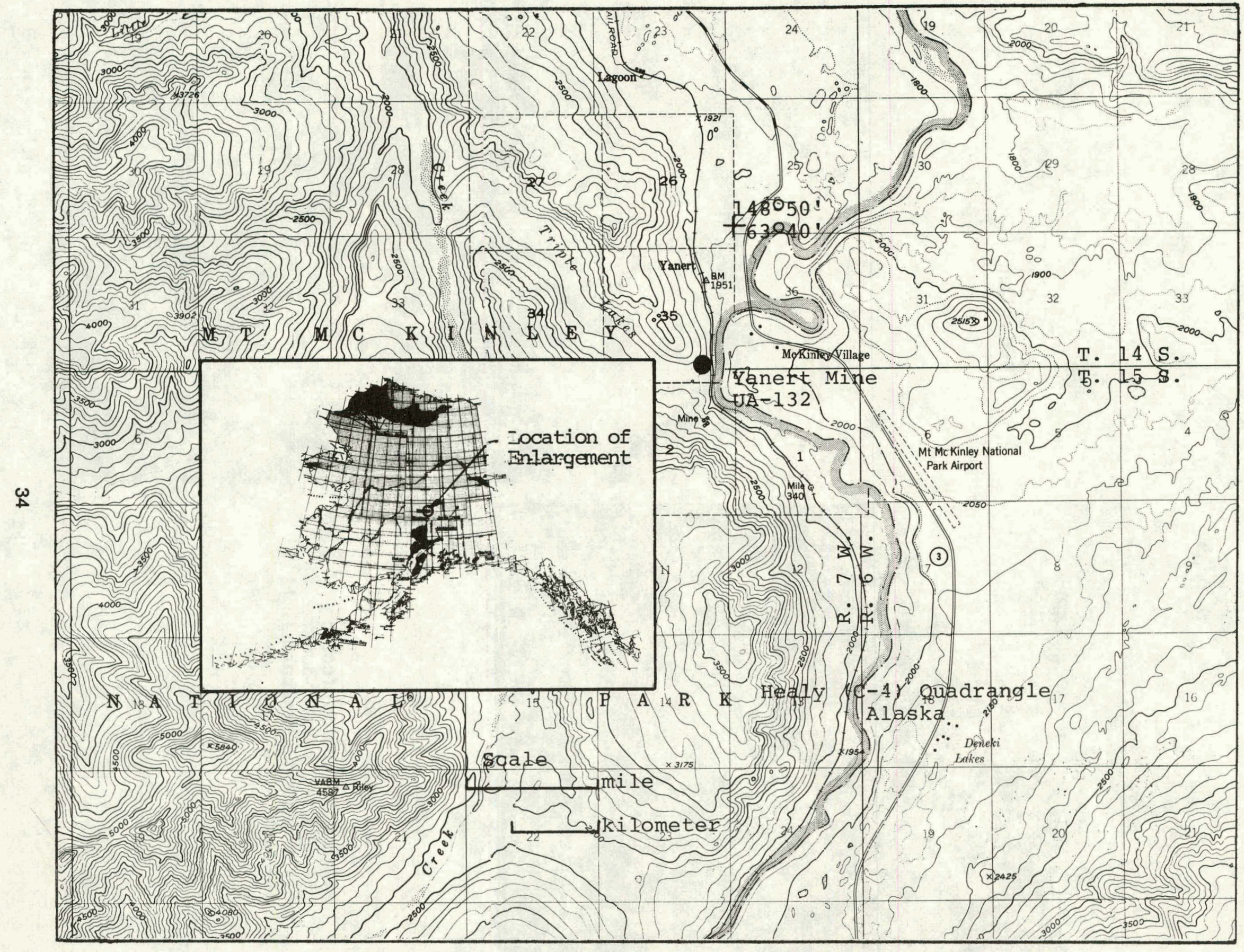

Figure 32. Location of sampling site at the Yanert mine, Nenana coal field. 


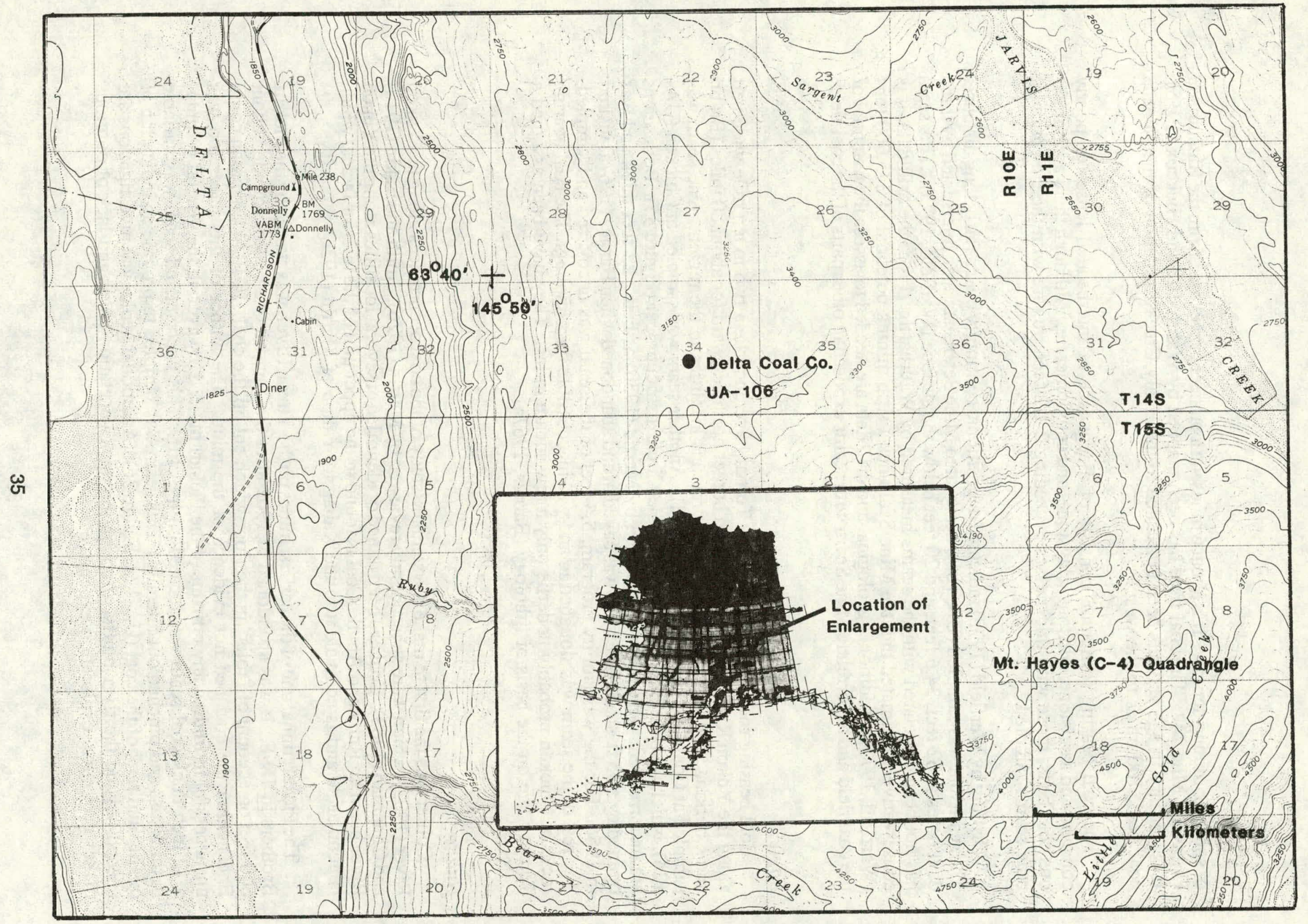

Figure 33. Location of sampling site in the Jarvis Creek coal field. 
of sporadic mining activity. It is about 6 miles via a pioneer gravel road from the Richardson Highway, Mile 242. The coal field has been mapped by Wahrhaftig and Hickcox (1955). It is Tertiary in age and has been correlated to the Healy Creek formation of the Nenana coal field, 100 miles to the west.

The coal bearing formation consists of a sequence of interbedded lenses of poorly consolidated sandstone, siltstone, claystone, and conglomerate. Although there are numerous coal beds, those with thicknesses exceeding 2-1/2 feet are rare with the exception of nine seams sampled.

Drilling by Warfield (1973) indicated depositional continuity over a fairly long distance. The seam that was sampled (UA-106), designated Mine Seam, has been intersected by three drill holes at 62 feet, 34.6 feet, and 20 feet below the surface (Warfield, 1973). This seam has not been correlated with the seams measured by Wahrhaftig. From the drill data, it is conservatively estimated that the Mine Seam has a strip mining potential of 375,000 tons (Warfield, 1973). Additional geological and drill data are needed to assess the potential of the coal field and to correlate Mine Seam with seams exposed in other parts of the coal field.

\section{Eagle}

Coal bearing rocks of probable early Tertiary age underlie a two to ten mile wide belt along the Yukon River from the Canadian border northwestward for about 80 miles (Brabb and Churkin, 1964). Coal crops out at numerous localities in the region. One seam was sampled at Coal Creek (UA-121, Figure 34). Another seam was sampled at Chicken (UA124), which is about 50 miles south of Eagle-Circle district proper (Figure 35). Both seams are uncorrelated. The seam is described by Mertie (1930) as being 22 feet thick and was opened by a $35 \mathrm{ft}$. shaft. The mine was caved in and abandoned when Barnes (1967a) visited in 1956. For the washability program, 5.5 feet of the seam was uncovered and sampled. The rest of the seam was sloughed in and was inaccessible for sampling. The coal bearing rocks at Chicken probably underlie only a few square miles. They have been assigned a Tertiary age on the basis of lithology (Barnes, 1967a).

\section{Nulato}

Collier was the first to make a systematic study of the coal occurrences along the Yukon River (1903), which were subsequently reviewed by Martin (1926), Smith and Eakin (1910) and Chapman (1963). Coal has been mined or identified at several localities along the Yukon River between Ruby and Anvik. Coal is found in the upper unit of the interior facies, which is nonmarine and is equivalent to the Kaltag formation of Martin (1926).

The Pickart mine, one of the earliest mines on the Yukon River, was started by the Pickart Brothers in 1898. It was abandoned in 1902 after the gangway had been extended about 600 feet on account of "rolls" in the floor which cut off the coal. In 1944 Chapman could find neither the coal bed nor evidence of the mine. The author of this paper too was unsuccessful in finding any remains of the Pickart mine. However, in the general vicinity, a 12 inch thick coal seam was located on the cliff. This uncorrelated seam was variable in thickness and pinched out laterally. This seam was sampled to provide an indication of quality and rank of the coal (UA-128, Figure 36). Additional geological investigations are needed beyond the river bluffs, although the thick vegetation cover and lack of outcrops makes geological exploration expensive. 


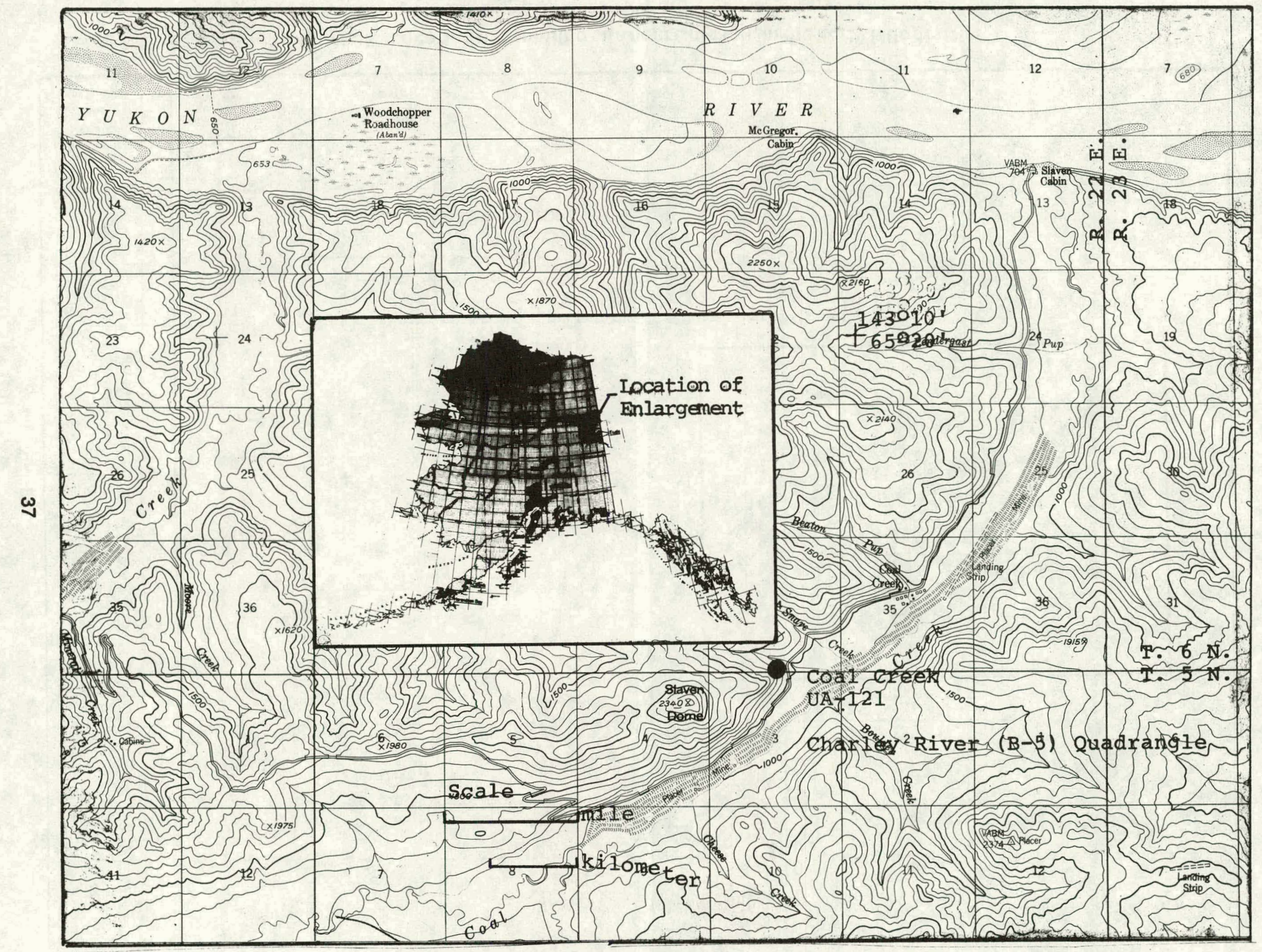

Figure 34. Location of sampling site on Coal Creek In the Eagle coal fleld. 


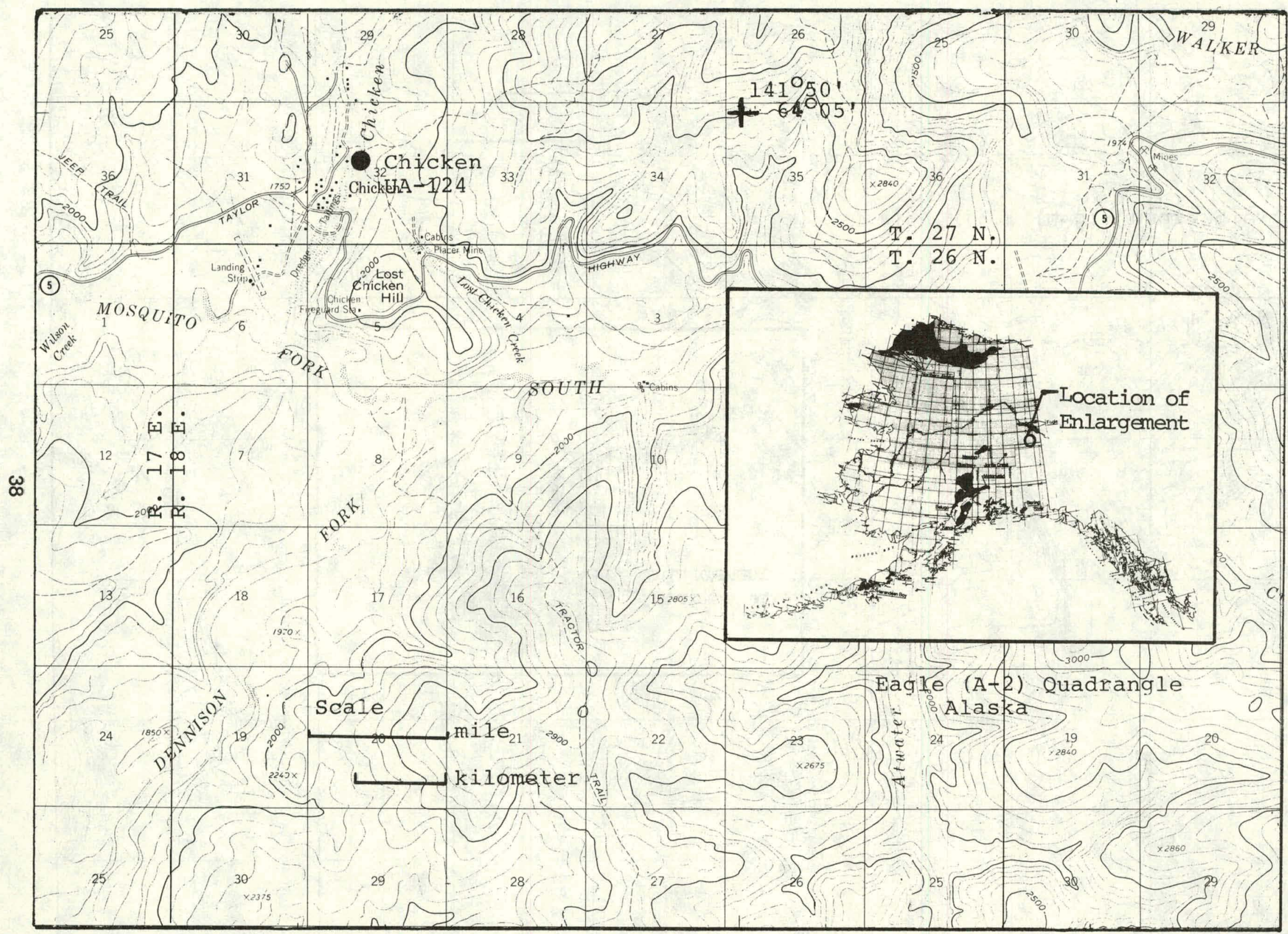

Figure 35. Location of sampling site near Chicken, in the Forty Mile district, Eagle coal field. 


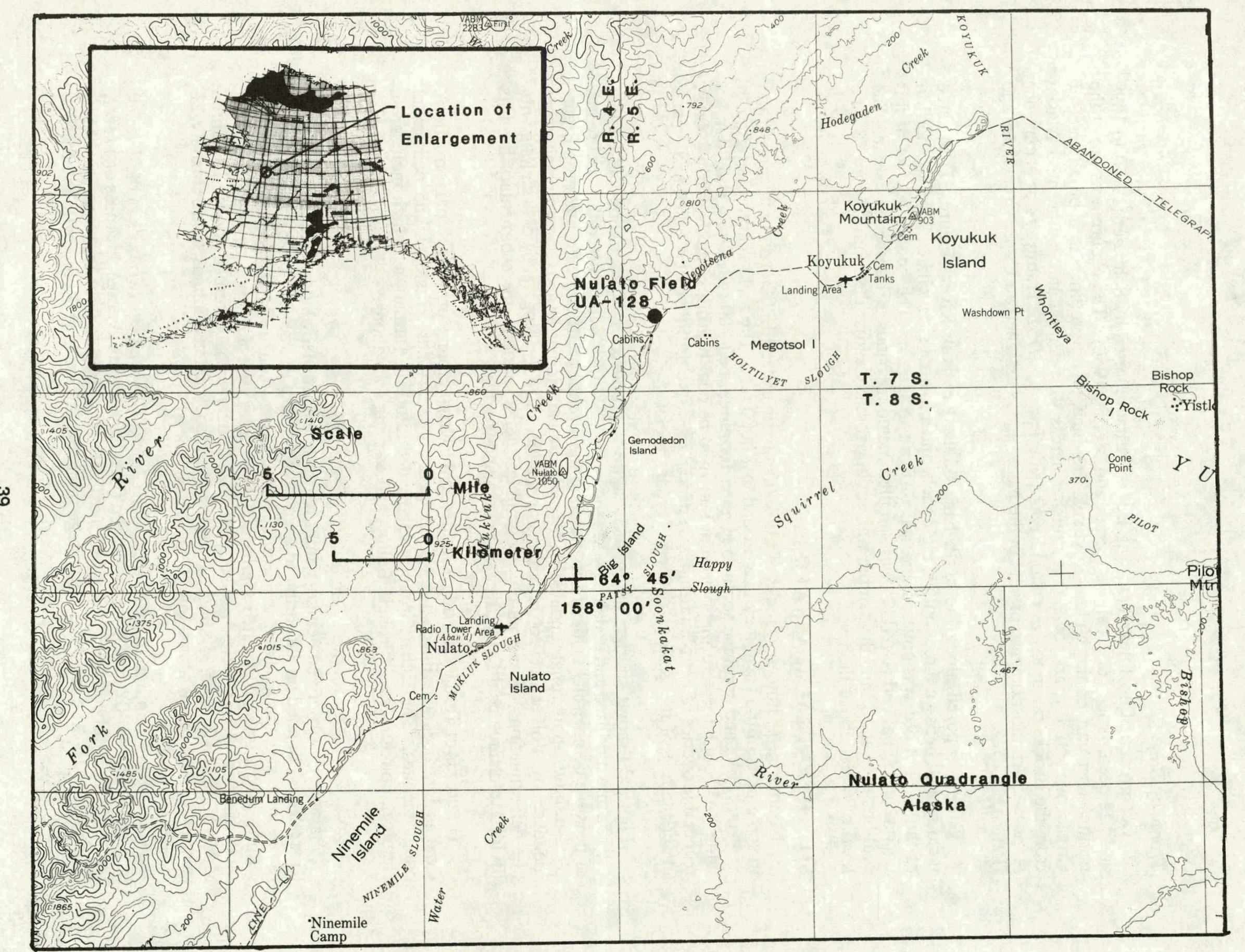

Figure 36. Location of sampling site at the Nulato field. 


\section{Tramway Bar}

Occurrence of coal near Tramway Bar was first reported by Schrader (1900) in 1899 and has been mined for local use (Smith and Mertie, 1930). The occurrences are at the northeastern part of the Yukon-Koyukuk Province. The province is a broad tract of Cretaceous and Tertiary rocks that stretches across west-central and southcentral Alaska from the Brooks range to the Yukon River delta (Patton, 1973). Tramway Bar occurrence is the western most outcrop of coal in the basin, and is assigned an Upper Cretaceous age (Patton, 1973).

Coal is exposed along the north bank of the Koyukuk River (Figure 37) in three uncorrelated beds - a three foot, an eight inch, and a 17 foot six inch bed. The top portion of the 17 foot bed was covered and was difficult to sample. The bottom 13 feet of this uncorrelated coal bed (UA-117) was sampled including bands of interbedded shale. The coal bed dips at $56^{\circ}$ and the sample was cut horizontally across the seam (Figure 38) at a level of 6 feet above the river.

\section{SOUTHCENTRAL ALASKA FIELDS}

Nonmarine sedimentary rocks of Cook Inlet basin exveed 18,000 feet in thickness, and in some parts of the basin they may extend to 27,000 feet. The rocks outcrop as far north as Peters Hills and continue south to Homer, forming a belt 200 miles long and 70 miles wide. Although these formations were known to be coal bearing since the early 1900's, recent discoveries of petroleum and gas sparked intensive drilling that resulted in a greater understanding of the geology of these Tertiary rocks.

Figure 39 shows stratigraphic nomenclature as proposed by Calderwood and Fackler (1972), and modified and updated by Magoon et al. (1976). It will be noted that coal seams of possible commercial value are restricted to the Tyonek and Beluga Formations. Figure 39 also shows approximate updated stages of Seldovian, Homerian and Clamgulchian stages identified by Wolf et al. (1966) from paleobotanical and palynological evidence along with age determinations. From purely geographical considerations, the sedimentary basin is divided into three coal fields: Kenai, Beluga and Yentna.

The coal is of Tertiary age and is limited to the Kenai group (formerly Kenai formation). Coal is interbedded with coarse to fine grained sandstones, siltstones and occasional conglomerates. The Kenai Group is subdivided into four formations which include the Hemlock conglomerate, Tyonek, Beluga and Sterling formations.

\section{Beluga}

Barnes (1966) defined Beluga-Yentna region as the broad lowland west of lower Susitna River that is bounded on the north and west by the Alaska Range and on the south by Upper Cook Inlet and the Chakachatna River. The Beluga coal field is part of Cook Inlet sedimentary basin and is located approximately 60 miles west of Anchorage on the northwest shore of Cook Inlet. The field can be subdivided into three coal bearing regions. The Three Mile Creek Basin, located about six miles from Cook Inlet, contains approximately 22 steeply dipping seams averaging 10 feet in thickness.

The Capps Basin lies 26 miles from Cook Inlet. This area has two beds in the Tyonek formation (Figure 40), the Upper Capps bed (UA-127) with an average thickness of 17 feet, and the Waterfall bed (Capps bed of Barnes) with an aggregate thickness from 20-49 feet (Figure 41,42 ). The latter has an average mineable thickness of 30 feet with interburden 


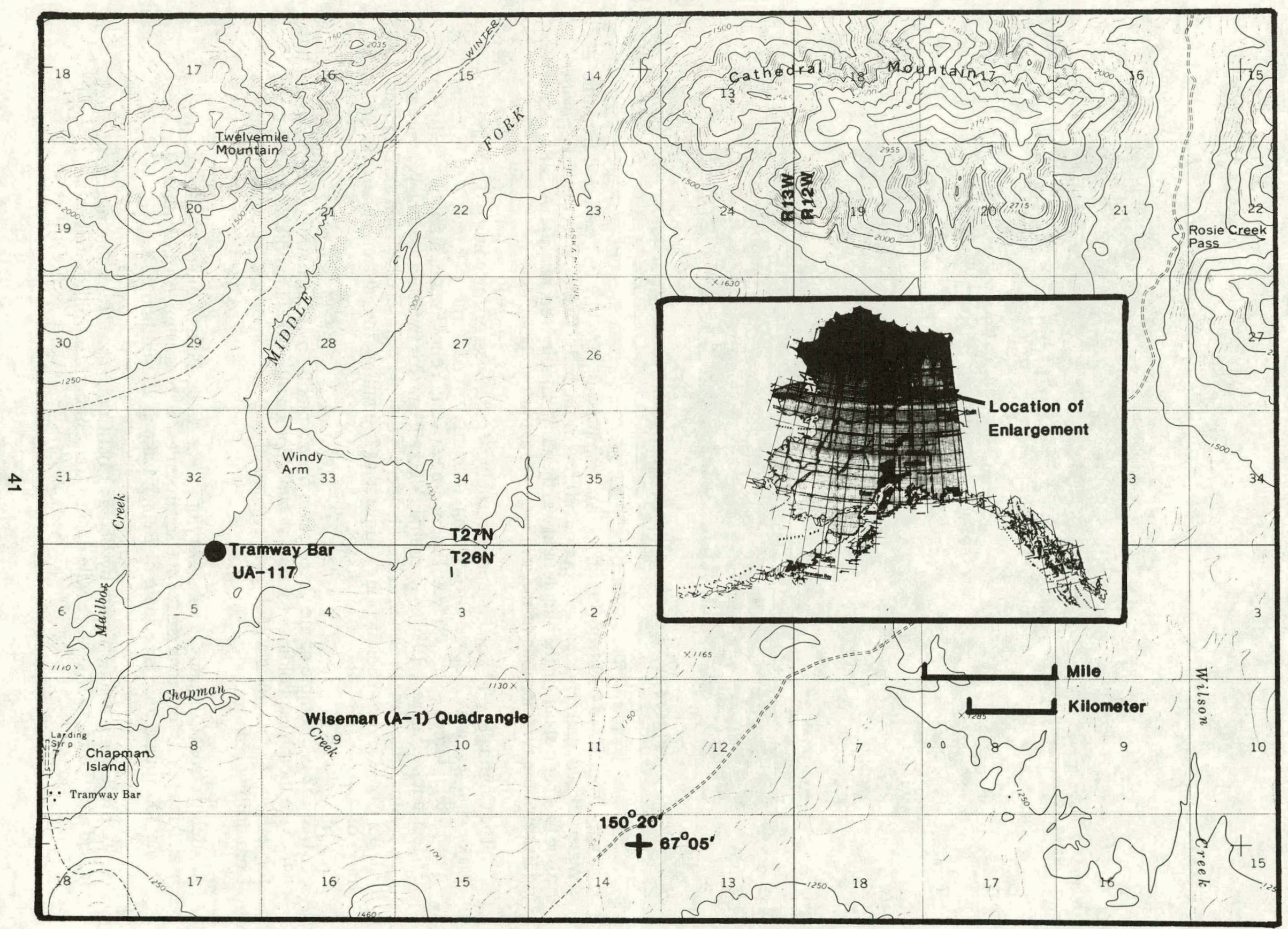

Figure 37. Sampling location of Tramway Bar field. 


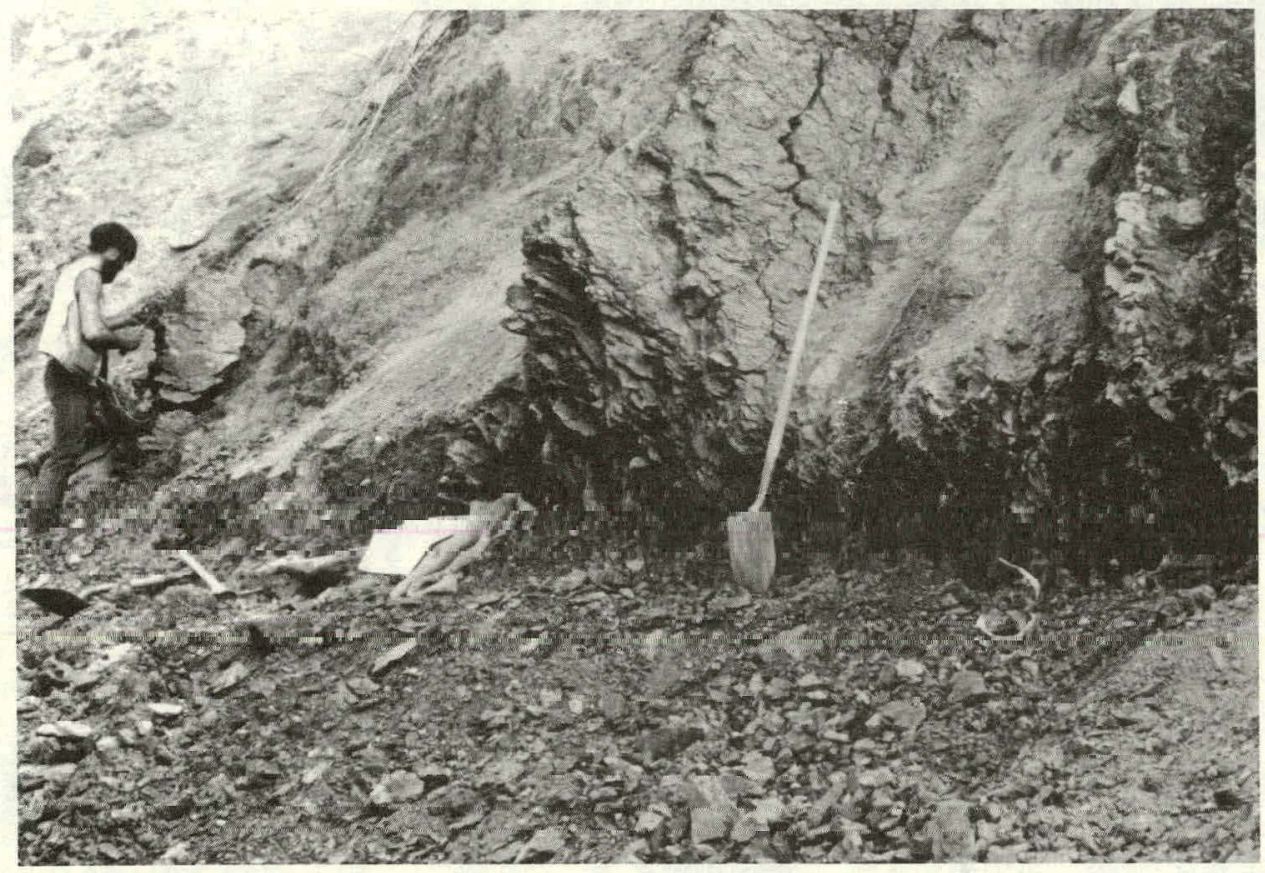

Figure 38. A closeup view of outcrop in Tramway Bar field.

varying from 80 to 280 feet (Laird, 1978). Sample No. UA-113 was collected from the Waterfall bed, and represents the bottom 30 feet of the bed. The top 6 feet is dirtier, with a one foot band of clay in the middle, and was therefore sampled separately (UA-148). Figure 43 shows the two portions of the seam, excavated in two benches.

'The Chuitna River basin lies approximately 50 miles west of Anchorage. There are five major coal seams as follows: Brown seam (Chuitna bed of Barnes) 28 feet; Yellow seam, 5 to 15 feet; Green seam, 20 feet; Blue seam, 28 feet; Yellow seam, 5 feet and red seam 33 feet thick (Ramsey, 1980). Diamond Alaska Coal Co. (with Bass-Hunt-Wilson) and Placer Amex, Inc. are the principal lease holders in the basin. Reserves within the DiamondAlaska Coal Co. lease holdings are estimated at 350 million tons at a cumulative stripping ratio of 4.4 .

UA-152 is a sample of the Green seam from a pit dug by Placer Amex, Inc., (Figures 44,45 ) in their lease holdings for mining and shipment of a 2000 ton bulk sample to Japan for testing. Figure 46 is a geological column of coal beds known to occur at the pit site from drilling records.

Beluga Coal Company, a subsidiary of Placer Amex, holds State of Alaska coal leases in all three basins for a total area of 400 square miles. Barnes estimates the indicated reserves in the 400 square mile area south of Beluga Lake at 200 million tons.

The following is an estimate by Beluga Coal Company of mineable reserves in their leased area (Laird, 1978). Three Mile Basin has an estimated 60 million tons in the 22 steeply 


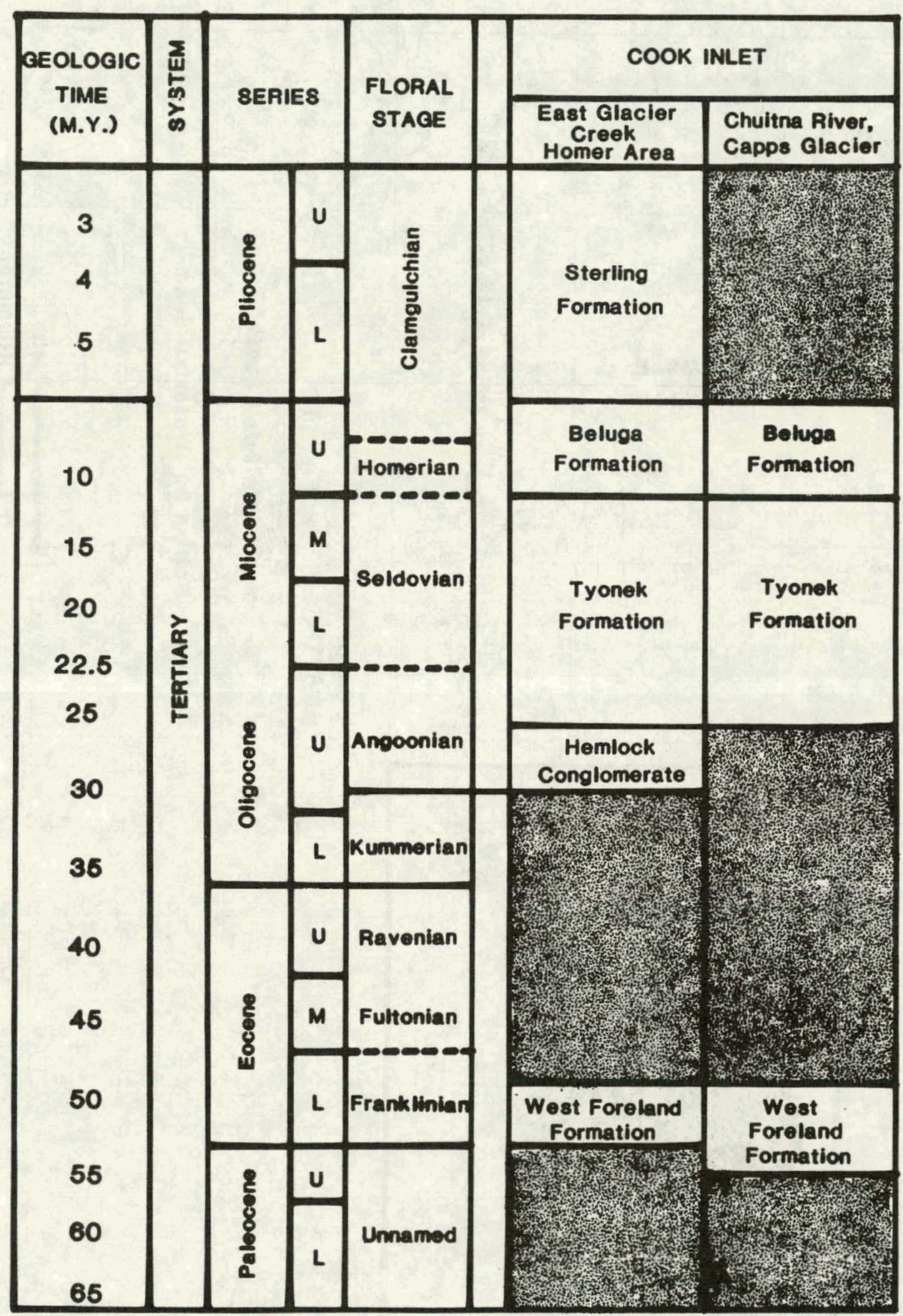

Figure 39. Correlation of Tertiary rocks in the Beluga coal field. (Source: Magoon, Adkison and Egbert, 1976). 


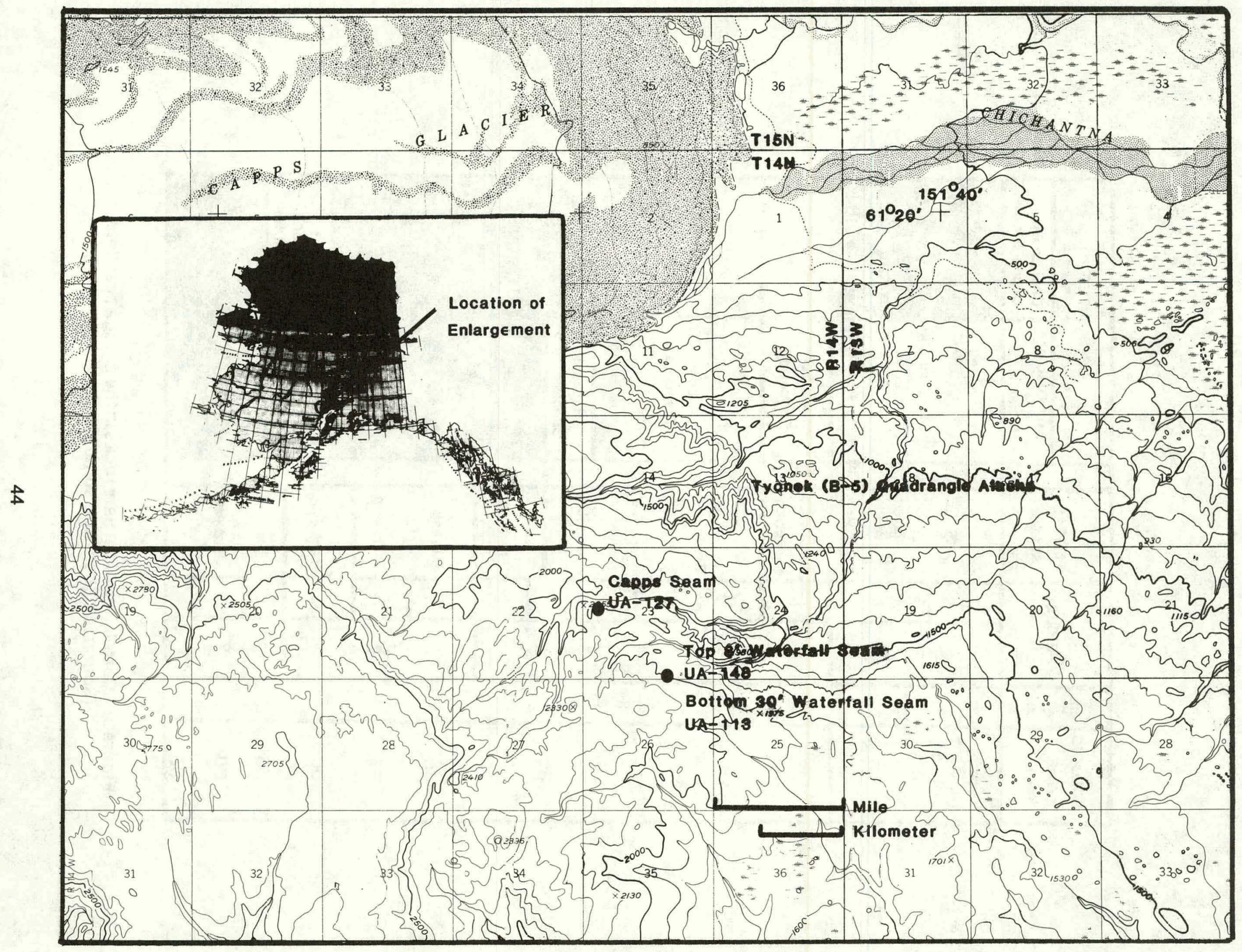

Figure 40. Location of sampling sites in the Capps Basin of the Beluga coal field. 


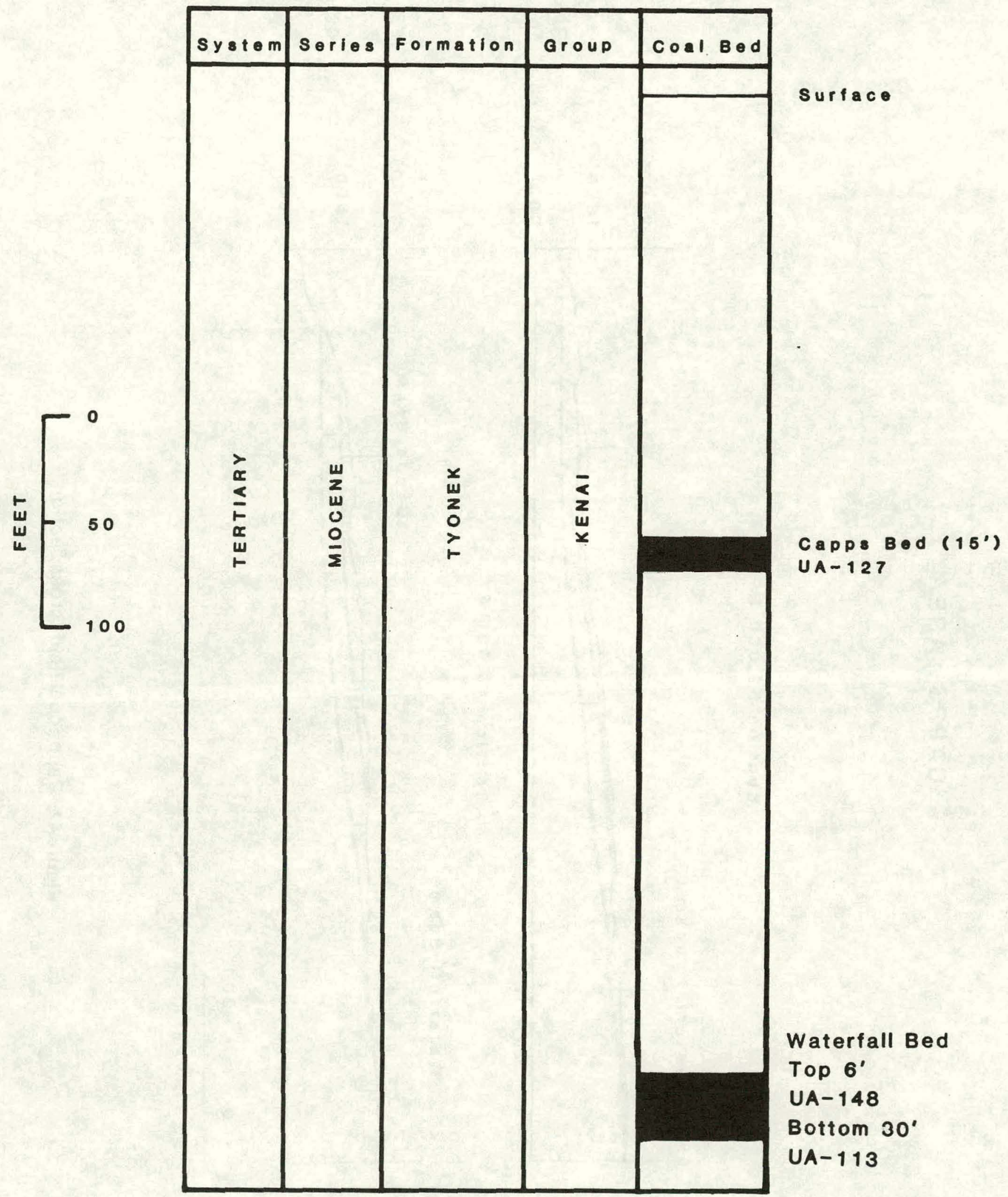

FIgure 41. Geological column showing mineable coal beds in the Capps basin, Beluga coalfield. 


\section{CAPPS AREA}

Section 52,000 E

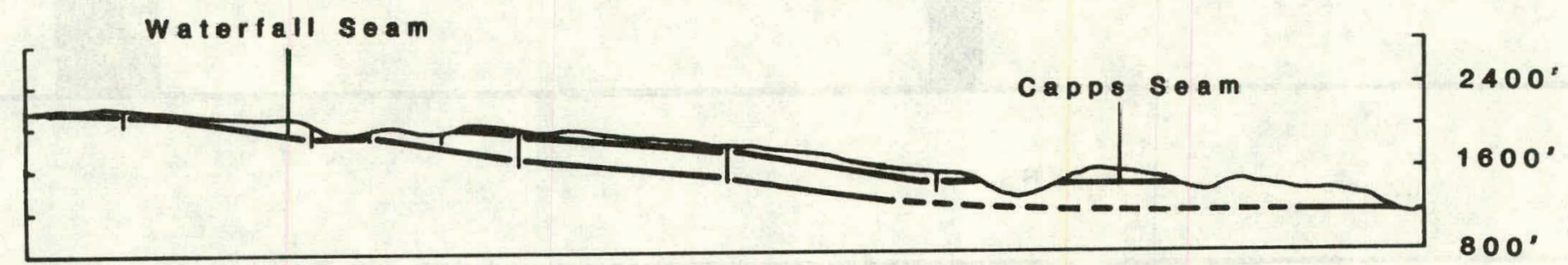

Section $48,000 \mathrm{E}$

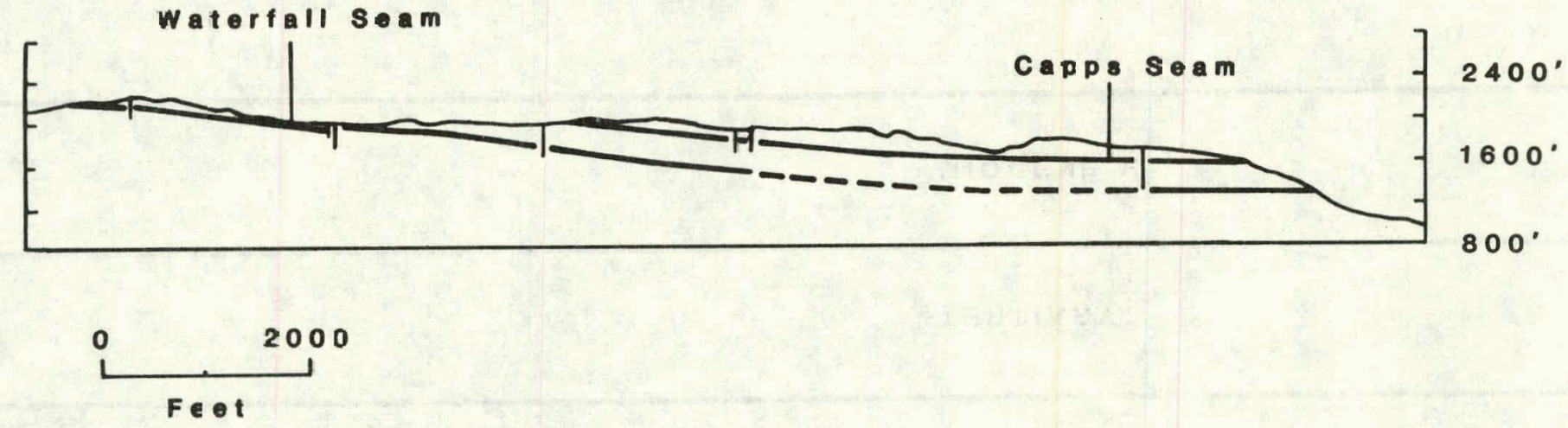

Figure 42. Cappscoal field-cross section. 


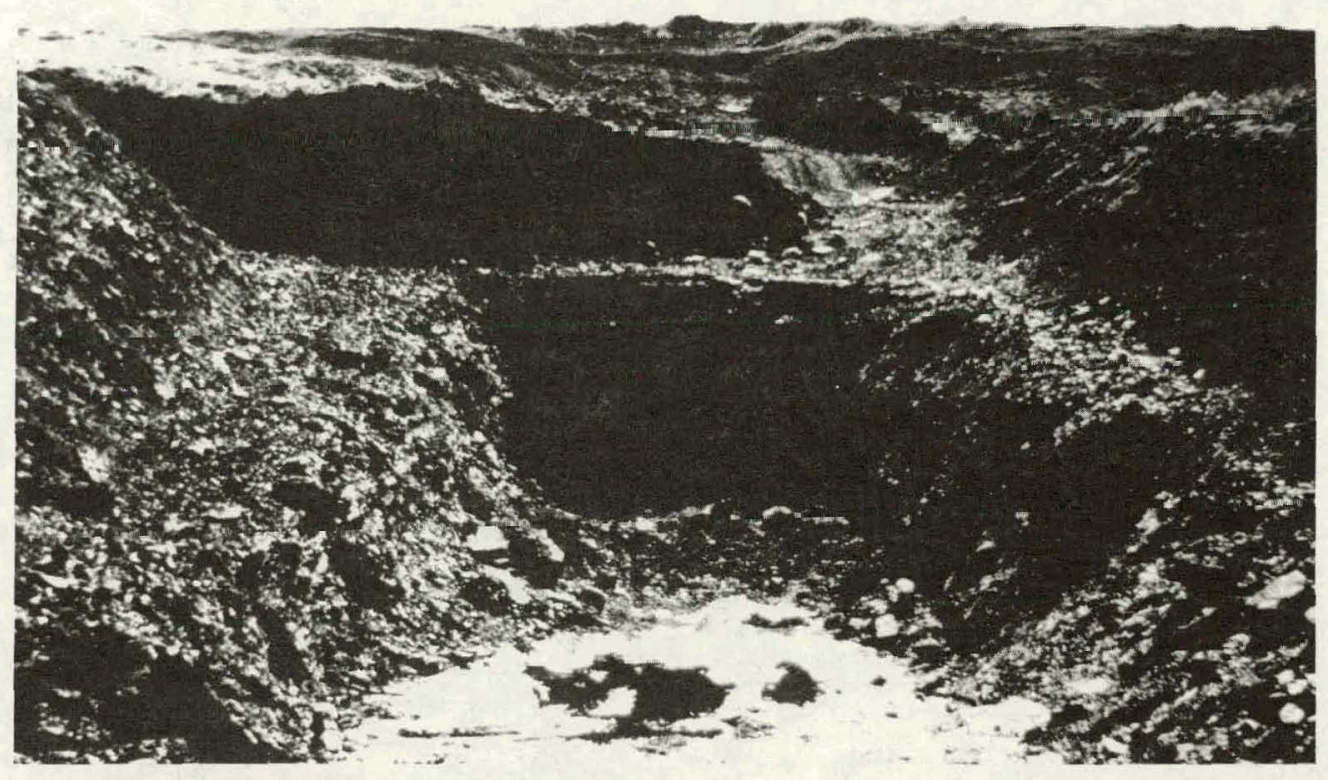

Figure 43. A subcrop of the Waterfall seam opened up in benches by Placer Amex for bulk sampling. The lower 30 foot bench and the upper 6 foot bench are distinguishable.

dipping beds averaging 10 feet thick at a stripping ratio of 9 to 1 . Chuitna Basin has approximately 200 million tons of near surface reserves on the west side of the river. In the Capps Basin the reserves of the Capps and Waterfall beds are estimated at 200 million tons at a stripping ratio of 5 to 1 .

The lower part of the Tyonek Formation is well exposed south of the Capps Glacier, and the section is described by Adkison et al. (1975). The location is about two miles north of the sample location of UA-113. These beds were designated part of the type section of the Seldovian stage by Wolff, et al. (1966).

\section{Yentna}

The coal seams in this region are confined to the Kenai formation which lies unconformably over a series of metamorphic and igneous rocks of early Jurassic to date Cretaceous age. Unconsolidated Quaternary deposits of glacial till, outwash materials, alluvial sands and gravels cover much of the coal bearing Kenai formation and make it impossible to correlate outcrops. Mobil Oil Corp. holds leases in the Johnson and Canyon Creek area and did drilling in 1975,1977 , and 1979. Although there are only three seams outcropping along Johnson Creek, drill data indicate the presence of five to seven seams ranging in thickness from 10 to 40 feet (Blumer, 1980). The seam sampled (UA-149), Figures 47, 48 and 49, is from locality 15 of Barnes (1966) and is apparently the same seam penetrated by drill hole ALJ77-6 (Blumer, 1980, p. 123, Figure 1) approximately $21 / 2$ miles south of the outcrop. The coal bed sampled on Canyon Creek UA-150 (Figures 50,51) is the same as location 24 of Barnes. The top of the seam appeared to be an erosional surface at the outcrop. The sampled seam represents the top seam of drill hole AL-7503 of Blumer (1980), (p. 123, Figure 1). 


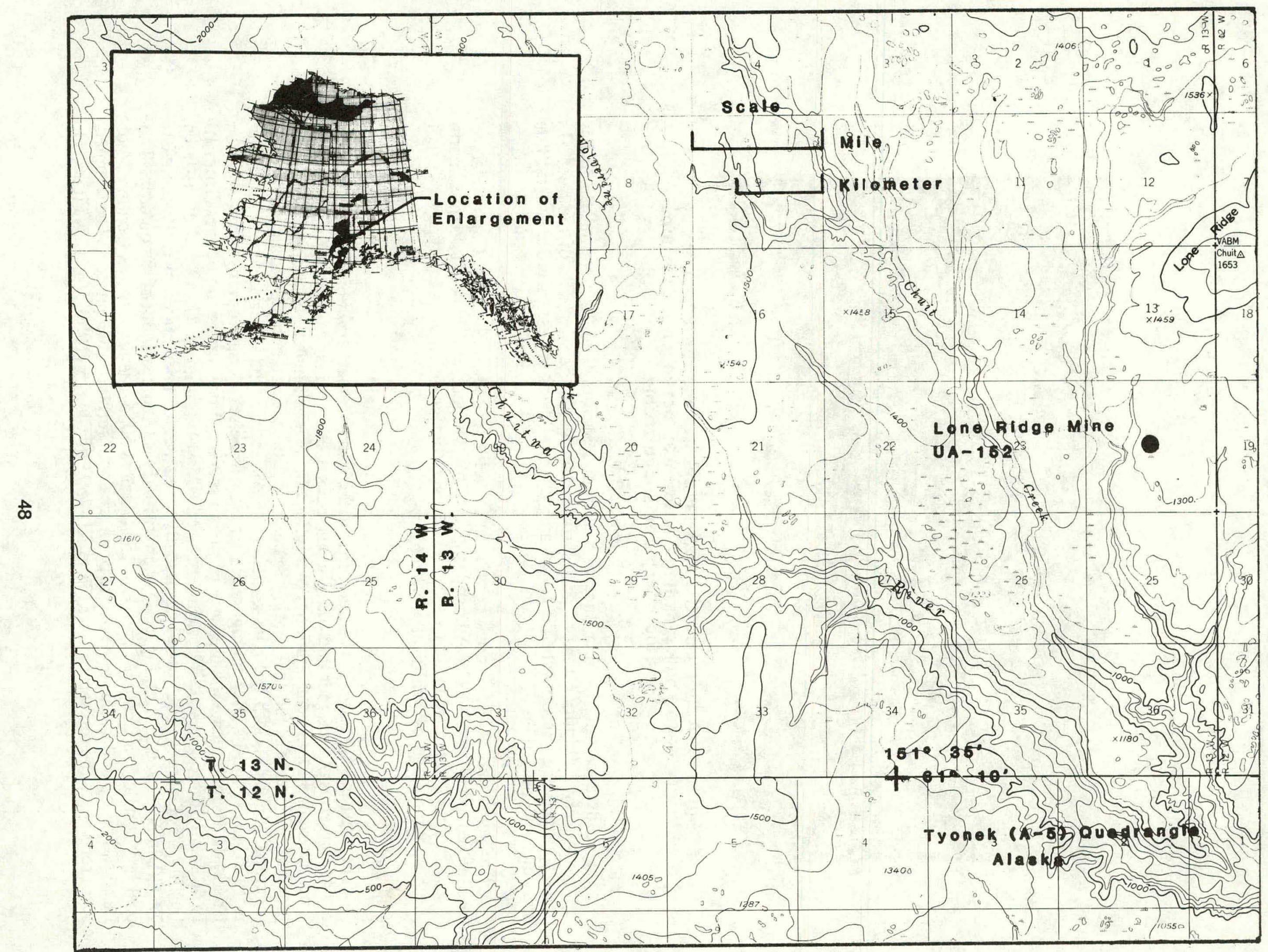

Figure 44. Location of sampling site at the Lone Ridge mine in the Beluga field. 


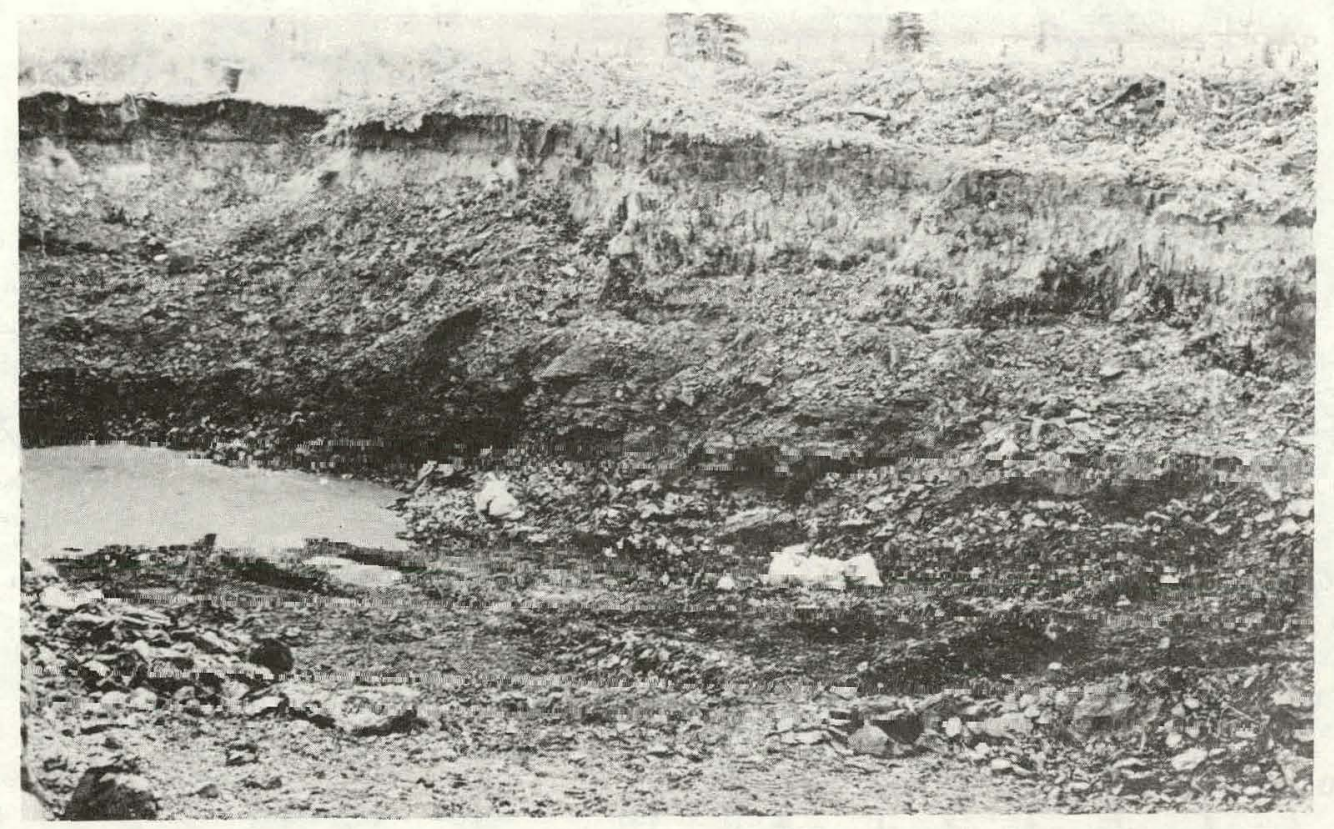

Figure 45. View of pit dug by Placer Amex, Inc. for obtaining bulk samples for shipment to Japan. Sample UA-152 was obtained from this pit.

Figure 52 is an aerial view of the sampling location on Canyon Creek and Figure 53 gives a closeup view of the seam sampled.

There are several outcrops in the Canyon Creek area, as indicated by Barnes (1966). The Mobil Oil Corp. drilling program seemed to indicate the presence of up to five seams ranging in thickness from 10 to 45 feet. In one area in Canyon Creek, Mobil Oil Corp. identified a coal zone where four distinct seams come close together, giving 63 feet of net coal in a 77 foot interval (Blumer). Mobil Oil Corp. identified an in-place resource of 500 million tons to a depth of 250 feet.

There are numerous outcrops of Kenai Group in the northern part of the Yentna region. Much of the area is covered by a mantle of Quaternary deposits (Barnes, 1966) concludes "outcrops of the Kenai Formation (now Kenai Group), though mostly of small extent, are so widely distributed as to leave little doubt that the formation underlies much of the lowland areas." Occurrences of coal in the Fairview Mountain area was first described by Capps. An outcrop on Chicago Gulch was determined by Wolff, et al. (1966) to be Seldovian (Figure 39). Of all the coal outcrops in the region, the thickest was Locality 2 (Figure 54, 55) described by Barnes (1966). This uncorrelated bed is 55 feet thick and has no visible partings. The middle part of the bed was covered with gravel and could not be reached for sampling. A sample (UA-115) was taken of the ten foot section of this uncorrelated bed below the gravel, and the ten foot section of this uncorrelated coal bed above the gravel (UA-116). The sampled outcrop is approximately 23 air miles from Peters Creek and access was via helicopter. Peters Creek is about 25 miles on Peters Creek Road from the Cache Creek Station on the Parks Highway. 


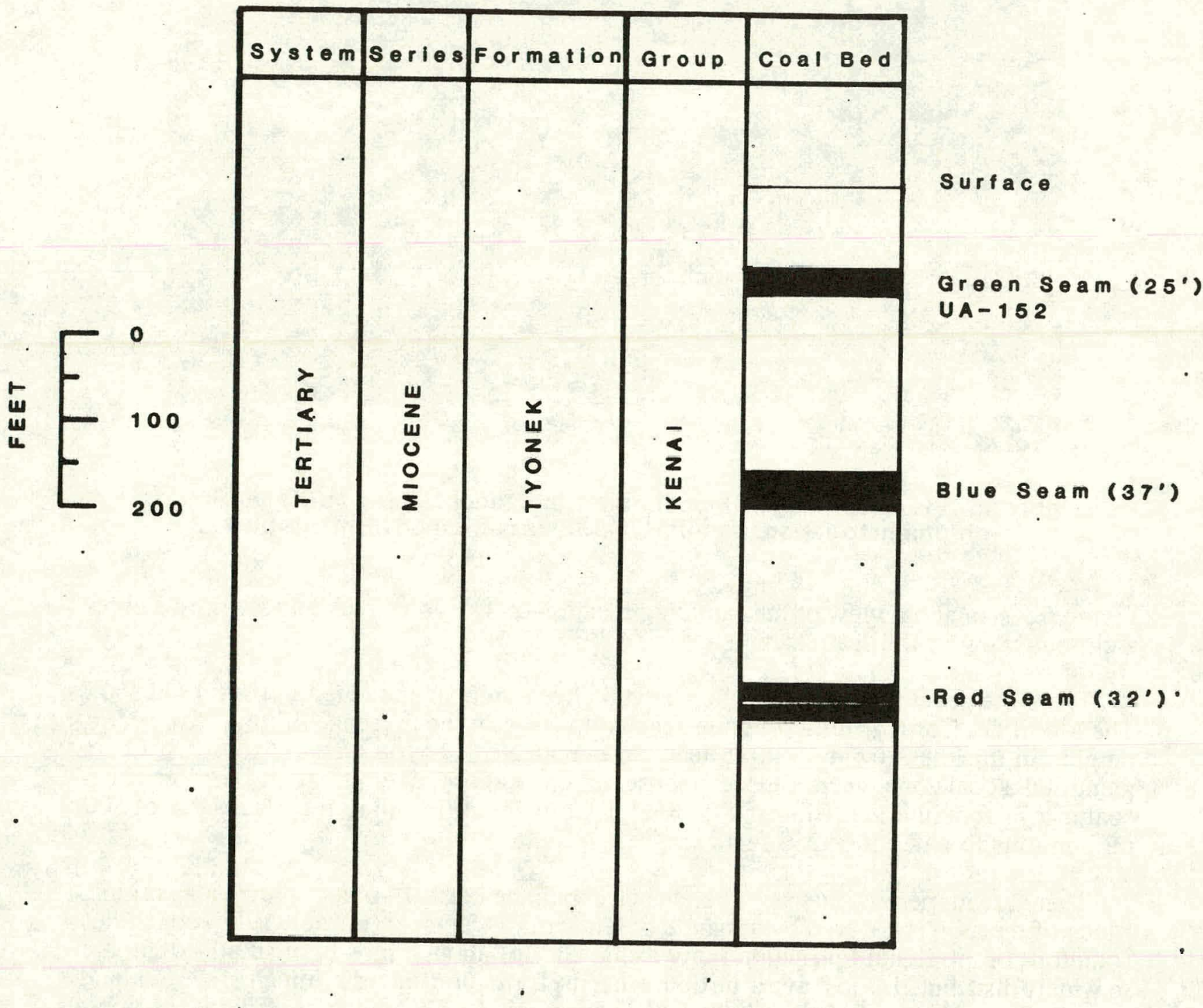

Figure 46. Geological column showing mineable coal beds at Lone Ridge mine, Beluga coal field. 


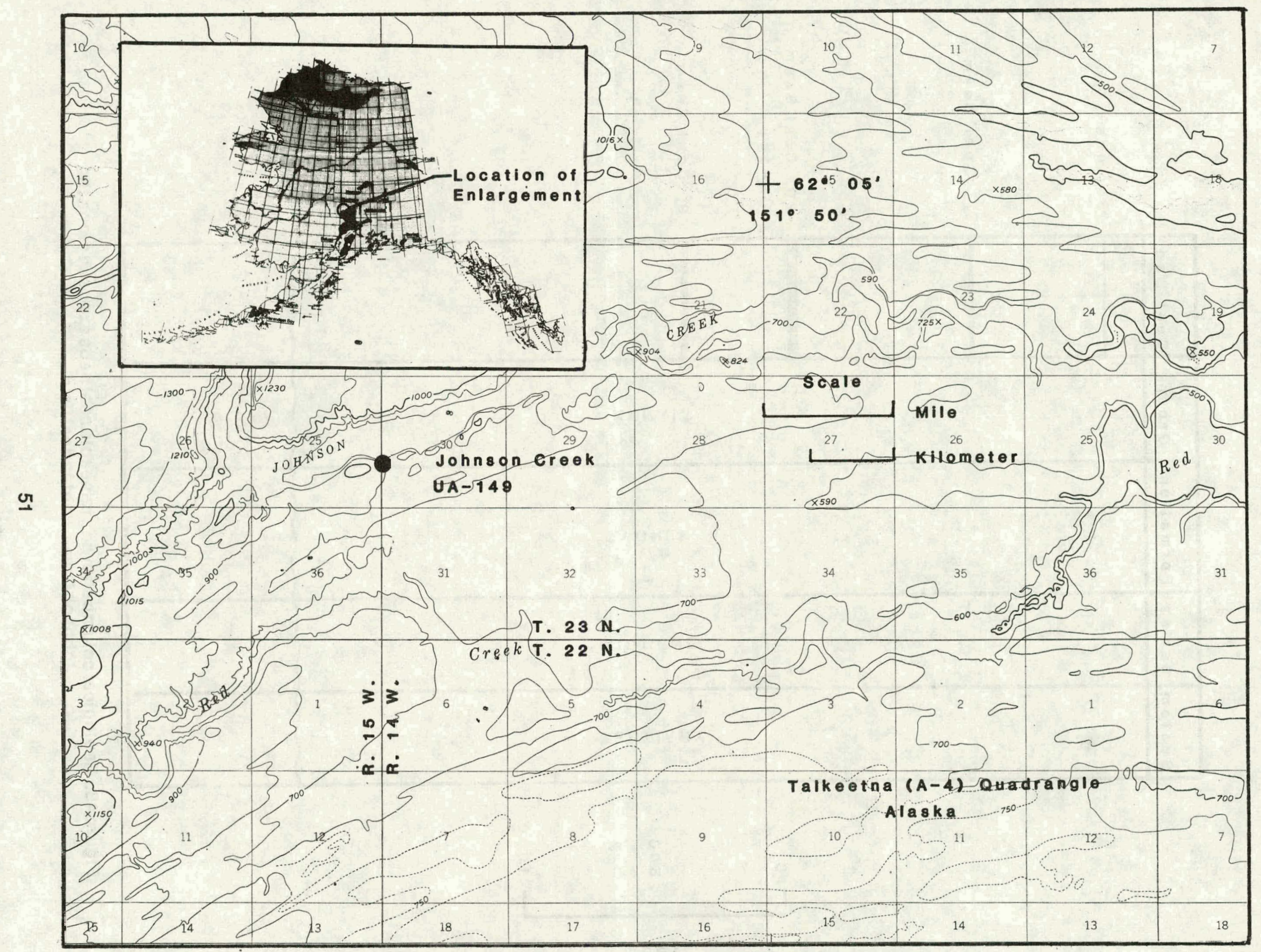

Figure 47. Location of sampling site on Johnson Creek in the Yentna field. 


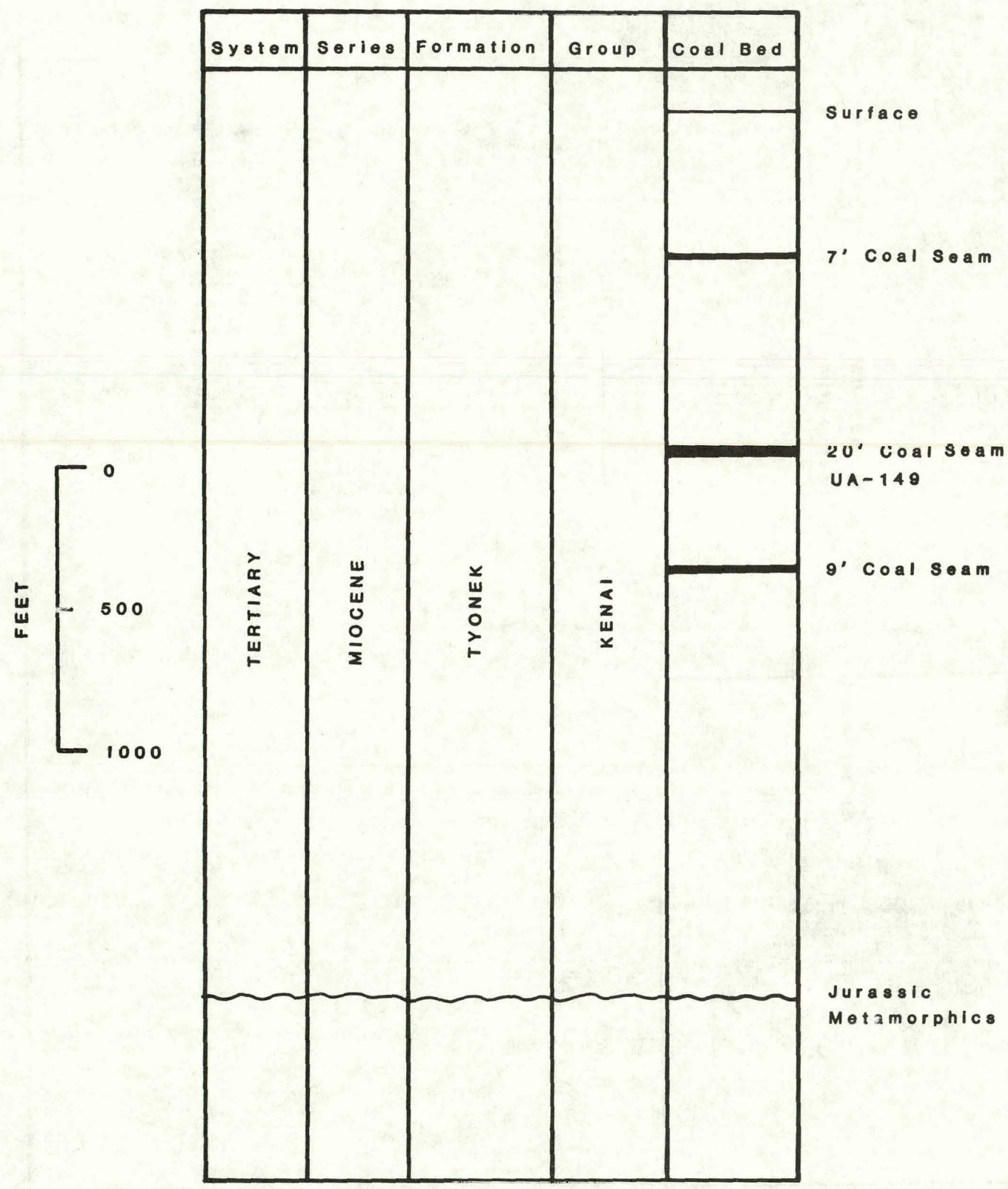

Figure 48. Geological column showing mineable coal beds exposed along the Johnson Creek, Yentna coal field. 


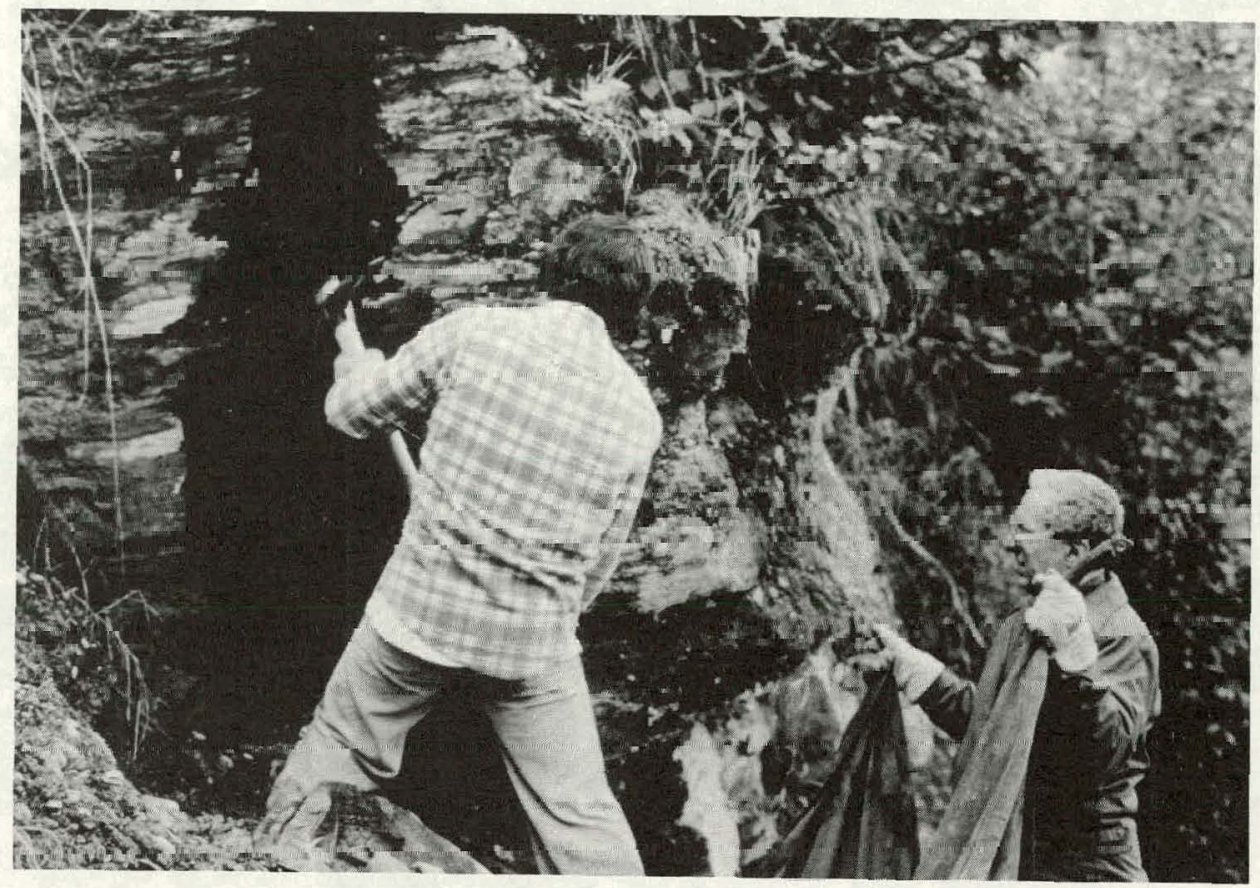

Figure 49. A closeup view of outcrop on Johnson Creek.

Kenai

Much of the Kenai lowland is underlain by coal bearing rocks. Coal exposures are found extensively on steep bluffs along the east shore of the Cook Inlet, rising at places to 200 feet above the beach. Barnes and Cobb (1959) made a detailed study of those outcrops and presented extensive sections of these exposures. The beds are not massive in thickness; however, Barnes identified at least 30 beds ranging in thickness from three to seven feet.

Coal has been mined in the Homer district since 1888 . There has been no mining since 1951 when the Homer Coal Corporation ceased operations. Some residents of the Homer areas still collect coal from the beach for domestic use, particularly after a severe storm. The sample collected (UA-118) is from the Cabin coal bed and is 6 feet thick and has about 5 feet of overburden at the sampling location (Figure 56). A geologic column showing the coal beds in the Kenai field is presented in Figure 57. The bed outcrops on a vertical face and sampling was accomplished with the aid of technical rock climbing equipment. Two other uncorrelated seams were sampled, one at Ninilchik (UA-122, Figure 58, 59) and one at Happy Creek (UA-131), located on Figure 60.

\section{Matanuska}

Matanuska coal field is about 45 miles northeast of Anchorage on the Glenn Highway. In the Upper Matanuska Valley, the coal increases in rank from high volatile A bituminous at the Castle Mountain Mine, to anthracite at the Anthracite Ridge. The coal in the Wishbone Hill District of the Lower Matanuska Valley is high volatile B bituminous. The coal seams are limited to the Chickaloon formation of Tertiary age. This formation consists of 


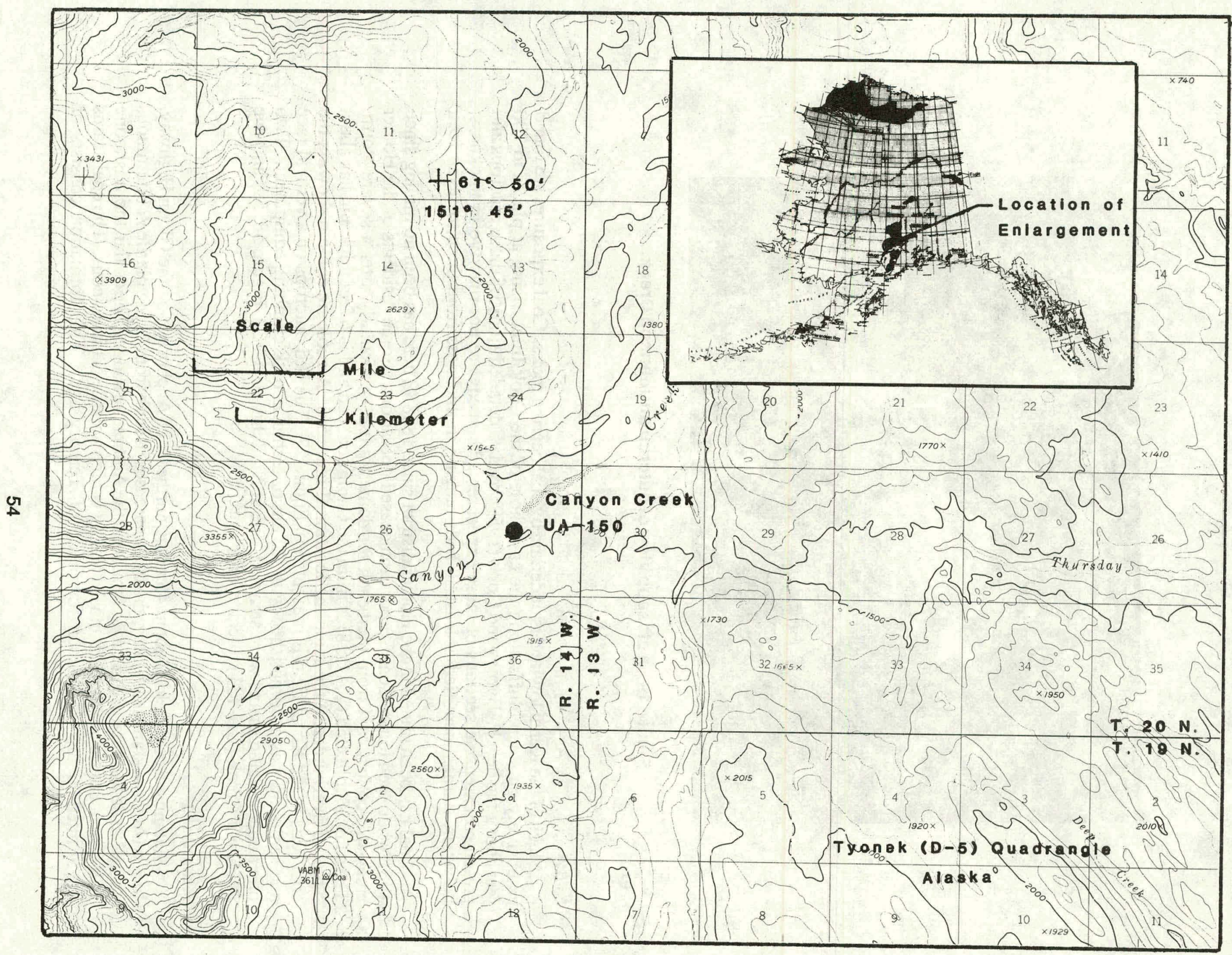

Figure 50. Location of sampling site on Canyon Creek in the Yentna field. 


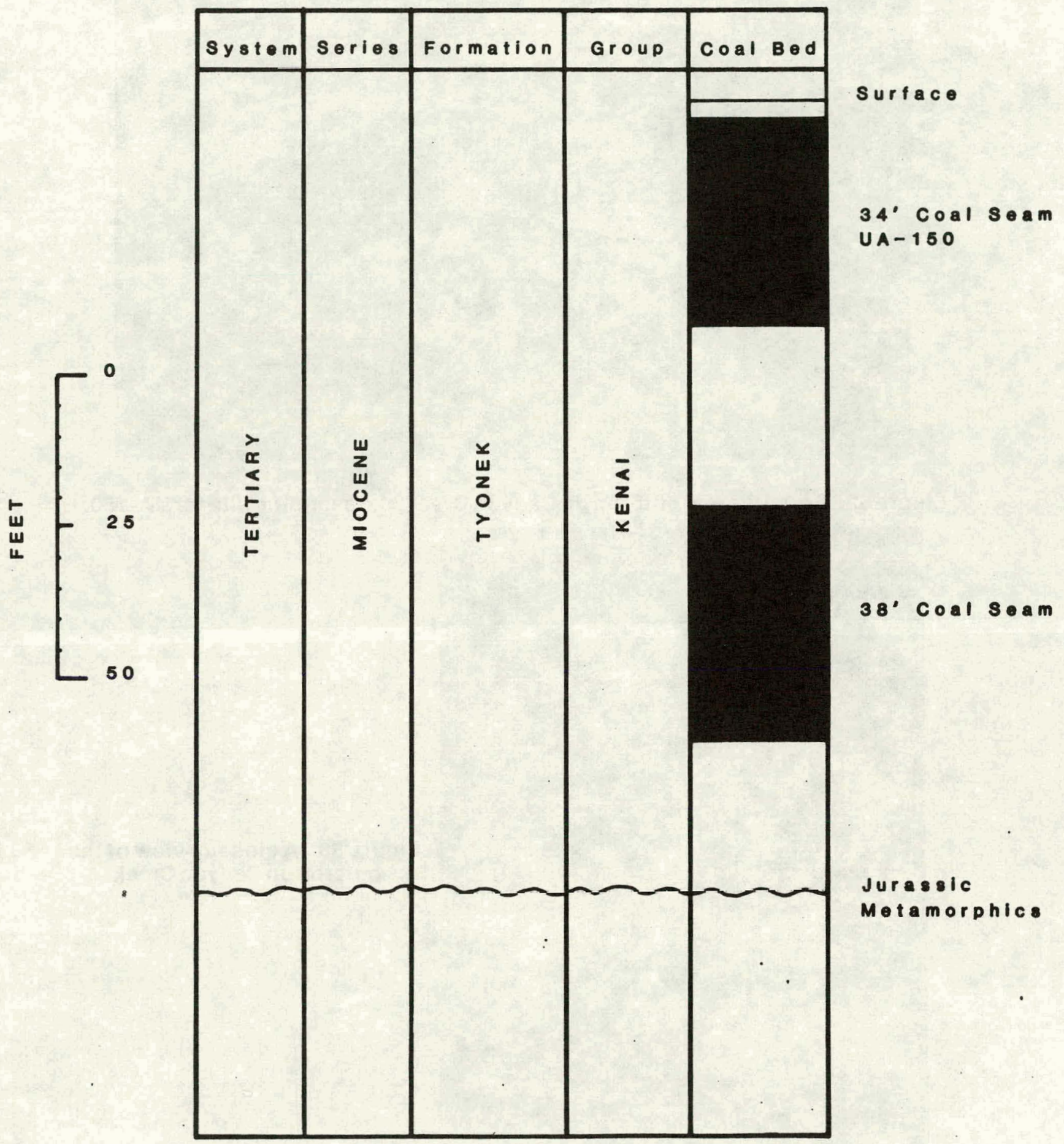

Figure 51. Geological column showing mineable coal beds exposed along the Canyon Creek, Yentna coal field. 


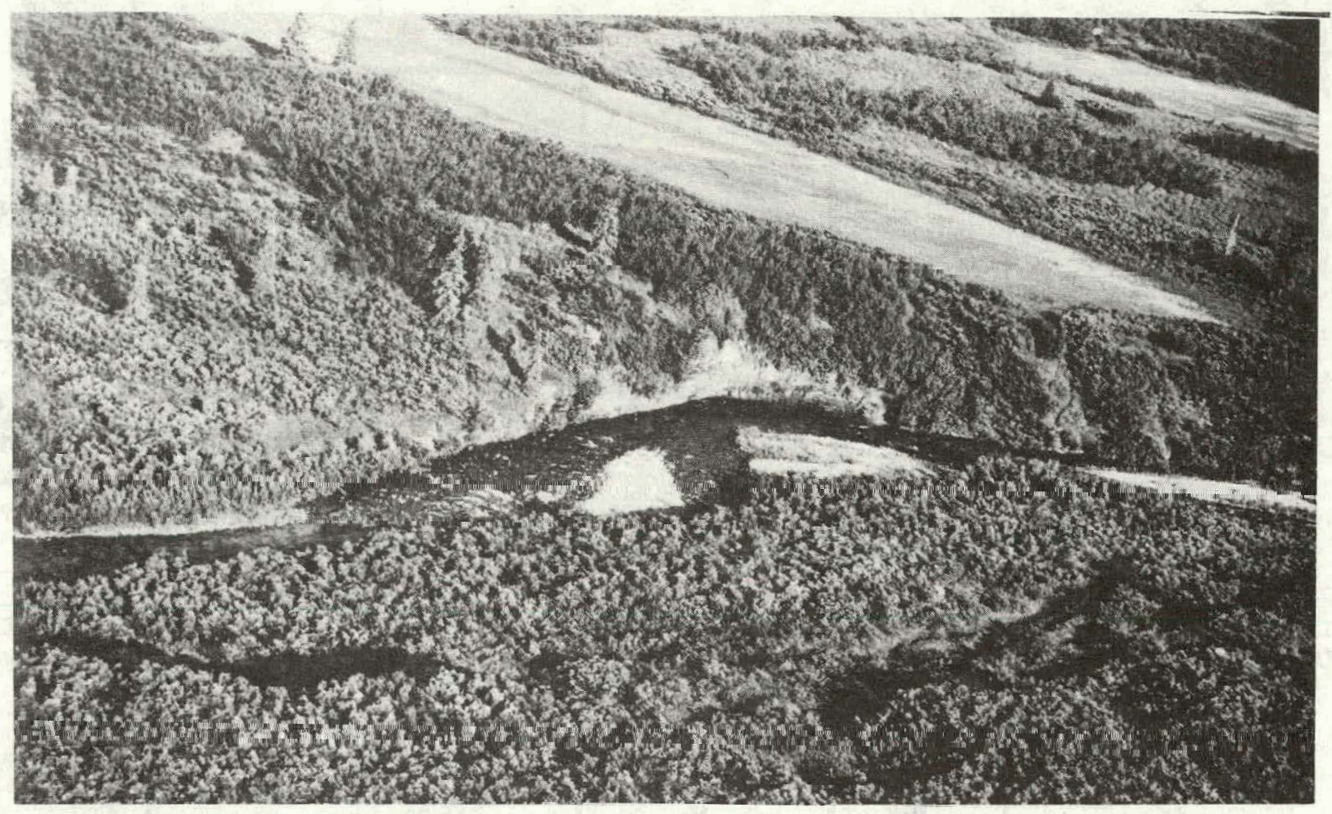

Figure 52. Aerlal view of outcrop on Canyon Creek, the sampling site for UA-150.

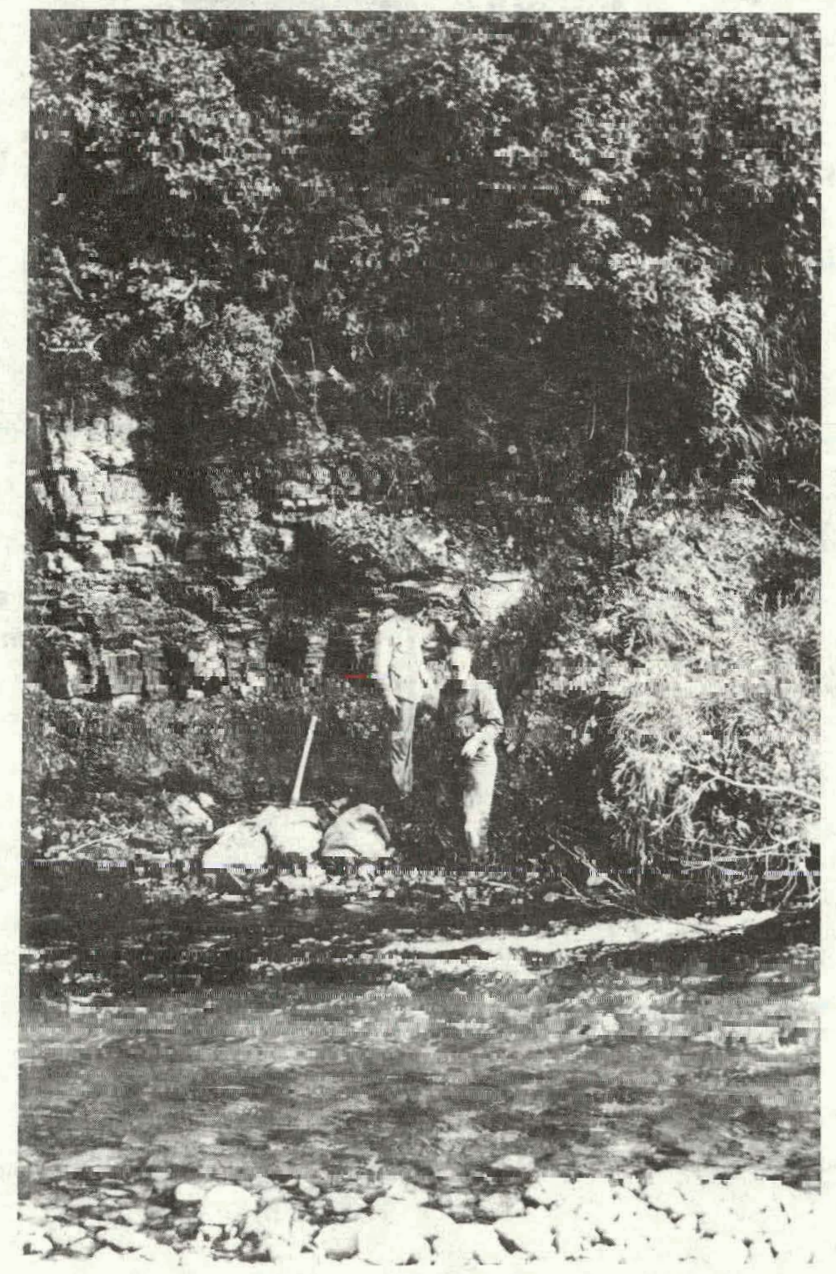

FIgure 53. A closeup view of the outcrop on Canyon Creek. 


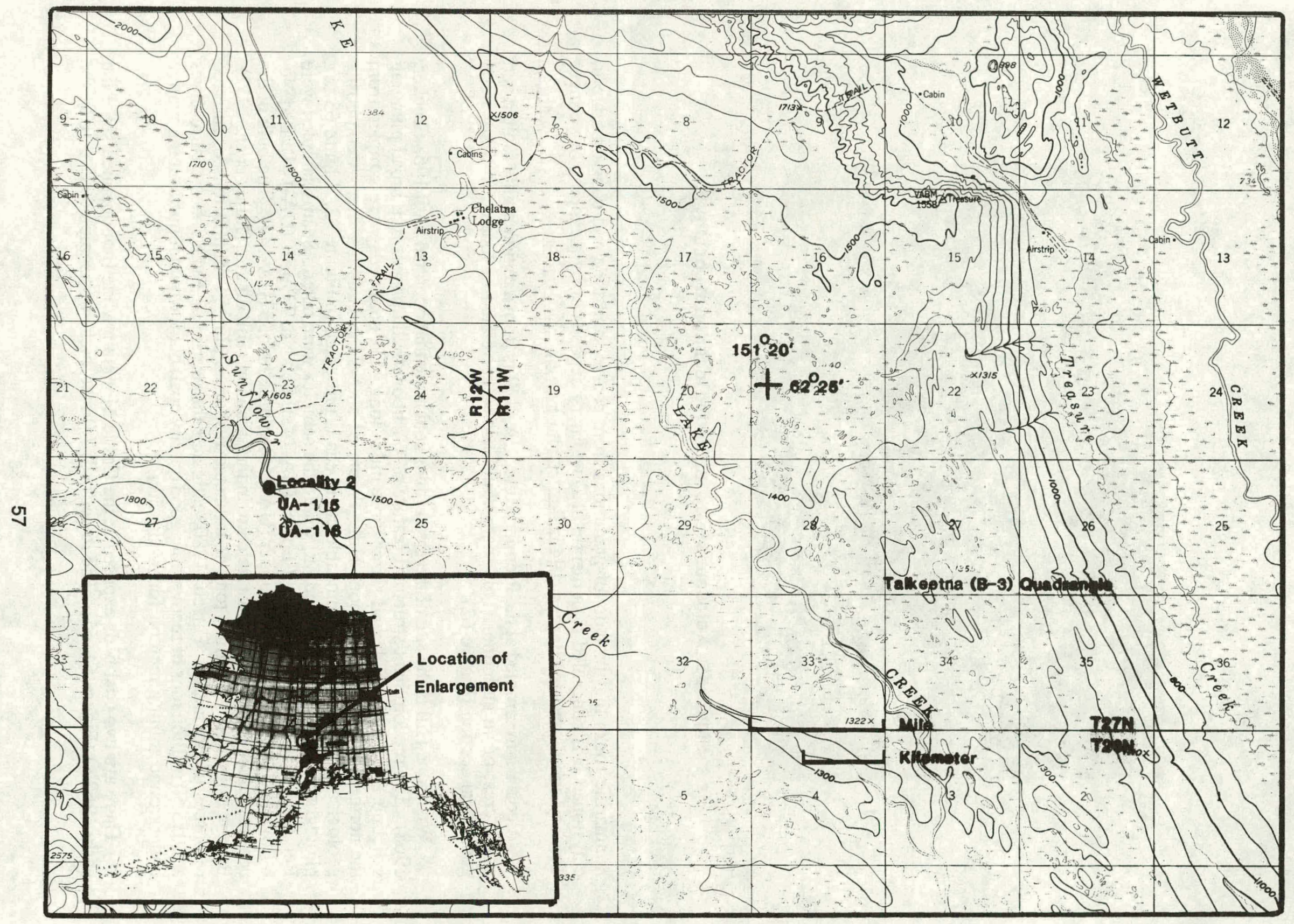

Figure 54. Sampling location in the Yentna field. 


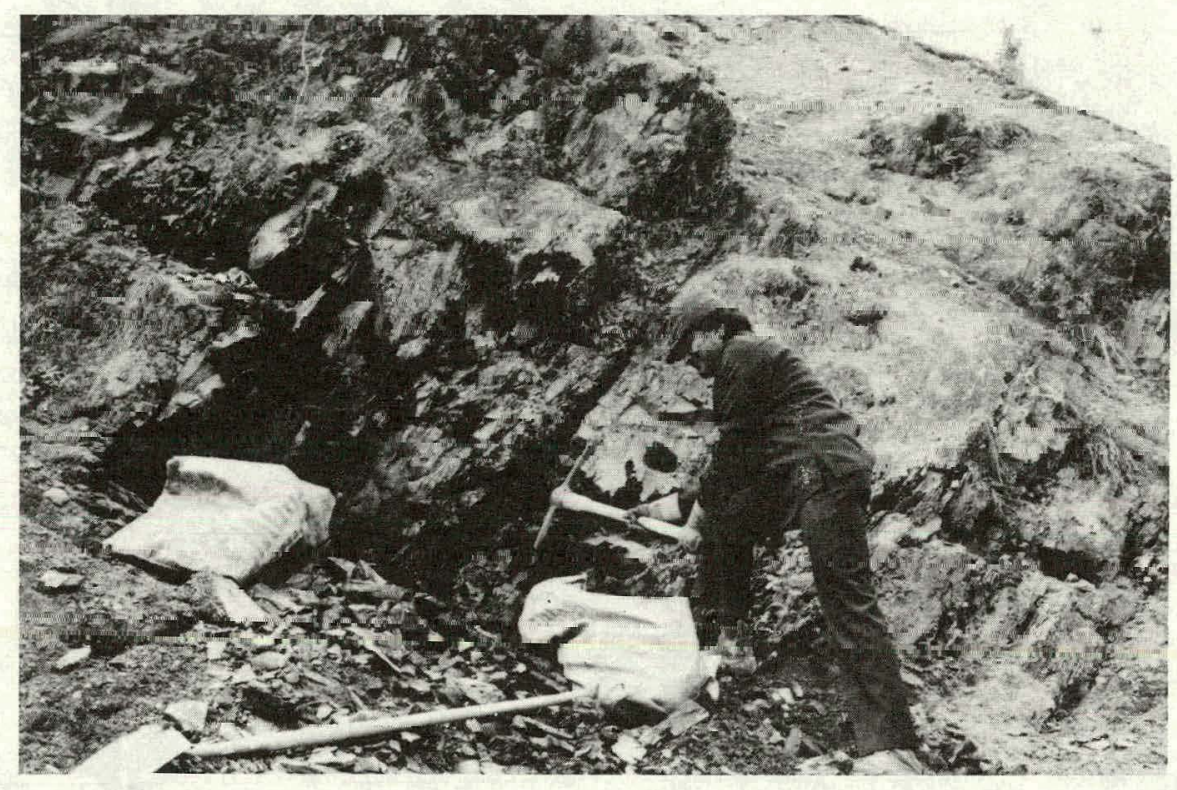

Figure 55. A closeup view of sampling location at Locality 2.

nonmarine rocks that include all gradations from coarse sandstone and conglomerate to claystone. It is concealed by a mantle of Quaternary deposits or by a capping of younger Tertiary conglomerate (Barnes, 1945, Barnes and Payne, 1956).

A coal seam sampled at the Premier Mine (UA-108) is from a region highly faulted and at the crest of an anticline. This seam could not be correlated or located in the general geological section (Figure 62).

Wishbone Hill is the site of the Evan Jones coal mine that operated until 1968 (Tucker; 1968). The predominant structural feature of Wishbone Hill consists of a broad plunging syncline 1-1/2 miles wide and six or more miles long. Six coal beds were sampled from the northeast corner of Wishbone Hill. Figure 61 shows the sampling site. A composite geological column showing mineable coal beds is presented in Figure 62 . Figure 63 is a photograph of the surface mined pit, where the samples were taken. Seams sampled were Bed No. 7 A (UA-142), Bed No. 7 Lower (UA-143), Bed No. 7 Upper (UA-144), Bed No. 6 Lower (UA-145), Bed No.' 6 Upper (UA 146) and Bed No. 5 (UA-147). The bulk of the coal resources of the Matanuska field are in the Wishbone Hill district (Jolley et al., 1952). Barnes estimates 52 million tons of indicated resources plus 54 million tons of inferred resources in the district. Patsch (1980) estimates the remaining Evan Jones coal reserves at 30 to 50 million tons of recoverable good quality coal, but it would require an innovative underground mining method for production.

There are two coal beds exposed at the Castle Mountain Mine (not operated since the early 1960's) (Figure 64, 65). The lower bed, 7.0 feet thick, was sampled (UA-107); the 


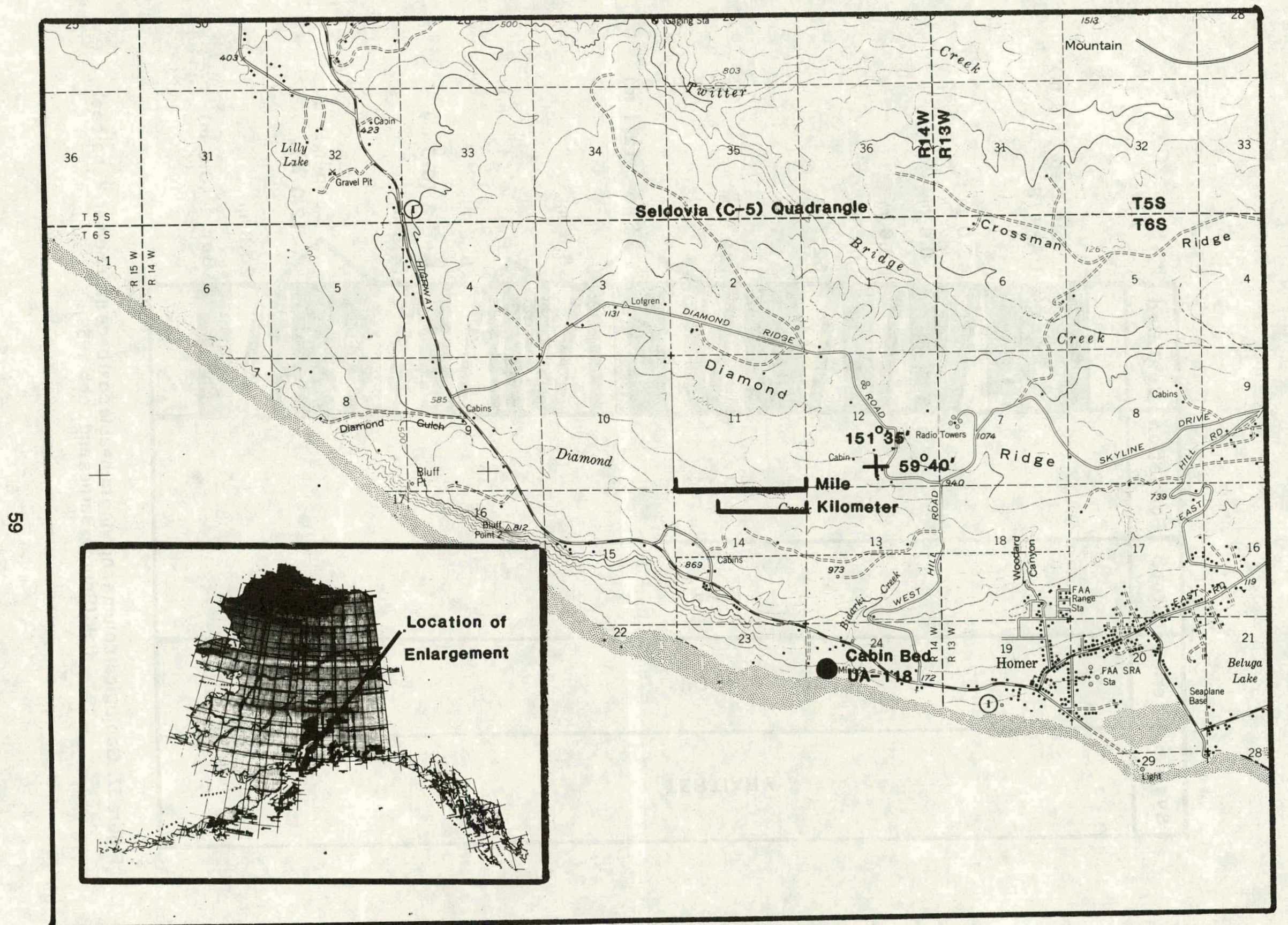

Figure 56. Sampling location in the Kenai field. 


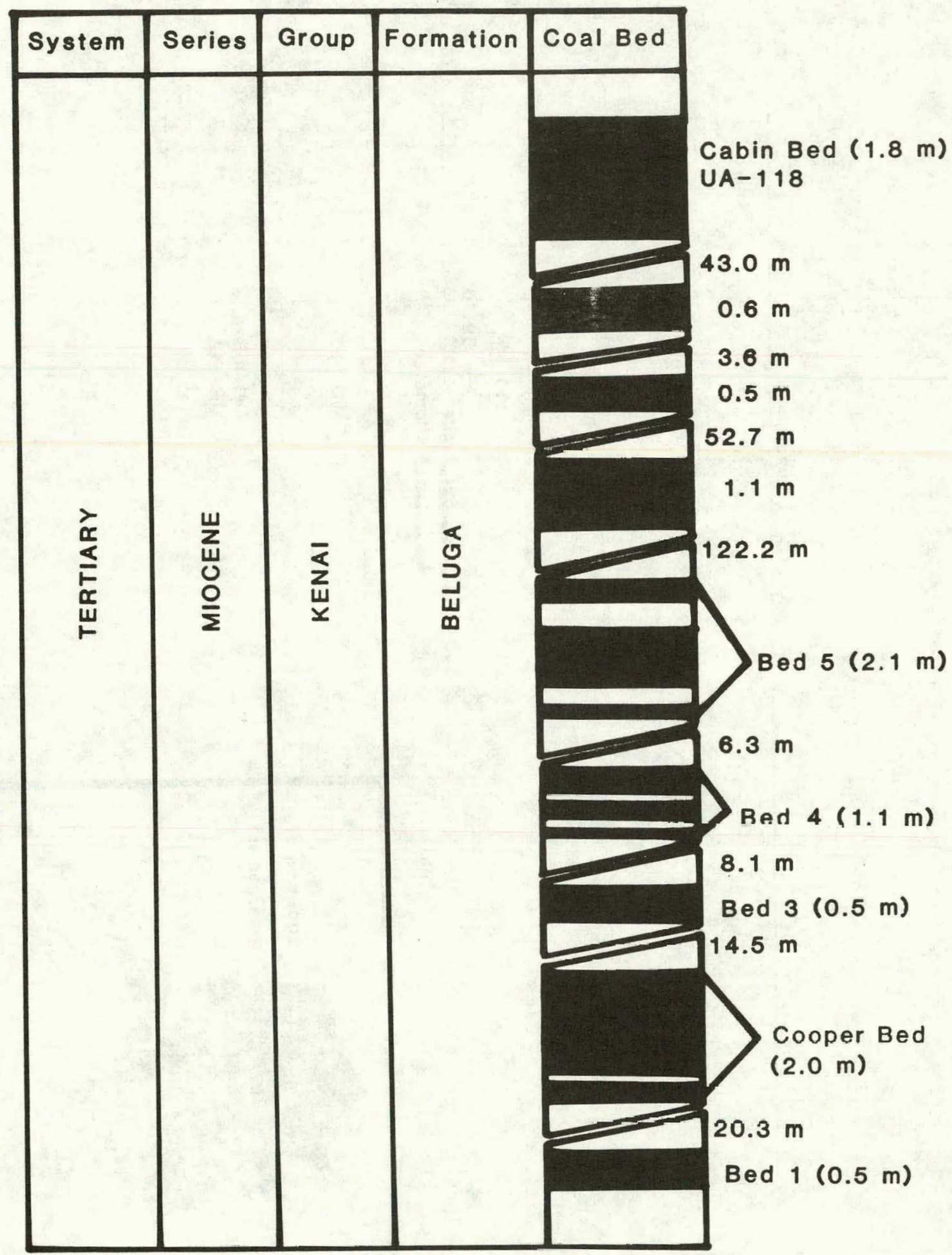

Figure 57. Geological column showing mineable coal beds near Homer, Kenai coal field (Source: Barnes and Cobb, 1959). 


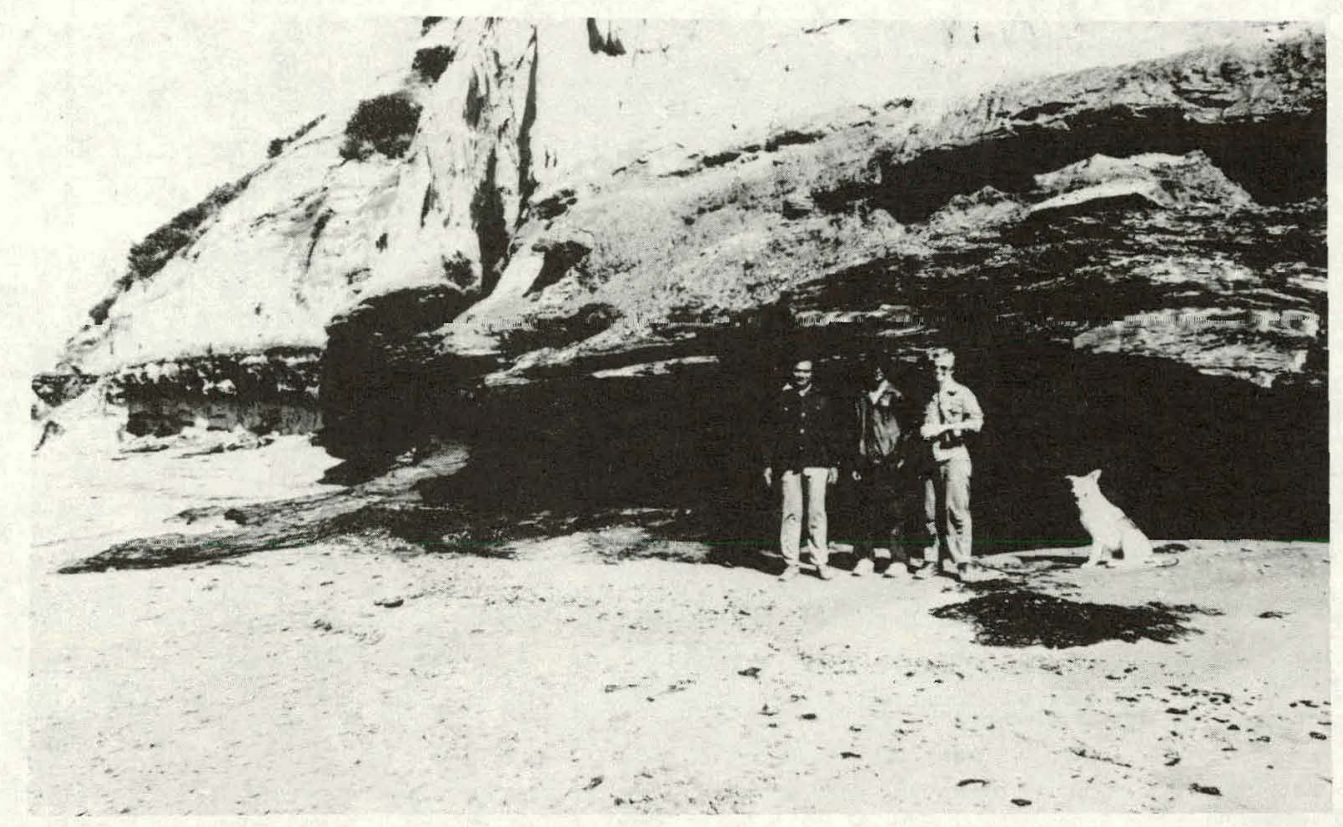

Figure 58. Coal outcrop near NInllchik, with underclays washed out by wave action, forming a natural cave with coal as resistant roof.

upper bed, 5.0 feet thick, was not. Continuity of the coal beds has not been established and the remaining resources of the seams are not known. Complex structure, lack of continuity of coal beds, and widespread igneous intrusions add to the difficulties in estimating the reserves (Barnes, 1962).

\section{Broad Pass}

Broad Pass coal field is located near Broad Pass station, 166 miles south of the Alaska Railroad and Parks Highway. The field may be divided into two basins.

Coal Creek Basin is located on the east side of the Alaska Railroad and lies in an area three miles long and one mile wide (Hopkins, 1951). About 1-1/2 square miles are known to be underlain by coal bearing rocks.

Coal was mined from the basin until the mid 1940's. A sample of the Coal Creek coal bed (UA-111) was collected from an outcrop near the former Coal Creek mine (Figure 66, 67). The Coal Creek coal bed is 8 feet thick and is covered by unconsolidated sediments. The locality can be accessed via an old wagon trail from the Parks Highway. The trail crosses several streams and the access is limited to four-wheel drive vehicles.

The Costello Creek Basin (Wahrhaftig, 1944) is on the west side of the railroad and covers about seven square miles. Coal occurs in Tertiary sequences of sandstone and claystones. There are three mineable coal beds in this basin, i.e. the Dunkle bed ( 5 feet thick), Lower Billie bed (3.4 feet thick) and Upper Billie bed (3.9 feet thick). Coal was mined from this basin until the early 1950's at the Dunkle Mine (Figure 68). Analyses of shipped coal samples 


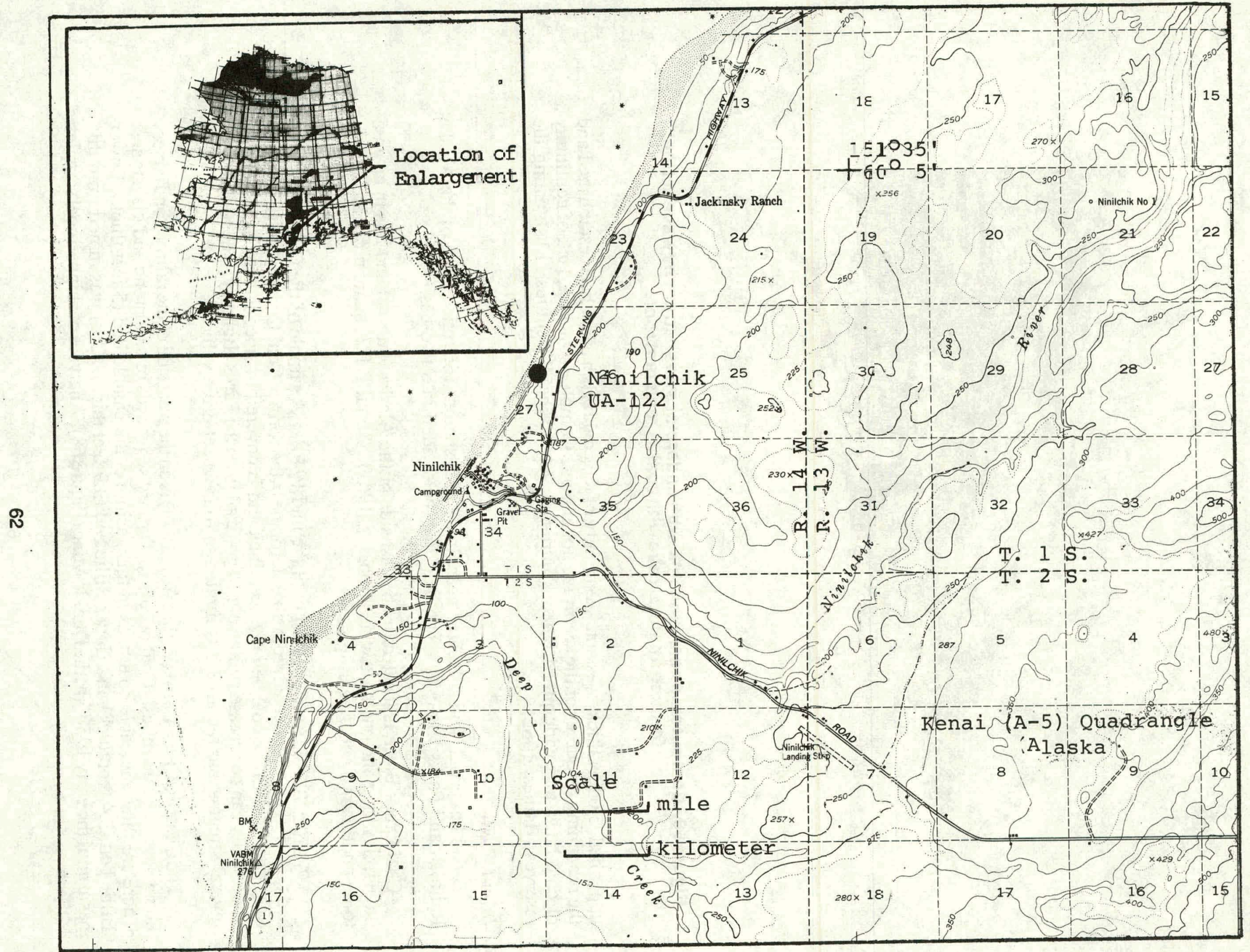

Figure 59. Location of sampling site near Ninilchik, Kenai coal field. 


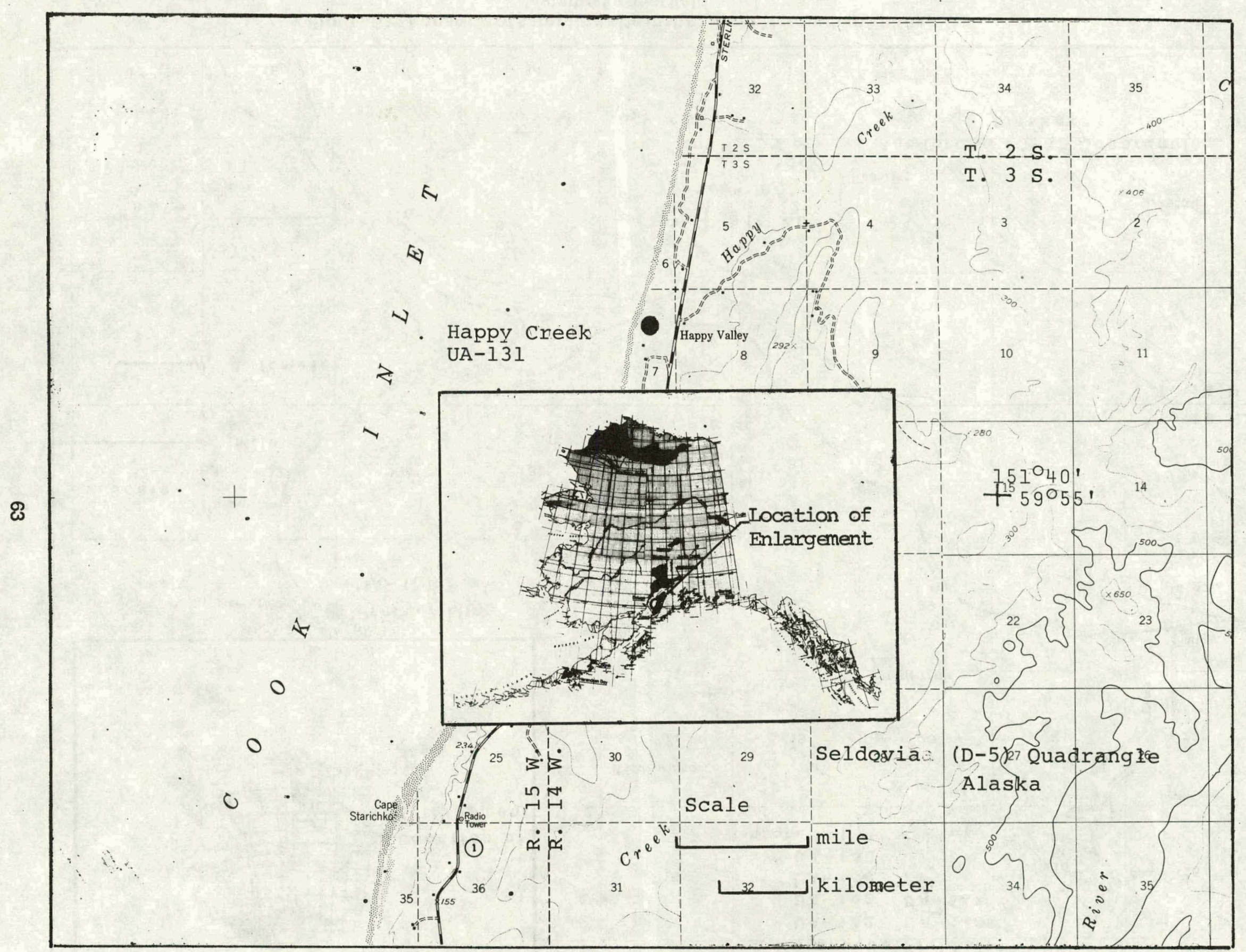

Figure 60. Location of sampling site on Happy Creek, Kenai coal field. 


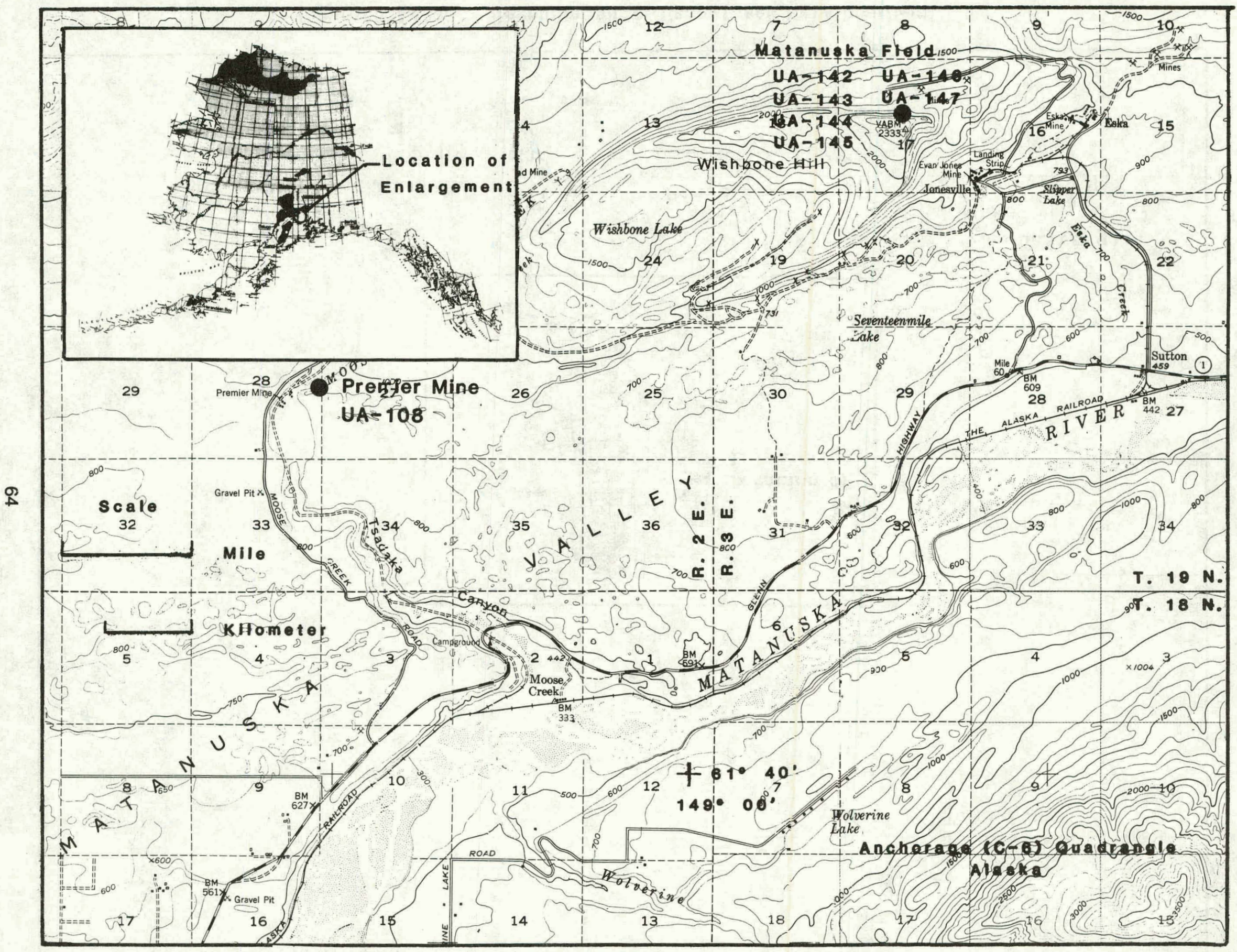

Figure 61. Location of sampling site in the Lower Matanuska Valley, Matanuska coal fleld. 


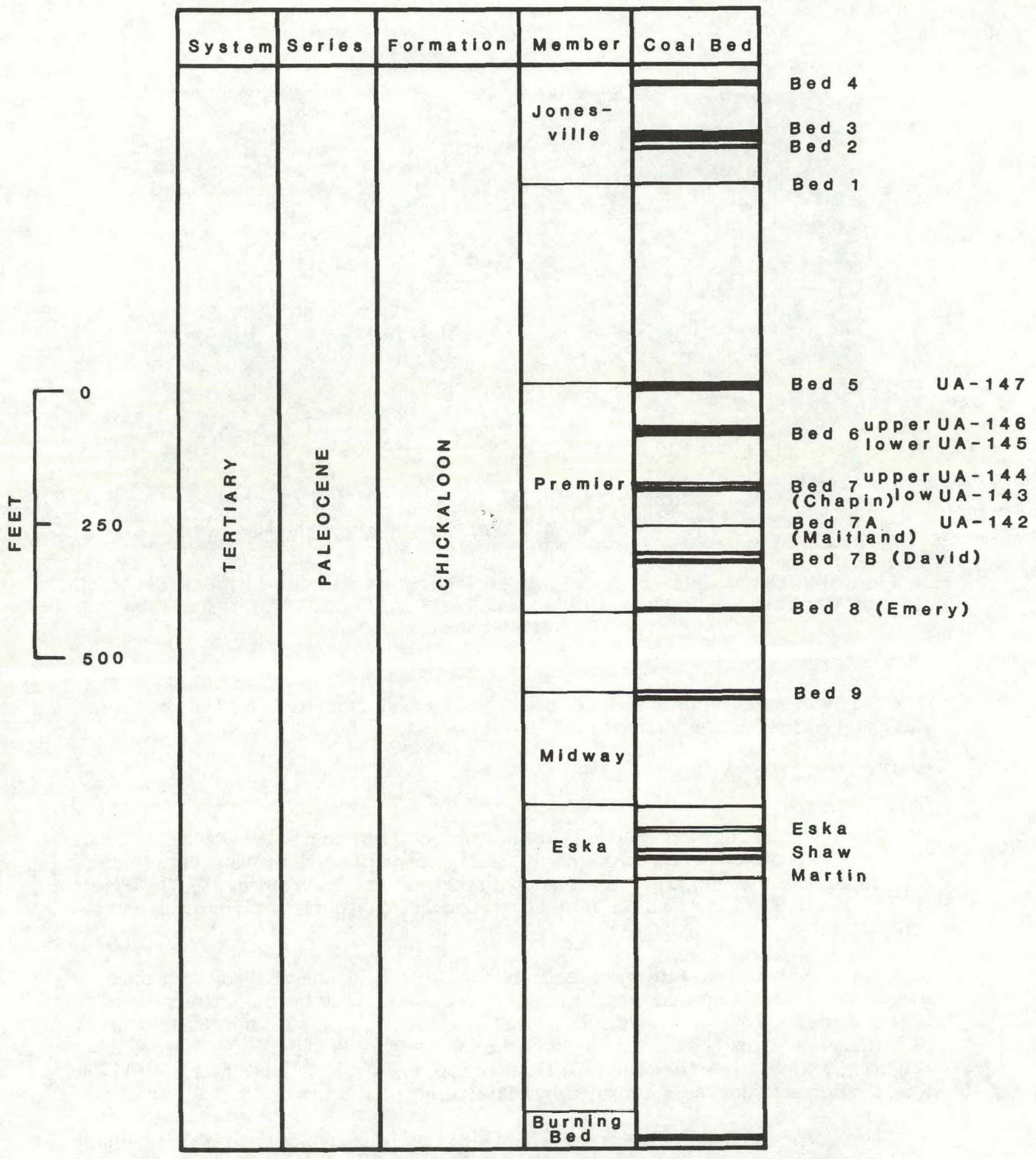

Figure 62. Geological column showing mineable coal beds in the Wishbone Hill District, Matanuska coal field. 


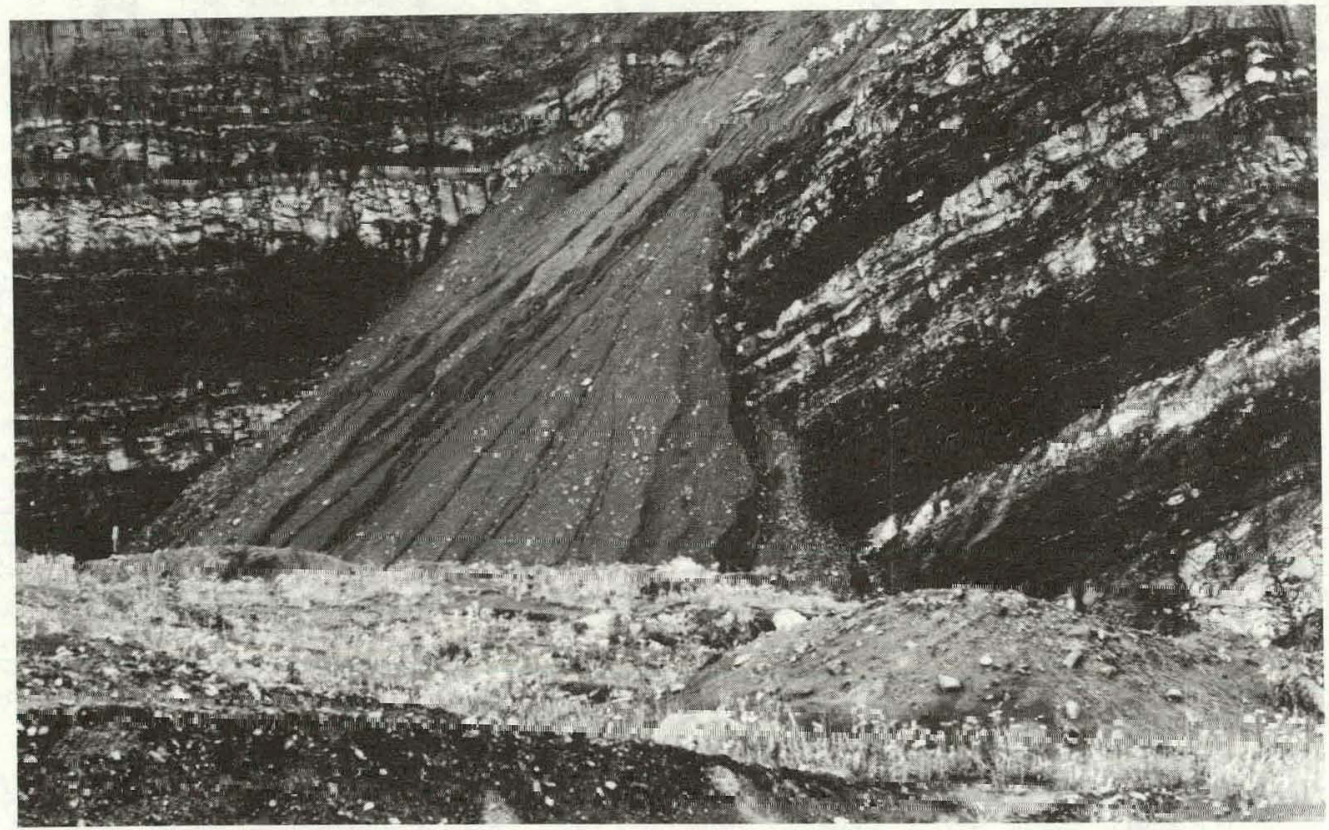

Figure 63. General view of Evan Jones surface mined pit at the northeast corner of Wishbone Hill. Samples UA-142,143,144, 145, 146 and 147 were obtained from this site.

reported by Wahrhaftig indicated the coal to be of subbituminous rank. The Dunkle bed was sampled for this study (UA-123).

\section{SOUTHWEST ALASKA FIELDS}

\section{Little Tonzona}

Occurrences of coal near Farewell were first observed by Brooks (1911) in 1902. Capps (1919) described 20 foot thick coal beds in tertiary nonmarine sedimentary rocks south of Kantishna; however, the Little Tonzona coal bed was first described in 1977 by Player (1976). A sample of this coal bed (UA-112) was collected from an outcrop section of the bed.

Coal beds occur in Tertiary nonmarine sandstone, siltstone and volcanic rocks in widespread isolated exposures north and south of Farewell fault from Big River northeast to Kantishna and beyond (Player, 1976). 'The sampled bed occurs in an isolated exposure of 'l'ertiary nonmarine sedimentary rocks on the suuth west bank of the Little Tonzona River (Figure 69). Beds strike $\mathrm{N} 60^{\circ} \mathrm{E}$ to $\mathrm{N} 70^{\circ} \mathrm{E}$ and dip $55^{\circ}$ to $70^{\circ}$ northwest (Player, 1976). The total stratigraphic thickness measured by Player is about 195 feet.

Subsequent to author's sampling in 1978 of the Little Tonzona Bed coal (UA-112, Figure 69) McIntyre Mines under the direction of Walter Thor conductcd prospecting and geological mapping during the summer of 1980. They identified a strike length of greater than three miles of coal bearing strata bearing a minimum cumulative width of 134 feet of coal beds. During the summer of 1981 they drilled 6 holes and collected a total of 147 samples of coal 


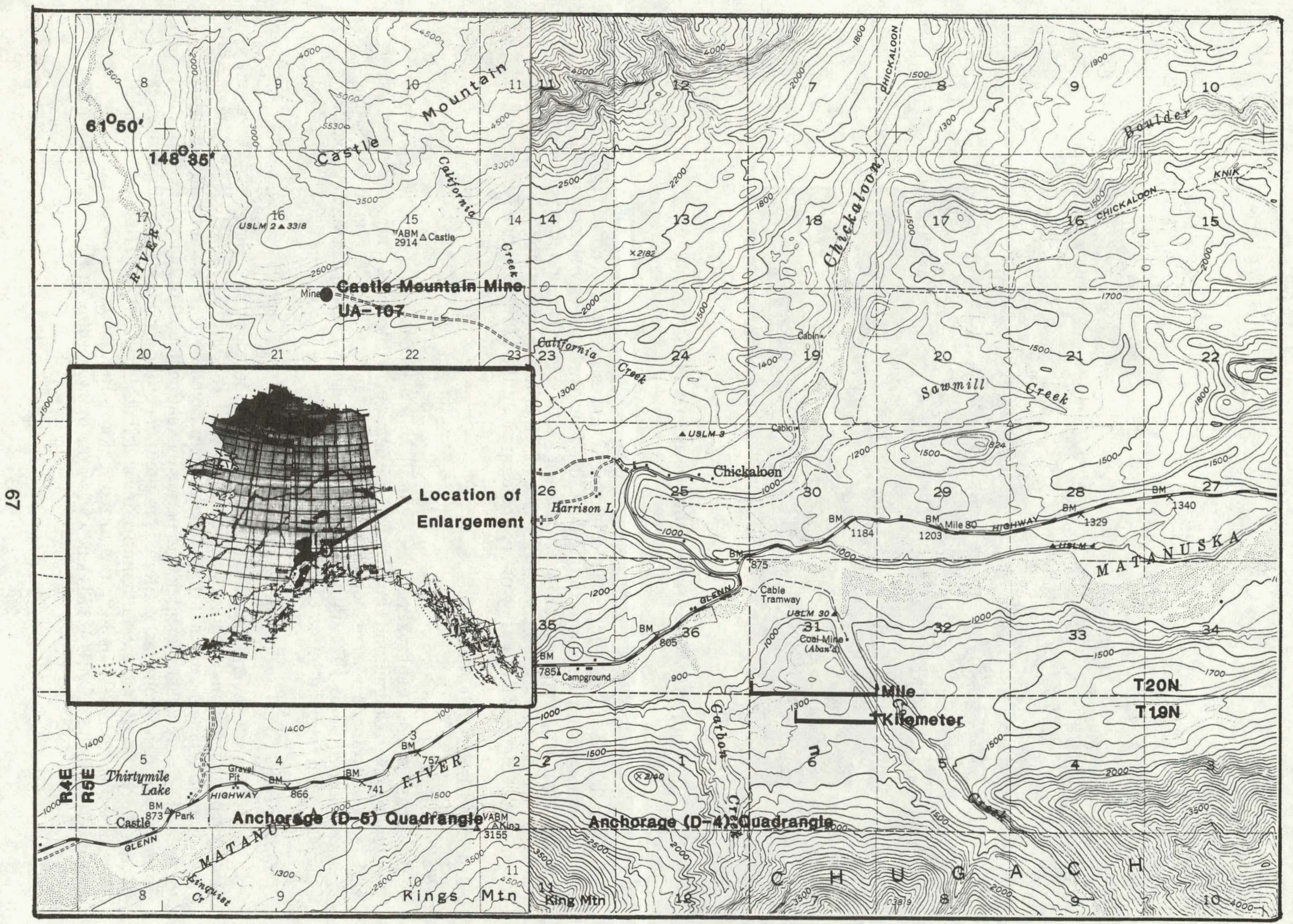

Figure 64. Location of sampling site In the Upper Matanuska Valley, Matanuska coalfield. 


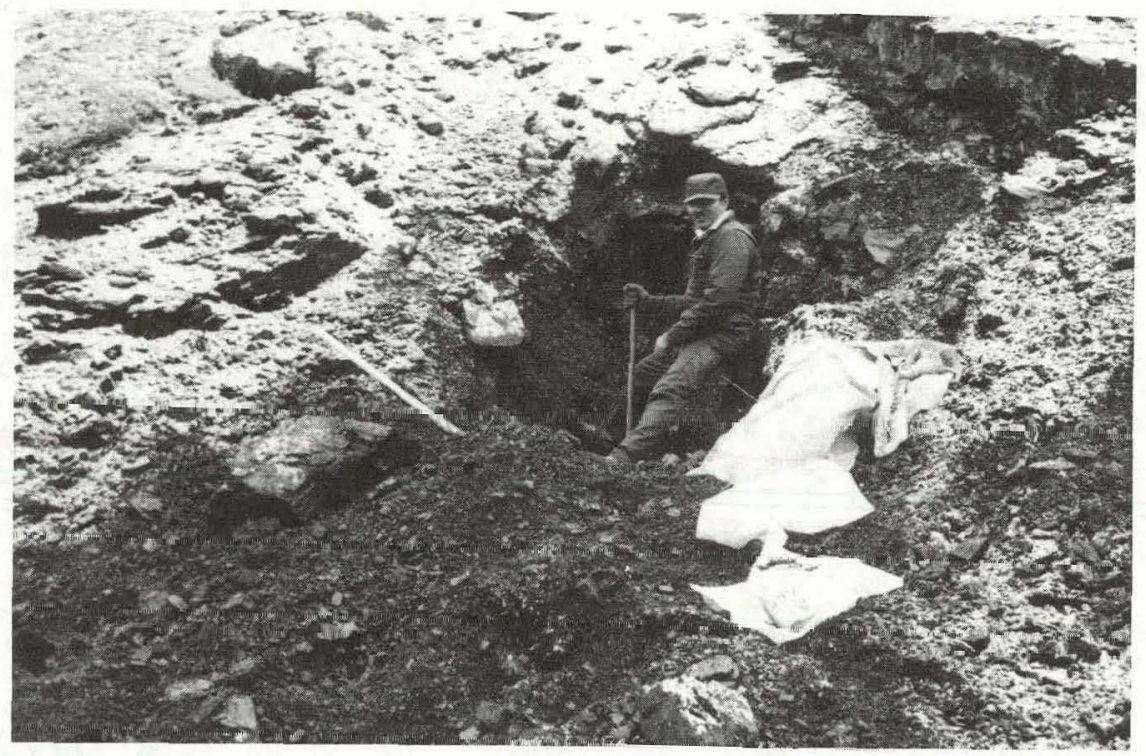

Figure 65. View of sampling site at Castle Mountain mine.

with a core-length of 2 feet or greater. Figure 70 is a crossection by Thorpe (1982) and is an interpretation from the outcrop along the Little Tonzona River as well as two drill holes located close to the river bank at two different angles. Rao (1981) reported washability and raw coal analyses of these core samples. One of the drill holes measured as much as 173 feet of coal. Figure 71 is a view of coal outcrop along the Little Tonzona River.

\section{ALASKA PENINSULAFIELDS \\ Chignik}

Coal has been reported at several localities in the Alaska Peninsula, and actually mined at Herendeen Bay, Chignik and Unga Island. The uncorrelated bed coal sample for this study was collected from the mine tunnel of the Chignik River mine (UA-136, Figure 72, 73) that operated from 1893 to 1911 , providing fuel for the nearby Alaska Packers Association Cannery. Coal is found in the Chignik formation of Upper Cretaceous age (Figure 74).

\section{Herendeen Bay}

Coal is known at several localities in the vicinity of Herendeen Bay (Gates, 1944). Paige (1906) reports that mining and development between 1890 and 1898 included 6 tunnels ranging up to 205 feet long and these tunnels were caved by 1905 when Paige examined the area. There are not sufficient data to permit evaluation of coal resources. Gates (1944) estimates 5 to 10 million tons of inferred resources under the most favorable circumstances of continuity of beds into the north limb of the syncline. Cornwell and Triplehorn sampled several seams from various locations in the region. The uncorrelated bed coal sample collected for washability (UA-138) study was from the west shore of Herendeen Bay, near 


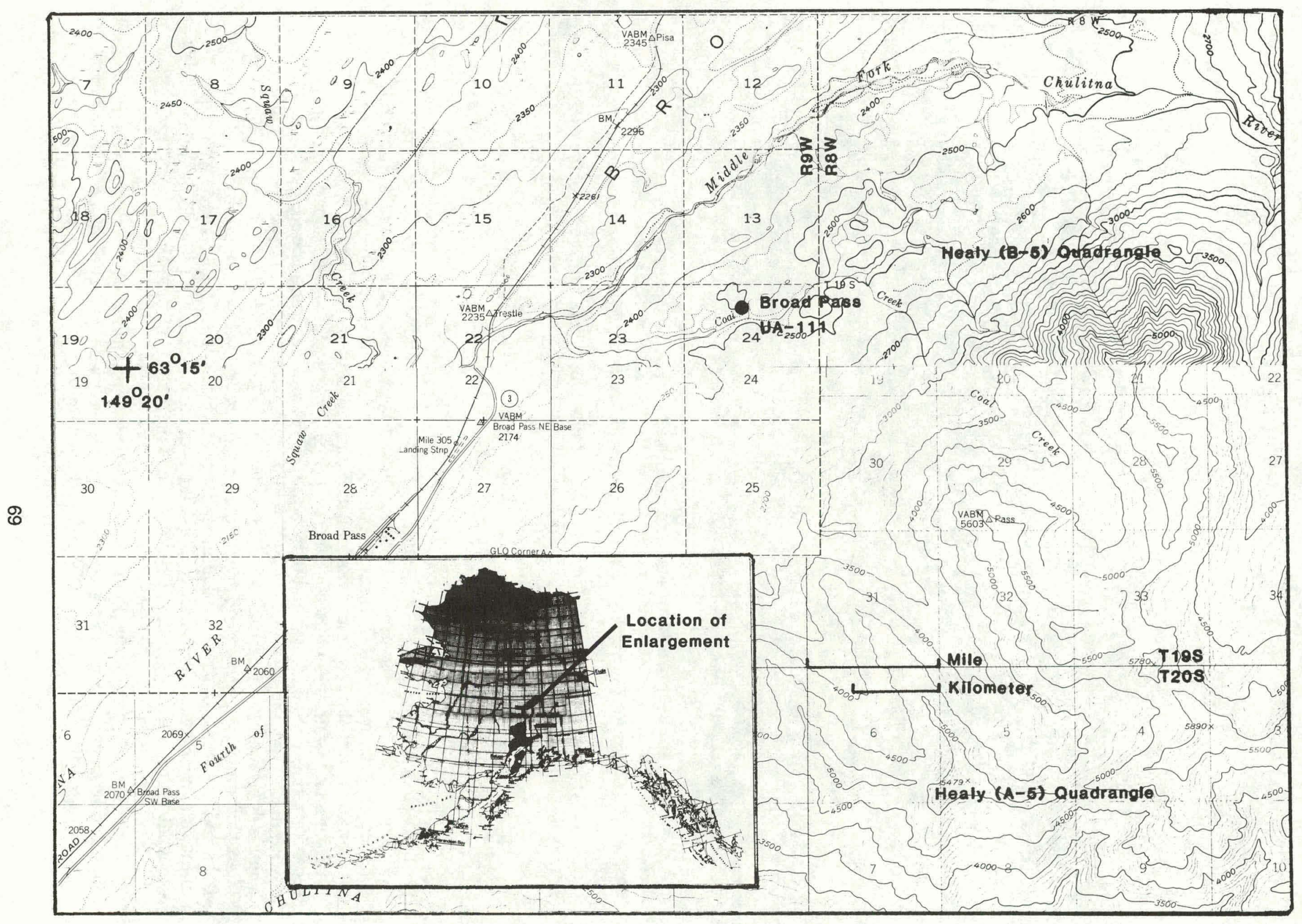

Figure 66. Sampling location in the Broad Pass field. 


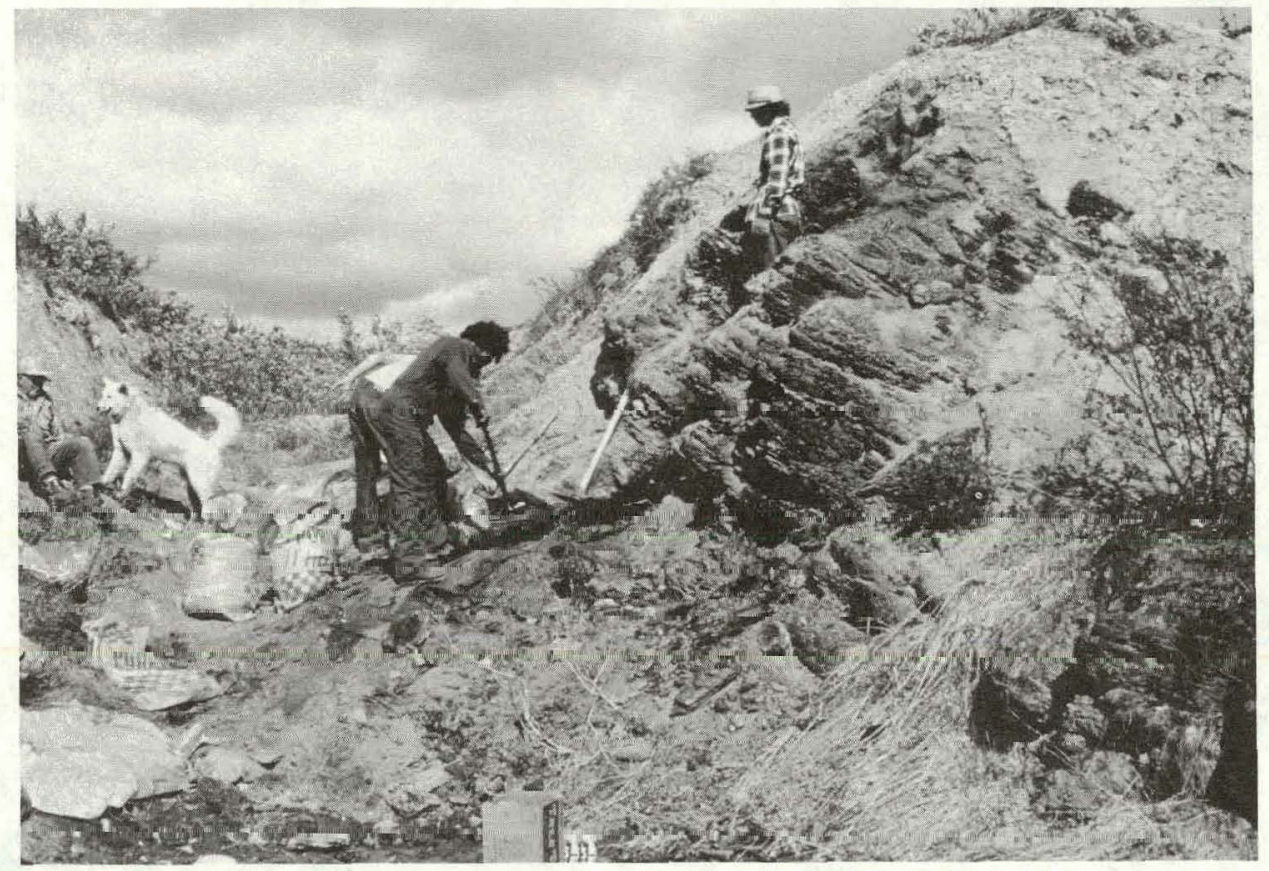

Figure 67. View of sampling site on Coal Creek.

Coal Point (Figure 75,76). Figure 74 shows the correlation of Cretaceous rocks of the Alaska Peninsula. The exact age of the formation in which coal occurs is uncertain.

\section{LABORATORYPROCEDURES}

This investigation closely followed the laboratory procedures described by Cavallaro et al. (1976) and described by the authors in Phase I (Rao and Wolff, 1978). Figure 77 is a flowsheet of procedures used in the laboratory for processing the samples. Raw coal samples were crushed to $1-1 / 2$ inches, $3 / 8$ inch, and 14 mesh sizes. Minus 100 mesh material was removed from the 1-1/2 inches and $3 / 8$ inch crushed samples, leaving the coarse fraction for float-sink testing in 60 liter containers. 14 mesh x 0 samples were separated in glass separatory flasks joined by ground taper joints. Float-sink separations were made at 1.30, 1.40 and 1.60 specific gravities, using perchlorethylene-naptha mixtures as heavy liquid. 'The air dried products were first crushed in a hammer mill to 14 mesh and pulverized to 60 mesh for analysis. Proximate and ultimate analyses of raw coals are presented in Table I. Table II shows Hardgrove Grindability Indexes and F.S.I. of raw coals. The concentration of major elements and the fusibility of ash are presented in Table III. Fusibility of ash of raw coal samples under oxidizing atmosphere is presented in Table IV.

For fine coal washability (Figure 78), air dried 14 mesh raw coal samples were first pulverized in a hammer mill to 65 mesh. A high speed model pulvette pulverizer hammer mill was used for finer grinding. With this pulverizer, use of 0.013 " slotted screen gave 


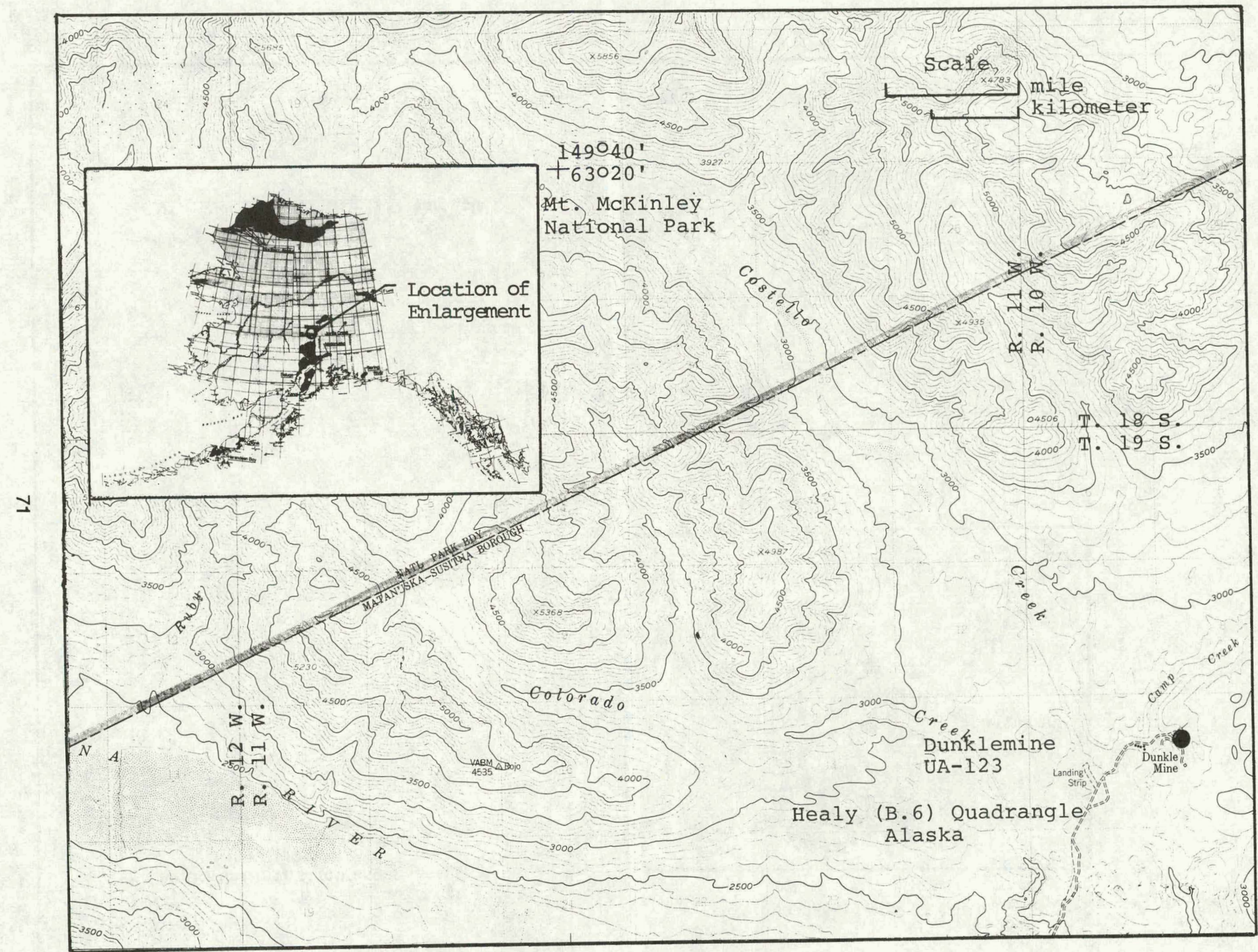

Figure 68. Location of sampling site at the Dunkle mine, Broad Pass coal field. 


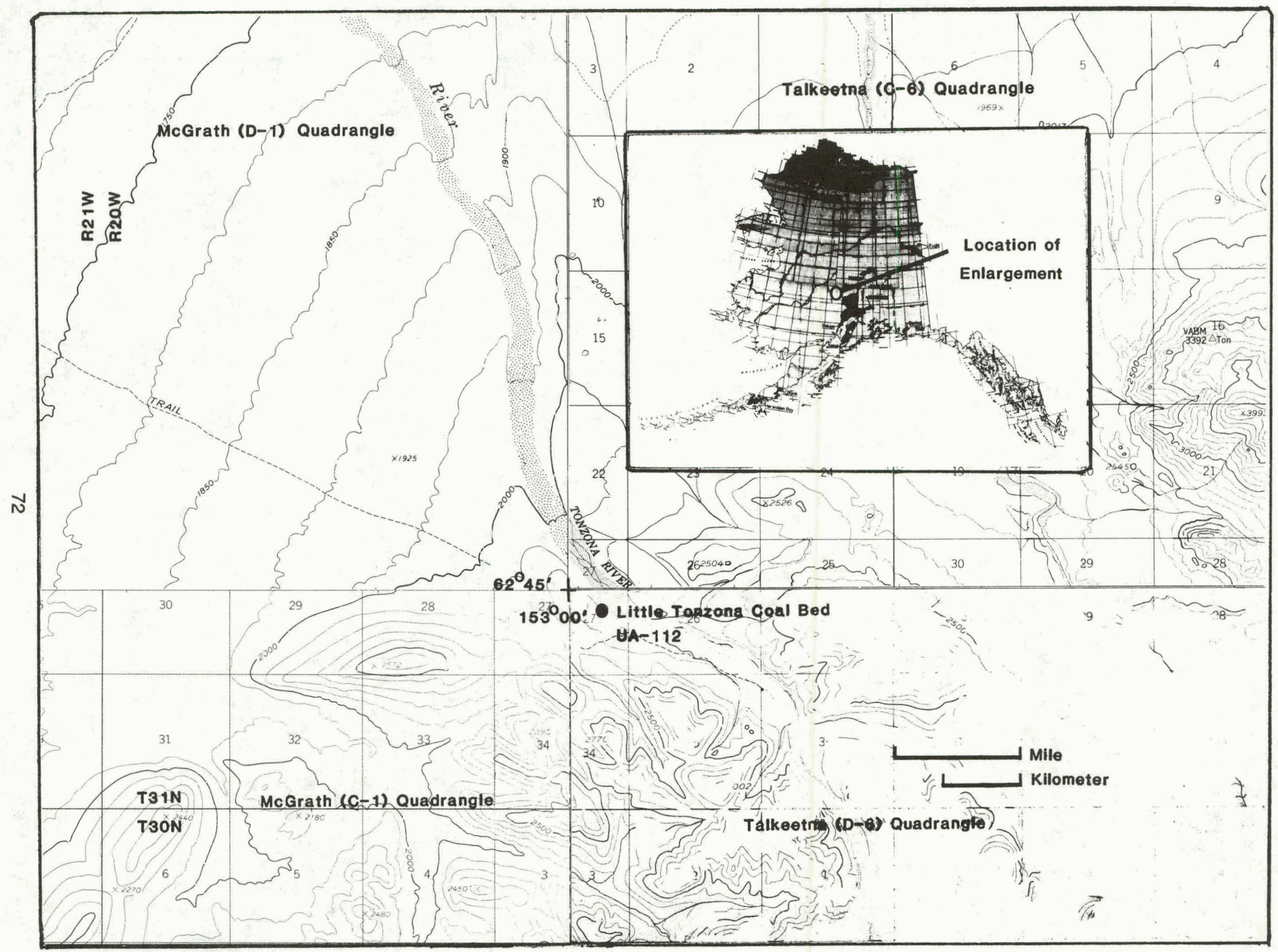

Figure 69. Sampling location of Little Tonzona field. 


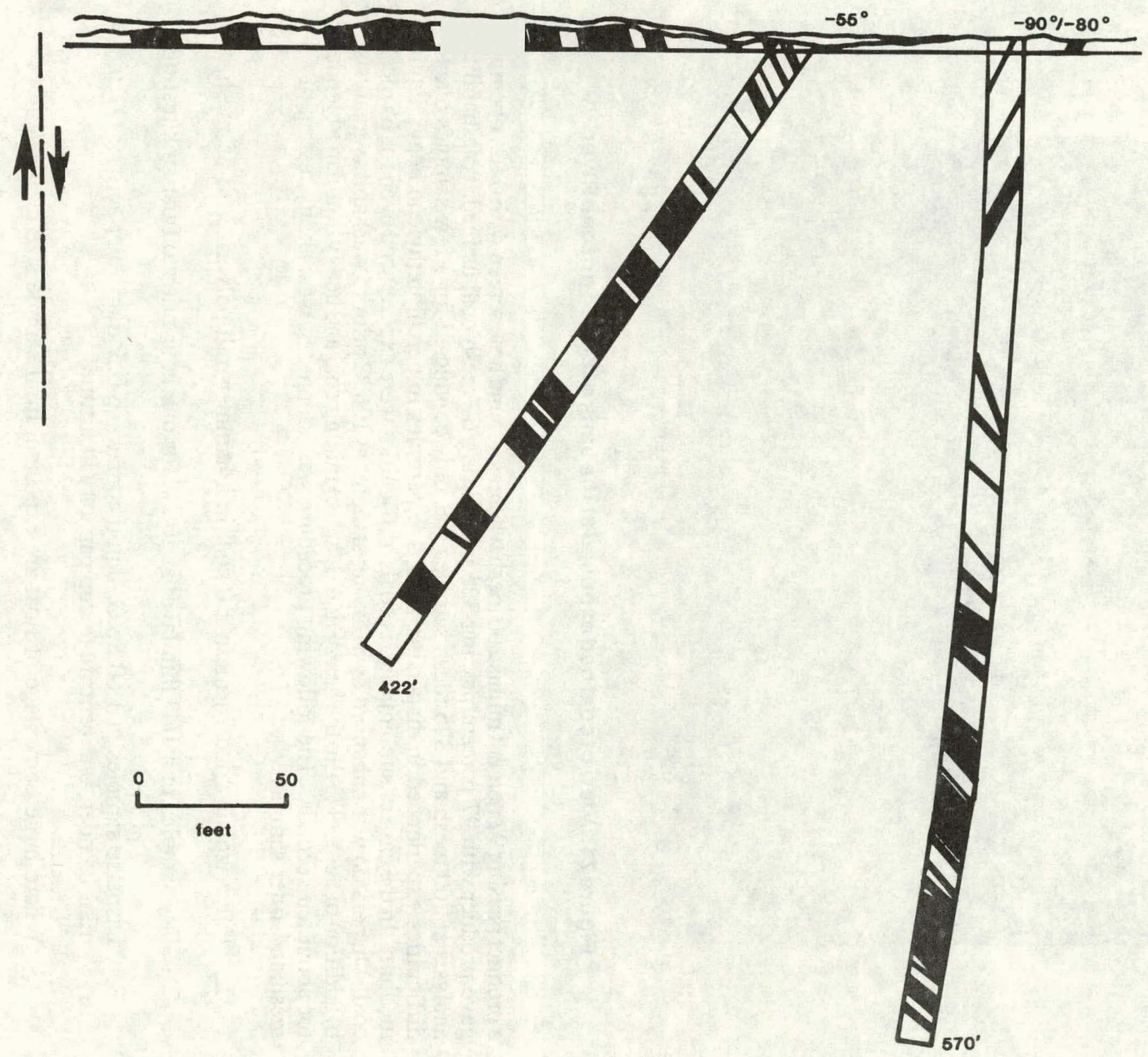

Figure 70. Geological column showing coal exposed along the river as well as two drill holes recorded adjacent to the outcrop. 


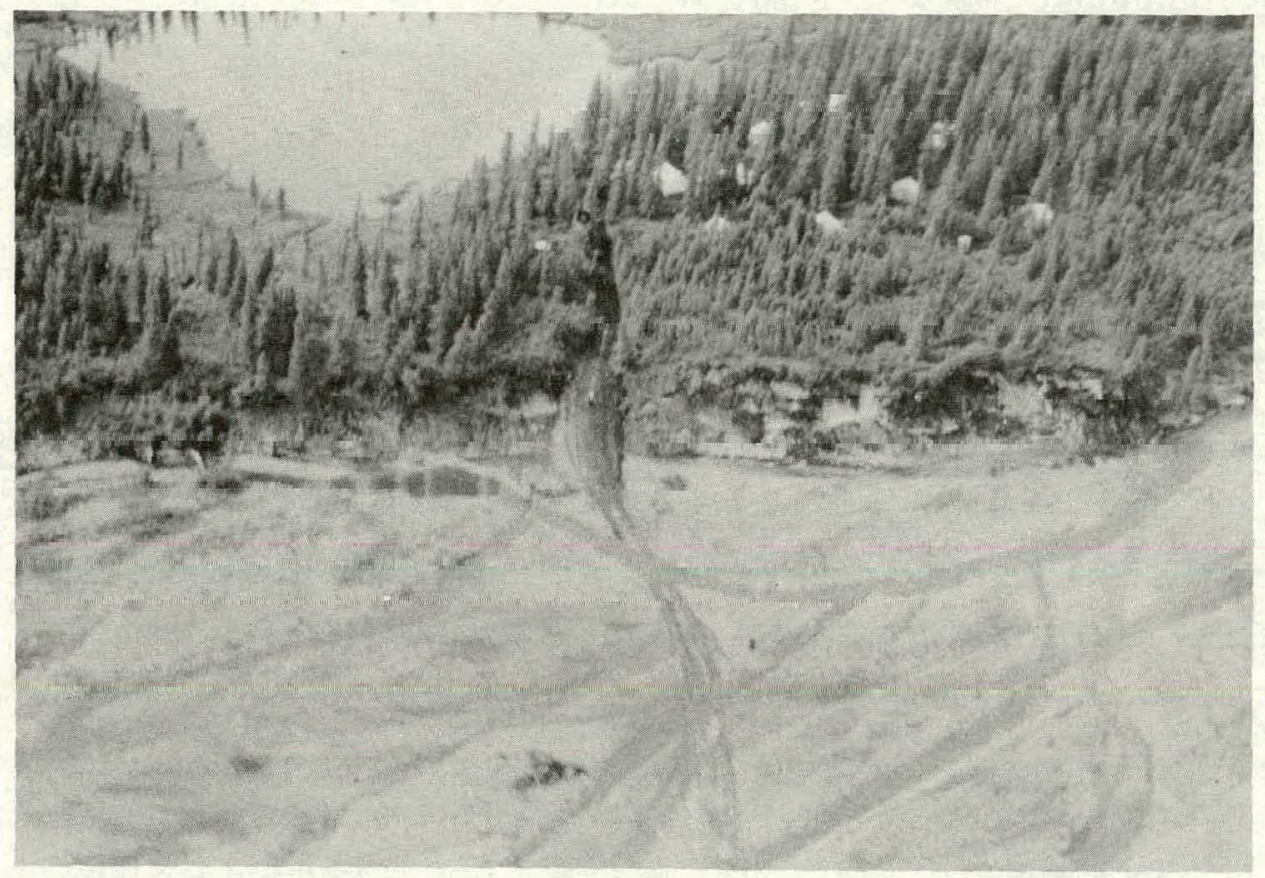

Figure 71. View of coal bed exposed at the bank of Little Tonzona River.

a product passing 97 percent minus 200 mesh whereas a round hole screen with 0.02 " opening gave product with 97 percent passing 325 mesh using 65 mesh coal as feed. Washability analysis at 200 mesh and 325 mesh samples was only conducted for a few samples due to difficulties experienced in dispersing such fine particles in perchlorethylene heavy liquid medium. In the case of subbituminous coals, difficulties were experienced even for 65 mesh coal. Dispersion was enhanced by a) drying samples at $106^{\circ} \mathrm{C}$ prior to washability analysis; b) addition of aerosol OT to the heavy liquid; and c) mixing coal and heavy liquid in a blender for about ten seconds. The following procedure was adopted in washability testing of 65 mesh and finer samples.

1. Pulverize air dried 14 mesh $\mathrm{x} 0 \mathrm{coal}$ in a hammer mill pulverizer to 65 mesh.

2. Dry samples in a $1 / 4^{\prime \prime}$ thin layer at $106^{\circ} \mathrm{C}$ for one hour prior to float-sink testing.

3. Disperse samples in $1.60 \mathrm{Sp} . \mathrm{G}$. liquid containing 0.5 grams/liter aerosol OT in a mini-blender, one centrifuge cup capacity at a time.

4. Where large percentage of float are expected, limit sample size to $10 \mathrm{~g} / \mathrm{cup}$.

5. Centrifuge for 20 minutes at 1500 RPM.

6. Filter floats and sinks, dry sinks.

7. Rinse floats with 1.40 Sp.G. liquid. 


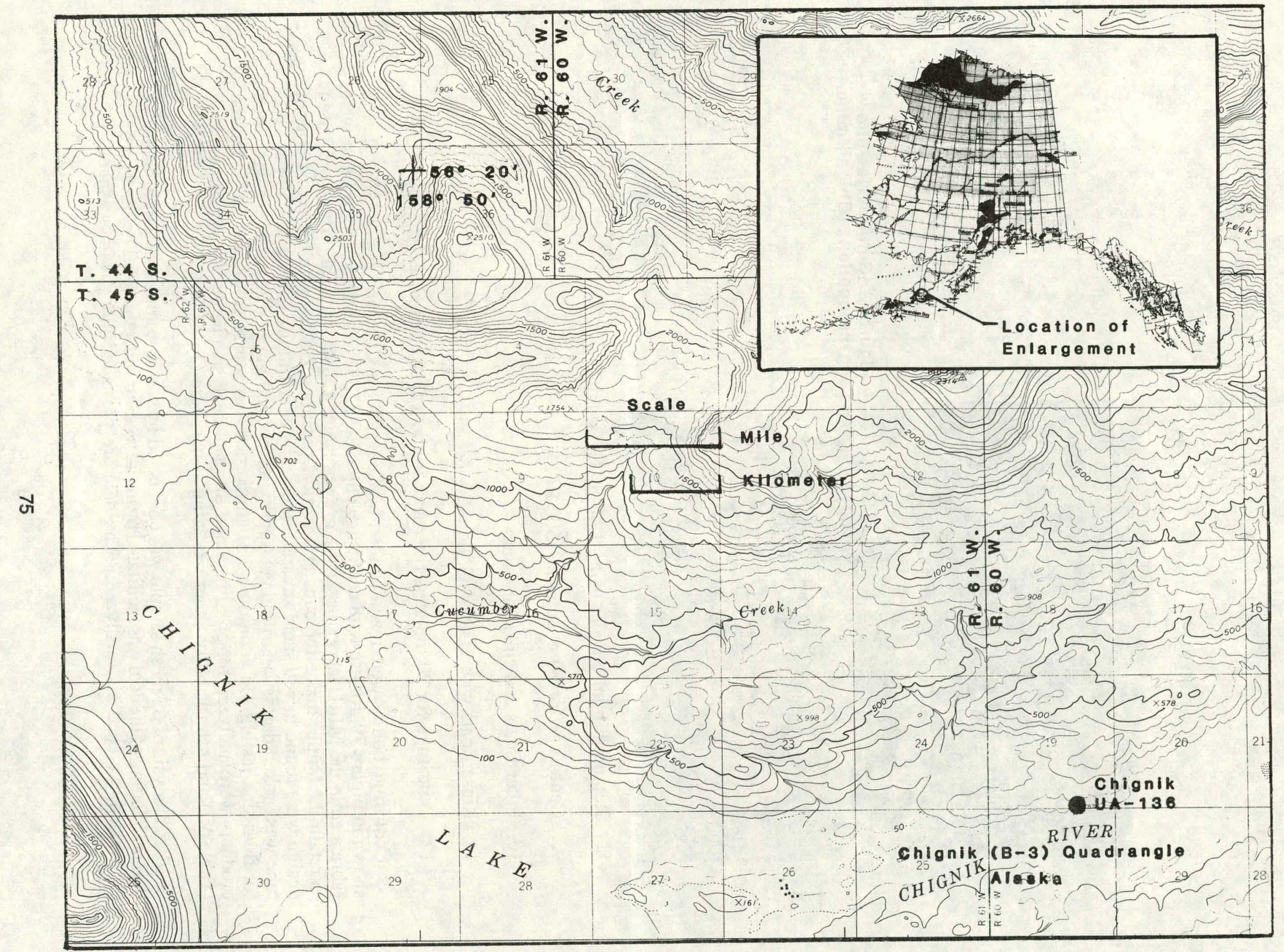

Figure 72. Location of sampling site in the Chignik field. 


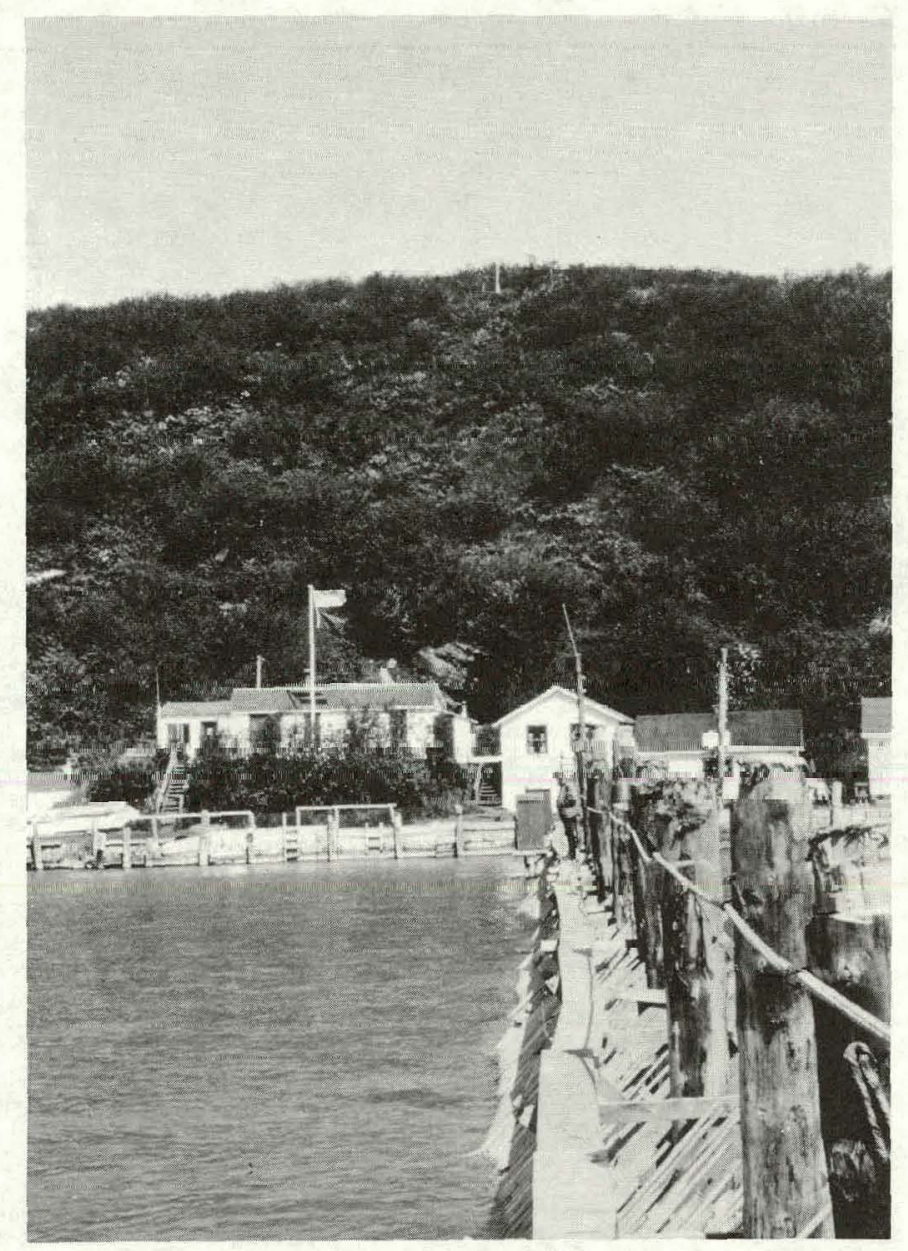

Figure 73. General vicw showing the location of Chignik mine.

8. Repulp in mini-blender using 1.40 Sp.G. liquid.

9. Centrifuge for 20 minutes at 1500 RPM.

10. Filter floats and sinks, dry sinks.

11. Rinse floats with 1.30 Sp.G. liquid.

12. Centrifuge for 20 minutes, filter and dry both floats and sinks.

Centrifuge bottles were manufactured by Kontes Gilass Company as per MIRL design shown in Figure 79, for use with centrifuge cups IEC-3535 without dome. Cushions were fabricated in the MIRL laboratory using tire retreading rubber material. Rings were used to retain the bottles inside the cups in a vertical position. Bottles with the round bottom design were found to withstand stresses induced by centrifuging quite well. Not a single tube was broken during centrifuging. Approximately $250 \mathrm{gm}$ of dried samples were used for float-sink testing. In addition a $250 \mathrm{gm}$ portion was separated at $1.60 \mathrm{Sp}$.G. and the products were analyzed for proximate and ultimate analysis (Table V), ash composition (Table VI) and ash fusibility under oxidizing atmosphere (Table VII ).

Size analysis of 65 mesh sample was conducted by wet screening using a Ro-top sieve shaker. Wetting of the coal was facilitated by initial wetting with ethanol. The sized products were dried, weighed and analyzed. The data are presented along with washability in thetables. 


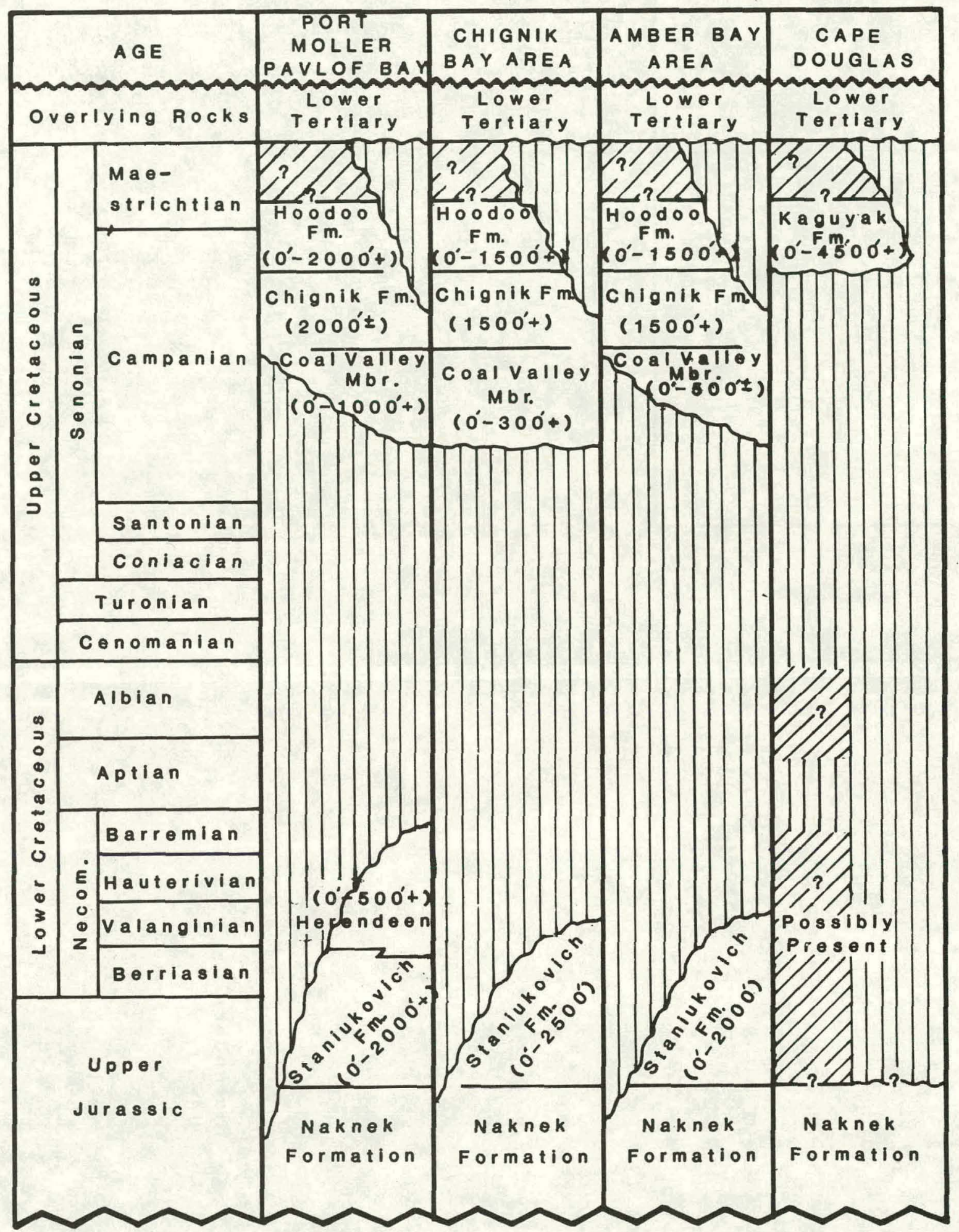

Figure 74. Correlation chart of Cretaceous rocks of Alaska Peninsula. 


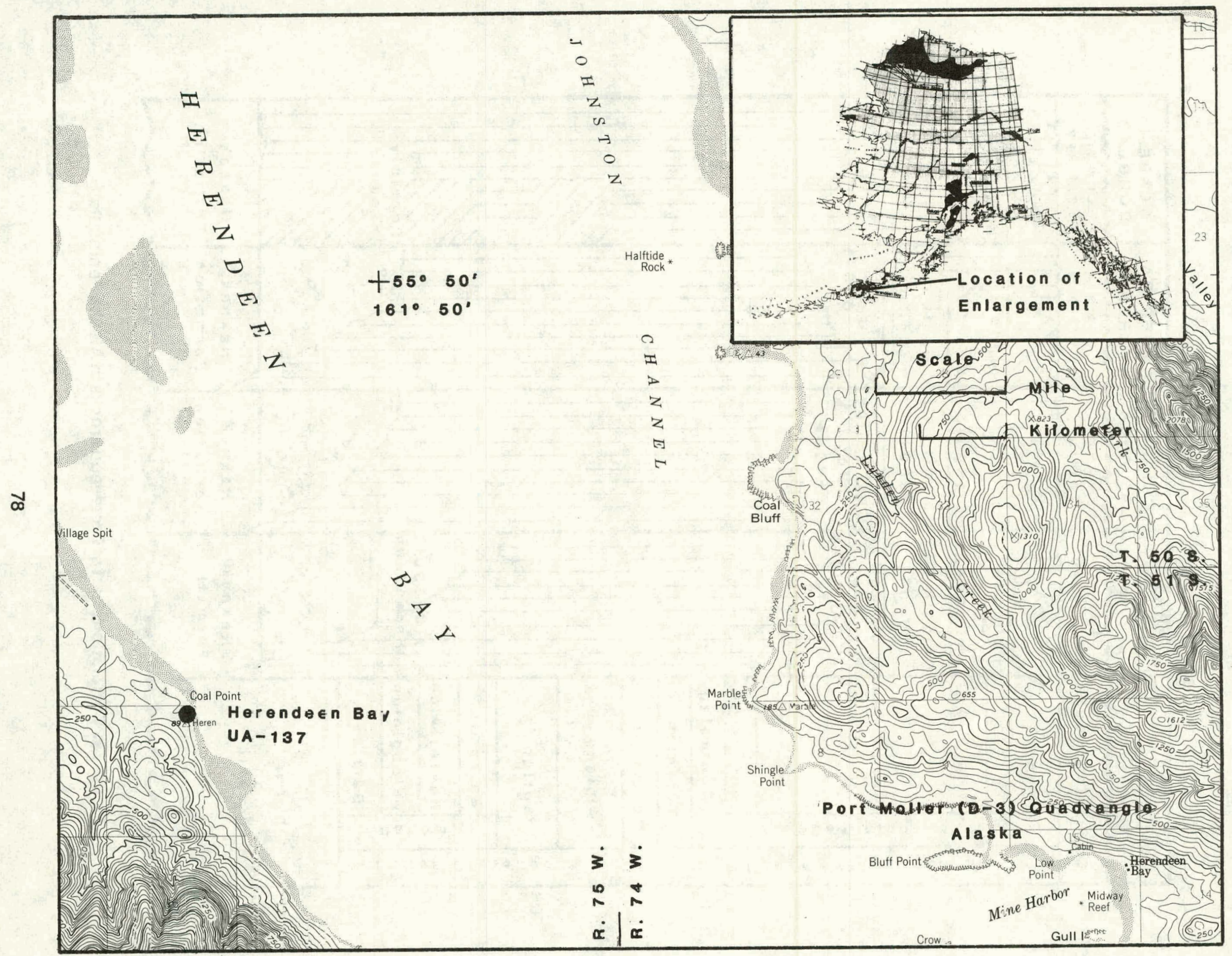

Figure 75. Location of sampling site at the Herendeen Bay field. 


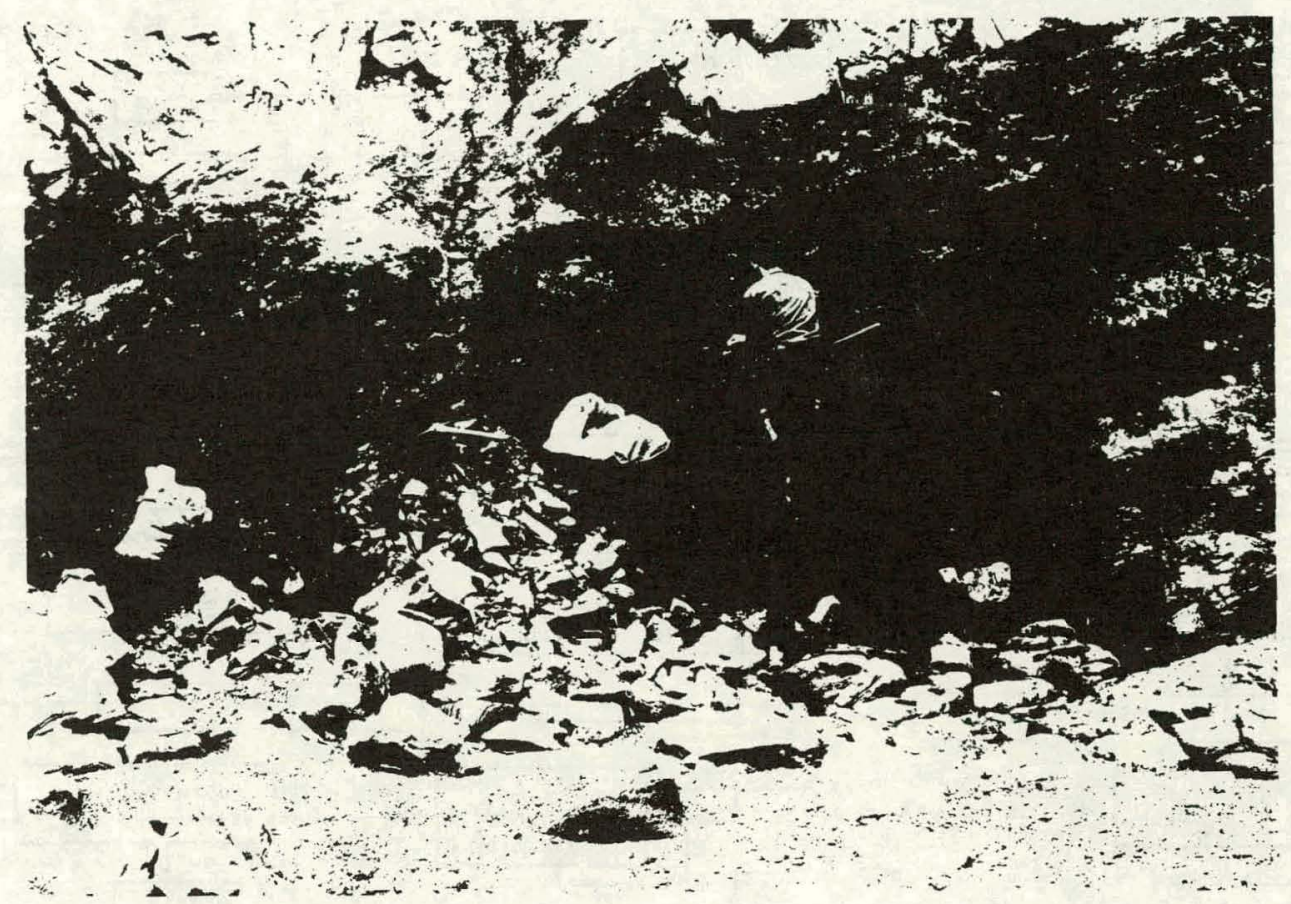

Figure 76. View of coalbed exposed at Coal Point on Herendeen Bay.

All float-sink and size analysis products of 65 mesh coal were analyzed for ash, moisture, heating value, total sulfur and pyritic sulfur. All data were calculated on a moisture free basis. The American Society for Testing and Materials (ASTM) standard procedures were used for all analyses.

\section{INTERPRETATION OF WASHABILITY DATA}

Tables VIII through LVII show washability data for the fifty samples processed. The tables show weight-percent and heating value distribution, ash, heating value, pyritic sulfur, and total sulfur on a moisture free basis for the various gravimetric fractions as well as values for cumulated floats. The quality of the float at any of the three densities can be directly read from the tables. The tables also show cumulative sink weight-percent and ash content that may be expected at any of the three densities.

These tables also show size distribution of samples pulverized to 65 mesh along with weight-percent distribution, ash, heating value, pyritic sulfur and total sulfur for individual size fractions as well as cumulative on size retained basis.

\section{NORTHERN ALASKA COAL FIELDS}

Coal bed No. 7 was sampled in a trench made by the U.S. Bureau of Mines in 1964 by bulldozing. The sample is equivalent to sample 21 of the U.S. Bureau of Mines (Warfield and Boley, 1969) with the exception that the entire seam is sampled and no partings were 


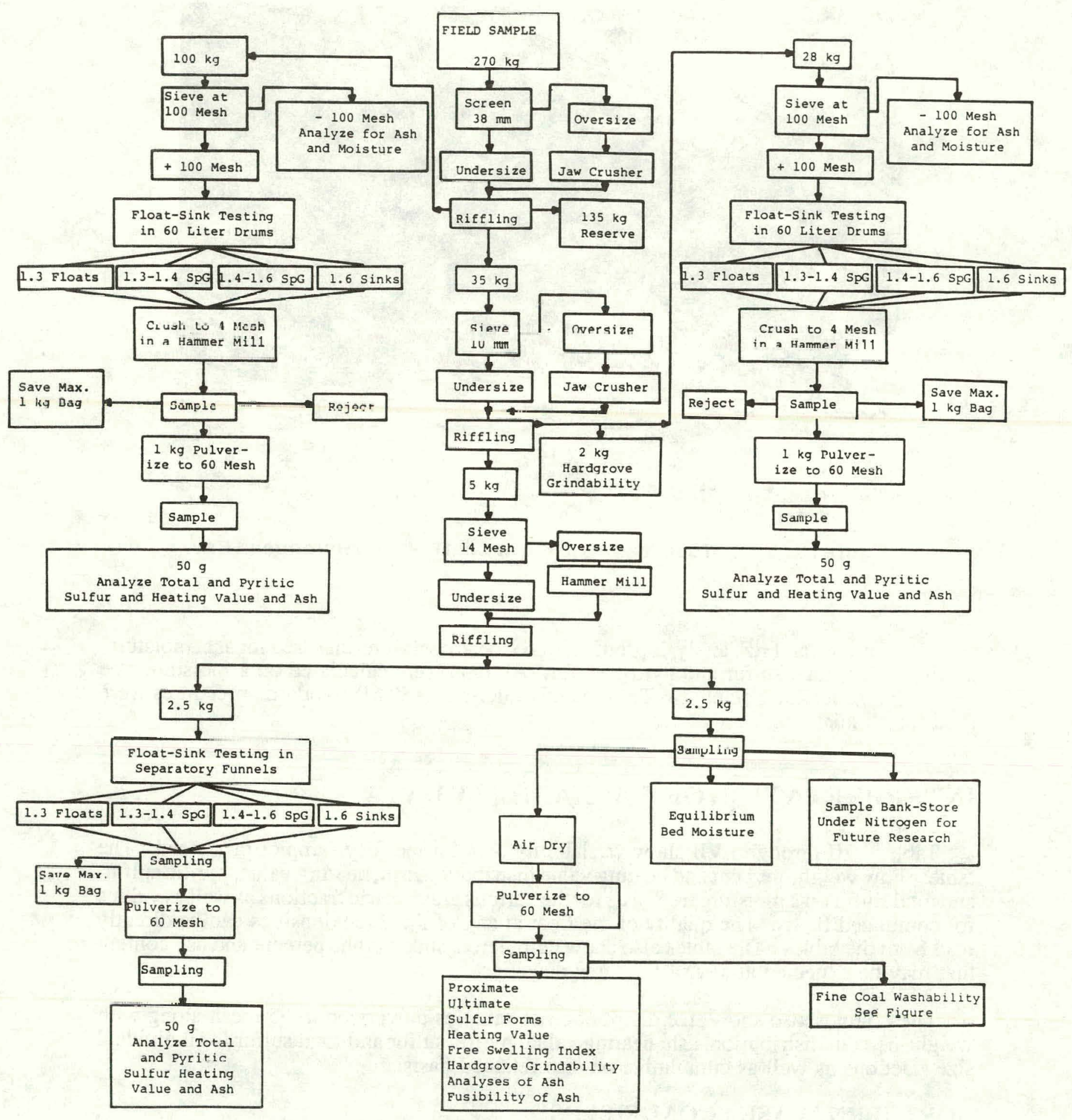

Figure 77. Flowsheet for washability characterization. 


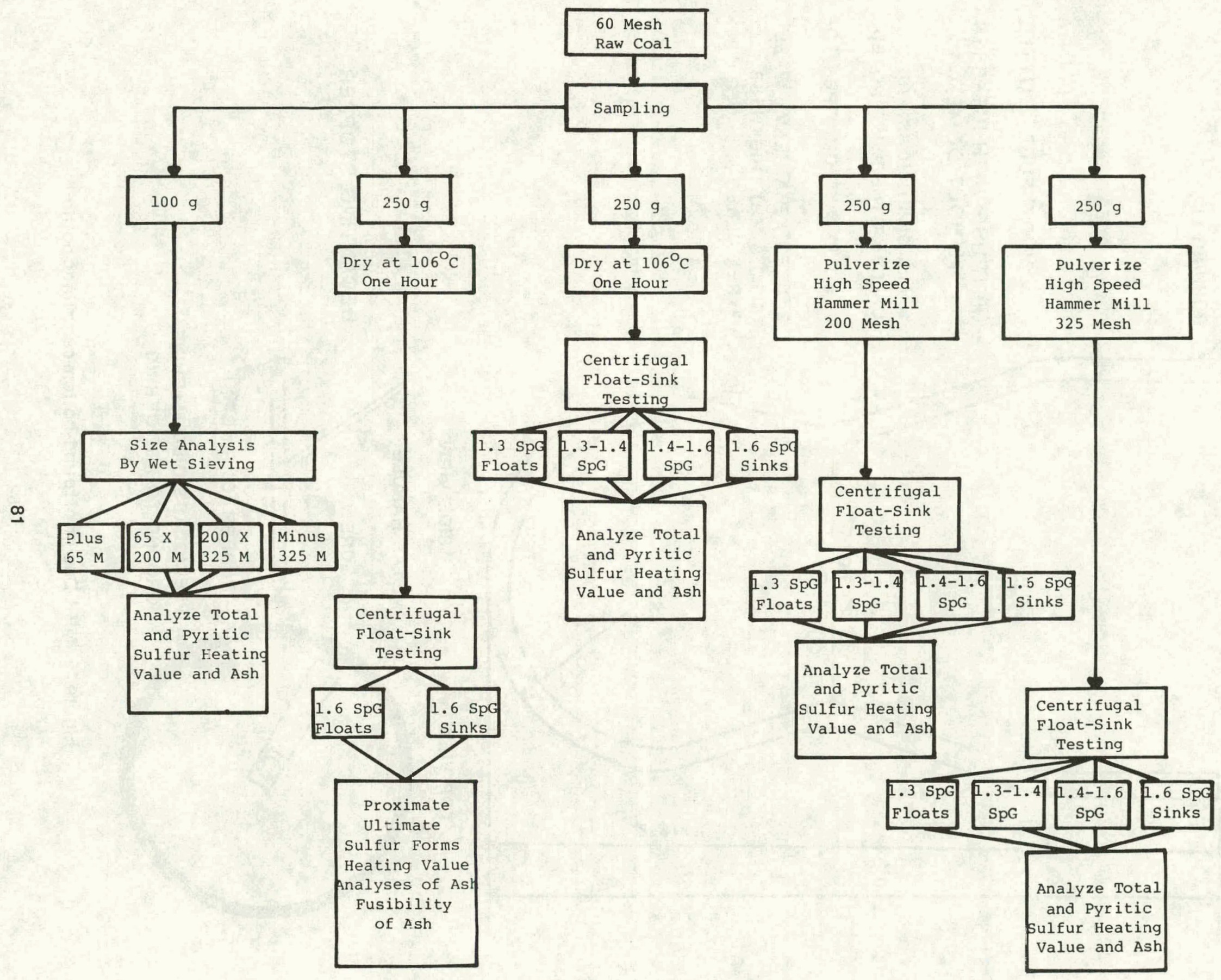

Figure 78. Flowsheet for fine coal washability characterization. 


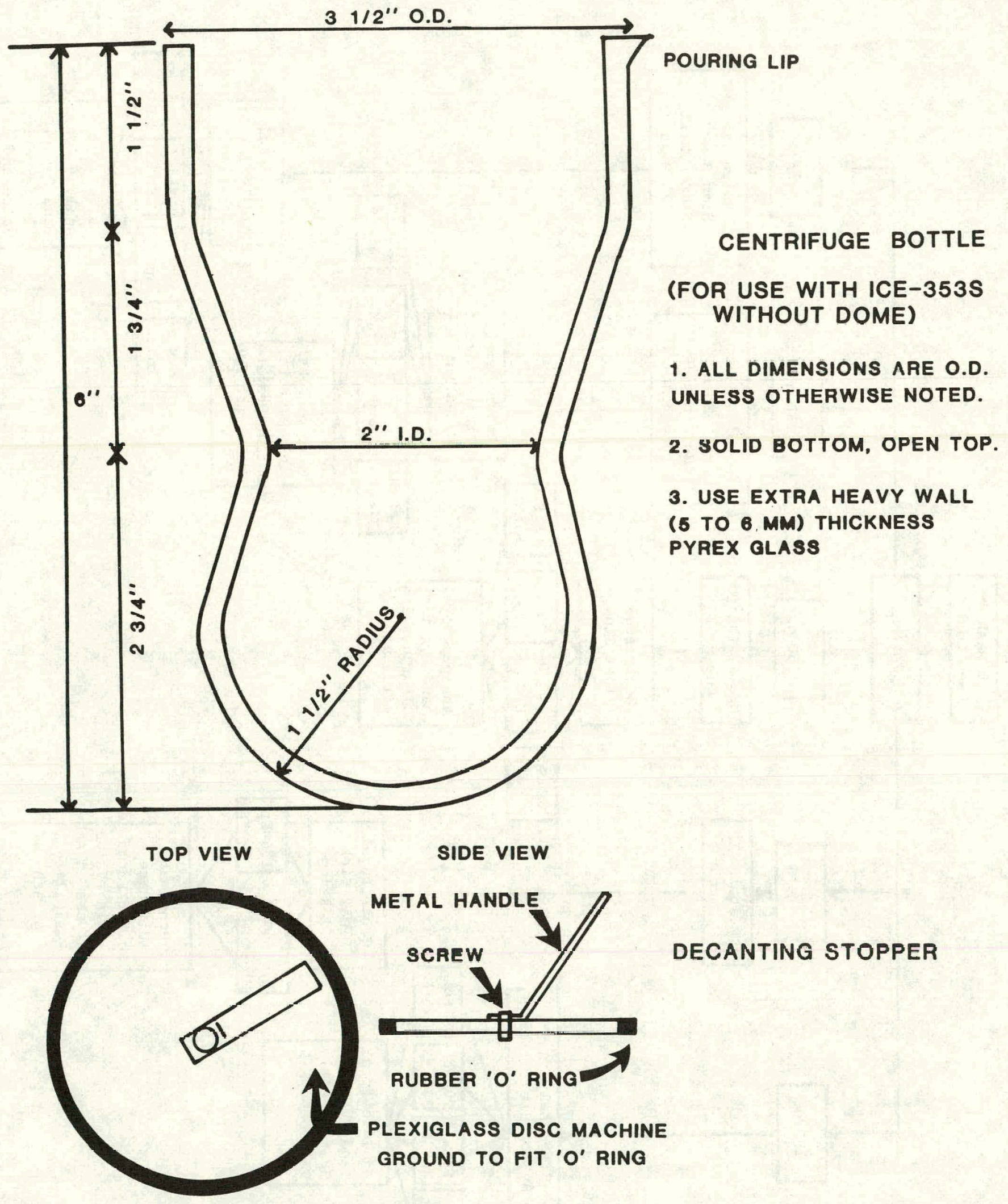

Figure 79. MIRL Design of round-bottom centrifuge bottle 
excluded from the sample (UA-139). The vitrinite reflectance of the sample is 0.53 indicating the rank to be high volatile $C$ bituminous. U.S. Bureau of Mines study of a nearby seam showed a loss of $>1,000 \mathrm{Btu} / \mathrm{lb}$ on a moisture and ash free basis for surface samples compared to fresh samples obtained by drilling (Warfield and Boley, 1969). Although the seam was exposed by trenching, it was close to the surface, and the heating values are lower than those of samples obtained by drilling (Callahan and Martin, 1980). The No. 7 bed coal sample contained 23.8 percent ash and 0.28 percent sulfur. Washing $1-1 / 2$ inches $\times 100$ mesh coal at 1.60 specific gravity gave a product analyzing 11.2 percent ash at 76.2 percent yield (Table XLIV). Washing 65 mesh $x 0$ coal at 1.60 specific gravity gave a lower ash product containing 8.4 percent ash at 68.4 percent yield. Washing 325 mesh x 0 coal showed further improvement. 1.60 specific gravity float product contained 7.7 percent ash with 67.5 percent yield.

Two coal beds were sampled, representative of coals in the Kokolik-Utukok River district in the national Petroleum Reserve, Alaska. The coal beds in the region have been extensively investigated by the U.S. Geological Survey, under the direction of J.E. Callahan (1980). The study was aided by shallow subsurface data from shot holes, deep exploration wells, and by tracing outcrops buried under the tundra by auger holes. A sure sign of a buried outcrop is the sighting from helicopter of black coal debris dug by ground squirrels (the squirrels find it easier to dig into coal). The auger holes positioned about 50' down dip from the coal debris. Several hundred samples of coals were collected from the region as drill cuttings from seismic shotholes. Auger cuttings, drill cuttings and several deep exploratory wells were sampled, and outcrops and beds were sampled by trenching (Callahan and Martin, 1980). The petrology of three hundred of these samples has been reported by Rao and Smith (1983).

The second bed sampled was from an outcrop on the Kokolik River. In 1964 the U.S. Bureau of Mines excavated the outcrop by hand digging and blasting. For the current investigation, the surface weathered part of the exposure was removed prior to sampling. However, the depth of the cut is not adequate to reach the unoxidized portion of the seam. Vitrinite reflectance was 0.90 percent, placing the rank at high volatile A bituminous.

The Kokolik River sample (UA-126) contained 6.42 percent ash and 0.28 percent sulfur on a moisture free basis. Washing $1-1 / 2$ inch $\times 100$ mesh coal can give a product with 3.6 percent ash and 0.26 percent total sulfur. Washing at 1.40 specific gravity can give 81.3 percent yield with 2.6 percent ash (Table XXXIV). Washing 65 mesh x 0 coal at 1.60 specific gravity gave a product with 2.6 percent ash at a yield of 88.6 percent.

No. 3 coal bed was sampled from an outcrop on Elusive Creek (UA-125). Callahan (1980) traced the bed by seismic shotholes to extend for 5 miles in an east-west direction with slight thinning, whereas it maintains a constant thickness in the north-south direction for a distance of over 2.3 miles (Callahan, 1980, p. 43). Mean maximum reflectance of vitrinite in oil $\left(R_{\text {om }}\right)$ was 0.71 , clearly placing the rank of the coal at high volatile $B$ bituminous. The raw coal is quite low in ash, 2.6 percent and sulfur, 0.31 percent. Washing of $1-1 / 2$ inch $\times 100$ mesh coal at 1.60 specific gravity can reduce ash to 2.1 percent at a yield of 98.7 percent. Washing $14 \mathrm{mcsh} \times 0$ coal at 1.60 specific gravity will further reduce ash to 2.0 percent at 98.7 percent yield, whereas washing at 1.40 would provide a product analyzing 1.6 percent ash at 90.5 percent yield (Table XXIII). Washing of 65 mesh x 0 coal at 1.40 specific gravity can reduce ash to as low as 1.1 percent but at a greatly reduced yield of 74.9 percent. Washing at 1.60 specific gravity can, however, give a product containing 1.7 percent ash at 92.1 percent yield. 
Coal beds near Wainwright have been known since 1889 (Smith and Mertie, 1930) and have been mined on a small scale. The mined coal is stored in sacks and transported by boat during summer and overland during winter for local use. Although several hundred tons have been mined in the past, current extraction rate is only a few tons a year. There has been increased interest in these coals for possible use in power generation at Wainwright.

This uncorrelated coal bed sample (UA-109) is subbituminous "B" rank and is 5 feet thick. The bottom of the bed was about 4 feet above the Kuk River level in August at the time of sampling. The raw coal sample contained 6.0 percent ash and 0.35 percent total sulfur. This coal was of low ash and low sulfur content as mined, however, crushing to 14 mesh top size and removing the sink 1.60 specific gravity material would provide a product analyzing 2.8 percent ash and $12,167 \mathrm{Btu} / \mathrm{lb}$ at a yield of 94.2 percent (Table XVII). Washing 65 mesh x 0 coal at 1.60 specific gravity gave a product containing 2.1 percent ash at 94.5 pereent yicld.

The No. 2 bed coal sample (UA-110) contained 4.4 percent ash and 0.52 perecnt total sulfur. Washing 1-1/2 inches $\times 100$ mesh coal at 1.30 specific gravity can give a product with 2.3 percent ash, 0.46 percent total sultur and 13,155 Btu/lb licating value with 78.1 percent yield. Washing at 1.40 specific gravity can give 96.9 percent yield with 4.1 percent ash. Washing 14 mesh x 0 coal at 1.40 specific gravity will give 89.4 percent yield with 2.1 percent ash (Table XVIII). Washing 65 mesh x 0 coal at 1.60 specific gravity can give a product containing 2.7 percent ash at 97.1 percent yield.

Sagwon Bluffs was sampled to obtain a representative sample of low rank coal in the eastern edge of the Northern Alaska field. The bed is readily accessible from the Trans Alaska Pipeline Haul Road (now the Dalton Highway). This uncorrelated coal bed sample (UA114) contained 63.2 percent ash, less that 0.1 percent total sulfur and $4,210 \mathrm{Btu} / \mathrm{lb}$. Washing the $3 / 8$ inch top size coal sample at 1.60 specific gravity would reduce the ash to 14.8 percent, upgrade the calorific value to $10,139 \mathrm{Btu} / \mathrm{lb}$, however, the yield would only be 22.8 percent (Table XXII). Washing 65 mesh $x 0$ coal at 1.60 specific gravity can, however, give a product containing 10.8 percent ash at a yield of 39.9 percent.

\section{NORTHWEST ALASKA COAL FIELDS}

\section{Chicago Creek}

The uncorrelated bed coal sample from Chicago Creek (UA-138) contained 15.1 percent ash and 0.84 percent sulfur. Washing $1-1 / 2$ inches $\times 100$ mesh coal at 1.10 specific gravity can give a product analyzing 8.8 percent ash with 86.7 percent yield. Washing $3 / 8$ inch $x$ 100 mesh at 1.60 specific gravity gave a product with 8.3 percent ash, $10,187 \mathrm{Btu} / \mathrm{lb}$ and 0.81 percent sulfur with 90.3 percent yield on a moisture free basis (Table XLIII). Crushing is of no benefit to sulfur reduction since 93 percent of the sulfui is organic. Washing at 65 mesh $\times 0$ coal did not show any improvement in the product quality or yield, partly dine to poor dispersion properties of low rank coals in organic heavy liquids.

\section{Unalakleet}

Sample (UA-151) from the uncorrelated bed near Unalakleet analyzed 11.2 percent ash and 0.54 percent sulfur. Washing $1-1 / 2$ inches $x 100$ mesh coal at 1.60 specific gravity gave a product analyzing 7.0 percent ash, $11,328 \mathrm{Btu} / \mathrm{lb}$ and 0.60 percent sulfur at 96.0 percent yield (Table LVI). No improvement in quality was observed by washing 65 mesh $x 0$ coal due to poor dispersion of low rank coal particles in organic liquids. 


\section{INTERIOR ALASKA COAL FIELDS}

\section{Nenana - Healy Creek}

No. 2 Seam (UA-105) is on Healy Creek. This seam is 27.8 feet thick and was mined before the mining of Moose and Caribou seams. The sampled area of the seam was exposed for 2 years prior to sampling. Although the ash content of the raw coal was quite low, 9.5 percent, improvements were made by washing. Minus 14-mesh raw coal washed at 1.40 specific gravity yielded 87.5 percent clean coal with 6.6 percent ash and 0.17 percent sulfur (Table XIII). Washing of 65 mesh $\times 0$ coal at 1.40 specific gravity gave a product containing 5.1 percent ash at 62.4 percent yield.

\section{Lignite Creek}

An uncorrelated bed coal outcrop from the Nenana field was sampled (UA-141) on the bluffs along Upper Lignite Creek. The coal bed was from the Suntrana formation although exact correlation to other seams on Lignite Creek was not investigated. The raw coal analyzed 12.8 percent ash and 0.33 percent sulfur. Washing $1-1 / 2$ inches $\times 100$ mesh coal at 1.40 gave a product analyzing 9.4 percent ash, $10,317 \mathrm{Btu} / \mathrm{b}$, and 0.35 percent sulfur at 88.6 percent yield. Washing at 1.60 specific gravity gave a product analyzing 11.7 percent ash, with $10,029 \mathrm{Btu} / \mathrm{lb}$ at 96.5 percent yield (Table XLVI). Crushing to finer sizes did not show any improvement in product quality and yield. Washing of 65 mesh $\times 0$ coal at 1.60 specific gravity gave a product containing 9.9 percent ash at 89.0 percent yield.

\section{Moose Seam and Caribou Seam}

Moose seam (UA-103) and Caribou seam (UA-104) are on Upper Lignite Creek. These seams are currently being mined and will continue to be mined for some time. These coals are low in ash and, like all other Nenana coals, are low in total sulfur $(0.21$ percent for sample UA-103 and 0.23 percent for sample UA-104).

Moose seam (UA-103) is 21.6 feet thick. The sample was quite low in ash, averaging 8.9 percent. Washing of minus 14 mesh coal at 1.40 specific gravity gave a product with 8.0 percent ash at 96.9 percent yield (Table XI). Washing of $65 \mathrm{mesh} \times 0$ coal at 1.60 specific gravity gave a product containing 6.9 percent ash at 91.4 percent yield. Washing of 200 mesh $\times 0$ and 325 mesh $\times 0$ showed no improvement, principally due to particle dispersion problems.

Caribou seam (UA-104) is 16.6 feet thick and had an ash content of 11.2 percent. Washing minus 14 mesh coal at 1.40 specific gravity yielded 95.6 percent clean coal with 9.7 percent ash and 0.23 percent sulfur (Table XII). Washing of 65 mesh x 0 coal at 1.60 specific gravity gave a product containing 9.0 percent ash with 95.1 percent yield.

A sample of basal bed (bed A) (Wahrhaftig et al., 1951, p. 164) was obtained from the location of former Arctic Coal Company operations (UA-140). The bed is 45 feet thick at the sampling location, and has an average thickness of 30 feet (Wahrhiaftig et al., 1951). Raw coal airalyzed 19.5 percent ash and 0.38 percent sulfur. Washing $1-1 / 2$ inches $\times 100$ mesh coal at 1.40 specific gravity gave a product analyzing 10.2 percent ash, and 10,671 Btu at 73.8 percent yield. Washing at 1.60 specific gravity will give a product with 13.5 percent ash, and 10,179 Btu/lb with 90.5 percent yield (Table XLV). Washing of 65 mesh $\mathrm{x} 0$ coal at 1.60 specific gravity gave a product containing 12.3 percent ash at 79.4 percent yield. 
Samples of No. 1 bed coal (UA-129) and No. 3 bed coal (UA-130) were collected from the Lower Lignite Creek, Poker Flat Pit, Usibelli Coal Mine. The coals are subbituminous C rank. No. 1 bed is not being mined at this time and is the lowest bed in the Suntrana formation. The raw coal analyzed 17.3 percent ash and 0.21 percent sulfur on a moisture free basis. Washing $1-1 / 2$ inches $\times 100$ mesh coal at 1.40 specific gravity gave 83.4 percent yield with 10.0 percent ash, and $10,858 \mathrm{Btu} / \mathrm{b}$. Washing at 1.60 specific gravity gave 93.7 percent yield with 12.3 percent ash and $10,531 \mathrm{Btu} / \mathrm{lb}$ (Table XXXVII). Washing of 65 mesh $\mathrm{x} 0$ coal at 1.60 specific gravity gave a product containing 9.5 percent ash at 80.3 percent yield.

No. 3 bed (UA-130) is the lowest of the three beds being mined by Usibelli Coal Mine, and is the lowest of the seams extractable at this time. The raw coal contained 12.5 percent ash and 0.22 percent sulfur on a molsture free basis. Washing the coal at 1.6 specific gravity gave a 91.8 percent yield with 6.9 percent ash, 0.13 percent sulfur and $10,774 \mathrm{Btu} / \mathrm{lb}$ on a moisture free basis (Table XXXVIII). Washing of $65 \mathrm{mcsh} \times 0$ coal at 1 .6() specific gravity gave a product containing 5.4 percent ash at 93.8 percent yield.

A sample of the No. 4 bed coal (UA-119) was collected from the Lower Lignite Creek, Poker Flat pit, of the Usibelli Coal Mine and is the middle seam of the three extractable seams in the mining area. Overburden of this bed was first stripped during the summer of 1977 and the bed was mined for the first time in 1978. This bed has the largest mineable reserves of the three seams, No. 6, No. 4 and No. 3. The raw coal analyzed 13.2 percent ash and 0.44 percent total sulfur. Washing $11 / 2$ inches $x 100$ mesh coal at 1.40 specific gravity (Table XXII) gave a 96.8 percent yield with 9.5 percent ash and 0.28 percent total sulfur on a moisture free basis. Pyritic sulfur in the sample is low and washing will not have any significant influence on the sulfur. Washing of 65 mesh $x 0$ coal at 1.60 specific gravity gave a product containing 7.3 percent ash at 90.2 percent yield.

\section{Poker Flat Pit}

Poker Flat Pit, now being developed for mining using a new dragline, will supply all coal requirements for Fairbanks and Interior Alaska for the near future. This pit is on Lower Lignite Creek. The sampled seam is No. 6 seam and is 24.8 feet thick. The top and bottom portions of the seam are high in ash, with as possible need for washing; the middle portion is low in ash and can be shipped directly. For this reason, the seam was sampled in three portions and the coal was processed in the laboratory as three independent samples. As with all coals from the Nenana coal field, these samples showed low total sulfur $(<0.2$ percent $)$ and barely detectable pyritic sulfur ( 0.01 percent); thus, physical beneficiation did not reduce the. sulfur content in the coal, since all sulfur is organically bound to the coal substance.

Sample UA-100 was obtained from the top 3.3 feet of the seam and contained an average of 20.9 percent ash. Washing this coal at 1.40 specific gravity and 14 mesh top size, yielded 51.7 percent as clcan coul with 11.4 percent ash, 0.18 percent sulfur and $10,413 \mathrm{Btu} / \mathrm{lb}$ on a moisture free basis (Table VIII). Washing of 65 mesh $\times 0$ coal at 1.60 specific gravity gave a product analyzing 14.3 percent ash at 69.9 percent yield.

Sample UA-101 was obtained from the middle 18.3 feet of the seam and had an ash content of 9.4 percent. Cleaning the 14 mesh $\times 0$ coal at 1.40 specific gravity gave a product with 8.6 percent ash and 0.15 percent sulfur with a heating value of $10,767 \mathrm{Btu} / \mathrm{lb}$ on a moisture free basis (Table IX). Washing of 65 mesh $\times 0$ coal at 1.60 specific gravity gave a product with 7.7 percent ash at 92.1 percent yield. 
Sample UA-102 was obtained from the bottom 3.3 feet of the seam and averaged 13.5 percent ash. Washing minus 14 mesh coal at 1.40 specific gravity reduced the ash content to 12.5 percent with 93.4 percent yield (Table $\mathrm{X}$ ). Washing of 65 mesh $\mathrm{x} 0$ coal at 1.60 specific gravity gave a product containing 11.9 percent ash at 91.5 percent yield.

The uncorrelated bed coal outcrop on Marguerite Creek west of Jumbo Dome was sampled (UA-120). This area of the Nenana coal field is undeveloped. Amax Coal Company has done preliminary coal exploration. The coal is subbituminous Crank and has 12.0 percent ash and 0.15 percent sulfur on a moisture free basis. Washing of 1-1/2 inches $x 100$ mesh material at 1.40 specific gravity gave a product with 8.3 percent ash, 0.12 percent sulfur and $10,535 \mathrm{Btu} / \mathrm{b}$ on a moisture free basis at a yield of 82.9 percent. Washing at 1.60 specific gravity gave 96.9 percent yield with 10.8 percent ash and 10,171 Btu/lb (Table XXVIII). Washing of 65 mesh $\times 0$ coal at 1.60 specific gravity gave a product containing 7.5 percent ash at 82.1 percent yield.

Coal was mined at the Yanert mine until 1924. The mine is located in Denali National Park (formerly Mt. McKinley National Park). The coal (UA-132) has a vitrinite reflectance of $0.76(R)$ indicating that unweathered coal shows a high volatile " $B$ " bituminous rank. The raw coal analyzed 54.6 percent ash and 0.19 percent sulfur on a moisture free basis. Washing $1-1 / 2$ inches $\times 100$ mesh coal at 1.60 specific gravity gave a product with 18.6 percent ash at 35.3 percent yield. Washing $3 / 8$ inch $\times 100$ mesh coal at 1.60 specific gravity gave an improved product with 14.2 percent ash at 37.6 percent yield on a moisture free basis (Table XL). Washing of 65 mesh $\times 0$ coal at 1.40 specific gravity gave a product containing 4.2 percent at 15.6 percent yield.

\section{Jarvis Creek}

The Jarvis Creek coal field has been mined sporadically for a number of years on a very small scale.

The No. 1 seam (UA-106) is of primary interest. It is exposed on Ober Creek and is 10 feet thick. It was sampled in an open pit off Ober Creek. The ash content of 14 mesh $\mathrm{x} 0$ raw coal was 11.1 percent on a moisture free basis and could be upgraded by washing at 1.40 specific gravity to give a product containing 9.4 percent ash, 0.98 percent sulfur and 84.9 percent yield on a moisture free basis. The sulfur content of this seam is unusually high for an Alaskan coal, i.e., 1.20 percent. Ahnut a third of this sulfur is pyritic sulfur. Only the luwest specific gravity fraction, i.e., 1.30, showed low pyritic sulfur (Table XIV). Washing of 65 mesh $\times 0$ coal at 1.60 specific gravity gave a product containing 9.0 percent ash at 93.1 percent yield.

\section{Eagle}

Two coal seams were sampled from this field, both from an area with a history of established placer gold mining activity.

A coal bed sampled from Coal Creek (UA-121) had vitrinite reflectance of $0.44\left(R_{0 m}\right)$. This places the rank of coal at subbituminous $B$ and the low heating value $(7,616 \mathrm{Btu} / \mathrm{fb})$ of the coal is attributable to the severely oxidized condition of the outcrop sample. The raw coal sample contained 23.0 percent ash and 0.61 percent sulfur. Washing $1-1 / 2$ inches $x$ 100 mesh coal at 1.40 specific gravity can give 22.0 percent yield with 9.6 percent ash. Washing at 1.60 specific gravity can improve yield to 82.7 percent with 13.7 percent ash 
(Table XXIX). Washing at finer sizes did not indicate any additional improvement in yield or ash content of the products. Washing of 65 mesh $\times 0$ coal at 1.60 specific gravity gave a product containing 10.5 percent ash at $\mathbf{5 9 . 5}$ percent yield.

The uncorrelated coal bed sample (UA-124) from Chicken was from a weathered outcrop. The vitrinite reflectance $\left(\mathrm{R}_{\text {om }}\right)$ was 0.36 percent equivalent to subbituminous $C$ rank. The sample contained 27.5 percent ash and 1.41 percent sulfur on a moisture free basis. Washing $1-1 / 2$ inches x 100 mesh at 1.30 specific gravity gave 40.7 percent yield with 10.0 percent ash and 1.35 percent sulfur. This is one of the few high sulfur coals in Alaska. Very little of the sulfur is in pyritic form and thus no reduction in sulfur is possible by washing (Table XXXII). Washing of 65 mesh x 0 coal at 1.60 specific gravity gave a product containing 9.5 percent ash and 1.27 percent sulfur at 54.0 percent yield.

\section{Nulato}

An uncorrelated thin bed of coal was sampled from a location ten miles upstream from Nulato, along the north bank of the Yukon River. The seam varied in thickness from six to eighteen inches and pinched out within 10 feet of the sampled exposure. The seam was still included in the program since a better seam could not be located, and the sample would give an indication of the quality and rank of the coal in this field. The raw coal sample (UA128) contains 65.4 percent ash and 0.38 percent sulfur. The coal is high volatile $A$ bituminous rank with vitrinite reflectance of $0.88 \%(R)$. Washing $1-1 / 2$ inches $\times 100$ mesh coal can give 16.4 percent yield with 6.9 percent ash, 0.94 percent sulfur and $13,672 \mathrm{Btu} / \mathrm{lb}$ heating value (Table XXXVI). Washing 65 mesh x 0 coal at 1.40 specific gravity gave a product containing 6.4 percent ash at 22.3 percent yield.

More extensive geological exploration is needed to uncover seams of economic value, which wnuld be of particular significance to the village of Nulato and other communities along the Yukon River now burdened with the lighl cost of liquid fuels.

\section{Tramway Bar}

Coal at the Tramway Bar occurrence has been used locally hy gold miners on a very small scale. The uncorrelated coal bed sample (UA-117) has several thin refuse bands that contribute to the 38.2 percent ash contained in the raw coal. The raw coal has low total sulfur, 0.15 percent and very low pyritic sulfur. Washing the 1-1/2 inches $x 100$ mesh matcrial at 1.60 specific gravity will give a product with 11.5 percent ash and 0.27 percent total sulfur and 11,523 Btu/lb heating value at a yield of 46.8 percent (Table XXV). Washing 65 mesh $x 0$ coal at 1.60 speciflc gravily gavc a products with 8.4 percent ash at 48.1 percent yield.

\section{Beluga}

There are two mineahle coal beds in the Capps basin, the Lower Waterfall bed and Upper Capps bed.

The Waterfall bed has been well drilled and delineated by the lease holder, Beluga Coal Company. The sample (UA-113) collected represents the lower 30 feet of the seam. The top 6 feet is very dirty and is sampled separately (UA-148). The raw coal (UA-113) is quite low in ash, and sulfur 10.2 percent and 0.18 percent, respectively, on a moisture free basis. Washing $1-1 / 2$ inches $\times 100$ mesh coal at 1.40 specific gravity gave a product with 7.2 percent ash, 0.20 percent total sulfur, and $11,222 \mathrm{Btu} / \mathrm{lb}$ at a yield of 92.7 percent. Crushing to $3 / 8$ inch and 14 mesh top size followed by float-sink testing did not show any further im- 
provement in the quality of the product (Table XXI). Washing of 65 mesh $x 0$ coal at 1.60 specific gravity, however, gave a product containing 6.5 percent ash at 95.0 percent yield.

The top 6 feet of the seam (UA-148) is high in ash principally due to a twelve inch thick clay parting. The raw coal contained 38.5 percent ash and 0.26 percent sulfur. Washing $1-1 / 2$ inches $\times 100$ mesh coal at 1.40 specific gravity gave a product analyzing 9.4 percent ash, $10,598 \mathrm{Btu} / \mathrm{lb}$ and 0.28 percent sulfur with 39.3 percent yield (Table LIII). Crushing to $3 / 8$ inch top size and separating at 1.60 specific gravity would provide a 59.2 percent yield of coal analyzing 13.2 percent ash, $9,902 \mathrm{Btu} / \mathrm{lb}$ and 0.29 percent sulfur. Washing of 65 mesh $x 0$ coal at 1.40 specific gravity gave a product containing 6.3 percent ash at 30.6 percent yield.

The Upper Capps bed sample (UA-127) contained 14.8 percent ash and 0.22 percent sulfur. Washing $1-1 / 2$ inches $\times 100$ mesh coal at 1.40 specific gravity gave a product analyzing 8.0 percent ash, $10,658 \mathrm{Btu} / \mathrm{b}$ and 0.19 percent sulfur with 72.7 percent yield. Washing at 1.60 specific gravity gave a product with 12.3 percent ash and 94.0 percent yield on a moisture free basis (Table XXXV). Washability results of 65 mesh $x 0$ coal did not prove to be beneficial.

The Green bed (UA-152) was sampled from a test pit excavated by Placer Amex, Inc. to obtain an 1,800 ton bulk sample for shipment to Japan. The coal has a low ash content and washing can make only slight improvement. Washing of 1-1/2 inches $x 100$ mesh coal gave a product analyzing 5.3 percent ash, $11,338 \mathrm{Btu} / \mathrm{b}$, and 0.17 percent sulfur at a yield of 98.5 percent. Washing $3 / 8$ inch $\times 100$ mesh coal at 1.60 specific gravity gave a product analyzing 5.8 percent ash at a yield of 97.9 percent on a moisture free basis (Table LVII). The raw coal sample analyzed 8.2 percent ash and 0.16 percent total sulfur. Washability results of 65 mesh $\times 0$ coal showed that finer grinding would not be beneficial.

\section{Yentna}

The coal bed sampled (UA-149) along Johnson Creek is the thickest of three beds outcropping. Washing $1-1 / 2$ inches $\times 100$ mesh coal at 1.40 specific gravity gave a product analyzing 8.5 percent ash, $10,782 \mathrm{Btu} / \mathrm{lb}$ and 0.26 percent sulfur at 79.2 percent yield. Washing at 1.60 specific gravity gave a product analyzing 11.6 percent ash and 10,307 Btu/ $\mathrm{lb}$ at a yield of 93.5 percent. Crushing to a smaller size improved the ash content of the product. Washing $3 / 8$ inch $\times 100$ mesh coal at 1.60 specific gravity gave a product analyzing 10.2 percent ash, $10,499 \mathrm{Btu} / \mathrm{lb}$ and 0.23 percent sulfur at a yield of 93.9 percent on a moisture free basis (Table LIV). The raw coal sampled analyzed 13.7 percent ash and 0.24 percent sulfur.

Washability results of coal pulverized to 65 mesh, 200 mesh and 325 mesh gave poorer results due to difficulties dispersing the coal particles in organic heavy liquids used.

The coal bed sampled at Canyon Creek (UA-150) is the upper of the two seams in the sedimentary sequence. Washing $1-1 / 2$ inches $x 100$ mesh coal at 1.40 specific gravity gave a product analyzing 9.8 percent ash, $10,951 \mathrm{Btu} / \mathrm{lb}$ and 0.18 percent sulfur at a yield of 71.2 percent. Washing at 1.60 specitic gravity gave a product analyzing 13.7 percent ash at 92.1 percent yield. Crushing to a finer size improved the quality of the product. Washing $3 /$ 8 inch $\times 100$ mesh at 1.40 specific gravity gave a product analyzing 7.7 percent ash with a yield of 73.0 percent and $11,179 \mathrm{Btu} / \mathrm{lb}$ on a moisture free basis. The raw coal sample analyzed 18.8 percent ash and 0.17 percent sulfur. Washing of 65 mesh $x 0$ coal at 1.60 specific gravity gave a product analyzing 10.0 percent ash at 80.5 percent yield (Table LV). 
The uncorrelated bed coal outcrop at Locality 2 (Barnes) was sampled in two sections, the lower 10 feet (UA-115) and the upper 10 feet (UA-116). The total bed is 67 feet thick. The coal has no visible bands of shale and is uniform in appearance. The ash and sulfur in both of the samples is very low. Table XXIII shows washability analysis for UA-115, the lower 10 feet of the seam, which is quite clean, containing 4.7 percent ash and 0.15 percent total sulfur. The washability analysis for the upper 10 feet of the bed is shown in Table XXIV, and UA-116 is better coal than UA-115, containing 3.6 percent ash and 0.11 percent total sulfur. Cleaning of these coals would be of minimal benefit.

\section{Kenai}

Numerous coal beds are exposed on the beach cliffs along the western shore of the Kenai Peninsula. Coal was and is mined near Homer on a small scale for domestic use. There is no coal mining in the Kenai field at this time.

The Cabin Bed sample (UA-118) is one of the numerous beds exposed on the beach cliffs near Homer and was mined on a small scale. The bed does not have any visible refuse bands at the sample location. Raw coal has 11.2 percent ash and 0.30 percent total sulfur on a moisture free basis. The coal has only traces of pyritic sulfur. Washing the $1-1 / 2$ inches $\mathrm{x} 100$ mesh material at 1.40 specific gravity gave a product analyzing 8.5 percent ash and 0.43 percent total sulfur with a yield of 89.3 percent. Washing $3 / 8$ inch x 100 mesh coal at 1.40 specific gravity will give 90.8 percent yield with 8.3 percent ash and 0.48 percent total sulfur on a moisture free basis (Table XXVI). Washability testing of 65 mesh x 0 coal showed that the particles were not totally dispersed.

A coal bed was sampled about a mile northeast of Ninilchik (UA-122). A natural cave is formed on the beach due to differential erosion of sediments underlying the coal seam by the action of the waves. Approach to the sampling site is through Ninilchik and along the beach by truck. The coal is subbituminous " $C$ " rank and has 17.4 percent ash and 0.33 percent sulfur. Washing $1-1 / 2$ inches $\times 100$ mesh coal at 1.40 specific gravity will give a product with 8.2 percent ash, $10,684 \mathrm{Btu} / \mathrm{lb}$, and 0.28 percent sulfur with a yield of 63.3 percent. Crushing to 14 mesh and washing at 1.60 specific gravity gave an acceptable product with 10.6 percent ash at a yield of 85.0 percent on a moisture free basis (Table XXX). Washing of 65 mesh $x \dot{U}$ coal at 1.60 specitic gravity gave product analyzing 8.5 percent ash at 72.5 percent yield.

A coal sample was obtained from an outcrop on Happy Creek along the beach bluff (UA131). The raw coal had 12.6 percent ash and 0.38 percent sulfur. Washing at 1.40 specific gravity gave a product with 9.0 percent ash, $11,074 \mathrm{Btu} / \mathrm{lb}$ and 0.39 percent sulfur with 86.8 percent yield on a moisture free basis. Washing coal crushed to 14 mesh at 1.60 specific gravity gave a product with 10.0 percent ash while improving the yield to 95.0 percent (Table XXIX). The advantages of crushing to a finer size for ash reduction are obvious. Washability data for 65 mesh $\times 0$ coal showed that the coal particles are poorly dispersed.

\section{Matanuska}

Big Seam (UA-108) was collected from the Premier Mine which is the only mine in this coal field that has produced coal since 1968. Paul Ohmlin mined on a small scale to supply a domestic market. One sample was collected from an area where mining has been done within a year prior to sample collection. Since the area was highly deformed, the seam thickness could not be determined, and the sample is not necessarily a true channel sample. The raw coal averaged 15.1 percent ash and could be upgraded to 5.1 percent ash by washing 
minus 14 mesh coal at 1.40 specific gravity, giving a 75.3 percent yield. The coal was low in total sulfur ( 0.37 percent). Pyritic sulfur was very low ( 0.02 percent) and physical beneficiation did not significantly reduce the total sulfur content (Table XVI). Washing of 65 mesh $\times 0$ coal at 1.60 specific gravity gave product analyzing 6.1 percent ash at 81.5 percent yield.

Six beds of coal were sampled from the former strip mine pit of the Evan Jones mine. The Evan Jones coal mine was operated as an underground coal mine from 1920 until 1959 when all mining was done by surface mining. The mine ceased operations altogether in 1968 when the Anchorage area converted to natural gas as a source of energy. Geer and Yancey (1946) of U.S. Bureau of Mines conducted washability studies on various seams in the coal field. Coal at the Evan Jones mine was washed using a Forrester-type jig from the early 20's until a heavy media plant was installed in the early 50's. Fine coal was cleaned with tables. Washability studies of Geer and Yancey were instrumental in working out the specific gravity settings for the heavy media circuit to obtain maximum recoveries while meeting desired specifications (Tucker, 1968).

In 1966 Rao sampled all seams mined at Evan Jones mine (Rao, 1975). The present washability program is intended to provide more complete information on the washability and raw coal characteristics of the remaining portion of the seams likely to be mined in the future. The ash-yield results of the present study reinforced the conclusion of earlier studies (Greer and Fennessy, 1962, p. 7) that it is possible to make a premium quality product by washing at 1.40 specific gravity while producing a middling product from 1.40 to 1.60 specific gravity fraction.

The raw coal sample collected from the No. 7A coal bed, Matanuska field analyzed 19.2 percent ash and 0.42 percent sulfur. Coal ( $1-1 / 2$ inches $\times 100$ mesh) from No. $7 \mathrm{~A}$ bed was washed at 1.40 specific gravity (UA-142). This gave a product analyzing 4.1 percent ash; $13,561 \mathrm{Btu} / \mathrm{lb}$ and 0.29 percent sulfur at 67.0 percent yield. The 1.40 to 1.60 specific gravity middling product will analyze 26.6 percent ash and $10,295 \mathrm{Btu} / \mathrm{lb}$ at 15.2 percent yield. Crushing to a finer size improved the ash content even more. Washing 14 mesh x 0 coal at 1.40 specific gravity gave a product analyzing 3.3 percent ash at 64.5 percent yield. The 1.4 to 1.6 middling product coal analyzed 23.8 percent ash, $10,393 \mathrm{Btu} / \mathrm{lb}$ at a ;yield of 11.7 percent (Table XLVII). Washing of 65 mesh $x 0$ coal at 1.60 specific gravity gave a product analyzing 5.5 percent ash at 77.6 percent yield. Washing 200 mesh $x 0$ coal, however, gave a product analyzing 5.1 percent ash at 77.2 percent yield.

Washing 1-1/2 inches $x 100$ mesh coal from No. 7 Lower bed coal (UA-143) at 1.4 specific gravity gave a product analyzing 5.0 percent ash, $13,686 \mathrm{Btu} / \mathrm{lb}$ and 0.40 percent sulfur with a yield of 66.2 percent. The middling product at 1.40 to 1.60 specific gravity analyzed 25.9 percent ash at 17.4 percent yield. Washing at finer sizes showed reduction in ash in the product (Table XLVIII). The raw coal sample analyzed 17.7 percent ash and 0.45 percent sulfur. Washing of 65 mesh $\times 0$ coal at 1.60 specific gravity gave a product analyzing 7.1 percent ash at 78.2 percent yield.

Coal, 1-1/2 inches $x 100$ mesh from No. 7 Upper bed (UA-144) was washed at 1.40 specific gravity, giving a product analyzing 5.6 percent ash, $13,448 \mathrm{Btu} / \mathrm{lb}$, and 0.36 percent sulfur at 63.8 percent yield. The 1.40 to 1.60 specific gravity middling product will analyze 26.3 percent ash, with a heat content of $10,116 \mathrm{Btu} / \mathrm{lb}$ at 28.8 percent yield. Washing at finer sizes improved the ash content of the products (Table XLIX). The raw coal sample analyzed 16.7 percent ash and 0.45 percent sulfur. Washing of 65 mesh x 0 coal at 1.40 
specific gravity gave a product analyzing 3.2 percent ash at 50.8 percent yield, whereas washing at 1.60 specific gravity gave a product analyzing 7.8 percent ash with 73.7 percent yield.

Washing 1-1/2 inches $x 100$ mesh No. 6 Lower bed (UA-145) coal at 1.40 specific gravity gave a product analyzing 5.8 percent ash, $13,298 \mathrm{Btu} / \mathrm{lb}$ and 0.28 percent sulfur at yield of 67.7 percent. The 1.40 to 1.60 specific gravity middling product will analyze 25.2 percent ash and 10,140 Btu/lb at 13.8 percent yield. Washing at finer sizes reduced the ash in the products even further (Table L). The raw coal sample analyzed 20.0 percent ash and 0.37 percent sulfur. Washing of 65 mesh $x 0$ coal at 1.40 specific gravity gave a product analyzing 4.3 percent ash at 59.8 percent yield.

The No. 6 Upper bed (UA-146) and No. 5 bed (UA-147) were more difficult to clean and will produce far less premium quality products, and only at finer sizes.

Washing 1-1/2 inches $\times 100$ mesh No. 6 Upper bed (UN 116) coal at 1.10 specific gravity gave a product analyzing 8.5 percent ash, $12,847 \mathrm{Btu} / \mathrm{lb}$ and 0.39 percent sulfur at 44.8 percent yield. Waching 14 mesh $x 0$ coal at 1.10 specific gravity, however, gave a better product analyzing 6.6 percent ash, $13.231 \mathrm{Btu} / \mathrm{lb}$ and 0.39 percent sulfur at 30.2 percent yield. The 1.40 to 1.60 specific gravity middlings analyzed 21.3 percent ash and $10,769 \mathrm{Btu} / \mathrm{b}$ at 30.5 percent yield (Table LI). The raw coal sample analyzed 31.2 percent ash and 01.37 percent sulfur. Washing of 65 mesh $x 0$ coal at 1.40 specific gravity gave product analyzing 5.3 percent ash at 37.3 percent yield.

Washing $1-1 / 2$ inches $\times 100$ mesh No. 5 bed (UA-147) coal at 1.40 specific gravity gave a product analyzing 7.6 percent ash, $13,129 \mathrm{Btu} / \mathrm{lb}$ and 0.34 percent sulfur at 33.7 percent yield. Washing 14 mesh $\times 0$ coal at 1.40 specific gravity, however, gave a product analyzing 5.3 percent ash, $13,879 \mathrm{Btu} / \mathrm{lb}$ and 0.31 percent sulfur. The 1.40 to 1.60 specific gravity middlings analyzed 22.6 percent ash, 10,672 Btu/lb at 21.8 percent yield (Table LII). The raw coal sample analyzed 35.9 percent ash and 0.26 percent sulfur. Washing 65 mesh $x$ 0 coal at 1.40 specific gravity gave a product analyzing 5.1 percent ash at 43.4 percent yield. Washing 325 mesh $x 0$ coal 151.40 specific gravity, however, gave a product analyzing 4.9 percent ash at 45.4 percent yield.

All seams sampled from the Evan Jones mine have only traces of sulfur in pyritic form and washing, therefore, will not influence the already low total sulfur in the washed product.

Lower Seam (UA-107) was mined in this area in the early 1960's, but mining has been discontinued due to lack of knowledge of the continuity of the beds. The sample was collectec from an open pit with two exposed seams. It was obtained from the lower bed, which is 7 feet thick, and is probably the best known coking coal in Alaska with a freeswelling index of 8 . The raw coal had 19.0 percent ash and 0.45 percent sulfur. Pyritic sulfur in this coal was low ( 0.05 percent) and washing would not reduce it. However, $w$ ashing minus 14 mesh coal at 1.40 specific gravity reduced the ash to 7.6 percent with 65.7 percent yield (Table XV). Washing of 65 mesh x 0 coal at 1.40 specific gravity gave product analyzing 4.7 percent ash at 69.3 percent yield.

\section{Broad Pass}

Coal was mined in the Coal Creek basin during 1920 to 1921 by Coal Creek Mine. A 2-1/2 mile wagon road was used for transportation to Broad Pass station and was sold to the Alaska Railroad Co. during its construction (Keller et al., 1961). Completion of the 
construction marked the end of mining due to lack of other markets. This was a sample of Coal Creek bed coal (UA-111) and is lignite in rank. The raw coal has 19.6 percent ash and washing $1-1 / 2$ inches $\times 100$ mesh coal at 1.40 specific gravity will give a product containing 11.4 percent ash, $9,939 \mathrm{Btu} / \mathrm{lb}$ heating value and 0.22 percent total sulfur, with 82.2 percent yield on a moisture free basis (Table XIX). Washing of 65 mesh $x 0$ coal at 1.40 specific gravity will give a product analyzing 8.7 percent ash at 79.0 percent yield.

Coal production from this field to meet local needs dates back to 1929 . Production has increased with the transfer of a coal prospecting permit to W.E. Dunkle in 1941. In the period 1940-54 about 64,000 tons of coal were produced. Mr. Dunkle installed a prototype reactor for steam drying of coal from Dunkle Mine and shipped twenty tons of processed coal to the Fairbanks Exploration Company power plant in 1958 for testing, and that appears to be the last reported activity of the mine. The Dunkle bed sample (UA-123) had 15.6 percent ash and 0.44 percent sulfur. Washing the $1-1 / 2$ inches $x 100$ mesh coal at 1.60 specific gravity gave 87.9 percent yield analyzing 9.0 percent ash, $12,016 \mathrm{Btu} / \mathrm{lb}$ and 0.46 percent sulfur. Crushing to 14 mesh and washing at 1.60 specific gravity will give a product analyzing 7.8 percent ash, $12,218 \mathrm{Btu} / \mathrm{lb}$, with 87.1 percent yield (Table XXXI). Washing of 65 mesh $\mathrm{x} 0$ coal at 1.40 specific gravity will give a product analyzing 6.3 percent ash at 85.2 percent yield.

\section{Little Tonzona}

The raw coal was a sample of the Tonzona coal bed (UA-112) and has 13.8 percent ash and 1.40 percent of sulfur. The sulfur is unusually high for Alaskan coals. The only other seam of those studied that had a sulfur content more than 1 percent was the mine seam in the Jarvis Creek field (UA-106). Pyritic sulfur in the Little Tonzona coal bed is low and washing will not reduce the sulfur content of the product. Washing the 1-1/2 inches $\times 100$ mesh coal at 1.40 specific gravity will give 83.4 percent yield with 8.9 percent ash and 10,539 Btu/lb heating value on a moisture free basis. Separation at 1.60 specific gravity, however, will increase the yield to 96.7 percent with ash content reduced to only 11 percent. Crushing to 3/8 inch and 14 mesh top size did not result in significant additional liberation of impurities (Table XX). Washability results of 65 mesh $x 0$ coal gave poor results due to incomplete dispersion of coal particles.

\section{ALASKA PENINSULA \\ Chignik Field}

The coal seam from the Chignik Bay coal mine (UA-136) was sampled at the entrance to the tunnel. The mine was abandoned nearly 70 years ago. The sample contained 36.2 percent ash and 1.12 percent sulfur. Washing $1-1 / 2$ inches $x 100$ mesh coal at 1.60 specific gravity gave a product that contained 11.0 percent ash, $12,340 \mathrm{Btu} / \mathrm{lb}$ and 1.9 percent sulfur with 50.2 percent yield (Table XLI). Although half of the total sulfur is in pyritic form, reduction in sulfur by washing at a finer size was only moderate. Washing of 65 mesh $x$ 0 coal at 1.60 specific gravity gave product analyzing 9.3 percent ash at 50.3 percent yield.

\section{Herendeen Bay}

An uncorrelatcd coal bed outcropping on the west bank of Herendeen Bay was sampled (UA-137). The seam was only about $12^{\prime \prime}$ thick and was chosen due to practical considerations of ready access and transportability of bulk sample. Thicker coal beds, inland from the east shore of the Bay were mined at the turn of the century. Conwell and Triplehorn (1978) measured nine coal beds at Mine Harbor ranging from 1.5 feet to more than 5 feet. Vitrinite reflectance of the sampled bed (UA-137) was 0.63 indicating the rank to be about high 
volatile B bituminous. The raw coal analyzed 43.6 percent ash and 1.91 percent sulfur. Washing the $1-1 / 2$ inches $\times 100$ mesh material at 1.40 specific gravity will give a product analyzing 9.9 percent ash, $12,841 \mathrm{Btu} / \mathrm{lb}$ and 1.59 percent sulfur at 31.8 percent yield. Crushing to a finer size resulted in further reduction in ash and total sulfur. Washing 14 mesh x 0 material at 1.40 specific gravity will give a product with 7.1 percent ash, 13,244 $\mathrm{Btu} / \mathrm{lb}$ and 1.03 percent sulfur at 29.3 percent yield (Table XLI). Washing of 65 mesh $\mathrm{x}$ 0 coal at 1.40 specific gravity gave a product analyzing 5.8 percent ash at 64.1 percent yield.

\section{CONCLUSIONS}

Washability studies showed that No. 7 seam from the Cape Beaufort region of the Northern Alaska field can be washed to give a product containing 11.2 percent ash.

Coals from Elusive Creek and Kokolik River can be cleancd to produce premium quality products containing less than 2 percent ash and 0.25 percent sulfur.

Coals from Wainwright can lw: cleaned to lcss than 2.5 percent ash and with sulfur as low as 0.24 percent for Wainwright and 0.46 percent for Meade River coals.

Coal from Chicago creek can be washed to give a product containing 8.3 percent ash.

Coal from Unalakleet can be washed to give a product containing 7.0 percent ash. Subbituminous "C" coal from the Basal bed can be washed to give a product containing 10.2 percent ash.

Subbituminous $\mathrm{C}$ coal from the Nenana coal field could be upgraded at high yield to produce low sulfur products ranging from slightly over 10,000 to nearly $12,000 \mathrm{Btu} / \mathrm{lb}$ on a moisture free basis.

The coal bed on Marguerite Creek contains 11.95 percent ash and can be washed to give a product containing 7.5 percent ashi when crushcd to 65 mesh.

The coal bed from the Yanert mine has 54.6 percent ash. Cleaning will give poor yield at higher than acceptable ash levels in the product.

The mine seam subbituminous C cual sample obtained from the Jarvis Creek coal field had an unusually high total sulfur content; 1.28 percent. However, appropriate crushing and gravimetric separation could yield a 1 percent sulfur product.

Subbituminous "B" coal from Coal Creek can be washed to give a product less than 10.0 percent ash at low yields.

Coal from the Eagle field near Chicken gave a product containing 6.6 percent ash in washed coal at 38.4 percent yields. The sulfur content in the sample is 1.41 percent. Much of the sulfur was organic an no significant reduction in sulfur is possible by cleaning.

High volatile A bituminous coal from Nulato has high ash content and could be cleaned to give a product with 10.1 percent ash and F.S.I. of 9.6 and ranks as one of the best coking quality coals in Alaska. However, economically recoverable seams have not yet been identified. 
The high volatile bituminous coal from Tramway Bar can yield significantly improved products containing 11.5 percent ash and 0.27 percent sulfur by washing.

The lower 30 feet of the Waterfall seam in the Capps basin of the Beluga coal field contained 10.2 percent ash. Washing, however, gave a product analyzing 7.2 percent ash and 0.20 percent sulfur.

The Capps bed and the top 6 feet of the Waterfall bed which is high in ash, can be washed to give a product containing less than 8.0 percent ash.

The Green bed from the Beluga field contained 8.2 percent ash and washing can further reduce the ash content to give a premium quality product containing 4.7 percent ash and 0.22 percent sulfur.

Subbituminous "C" coals from Johnson and Canyon Creeks in the Yentna field can be washed to give acceptable grade washed coal i.e. about 10.0 percent ash.

The 55 foot-thick seam at Locality 2 in the Yentna coal field had an ash content of 4.1 percent and washing will not significantly reduce ash.

Coal beds from Ninilchik, Happy Creek and Cabin bed in the Kenai field can be washed to give products containing less than 9.0 percent ash and 0.5 percent sulfur.

The two samples, a high volatile A and a high volatile B bituminous coal, collected from the Matanuska coal field were low in total sulfur and nearly free of pyritic sulfur, however, appropriate crushing and specific gravity separation would provide significant ash reductions.

Washability studies of the six beds of coal from the Evan Jones mine showed it is possible to obtain a premium quality product with approximately 8 percent ash and less than 0.4 percent sulfur, by washing at 1.40 specific gravity while producing a middling product containing approximately 20 percent ash and less than 0.4 percent sulfur by further washing at 1.60 specific gravity. $\Omega$

Coal from Coal Creek basin of the Broad Pass coal field can give a product containing 8.7 percent ash and 0.21 percent sulfur when crushed to 65 mesh top size.

Coal from the Dunkle Mine in the Broad Pass field can be washed to obtain an acceptable product containing 9.0 percent ash and 0.42 percent sulfur. Finer crushing to 65 mesh improved liberation of ash forming impurities to give a clean coal product containing 6.4 percent ash and 0.46 percent sulfur.

Sulfur in the Little Tonzona coal bed is high and very little of it is in pyritic form. Although washing will reduce ash, it will not reduce sulfur in the product.

The coal bed from the Chignik Bay coal mines can be washed to give a product with 9.3 percent ash and 1.36 percent sulfur when crushed to 65 mesh.

The coal bed from the Herendeen Bay field can be washed to give a product containing less than 10.0 percent ash. 
Washing at 65 mesh gave further improvements of products in most cases. Centrifugal techniques, in general, appear to give good yield/ash relationships down to 65 mesh top size. Float-sink tests on samples crushed to 200 and 325 mesh either did not show any significant improvement over 65 mesh top size coal or gave anomalous results. Although bituminous coals appeared to disperse well at 325 mesh top size, subbituminous coals tended to flocculate resulting in inaccurate float-sink data. Further tests on 200 and 325 mesh top size coals were discontinued.

Proximate and ultimate analyses showed that Alaskan coals in general are low in sulfur with the exception of a few localities.

Hardgrove grindability data show that subbituminous " $C$ " coals of Nenana and Beluga fields are quite difficult to grind with H.G.I. of as low as 23. Very few of Alaska's coals have good Free Swelling Indexes. These are coals from Nulato and Castle Mountain Mine coals in the Matanuska field. High volatile B bituminous coals from Matanuska field had a F.S.I. of 2.

An evaluation of the concentration of major elements in the ash of 1.60 spccific gravily float-siluk pivducis showed that $\mathrm{Ca}, \mathrm{Mg}, \mathrm{Na}$ are more concentrated in the float fraction low rank coals since these elements are associated with coal as exchangeable cations. In high rank coals $\mathrm{Ca}, \mathrm{Mg}$ and $\mathrm{Fe}$ are present as carbonates and are therefore concentrated in the sink fractions. $\mathrm{SiO}_{2}, \mathrm{Al}_{2} \mathrm{O} 3$, and $\mathrm{K}_{2} \mathrm{O}$ are more concentrated in the sink fraction since these are contained in detrital minerals in coal. 
Table I

Proximate and Ultimate Analyses of Raw Coals

\begin{tabular}{|c|c|c|c|c|c|c|c|c|c|c|c|c|c|c|c|}
\hline $\begin{array}{c}\text { Coal } \\
\text { Field and } \\
\text { Seam }\end{array}$ & $\begin{array}{l}\text { Apparent } \\
\text { ASTM } \\
\text { Rank }\end{array}$ & $\begin{array}{l}\text { Thickness } \\
\text { (feet) }\end{array}$ & $\begin{array}{l}\text { Sample } \\
\text { Numbers }\end{array}$ & Basis* & $\begin{array}{c}\text { Moisture } \\
\%\end{array}$ & $\begin{array}{r}\text { Volatile } \\
\text { Matter,\% }\end{array}$ & $\begin{array}{c}\text { Fixed } \\
\text { Carbon,\% }\end{array}$ & $\begin{array}{c}\text { Ash } \\
\%\end{array}$ & $\begin{array}{l}\text { Heating } \\
\text { Value } \\
\text { BTU/b }\end{array}$ & $\mathrm{C}, \%$ & $\mathrm{H}, \%$ & $\mathrm{~N}, \%$ & $0, \%$ & $\begin{array}{l}\text { Sulf } \\
\text { Pyritic }\end{array}$ & $\begin{array}{l}\text { fur } \\
\text { Total }\end{array}$ \\
\hline \multicolumn{16}{|c|}{ Northern Alaska Coal Fields } \\
\hline $\begin{array}{l}\text { No. } 7 \text { Bed } \\
\text { Cape Beaufor }\end{array}$ & $\mathrm{hv} C b$ & 17 & (UA-13G) & $\begin{array}{l}1 \\
2 \\
3\end{array}$ & 11.25 & $\begin{array}{l}24.74 \\
27.88 \\
36.62\end{array}$ & $\begin{array}{l}42.82 \\
48.24 \\
63.38\end{array}$ & $\begin{array}{l}21.1 \mathrm{C} \\
23.8 \varepsilon\end{array}$ & $\begin{array}{r}8,252 \\
9,298 \\
12,215\end{array}$ & $\begin{array}{l}50.61 \\
57.03 \\
74.92\end{array}$ & $\begin{array}{l}4.03 \\
3.12 \\
4.10\end{array}$ & $\begin{array}{l}0.82 \\
0.93 \\
1.22\end{array}$ & $\begin{array}{l}23.10 \\
14.76 \\
19.39\end{array}$ & $\begin{array}{l}0.02 \\
0.02 \\
0.03\end{array}$ & $\begin{array}{l}0.25 \\
0.28 \\
0.37\end{array}$ \\
\hline $\begin{array}{l}\text { Kokolik } \\
\text { River }\end{array}$ & hv Ab & 11.6 & (UA-120) & $\begin{array}{l}1 \\
2 \\
3\end{array}$ & 15.58 & $\begin{array}{l}26.43 \\
31.31 \\
33.46\end{array}$ & $\begin{array}{l}52.57 \\
62.27 \\
66.54\end{array}$ & $\begin{array}{l}5.42 \\
6.42\end{array}$ & $\begin{array}{l}10,904 \\
12,916 \\
13,803\end{array}$ & $\begin{array}{l}63.44 \\
75.15 \\
80.31\end{array}$ & $\begin{array}{l}5.63 \\
4.61 \\
4.93\end{array}$ & $\begin{array}{l}1.03 \\
1.22 \\
1.30\end{array}$ & $\begin{array}{l}24.24 \\
12.32 \\
13.17\end{array}$ & $\begin{array}{l}0.04 \\
0.05 \\
0.06\end{array}$ & $\begin{array}{l}0.24 \\
0.28 \\
0.29\end{array}$ \\
\hline $\begin{array}{l}\text { No. } 3 \text { Bed } \\
\text { Elusive Creel }\end{array}$ & hv Bb & 11.5 & (UA-125) & $\begin{array}{l}1 \\
2 \\
3\end{array}$ & 11.95 & $\begin{array}{l}30.36 \\
34.48 \\
35.42\end{array}$ & $\begin{array}{l}55.37 \\
62.88 \\
64.58\end{array}$ & $\begin{array}{l}2.37 \\
2.64\end{array}$ & $\begin{array}{l}11,242 \\
12,768 \\
13,114\end{array}$ & $\begin{array}{l}65.90 \\
74.84 \\
76.87\end{array}$ & $\begin{array}{l}5.20 \\
4.39 \\
4.51\end{array}$ & $\begin{array}{l}1.31 \\
1.49 \\
1.53\end{array}$ & $\begin{array}{l}25.00 \\
16.33 \\
16.77\end{array}$ & $\begin{array}{l}0.06 \\
0.07 \\
0.07\end{array}$ & $\begin{array}{l}0.27 \\
0.31 \\
0.32\end{array}$ \\
\hline Wainwright & Subbit. B & 5 & (UA-109) & $\begin{array}{l}1 \\
2 \\
3\end{array}$ & 20.28 & $\begin{array}{l}30.20 \\
37.88 \\
40.29\end{array}$ & $\begin{array}{l}44.75 \\
56.13 \\
59.71\end{array}$ & $\begin{array}{l}4.77 \\
5.99\end{array}$ & $\begin{array}{r}9,292 \\
11,655 \\
12,398\end{array}$ & $\begin{array}{l}54.79 \\
68.73 \\
73.10\end{array}$ & $\begin{array}{l}5.71 \\
4.31 \\
4.58\end{array}$ & $\begin{array}{l}1.13 \\
1.42 \\
1.51\end{array}$ & $\begin{array}{l}33.32 \\
19.20 \\
20.43\end{array}$ & $\begin{array}{l}0.08 \\
0.10 \\
0.10\end{array}$ & $\begin{array}{l}0.28 \\
0.35 \\
0.35\end{array}$ \\
\hline $\begin{array}{l}\text { Meade } \\
\text { River }\end{array}$ & Subbic. B & 5 & (UA-110) & $\begin{array}{l}1 \\
2 \\
3\end{array}$ & 17.88 & $\begin{array}{l}30.30 \\
36.90 \\
38.59\end{array}$ & $\begin{array}{l}48.22 \\
58.72 \\
61.41\end{array}$ & $\begin{array}{l}3.60 \\
4.38\end{array}$ & $\begin{array}{l}10,425 \\
12,695 \\
13,277\end{array}$ & $\begin{array}{l}60.04 \\
73.12 \\
76.47\end{array}$ & $\begin{array}{l}5.87 \\
4.72 \\
4.94\end{array}$ & $\begin{array}{l}1.35 \\
1.64 \\
1.71\end{array}$ & $\begin{array}{l}28.71 \\
15.61 \\
16.33\end{array}$ & $\begin{array}{l}0.06 \\
0.07 \\
0.08\end{array}$ & $\begin{array}{l}0.43 \\
0.53 \\
0.55\end{array}$ \\
\hline $\begin{array}{l}\text { Sagwon } \\
\text { Bluffs }\end{array}$ & hv Cb & 6.5 & (UA-114! & $\begin{array}{l}1 \\
2 \\
3\end{array}$ & 14.71 & $\begin{array}{l}15.74 \\
18.45 \\
50.13\end{array}$ & $\begin{array}{l}15.65 \\
18.36 \\
49.87\end{array}$ & $\begin{array}{l}53.90 \\
63.19\end{array}$ & $\begin{array}{r}3,591 \\
4,210 \\
11,439\end{array}$ & $\begin{array}{l}20.98 \\
24.60 \\
66.83\end{array}$ & $\begin{array}{l}.37 \\
2.02 \\
5.49\end{array}$ & $\begin{array}{l}0.53 \\
0.62 \\
1.67\end{array}$ & $\begin{array}{r}21.16 \\
9.50 \\
25.81\end{array}$ & $\begin{array}{l}0.04 \\
0.05 \\
0.14\end{array}$ & $\begin{array}{l}0.06 \\
0.07 \\
0.20\end{array}$ \\
\hline Northwest & Alaska Coa & al Fields & & & & & & & & & & & & & \\
\hline $\begin{array}{l}\text { Chicago } \\
\text { Creek } \\
\text { Seward Penin }\end{array}$ & $\begin{array}{l}\text { Subbil. C } \\
\text { nsula }\end{array}$ & 3 & (UA-138; & $\begin{array}{l}1 \\
2 \\
3\end{array}$ & 30.70 & $\begin{array}{l}29.62 \\
42.73 \\
50.33\end{array}$ & $\begin{array}{l}29.22 \\
42.18 \\
49.67\end{array}$ & $\begin{array}{l}10.46 \\
15.09\end{array}$ & $\begin{array}{r}6,643 \\
9,586 \\
11,290\end{array}$ & $\begin{array}{l}39.98 \\
57.69 \\
67.94\end{array}$ & $\begin{array}{l}6.28 \\
4.11 \\
4.78\end{array}$ & $\begin{array}{l}0.83 \\
1.20 \\
1.77\end{array}$ & $\begin{array}{l}41.85 \\
21.07 \\
24.53\end{array}$ & $\begin{array}{l}0.04 \\
0.06 \\
0.07\end{array}$ & $\begin{array}{l}0.60 \\
0.84 \\
0.98\end{array}$ \\
\hline
\end{tabular}

*1-EQUILIBRIUM MOISTURE

2-MOISIURE FREE

3-MOISTURE AND ASH FREE 
Table I (Continued)

Proximate and Ultimate Analyses of Raw Coals

\begin{tabular}{|c|c|c|c|c|c|c|c|c|c|c|c|c|c|c|c|}
\hline $\begin{array}{l}\text { Coal } \\
\text { Field and } \\
\text { Seam }\end{array}$ & $\begin{array}{c}\text { Apparent } \\
\text { ASTM } \\
\text { Rank }\end{array}$ & $\begin{array}{c}\text { Thickness } \\
\text { (feet) }\end{array}$ & $\begin{array}{l}\text { S.ample } \\
\text { Numbers }\end{array}$ & Basis* & $\begin{array}{c}\text { Moisture } \\
\%\end{array}$ & $\begin{array}{l}\text { Volatile } \\
\text { Mater,\% }\end{array}$ & $\begin{array}{c}\text { Fixed } \\
\text { Carbon,\% }\end{array}$ & $\begin{array}{c}\text { Ash } \\
\%\end{array}$ & $\begin{array}{l}\text { Heating } \\
\text { Value } \\
\text { BTU/b }\end{array}$ & $\mathrm{C}, \%$ & $\mathrm{H}, \%$ & $\mathrm{~N}, \%$ & $0, \%$ & $\begin{array}{l}\text { Sul } \\
\text { Pyritic }\end{array}$ & $\begin{array}{l}\text { Tur } \\
\text { Total }\end{array}$ \\
\hline $\begin{array}{l}\text { Unalakleet } \\
\text { Coal Creek }\end{array}$ & Stbbit. C & & $(\mathrm{CA}-151)$ & $\begin{array}{l}1 \\
2 \\
3\end{array}$ & 19.32 & $\begin{array}{l}4: .45 \\
5 \ldots .71 \\
58.23\end{array}$ & $\begin{array}{l}29.73 \\
37.09 \\
41.77\end{array}$ & $\begin{array}{r}8.98 \\
11.20\end{array}$ & $\begin{array}{r}8,741 \\
10,91) 5 \\
12,231\end{array}$ & $\begin{array}{l}50.35 \\
52.81 \\
70.73\end{array}$ & $\begin{array}{l}6.71 \\
5.60 \\
6.31\end{array}$ & $\begin{array}{l}0.69 \\
0.87 \\
0.97\end{array}$ & $\begin{array}{l}32.83 \\
18.98 \\
21.38\end{array}$ & $\begin{array}{l}0.01 \\
0.01 \\
0.01\end{array}$ & $\begin{array}{l}0.44 \\
0.54 \\
0.61\end{array}$ \\
\hline Interior Ala & laska Coal & Fields & & & & & & & & & & & & & \\
\hline $\begin{array}{l}\text { Nenana } \\
\text { No. } 2 \text { Seam }\end{array}$ & Subbit. C & 27.8 & (LA-105) & $\begin{array}{l}1 \\
2 \\
3\end{array}$ & 26.76 & $\begin{array}{l}33.12 \\
45.23 \\
50.67\end{array}$ & $\begin{array}{l}32.25 \\
44.03 \\
49.33\end{array}$ & $\begin{array}{r}7.87 \\
10.74\end{array}$ & $\begin{array}{r}7,956 \\
10,876 \\
12,185\end{array}$ & $\begin{array}{l}46.41 \\
63.38 \\
71.01\end{array}$ & $\begin{array}{l}6.42 \\
4.68 \\
5.24\end{array}$ & $\begin{array}{l}0.63 \\
0.86 \\
0.96\end{array}$ & $\begin{array}{l}38.50 \\
20.11 \\
22.54\end{array}$ & $\begin{array}{l}0.02 \\
0.02 \\
0.03\end{array}$ & $\begin{array}{l}0.17 \\
0.23 \\
0.25\end{array}$ \\
\hline $\begin{array}{l}\text { Lignite } \\
\text { Creek }\end{array}$ & Lignite & 7 & (UA-141) & $\begin{array}{l}1 \\
2 \\
3\end{array}$ & 28.46 & $\begin{array}{l}32.75 \\
45.78 \\
52.49\end{array}$ & $\begin{array}{l}29.40 \\
41.45 \\
47.51\end{array}$ & $\begin{array}{r}9.39 \\
12.77\end{array}$ & $\begin{array}{r}6,757 \\
9,445 \\
10,829\end{array}$ & $\begin{array}{l}41.96 \\
58.66 \\
67.24\end{array}$ & $\begin{array}{l}6.64 \\
4.83 \\
5.54\end{array}$ & $\begin{array}{l}0.56 \\
0.79 \\
0.91\end{array}$ & $\begin{array}{l}41.21 \\
22.62 \\
25.93\end{array}$ & $\begin{array}{l}0.01 \\
0.01 \\
0.01\end{array}$ & $\begin{array}{l}0.24 \\
0.33 \\
0.38\end{array}$ \\
\hline Moose Seam & Sabbit. C & 21.6 & (UA-103) & $\begin{array}{l}1 \\
2 \\
3\end{array}$ & 21.42 & $\begin{array}{l}35.02 \\
45.85 \\
51.81\end{array}$ & $\begin{array}{r}34.88 \\
44.38 \\
49.19\end{array}$ & $\begin{array}{l}7.68 \\
9.77\end{array}$ & $\begin{array}{r}8,953 \\
11,393 \\
12,627\end{array}$ & $\begin{array}{l}51.69 \\
65.78 \\
72.90\end{array}$ & $\begin{array}{l}6.34 \\
5.02 \\
5.56\end{array}$ & $\begin{array}{l}0.81 \\
1.03 \\
1.15\end{array}$ & $\begin{array}{l}33.33 \\
18.25 \\
20.18\end{array}$ & $\begin{array}{l}0.01 \\
0.01 \\
0.01\end{array}$ & $\begin{array}{l}0.15 \\
0.15 \\
0.21\end{array}$ \\
\hline $\begin{array}{l}\text { Caribou } \\
\text { Seam }\end{array}$ & Subbit. C & $1 \epsilon: 6$ & (UA-1104) & $\begin{array}{l}1 \\
2 \\
3\end{array}$ & 21.93 & $\begin{array}{l}35.88 \\
45.96 \\
52.20\end{array}$ & $\begin{array}{l}32.85 \\
42.08 \\
47.80\end{array}$ & $\begin{array}{r}9.34 \\
11.96\end{array}$ & $\begin{array}{r}8,567 \\
10,573 \\
12,464\end{array}$ & $\begin{array}{l}49.44 \\
63.33 \\
71.93\end{array}$ & $\begin{array}{l}6.10 \\
4.67 \\
5.30\end{array}$ & $\begin{array}{l}0.69 \\
0.88 \\
1.00\end{array}$ & $\begin{array}{l}34.30 \\
18.99 \\
21.57\end{array}$ & $\begin{array}{l}0.02 \\
0.02 \\
0.03\end{array}$ & $\begin{array}{l}0.13 \\
0.17 \\
0.20\end{array}$ \\
\hline $\begin{array}{l}\text { Basal } \\
\text { Bed (Bed A) } \\
\text { Arctic Mine }\end{array}$ & Subbit. C & 60 & (UA-1*0) & $\begin{array}{l}1 \\
2 \\
3\end{array}$ & 24.32 & $\begin{array}{l}33.75 \\
44.59 \\
55.42\end{array}$ & $\begin{array}{l}27.15 \\
35.88 \\
44.58\end{array}$ & $\begin{array}{l}14.78 \\
19.53\end{array}$ & $\begin{array}{r}7, \geq 60 \\
9,725 \\
12,[86\end{array}$ & $\begin{array}{l}42.73 \\
56.46 \\
70.16\end{array}$ & $\begin{array}{l}6.15 \\
4.53 \\
5.63\end{array}$ & $\begin{array}{l}0.55 \\
0.72 \\
0.89\end{array}$ & $\begin{array}{l}35.50 \\
18.38 \\
22.84\end{array}$ & $\begin{array}{l}0.02 \\
0.02 \\
0.03\end{array}$ & $\begin{array}{l}0.29 \\
0.38 \\
0.48\end{array}$ \\
\hline $\begin{array}{l}\text { No. } 1 \text { Bed } \\
\text { Usibelli Mine }\end{array}$ & $e^{\text {Subbit. C }}$ & 18. & (UA-129) & $\begin{array}{l}1 \\
2 \\
3\end{array}$ & 24.33 & $\begin{array}{l}35.09 \\
46.37 \\
56.04\end{array}$ & $\begin{array}{l}27.52 \\
36.37 \\
43.96\end{array}$ & $\begin{array}{l}13.06 \\
17.26\end{array}$ & $\begin{array}{r}7,464 \\
9,864 \\
11,922\end{array}$ & $\begin{array}{l}44.58 \\
58.92 \\
71.21\end{array}$ & $\begin{array}{l}5.91 \\
4.21 \\
5.09\end{array}$ & $\begin{array}{l}0.52 \\
0.69 \\
0.83\end{array}$ & $\begin{array}{l}35.77 \\
18.71 \\
22.62\end{array}$ & $\begin{array}{l}0.01 \\
0.01 \\
0.02\end{array}$ & $\begin{array}{l}0.16 \\
0.21 \\
0.25\end{array}$ \\
\hline Usibelli Mine & $e^{\text {Subbit. C }}$ & 17 & (UA-130) & $\begin{array}{l}1 \\
2 \\
3\end{array}$ & 24.54 & $\begin{array}{l}36.42 \\
48.27 \\
55.17\end{array}$ & $\begin{array}{l}29.59 \\
39.22 \\
44.83\end{array}$ & $\begin{array}{r}9.44 \\
12.51\end{array}$ & $\begin{array}{r}8,047 \\
10,663 \\
12,88\end{array}$ & $\begin{array}{l}46.53 \\
61.66 \\
70.47\end{array}$ & $\begin{array}{l}6.05 \\
4.38 \\
5.01\end{array}$ & $\begin{array}{l}0.52 \\
0.69 \\
0.79\end{array}$ & $\begin{array}{l}37.30 \\
20.54 \\
23.48\end{array}$ & $\begin{array}{l}0.01 \\
0.01 \\
0.02\end{array}$ & $\begin{array}{l}0.16 \\
0.22 \\
0.25\end{array}$ \\
\hline
\end{tabular}

*1-EQUILIBRTUM MOISTURE

2-MOISIURE FREE

3-MOISTURE AND ASH FREE 
Table I (Continued)

Proximate and Ultimate Analyses of Raw Coals

\begin{tabular}{|c|c|c|c|c|c|c|c|c|c|c|c|c|c|c|c|}
\hline $\begin{array}{l}\text { Coal } \\
\text { Field and } \\
\text { Seam }\end{array}$ & $\begin{array}{l}\text { Apparent } \\
\text { ASTM } \\
\text { Rank }\end{array}$ & $\begin{array}{l}\text { Thickness } \\
\text { (feet) }\end{array}$ & $\begin{array}{l}\text { Sample } \\
\text { Numbers }\end{array}$ & Basis* & $\begin{array}{c}\text { Moisture } \\
\%\end{array}$ & $\begin{array}{l}\text { Volatile } \\
\text { Matter,\% }\end{array}$ & $\begin{array}{c}\text { Fixed } \\
\text { Carbon,\% }\end{array}$ & $\begin{array}{c}\text { Ash } \\
\%\end{array}$ & $\begin{array}{l}\text { Heating } \\
\text { Value } \\
\text { BTU/hb }\end{array}$ & C,\% & $\mathrm{H}, \%$ & $\mathrm{~N}, \%$ & $0, \%$ & $\begin{array}{r}\text { Su } \\
\text { Pyritic }\end{array}$ & Total \\
\hline $\begin{array}{l}\text { Poker Flat } \\
\text { Pit } \\
\text { Nio. } 4 \text { Seam }\end{array}$ & Subbit. C & 24 & (UA-119) & $\begin{array}{l}1 \\
2 \\
3\end{array}$ & 25.29 & $\begin{array}{l}32.51 \\
43.52 \\
50.13\end{array}$ & $\begin{array}{l}32.55 \\
43.30 \\
49.87\end{array}$ & $\begin{array}{r}9.85 \\
13.18\end{array}$ & $\begin{array}{r}7,779 \\
10,412 \\
11,993\end{array}$ & $\begin{array}{l}45.28 \\
60.61 \\
69.81\end{array}$ & $\begin{array}{l}6.30 \\
4.64 \\
5.34\end{array}$ & $\begin{array}{l}1.13 \\
1.51 \\
1.74\end{array}$ & $\begin{array}{l}37.11 \\
19.62 \\
22.60\end{array}$ & $\begin{array}{l}0.02 \\
0.02 \\
0.03\end{array}$ & $\begin{array}{l}0.33 \\
0.44 \\
0.51\end{array}$ \\
\hline $\begin{array}{l}\text { No. } 6 \text { Seam } \\
\text { Top }\end{array}$ & Subbit. C & 3.2 & (UA-100: & $\begin{array}{l}1 \\
2 \\
3\end{array}$ & 23.61 & $\begin{array}{l}32.80 \\
42.94 \\
55.28\end{array}$ & $\begin{array}{l}26.54 \\
34.74 \\
44.72\end{array}$ & $\begin{array}{l}17.05 \\
22.32\end{array}$ & $\begin{array}{r}7,022 \\
9,193 \\
11,834\end{array}$ & $\begin{array}{l}40.59 \\
53.14 \\
68.40\end{array}$ & $\begin{array}{l}5.93 \\
4.30 \\
5.54\end{array}$ & $\begin{array}{l}0.56 \\
0.73 \\
0.94\end{array}$ & $\begin{array}{l}35.70 \\
19.29 \\
24.84\end{array}$ & $\begin{array}{l}0.01 \\
0.01 \\
0.01\end{array}$ & $\begin{array}{l}0.17 \\
0.22 \\
0.28\end{array}$ \\
\hline $\begin{array}{l}\text { Mo. } 6 \text { Seam } \\
\text { Middle }\end{array}$ & Subbit. C & 18.3 & (UA-101! & $\begin{array}{l}1 \\
2 \\
3\end{array}$ & 25.23 & $\begin{array}{l}35.71 \\
47.76 \\
53.22\end{array}$ & $\begin{array}{l}31.40 \\
41.99 \\
46.78\end{array}$ & $\begin{array}{r}7.66 \\
10.25\end{array}$ & $\begin{array}{r}8,136 \\
10,882 \\
12,124\end{array}$ & $\begin{array}{l}46.08 \\
61.64 \\
68.68\end{array}$ & $\begin{array}{l}6.30 \\
4.65 \\
5.18\end{array}$ & $\begin{array}{l}0.60 \\
0.80 \\
0.89\end{array}$ & $\begin{array}{l}39.24 \\
22.50 \\
25.07\end{array}$ & $\begin{array}{l}0.01 \\
0.01 \\
0.01\end{array}$ & $\begin{array}{l}0.12 \\
0.16 \\
0.18\end{array}$ \\
\hline $\begin{array}{l}\text { No. } 6 \text { Seam } \\
\text { Lcwer }\end{array}$ & Subbit. C & 3.3 & (UA-102i & $\begin{array}{l}1 \\
2 \\
3\end{array}$ & 25.68 & $\begin{array}{l}34.12 \\
45.91 \\
53: 36\end{array}$ & $\begin{array}{l}29.83 \\
40.14 \\
46.64\end{array}$ & $\begin{array}{l}10.37 \\
13.95\end{array}$ & $\begin{array}{r}7,516 \\
10,113 \\
11,752\end{array}$ & $\begin{array}{l}43.87 \\
59.03 \\
58.60\end{array}$ & $\begin{array}{l}6.05 \\
4.28 \\
4.97\end{array}$ & $\begin{array}{l}0.59 \\
0.80 \\
0.93\end{array}$ & $\begin{array}{l}38.99 \\
21.77 \\
25.30\end{array}$ & $\begin{array}{l}0.01 \\
0.01 \\
0.01\end{array}$ & $\begin{array}{l}0.13 \\
0.17 \\
0.20\end{array}$ \\
\hline $\begin{array}{l}\text { Marguerite } \\
\text { Creek }\end{array}$ & Subbit. C & 30.5 & (UA-120) & $\begin{array}{l}1 \\
2 \\
3\end{array}$ & 29.05 & $\begin{array}{l}32.03 \\
45.14 \\
51.27\end{array}$ & $\begin{array}{l}30.44 \\
42.91 \\
48.73\end{array}$ & $\begin{array}{r}8.48 \\
11.95\end{array}$ & $\begin{array}{r}7,445 \\
10,493 \\
11,917\end{array}$ & $\begin{array}{l}44.24 \\
62.36 \\
70.82\end{array}$ & $\begin{array}{l}6.23 \\
4.20 \\
4.77\end{array}$ & $\begin{array}{l}0.50 \\
0.71 \\
0.81\end{array}$ & $\begin{array}{l}40.44 \\
20.63 \\
23.43\end{array}$ & $\begin{array}{l}0.00 \\
0.00 \\
0.00\end{array}$ & $\begin{array}{l}0.11 \\
0.15 \\
0.17\end{array}$ \\
\hline $\begin{array}{l}\text { Yanert } \\
\text { Mine }\end{array}$ & hv Bb & 5 & (UA-132) & $\begin{array}{l}1 \\
2 \\
3\end{array}$ & 5.51 & $\begin{array}{l}17.67 \\
18.70 \\
41.20\end{array}$ & $\begin{array}{l}25.22 \\
26.69 \\
58.80\end{array}$ & $\begin{array}{l}51.60 \\
54.61\end{array}$ & $\begin{array}{r}5,412 \\
5,728 \\
12,650\end{array}$ & $\begin{array}{l}31.73 \\
33.58 \\
73.98\end{array}$ & $\begin{array}{l}3.34 \\
2.88 \\
6.35\end{array}$ & $\begin{array}{l}0.63 \\
0.66 \\
1.46\end{array}$ & $\begin{array}{r}12.52 \\
8.08 \\
17.80\end{array}$ & $\begin{array}{l}0.07 \\
0.07 \\
0.16\end{array}$ & $\begin{array}{l}0.18 \\
0.19 \\
0.41\end{array}$ \\
\hline $\begin{array}{l}\text { Jarvis } \\
\text { Creek } \\
\text { No. } 1 \text { Seam }\end{array}$ & Subbit. C & 10 & (UA-106) & $\begin{array}{l}1 \\
2 \\
3\end{array}$ & 20.58 & $\begin{array}{l}36.20 \\
45.58 \\
51.45\end{array}$ & $\begin{array}{l}34.16 \\
43.01 \\
48.55\end{array}$ & $\begin{array}{r}9.06 \\
11.41\end{array}$ & $\begin{array}{r}8,746 \\
11,012 \\
12,430\end{array}$ & $\begin{array}{l}49.83 \\
62.75 \\
70.83\end{array}$ & $\begin{array}{l}5.84 \\
4.45 \\
5.02\end{array}$ & $\begin{array}{l}0.80 \\
1.00 \\
1.13\end{array}$ & $\begin{array}{l}33.42 \\
19.07 \\
21.53\end{array}$ & $\begin{array}{l}0.31 \\
0.39 \\
0.44\end{array}$ & $\begin{array}{l}1.05 \\
1.32 \\
1.49\end{array}$ \\
\hline $\begin{array}{l}\text { Eagle } \\
\text { Coal Creek }\end{array}$ & Subbit. B & 30 & (UA-121) & $\begin{array}{l}1 \\
2 \\
3\end{array}$ & 24.94 & $\begin{array}{l}32.44 \\
43.22 \\
56.15\end{array}$ & $\begin{array}{l}25.33 \\
33.75 \\
43.85\end{array}$ & $\begin{array}{l}17.29 \\
23.03\end{array}$ & $\begin{array}{l}5,717 \\
7,616 \\
9,894\end{array}$ & $\begin{array}{l}38.54 \\
51.35 \\
66.71\end{array}$ & $\begin{array}{l}4.92 \\
2.84 \\
3.69\end{array}$ & $\begin{array}{l}0.77 \\
1.02 \\
1.32\end{array}$ & $\begin{array}{l}38.02 \\
21.15 \\
27.49\end{array}$ & $\begin{array}{l}0.02 \\
0.02 \\
0.03\end{array}$ & $\begin{array}{l}0.46 \\
0.61 \\
0.79\end{array}$ \\
\hline
\end{tabular}

*1-EQUILIBRIUM MOISTURE

2-MOISTURE FREE

3-MOISTURE AND ASH FREE 
Table I (Continued)

Proximate and Ultimate Analyses of Raw Coals

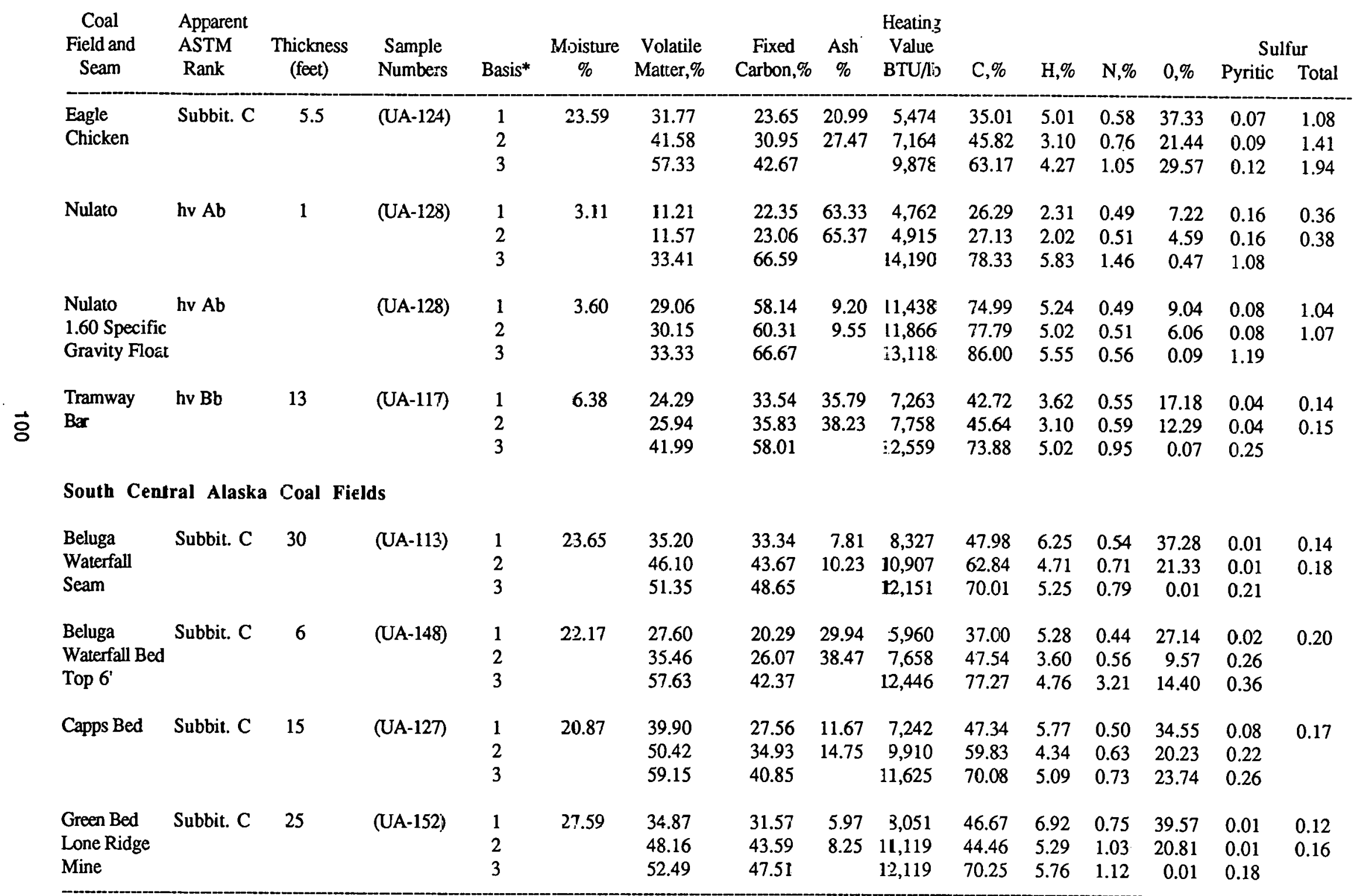

*1-EQULILIBRIUM MOISTURE

2-MOISTURE FREE

3-MOISTURE AND ASH FREE 
Table I (Continued)

Proximate and Ultimate Analyses of Raw Coals

\begin{tabular}{|c|c|c|c|c|c|c|c|c|c|c|c|c|c|c|c|}
\hline $\begin{array}{l}\text { Coal } \\
\text { Field and } \\
\text { Seam }\end{array}$ & $\begin{array}{l}\text { Apparent } \\
\text { ASTM } \\
\text { Rank }\end{array}$ & $\begin{array}{l}\text { Thickness } \\
\text { (feet) }\end{array}$ & $\begin{array}{l}\text { Sample } \\
\text { Numbers }\end{array}$ & Basis* & $\begin{array}{c}\text { Moisture } \\
\%\end{array}$ & $\begin{array}{c}\text { Volatile } \\
\text { Matter,\% }\end{array}$ & $\begin{array}{c}\text { Fixed } \\
\text { Carbon,\% }\end{array}$ & $\begin{array}{c}\text { Ash } \\
\%\end{array}$ & $\begin{array}{l}\text { Heating } \\
\text { Value } \\
\text { BTU/b }\end{array}$ & $\mathrm{C}, \%$ & $\mathrm{H}, \%$ & $\mathrm{~N}, \%$ & $0, \%$ & $\begin{array}{r}\text { Sul } \\
\text { Pyritic }\end{array}$ & $\begin{array}{l}\text { fur } \\
\text { Total }\end{array}$ \\
\hline $\begin{array}{l}\text { Yentna } \\
\text { Johnson Creek }\end{array}$ & Subbit. C & 24 & (UA-149; & $\begin{array}{l}1 \\
2 \\
3\end{array}$ & 25.34 & $\begin{array}{l}33.74 \\
45.19 \\
52.35\end{array}$ & $\begin{array}{l}30.71 \\
41.14 \\
47.65\end{array}$ & $\begin{array}{l}10.21 \\
13.67\end{array}$ & $\begin{array}{r}7,743 \\
10,371 \\
12,013\end{array}$ & $\begin{array}{l}44.99 \\
60.26 \\
69.80\end{array}$ & $\begin{array}{l}6.42 \\
4.80 \\
5.56\end{array}$ & $\begin{array}{l}0.64 \\
0.86 \\
0.99\end{array}$ & $\begin{array}{r}37.56 \\
20.17 \\
0.02\end{array}$ & $\begin{array}{l}0.01 \\
0.01 \\
0.28\end{array}$ & $\begin{array}{l}0.18 \\
0.24\end{array}$ \\
\hline $\begin{array}{l}\text { Yentna } \\
\text { Canyon Creek }\end{array}$ & Subbit. C & 34 & (UA-150) & $\begin{array}{l}1 \\
2 \\
3\end{array}$ & 20.80 & $\begin{array}{l}35.78 \\
45.18 \\
55.64\end{array}$ & $\begin{array}{l}28.54 \\
36.03 \\
44.36\end{array}$ & $\begin{array}{l}14.88 \\
18.79\end{array}$ & $\begin{array}{r}7,857 \\
9,921 \\
12,216\end{array}$ & $\begin{array}{l}45.22 \\
57.09 \\
50.30\end{array}$ & $\begin{array}{l}6.20 \\
4.89 \\
6.03\end{array}$ & $\begin{array}{l}0.66 \\
0.83 \\
1.02\end{array}$ & $\begin{array}{l}32.90 \\
18.23 \\
22.44\end{array}$ & $\begin{array}{l}0.01 \\
0.01 \\
0.02\end{array}$ & $\begin{array}{l}0.14 \\
0.17 \\
0.21\end{array}$ \\
\hline $\begin{array}{l}\text { Yentna } \\
\text { Locality } 2 \\
\text { Lower }\end{array}$ & Lignite & 10 & (UA-115) & $\begin{array}{l}1 \\
2 \\
3\end{array}$ & 29.80 & $\begin{array}{l}38.26 \\
54.50 \\
57.21\end{array}$ & $\begin{array}{l}28.61 \\
40.76 \\
42.79\end{array}$ & $\begin{array}{l}3.33 \\
4.74\end{array}$ & $\begin{array}{r}7,943 \\
11,315 \\
11,879\end{array}$ & $\begin{array}{l}45.20 \\
64.39 \\
67.59\end{array}$ & $\begin{array}{l}6.76 \\
4.87 \\
5.11\end{array}$ & $\begin{array}{l}0.53 \\
0.75 \\
0.79\end{array}$ & $\begin{array}{l}44.07 \\
25.10 \\
26.35\end{array}$ & $\begin{array}{l}0.01 \\
0.01 \\
0.01\end{array}$ & $\begin{array}{l}0.11 \\
0.15 \\
0.16\end{array}$ \\
\hline $\begin{array}{l}\text { Yentna } \\
\text { Lccality } 2 \\
\text { Upper }\end{array}$ & Lignite & 10 & (UA-116) & $\begin{array}{l}1 \\
2 \\
3\end{array}$ & 29.86 & $\begin{array}{l}39.29 \\
56.02 \\
58.02\end{array}$ & $\begin{array}{l}28.43 \\
40.54 \\
41.98\end{array}$ & $\begin{array}{l}2.42 \\
3.44\end{array}$ & $\begin{array}{r}8,017 \\
11,429 \\
11,837\end{array}$ & $\begin{array}{l}45.28 \\
64.84 \\
67.16\end{array}$ & $\begin{array}{l}6.89 \\
5.06 \\
5.24\end{array}$ & $\begin{array}{l}0.49 \\
0.70 \\
0.73\end{array}$ & $\begin{array}{l}44.67 \\
25.89 \\
26.35\end{array}$ & $\begin{array}{l}0.01 \\
0.01 \\
0.01\end{array}$ & $\begin{array}{l}0.05 \\
0.07 \\
0.08\end{array}$ \\
\hline $\begin{array}{l}\text { Kenai } \\
\text { Cabin } \\
\text { Bed }\end{array}$ & Subbit. C & 6 & (UA-118) & $\begin{array}{l}1 \\
2 \\
3\end{array}$ & 23.01 & $\begin{array}{l}35.63 \\
46.28 \\
52.13\end{array}$ & $\begin{array}{l}32.71 \\
42.49 \\
47.87\end{array}$ & $\begin{array}{r}8.65 \\
11.23\end{array}$ & $\begin{array}{r}8,028 \\
10,428 \\
11,747\end{array}$ & $\begin{array}{l}47.23 \\
61.35 \\
69.11\end{array}$ & $\begin{array}{l}6.07 \\
4.54 \\
5.11\end{array}$ & $\begin{array}{l}0.62 \\
0.81 \\
0.91\end{array}$ & $\begin{array}{l}37.20 \\
21.77 \\
24.53\end{array}$ & $\begin{array}{l}0.01 \\
0.01 \\
0.01\end{array}$ & $\begin{array}{l}0.23 \\
0.30 \\
0.34\end{array}$ \\
\hline $\begin{array}{l}\text { Kenai } \\
\text { Ninilchik }\end{array}$ & Subbit. C & 6 & (UA-122) & $\begin{array}{l}1 \\
2 \\
3\end{array}$ & 23.72 & $\begin{array}{l}36.01 \\
47.21 \\
57.13\end{array}$ & $\begin{array}{l}27.02 \\
35.42 \\
42.87\end{array}$ & $\begin{array}{l}13.25 \\
17.37\end{array}$ & $\begin{array}{r}7,437 \\
9,750 \\
11,800\end{array}$ & $\begin{array}{l}42.58 \\
55.82 \\
67.55\end{array}$ & $\begin{array}{l}6.23 \\
4.69 \\
5.68\end{array}$ & $\begin{array}{l}0.66 \\
0.87 \\
1.05\end{array}$ & $\begin{array}{l}37.03 \\
20.92 \\
25.33\end{array}$ & $\begin{array}{l}0.04 \\
0.05 \\
0.06\end{array}$ & $\begin{array}{l}0.25 \\
0.33 \\
0.39\end{array}$ \\
\hline $\begin{array}{l}\text { Kenai } \\
\text { Happy Creek }\end{array}$ & Subbit. C & 6 & (UA-131) & $\begin{array}{l}1 \\
2 \\
3\end{array}$ & 23.25 & $\begin{array}{l}35.32 \\
46.01 \\
52.67\end{array}$ & $\begin{array}{l}31.74 \\
41.35 \\
47.33\end{array}$ & $\begin{array}{r}9.69 \\
12.63\end{array}$ & $\begin{array}{r}8,292 \\
10,803 \\
12,365\end{array}$ & $\begin{array}{l}47.86 \\
62.36 \\
71.38\end{array}$ & $\begin{array}{l}5.99 \\
4.42 \\
5.06\end{array}$ & $\begin{array}{l}0.84 \\
1.09 \\
1.25\end{array}$ & $\begin{array}{l}35.33 \\
19.12 \\
21.88\end{array}$ & $\begin{array}{l}0.03 \\
0.04 \\
0.04\end{array}$ & $\begin{array}{l}0.29 \\
0.38 \\
0.43\end{array}$ \\
\hline $\begin{array}{l}\text { Matanuska } \\
\text { Big Seam }\end{array}$ & hv Bb & & (UA-108) & $\begin{array}{l}1 \\
2 \\
3\end{array}$ & 5.87 & $\begin{array}{l}35.73 \\
37.96 \\
44.84\end{array}$ & $\begin{array}{l}43.96 \\
46.70 \\
55.16\end{array}$ & $\begin{array}{l}14.44 \\
15.34\end{array}$ & $\begin{array}{l}11,101 \\
11,794 \\
13,864\end{array}$ & $\begin{array}{l}63.63 \\
67.60 \\
79.85\end{array}$ & $\begin{array}{l}5.11 \\
4.73 \\
5.59\end{array}$ & $\begin{array}{l}1.14 \\
1.21 \\
1.43\end{array}$ & $\begin{array}{l}15.33 \\
10.75 \\
12.70\end{array}$ & $\begin{array}{l}0.04 \\
0.04 \\
0.05\end{array}$ & $\begin{array}{l}0.35 \\
0.37 \\
0.43\end{array}$ \\
\hline
\end{tabular}

*1-EQUILIBRIUM MOISTURE

2-MOISTURE FREE

3-MOISTURE AND ASH FREE 
Table I (Continued)

Proximate and Ultimate Analyses of Raw Coal;

\begin{tabular}{|c|c|c|c|c|c|c|c|c|c|c|c|c|c|c|c|}
\hline $\begin{array}{c}\text { Coal } \\
\text { Field and } \\
\text { Seam }\end{array}$ & $\begin{array}{l}\text { Afparent } \\
\text { ASTM } \\
\text { Rank }\end{array}$ & $\begin{array}{l}\text { Thickness } \\
\text { (feet) }\end{array}$ & $\begin{array}{c}\text { Sample } \\
\text { Numbers }\end{array}$ & Basis* & $\underset{\%}{\text { Moisture }}$ & $\begin{array}{c}\text { Volatile } \\
\text { Matter,\% }\end{array}$ & $\begin{array}{c}\text { Fixed } \\
\text { Carbon,\% }\end{array}$ & $\begin{array}{l}\text { Ash } \\
\%\end{array}$ & $\begin{array}{l}\text { Heating } \\
\text { Value } \\
\text { BTU,1 }\end{array}$ & $C, 7$ & $\mathrm{H}, \%$ & $\mathrm{~N}, \%$ & $0, \%$ & $\begin{array}{l}\text { Sul } \\
\text { Pyritic }\end{array}$ & $\begin{array}{l}\text { fur } \\
\text { Total }\end{array}$ \\
\hline $\begin{array}{l}\text { No. } 7 \text { A Bed } \\
\text { Evan Jones } \\
\text { Mine }\end{array}$ & hv Bb & 10 & (LiA-142) & $\begin{array}{l}1 \\
2 \\
3\end{array}$ & 4.84 & $\begin{array}{r}34.63 \\
.36 .39 \\
45.02\end{array}$ & $\begin{array}{l}42.30 \\
44.45 \\
54.98\end{array}$ & $\begin{array}{l}18.23 \\
19.16\end{array}$ & $\begin{array}{l}10,730 \\
11,276 \\
13,948\end{array}$ & $\begin{array}{l}50: 31 \\
53.33 \\
78.43\end{array}$ & $\begin{array}{l}5.31 \\
5.01 \\
6.20\end{array}$ & $\begin{array}{l}1.30 \\
1.36 \\
1.68\end{array}$ & $\begin{array}{l}14.45 \\
10.67 \\
13.20\end{array}$ & $\begin{array}{l}0.02 \\
0.02 \\
0.02\end{array}$ & $\begin{array}{l}0.40 \\
0.42 \\
0.52\end{array}$ \\
\hline $\begin{array}{l}\text { No. } 7 \text { Lower } \\
\text { Bed - Evan Jo } \\
\text { Mine }\end{array}$ & $\begin{array}{l}\text { hv Bb } \\
\text { nes }\end{array}$ & 2.7 & $(\mathrm{UA}-1<3)$ & $\begin{array}{l}1 \\
2 \\
3\end{array}$ & 4.54 & $\begin{array}{l}37.95 \\
39.80 \\
48.38\end{array}$ & $\begin{array}{l}40.50 \\
42.47 \\
51.62\end{array}$ & $\begin{array}{l}16.91 \\
17.73\end{array}$ & $\begin{array}{l}10,9133 \\
11,439 \\
13,994\end{array}$ & $\begin{array}{l}5120 \\
64.18 \\
7 \varepsilon .01\end{array}$ & $\begin{array}{l}5.29 \\
5.00 \\
6.08\end{array}$ & $\begin{array}{l}1.31 \\
1.38 \\
1.67\end{array}$ & $\begin{array}{l}14.86 \\
11.26 \\
13.69\end{array}$ & $\begin{array}{l}0.04 \\
0.04 \\
0.05\end{array}$ & $\begin{array}{l}0.43 \\
0.45 \\
0.55\end{array}$ \\
\hline $\begin{array}{l}\text { No. } 7 \text { Upper } \\
\text { Bed - Evan Jor } \\
\text { Mine }\end{array}$ & hy Bb & 2.6 & (UA-144) & $\begin{array}{l}1 \\
2 \\
3\end{array}$ & 4.87 & $\begin{array}{l}37.70 \\
39.62 \\
47.56\end{array}$ & $\begin{array}{l}41.56 \\
43.70 \\
52.44\end{array}$ & $\begin{array}{l}15.87 \\
16.68\end{array}$ & $\begin{array}{l}11,116 \\
11,685 \\
14,024\end{array}$ & $\begin{array}{l}68.16 \\
65.24 \\
78.30\end{array}$ & $\begin{array}{l}5.48 \\
5.19 \\
6.23\end{array}$ & $\begin{array}{l}1.39 \\
1.46 \\
1.76\end{array}$ & $\begin{array}{l}14.77 \\
10.98 \\
13.17\end{array}$ & $\begin{array}{l}0.01 \\
0.01 \\
0.01\end{array}$ & $\begin{array}{l}0.43 \\
0.45 \\
0.54\end{array}$ \\
\hline $\begin{array}{l}\text { No. } 6 \text { Lower } \\
\text { Bed - Evan Jor } \\
\text { Mine }\end{array}$ & hw Bb & 3.7 & (UA-145) & $\begin{array}{l}1 \\
2 \\
3\end{array}$ & $5.1 \mathrm{~J}$ & $\begin{array}{l}33.86 \\
35.68 \\
44.61\end{array}$ & $\begin{array}{l}42.04 \\
44.30 \\
55.39\end{array}$ & $\begin{array}{l}19.00 \\
20.02\end{array}$ & $\begin{array}{l}10,5: 1 \\
11,0 \leq 7 \\
13,874\end{array}$ & $\begin{array}{l}59.19 \\
62.37 \\
77.98\end{array}$ & $\begin{array}{l}5.29 \\
4.98 \\
6.22\end{array}$ & $\begin{array}{l}1.30 \\
1.37 \\
1.71\end{array}$ & $\begin{array}{l}14.87 \\
10.89 \\
13.62\end{array}$ & $\begin{array}{l}0.02 \\
0.02 \\
0.02\end{array}$ & $\begin{array}{l}0.35 \\
0.37 \\
0.47\end{array}$ \\
\hline $\begin{array}{l}\text { No. } 6 \text { Upper } \\
\text { Bed - Evan Jor } \\
\text { Mine }\end{array}$ & $\begin{array}{l}\text { tv Bb } \\
\text { ones }\end{array}$ & 3.8 & (UA-146: & $\begin{array}{l}1 \\
2 \\
3\end{array}$ & 4.71 & $\begin{array}{l}33.68 \\
55.34 \\
51.40\end{array}$ & $\begin{array}{l}31.84 \\
33.42 \\
48.60\end{array}$ & $\begin{array}{l}29.77 \\
31.24\end{array}$ & $\begin{array}{r}8,979 \\
9,423 \\
13,704\end{array}$ & $\begin{array}{l}55.92 \\
53.74 \\
77.71\end{array}$ & $\begin{array}{l}4.65 \\
4.32 \\
6.29\end{array}$ & $\begin{array}{l}1.13 \\
1.19 \\
1.73\end{array}$ & $\begin{array}{r}13.18 \\
9.44 \\
13.73\end{array}$ & $\begin{array}{l}0.02 \\
0.02 \\
0.03\end{array}$ & $\begin{array}{l}0.35 \\
0.37 \\
0.54\end{array}$ \\
\hline $\begin{array}{l}\text { No. } 5 \text { Bed } \\
\text { Evan Jones } \\
\text { Mine }\end{array}$ & lv Bb & 15 & UA-177 & $\begin{array}{l}1 \\
2 \\
3\end{array}$ & 4.82 & $\begin{array}{l}30.52 \\
32.06 \\
50.06\end{array}$ & $\begin{array}{l}30.45 \\
32.00 \\
49.94\end{array}$ & $\begin{array}{l}34.21 \\
35.94\end{array}$ & $\begin{array}{r}8,256 \\
8,584 \\
13,557\end{array}$ & $\begin{array}{l}46.44 \\
48.79 \\
76.17\end{array}$ & $\begin{array}{l}4.49 \\
4.15 \\
6.48\end{array}$ & $\begin{array}{l}1.11 \\
1.16 \\
1.82\end{array}$ & $\begin{array}{r}13.51 \\
9.70 \\
15.13\end{array}$ & $\begin{array}{l}0.05 \\
0.05 \\
0.08\end{array}$ & $\begin{array}{l}0.24 \\
0.26 \\
0.40\end{array}$ \\
\hline $\begin{array}{l}\text { Matanuska } \\
\text { Lower Seam }\end{array}$ & .. $\mathbf{A} \mathrm{Ab}$ & 7 & (UA-107) & $\begin{array}{l}1 \\
2 \\
3\end{array}$ & 1.78 & $\begin{array}{l}28.23 \\
28.75 \\
35.10\end{array}$ & $\begin{array}{l}52.20 \\
53.15 \\
64.90\end{array}$ & $\begin{array}{l}17.78 \\
18.10\end{array}$ & $\begin{array}{l}12: 258 \\
12.480 \\
15: 38\end{array}$ & $\begin{array}{l}69.33 \\
70.59 \\
86.19\end{array}$ & $\begin{array}{l}4.66 \\
4.54 \\
5.54\end{array}$ & $\begin{array}{l}1.64 \\
1.68 \\
2.05\end{array}$ & $\begin{array}{l}6.13 \\
4.62 \\
5.65\end{array}$ & $\begin{array}{l}0.09 \\
0.09 \\
0.11\end{array}$ & $\begin{array}{l}0.46 \\
0.47 \\
0.57\end{array}$ \\
\hline $\begin{array}{l}\text { Broad Pass } \\
\text { Coal Creek } \\
\text { Seam }\end{array}$ & Lignite & 8 & (UA:-1:) & $\begin{array}{l}1 \\
2 \\
3\end{array}$ & 28.32 & $\begin{array}{l}33.53 \\
46.77 \\
58.20\end{array}$ & $\begin{array}{l}24.08 \\
33.60 \\
41.80\end{array}$ & $\begin{array}{l}14.07 \\
19.63\end{array}$ & $\begin{array}{r}6,395 \\
8,921 \\
11 ;-00\end{array}$ & $\begin{array}{l}38.14 \\
53.21 \\
56.20\end{array}$ & $\begin{array}{l}6.06 \\
4.04 \\
5.03\end{array}$ & $\begin{array}{l}0.54 \\
0.75 \\
0.93\end{array}$ & $\begin{array}{l}41.04 \\
22.16 \\
27.58\end{array}$ & $\begin{array}{l}0.03 \\
0.04 \\
0.05\end{array}$ & $\begin{array}{l}0.15 \\
0.21 \\
0.26\end{array}$ \\
\hline
\end{tabular}

*1-EQUILIBRIUM MOISTURE

2-MOISTURE FREE

3-MOISTURE AND ASH FREE 
Table I (Continued)

Proximate and Ultimate Analyses of Raw Coals

\begin{tabular}{|c|c|c|c|c|c|c|c|c|c|c|c|c|c|c|c|}
\hline $\begin{array}{l}\text { Coal } \\
\text { Field and } \\
\text { Seam }\end{array}$ & $\begin{array}{l}\text { Apparent } \\
\text { ASTM } \\
\text { Rank }\end{array}$ & $\begin{array}{l}\text { Thickness } \\
\text { (feet) }\end{array}$ & $\begin{array}{l}\text { Sample } \\
\text { Numbers }\end{array}$ & Basis* & $\begin{array}{c}\text { Moisture } \\
\%\end{array}$ & $\begin{array}{c}\text { Volatile } \\
\text { Matter,\% }\end{array}$ & $\begin{array}{c}\text { Fixed } \\
\text { Carbon,\% }\end{array}$ & $\begin{array}{l}\text { Ash } \\
\%\end{array}$ & $\begin{array}{l}\text { Heating } \\
\text { Value } \\
\text { BTU//b }\end{array}$ & $C, \%$ & $\mathrm{H}, \%$ & $\mathrm{~N}, \%$ & $0, \%$ & $\begin{array}{r}\text { Sul } \\
\text { Pyritic }\end{array}$ & $\begin{array}{l}\text { fur } \\
\text { Total }\end{array}$ \\
\hline $\begin{array}{l}\text { Broad Pass } \\
\text { Dunkle Bed }\end{array}$ & Subbit. B & 5.3 & ( & $\begin{array}{l}1 \\
2 \\
3\end{array}$ & 33.0 & $\begin{array}{l}27.63 \\
41.28 \\
48.89\end{array}$ & $\begin{array}{l}28.88 \\
43.15 \\
51.11\end{array}$ & $\begin{array}{l}10.42 \\
15.57\end{array}$ & $\begin{array}{r}7,305 \\
10,915 \\
12,928\end{array}$ & $\begin{array}{l}41.37 \\
61.81 \\
73.21\end{array}$ & $\begin{array}{l}6.79 \\
4.61 \\
5.46\end{array}$ & $\begin{array}{l}0.56 \\
0.83 \\
0.99\end{array}$ & $\begin{array}{l}40.57 \\
16.74 \\
19.82\end{array}$ & $\begin{array}{l}0.11 \\
0.16 \\
0.19\end{array}$ & $\begin{array}{l}0.29 \\
0.44 \\
0.52\end{array}$ \\
\hline
\end{tabular}

Southwest Alaska Coal Fields

\begin{tabular}{|c|c|c|c|c|c|c|c|c|c|c|c|c|c|c|c|}
\hline $\begin{array}{l}\text { Little } \\
\text { Tonzona } \\
\text { Coal Bed }\end{array}$ & Subbit. C & 127 & (UA-112) & $\begin{array}{l}1 \\
2 \\
3\end{array}$ & 21.21 & $\begin{array}{l}37.59 \\
47.72 \\
55.33\end{array}$ & $\begin{array}{l}30.36 \\
38.53 \\
44.67\end{array}$ & $\begin{array}{l}10.84 \\
13.75\end{array}$ & $\begin{array}{r}7,663 \\
9,725 \\
11,277\end{array}$ & $\begin{array}{l}45.02 \\
57.14 \\
66.25\end{array}$ & $\begin{array}{l}5.80 \\
4.34 \\
5.03\end{array}$ & $\begin{array}{l}0.64 \\
0.81 \\
0.94\end{array}$ & $\begin{array}{l}36.59 \\
22.56 \\
26.15\end{array}$ & $\begin{array}{l}0.06 \\
0.08 \\
0.09\end{array}$ & $\begin{array}{r}1.11 \\
1.40 \\
1.63\end{array}$ \\
\hline $\begin{array}{l}\text { Chignik } \\
\text { Chignik Bay } \\
\text { Mine }\end{array}$ & hv Cb & 9 & (UA-136) & $\begin{array}{l}1 \\
2 \\
3\end{array}$ & 6.66 & $\begin{array}{l}30.29 \\
32.45 \\
50.85\end{array}$ & $\begin{array}{l}29.28 \\
31.37 \\
49.15\end{array}$ & $\begin{array}{l}33.77 \\
36.18\end{array}$ & $\begin{array}{r}8,106 \\
8,685 \\
13,609\end{array}$ & $\begin{array}{l}45.70 \\
48.96 \\
76.71\end{array}$ & $\begin{array}{l}4.48 \\
4.00 \\
6.19\end{array}$ & $\begin{array}{l}0.52 \\
0.55 \\
2.88\end{array}$ & $\begin{array}{r}13.89 \\
8.55 \\
11.46\end{array}$ & $\begin{array}{l}1.05 \\
1.12 \\
1.76\end{array}$ & $\begin{array}{l}1.64 \\
1.76 \\
2.76\end{array}$ \\
\hline $\begin{array}{l}\text { Herendeen } \\
\text { Bay } \\
\text { Coal Point }\end{array}$ & hv Bb & 1 & (UA-137) & $\begin{array}{l}1 \\
2 \\
3\end{array}$ & 5.46 & $\begin{array}{l}25.50 \\
26.97 \\
47.81\end{array}$ & $\begin{array}{l}27.83 \\
29.44 \\
52.19\end{array}$ & $\begin{array}{l}41.21 \\
43.59\end{array}$ & $\begin{array}{r}6,897 \\
7,295 \\
12,933\end{array}$ & $\begin{array}{l}40.17 \\
42.49 \\
75.32\end{array}$ & $\begin{array}{l}3.81 \\
3.39 \\
6.01\end{array}$ & $\begin{array}{l}1.04 \\
1.10 \\
1.94\end{array}$ & $\begin{array}{r}11.96 \\
7.52 \\
13.34\end{array}$ & $\begin{array}{l}0.87 \\
0.89 \\
1.58\end{array}$ & $\begin{array}{l}1.81 \\
1.91 \\
3.39\end{array}$ \\
\hline
\end{tabular}

*1-EQUILIBRIUM MOISTURE

2-MOISTURE FREE

3-MOISTURE AND ASH FREE 
Table II

Hardgrove Grindability and Free Swelling Indexes of Raw Coal

\begin{tabular}{ccc}
\hline $\begin{array}{c}\text { Coal Field } \\
\text { and Seam }\end{array}$ & Sample & \multicolumn{2}{c}{ Air Dried Samples } \\
\hline
\end{tabular}

Northern Alaska Coal Fields

No. 7 Bcd

Cape Beaufort

Kokolik River

No. 3 Bed

Elusive Creek

Wainwright

Meade River

Sagwon Bluffs
UA-139

UA-126

UA-125

UA-109

UA-110

UA-114

Northwest Alaska Coal Fields

Chicago Creek

UA-138

Unalakleet

Coal Creek

UA-151

42

0

22

0

Interior Alaska Coal Fields

$\begin{array}{llll}\begin{array}{l}\text { Nenana } \\ \text { No. } 2 \text { Scam }\end{array} & \text { UA-105 } & 28 & 0 \\ \text { Lignite Creek } & \text { UA-141 } & 24 & 0 \\ \text { Moose Seam } & \text { UA-103 } & 28 & 0 \\ \text { Caribou Seam } & \text { UA-104 } & 31 & 0 \\ \begin{array}{l}\text { Basal Bed } \\ \text { Arctic Mine }\end{array} & \text { UA-140 } & 26 & 0 \\ \begin{array}{l}\text { No. 1 Bed } \\ \text { Usibelli Mine }\end{array} & \text { UA-129 } & 38 & 0 \\ \begin{array}{l}\text { No. 3 Bed } \\ \text { Usibelli Mine }\end{array} & \text { UA-130 } & 32 & 0 \\ \end{array}$


Table II (Continued)

\section{Hardgrove Grindability and Free Swelling Indexes of Raw Coal}

\begin{tabular}{|c|c|c|c|}
\hline \multirow{2}{*}{$\begin{array}{l}\text { Coal Field } \\
\text { and Seam }\end{array}$} & \multirow{2}{*}{$\begin{array}{l}\text { Sample } \\
\text { Number }\end{array}$} & \multicolumn{2}{|c|}{ Air Dried Samples } \\
\hline & & HGI & \\
\hline $\begin{array}{l}\text { Poker Flat Pit } \\
\text { No. } 4 \text { Seam }\end{array}$ & UA-119 & 27 & 0 \\
\hline $\begin{array}{l}\text { No. } 6 \text { Seam } \\
\text { Top }\end{array}$ & UA-100 & 32 & 0 \\
\hline $\begin{array}{l}\text { No. } 6 \text { Seam } \\
\text { Middle }\end{array}$ & UA-101 & 31 & 0 \\
\hline $\begin{array}{l}\text { No. } 6 \text { Seam } \\
\text { Lower }\end{array}$ & UA-102 & 32 & 0 \\
\hline Marguerite Creek & UA-120 & 38 & 0 \\
\hline Yanert Mine & UA-132 & 48 & 0 \\
\hline $\begin{array}{l}\text { Jarvis Creek } \\
\text { No. } 1 \text { Seam }\end{array}$ & UA-106 & 28 & 0 \\
\hline $\begin{array}{l}\text { Eagle } \\
\text { Coal Creek }\end{array}$ & UA-121 & 70 & 0 \\
\hline $\begin{array}{l}\text { Eagle } \\
\text { Chicken }\end{array}$ & UA-124 & 62 & 0 \\
\hline Nulato & UA-128 & 56 & 0 \\
\hline Nulato & UA-128(1.6 Float) & - & 9.6 \\
\hline Tramway Bar & UA-117 & 45 & 0 \\
\hline
\end{tabular}

South Central Alaska Coal Fields

$\begin{array}{llcc}\begin{array}{l}\text { Beluga } \\ \text { Waterfall Seam }\end{array} & \text { UA-113 } & 23 & 0 \\ \begin{array}{l}\text { Beluga } \\ \text { Waterfall Top 6' }\end{array} & \text { UA-148 } & 32 & 0 \\ \begin{array}{l}\text { Capps Bed } \\ \text { Green Bed }\end{array} & \text { UA-127 } & 42 & 0 \\ \text { Lone Ridge Mine } & \text { UA-152 } & 28 & 0\end{array}$


Table II (Continued)

Hardgrove Grindability and Free Swelling Indexes of Raw Coal

\begin{tabular}{|c|c|c|c|}
\hline \multirow{2}{*}{$\begin{array}{l}\text { Coal Field } \\
\text { and Seam }\end{array}$} & \multirow{2}{*}{$\begin{array}{l}\text { Sample } \\
\text { Number }\end{array}$} & \multicolumn{2}{|c|}{ Air Dried Samples } \\
\hline & & HGI & FSI \\
\hline $\begin{array}{l}\text { Yentna } \\
\text { Johnson Creek }\end{array}$ & UA-149 & 24 & 0 \\
\hline $\begin{array}{l}\text { Yentula } \\
\text { Canyon Creek }\end{array}$ & UA-150 & 28 & 0 \\
\hline $\begin{array}{l}\text { Yentna } \\
\text { Locality } 2 \\
\text { Lower }\end{array}$ & UA-115 & 35 & 0 \\
\hline $\begin{array}{l}\text { Yentna } \\
\text { Locality } 2 \\
\text { Upper }\end{array}$ & UA-116 & 32 & 0 \\
\hline $\begin{array}{l}\text { Kenai } \\
\text { Cabin Bed }\end{array}$ & UA-118 & 23 & 0 \\
\hline $\begin{array}{l}\text { Kenai } \\
\text { Nimilchik }\end{array}$ & UA-122 & 25 & 0 \\
\hline $\begin{array}{l}\text { Kenai } \\
\text { Happy Creek }\end{array}$ & IIA-131 & 32 & 0 \\
\hline $\begin{array}{l}\text { Matanuska } \\
\text { Big Seam }\end{array}$ & UA-108 & 37 & 3 \\
\hline $\begin{array}{l}\text { No. 7A Bed } \\
\text { Evan Jones }\end{array}$ & UA-142 & 41 & 2 \\
\hline $\begin{array}{l}\text { No. } 7 \text { Lower Bed } \\
\text { Evan Jones }\end{array}$ & UA-143 & 40 & 2 \\
\hline $\begin{array}{l}\text { No. } 7 \text { Upper Bed } \\
\text { Evan Jones }\end{array}$ & UA-144 & 46 & 2 \\
\hline $\begin{array}{l}\text { No. } 6 \text { Lower Bed } \\
\text { Evan Jones }\end{array}$ & UA-145 & 44 & 2 \\
\hline $\begin{array}{l}\text { No. } 6 \text { Upper Bed } \\
\text { Evan Jones }\end{array}$ & UA-146 & 44 & 2 \\
\hline
\end{tabular}


Table II (Continued)

\section{Hardgrove Grindability and Free Swelling \\ Indexes of Raw Coal}

\begin{tabular}{|c|c|c|c|}
\hline \multirow{3}{*}{$\begin{array}{l}\begin{array}{c}\text { Coal Field } \\
\text { and Seam }\end{array} \\
\begin{array}{l}\text { No. } 5 \text { Bed } \\
\text { Evan Jones }\end{array}\end{array}$} & \multirow{3}{*}{$\begin{array}{c}\text { Sample } \\
\text { Number }\end{array}$} & \multicolumn{2}{|c|}{ Air Dried Samples } \\
\hline & & HGI & FSI \\
\hline & & 50 & 2 \\
\hline $\begin{array}{l}\text { Matanuska } \\
\text { Lower Seam }\end{array}$ & UA-107 & 65 & 8 \\
\hline $\begin{array}{l}\text { Broad Pass } \\
\text { Coal Creek Seam }\end{array}$ & UA-111 & 49 & 0 \\
\hline $\begin{array}{l}\text { Broad Pass } \\
\text { Dunkle Bed }\end{array}$ & UA-123 & 38 & 0 \\
\hline Southwest Alaska Coal & Fields & & \\
\hline $\begin{array}{l}\text { Little Tonzona } \\
\text { Coal Bed }\end{array}$ & UA-112 & 28 & 0 \\
\hline $\begin{array}{l}\text { Chignik } \\
\text { Chignik Bay Mine }\end{array}$ & UA-136 & 46 & 1 \\
\hline $\begin{array}{l}\text { Herendeen Bay } \\
\text { Coal Point }\end{array}$ & UA-137 & 52 & 0 \\
\hline
\end{tabular}


Table III

Concentration of Major Elemerts in the Raw Coal Ash $\left(750^{\circ} \mathrm{C}\right)$, percent

\begin{tabular}{|c|c|c|c|c|c|c|c|c|c|c|c|}
\hline Coal Field & Sample No. & $\mathrm{SiO}_{2}$ & $\mathrm{Al}_{2} \mathrm{O}_{3}$ & $\mathrm{Fe}_{2} \mathrm{O}_{3}$ & $\mathrm{MgO}$ & $\mathrm{CaO}$ & $\mathrm{Na}_{2} \mathrm{O}$ & $\mathrm{K}_{2} \mathrm{O}$ & $\mathrm{TiO}_{2}$ & $\mathrm{SO}_{3}$ & $\mathrm{MnO}$ \\
\hline Northern Alaska & Coal Fields & & & & & & & & & & \\
\hline $\begin{array}{l}\text { No. } 7 \text { Bed } \\
\text { Cape Beaufort }\end{array}$ & UA 139 & 59.0 & 21.8 & 2.4 & 2.2 & 4.9 & 3.05 & 1.1 & 0.8 & 1.4 & 0.03 \\
\hline Kokolik River & UA 126 & 42.4 & 27.1 & 5.5 & 3.0 & 6.1 & 1.63 & 1.9 & 2.2 & 4.6 & 0.03 \\
\hline $\begin{array}{l}\text { No. } 3 \text { Bed } \\
\text { Elusive Creek }\end{array}$ & UA 125 & 22.3 & 26.5 & 12.3 & 6.6 & 15.0 & 2.14 & 1).7 & 0.8 & 3.0 & 0.03 \\
\hline Wainwright & UA 109 & 41.7 & 5.9 & 18.8 & 13.0 & 13.2 & 2.16 & 1.0 & 0.1 & 13.1 & 0.29 \\
\hline Meade River & UA 110 & 43.8 & 23.3 & 6.1 & 3.3 & 4.4 & .97 & 1.8 & 1.3 & 2.1 & 0.06 \\
\hline Sagwon Bluffs & UA 114 & 66.5 & 20.1 & 3.9 & 2.2 & 1.8 & .16 & 3.5 & 1.3 & .7 & 0.04 \\
\hline Northwest Alaska & Coal Fields & & & & & & & & & & \\
\hline $\begin{array}{l}\text { Chicago Creek } \\
\text { Seward Peninsula }\end{array}$ & UA 138 & 22.0 & 13.6 & 20.2 & 2.9 & 13.7 & 0.46 & 3.5 & 0.6 & 11.7 & 0.72 \\
\hline $\begin{array}{l}\text { Unalakleet } \\
\text { Coal Creek }\end{array}$ & UA 151 & 40.8 & 20.5 & 5.4 & 5.9 & 11.2 & 2.21 & 1.6 & 1.0 & 6.4 & 0.02 \\
\hline
\end{tabular}

\section{Interior Alaska Coal Fields}

$\begin{array}{lccccccccccc}\text { No. 2 Seam } & \text { UA 105 } & 47.3 & 20.7 & 8.9 & 2.8 & 12.9 & 0.15 & 1.2 & 0.9 & 6.3 & 0.44 \\ \text { Lignite Creek } & \text { UA 141 } & 43.0 & 20.2 & 7.4 & 4.2 & 15.2 & 0.19 & 1.4 & 0.8 & 4.8 & 0.32 \\ \text { Moose Seam } & \text { UA 103 } & 34.7 & 25.0 & 5.2 & 7.7 & 15.7 & 0.38 & 1.6 & 1.2 & 7.2 & 0.06 \\ & & & & & & & & & & & \\ \text { Caribou Seam } & \text { UA 104 } & 43.1 & 21.4 & 9.0 & 5.2 & 14.7 & 0.97 & 1.8 & 1.1 & 5.6 & 0.07\end{array}$


Table III (Continued)

Concentration of Major Elements in the Raw Coal Ash $\left(750^{\circ} \mathrm{C}\right)$, percent

\begin{tabular}{|c|c|c|c|c|c|c|c|c|c|c|c|}
\hline Coal Field & Sample No. & $\mathrm{SiO}_{2}$ & $\mathrm{Al}_{2} \mathrm{O}_{3}$ & $\mathrm{Fe}_{2} \mathrm{O}_{3}$ & $\mathrm{MgO}$ & $\mathrm{CaO}$ & $\mathrm{Na}_{2} \mathrm{O}$ & $\mathrm{K}_{2} \mathrm{O}$ & $\mathrm{TiO}_{2}$ & $\mathrm{SO}_{3}$ & $\mathrm{MnO}$ \\
\hline $\begin{array}{l}\text { Basal Bed (A) } \\
\text { Arctic Mine }\end{array}$ & UA 140 & 56.3 & 24.6 & 3.2 & 2.7 & 6.3 & 0.95 & 2.4 & 1.4 & 1.7 & 0.04 \\
\hline $\begin{array}{l}\text { No. } 1 \text { Bed } \\
\text { Usibelli Mine }\end{array}$ & UA 129 & 47.1 & 20.8 & 4.1 & 2.6 & 16.4 & 0.40 & 1.2 & 1.1 & 2.5 & 0.07 \\
\hline $\begin{array}{l}\text { No. } 3 \text { Bed } \\
\text { Usibelli Mine }\end{array}$ & UA 130 & 44.4 & 14.6 & 5.8 & 2.6 & 17.3 & 0.33 & 1.1 & 0.9 & 2.8 & 0.17 \\
\hline $\begin{array}{l}\text { Poker Flat Pit } \\
\text { No. } 4 \text { Seam }\end{array}$ & UA 119 & 43.4 & 22.7 & 6.7 & 2.7 & 16.6 & 1.08 & 2.2 & 1.1 & 6.5 & 0.21 \\
\hline $\begin{array}{l}\text { No. } 6 \text { Seam } \\
\text { Top }\end{array}$ & UA 100 & 55.3 & 19.3 & 7.1 & 2.2 & 9.4 & 0.28 & 1.8 & 1.0 & 3.1 & 0.44 \\
\hline $\begin{array}{l}\text { No. } 6 \text { Seam } \\
\text { Middle }\end{array}$ & UA 101 & 37.7 & 22.6 & 9.4 & 3.8 & 22.8 & 0.48 & 1.1 & 0.9 & 5.0 & 0.37 \\
\hline $\begin{array}{l}\text { No. } 6 \text { Seam } \\
\text { Lower }\end{array}$ & UA 102 & 39.5 & 21.4 & 6.6 & 2.5 & 24.1 & 0.05 & 1.1 & 1.0 & 3.5 & 0.19 \\
\hline $\begin{array}{l}\text { Marguerite } \\
\text { Creek }\end{array}$ & UA 120 & 44.8 & 15.8 & 3.5 & 4.1 & 21.3 & 0.29 & 1.0 & 0.8 & 3.3 & 0.10 \\
\hline Yanert Mine & UA 132 & 64.0 & 22.7 & 4.0 & 1.2 & 1.1 & 0.49 & 2.8 & 1.0 & 0.6 & 0.02 \\
\hline $\begin{array}{l}\text { Jarvis Creek } \\
\text { No. } 1 \text { Seam }\end{array}$ & UA 106 & 42.7 & 16.6 & 11.2 & 2.2 & 20.8 & 0.45 & 0.7 & 1.1 & 21.7 & 0.12 \\
\hline $\begin{array}{l}\text { Eagle } \\
\text { Coal Creek }\end{array}$ & UA 121 & 47.5 & 20.3 & 5.5 & 2.9 & 11.7 & 0.62 & 0.7 & 1.2 & 5.3 & 0.12 \\
\hline $\begin{array}{l}\text { Eagle } \\
\text { Chicken }\end{array}$ & UA 124 & 510 & 22.4 & 6.5 & 1.5 & 6.0 & 0.77 & 1.4 & 0.7 & 8.5 & 0.08 \\
\hline Nulato & UA 128 & 62.7 & 21.8 & 3.8 & 1.5 & 0.3 & 1.88 & 4.4 & 1.1 & 0.8 & 0.01 \\
\hline Tramway Bar & UA 117 & 52.3 & 30.8 & 5.1 & 1.4 & 2.3 & 0.51 & 4.0 & 1.7 & .9 & 0.05 \\
\hline
\end{tabular}


Table III (Continued)

Concentration ef Major Elements in the Raw Coal Ash $\left(750^{\circ} \mathrm{C}\right)$, percent

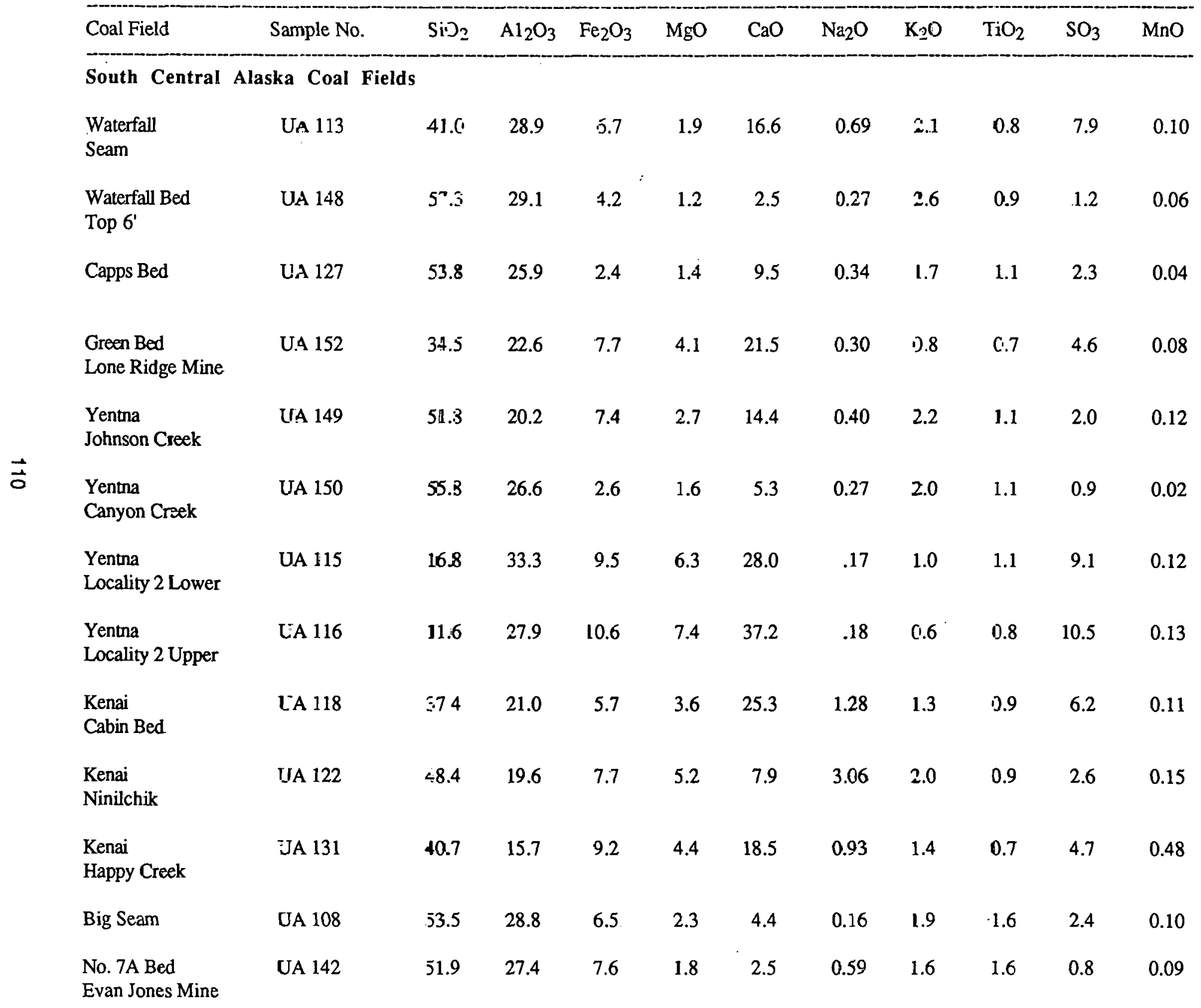


Table III (Continued)

Concentration of Major Elements in the Raw Coal Ash $\left(750^{\circ} \mathrm{C}\right)$, percent

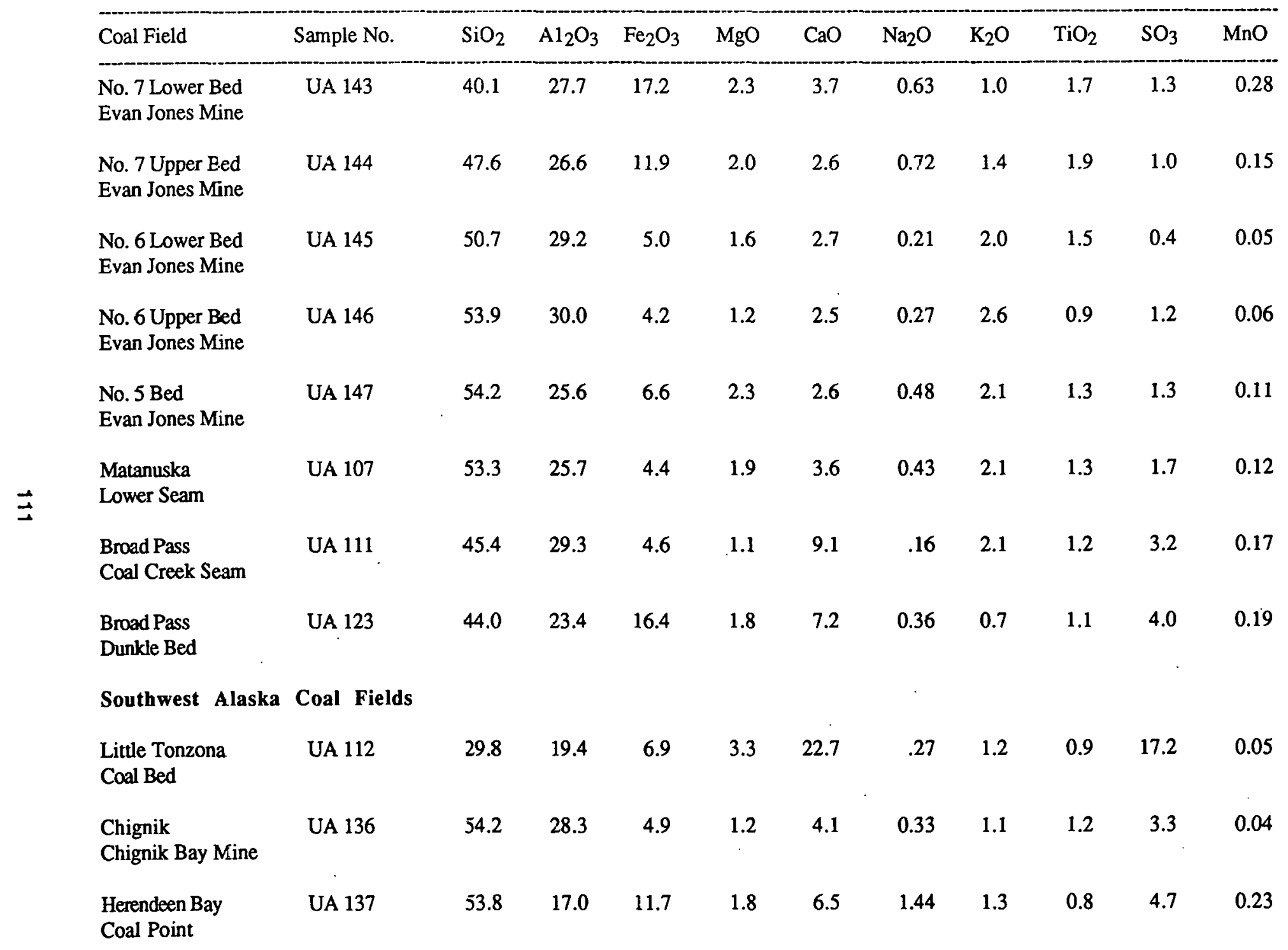


Table IV

Fusibility of Ash of the

Raw Coal Samples

\begin{tabular}{|c|c|c|c|c|}
\hline $\begin{array}{l}\text { COAL } \\
\text { FIELD } \\
\& \text { SEAM }\end{array}$ & $\begin{array}{l}\text { SAMPLE } \\
\text { NUMBER }\end{array}$ & $\begin{array}{c}\text { INITIAL } \\
\text { DEFORMATION } \\
{ }^{\circ} \mathrm{F}\end{array}$ & $\begin{array}{l}\text { SOFTENING } \\
{ }^{\circ} \mathrm{F}\end{array}$ & $\begin{array}{l}\text { FLUID } \\
\text { ०F }\end{array}$ \\
\hline \multicolumn{5}{|c|}{ Northern Alaska Coal Fields } \\
\hline $\begin{array}{l}\text { No. } 7 \text { Bed } \\
\text { Cape Beaufort }\end{array}$ & UA-139 & 2320 & 2410 & 2520 \\
\hline Kokolik River & UA-126 & 2347 & 2356 & 2561 \\
\hline $\begin{array}{l}\text { No. } 3 \text { Bed } \\
\text { Elusive Creek }\end{array}$ & UA-125 & 2454 & 2514 & 2572 \\
\hline Wainwright & UA-109 & 2540 & 2590 & 2630 \\
\hline Meade River & UA-110 & 2500 & 2540 & 2580 \\
\hline Sagwon Bluffs & UA-114 & 2670 & 2730 & 2840 \\
\hline \multicolumn{3}{|c|}{ Northwest Alaska Coal Fields } & - & \\
\hline $\begin{array}{l}\text { Chicago Creek } \\
\text { Seward Peninsula }\end{array}$ & UA-138 & 2333 & 2350 & 2564 \\
\hline $\begin{array}{l}\text { Unalakleet } \\
\text { Coal Creek }\end{array}$ & UA-151 & 2240 & 2258 & 2334 \\
\hline Interior Alaska & Coal Fields & & & \\
\hline No. 2 Seam & UA-105 & 2150 & 2180 & 2210 \\
\hline Lignite Creek & UA-141 & 2287 & 2303 & 2377 \\
\hline Moose Seam & UA-103 & 2200 & 2250 & 2300 \\
\hline Caribou Seam & UA-104 & 2150 & 2180 & 2210 \\
\hline $\begin{array}{l}\text { Basal Bed (A) } \\
\text { Arctic Mine }\end{array}$ & UA-140 & 2220 & 2536 & 2620 \\
\hline
\end{tabular}


Table IV (Continued)

Fusibility of Ash of the

Raw Coal Samples

\begin{tabular}{|c|c|c|c|c|}
\hline $\begin{array}{l}\text { COAL } \\
\text { FIELD } \\
\& \text { SEAM }\end{array}$ & $\begin{array}{l}\text { SAMPLE } \\
\text { NUMBER }\end{array}$ & $\begin{array}{c}\text { INITIAL } \\
\text { DEFORMATION } \\
\text { OF }\end{array}$ & $\begin{array}{c}\text { SOFTENING } \\
{ }^{\circ} \mathrm{F}\end{array}$ & $\begin{array}{l}\text { FLUID } \\
\text { oF }\end{array}$ \\
\hline $\begin{array}{l}\text { No. } 1 \text { Bed } \\
\text { Usibelli Mine }\end{array}$ & UA-129 & 2383 & 2420 & 2501 \\
\hline $\begin{array}{l}\text { No. } 3 \text { Bed } \\
\text { Usibelli Mine }\end{array}$ & UA-130 & 2217 & 2228 & 2324 \\
\hline $\begin{array}{l}\text { Poker Flat Pit } \\
\text { No. } 4 \text { Seam }\end{array}$ & UA-119 & 2130 & 2180 & 2380 \\
\hline $\begin{array}{l}\text { No. } 6 \text { Seam } \\
\text { Top }\end{array}$ & UA-100 & 2350 & 2400 & 2560 \\
\hline $\begin{array}{l}\text { No. } 6 \text { Seam } \\
\text { Middle }\end{array}$ & UA-101 & 2100 & 2130 & 2160 \\
\hline $\begin{array}{l}\text { No. } 6 \text { Seam } \\
\text { Lower }\end{array}$ & UA-102 & 2150 & 2180 & 2210 \\
\hline $\begin{array}{l}\text { Marguerite } \\
\text { Creek }\end{array}$ & UA-120 & 2250 & 2259 & 2277 \\
\hline Yanert Mine & UA-132 & 2742 & $2800+$ & $2800+$ \\
\hline $\begin{array}{l}\text { Jarvis Creek } \\
\text { No. } 1 \text { Seam }\end{array}$ & UA-106 & 1980 & 2030 & 2080 \\
\hline $\begin{array}{l}\text { Eagle } \\
\text { Coal Crcck }\end{array}$ & UA-121 & 2371 & 2375 & 2430 \\
\hline $\begin{array}{l}\text { Eüglc } \\
\text { Chicken }\end{array}$ & UA-124 & 2490 & 2503 & 2540 \\
\hline Nulato & UA-128 & 2468 & 2593 & 2723 \\
\hline Tramway Bar & UA-117 & 2680 & 2730 & 2840 \\
\hline South Central & Alaska Coal & Fields & & \\
\hline $\begin{array}{l}\text { Waterfall } \\
\text { Seam }\end{array}$ & UA-113 & 2400 & 2450 & 2500 \\
\hline
\end{tabular}


Table IV (Continued)

Fusibility of Ash of the

Raw Coal Samples

\begin{tabular}{|c|c|c|c|c|}
\hline $\begin{array}{l}\text { COAL } \\
\text { FIELD } \\
\& \text { SEAM }\end{array}$ & $\begin{array}{l}\text { SAMPLE } \\
\text { NUMBER }\end{array}$ & $\begin{array}{c}\text { INITIAL } \\
\text { DEFORMATION } \\
\text { OF }\end{array}$ & $\begin{array}{l}\text { SOFTENING } \\
{ }^{\circ} \mathrm{F}\end{array}$ & $\begin{array}{l}\text { FLUID } \\
\text { of }\end{array}$ \\
\hline $\begin{array}{l}\text { Waterfall Bed } \\
\text { Top 6' }\end{array}$ & UA-148 & $2800+$ & $2800+$ & $2800+$ \\
\hline Capps Bed & UA-127 & 2457 & 2464 & 2539 \\
\hline $\begin{array}{l}\text { Green Bed } \\
\text { Lone Ridge Mine }\end{array}$ & UA-152 & $22 \%$ & 2295 & 2107 \\
\hline $\begin{array}{l}\text { Yentna } \\
\text { Johnson Creek }\end{array}$ & UA-149 & 2346 & 2370 & 2515 \\
\hline $\begin{array}{l}\text { Yentna } \\
\text { Canyon Creek }\end{array}$ & UA-150 & 2703 & 2790 & $2790+$ \\
\hline $\begin{array}{l}\text { Ycntna } \\
\text { Locality } 2 \text { Lower }\end{array}$ & UA-115 & 2520 & 2550 & 2580 \\
\hline $\begin{array}{l}\text { Yentna } \\
\text { Locality } 2 \text { Upper }\end{array}$ & UA-116 & 2140 & 2170 & 2200 \\
\hline $\begin{array}{l}\text { Kenai } \\
\text { Cabin Bed }\end{array}$ & UA-118 & 2090 & 2120 & 2150 \\
\hline $\begin{array}{l}\text { Kenai } \\
\text { Ninilchik }\end{array}$ & UA-122 & 2218 & 2246 & 2296 \\
\hline $\begin{array}{l}\text { Kenai } \\
\text { llappy Creek }\end{array}$ & UA-131 & 2240 & 2243 & 2272 \\
\hline Big Seam & UA-1U8̈ & 2520 & 2570 & $2 \kappa 70$ \\
\hline $\begin{array}{l}\text { No. } 7 \Lambda \text { Bed } \\
\text { Evan Jones Mine }\end{array}$ & UAA 142 & 2200 & 2511 & 2590 \\
\hline $\begin{array}{l}\text { No. } 7 \text { Lower Bed } \\
\text { Evan Jones Mine }\end{array}$ & UA-143 & 2535 & 2593 & 2606 \\
\hline $\begin{array}{l}\text { No. } 7 \text { Upper Bed } \\
\text { Evan Jones Mine }\end{array}$ & UA-144 & 2590 & 2675 & 2697 \\
\hline
\end{tabular}


Table IV (Continued)

Fusibility of Ash of the

Raw Coal Samples

\begin{tabular}{|c|c|c|c|c|}
\hline $\begin{array}{l}\text { COAL } \\
\text { FIELD } \\
\& \text { SEAM }\end{array}$ & $\begin{array}{l}\text { SAMPLE } \\
\text { NUMBER }\end{array}$ & $\begin{array}{c}\text { INITIAL } \\
\text { DEFORMATION } \\
{ }^{\circ} \mathrm{F}\end{array}$ & $\begin{array}{c}\text { SOFTENING } \\
{ }^{\circ} \mathrm{F}\end{array}$ & $\begin{array}{l}\text { FLUID } \\
{ }^{\circ} \mathrm{F}\end{array}$ \\
\hline $\begin{array}{l}\text { No. } 6 \text { Lower Bed } \\
\text { Evan Jones Mine }\end{array}$ & UA-145 & 2707 & 2790 & $2790+$ \\
\hline $\begin{array}{l}\text { No. } 6 \text { Upper Bed } \\
\text { Evan Jones Mine }\end{array}$ & UA-146 & 2794 & $2800+$ & $2800+$ \\
\hline $\begin{array}{l}\text { No. } 5 \text { Bed } \\
\text { Evan Jones Mine }\end{array}$ & UA-147 & 2723 & 2751 & 2793 \\
\hline $\begin{array}{l}\text { Matanuska } \\
\text { Lower Seam }\end{array}$ & UA-107 & 2670 & 2720 & 2830 \\
\hline $\begin{array}{l}\text { Broad Pass } \\
\text { Coal Creek Seam }\end{array}$ & UA-111 & 2300 & 2350 & 2440 \\
\hline $\begin{array}{l}\text { Broad Pass } \\
\text { Dunkle Bed }\end{array}$ & UA-123 & 2479 & 2505 & 2548 \\
\hline Southwest Alaska & ka Coal & & & \\
\hline $\begin{array}{l}\text { Little Tonzona } \\
\text { Coal Bed }\end{array}$ & UA-112 & 2060 & 2090 & 2120 \\
\hline $\begin{array}{l}\text { Chignik } \\
\text { Chignik Bay Mine }\end{array}$ & UA-136 & 2794 & $2800+$ & $2800+$ \\
\hline $\begin{array}{l}\text { Herendeen Bay } \\
\text { Coal Point }\end{array}$ & UA-137 & 2701 & $2800+$ & $2800+$ \\
\hline
\end{tabular}


TABLE V

Proximate and Ultimate Analysis of Float-Sink Prcducts

\begin{tabular}{|c|c|c|c|c|c|c|c|c|c|c|c|c|c|}
\hline \multirow{2}{*}{$\begin{array}{l}\text { Coal Field } \\
\text { and Seam }\end{array}$} & \multirow{2}{*}{\multicolumn{2}{|c|}{$\begin{array}{c}\text { Sample } \\
\text { Numbers }\end{array}$}} & \multirow{2}{*}{$\begin{array}{l}\text { Weight } \\
(\%)\end{array}$} & \multirow{2}{*}{$\begin{array}{c}\text { Volatile } \\
\text { Matter,\% }\end{array}$} & \multirow{2}{*}{$\begin{array}{c}\text { Fixed } \\
\text { Carbon,\% }\end{array}$} & \multirow{2}{*}{$\begin{array}{c}\text { Ash } \\
\%\end{array}$} & \multirow{2}{*}{$\begin{array}{c}\text { Heating } \\
\text { Value } \\
\text { BTU/b. }\end{array}$} & \multirow[b]{2}{*}{$\mathrm{C}, \%$} & \multirow[b]{2}{*}{$\mathrm{H}, \%$} & \multirow[b]{2}{*}{$\mathrm{N}, \%$} & \multirow[b]{2}{*}{$0, \%$} & \multicolumn{2}{|c|}{ Sulfur } \\
\hline & & & & & & & & & & & & Pyritic & Total \\
\hline \multicolumn{14}{|c|}{ Northern Alaska Coal Fiefds } \\
\hline No. $7 \mathrm{Bed}$ & UA-139 & Float 160 & 67.07 & 34.71 & 57.81 & 7.48 & 11,492 & 70.18 & 3.59 & 1.13 & 17.37 & 0.01 & 0.24 \\
\hline Cape Beaufort & UA-139 & Sink 1.60 & 32.93 & 17.74 & 18.32 & 63.94 & 4,095 & 24.34 & 1.80 & 0.39 & 9.37 & 0.01 & 0.16 \\
\hline \multirow[t]{2}{*}{ Kokolik River } & UA-126 & Float 1.60 & 90.63 & 33.40 & 63.98 & 2.62 & 13,381 & 78.61 & 4.89 & 1.30 & 12.33 & 0.02 & 0.26 \\
\hline & UA-126 & Sink 1.60 & 9.37 & 25.41 & 29.51 & 45.08 & 7,123 & 70.41 & 2.86 & 0.71 & 10.76 & 0.01 & 0.17 \\
\hline No. $3 \mathrm{Bed}$ & UA-125 & Float $\mathbf{L} 60$ & 93.31 & 36.36 & 62.22 & 1.42 & 12,685 & 74.28 & 4.60 & 1.75 & 17.71 & 0.01 & 0.24 \\
\hline Elusive Creek & UA-125 & Sink 1.60 & 6.69 & 35.28 & 47.14 & 17.58 & 10,182 & 60.88 & 3.92 & 1.40 & 15.97 & 0.09 & 0.25 \\
\hline \multirow[t]{2}{*}{ Wainwright } & UA-10G & Float $\mathbf{1 . 6 0}$ & 89.42 & 37.88 & 59.20 & 2.92 & 12,084 & 74.25 & 4.43 & 1.44 & 16.62 & 0.03 & 0.34 \\
\hline & UA-100 & Sink 1.60 & 11.25 & 38.58 & 12.72 & 48.70 & 4,356 & 24.64 & 1.14 & 0.44 & 24.32 & 0.49 & 0.77 \\
\hline \multirow[t]{2}{*}{ Meade River } & UA-110 & Float 1.60 & 95.61 & 38.13 & 59.49 & 2.38 & 13,282 & 76.76 & 3.15 & 1.70 & 15.32 & 0.02 & 0.69 \\
\hline & UA-110 & Sink 1.60 & 4.39 & 31.68 & 42.74 & 25.58 & 7,263 & 53.93 & 3.49 & 1.30 & 14.61 & 1.20 & 1.42 \\
\hline \multirow[t]{2}{*}{ Sagwon Bluffs } & UA-114 & Float 1.60 & 29.76 & 38.56 & 51.67 & 9.77 & 10,255 & 60.41 & 3.48 & 1.17 & 24.93 & 0.02 & 0.25 \\
\hline & UA-114 & Sink 1.60 & 70.24 & 15.50 & 10.47 & 74.03 & 2,481 & 15.37 & 2.18 & 0.40 & 7.91 & 0.06 & 0.10 \\
\hline \multicolumn{14}{|c|}{ Northwest Alaska Coal Fields } \\
\hline Chicago Creek & UA-138 & Float 1.60 & 78.78 & 43.99 & 47.21 & 8.80 & 10,328 & $61.8 ?$ & 4.16 & 1.27 & 23.06 & 0.06 & 0.88 \\
\hline Seward Peninsula & UA138 & Sink 1.60 & 21.22 & 39.52 & 23.99 & 36.49 & 6,632 & 40.36 & 2.96 & 0.87 & 18.67 & 0.25 & 0.65 \\
\hline Unalakleet & UA-15i & Float 1.60 & 86.25 & 52.77 & 39.89 & 7.34 & 11,456 & $63.9<$ & 4.97 & 0.88 & 22.16 & 0.02 & 0.71 \\
\hline Coal Creek & UA-151 & Sink 1.60 & 13.75 & 31.80 & 25.66 & 42.55 & 8,025 & $45.2 ?$ & 3.95 & 0.60 & 7.05 & 0.15 & 0.59 \\
\hline \multicolumn{14}{|c|}{ Interior Alaska Coal Fields } \\
\hline \multirow[t]{2}{*}{ No. 2 Seam } & UA-105 & Float 1.60 & 94.52 & $47.0 \mathrm{C}$ & 45.37 & 7.63 & 10,987 & 62.79 & 4.52 & 0.90 & 23.91 & 0.01 & 0.25 \\
\hline & UA-105 & Sink 1.60 & 5.48 & 34.36 & 24.77 & 40.87 & 6,564 & 40.9 .9 & 3.42 & 0.58 & 13.64 & 0.05 & 0.49 \\
\hline \multirow[t]{2}{*}{ Lignite Creek } & UA-141 & Float 1.60 & 91.63 & 50.51 & 40.36 & 9.13 & 10,021 & 57.07 & 4.47 & 0.78 & 28.03 & 0.02 & 0.51 \\
\hline & UA-141 & Sink 1.60 & 8.37 & 28.56 & 20.64 & 50.80 & 5,538 & 29.27 & 2.67 & 0.51 & 16.54 & 0.03 & 0.24 \\
\hline
\end{tabular}

All results on a moisture free basis. 
TABLE V (Continued)

Proximate and Ultimate Analysis of Float-Sink Products

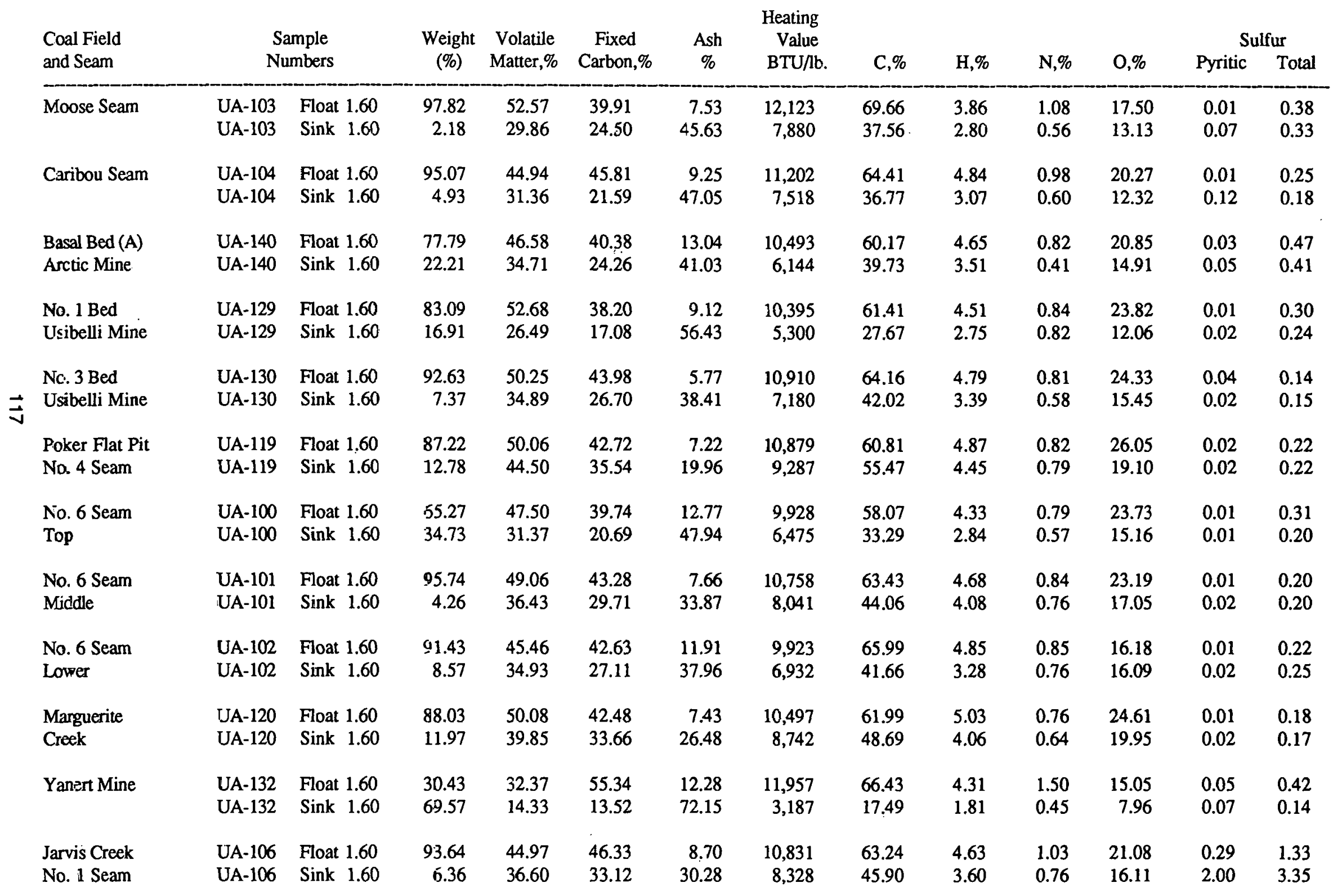

All results on a moisture free basis. 
TABLE V (Ccntinued)

Proximate and Ultimate Analysis of Float-Sink Products

\begin{tabular}{|c|c|c|c|c|c|c|c|c|c|c|c|c|c|}
\hline \multirow{2}{*}{$\begin{array}{l}\text { Coal Field } \\
\text { and Seam }\end{array}$} & \multirow{2}{*}{\multicolumn{2}{|c|}{$\begin{array}{l}\text { Sample } \\
\text { Numbers }\end{array}$}} & \multirow{2}{*}{$\begin{array}{c}\text { Weight } \\
(\%)\end{array}$} & \multirow{2}{*}{$\begin{array}{l}\text { Volatile } \\
\text { Matter,\% }\end{array}$} & \multirow{2}{*}{$\begin{array}{c}\text { Fixed } \\
\text { Carbon,\% }\end{array}$} & \multirow{2}{*}{$\begin{array}{c}\text { Ash } \\
\%\end{array}$} & \multirow{2}{*}{$\begin{array}{l}\text { Heating } \\
\text { Value } \\
\text { BTU/lb. }\end{array}$} & \multirow[b]{2}{*}{$c, \%$} & \multirow[b]{2}{*}{$\mathrm{H}, \%$} & \multirow[b]{2}{*}{$\mathrm{N}, \%$} & \multirow[b]{2}{*}{$0, \%$} & \multicolumn{2}{|c|}{ Sulfur } \\
\hline & & & & & & & & & & & & Pyritic & Total \\
\hline Eagle & UA-121 & Float 1.60 & 59.55 & 49.57 & 39.95 & 10.48 & 8,789 & 57.30 & 3.34 & 1.29 & 29.87 & 0.03 & 0.72 \\
\hline Coal Creek & UA-121 & Sink 1.6 .0 & 40.45 & 30.46 & $21.9 ?$ & 47.57 & 4,146 & 31.20 & 2.63 & 0.90 & 17.24 & 0.04 & 0.45 \\
\hline Eagle & UA-124 & Float 1.60 & 58.46 & 48.80 & 42.03 & 9.17 & 9,563 & 58.79 & 4.04 & 0.95 & 25.74 & 0.04 & 1.31 \\
\hline Chicken & UA-124 & Sink 1.60 & 41.54 & 29.79 & 14.13 & 56.08 & 4,315 & 26.19 & 2.42 & 0.65 & 12.75 & 0.08 & 1.91 \\
\hline Nulato & UA-128 & Flcat 1.60 & 31.09 & 26.70 & 62.15 & 11.15 & 13,451 & 71.63 & 4.59 & 1.44 & 10.13 & 0.07 & 1.05 \\
\hline & UA-128 & Sink 1.60 & 68.91 & 10.59 & 15.04 & 74.37 & 3,261 & 18.94 & 1.71 & 0.46 & 3.80 & 0.25 & 0.71 \\
\hline Tramway Bar & UA-117 & Float 1.60 & 48.40 & 35.74 & 56.25 & 8.01 & 11,723 & 68.81 & 4.29 & 0.98 & 17.59 & 0.02 & 0.32 \\
\hline & UA-117 & Sink 1.50 & 51.60 & 17.37 & 14.07 & 68.56 & 33,670 & 2.15 & 0.21 & 0.08 & 29.00 & 0.12 & 0. \\
\hline Southcentral A & iska Coal & Fields & & & & & & & & & & & \\
\hline Waterfall & UA-113 & Float 1.50 & 92.92 & 50.14 & 43.47 & 6.39 & 10,934 & 52.88 & 4.39 & 0.70 & 25.38 & 0.01 & 0.26 \\
\hline Seam & UA-113 & Sink 1.60 & 7.08 & 34.11 & 22.76 & 43.13 & 6,558 & 36.81 & 3.24 & 0.53 & 15.94 & 0.03 & 0.35 \\
\hline Waterfall Bed & UA-148. & Float 1.60 & 42.41 & 46.05 & 40.01 & 13.94 & 9,713 & 77.24 & 2.91 & 0.64 & 34.96 & 0.02 & 0.31 \\
\hline Top 6' & UA-148 & Sink 160 & 57.59 & 28.14 & 20.47 & 51.39 & 4,872 & 26.53 & 2.58 & 0.47 & 18.83 & 0.05 & 0.21 \\
\hline Capps Bed & UA-127 & Float 1.60 & 78.53 & 46.74 & 41.78 & 11.48 & 10,196 & 50.22 & 4.62 & 0.99 & 22.43 & 0.02 & 0.26 \\
\hline & UA-127 & Sink 1.60 & 21.47 & 30.76 & 23.04 & 46.20 & 5,675 & 34.38 & 3.13 & 0.87 & 15.23 & 0.01 & 0.19 \\
\hline Green Bed & UA-152 & Float 1.60 & 94.19 & 48.75 & 45.35 & 5.90 & 11,157 & 65.40 & 5.02 & 1.07 & 22.39 & 0.02 & 0.22 \\
\hline Lone Ridge Mine & UA-152 & Sink 1.60 & 5.81 & 35.38 & 26.07 & 38.55 & 5,919 & 40.25 & 3.50 & 0.73 & 16.80 & 0.03 & 0.17 \\
\hline Yentna & UA-149 & Float 1.60 & 82.44 & 47.97 & 24.199 & 9.95 & 10,544 & 61.64 & 4.36 & 0.90 & 23.00 & 0.01 & 0.15 \\
\hline Johnson Creek & UA-149 & Sink 1.60 & 17.56 & 27.67 & 17.51 & 54.82 & 5,073 & 29.49 & 2.61 & 0.56 & 12.26 & 0.02 & 0.26 \\
\hline Yentna & UA-150 & Float 1.60 & 70.72 & $48.1) 5$ & 42.06 & 9.89 & 10,888 & 63.17 & 4.91 & 0.97 & 20.82 & 0.01 & 0.24 \\
\hline Canyon Creek & UA-150 & Sink 1.60 & 29.28 & 29.32 & 20.15 & 50.53 & 5,414 & 32.30 & 3.12 & 0.61 & 13.29 & 0.01 & 0.15 \\
\hline Yentna & UA-11j & Float 1.60 & 89.61 & 54.51 & 41.60 & 3.89 & 11,301 & 62.38 & 4.88 & 0.78 & 27.89 & 0.01 & 0.18 \\
\hline Locality 2 Lcwer & UA-115 & Sink $: .60$ & 10.39 & 54.07 & 40.21 & 5.75 & 11,005 & 58.55 & 5.18 & 0.78 & 29.55 & 0.02 & 0.18 \\
\hline
\end{tabular}

All results on a moisture free izasis. 
TABLE V (Continued)

Proximate and Ultimate Analysis of Float-Sink Products

\begin{tabular}{|c|c|c|c|c|c|c|c|c|c|c|c|c|c|}
\hline \multirow{2}{*}{$\begin{array}{l}\text { Coal Field } \\
\text { and Seam } \\
\text { Yentna }\end{array}$} & \multicolumn{2}{|c|}{$\begin{array}{c}\text { Sample } \\
\text { Numbers }\end{array}$} & $\begin{array}{c}\text { Weight } \\
(\%)\end{array}$ & $\begin{array}{c}\text { Volatile } \\
\text { Matter,\% }\end{array}$ & $\begin{array}{c}\text { Fixed } \\
\text { Carbon,\% }\end{array}$ & $\begin{array}{l}\text { Ash } \\
\%\end{array}$ & $\begin{array}{l}\text { Heating } \\
\text { Value } \\
\text { BTU/lb. }\end{array}$ & $\mathrm{C}, \%$ & $\mathrm{H}, \%$ & $\mathbf{N}, \%$ & $0, \%$ & \multicolumn{2}{|c|}{ Sulfur } \\
\hline & UA-116 & Float 1.60 & 78.28 & 56.04 & 40.90 & 3.06 & 11,328 & 64.42 & 6.16 & 0.76 & 25.43 & 0.01 & 0.16 \\
\hline Locality 2 Upper & UA-116 & Sink 1.60 & 21.72 & 55.92 & 39.97 & 4.11 & 11,104 & 62.15 & 4.98 & 0.80 & 27.80 & 0.01 & 0.17 \\
\hline Kenai & UA-118 & Float 1.60 & 83.80 & 47.13 & 43.17 & 9.71 & 10,929 & 56.67 & 4.56 & 1.50 & 27.12 & 0.02 & 0.45 \\
\hline Cabin Bed & UA-118 & Sink 1.60 & 16.20 & 35.02 & 28.18 & 36.80 & 7,372 & 46.58 & 4.42 & 0.66 & 11.15 & 0.02 & 0.39 \\
\hline Kenai & UA-122 & Float 1.60 & 74.99 & 40.89 & 50.11 & 9.00 & 10,328 & 58.36 & 4.69 & 1.11 & 26.49 & 0.03 & 0.35 \\
\hline Ninilchik & UA-122 & Sink 1.60 & 25.01 & 28.43 & 16.47 & 55.09 & 4,570 & 24.48 & 2.62 & 0.63 & 16.91 & 0.06 & 0.27 \\
\hline Kenai & UA-131 & Float 1.60 & 81.92 & 50.19 & 40.44 & 9.37 & 10,100 & 55.76 & 4.36 & 1.09 & 28.99 & 0. & 0.42 \\
\hline Happy Creek & UA-131 & Sink 1.60 & 13.08 & 24.85 & 10.79 & 64.36 & 3,528 & 21.19 & 2.46 & 0.64 & 11.12 & 0. & 0.23 \\
\hline Big Seam & UA-108 & Float 1.60 & 82.12 & 38.32 & 55.61 & 6.08 & 13,268 & 74.56 & 3.64 & 1.44 & 13.86 & 0.01 & 0.42 \\
\hline & UA-108 & Sink 1.60 & 17.88 & 26.89 & 15.61 & 57.50 & 4,846 & 27.64 & 2.33 & 0.52 & 11.84 & 0.14 & 0.16 \\
\hline No. TA Bed & U'A-142 & Float 1.60 & 74.03 & 39.98 & 54.93 & 5.10 & 13,534 & 76.08 & 5.16 & 1.55 & 11.77 & 0.01 & 0.34 \\
\hline Evan Jones Mine & UA-142 & Sink 1.60 & 25.97 & 23.16 & 13.61 & 63.23 & 4,141 & 24.22 & 2.37 & 0.53 & 9.14 & 0.01 & 0.51 \\
\hline No. 7 Lower Bed & UA-143 & Float 1.60 & 75.72 & 41.92 & 51.83 & 6.25 & 13,390 & 73.69 & 5.67 & 1.24 & 12.74 & 0.03 & 0.41 \\
\hline Evan Jones Mine & UA-143 & Sink 1.60 & 24.28 & 29.12 & 15.69 & 55.19 & 4,366 & 26.05 & 2.62 & 1.04 & 14.90 & 0.18 & 0.20 \\
\hline No. 7 Upper Bed & UA-144 & Float 1.60 & 71.52 & 41.35 & 51.18 & 7.47 & 13,095 & 72.41 & 2.41 & 1.60 & 15.75 & 0.02 & 0.36 \\
\hline Evan Jones Mine & UA-144 & Sink 1.60 & 28.48 & 33.91 & 25.56 & 40.53 & 7,782 & 44.24 & 3.60 & 0.99 & 10.40 & 0.11 & 0.24 \\
\hline No. 6 Lower Bed & UA-145 & Float 1.60 & 80.31 & 38.04 & 52.46 & 9.50 & 12,704 & 71.64 & 5.16 & 1.03 & 12.33 & 0.02 & 0.34 \\
\hline Evan Jones Mine & UA-145 & Sink 1.60 & 19.69 & 21.65 & 14.33 & 64.02 & 4,512 & 24.08 & 5.22 & 0.84 & 5.66 & 0.09 & 0.18 \\
\hline No. 6Upper Bed & UA-146 & Float 1.60 & 57.77 & 38.01 & 48.90 & 13.09 & 12,173 & 68.43 & 5.05 & 1.51 & 11.55 & 0.02 & 0.37 \\
\hline Evan Jones Mine & UA-146 & Sink 1.60 & 42.23 & 25.59 & 19.92 & 54.49 & 5,648 & 31.82 & 2.92 & 0.80 & 9.78 & 0.09 & 0.19 \\
\hline No. 5 Bed & UA-147 & Float 1.60 & 58.15 & 39.10 & 52.84 & 8.06 & 13,017 & 73.20 & 5.16 & 1.62 & 11.56 & 0.01 & 0.40 \\
\hline Evan Jones Mine & UA-147 & Sink 1.60 & 41.85 & 22.40 & 12.31 & 65.29 & 3,934 & 22.76 & 2.25 & 0.54 & 8.88 & 0.01 & 0.28 \\
\hline Matanuska & UA-107 & Float 1.60 & 83.14 & 28.69 & 64.11 & 7.20 & 14,337 & 79.31 & 5.15 & 1.80 & 6.09 & 0.03 & 0.45 \\
\hline Lower Seam & UA-107 & Sink 1.60 & 16.86 & 17.10 & 22.38 & 60.52 & 5,065 & 28.91 & 2.36 & 0.74 & 7.18 & 0.21 & 0.28 \\
\hline
\end{tabular}


TABLE V (Continued)

Proximate and Ultimate Analysis of Float-Sink Prodıcts

\begin{tabular}{|c|c|c|c|c|c|c|c|c|c|c|c|c|c|}
\hline \multirow{3}{*}{$\begin{array}{l}\text { Coal Field } \\
\text { and Seam }\end{array}$} & \multirow{2}{*}{\multicolumn{2}{|c|}{$\begin{array}{c}\text { Sample } \\
\text { Numbers }\end{array}$}} & \multirow{2}{*}{$\begin{array}{c}\text { Weight } \\
(\%)\end{array}$} & \multirow{2}{*}{$\begin{array}{c}\text { Volatile } \\
\text { Matter, }, \%\end{array}$} & \multirow{2}{*}{$\begin{array}{c}\text { Fixed } \\
\text { Carbon,\% }\end{array}$} & \multirow{2}{*}{$\begin{array}{c}\text { Ash } \\
\%\end{array}$} & \multirow{2}{*}{$\begin{array}{l}\text { Heating } \\
\text { Value } \\
\text { BTU/lb. }\end{array}$} & \multirow[b]{2}{*}{$\mathrm{C}, \%$} & \multirow[b]{2}{*}{$\mathrm{H}, \%$} & \multirow[b]{2}{*}{$\mathrm{N}, \%$} & \multirow[b]{2}{*}{$0, \%$} & \multicolumn{2}{|c|}{ Sulfur } \\
\hline & & & & & & & & & & & & Pyritic & Total \\
\hline & UA-111 & Float 1.60 & 76.31 & 49.22 & 42.55 & 8.23 & 10,232 & 59.95 & 4.80 & 0.76 & 26.02 & 0.02 & 0.24 \\
\hline Coal Creek Seam & UA111 & Sink 1.60 & 23.69 & 35.64 & 19.52 & 44.84 & 6,153 & 3584 & 3.26 & 0.66 & 15.24 & 0.03 & 0.16 \\
\hline Broad Pass & UA-123 & Float 1.60 & 85.02 & 43.67 & 50.33 & 6.00 & 11,828 & 68.29 & 4.93 & 1.02 & 19.28 & 0.04 & 0.48 \\
\hline Dunkle Bed & UA-123 & Sink 1.60 & 14.98 & 31.79 & 10.40 & 57.81 & 4,348 & 26.63 & 2.48 & 0.20 & 12.65 & 0.14 & 0.23 \\
\hline Southwest Alaska & Coal F & dds & & & & & & & & & & & \\
\hline Little Tonzona & UA-112 & Flcat 1.60 & 88.91 & 50.93 & 39.44 & 9.63 & 10,128 & 59.66 & 5.03 & 0.84 & 23.43 & 0.04 & 1.41 \\
\hline Coal Bed & UA-112 & Sink 1.60 & 11.09 & 35.25 & 16.67 & 48.09 & 5,445 & 33.68 & 4.24 & 0.59 & 11.99 & 0.23 & 1.41 \\
\hline Chignik & UA-136 & Float 1.60 & 52.59 & 37.44 & 53.49 & 9.07 & 12,712 & 70.99 & 4.87 & 0.75 & 13.06 & 0.21 & 1.26 \\
\hline Chignik Bay Mine & UA136 & Sink 1.60 & 47.41 & 20.54 & 12.80 & 66.66 & 4,021 & 21.66 & 2.17 & 0.23 & 8.01 & 1.53 & 1.27 \\
\hline Herendeen Bay & UA-137 & Float 1.60 & 52.34 & 32.23 & 53.80 & 13.97 & 12,140 & $6 \pi .39$ & 4.79 & 1.60 & 11.20 & 0.40 & 1.05 \\
\hline Coal Point & UA-137 & Sink 1.60 & 47.66 & 19.29 & 9.60 & 71.11 & 3.432 & $1 \subseteq .06$ & 1.69 & 0.49 & 5.97 & 1.82 & 1.68 \\
\hline
\end{tabular}

All results on a moisture free basis. 
TABLE VI

Concentration of Major Elements in Ash of 1.60 Specific Gravity Float-Sink Products of Coals Crushed to 65 Mesh Size, percent

$\begin{array}{llllllllllllll}\text { Coal Field } & \text { Sample No. } & \mathrm{SiO}_{2} & \mathrm{Al}_{2} \mathrm{O}_{3} & \mathrm{Fe}_{2} \mathrm{O}_{3} & \mathrm{MgO} & \mathrm{CaO} & \mathrm{Na}_{2} \mathrm{O} & \mathrm{K}_{2} \mathrm{O} & \mathrm{TiO}_{2} & \mathrm{MnO}_{2} & \mathrm{P}_{2} \mathrm{O}_{5} & \mathrm{SO}_{3}\end{array}$

\section{Northern Alaska Coal Fields}

No. 7 Bed UA 139 Float 1.60

Cape Beaufort

$\begin{array}{rrrrrrrrrrrr}38.7 & 24.8 & 3.6 & 3.8 & 14.0 & 5.88 & 0.86 & 1.81 & .10 & & 4.25 \\ 64.3 & 24.0 & 2.0 & 1.5 & 2.7 & 2.36 & 1.22 & 0.55 & 0.02 & & 0.35 \\ & & & & & & & & & & \\ 31.1 & 31.5 & 5.85 & 2.31 & 8.77 & 2.49 & 1.58 & 3.29 & 0.05 & 4.78 & 3.23 \\ 53.7 & 26.3 & 5.90 & 3.50 & 5.01 & 1.17 & 2.20 & 1.49 & 0.03 & 0.80 & 0.58 \\ & & & & & & & & & & \\ 17.2 & 30.2 & 8.41 & 3.81 & 12.4 & 4.36 & 0.86 & 1.49 & 0.03 & 0.87 & 11.35 \\ 25.0 & 23.9 & 18.3 & 8.87 & 15.6 & 0.75 & 0.35 & 0.31 & 0.04 & 0.41 & 4.31 \\ & & & & & & & & & & \\ 4.8 & 13.2 & 12.4 & 19.0 & 11.4 & 13.0 & 1.62 & 0.44 & 0.17 & 0.13 & 24.75 \\ 3.4 & 0.8 & 61.2 & 7.83 & 9.06 & 0.22 & 0.11 & 0.04 & 0.50 & 0.25 & - \\ & & & & & & & & & & \\ 38.9 & 34.0 & 6.64 & 4.57 & 5.51 & 2.08 & 2.01 & 1.47 & 0.05 & 1.94 & 0.91 \\ 48.6 & 29.2 & 5.97 & 0.68 & 1.94 & 0.14 & 0.92 & 0.57 & 0.03 & 0.69 & - \\ & & & & & & & & & & \\ 41.2 & 20.8 & 7.87 & 4.94 & 16.1 & 0.42 & 2.09 & 3.20 & 0.06 & 0.03 & 1.94 \\ 66.0 & 23.3 & 3.42 & 2.20 & 1.08 & 0.24 & 3.04 & 1.09 & 0.02 & 0.06 & 1.66\end{array}$

Sagwon Bluffs

UA 139 Sink 1.60

Kokolik River

UA 126 Float 1.60

UA 126 Sink 1.60

No. 3 Bed

UA 125 Float 1.60

UA 125 Sink 1.60

Elusive Creek

UA 109 Float 1.60

UA 109 Sink 1.60

66.0 23.3

0.24

\section{Northwest Alaska Coal Fields}

\begin{tabular}{|c|c|c|c|c|c|c|c|c|c|c|c|c|}
\hline Chicago Creek & UA 138 Float 1.60 & 13.4 & 13.9 & 24.0 & 4.42 & 22.4 & 0.15 & 0.36 & 0.69 & 0.42 & 0.12 & 16.60 \\
\hline Seward Peninsula & UA 138 Sink 1.60 & 27.8 & 11.9 & 33.2 & 1.45 & 4.47 & 0.45 & 0.97 & 0.49 & 0.57 & 0.08 & 2.47 \\
\hline Unalakleet & UA 151 Float 1.60 & 26.5 & 24.0 & 6.02 & 8.78 & 17.2 & 3.27 & 1.25 & 0.73 & 0.03 & 2.00 & 6.13 \\
\hline Coal Creek & UA 151 Sink 1.60 & 65.1 & 18.0 & 4.20 & 2.08 & 2.38 & 0.96 & 1.93 & 0.92 & 0.02 & 0.65 & 2.02 \\
\hline Interior Alaska & Coal Fields & & & & & & & & & & & \\
\hline No. 2 Seam & $\begin{array}{l}\text { UA } 105 \text { Float } 1.60 \\
\text { UA } 105 \text { Sink } 1.60\end{array}$ & $\begin{array}{l}33.2 \\
54.8\end{array}$ & $\begin{array}{l}18.1 \\
20.9\end{array}$ & $\begin{array}{l}8.03 \\
3.41\end{array}$ & $\begin{array}{l}2.91 \\
0.80\end{array}$ & $\begin{array}{c}23.9 \\
4.81\end{array}$ & $\begin{array}{l}0.15 \\
0.18\end{array}$ & $\begin{array}{l}0.55 \\
1.28\end{array}$ & $\begin{array}{l}0.84 \\
0.64\end{array}$ & $\begin{array}{l}0.41 \\
0.06\end{array}$ & $\begin{array}{l}0.58 \\
0.20\end{array}$ & $\begin{array}{l}4.12 \\
0.73\end{array}$ \\
\hline
\end{tabular}




\section{TABLE :1/ (Continued)}

Concentration of Major Elements in Ash of 1.60 Specific Gravity Float-Sink Profucts of Coals Crushed to 65 Mesh Size, percent

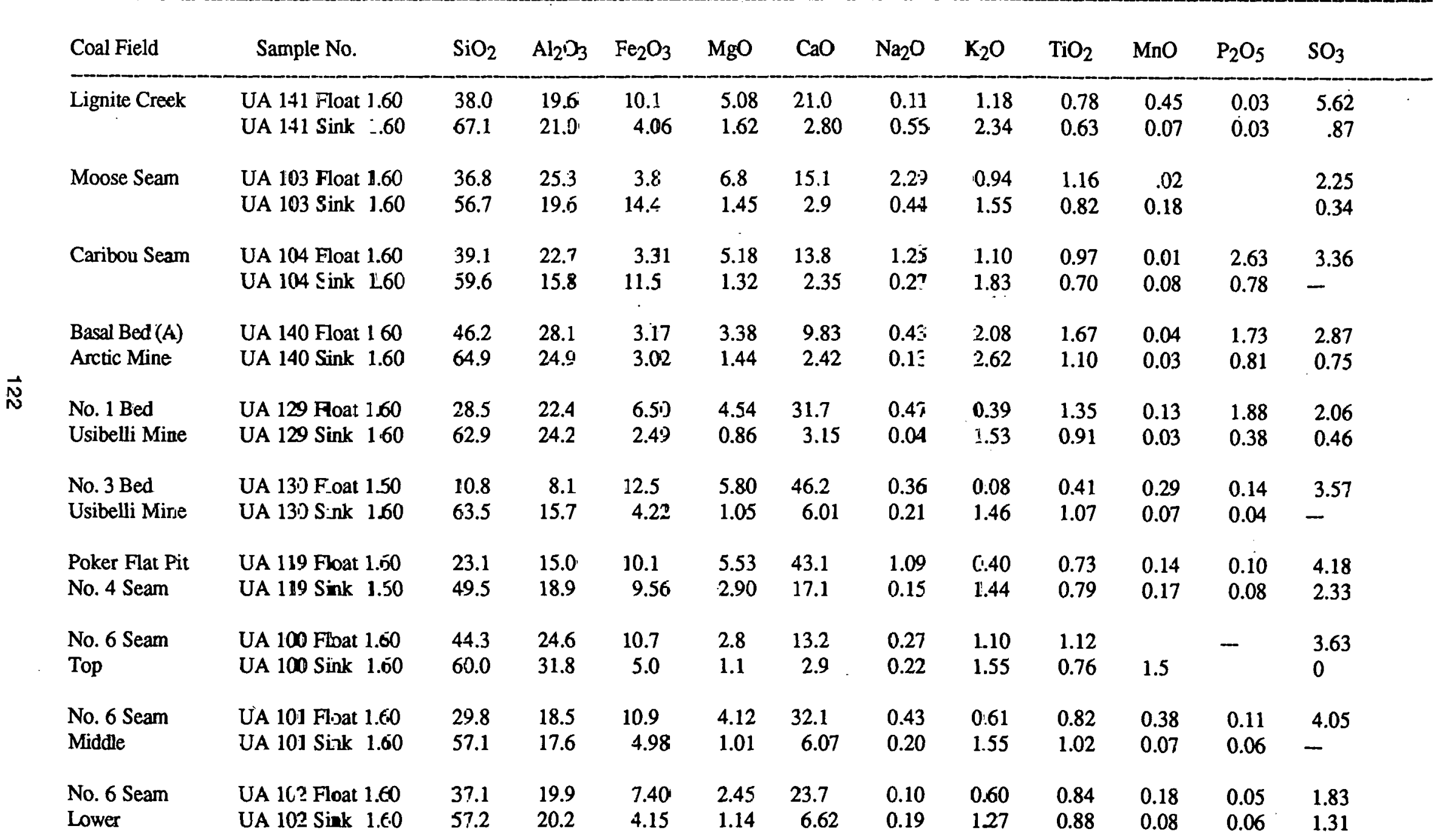


TABLE Vl (Continued)

Concentration of Major Elements in Ash of 1.60 Specific Gravity Float-Sink Products of Coals Crushed to 65 Mesh Size, percent

\begin{tabular}{|c|c|c|c|c|c|c|c|c|c|c|c|c|}
\hline Coal Field & Sample No. & $\mathrm{SiO}_{2}$ & $\mathrm{Al}_{2} \mathrm{O}_{3}$ & $\mathrm{Fe}_{2} \mathrm{O}_{3}$ & $\mathrm{MgO}$ & $\mathrm{CaO}$ & $\mathrm{Na}_{2} \mathrm{O}$ & $\mathrm{K}_{2} \mathrm{O}$ & $\mathrm{TiO}_{2}$ & $\mathrm{MnO}$ & $\mathrm{P}_{2} \mathrm{O}_{5}$ & $\mathrm{SO}_{3}$ \\
\hline Yanert Mine & $\begin{array}{l}\text { UA } 132 \text { Float } 1.60 \\
\text { UA } 132 \text { Sink } 1.60\end{array}$ & $\begin{array}{l}56.0 \\
66.9\end{array}$ & $\begin{array}{l}26.6 \\
23.7\end{array}$ & $\begin{array}{l}5.50 \\
3.65\end{array}$ & $\begin{array}{l}1.69 \\
1.10\end{array}$ & $\begin{array}{l}3.09 \\
0.75\end{array}$ & $\begin{array}{l}0.36 \\
0.34\end{array}$ & $\begin{array}{l}2.68 \\
2.93\end{array}$ & $\begin{array}{l}1.54 \\
0.77\end{array}$ & $\begin{array}{l}0.05 \\
0.02\end{array}$ & $\begin{array}{l}1.02 \\
0.35\end{array}$ & $\begin{array}{r}1.33 \\
.75\end{array}$ \\
\hline $\begin{array}{l}\text { Eagle } \\
\text { Coal Creek }\end{array}$ & $\begin{array}{l}\text { UA } 121 \text { Float } 1.60 \\
\text { UA } 121 \text { Sink } 1.60\end{array}$ & $\begin{array}{l}27.5 \\
60.3\end{array}$ & $\begin{array}{l}19.7 \\
24.8\end{array}$ & $\begin{array}{l}6.84 \\
3.57\end{array}$ & $\begin{array}{l}5.48 \\
1.38\end{array}$ & $\begin{array}{c}26.8 \\
4.42\end{array}$ & $\begin{array}{l}0.58 \\
0.57\end{array}$ & $\begin{array}{l}0.45 \\
0.93\end{array}$ & $\begin{array}{l}1.75 \\
1.04\end{array}$ & $\begin{array}{l}0.27 \\
0.06\end{array}$ & $\begin{array}{l}0.15 \\
0.10\end{array}$ & $\begin{array}{r}11.04 \\
2.19\end{array}$ \\
\hline $\begin{array}{l}\text { Eagle } \\
\text { Chicken }\end{array}$ & $\begin{array}{l}\text { UA } 124 \text { Float } 1.60 \\
\text { UA } 124 \text { Sink } 1.60\end{array}$ & $\begin{array}{l}42.2 \\
53.8\end{array}$ & $\begin{array}{l}27.6 \\
21.1\end{array}$ & $\begin{array}{c}14.6 \\
4.19\end{array}$ & $\begin{array}{l}2.28 \\
1.14\end{array}$ & $\begin{array}{l}4.49 \\
5.35\end{array}$ & $\begin{array}{l}0.93 \\
0.52\end{array}$ & $\begin{array}{l}0.95 \\
1.54\end{array}$ & $\begin{array}{l}1.53 \\
0.54\end{array}$ & $\begin{array}{l}0.20 \\
0.04\end{array}$ & $\begin{array}{l}2.84 \\
1.43\end{array}$ & $\begin{array}{l}2.49 \\
4.73\end{array}$ \\
\hline Tramway Bar & $\begin{array}{l}\text { UA } 117 \text { Float } 1.60 \\
\text { UA } 117 \text { Sink } 1.60\end{array}$ & $\begin{array}{l}43.6 \\
55.2\end{array}$ & $\begin{array}{l}29.6 \\
27.6\end{array}$ & $\begin{array}{l}3.33 \\
4.97\end{array}$ & $\begin{array}{l}1.72 \\
1.18\end{array}$ & $\begin{array}{l}6.36 \\
1.16\end{array}$ & $\begin{array}{l}0.59 \\
0.68\end{array}$ & $\begin{array}{l}2.20 \\
3.54\end{array}$ & $\begin{array}{l}2.70 \\
1.34\end{array}$ & $\begin{array}{l}.018 \\
.032\end{array}$ & $\begin{array}{r}2.74 \\
.39\end{array}$ & $\begin{array}{l}1.2 \\
0.16\end{array}$ \\
\hline Southcentral & Alaska Coal Fields & & & & & & & & & & & \\
\hline $\begin{array}{l}\text { Waterfall } \\
\text { Seam }\end{array}$ & $\begin{array}{l}\text { UA } 113 \text { Float } 1.60 \\
\text { UA } 113 \text { Sink } 1.60\end{array}$ & $\begin{array}{l}32.5 \\
57.1\end{array}$ & $\begin{array}{l}26.6 \\
30.2\end{array}$ & $\begin{array}{l}7.5 \\
4.6\end{array}$ & $\begin{array}{l}2.3 \\
1.1\end{array}$ & $\begin{array}{r}21.9 \\
3.5\end{array}$ & $\begin{array}{l}0.77 \\
0.30\end{array}$ & $\begin{array}{l}1.22 \\
2.31\end{array}$ & $\begin{array}{l}0.85 \\
0.57\end{array}$ & $\begin{array}{l}0.08 \\
0.06\end{array}$ & . & $\begin{array}{l}3.55 \\
0.24\end{array}$ \\
\hline $\begin{array}{l}\text { Waterfall Bed } \\
\text { Top 6' }\end{array}$ & $\begin{array}{l}\text { UA } 148 \text { Float } 1.60 \\
\text { UA } 148 \text { Sink } 1.60\end{array}$ & $\begin{array}{l}52.9 \\
62.1\end{array}$ & $\begin{array}{l}30.6 \\
29.1\end{array}$ & $\begin{array}{l}5.69 \\
3.20\end{array}$ & $\begin{array}{l}1.15 \\
0.96\end{array}$ & $\begin{array}{l}5.42 \\
0.85\end{array}$ & $\begin{array}{l}0.19 \\
0.14\end{array}$ & $\begin{array}{l}2.44 \\
2.74\end{array}$ & $\begin{array}{l}0.89 \\
0.59\end{array}$ & $\begin{array}{l}0.08 \\
0.04\end{array}$ & $\begin{array}{l}0.33 \\
0.27\end{array}$ & $\begin{array}{l}1.74 \\
2.26\end{array}$ \\
\hline Capps Bed & $\begin{array}{l}\text { UA } 127 \text { Float } 1.60 \\
\text { UA } 127 \text { Sink } 1.60\end{array}$ & $\begin{array}{l}48.8 \\
60.2\end{array}$ & $\begin{array}{l}26.9 \\
24.6\end{array}$ & $\begin{array}{l}3.44 \\
1.82\end{array}$ & $\begin{array}{l}1.50 \\
0.73\end{array}$ & $\begin{array}{l}12.4 \\
2.68\end{array}$ & $\begin{array}{l}0.30 \\
0.30\end{array}$ & $\begin{array}{l}1.41 \\
1.66\end{array}$ & $\begin{array}{l}1.25 \\
0.90\end{array}$ & $\begin{array}{l}0.05 \\
0.02\end{array}$ & $\begin{array}{l}0.63 \\
0.33\end{array}$ & $\begin{array}{l}2.29 \\
0.36\end{array}$ \\
\hline
\end{tabular}


TABLE VI (Continued)

Concentration of Major Elements in Ash of 1.60 Specific Gravity Float-Sink Products of Coals Crushed to 65 Mesh Size, percent

\begin{tabular}{|c|c|c|c|c|c|c|c|c|c|c|c|c|}
\hline Coal Field & Sample No. & $\mathrm{SiO}_{2}$ & $\mathrm{Al}_{2} \mathrm{O}_{3}$ & $\mathrm{Fe}_{2} \mathrm{O}_{3}$ & $\mathrm{MgO}$ & $\mathrm{CaO}$ & $\mathrm{Na}_{2} \mathrm{O}$ & $\mathrm{K}_{2} \mathrm{O}$ & $\mathrm{TiO}_{2}$ & $\mathrm{MnO}$ & $\mathrm{P}_{2} \mathrm{O}_{5}$ & $\mathrm{SO}_{3}$ \\
\hline Green Bed & UA 152 Float 1.60 & 25.4 & 21.5 & 8.40 & 4.29 & 24.9 & 0.27 & 0.66 & 0.71 & 0.09 & 0.01 & 4.07 \\
\hline Lone Ridge Mine & UA 152 Sink 1.60 & 52.0 & 28.8 & 6.02 & 1.01 & 4.11 & 0.22 & 0.80 & 0.76 & 0.07 & 0.24 & - \\
\hline Yentna & UA 149 Float 1.60 & 38.4 & 24.6 & 7.2 & 3.6 & 18.1 & 0.41 & 1.46 & 1.13 & 0.14 & & 2.79 \\
\hline Johnson Creek & UA 149 Sink 1.60 & 64.6 & 22.9 & 4.4 & 1.3 & 3.1 & $(1.32$ & 2.31 & 0.86 & 0.05 & & 0.30 \\
\hline Yentna & UA 150 Float 1.60 & 45.3 & 31.2 & 3.46 & 1.94 & 9.75 & 0.22 & 1.23 & 1.40 & 0.03 & 0.50 & 2.06 \\
\hline Canyon Creek & UA 150 Sink 1.60 & 60.8 & 24.1 & 1.58 & 0.99 & 1.53 & C.26 & 2.33 & 0.80 & 0.01 & 0.16 & 0.21 \\
\hline Yentna & UA'11 15 Float 1.60 & 7.2 & 34.3 & 8.43 & 7.43 & 36.1 & a.11 & 0.15 & 0.89 & 0.10 & 1.52 & 5.32 \\
\hline Locality 2 Lower & UA 1,15 Sink 1.60 & 22.6 & 30.1 & 8.60 & 5.41 & 24.5 & 0.31 & 0.77 & 0.85 & 0.10 & 1.81 & 3.70 \\
\hline Yentna & UA 116 Float 1.60 & 6.54 & 27.8 & 9.83 & 7.47 & 42.1 & 0.13 & 0.10 & 0.61 & 0.13 & 0.68 & 5.91 \\
\hline Locality 2 Upper & UA 116 Sink 1.60 & 18.6 & 25.5 & 10.87 & 5.72 & 32.4 & 0.27 & 0.64 & 0.62 & 0.12 & 0.73 & 4.95 \\
\hline Kenai & UA 118 Float 1.60 & 38.0 & 20.7 & 7.87 & 3.20 & 20.0 & 126 & 1.61 & 1.14 & 0.22 & 2.09 & 6.03 \\
\hline Cabin Bed & UA 118 Sink 1.60 & 55.0 & 23.6 & 5.62 & 2.22 & 6.24 & 1.78 & 2.30 & 0.66 & 0.09 & 1.10 & 1.38 \\
\hline Kenai & UA 122 Float 1.60 & 38.5 & 19.4 & 6.47 & 8.76 & 16.0 & 5.36 & 1.50 & 1.25 & 0.10 & 1.14 & 3.56 \\
\hline Ninilchik & UA $122 \operatorname{Sink} 1.60$ & 61.1 & 22.4 & 6.95 & 2.81 & 2.37 & 1.83 & 2.39 & 0.65 & 0.13 & 0.04 & 0.42 \\
\hline Kenai & UA 131 Float 1.60 & 34.0 & 15.4 & 10.1 & 5.57 & 26.5 & 0.65 & 0.79 & 0.76 & 0.72 & 0.44 & 6.21 \\
\hline Happy Creek & UA 131 Sink 1.60 & 59.2 & 18.4 & 13.7 & 2.45 & 3.40 & 1.52 & 1.96 & 0.63 & 0.35 & 0.45 & 0.52 \\
\hline Big Seam & UA 108 Float 1.60 & 48.8 & 29.2 & 4.28 & 1.46 & 3.54 & 0.59 & 1.21 & 2.67 & 0.02 & 1.00 & 2.79 \\
\hline & UA 108 Sink 1.60 & 48.5 & 21.1 & 15.9 & 2.76 & 4.06 & 0.11 & 1.14 & 0.72 & 0.18 & 0.17 & 0.80 \\
\hline No. $7 \mathrm{~A}$ Bed & UA 142 Float 1.60 & 48.9 & 34.8 & 2.6 & 1.0 & 2.3 & 1.25 & 1.40 & 3.90 & 0.01 & & 0.16 \\
\hline Evan Jones Mine & UA 142 Sink 1.60 & 54.2 & 28.3 & 8.2 & 1.9 & 2.5 & 0.48 & 1.67 & 1.05 & 0.12 & & 0.48 \\
\hline No. 7 Lcwer Bed & UA 143 Float 1.60 & 47.1 & 30.0 & 2.36 & 1.11 & 2.26 & 0.69 & 1.60 & 2.08 & 0.01 & 3.47 & 1.52 \\
\hline Evan Jones Mine & UA 143 Sink 1.60 & 39.1 & 27.9 & 19.2 & 2.39 & 4.31 & 0.33 & 0.96 & 1.17 & 0.29 & 3.80 & 0.86 \\
\hline
\end{tabular}


TABLE Vl (Continued:

Concentration of Major Elements in Ash of 1.60 Specific Gravity Float-Sink Products of Coals Crushed to 65 Mesh Size, percent

\begin{tabular}{|c|c|c|c|c|c|c|c|c|c|c|c|c|}
\hline Coal Field & Sample No. & $\mathrm{SiO}_{2}$ & $\mathrm{Al}_{2} \mathrm{O}_{3}$ & $\mathrm{Fe}_{2} \mathrm{O}_{3}$ & $\mathrm{MgO}$ & $\mathrm{CaO}$ & $\mathrm{Na}_{2} \mathrm{O}$ & $\mathrm{K}_{2} \mathrm{O}$ & $\mathrm{TiO}_{2}$ & $\mathrm{MnO}$ & $\mathrm{P}_{2} \mathrm{O}_{5}$ & $\mathrm{SO}_{3}$ \\
\hline No. 7 Upper Bed & UA 144 Float 1.60 & 47.0 & 29.1 & 3.06 & 1.35 & 2.14 & 1.07 & 1.40 & 3.19 & 0.02 & 1.49 & 0.56 \\
\hline Evan Jones Mine & UA 144 Sink 1.60 & 48.7 & 25.9 & 16.8 & 2.57 & 2.70 & 0.34 & 1.51 & 0.92 & 0.21 & 1.36 & 1.44 \\
\hline No. 6 Lower Bed & UA 145 Float 1.60 & 53.5 & 33.7 & 2.69 & 1.27 & 2.18 & 0.75 & 1.79 & 2.33 & 0.02 & 3.51 & 1.49 \\
\hline Evan Jones Mine & UA 145 Sink 1.60 & 48.9 & 26.0 & 5.40 & 1.55 & 2.45 & 0.60 & 1.82 & 0.80 & 0.06 & 4.39 & 0.49 \\
\hline No. 6 Upper Bed & UA 146 Float 1.60 & 57.6 & 32.6 & 2.44 & 1.04 & 1.14 & 0.44 & 1.78 & 3.15 & 0.02 & 0.64 & 0.10 \\
\hline Evan Jones Mine & UA 146 Sink 1.60 & 54.0 & 29.0 & 6.34 & 1.25 & 1.74 & 0.28 & 1.59 & 0.98 & 0.09 & 0.32 & 0.60 \\
\hline No. 5 Bed & UA 147 Float 1.60 & 50.7 & 32.7 & 2.8 & 1.3 & 2.0 & 1.11 & 1.79 & 4.59 & 0.02 & & 0.15 \\
\hline Evan Jones Mine & UA 147 Sink 1.60 & 55.8 & 27.5 & 6.9 & 2.1 & 2.6 & 0.58 & 2.01 & 0.74 & 0.12 & & 0.32 \\
\hline Matanuska & UA 107 Float 1.60 & 49.8 & 32.0 & 3.24 & 1.26 & 2.63 & 0.53 & 1.53 & 2.48 & 0.01 & 1.78 & 2.19 \\
\hline Lower Seam & UA 107 Sink 1.60 & 54.4 & 27.4 & 5.95 & 1.85 & 3.50 & 0.51 & 1.73 & 0.72 & 0.09 & 1.25 & 0.23 \\
\hline Broad Pass & UA 111 Float 1.60 & 42.0 & 27.9 & 5.95 & 1.00 & 14.2 & 0.06 & 1.29 & 1.28 & 0.25 & 5.65 & 3.17 \\
\hline Coal Creek Seam & UA 111 Sink 1.60 & 59.3 & 25.9 & 3.23 & 0.79 & 4.04 & 0.24 & 1.98 & 0.98 & 0.08 & 0.31 & 1.11 \\
\hline Broad Pass & UA 123 Float 1.60 & 35.3 & 28.8 & 9.40 & 2.18 & 12.7 & 0.09 & 0.70 & 1.44 & 0.07 & 0.34 & 7.13 \\
\hline Dunkle Bed & UA 123 Sink 1.60 & 49.8 & 19.9 & 24.5 & 1.10 & 2.12 & 0.00 & 0.78 & 0.71 & 0.27 & 0.27 & 1.06 \\
\hline \multicolumn{13}{|c|}{ Southwest Alaska Coalfields } \\
\hline Little Tonzona & UA 112 Float 1.60 & 18.9 & 16.2 & 6.68 & 3.78 & 29.8 & 0.06 & 0.60 & 0.68 & 0.03 & 0.18 & 21.07 \\
\hline Coal Bed & UA $112 \operatorname{Sink} 1.60$ & 53.5 & 20.2 & 6.92 & 1.82 & 6.82 & 0.52 & 1.52 & 0.90 & 0.04 & 0.21 & 4.92 \\
\hline Chignik & UA 136 Float 1.60 & 46.1 & 33.1 & 6.23 & 2.07 & 3.47 & 0.14 & 0.78 & 2.75 & 0.04 & 3.88 & 3.18 \\
\hline Chignik Bay Mine & UA 136 Sink 1.60 & 52.2 & 27.5 & 3.90 & 0.91 & 3.51 & 0.06 & 0.98 & 0.84 & 0.03 & 1.09 & 1.73 \\
\hline Herendeen Bay & UA 137 Float 1.60 & 48.6 & 20.0 & 11.1 & 1.97 & 4.93 & 1.02 & 1.34 & 1.85 & 0.15 & 0.01 & 1.81 \\
\hline Coal Point & UA 137 Sink 1.60 & 57.0 & 16.5 & 12.2 & 1.76 & 6.59 & 1.51 & 1.29 & 0.63 & 0.22 & 0.09 & 4.50 \\
\hline
\end{tabular}


Table VII Fusibility of Ash of 1.60 Specific Gravity Float-Sink
Products of Coals Crushed to Minus 65 Mesh Size

COAL

INTTIAL

FIELD

SAMPLE

DEFORMATION

\& SEAM

NUMBER GRAVITY

oF

${ }^{\circ} \mathrm{F}$

FLUID

of

\section{Northern Alaska Coal Fields}

No. 7 Bed

UA-139

Flcat 1.60

2148

Sink 1.60

2264

2229

2618

2492

Cape Beaufort

Float 1.60

2217

2305

2276

2329

2328

Sink 1.00

2262

2265

2427

2285

Elusive Creak

Sink 1.60

$+2800$

$+2800$

2795

$+2800$

Sink 1.60

2637

2297

2352

Meade River

UA-110

Float 1.60

2065

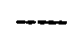

2211

2226

2636

2281

$\begin{array}{ll}\text { Sink } & 1.60\end{array}$

2559

2766

\section{Northwest Alaska Coal Fields}

Chicago Creek UA-138

Finat. 1,60

2107

Sink 1.60

2322

2428

25())

2439

Scward Feniiisula

Flcat 1.60

2225

2247

2565

Unalakleet

UA-151

Sink 1.60

2325

2466

2314

2596

\section{Interior Alaska Coal Fields}

\begin{tabular}{|c|c|c|c|c|c|}
\hline No. 2 Seam & UA-105 & Float 1.60 & $216 ?$ & 2219 & 2257 \\
\hline & & Sink 1.60 & 2394 & 2504 & 2601 \\
\hline Lignite Creek & UA-141 & Ficat 1.60 & 2209 & 2259 & 2.285 \\
\hline & & Sink 1.60 & 2266 & 2495 & 2797 \\
\hline Moose Seam & UA-103 & Float 1.60 & 2166 & 2181 & 2354 \\
\hline & & Sink 1.60 & 2064 & 2433 & 2493 \\
\hline Caribou Seanl & UA-104 & Flcat 1.60 & 2186 & 2298 & 23 \\
\hline & & Sink 1.60 & 2458 & 2518 & 2599 \\
\hline Basal Bed (A) & UA-140 & Float 1.60 & 2215 & 2378 & 3 \\
\hline Arctic Mine & & Sink 1.60 & 2364 & 2552 & 2568 \\
\hline
\end{tabular}


Table VII (Continued)

Fusibility of Ash of 1.60 Specific Gravity Float-Sink Products of Coals Crushed to Minus 65 Mesh Size

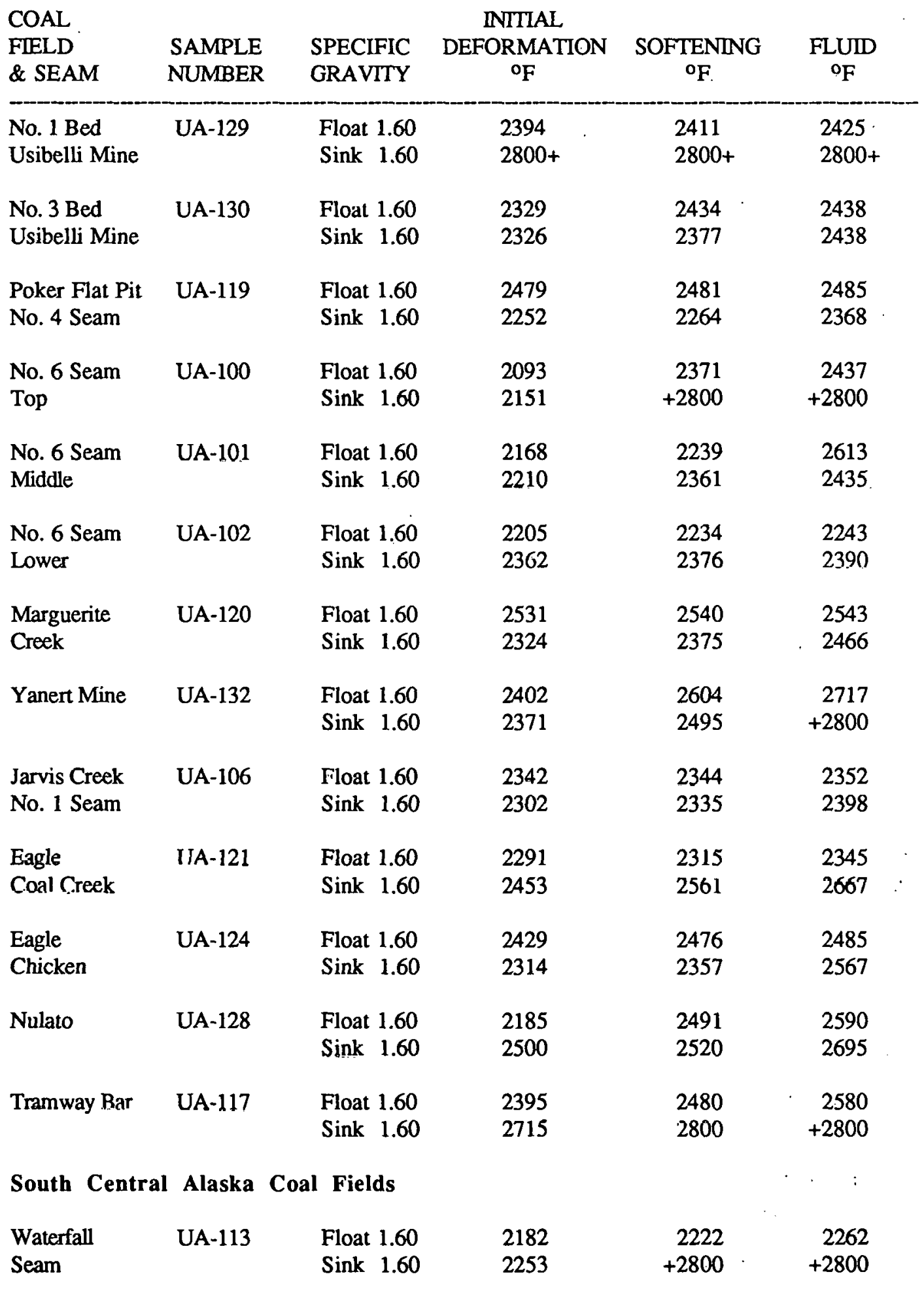


Table VII (Continued)

Fusibility of Ash of 1.60 Specific Gravity Float-Sink Products of Coals Crushed to Minus 65 Mesh Size

\begin{tabular}{|c|c|c|c|c|c|}
\hline $\begin{array}{l}\text { COAL } \\
\text { FIELD } \\
\& \text { SEAM }\end{array}$ & $\begin{array}{l}\text { SAMPLE } \\
\text { NUMBER }\end{array}$ & $\begin{array}{l}\text { SPECIFIC } \\
\text { GRAVITY }\end{array}$ & $\begin{array}{c}\text { INITIAL } \\
\text { DEFORMATION } \\
\text { OF }\end{array}$ & $\begin{array}{c}\text { SOFTENING } \\
{ }^{\circ} \mathrm{F}\end{array}$ & $\begin{array}{l}\text { FLUID } \\
{ }^{\circ} \mathrm{F}\end{array}$ \\
\hline $\begin{array}{l}\text { Waterfall Bed } \\
\text { Top 6' }\end{array}$ & UA-148 & $\begin{array}{ll}\text { Float } & 1.60 \\
\text { Sink } & 1.60\end{array}$ & $\begin{array}{r}2266 \\
+2800\end{array}$ & $\begin{array}{r}2563 \\
+2800\end{array}$ & $\begin{array}{r}2721 \\
+2800\end{array}$ \\
\hline Capps Bed & UA-127 & $\begin{array}{l}\text { Float } 1.60 \\
\text { Sink } 1.60\end{array}$ & $\begin{array}{l}2195 \\
2800+\end{array}$ & $\begin{array}{l}2552 \\
2800+\end{array}$ & $\begin{array}{l}2582 \\
2800+\end{array}$ \\
\hline $\begin{array}{l}\text { Green Bed } \\
\text { Lone Ridye MIne }\end{array}$ & UA-152 & $\begin{array}{ll}\text { Flcat } & 1.60 \\
\text { Sink } & 1.60\end{array}$ & $\begin{array}{l}2170 \\
2800+\end{array}$ & $\begin{array}{l}2245 \\
2800+\end{array}$ & $\begin{array}{l}2435 \\
2800+\end{array}$ \\
\hline $\begin{array}{l}\text { Yontna } \\
\text { Johnson Creek }\end{array}$ & UA-149 & $\begin{array}{l}\text { Hloat } 1.60 \\
\text { Sink } 1.60\end{array}$ & $\begin{array}{l}2122 \\
2224\end{array}$ & $\begin{array}{l}2303 \\
2597\end{array}$ & $\begin{array}{l}2392 \\
2704\end{array}$ \\
\hline $\begin{array}{l}\text { Yentna } \\
\text { Canyon Creek }\end{array}$ & UA-150 & $\begin{array}{ll}\text { Float } 1.60 \\
\text { Sink } 1.60\end{array}$ & $\begin{array}{l}2567 \\
2800+\end{array}$ & $\begin{array}{l}2601 \\
2800+\end{array}$ & $\begin{array}{l}2619 \\
2800+\end{array}$ \\
\hline $\begin{array}{l}\text { Yentna } \\
\text { Locality } 2 \text { Lower }\end{array}$ & UA-115 & $\begin{array}{l}\text { Float } 1.60 \\
\text { Sink } 1.60\end{array}$ & 2668 & 2733 & 2771 \\
\hline $\begin{array}{l}\text { Ycntna } \\
\text { Locality } 2 \text { Upper }\end{array}$ & UA-116 & $\begin{array}{ll}\text { Flcat } & 1.60 \\
\text { Sink } & 1.60\end{array}$ & 2552 & 2586 & 2652 \\
\hline $\begin{array}{l}\text { Kenai } \\
\text { Cabin Bed }\end{array}$ & UA-118 & $\begin{array}{l}\text { Float } 1.60 \\
\text { Sink } 1.60\end{array}$ & $\begin{array}{l}2164 \\
2266\end{array}$ & $\begin{array}{l}2183 \\
2.289\end{array}$ & $\begin{array}{l}2199 \\
2333\end{array}$ \\
\hline $\begin{array}{l}\text { Kenai } \\
\text { Ninilchik }\end{array}$ & UA-122 & $\begin{array}{l}\text { Flcat } 1.60 \\
\text { Sink } 1.60\end{array}$ & $\begin{array}{l}2158 \\
2328\end{array}$ & $\begin{array}{l}2172 \\
2428\end{array}$ & $\begin{array}{l}2276 \\
2552\end{array}$ \\
\hline $\begin{array}{l}\text { Kenai } \\
\text { Happy Creek }\end{array}$ & UA-131 & $\begin{array}{l}\text { Float } 1.60 \\
\text { Sink } 1.60\end{array}$ & $\begin{array}{l}2163 \\
2257\end{array}$ & $\begin{array}{l}2224 \\
2305\end{array}$ & $\begin{array}{l}2228 \\
2419\end{array}$ \\
\hline Big Seam & UA-108 & $\begin{array}{l}\text { Float } 1.60 \\
\text { Sink } 1.60\end{array}$ & $\begin{array}{l}2431 \\
2344\end{array}$ & $\begin{array}{l}2764 \\
2405\end{array}$ & $\begin{array}{l}2790 \\
2466\end{array}$ \\
\hline $\begin{array}{l}\text { No. } 7 \mathrm{~A} \text { Bed } \\
\text { Evan Jones Mine }\end{array}$ & UA 142 & $\begin{array}{l}\text { Float } 1.60 \\
\text { Sink } 1.60\end{array}$ & $\begin{array}{l}2176 \\
2272\end{array}$ & $\begin{array}{r}+2800 \\
2716\end{array}$ & $\begin{array}{r}+2800 \\
2742\end{array}$ \\
\hline $\begin{array}{l}\text { No. } 7 \text { Lower Bed } \\
\text { Evan Jones Mine }\end{array}$ & UA-143 & $\begin{array}{l}\text { Float } 1.60 \\
\text { Sink } 1.60\end{array}$ & $\begin{array}{l}2366 \\
2800+\end{array}$ & $\begin{array}{l}2552 \\
2800+\end{array}$ & $\begin{array}{l}2582 \\
2800+\end{array}$ \\
\hline $\begin{array}{l}\text { No. } 7 \text { Upper Bed } \\
\text { Evan Jones Mine }\end{array}$ & UA-144 & $\begin{array}{l}\text { Float } 1.60 \\
\text { Sink } 1.60\end{array}$ & $\begin{array}{l}2752 \\
2324\end{array}$ & $\begin{array}{l}2800+ \\
2717\end{array}$ & $\begin{array}{l}2800+ \\
2767\end{array}$ \\
\hline $\begin{array}{l}\text { No. } 6 \text { Lower Bed } \\
\text { Evan Jones Mine }\end{array}$ & UA-145 & $\begin{array}{l}\text { Float } 1.60 \\
\text { Sink } 1.60\end{array}$ & $\begin{array}{l}2385 \\
2800+\end{array}$ & $\begin{array}{l}2666 \\
2800+\end{array}$ & $\begin{array}{l}2725 \\
2800+\end{array}$ \\
\hline
\end{tabular}




\section{Table VII (Continued)}

Fusibility of Ash of 1.60 Specific Gravity Float-Sink

Products of Coals Crushed to Minus 65 Mesh Size

\begin{tabular}{|c|c|c|c|c|c|}
\hline $\begin{array}{l}\text { COAL } \\
\text { FIELD } \\
\& \text { SEAM }\end{array}$ & $\begin{array}{l}\text { SAMPLE } \\
\text { NUMBER }\end{array}$ & $\begin{array}{l}\text { SPECIFIC } \\
\text { GRAVITY }\end{array}$ & $\begin{array}{c}\text { INITIAL } \\
\text { DEFORMATION } \\
{ }^{\circ} \mathrm{F}\end{array}$ & $\begin{array}{l}\text { SOFTENING } \\
\text { OF }\end{array}$ & $\begin{array}{l}\text { FLUID } \\
\text { OF }\end{array}$ \\
\hline No. 6 Upper Bed & UA-146 & Float 1.60 & $2800+$ & $2800+$ & $2800+$ \\
\hline Evan Jones Mine & & Sink 1.60 & $2800+$ & $2800+$ & $2800+$ \\
\hline No. 5 Bed & UA-147 & Float 1.60 & 2091 & +2800 & +2800 \\
\hline Evan Jones Mine & & Sink 1.60 & 2554 & 2708 & 2759 \\
\hline Matanuska & UA-107 & Float 1.60 & 2599 & $2800+$ & $2800+$ \\
\hline Lower Seam & & Sink 1.60 & 2522 & 2670 & 2729 \\
\hline Broad Pass & UA-111 & Float 1.60 & 2465 & 2473 & 2490 \\
\hline Coal Creek Seam & & Sink 1.60 & 2427 & 2484 & 2493 \\
\hline Broad Pass & UA-123 & Float 1.60 & 2430 & 2548 & 2561 \\
\hline Dunkle Bed & & Sink 1.60 & 2501 & 2538 & 2543 \\
\hline Southwest Ala & aska Coal & Fields & & & \\
\hline Little Tonzona & UA-1.12 & Flcat 1.60 & 2574 & 2702 & 2771 \\
\hline Coal Bed & & Sink 1.60 & 2292 & 2317 & II 2414 \\
\hline Chignik & UA-136 & Float 1.60 & 2564 & $2800+$ & $2800+$ \\
\hline Chignik Bay Min & & Sink 1.60 & 2704 & $2800+$ & $2800+$ \\
\hline $\begin{array}{l}\text { Herendeen Bay } \\
\text { Coal Point }\end{array}$ & UA-137 & $\begin{array}{l}\text { Float } 1.60 \\
\text { Sink } 1.60\end{array}$ & $\begin{array}{l}2267 \\
2246\end{array}$ & $\begin{array}{l}2290 \\
2291\end{array}$ & $\begin{array}{l}2392 \\
2439\end{array}$ \\
\hline
\end{tabular}


TABLE VIII

WASHABILITY ANALYSIS SHOWING THE EFFECTS OF CRUSHING ON THE LIBERATION OF ASH FORMING IMPURITIES AND PYRITIC SULFUR FOR SAMPLE UA 100

STATE: ALASKA

COUNTY: KOVUKUK-MIDDLE YUKON

TOWN: HEALY

\begin{tabular}{|c|c|c|c|c|c|c|}
\hline \multirow[b]{2}{*}{ PRODUCT } & \multicolumn{6}{|c|}{ DIRECT } \\
\hline & \multicolumn{2}{|c|}{$\begin{array}{l}\text { RECOVERY } \\
\text { WEIGHT BTU }\end{array}$} & BTU/LB & \multicolumn{2}{|c|}{ ASH } & $\begin{array}{c}\text { SULF } \\
\text { PYR }\end{array}$ \\
\hline \multicolumn{7}{|l|}{$11 / 2 \times 0$} \\
\hline OAT 1.30 & 10.5 & 13.5 & 10829 . & 6.9 & 0.04 & \\
\hline $1.30-1.40$ & 57.6 & 65.2 & 9970. & 15.1 & 0.09 & \\
\hline 1.40- & 27.0 & 21.3 & 6897. & 32.4 & 0.01 & \\
\hline SLNK 1.60 & 4.5 & 0.0 & 34. & 55.9 & 0.03 & \\
\hline \multicolumn{7}{|l|}{$3 / 8 \times 0$} \\
\hline FLOAT 1.30 & 24.11 & 28.4 & 11144. & 7.1 & $0.0:$ & \\
\hline $1.30-1.40$ & 48.3 & 50.9 & $\begin{array}{l}9985 . \\
7782\end{array}$ & 16.8 & 0.0 & \\
\hline $\begin{array}{l}1.40-1.1 .00 \\
\text { SiNK } 1.60\end{array}$ & $\begin{array}{r}22.1 \\
5.4\end{array}$ & $\begin{array}{r}18.2 \\
2.6\end{array}$ & 4486. & 55.0 & 0.02 & \\
\hline \multicolumn{7}{|l|}{$14 \mathrm{M} \mathrm{XO}$} \\
\hline & & 5.3 & & 3.1 & 0.0 : & \\
\hline $1.30-1.40$ & 47.5 & 53.8 & $103(19$. & 12.1 & 0.0 & \\
\hline $1.40-$ & 41.5 & 37.2 & 31 & 28.7 & $a$ & \\
\hline SINKK 1.60 & 6.8 & 3.6 & 4846. & 58.5 & $0.0 \bar{s}$ & \\
\hline
\end{tabular}

1.60

$65 \mathrm{M} \mathrm{X} 0$

FLAT 1.30
$1.30-1.40$
$1.40-1.60$
SINK 1.60

$$
\begin{array}{rrrrrr}
0.3 & 0.5 & 11210 . & 5.4 & 0.01 & 0.24 \\
24.3 & 30.6 & 10945.5 & 7.1 & 0.01 & 0.36 \\
45.2 & 48.2 & 9284 . & 18.3 & 0.01 & 0.30 \\
30.1 & 20.7 & 5982 . & 48.6 & 0.01 & 0.136
\end{array}
$$

201) M X 0

$\begin{array}{rrrrrrr}\text { FLOAT } 1.30 & 0.4 & 0.6 & 11221 . & 5.8 & 0.01 & 0.27\end{array}$

$\begin{array}{rrrrrrr}1.30-1.40 & 14.0 & 18.4 & 11207 . & 6.0 & 0.01 & C .47 \\ 1.40-1.60 & 53.4 & 60.1 & 9603 . & 14.7 & 0.01 & C .31 \\ \text { SNMK } 1.60 & 32.2 & 21.0 & 5573 . & 48.5 & 0.01 . & C .21\end{array}$

$325 \mathrm{M} \mathrm{X} 0$

$\begin{array}{rrrrrrr}\text { FIOAT 1.30 } & 0.3 & 0.4 & 11215 . & 5.6 & 0.01 & 025 \\ 1.30-1.40 & 13.1 & 17.1 & 11157 . & 6.4 & 0.01 & 0.37 \\ 1.40-1.60 & 51.8 & 58.5 & 9642 & 14.1 & 0.01 & 13.25 \\ \text { SINK } 1.60 & 34.7 & 34.0 & 5899 & 47.7 & 0.01 & 10.24\end{array}$

SAMPLE MESH SIZE

$\begin{array}{rrrrrrr}\text { PLUS 65 } & 2.4 & 2.5 & 9200 & 19.2 & 0.01 & 0.31 \\ 65-200 & 38.2 & 40.7 & 9260 & 20.1 & 0.01 & 0.29 \\ 200-325 & 22.6 & 23.1 & 8872 & 23.7 & 0.01 & 0.33 \\ \text { MINUIS 325 } & 36.9 & 33.6 & \mathbf{7 9 0 5} & 30.6 & 0.01 & 0.25\end{array}$

MINE:

USIBELLI

COALBED: NO. SIX

COMPANY: USIBELLI COAL CO.

\begin{tabular}{|c|c|c|c|c|c|c|}
\hline \multicolumn{2}{|c|}{$=$ RECOVERY } & \multirow[b]{2}{*}{$\mathrm{BTU} / \mathrm{LB}$} & \multirow[t]{2}{*}{ ASH } & \multicolumn{2}{|c|}{ SULFUR } & \multirow{2}{*}{$\begin{array}{l}\text { LB SO2/ } \\
\text { MM BTU }\end{array}$} \\
\hline WEIGHT & BTU & & & PYR & TOTAL & \\
\hline $\begin{array}{r}10.9 \\
68.1 \\
95.1 \\
100.0\end{array}$ & $\begin{array}{r}13.5 \\
78.7 \\
100.0 \\
100.0\end{array}$ & $\begin{array}{r}10829 . \\
10108 . \\
9197 . \\
8751 .\end{array}$ & $\begin{array}{r}6.9 \\
13.8 \\
19.1 \\
20.9\end{array}$ & $\begin{array}{l}0.01 \\
0.01 \\
0.01 \\
0.01\end{array}$ & $\begin{array}{l}0.19 \\
0.23 \\
0.25 \\
0.24\end{array}$ & $\begin{array}{l}0.4 \\
0.5 \\
0.5 \\
0.6\end{array}$ \\
\hline $\begin{array}{r}24.1 \\
72.4 \\
94.6 \\
100.0\end{array}$ & $\begin{array}{r}28.4 \\
79.2 \\
97.4 \\
100.0\end{array}$ & $\begin{array}{r}11144 . \\
10371 . \\
9765 . \\
9478 .\end{array}$ & $\begin{array}{r}7.1 \\
33.5 \\
i 8.0 \\
20.0\end{array}$ & $\begin{array}{l}0.31 \\
0.31 \\
0.31 \\
0.31\end{array}$ & $\begin{array}{l}0.26 \\
0.28 \\
0.28 \\
0.27\end{array}$ & $\begin{array}{l}0.5 \\
0.5 \\
0.6 \\
0.6\end{array}$ \\
\hline $\begin{array}{r}4.2 \\
51.7 \\
93.2 \\
100.0\end{array}$ & $\begin{array}{r}5.3 \\
59.1 \\
96.4 \\
100.0\end{array}$ & $\begin{array}{c}11603 . \\
10413 . \\
9420 . \\
9108 .\end{array}$ & $\begin{array}{r}3.1 \\
11.4 \\
19.1 \\
21.8\end{array}$ & $\begin{array}{l}0.011 \\
0.01 \\
0.01 \\
0.01\end{array}$ & $\begin{array}{l}0.34 \\
0.18 \\
0.20 \\
0.19\end{array}$ & $\begin{array}{l}0.6 \\
0.4 \\
0.4 \\
0.4\end{array}$ \\
\hline $\begin{array}{r}0.3 \\
24.7 \\
69.9 \\
100.0\end{array}$ & $\begin{array}{r}0.5 \\
31.1 \\
79.3 \\
100.0\end{array}$ & $\begin{array}{c}11210 . \\
10949 . \\
9872 . \\
8700 .\end{array}$ & $\begin{array}{r}5.4 \\
7.0 \\
14.3 \\
24.6\end{array}$ & $\begin{array}{l}0.01 \\
0.01 \\
0.01 \\
0.01\end{array}$ & $\begin{array}{l}0.24 \\
0.36 \\
0.32 \\
0.33\end{array}$ & $\begin{array}{l}0.4 \\
0.7 \\
0.6 \\
0.8\end{array}$ \\
\hline $\begin{array}{r}0.4 \\
14.4 \\
67.8 \\
100.0\end{array}$ & $\begin{array}{r}0.6 \\
18.9 \\
79.0 \\
100.0\end{array}$ & $\begin{array}{c}11221 . \\
11207 . \\
9948 . \\
8543 .\end{array}$ & $\begin{array}{r}5.8 \\
5.0 \\
12.9 \\
24.3\end{array}$ & $\begin{array}{l}3.01 \\
3.01 \\
) .61 \\
) .01\end{array}$ & $\begin{array}{l}0.24 \\
0.46 \\
0.33 \\
0.29\end{array}$ & $\begin{array}{l}0.4 \\
0.8 \\
0.7 \\
0.7\end{array}$ \\
\hline $\begin{array}{r}0.3 \\
13.4 \\
65.3 \\
100.0\end{array}$ & $\begin{array}{r}0.4 \\
17.5 \\
76.0 \\
100.0\end{array}$ & $\begin{array}{r}11215 . \\
11158 . \\
9954 . \\
8546 .\end{array}$ & $\begin{array}{r}5.6 \\
6.4 \\
! 2.5 \\
\geq 4.8\end{array}$ & $\begin{array}{l}0.0 \mathrm{~L} \\
0.0 \mathrm{~L} \\
C .0 \mathrm{~L} \\
0.0 \mathrm{I}\end{array}$ & $\begin{array}{l}0.25 \\
0.37 \\
0.27 \\
0.26\end{array}$ & $\begin{array}{l}0.4 \\
0.7 \\
0.6 \\
0.6\end{array}$ \\
\hline
\end{tabular}

CUMULATTE

$\begin{array}{rrrrrrr}2.4 & 2.5 & 9200 . & -9.2 & C 0: & 0.31 & 0.7\end{array}$

$\begin{array}{rrrrrrr}40.5 & 43.3 & 9256 . & 20.0 & \mathrm{C} 0: & 0.29 & 0.6 \\ 63.1 & 66.4 & 9119 . & 31.4 & \mathrm{CO} 0: & 0.31 & 0.7\end{array}$


TABLE IX

WASHABILITY ANALYSIS SHOWING THE EFFECTS OF CRUSHING ON THE LIBERATION OF ASH FORMING IMPLiRITIES AND PYRITIC SULFUR FOR SAMPLE UA 101

\section{STATE: ALASKA \\ COUNTY: KOYUKUK-MIDDLE YUKON \\ TOWN: HEALY}

DIRECT

PRODUCT RECOVERY WEIGHT BTU BTU/LB

ASH

SULFUR
PYR TOTA

$11 / 2 \times 0$

FLOAT 1.30

$1.30-1.40$

$1.40-1.60$

SINK 1.60

$\begin{array}{rr}40.5 & 42.3 \\ 55.0 & 55.2 \\ 3.3 & 2.4\end{array}$

11430.

10789.
8015.

8015
5405

6.5
10.5
30.1

0.01

0.01

0.01

0.02

0.13

$3 / 8 \times 0$

$\vec{\omega}$

FLOAT 1.30
$1.30-1.40$
$1.40-1.60$

SINK 1.60

$\begin{array}{rr}40.6 & 41.5 \\ 56.2 & 55.5 \\ 2.9 & 2.8\end{array}$

$14 \mathrm{M} \times 0$

\section{FLOAT 1.30}

$1.30-1.40$

$1.40-1.60$
SINK 1.60

$\begin{array}{rr}28.6 & 30.1 \\ 67.3 & 66.8 \\ 3.2 & 2.6 \\ 0.9 & 0.5\end{array}$

$65 \mathrm{MX} 0$

FLOAT 1.30

1.30- 1.40

$1.40-1.60$

$\begin{array}{rr}0.1 & 0.1 \\ 46.0 & 49.2 \\ 46.0 & 45.2 \\ 7.9 & 5.5\end{array}$

$\begin{array}{rrr}11102 . & 6.8 \\ 10712 . & 10.3 \\ 10361 . & 24.4 & 0.0 \\ 1 & \end{array}$

$\begin{array}{rr}10361 . & 24.4 \\ 7617 . & 29.8\end{array}$

$\begin{array}{ll}0.01 & 0.14 \\ 0.01 & 0.21 \\ 0.01 & 0.19\end{array}$

0.05

$\begin{array}{rrrr}11205 . & 6.0 & 0.01 & 0.12 \\ 10581 . & 9.7 & 0.01 & 0.16 \\ 8728 . & 21.7 & 0.01 & 0.15 \\ 5633 . & 43.1 & 0.03 & 0.08\end{array}$

5633.

\section{3.}

11220.

10313.

7375.

$\begin{array}{rrr}2.2 & 0.01 & 0.19 \\ 5.6 & 0.01 & 0.19 \\ 9.9 & 0.01 & 0.21 \\ 29.1 & 0.02 & 0.20\end{array}$

SAMPLE MESH SIZE

$\begin{array}{rr}\text { PLUS 65 } & 14.4 \\ 65-100 & 15.8 \\ 100-200 & 27.8 \\ 200-325 & 13.3\end{array}$

MINUS $325 \quad 28.7$

$\begin{array}{rrrrr}14.3 & 10687 . & 8.2 & 0.01 & 0.19 \\ 15.8 & 10715 . & 8.1 & 0.01 & 0.19 \\ 28.8 & 11099 . & 8.3 & 0.01 & 0.20 \\ 13.1 & 10589 . & 8.9 & 0.01 & 0.20 \\ 28.0 & 10481 . & 10.6 & 0.01 & 0.20\end{array}$

MINE:

COALBED: NO. SIX

COMPANY: USIBELLI COAL CO.

\section{CUMULATIVE}

\begin{tabular}{ccccccc}
\multicolumn{2}{c}{ RECOVERY } & & ASH & \multicolumn{2}{c}{ SULFUR } & LB SO2/ \\
WEIGHT & BTU & BTU/LB & & PYR & TOTAL & MM BTU
\end{tabular}

$\begin{array}{rrrrrrr}40.5 & 42.3 & 11430 . & 6.5 & 0.01 & 0.13 & 0.2 \\ 96.5 & 97.5 & 11058 . & 8.8 & 0.01 & 0.15 & 0.3 \\ 99.8 & 99.9 & 10957 . & 9.5 & 0.01 & 0.15 & 0.3 \\ 100.0 & 100.0 & 10944 . & 9.6 & 0.01 & 0.15 & 0.3\end{array}$

$\begin{array}{rrlllll}40.6 & 41.5 & 11102 . & 6.8 & 0.01 & 0.14 & 0.3 \\ 96.8 & 97.0 & 10876 . & 8.8 & 0.01 & 0.18 & 0.3 \\ 99.7 & 99.8 & 10861 . & 9.3 & 0.01 & 0.18 & 0.3 \\ 100.0 & 100.0 & 10851 . & 9.3 & 0.01 & 0.18 & 0.3\end{array}$

$\begin{array}{rrrrrrr}28.6 & 30.1 & 11205 . & 6.0 & 0.01 & 0.12 & 0.2 \\ .95 .9 & 96.9 & 10767 . & 8.6 & 0.01 & 0.15 & 0.3 \\ 99.1 & 99.5 & 10702 . & 9.0 & 0.01 & 0.15 & 0.3 \\ 100.0 & 100.0 & 10656 . & 9.3 & 0.01 & 0.15 & 0.3\end{array}$

$\begin{array}{rrrrrrr}0.1 & 0.1 & 11863 . & 2.2 & 0.01 & 0.19 & 0.3 \\ 46.1 & 49.3 & 11221 . & 5.6 & 0.01 & 0.19 & 0.3 \\ 92.1 & 94.5 & 10768 . & 7.7 & 0.01 & 0.20 & 0.4 \\ 100.0 & 100.0 & 10501 . & 9.4 & 0.01 & 0.20 & 0.4\end{array}$

$\begin{array}{rrrrrrr}14.4 & 14.3 & 10687 . & 8.2 & 0.01 & 0.19 & 0.4 \\ 30.2 & 30.1 & 10702 . & 8.2 & 0.01 & 0.19 & 0.4 \\ 58.0 & 58.9 & 10892 . & 8.2 & 0.01 & 0.19 & 0.4 \\ 71.3 & 72.0 & 10836 . & 8.4 & 0.01 & 0.20 & 0.4 \\ 100.0 & 100.0 & 10734 . & 9.0 & 0.01 & 0.20 & 0.4\end{array}$


TABLE $X$

WASHABILITY ANALYSIS SHOWING THE EFFECTS OF CR'JSHING ON THE LIBERATION OF ASH FORMING IMPURITIES AND PYRITIC SULFER FOR SAMPLE UA 102

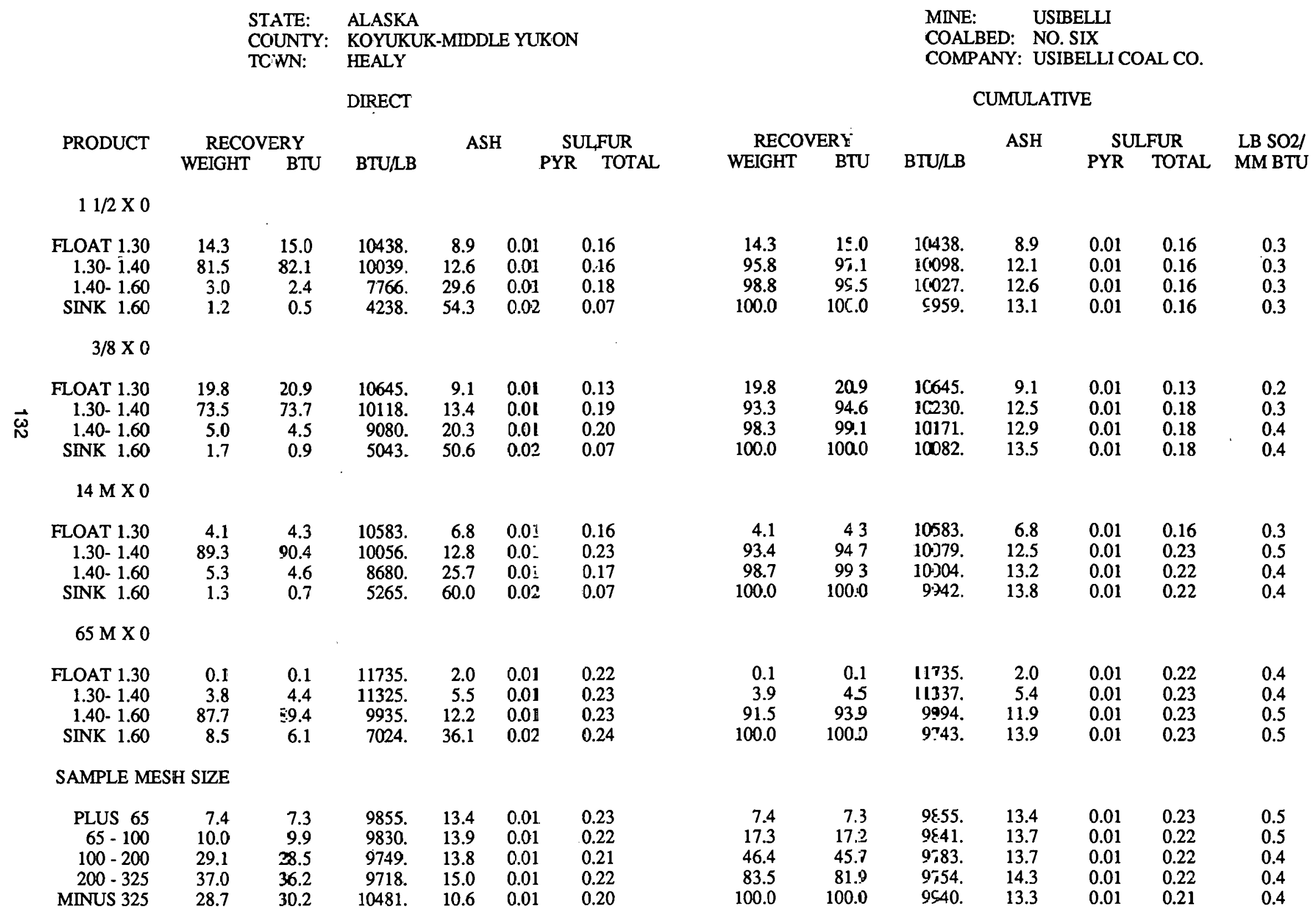


TABLE XI

WASHABILITY ANALYSIS SHOWING THE EFFECTS OF CRUSHING ON THE LIBERATION OF ASH FORMING IMPURITIES AND PYRITIC SULFUR FOR SAMPLE UA 103

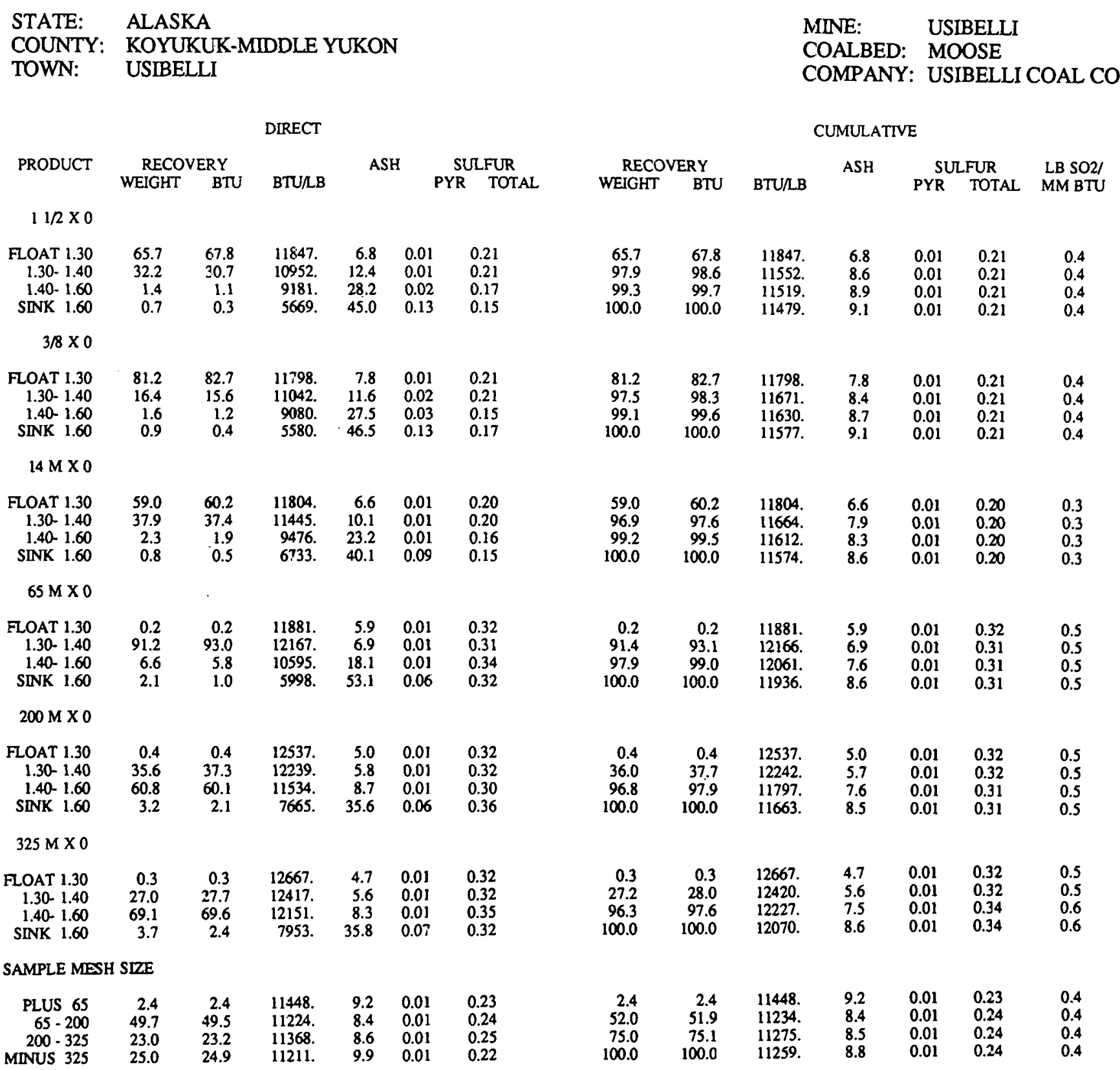


TABLE XII

WASHABILITY ANALYSIS SHOWING THE EFFECTS OF CRUSHING ON THE LIBERATION OF ASH FORMING IMFURITIES AND PYRITIC SULFUR FOR SAMPLE UA 104

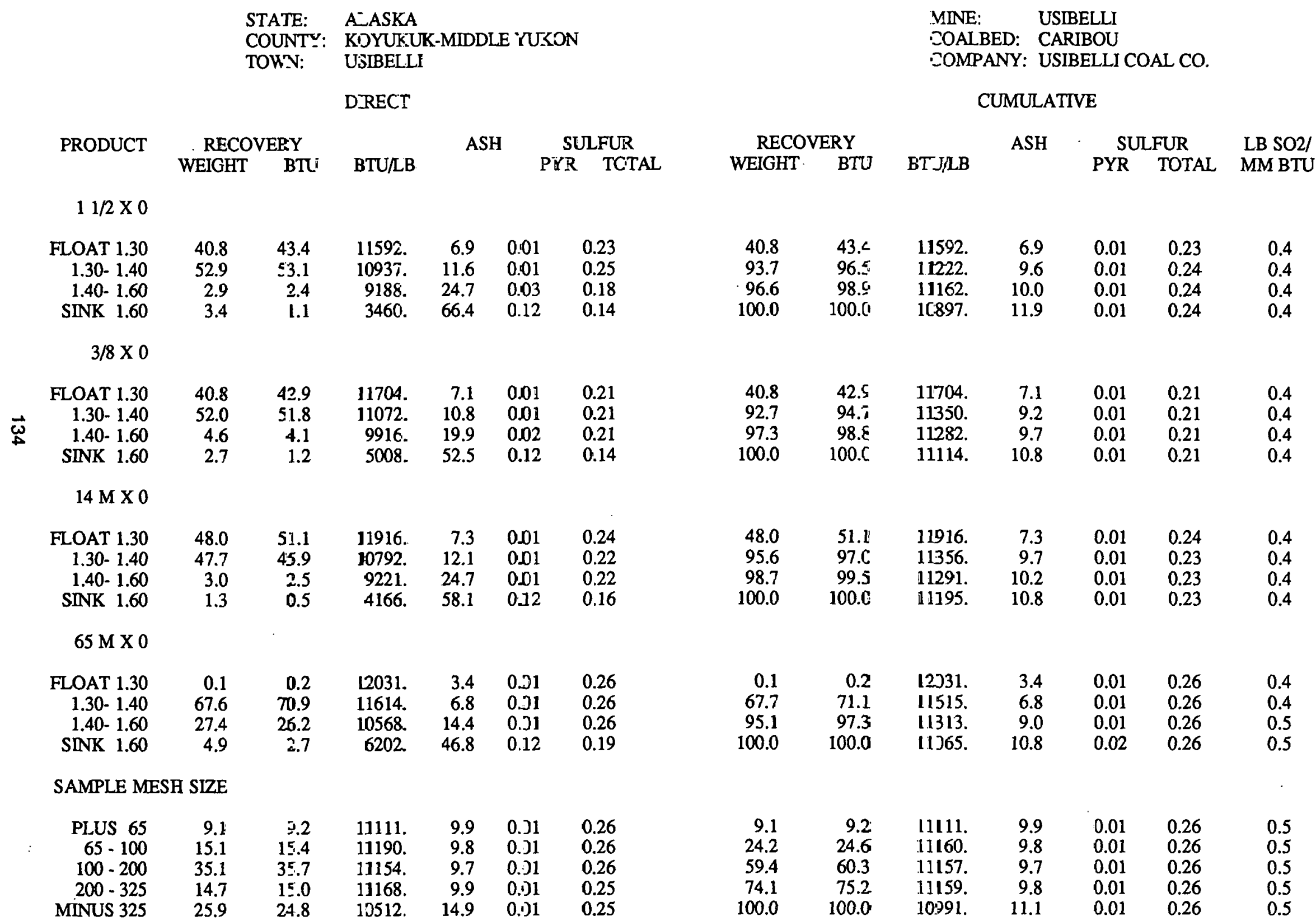


TABLE XIII

WASHABILITY ANALYSIS SHOWING THE EFFECTS OF CRUSHING ON THE LIBERATION OF ASH FORMING IMPURITIES AND PYRITIC SULFUR FOR SAMPLE UA 105

\section{STATE: ALASKA:}

COUNTY: KOYUKUK-MIDDLE YUKON

TCWN: USIBELLI

DIRECT

PRODUCT

RECOVERY

WEIGHT BTU BTU/LB

ASH

SULFUR

FLOAT 1.30

1.30- 1.40

$1.40-1.60$

SINK 1.60

$\begin{array}{rr}68.7 & 72.2 \\ 24.7 & 23.3 \\ 5.1 & 3.8 \\ 1.5 & 0.7\end{array}$

$3 / 8 \times 0$

$\begin{array}{rr} & \text { FLOAT } 1.30 \\ & 1.30-1.40 \\ \mathbf{G} & 1.40-1.60\end{array}$

$\begin{array}{rrrrrr}63.4 & 65.8 & 11475 . & 5.9 & 0.01 & 0.16 \\ 27.5 & 26.9 & 10849 . & 10.4 & 0.02 & 0.20 \\ 7.3 & 6.2 & 9424 . & 23.9 & 0.02 & 0.27 \\ 1.8 & 1.0 & 6213 . & 41.2 & 0.05 & 0.26\end{array}$

$14 \mathrm{M} \mathrm{X} 0$

FLOAT 1.30
$1.30-1.40$
$1.40-1.60$
SINK 1.60

$\begin{array}{rr}12.3 & 13.2 \\ 75.2 & 76.3 \\ 9.7 & 8.9 \\ 2.8 & 1.5\end{array}$

$65 \mathrm{M} \mathrm{X} 0$

FLOAT 1.30

$1.30-1.40$

$1.40-1.60$

SINK 1.60

0.2
64.6
31.6
3.6

$\begin{array}{rrrr}11566 . & 6.5 & 0.01 & 0.18 \\ 10356 . & 12.5 & 0.01 & 0.21 \\ 8254 . & 30.8 & 0.02 & 0.26 \\ 5262 . & 51.8 & 0.07 & 0.26\end{array}$

S262. 51.80 .070 .26

$\begin{array}{rrrr}11638 . & 3.8 & 0.01 & 0.13 \\ 10997 . & 7.1 & 0.02 & 0.18 \\ 9969 . & 23.6 & 0.04 & 0.23 \\ 6015 . & 56.0 & 0.13 & 0.37\end{array}$

SAMPLE MESH SIZE

$\begin{array}{rrrrrrr}\text { PLUS 65 } & 9.4 & 9.4 & 10822 . & 8.6 & 0.01 & 0.23 \\ 65-100 & 13.5 & 13.5 & 10823 . & 8.7 & 0.01 & 0.24 \\ 100-200 & 32.9 & 33.1 & 10893 . & 8.5 & 0.01 & 0.22 \\ 200-325 & 16.6 & 16.9 & 11023 . & 8.8 & 0.01 & 0.24 \\ \text { MINUS 325 } & 27.7 & 27.1 & 10600 . & 11.3 & 0.01 & 0.23\end{array}$

MINE:

COALBED: NO. TWO

COMPANY: USIBELLI COAL $C O$.

\section{CUMULATIVE}

\begin{tabular}{ccccccc}
\multicolumn{2}{c}{ RECOVERY } & & ASH & \multicolumn{2}{c}{ SULFUR } & LB SO2/ \\
WEIGHT & BTU & BTU/LB & & PYR & TOTAL & MM BTU
\end{tabular}

93.4

98.5

100.0

$\begin{array}{ll}72.2 & 11566 . \\ 95.5 & 11246 . \\ 99.3 & 11091 .\end{array}$

6.5

8.1

$-00.0$

11005.

9.9

0.01
0.01

$\begin{array}{ll}0.01 & 0.19\end{array}$

$0.01 \quad 0.19$

$0.01 \quad 0.19$

0.3

0.3

0.3

63.4

90.9

98.2

100.0

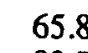

65.8
92.7

92.7

100.0

11475.

11286.

11147.

11057.

5.9
7.2
8.5
9.1

0.01

$\begin{array}{ll}0.01 & 0.16\end{array}$

$0.01 \quad 0.18$

$0.01 \quad 0.18$

0.3

0.3

0.3

0.3

12.3

87.5

13.2
89.5
98.5

11638.

11087.

10975.

3.8
6.6
8.3

0.01

0.13

100.0

100.0

10838.

9.6

0.02

0.17

0.18

0.18

0.2
0.3

0.3
0.3

$\begin{array}{rrrr}11787 . & 2.5 & 0.01 & 0.22 \\ 10927 . & 5.1 & 0.01 & 0.23 \\ 10216 . & 12.7 & 0.01 & 0.26 \\ 7442 . & 42.2 & 0.05 & 0.53 \\ & & & \\ & & & \\ 10822 . & 8.6 & 0.01 & 0.23 \\ 10823 . & 8.7 & 0.01 & 0.24 \\ 10893 . & 8.5 & 0.01 & 0.22 \\ 11023 . & 8.8 & 0.01 & 0.24 \\ 10600 . & 11.3 & 0.01 & 0.23\end{array}$

11787.

10929.

10685.

10522.

2.5
5.1
7.7
9.4

0.01

0.01
0.01

0.22

0.23

$0.01 \quad 0.24$

0.25

0.4
0.4
0.4
0.5

0.2
64.8
96.4
100.0


TABLE XIV

WASHABILITY ANALYSIS SHOWING THE EFFECTS OF CRUSHING ON THE LIBERATION OF ASH FORMING IMPURITIES AND PYRITIC SULFUR FOR SAMPLE UA 106

STATE: ALASKA

COUNTY: SOUTH EAST FAIRBANKS

TOWN: DELTA JUNCTION

DIRF.CT

\begin{tabular}{|c|c|c|c|c|c|c|}
\hline \multirow[t]{2}{*}{ PRODUCT } & \multicolumn{2}{|c|}{ RECOVERY } & & \multicolumn{2}{|c|}{ ASH } & SULFU \\
\hline & WEIGHT & ITU & BTU/LB & & & \\
\hline \multicolumn{7}{|l|}{$11 / 2 \times 0$} \\
\hline FLOAT 1.30 & 25.4 & 23.2 & 11546. & 8.0 & 0.08 & 0.97 \\
\hline $1.30-1.40$ & 61.8 & 62.3 & 10882. & 10.1 & 0.38 & 1.36 \\
\hline $1.40-1.60$ & 10.8 & 3.4 & 9388. & 20.0 & 0.90 & 1.20 \\
\hline SINK 1.60 & 2.0 & L.1 & 5798. & 47.4 & 1.11 & 1.24 \\
\hline \multicolumn{7}{|l|}{$3 / 8 \times 0$} \\
\hline FLOAT 1.30 & 25.7 & 27.3 & 11554. & 7.8 & 0.08 & 1.01 \\
\hline $1.30-1.40$ & 56.9 & 57.7 & 11037. & 9.1 & 0.29 & 1.31 \\
\hline $1.40-1.60$ & 14.9 & 13.5 & 9902. & 16.6 & 0.86 & 1.02 \\
\hline SNNK 1.60 & 2.5 & 1.5 & 6675. & 41.7 & 1.12 & 2.32 \\
\hline \multicolumn{7}{|l|}{$14 \mathrm{M} \mathrm{X} 0$} \\
\hline FLOAT 1.30 & 2.6 & 2.8 & 12177. & 8.6 & 0.08 & 0.88 \\
\hline $1.30-1.40$ & 82.3 & 84.1 & 11244. & 9.4 & 0.29 & 0.98 \\
\hline $1.40-1.60$ & 12.6 & 11.6 & 10169. & 15.7 & 0.92 & 1.98 \\
\hline K 1.60 & 2.6 & 1.4 & 6198. & 44.6 & 1.16 & 2.6 \\
\hline
\end{tabular}

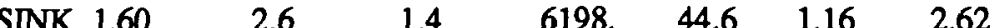

$65 \mathrm{M} \mathrm{X} 0$

FLOAT 1.30

$1.30-1.40$

$1.40-1.60$

0.0
39.8

39.8

SINK 1.60

1.0
42.6
52.1
5.3

$\begin{array}{rrrr}0 . & 0.0 & 0.00 & 0.00 \\ 11413 . & 6.8 & 0.09 & 0.90 \\ 10396 . & 10.6 & 0.43 & 1.34\end{array}$

8174.

$29.1 \quad 2.00$

SAMPLE MESH SIZE

$\begin{array}{rrrrrrr}\text { PLUS 65 } & 8.0 & \mathbf{8 . 1} & 10707 . & 10.4 & 0.36 & 1.28 \\ 65-100 & 14.4 & 14.6 & 10696 . & 10.3 & 0.39 & 1.21 \\ 100-200 & 32.3 & 32.7 & 10686 . & 10.3 & 0.39 & 1.26 \\ 200-325 & 16.7 & 17.0 & 10680 . & 10.8 & 0.43 & 1.26 \\ \text { MINUS 325 } & 28.6 & 27.5 & 10193 . & 15.3 & 0.72 & 1.48\end{array}$

MINE:

COALBED: MINE

COMPANY: DELTA COAL CO

\section{CUMULATIVE}

ASH

SULFUR

LB SO2 RECOVERY
WEIGHT BTU

ETU/LB PYR TOTA

MM BTU

$+$

$\begin{array}{rrrrrrr}25.4 & 27.2 & 11546 . & 8.0 & 0.08 & 0.97 & 1.7 \\ 87.2 & 89.5 & 11076 . & 9.5 & 0.29 & 1.25 & 2.3 \\ 98.0 & 98.9 & 10890 . & 10.6 & 0.36 & 1.24 & 2.3 \\ 100.0 & 100.0 & 10787 . & 11.4 & 0.37 & 1.24 & 2.3\end{array}$

$\begin{array}{rrrrrrr}25.7 & 27.3 & 11554 . & 7.8 & 0.08 & 1.01 & 1.7 \\ 82.6 & 84.9 & 11198 . & 8.7 & 0.22 & 1.22 & 2.2 \\ 97.5 & 98.5 & 11000 . & 9.9 & 0.32 & 1.19 & 2.2 \\ 100.0 & 100.0 & -0892 . & 10.7 & 0.34 & 1.21 & 2.2\end{array}$

$\begin{array}{lllllll}900.0 & 100.0 & -0892 & 10.7 & 0.34 & 1.21 & 2.2\end{array}$

$\begin{array}{lrlllll}84.9 & 86.9 & 11272 . & 9.4 & 0.28 & 0.98 & 1.7\end{array}$

$\begin{array}{lllllll}97.4 & 98.6 & 11130 . & 10.2 & 0.37 & 1.11 & 2.0\end{array}$

$\begin{array}{lllllll}100.0 & 100.0 & 11003 . & 11.1 & 0.39 & 1.15 & 2.1\end{array}$ 
TABLE XV

WASHABILITY ANALYSIS SHOWING THE EFFECTS OF CRUSHING ON THE LIBERATION OF ASH FORMING IMPURITIES AND PYRITIC SULFUR FOR SAMPLE UA 107

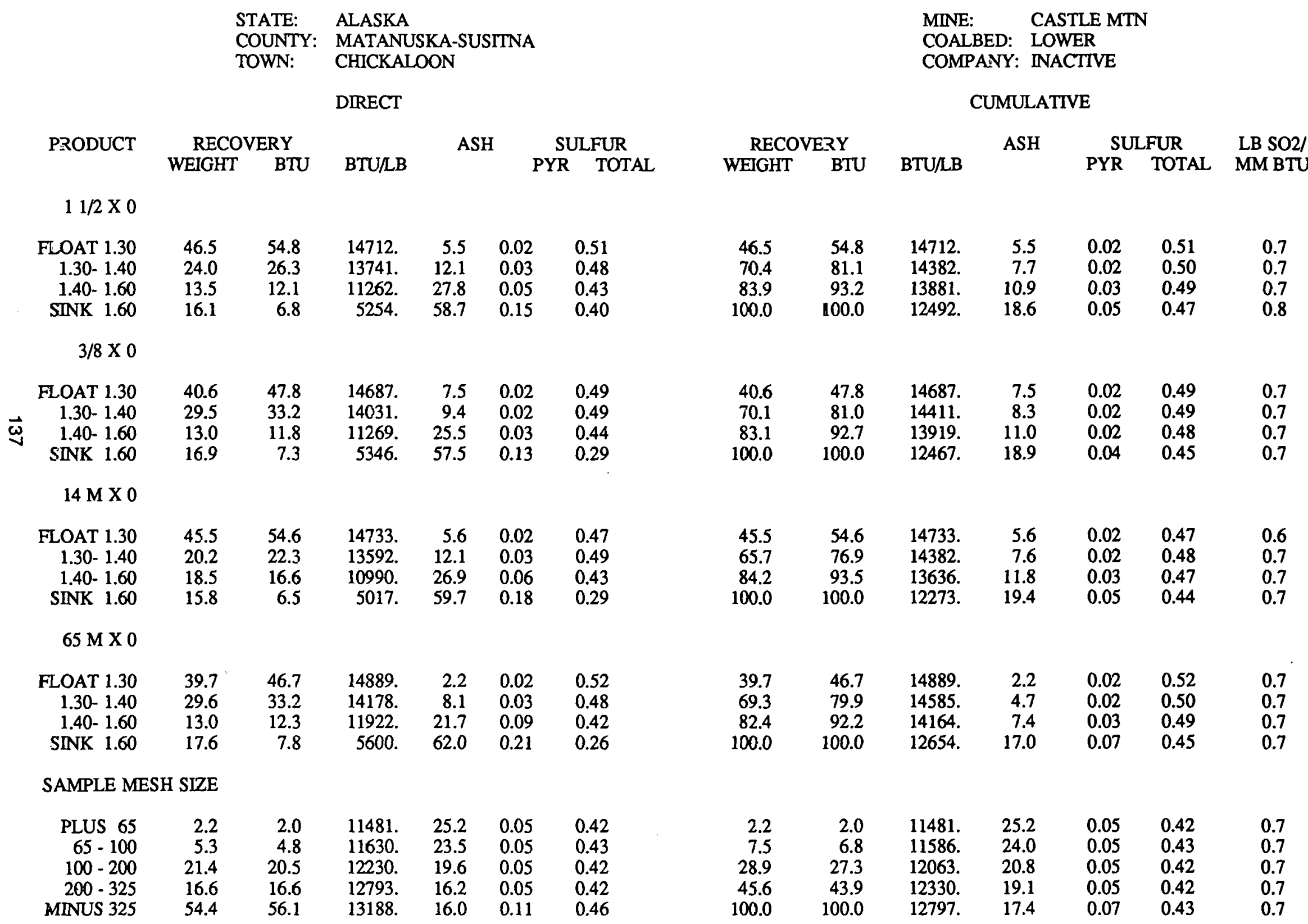


TABLE XVI

WASHAEILITY ANALYSIS SHOWING THE EFFECTS OF CRUSHING ON THE LIBERATION OF ASH FORMING IMPURITIES AND PYRITIC SULFUR FOR SAMPLE UA 108

STATE: ALASZA

COUNTY: MATANUSKA-SUSITNA

TOWN: SUTTON

IIRECT

PRODUCT

\section{RECOVERY}

WEIGHT BTU BTU/LB

ASH

SULFUR

$11 / 2 \times 0$

FLOAT 1.30

1.30- 1.40

1.40- 1.60

45.5 .

21.4

17.9

15.2

53.5
$\dot{3} .0$
15.7
7.9

$1384 i$.

$1267 \epsilon$.

$-0304$

6102

2.8
9.6
25.3
50.8

0.01

\subsection{1}

0.01

0.42

0.41

0.35

$3 / 8 \times 0$

FLOAT 1.30

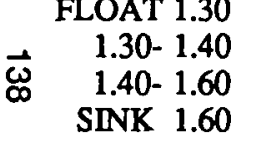

$46.3 \quad 53.6$

25.5

12.9

15.3

27.8
10.7
7.8

13671 .

12877 .

9798.

6028

3.1
7.8
28.2
50.7

0.02
0.01

0.01

0.08

0.49

0.32

$14 \mathrm{M} \mathrm{X} 0$

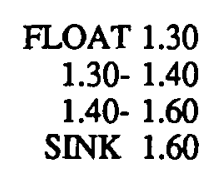

$\begin{array}{rr}49.2 & 55.6 \\ 26.1 & 28.2 \\ 10.0 & 8.6\end{array}$

13661.

12825

12270

5359

14.8

$\begin{array}{ll}0.01 & 0.42 \\ 0.01 & 0.42 \\ 0.02 & 0.30 \\ 0.07 & 0.16\end{array}$

$65 \mathrm{M} \mathrm{X} 0$

FLOAT 1.30

1.30- 1.40

$1.40-1.60$

$\begin{array}{ll}24.9 & 23.9 \\ 42.5 & 49.6 \\ 14.1 & 13.3 \\ 18.5 & 7.2\end{array}$

14028.

13651.

11031.

4565 .

1.7
3.8
20.6
56.9

0.01

0.01

0.03

0.14

0.43

0.43

0.37

SAMPLE MESH SIZE

$\begin{array}{rrrrrrr}\text { PLUS 65 } & 3.5 & 3.3 & 11159 . & 18.5 & 0.09 & 0.35 \\ 65-100 & 9.4 & 9.2 & 11487 . & 16.8 & 0.09 & 0.37 \\ 100-200 & 29.0 & 29.6 & 11948 . & 13.9 & 0.08 & 0.38 \\ 200-325 & 20.0 & 21.0 & 12373 . & 11.7 & 0.09 & 0.41 \\ \text { MINUS 325 } & 38.1 & 36.9 & 11358 . & 17.1 & 0.10 & 0.36\end{array}$

MINUS 325

11358. $17.1 \cdot 0.10 \quad 0.36$

MINE:

COALBED: BIG

COMPANY: INACTIVE

\section{CUMULATTVE}

\begin{tabular}{ccccccc}
\multicolumn{2}{c}{ RECOVERY } & ASH & SULFUR & LB SO2/ \\
WEIGHT & BTU & BTU/LB & & PYR TOTAL & MM BTU
\end{tabular}

$\begin{array}{rrrrrrr}45.5 & 53.5 & 13847 . & 2.8 & 0.01 & 0.42 & 0.6 \\ 66.9 & 76.4 & 13<73 . & 5.0 & 0.01 & 0.42 & 0.6 \\ 84.8 & 92.1 & 128.02 . & 9.3 & 0.01 & 0.40 & 0.6 \\ 100.0 & 100.0 & 11.84 . & 15.6 & 0.01 & 0.37 & 0.6\end{array}$

$\begin{array}{rr}46.3 & 53.6 \\ 71.8 & 81.5 \\ 84.7 & 92.2 \\ 100.0 & 100.0\end{array}$

$\begin{array}{ll}13 E 71 . & 3.1 \\ 133899 . & 4.8 \\ 12843 . & 8.3\end{array}$

$\begin{array}{ll}0.02 & 0.43 \\ 0.02 & 0.42\end{array}$

$0.02 \quad 0.42$

$0.02 \quad 0.40$

11801 .

0.03

0.36

0.6
0.6

0.6

49.2

75.3

85.2

$$
56 .
$$

56.6
84.7
93.3

13371. $\quad 3.0$

$130178 . \quad 7.6$

11879 . $\quad 15.1$

$\begin{array}{lll}0.01 & 0.42 & 0.6 \\ 0.01 & 0.42 & 0.6 \\ 0.01 & 0.41 & 0.6\end{array}$

100.0

0.02

0.37

0.6

$\begin{array}{rrrrrrr}24.9 & 29.9 & 14028 . & 1.7 & 0.01 & 0.43 & 0.6 \\ 67.4 & 79.5 & 13790 . & 3.0 & 0.01 & 0.43 & 0.6 \\ 81.5 & 92.8 & 13314 . & 6.1 & 0.01 & 0.42 & 0.6 \\ 100.0 & 100.0 & -1694 . & 15.5 & 0.04 & 0.37 & 0.6\end{array}$

-1694 .

$\begin{array}{rr}3.5 & 3.3 \\ 12.9 & 12.5 \\ 41.9 & 42.1 \\ 61.9 & 63.1 \\ 100.0 & 100.0\end{array}$

$\begin{array}{ll}11199 & 18.5 \\ 11398 & 17.3 \\ 11779 . & 14.9 \\ 11970 & 13.9 \\ 11737 . & 15.1\end{array}$

$\begin{array}{ll}0.09 & 0.35 \\ 0.09 & 0.36 \\ 0.08 & 0.38 \\ 0.09 & 0.39 \\ 0.09 & 0.38\end{array}$


TABLE XVII

WASHABILITY ANALYSIS SHOWING THE EFFECTS OF CRUSHING ON THE LIBERATION

OF ASH FORMING IMPURITIES AND PYRITIC SULFUR FOR SAMPLE UA 109

STATE: ALASKA

COUNTY: BARRCW-POINT HOPE

TOWN: WAINWRIGHT

DIREC -

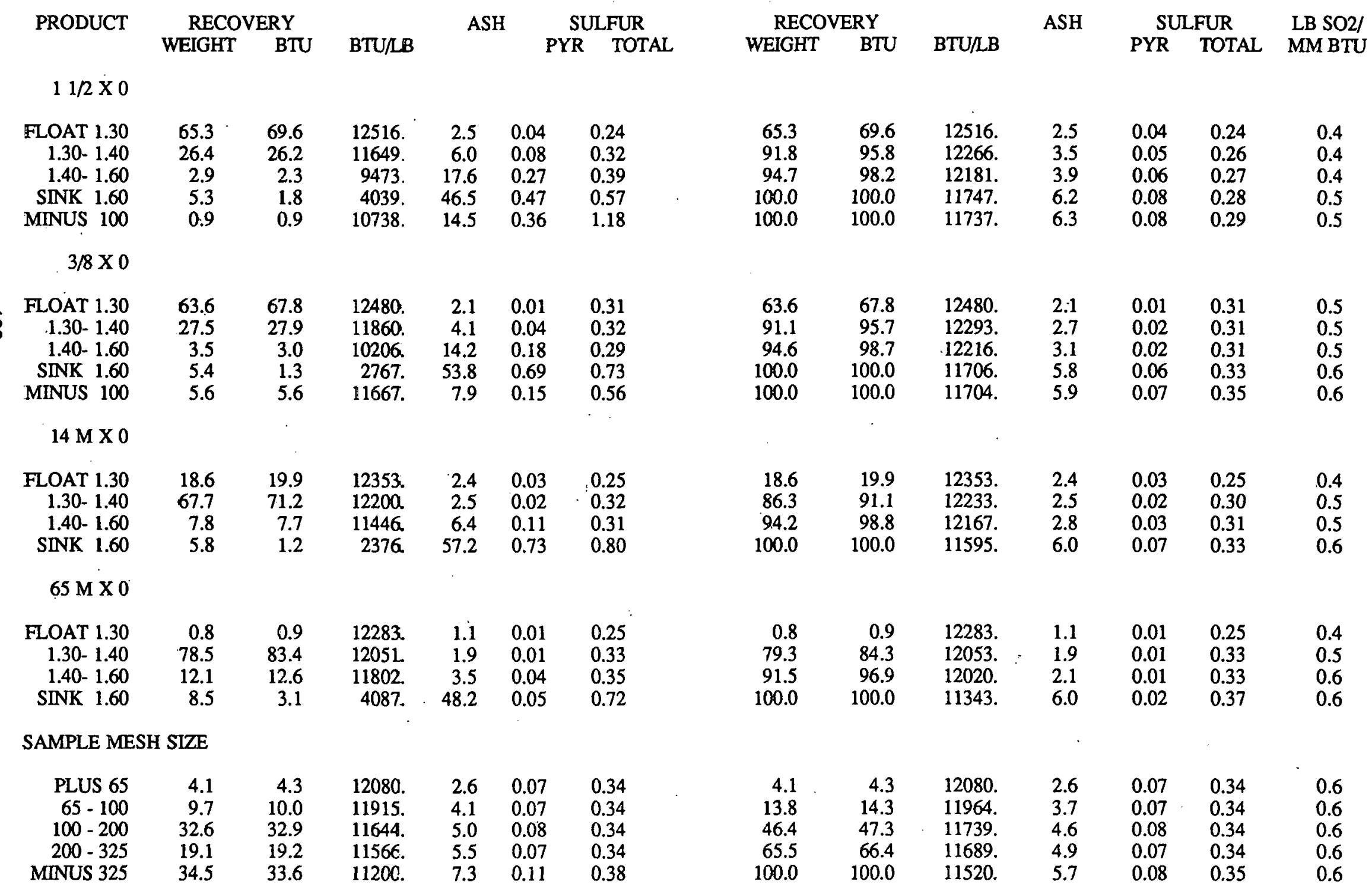

$\begin{array}{ll}\text { MINE: } & \text { MINE NO. } 2 \\ \text { COALBED: } & 5 \text { FT BED }\end{array}$

COMPANY: INACTIVE

\section{CUMULATTVE}


TABLE XVIII

WASHABILITY ANALYSIS SHOWING THE EFFECTS OF CRUSHING ON THE LIBERATION OF ASH FORMING IMPURITIES ANR PYRITIC SULFUR FOR SAMPLE UA 110

STATE: ALASKA

COUNTY: BARROW-POINT HOPE

TOWN: ATKASOOK

DIRECT

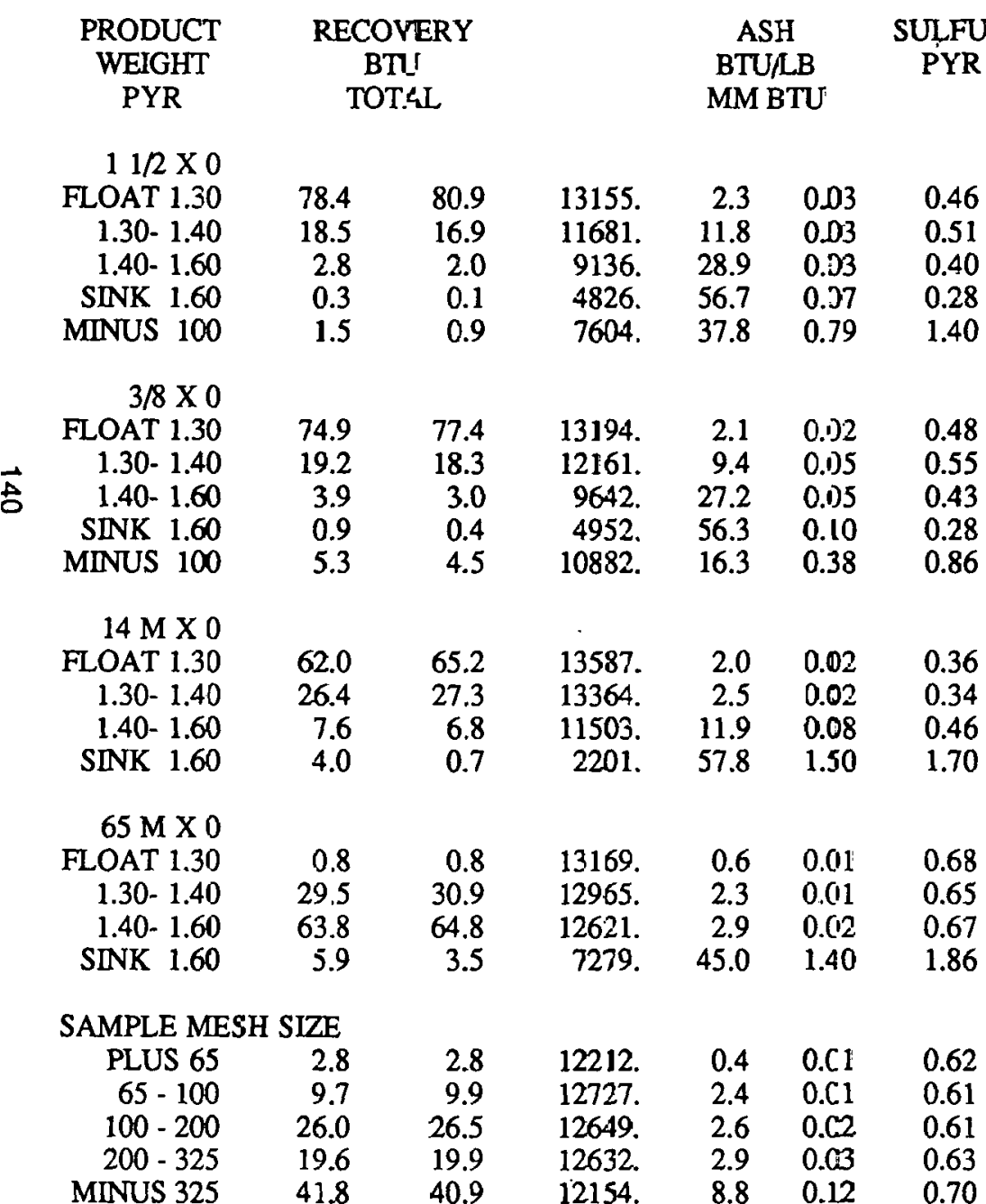

MINE: MEADE RIVER

COALBED: NO. TWO

COMPANY: INACTIVE

\section{CUMULATIVE}

\section{RECOVERY TOTAL}

YR

0.46

0.51

1.40

0.48

0.55

0.28

0.86

0.36

0.34

170

0.68

0.65

1.86

0.62

0.61

0.63

0.70

$74.9 \quad 77$

100.0

$62.0 \quad 65$

$\begin{array}{rr}0.8 & 0.8 \\ 30.3 & 31.7 \\ 94.1 & 96 . \\ 100.0 & 100\end{array}$

$\begin{array}{ccc}\text { ASH } & \text { SULFUR } & \text { LB SO2/ } \\ \text { WEIGHT } & \text { BTU } & \text { BTU/LB }\end{array}$

$\begin{array}{rr}78.4 & 80.9 \\ 96.9 & 97.9 \\ 99.7 & 99.9 \\ 100.0 & 100.0 \\ 100.0 & 100.0\end{array}$

$\begin{array}{lllll}13155 . & 2.3 & 0.03 & 0.46 & 0.7 \\ 12874 . & 4.1 & 0.03 & 0.47 & 0.7 \\ 12769 . & 4.8 & 0.03 & 0.47 & 0.7 \\ 12748 . & 4.9 & 0.03 & 0.47 & 0.7 \\ 12674 . & 5.4 & 0.04 & 0.48 & 0.8\end{array}$

$94.1 \quad 95.7$

$98.0 \quad 98.6$

$99.0 \quad 99.0$

100.0

13194.

12983.

12849.

12774 .

12679.

2.1
3.6
4.5
5.0
5.6

0.02

0.03

0.03

0.03

0.05

0.48

0.49

0.49

0.49

0.51

0.7

0.8
0.8

0.8

0.8

$88.4 \quad 92.5$

13587.

13520.

2.0

0.02

0.02
0.02
0.02

0.36

0.35

0.36

$100.0 \quad 100.0$

12914.

5.9

0.08

0.42

0.5

0.5

0.6

$\begin{array}{lllll}13169 . & 0.6 & 0.01 & 0.68 & 1.0 \\ 12970 . & 2.3 & 0.01 & 0.65 & 1.0 \\ 12733 . & 2.7 & 0.02 & 0.66 & 1.0 \\ 12409 . & 5.2 & 0.10 & 0.73 & 1.2\end{array}$

$\begin{array}{rr}2.8 & 2.8 \\ 12.6 & 12.7 \\ 38.6 & 39.2 \\ 58.2 & 59.1 \\ 100.0 & 100.0\end{array}$

12212.
12610.
12636.
12635.

0.4
2.0
2.4
2.6
5.2

0.01
0.01
0.02
0.02
0.05 
TABLE XIX

WASHABILITY ANALYSIS SHOWING THE EFFECTS OF CRUSHING ON THE LIBERATION OF ASH FORMING IMPURITIES AND PYRITIC SULFUR FOR SAMPLE UA 111

STATE: ALASKA

COUNTY: MATANUSKA-SUSITNA

TOWN: BROAD PASS

DIRECT

PRODUCT

RECOVERY

WEIGHT BTU BTU/LB

ASH

SULFUR

$11 / 2 \times 0$

FLOAT 1.30

$1.30-1.40$

$1.40-1.60$

SINK 1.60

MINUS 100

$\begin{array}{rrrrrr}34.7 & 42.5 & 11172 . & 4.2 & 0.01 & 0.21 \\ 47.6 & 47.2 & 9040 . & 16.7 & 0.02 & 0.22 \\ 10.6 & 7.8 & 6716 . & 35.5 & 0.03 & 0.13 \\ 7.1 & 2.5 & 3198 . & 65.5 & 0.05 & 0.08 \\ 1.9 & 1.4 & 6571 . & 36.9 & 0.01 & 0.10\end{array}$

$3 / 8 \times 0$

$\rightarrow \quad$ FLOAT 1.30

$1.30-1.40$
$1.40-1.60$

SINK 1.60

$\begin{array}{rr}31.3 & 38.4 \\ 47.5 & 48.2 \\ 13.1 & 10.3 \\ 3.1 & 3.1 \\ 6.6 & 5.1\end{array}$

11389.

$\begin{array}{rrr}9402 . & 14.8 & 0.04\end{array}$

7226. $31.2 \quad 0.04$

3512. $62.6 \quad 0.05$

$\begin{array}{lll}7029 . & 33.7 & 0.01\end{array}$

0.20

0.30

0.11

0.10

MINUS 100

$14 \mathrm{M} \mathrm{X} 0$

FLOAT 1.30

1.30- 1.40

$1.40-1.60$

28.0

51.3

34.7

52.1

$11530 . \quad 2.6 \quad 0.01$

$\begin{array}{lll}9435 . & 14.7 & 0.01 \\ 7307 . & 29.7 & 0.01\end{array}$

3768. $58.5 \quad 0.04$

0.18

0.19

0.15

SINK 1.60

$65 \mathrm{MXO}$

FLOAT 1.30

$1.30-1.40$

$1.40-1.60$

SINK 1.60

$\begin{array}{rr}0.0 & 0.0 \\ 34.1 & 42.2 \\ 44.8 & 45.2 \\ 21.0 & 12.6\end{array}$

$\begin{array}{rrr}0 . & 0.0 & 0.00 \\ 11160 . & 2.1 & 0.01 \\ 9091 . & 13.6 & 0.02 \\ 5385 . & 46.4 & 0.03\end{array}$

0.00

0.18

0.24
0.18

SAMPLE MESH SIZE

$\begin{array}{rrrrrrr}\text { PLUS 65 } & 9.4 & 10.7 & 10399 . & 10.1 & 0.02 & 0.20 \\ 65-100 & 9.9 & 11.0 & 10173 . & 10.6 & 0.02 & 0.23 \\ 100-200 & 27.5 & 29.8 & 9903 . & 12.1 & 0.02 & 0.22 \\ 200-325 & 14.4 & 14.8 & 9422 . & 13.0 & 0.02 & 0.22 \\ \text { MINUS 325 } & 38.9 & 33.7 & 7910 & 26.1 & 0.02 & 0.21\end{array}$

MINE:

COAL CREEK

COALBED: COAL CREEK

COMPANY: INACTTVE

\section{CUMULATIVE}

\begin{tabular}{ccccccc}
\multicolumn{2}{c}{ RECOVERY } & ASH & \multicolumn{2}{c}{ SULFUR } & LB SO2/ \\
WEIGHT & BTU & BTU/LB & & PYR & TOTAL & MM BTU
\end{tabular}

$\begin{array}{rrrrrrr}34.7 & 42.5 & 11172 . & 4.2 & 0.01 & 0.21 & 0.4 \\ 82.3 & 89.7 & 9939 . & 11.4 & 0.02 & 0.22 & 0.4 \\ 92.9 & 97.5 & 9570 . & 14.2 & 0.02 & 0.21 & 0.4 \\ 100.0 & 100.0 & 9116 . & 17.8 & 0.02 & 0.20 & 0.4 \\ 100.0 & 100.0 & 9069 . & 18.2 & 0.02 & 0.20 & 0.4\end{array}$

$\begin{array}{rrrrrrr}31.3 & 38.4 & 11389 . & 4.2 & 0.01 & 0.20 & 0.4 \\ 78.7 & 86.7 & 10191 . & 10.6 & 0.03 & 0.26 & 0.5 \\ 91.9 & 96.9 & 9767 . & 13.5 & 0.03 & 0.24 & 0.5 \\ 100.0 & 100.0 & 9259 . & 17.5 & 0.03 & 0.23 & 0.5 \\ 100.0 & 100.0 & 9122 . & 18.5 & 0.03 & 0.23 & 0.5\end{array}$

$\begin{array}{lllllll}100.0 & 100.0 & 9122 . & 18.5 & 0.03 & 0.23 & 0.5\end{array}$

28.0

79.3

91.7

100.0

34.7

11530.

10174.

9787.

96.6

100.0

9285.

2.6
10.4

13.0

$\begin{array}{ll}0.01 & 0.18 \\ 0.01 & 0.19\end{array}$

$0.01 \quad 0.18$

0.3

0.4

0.4

0.0
34.1
79.0

0.0
42.2

42.2
87.4

0
11160

0.

9985.

9017.

0.0
2.1
8.7
16.6

0.00

$0.01 \quad 0.18$

$0.02 \quad 0.21$

$\begin{array}{ll}0.02 & 0.21\end{array}$

0.0

0.3

0.5

MINUS 325

33.7

7910.

0.21

$\begin{array}{rr}9.4 & 10.7 \\ 19.3 & 21.7 \\ 46.8 & 15.5 \\ 61.1 & 66.3 \\ 100.0 & 100.0\end{array}$

$\begin{array}{rr}10399 . & 10.1 \\ 10283 . & 10.4 \\ 10060 . & 11.4 \\ 9910 . & 11.8 \\ 9133 . & 17.3\end{array}$

$\begin{array}{ll}0.02 & 0.20 \\ 0.02 & 0.22 \\ 0.02 & 0.22 \\ 0.02 & 0.22 \\ 0.02 & 0.22\end{array}$

0.4

0.4

0.4

0.4
0.5 
TABLE XX

WASHABILITY ANALYSIS SHOWING THE EFFECTS OF CRUSHING ON THE LIBERATION OF ASH FORMING IMPURITIES AND PYRITIC SULFUR FOR SAMPLE UA 112

STATE: AंASKA

COUNTY: MCGRATH-HOLY CROS̈

TOWN: KANTISFNA

DIRECT

PRODUCT RECOVERY

WEIGHT BTU BTU/LB
ASH

S:JLFUR

PYR TOTAL
MINE

COALBED:

COMPANY: INACTIVE

\section{CUMULATIVE}

RECOVERY WEIGHT BTI BTUILB
SULFUR LB.SO2/ PYR TOTAL MMBTU

$11 / 2 \times 0$

FLOAT 1.30
$1.30-1.40$
$1.40-1.60$
SINK 1.60
MINUS 100

$\begin{array}{rrrrrr}3.6 & 4.3 & 11681 . & 5.3 & 0.03 & 1.33 \\ 79.8 & 81.2 & 10487 . & 9.0 & 0.06 & 1.40 \\ 12.3 & 11.2 & 8251 . & 26.4 & 0.05 & 1.24 \\ 4.3 & 1.3 & 2908 . & 68.0 & 0.06 & 0.67 \\ 1.0 & 1.5 & 5108 . & 52.3 & 0.08 & 1.07\end{array}$

$3 / 8 \times 0$

SINK 1.60

$\begin{array}{rr}5.3 & 6.4 \\ 74.5 & 78.8 \\ 15.4 & 13.5 \\ 4.7 & 1.3 \\ 4.1 & 2.6\end{array}$

$\begin{array}{rrrr}\text { 11618. } & 4.6 & 0.02 & 1.46 \\ 10266 . & 9.3 & 0.06 & 1.64 \\ 3520 . & 22.1 & 0.06 & 1.41 \\ 2688 . & 68.9 & 0.11 & 0.62 \\ 5071 . & 44.4 & 0.08 & 0.97\end{array}$

$14 \mathrm{M}$ X 0

FLOAT 1.30
$1.30-1.40$
$1.40-1.60$

0.4
74.5
18.5

$1.40-1.60$
SINK 1.60

$\begin{array}{rrrrr}0.5 & 10755 . & 8.7 & 0.02 & 1.34 \\ 8 C .1 & 10429 . & 9.9 & 0.05 & 1.41 \\ 16.9 & 8862 . & 19.1 & 0.06 & 1.38 \\ 2.5 & \vdots 762 . & 51.3 & 0.10 & 1.00\end{array}$

$65 \mathrm{M} \mathrm{X} 0$

FLOAT 1.30
$1.30-1.40$
$1.40-1.60$

0.2
19.4

SINK 1.60

0.2
22.7
65.6
11.5

$\begin{array}{rrrr}11144 . & 4.4 & 0.04 & 1.35 \\ 11093 . & 5.0 & 0.04 & 1.57 \\ \text { S703. } & 11.2 & 0.04 & 1.39 \\ \text { E730. } & 37.9 & 0.23 & 1.34\end{array}$

$\begin{array}{rr}0.2 & 0.2 \\ 19.6 & 22.9 \\ 83.8 & 88.5 \\ 100.0 & 100.0\end{array}$

$$
\begin{gathered}
-1144 \\
\vdots 1093 \\
10028 . \\
0<93
\end{gathered}
$$
4.4
5.0

5.0
9.7

$\begin{array}{lll}0.04 & 1.35 & 2.4 \\ 0.04 & 1.57 & 2.8 \\ 0.04 & 1.43 & 2.9 \\ 0.07 & 1.42 & 3.0\end{array}$

SAMPLE MESH SIZE

$\begin{array}{rr}\text { PLUS 65 } & 8.3 \\ 65-100 & 16.1 \\ 100-200 & 33.1 \\ 200-325 & 14.3 \\ \text { MINUS 325 } & 28.2\end{array}$

$\begin{array}{rrrrr}8.6 & 9980 . & 10.7 & 0.09 & 1.47 \\ 1 \epsilon .7 & 10002 . & 10.7 & 0.09 & 1.57 \\ 34.4 & 10011 . & 11.1 & 0.06 & 1.38 \\ 14.6 & 9300 . & 12.2 & 0.09 & 1.34 \\ 25.7 & 8748 . & 20.9 & 0.09 & 1.23\end{array}$

8.3
24.4
57.4
71.8
100.0

8.6
25.3
59.7
74.3
100.0

$\begin{array}{rr}9680 . & 10.7 \\ 9695 . & 10.7 \\ 10604 . & 10.9 \\ 9663 . & 11.2 \\ 9620 . & 13.9\end{array}$

$\begin{array}{ll}0.09 & 1.47 \\ 0.09 & 1.54 \\ 0.07 & 1.45 \\ 0.08 & 1.42 \\ 0.08 & 1.38\end{array}$

2.3

$\begin{array}{rrrrrrr}5.3 & 6.6 & 11618 . & 4.6 & 0.02 & 1.46 & 2.5 \\ 79.9 & 85.2 & 10356 . & 9.0 & 0.06 & 1.63 & 3.1 \\ 95.3 & 98.2 & 10059 . & 11.1 & 0.06 & 1.59 & 3.2 \\ 100.0 & 100.6 & 97: 2 . & 13.8 & 0.06 & 1.55 & 3.2 \\ 100.0 & 100 . C & 9569 . & 15.0 & 0.06 & 1.52 & 3.2\end{array}$


TABLE XXI

WASHABILITY ANALYSIS SHOWING THE EFFECTS OF CRUSHING ON THE LIBERATION OF ASH FORMING IMPURITIES AND PYRITIC SULFUR FOR SAMPLE UA 113

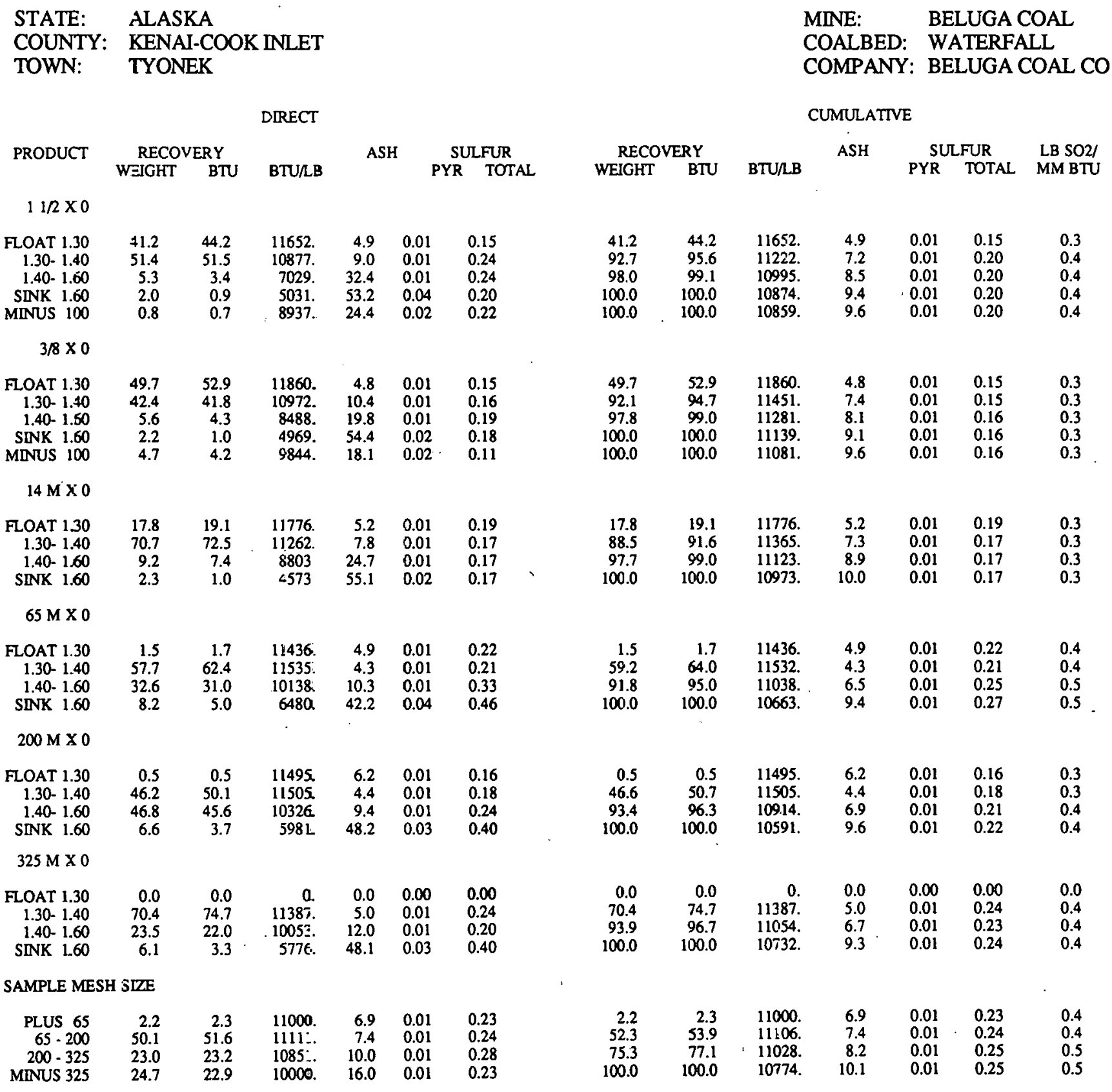


TABLE XXII

WASHABILITY ANALYSIS SHOWING THE EFFECTS OF CRUSHING ON THE LIBERATION OF ASH FORMING IMPURITIES AND PYRITIC SULFUR FOR SAMPLE UA 114

STATE: ALASKA

COUNTY: PRUDOE BAY-KAKTOVIK

TOWN: SAGWON

DIRECT

PRODUCT

RECOVERY

WEIGHT BTU

BTU/LE

ASH

SULFUR

?YR TOTAL

$11 / 2 \times 0$

\section{FLOAT 1.30}

$1.30-1.40$

$1.40-1.60$

SINK 1.60

MINUS 100

0.2
14.6
11.8
73.5
2.5

0.5
36.9
22.1
40.4
1.5

$\begin{array}{rrr}14088 . & 6.5 & 0.01 \\ 11305 . & 9.7 & 0.01 \\ 8393 . & 29.0 & 0.01 \\ 2449 . & 74.3 & 0.03 \\ 2716 . & 70.0 & 0.05\end{array}$

0.14
0.16
0.16
0.07
0.09

$3 / 8 \times 0$

FLOAT 1.30
$1.30-1.40$
$1.40-1.60$
SINK 1.60

SINK 1.60
MINUS 100

0.1
13.3
9.4
77.3
4.3

0.4
$\vdots 5.8$
19.4
44.4

11182 .

8605.

26.4

74.4
2.8

2627.

$14 \mathrm{M} \mathrm{X} 0$

FLOAT 1.30
$1.30-1.40$
$1.40-1.60$

SINK 1.60

\subsection{7}

10.3

77.9

$$
\begin{array}{r}
0.3 \\
30.6 \\
23.2 \\
46.0
\end{array}
$$

11273.

11094 .

9599.
2513.

$65 \mathrm{M} \mathrm{X} 0$

FLOAT 1.30

$1.30-1.40$

$1.40-1.60$

SINK 1.60

0.0
12.4
10.5
77.1

0.0

32.8

32.8
23.6

43.6

$\begin{array}{rrr}0 . & 0.0 & 0.00 \\ 11514 & 4.0 & 0.02 \\ 9798 . & 15.8 & 0.02 \\ 2462 . & 73.9 & 0.06\end{array}$

0.00

0.26

0.22

0.10

SAMPLE MESH SIZE

$\begin{array}{rrrllll}\text { PLUS 65 } & 1.9 & 3.7 & 8474 . & 21.5 & 0.04 & 0.14 \\ 65-100 & 4.9 & 9.4 & 8411 . & 17.6 & 0.04 & 0.18 \\ 100-200 & 15.9 & 30.2 & 8362 . & 21.9 & 0.04 & 0.16 \\ 200-325 & 9.5 & 17.9 & 8280 . & 28.0 & 0.04 & 0.17 \\ \text { MINUS 325 } & 67.8 & 38.8 & 2514 . & 74.4 & 0.03 & 0.09\end{array}$

MINE: SAGWON

COALBED: SAGWON

COMPANY: INACTIVE

CUMULATIVE

RECOVERY WEIGHT BTU BTU/LB

ASH

SULFUR
PYR TOTAI

LB SO2/

PYR TOTAL MM BTU

$14.7 \quad 37.5$

$26.5 \quad 59.6$

$100.0 \quad 100.0$

$100.0 \quad 100.0$

$\begin{array}{rrrrr}14088 . & 6.5 & 0.01 & 0.14 & 0.2 \\ 11337 . & 9.7 & 0.01 & 0.16 & 0.3 \\ 10031 . & 18.2 & 0.01 & 0.16 & 0.3 \\ 4458 . & 59.4 & 0.02 & 0.09 & 0.4 \\ 4416 . & 59.7 & 0.03 & 0.09 & 0.4\end{array}$

4416. $\quad 59.7$

$\begin{array}{rr}0.1 & 0.4 \\ 13.4 & 36.2\end{array}$

14170 .

11209.

6.6

0.01

$22.8 \quad 55.6$

10139.

4148.

16.1

100.0

100.0

4085.

61.3
61.6

0.01

0.01

0.02

0.02

0.12

0.12

0.12

0.07

0.07

0.2

0.2

$100.0 \quad 100.0$

$\begin{array}{rr}0.1 & 0.3\end{array}$

$\begin{array}{ll}11.8 & 30.9 \\ 22.1 & 54.0\end{array}$

11273.

$11096 . \quad 7.5$

10400 . 14.3

0.02

0.25
0.16

4257. $\quad 60.3$

$\begin{array}{ll}0.02 & 0.15 \\ 0.03 & 0.08\end{array}$

0.4

$100.0 \quad 100.0$

0.0

0.0
12.4

12.4
22.9

100.0

0.0
32.8
56.4
100.0

0

11514.

10728.

0.0
4.0
9.4
59.2

0.00

0.02
0.02

0.05

0.00

0.26

0.24

100.0

$\begin{array}{rr}1.9 & 3.7 \\ 6.8 & 13.1 \\ 22.7 & 43.3 \\ 32.2 & 61.2 \\ 100.0 & 100.0\end{array}$

8474.
8429.
8382.
8352.
4394.

21.5

0.04

$0.04 \quad 0.17$

$0.04 \quad 0.16$

$0.04 \quad 0.16$

$\begin{array}{ll}0.04 & 0.13\end{array}$

0.3

0.4

0.4

0.4

0.4 
XXIII

WASHABILITY ANALYSIS SHOWING THE EFFECTS OF CRUSHING ON THE LIBERATION OF ASH FORMING IMPURITIES AND PYRITIC SULFUR FOR SAMPLE UA 115

STATE: ALASKA

COUNTY: MATANUSKA-SUSITNA

TOWN: PETERS CREEK

DIRECT

PRODUCT RECOVERY

SULFUR

PYR TOTAL
MINE:

LOCALITY 2

COALBED: LOWER

COMPANY: INACTIVE

CUMULATIVE

$11 / 2 \times 0$

FLOAT 1.30

$1.30-1.40$

$1.40-1.60$

SINK 1.60

MINUS 100

$\begin{array}{rr}97.7 & 98.3 \\ 1.3 & 1.1 \\ 0.5 & 0.4 \\ 0.5 & 0.2 \\ 0.8 & 0.7\end{array}$

11531.

9587.

9218. 22.0

3846. 65.1

9268.

21.3

0.01
0.01
0.01
0.04
0.03

0.15

0.04

0.14

0.07

0.13

$3 / 8 \times 0$

FLOAT 1.30
$1.30-1.40$
$1.40-1.60$
SINK 1.60

$95.8 \quad 96.2$

11587.

10854.

8694.

4.2
8.6

0.01

$\begin{array}{ll}3.8 & 3.6 \\ 0.2 & 0.2\end{array}$

1630.

8.6
28.4
80.9

0.01
0.05

0.05

MINUS 100

3.2

11108.

0.03

0.19

0.08

0.10

$14 \mathrm{M} \times 0$

FLOAT 1.30
$1.30-1.40$
$1.40-1.60$

$1.40-1.60$
SINK 1.60

$\begin{array}{rr}97.9 & 98.5 \\ 1.0 & 0.9 \\ 0.6 & 0.5 \\ 0.5 & 0.1\end{array}$

11384.

10430.

16.0

2522 .

36.4

0.01
0.02
0.05
0.07

0.16

0.15

0.18

0.08

$65 \mathrm{M} \mathrm{X} 0$

\section{FLOAT 1.30}

$1.30-1.40$

$1.40-1.60$

$\begin{array}{rr}0.8 & 0.8 \\ 58.7 & 60.0 \\ 25.5 & 24.6\end{array}$

11462.

11568.

10940.

11017.

$\begin{array}{ll}2.3 & 0.01 \\ 3.5 & 0.01 \\ 5.1 & 0.01\end{array}$

0.18

0.19

0.19

0.18

RECOVERY

WEIGHT

BTU BTU/LB

ASH

SULFUR

LB SO2/

PYR TOTAL MM BTU

SAMPLE MESH SIZE

$\begin{array}{rrrllll}\text { PLUS 65 } & 9.5 & 9.6 & 11353 . & 3.5 & 0.01 & 0.16 \\ 65-100 & 13.8 & 13.8 & 11280 . & 3.8 & 0.01 & 0.15 \\ 100-200 & 31.3 & 31.5 & 11372 . & 4.0 & 0.01 & 0.16 \\ 200-325 & 15.1 & 15.2 & 11322 . & 4.1 & 0.01 & 0.18\end{array}$

MINUS 325

30.2

30.0

11266.

$\begin{array}{lll}5.7 & 0.01 & 0.17\end{array}$

$\begin{array}{rr}97.7 & 98.3 \\ 99.0 & 99.4 \\ 99.5 & 99.8 \\ 100.0 & 100.0 \\ 100.0 & 100.0\end{array}$

11531.

11505.

11494.

11452.

11435 .

4.5
4.6
4.7
5.0
5.2

0.01

0.01

0.15

0.3

100.0

0.01

$0.01 \quad 0.15$

0.3

100.0

95.8

96.2

99.6

99.8

99.8

99.8
100.0

$100.0 \quad 100.0$

11587.

11559.

11553.

11535.

$100.0 \quad 11522$.

4.2
4.3
4.4
4.5
4.7

0.01

0.01

0.01
0.01

0.01

0.14

0.14

0.01

0.14

100.0

97.9

98.9

$98.5 \quad 11384$.

$99.4 \quad 11374$.

$99.9 \quad 11361$.

11318.

4.2
4.2
4.3
4.4

0.01

0.16

$0.01 \quad 0.16$

$0.01 \quad 0.16$

100.0

100.0

0.01

0.16

0.3

0.3

0.3

0.17
0.8
6.8
85.5

11462.

11567.

11379.

11325.

2.3
3.5
4.0
4.2

0.01

0.18

0.3

100.0

100.0

4.0
4.2

0.01

0.01
0.01

0.19

0.19

0.3

0.3 
TABLE XXIV

WASHABILITY ANALYSIS SHOWING THE EFFECTS OF CRUSHING ON THE LIBERATION

OF ASH FORMING IMPURITIES AND PYRITIC SULFLR FOR SAMPLE UA 116

STATE: ALASKA

CCUNTY: MATANUSKA-SUSTTNA

TOWN: $\quad$ PETERS CREEK

DIRECT

PRODUCT

\section{RECOVERY} WEIGHT BTU
ASH
MINE:

COMPANY: INACTIVE

\section{CUMULATIVE}

$11 / 2 \times 0$

$\begin{array}{rrrrrrr}\text { FLOAT 1.30 } & 99.1 & 99.3 & 11401 . & 3.6 & 0.01 & 0.10 \\ 1.30-1.40 & 0.6 & 0.5 & 10160 . & 11.4 & 0.01 & 0.13 \\ 1.40-1.60 & 0.2 & 0.1 & 7213 . & 33.5 & 0.11 & 0.11 \\ \text { SINK 1.60 } & 0.1 & 0.1 & 2116 . & 77.5 & 0.10 & 0.13 \\ \text { MINUS 100 } & 0.8 & 0.7 & 10662 . & 12.4 & 0.05 & 0.09\end{array}$

$3 / 8 \times 0$

$\overrightarrow{0}$

FLOAT 1.30
$1.30-1.40$
$1.40-1.60$
SINK 1.60
MINUS 100

$\begin{array}{rrrrrr}97.0 & 77.5 & 11393 . & 3.5 & 0.01 & 0.13 \\ 2.9 & 2.4 & 9627 . & 7.6 & 0.01 & 0.19 \\ 0.1 & 0.5 & 9293 . & 21.2 & 0.04 & 0.24 \\ 0.0 & 0.0 & 4199 . & 63.0 & 0.03 & 0.14 \\ 3.0 & 2.8 & 10470 . & 4.2 & 0.01 & 0.11\end{array}$

$14 \mathrm{M} \mathrm{X} 0$

FLOAT 1.30
$1.30-1.40$
$1.40-1.60$

$99.2 \quad 99.4$

$1.40-1.60$

0.4

0.2
0.2

99.2
0.5
0.2
0.1

11499

10819.

9352

SULFUR

RECOVERY
WEIGHT

BTU/LB

ASH SYRTFUR

LB SO2/ PYR TOTAL

$\begin{array}{rrrrrrr}99.1 & 95.3 & 11 \neq 01 . & 3.6 & 0.01 & 0.10 & 0.2 \\ 99.7 & 95.9 & i 1394 . & 3.6 & 0.01 & 0.10 & 0.2 \\ 99.9 & 10 C .0 & 11385 . & 3.7 & 0.01 & 0.10 & 0.2 \\ 100.0 & 10 C .0 & 11374 . & 3.8 & 0.01 & 0.10 & 0.2 \\ 100.0 & 10 C .0 & 11369 . & 3.8 & 0.01 & 0.10 & 0.2\end{array}$

$65 \mathrm{M} \times 0$

FLOAT 1.30

1.30- 1.40

$1.40-1.60$

0.4
63.7

0.4
64.5

3511.

6.2

14.2

0.02

0.02
0.09

0.10
0.14
0.20

0.10

SINK 1.60

21.0

14.9

11639.

11529.

10833.

11117.

$\begin{array}{lll}1.4 & 0.01 & 0.19 \\ 2.8 & 0.01 & 0.17 \\ 4.3 & 0.01 & 0.17 \\ 4.4 & 0.01 & 0.17\end{array}$

SAMPLE MESH SIZE

$\begin{array}{rllllll}\text { PLUS 65 } & 20.1 & -0.3 & 11430 . & 3.0 & 0.01 & 0.13 \\ 65-100 & 11.6 & 11.7 & 11414 . & 3.2 & 0.01 & 0.13 \\ 100-200 & 26.0 & -6.1 & 11371 . & 3.3 & 0.01 & 0.12 \\ 200-325 & 11.9 & 11.9 & 11304 . & 3.8 & 0.01 & 0.12 \\ \text { MINUS 325 } & 30.4 & 30.0 & 11204 . & 4.9 & 0.01 & 0.13\end{array}$

\section{7.}

99.9

100.0

100.0

100.0

99.2

99.6

99.8

100.0

0.4

64.1

85.1

100.0

97.5
99.9
100
100

97.5
99.9
100.0
1000
100.0

11393.

11342.

11340.

11337.

11312 .

99.4
997
999

11499.

11496.

11491.

11477.

3.3
3.3
3.3
3.4

0.01

0.01

0.01

0.01

0.10

0.10

0.10

0.4
653

0.4
653
853

11639.

11530.

113.58

1000

11322.

1.4
2.8
3.1
3.3

0.01

$\begin{array}{ll}0.01 & 0.17\end{array}$

$0.01 \quad 0.17$

$\begin{array}{ll}0.01 & 0.17\end{array}$

0.3

0.3 


\section{TABLE XXV}

WASHABILITY ANALYSIS SHOWING THE EFFECTS OF CRUSHING ON THE LIBERATION

OF ASH FORMING IMPURITIES AND PYRITIC SULFUR FOR SAMPLE UA 117

STATE: ALASKA

COUNTY: BARRCW-POINT HOPE

TOWN: TRAMWAY BAR

DIRECT

PRODUCT

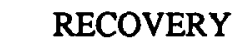

WEIGHT BTU BTU/LB

ASH

SULFUR

PYR TOTAL

$11 / 2 \times 0$

FLOAT 1.30

1.30- 1.40

$1.40-1.60$

SINK 1.60

$\begin{array}{rr}0.0 & 0.1 \\ 22.1 & 37.2 \\ 24.6 & 37.2 \\ 53.2 & 25.6 \\ 0.9 & 0.6\end{array}$

$\begin{array}{rrrr}12093 . & 4.6 & 0.02 & 0.20 \\ 12183 . & 6.3 & 0.02 & 0.29 \\ 10930 . & 16.2 & 0.02 & 0.26 \\ 3483 . & 66.3 & 0.07 & 0.08 \\ 4963 . & 56.8 & 0.06 & 0.10\end{array}$

$3 / 8 \times 0$

$\overrightarrow{ \pm} \quad$ FLOAT 1.30
$\quad 1.30-1.40$

$1.40-1.60$

SINK 1.60

MINUS 100

$\begin{array}{rrrrrr}0.1 & 0.1 & 11995 . & 3.6 & 0.01 & 0.26 \\ 23.9 & 39.5 & 12610 & 5.7 & 0.01 & 0.29 \\ 23.4 & 34.9 & 11393 . & 13.8 & 0.01 & 0.12 \\ 52.6 & 25.4 & 3693 . & 65.6 & 0.02 & 0.08 \\ 2.5 & 1.7 & 5197 . & 55.4 & 0.04 & 0.09\end{array}$

$14 \mathrm{M} \mathrm{X} 0$

FLOAT 1.30
$1.30-1.40$
$1.40-1.60$

$1.40-1.60$
SINK 1.60

0.1

24.2

27.7

0.2
40.0
39.5

39.5
20.2

12050.

$1257 \mathrm{C}$.

10867.

3.8
5.3
17.4
67.8

0.02

0.01

0.06

\subsection{0}

0.32

0.21

$65 \mathrm{MX0}$

FLOAT 1.30

$1.30-1.40$

$1.40-1.60$

SINK 1.60

$\begin{array}{ll}0.0 & 0.0\end{array}$

26.9

21.3

0.0
44.3

30.7

25.0

$\begin{array}{rrr}\text { C. } & 0.0 & 0.00 \\ 12401 . & 3.3 & 0.02 \\ 10855 . & 14.9 & 0.02 \\ 3625 . & 69.6 & 0.08\end{array}$

0.00

0.37

0.26

0.12

SAMPLE MESH SIZE

$\begin{array}{rrr}\text { PLUS 65 } & 2.9 & 3.3 \\ 65-100 & 2.9 & 3.5 \\ 100-200 & 17.2 & 21.3 \\ 200-325 & 16.9 & 20.2 \\ \text { MINUS } 325 & 60.0 & 51.7\end{array}$

$\begin{array}{llll}909 ? . & 26.3 & 0.05 & 0.27 \\ 6554 . & 46.0 & 0.02 & 0.19\end{array}$
MINE:

COALBED: 17 FT BED

COMPANY: INACTIVE

\section{CUMULATIVE}

RECOVERY

WEIGHT

BTU

BTU/LB

ASH

SULFUR

PYR TOTAL MMBTU

$\begin{array}{rrrrrrr}0.0 & 0.1 & 12093 . & 4.6 & 0.02 & 0.20 & 0.3 \\ 22.2 & 37.3 & 12183 . & 6.2 & 0.02 & 0.29 & 0.5 \\ 46.8 & 74.4 & 11523 . & 11.5 & 0.02 & 0.27 & 0.5 \\ 100.0 & 100.0 & 7244 . & 40.7 & 0.05 & 0.17 & 0.5 \\ 100.0 & 100.0 & 7225 . & 40.8 & 0.05 & 0.17 & 0.5\end{array}$

$100.0 \quad 100.0$

7225. $\quad 40.8$

0.1

24.0

47.4

100.0

100.0

0.1
39.6
74.6
100.0
100.0

11995.

12608 .

12008 .

7637.

7577.

3.6
5.6
9.7
39.0
39.5

0.01

0.01

0.01

0.02

0.02

0.26
0.29

0.21

0.14

0.14

0.5

0.3

0.3
0.4

0.4

$\begin{array}{rr}0.1 & 0.2 \\ 24.3 & 40.2 \\ 52.0 & 79.8 \\ 100.0 & 100.0\end{array}$

$\begin{array}{rr}12050 . & 3.8 \\ 12567 . & 5.3 \\ 11663 . & 11.8 \\ 7607 & 38.6\end{array}$

0.02

$\begin{array}{ll}0.02 & 0.20 \\ 0.01 & 0.32\end{array}$

$0.03 \quad 0.26$

$0.05 \quad 0.16$

0.3

0.5

0.4
0.4

100.0

0.0

26.9

48.1

100.0

0.0

44.3
75.0

75.0
100.0

1240

0.0

$0.00 \quad 0.00$

$0.02 \quad 0.37$

$0.02 \quad 0.32$

$0.05 \quad 0.22$

0.0

7517. $\quad 40.2$

$\begin{array}{rr}2.9 & 3.3 \\ 5.8 & 6.8 \\ 23.1 & 28.1 \\ 40.0 & 48.3 \\ 100.0 & 100.0\end{array}$

8574. 23.9

8909. 24.8

9275. 24.6

$9199 . \quad 25.3$

$\begin{array}{ll}7612 . & 37.7\end{array}$

0.05
0.05
0.04
0.05
0.04

0.25

0.27

0.25

0.26

0.23

0.6
0.6

0.5

0.6 
TABLE XXVI

WASHABILITY ANALYSIS SHOWING THE EFFECTS OF CRUSHING ON THE LIBERATION C.F ASH FORMING IMPURITIES AND PYRITIC SULFUR FOR SAMPLE UA 118

STATE: ALASKA

COUNTY: KENAI-COOK INLET

TOWN: HOMER

DIRECT

PRODUCT RECOVERY

WEIGHT BTU BTU/LB

ASH

SULFUR
PYR TOTAL

$11 / 2 \times 0$

FLOAT 1.30

1.30- 1.40

$1.40-1.60$

SINK 1.60

MINUS 100

$\begin{array}{rrrrrr}35.0 & 38.5 & 11578 . & 4.5 & 0.03 & 0.48 \\ 54.3 & 54.4 & 10531 . & 11.1 & 0.01 & 0.40 \\ 8.6 & 6.4 & 7855 . & 32.5 & 0.02 & 0.35 \\ 2.1 & 0.6 & 3116 . & 68.1 & 0.13 & 0.10 \\ 0.6 & 0.5 & 8855 . & 26.6 & 0.02 & 0.42\end{array}$

$3 / 8 \times 0$

FLOAT 1.30

1.30- 1.40

$1.40-1.60$

SINK 1.60

MINUS 100

$\begin{array}{rr}39.0 & 41.9 \\ 51.7 & 51.7 \\ 5.2 & 4.3 \\ 4.1 & 2.1 \\ 3.5 & 3.4\end{array}$

11644

$10845 . \quad 5.0$

$\begin{array}{rr}10845 . & 10.8 \\ 9041 . & 25.9\end{array}$

5594. 50.8

10303.

$14 \mathrm{MXO}$

FLOAT 1.30

1.30- 1.40

$1.40-1.60$

SINK 1.60

$\begin{array}{rr}21.0 & 23.0 \\ 56.7 & 59.0 \\ 16.8 & 14.9 \\ 5.5 & 3.1\end{array}$

11880

11279.

9604

6030.

4.0
7.3
21.0

7.3
1.0

0.01

0.01

\subsection{1}

0.01

0.11

0.05
0.01

0.51

0.47

0.42

0.31

0.43

$65 \mathrm{M} \mathrm{X} 0$

FLOAT 1.30

$1.30-1.40$
$1.40-1.60$

SINK 1.60

$\begin{array}{rrrrrr}0.3 & 0.4 & 11536 . & 4.6 & 0.12 & 0.39 \\ 36.0 & 40.7 & 11490 . & 4.9 & 0.62 & 0.49 \\ 49.3 & 48.9 & 10083 . & 13.6 & 0.62 & 0.50\end{array}$

SAMPLE MESH SIZE

$\begin{array}{rrrrrrr}\text { PLUS 65 } & 11.0 & 11.4 & 10576 . & 11.8 & 0.02 & 0.33 \\ 65-100 & 11.9 & 12.5 & 10678 . & 11.0 & 0.02 & 0.32 \\ 100-200 & 30.4 & 31.6 & 10597 . & 11.5 & 0.02 & 0.34 \\ 200-325 & 16.3 & 16.8 & 10533 . & 12.2 & 0.02 & 0.31 \\ \text { MINUS 325 } & 30.4 & 27.7 & 9292 . & 21.8 & 0.02 & 0.27\end{array}$

MINE:

COALBED: CABIN

COMPANY: INACTIVE

CUMULATIVE

\begin{tabular}{ccccccc}
\multicolumn{2}{c}{ RECOVERY } & & ASH & \multicolumn{2}{c}{ SULFUR } & LB SO2/ \\
WEIGHT & BTU & BTU/LB & & PYR TOTAL & MM BTU
\end{tabular}

$\begin{array}{rrrrrrr}35.0 & \vdots 8.5 & 11578 . & 4.5 & 0.03 & 0.48 & 0.8 \\ 89.3 & 53.0 & 10941 . & 8.5 & 0.02 & 0.43 & 0.8 \\ 97.9 & 59.4 & 10671 . & 10.6 & 0.02 & 0.42 & 0.8 \\ 100.0 & 1 C 0.0 & 10513 . & 11.8 & 0.02 & 0.42 & 0.8 \\ 100.0 & 1 C 0.0 & 10502 . & 11.9 & 0.02 & 0.42 & 0.8\end{array}$

$\begin{array}{rrrrrrr}39.0 & 41.9 & 11644 . & 5.0 & 0.01 & 0.51 & 0.9 \\ 90.8 & 93.6 & 11189 . & 8.3 & 0.01 & 0.49 & 0.9 \\ 96.0 & 97.9 & 11073 . & 9.3 & 0.02 & 0.48 & 0.9 \\ 100.0 & 109.0 & 10851 . & 10.9 & 0.02 & 0.48 & 0.9 \\ 100.0 & 109.0 & 10832 . & 11.1 & 0.02 & 0.47 & 0.9\end{array}$

$\begin{array}{lllllll}100.0 & 10.0 & 10832 & 11.1 & 0.02 & 0.47 & 0.9\end{array}$

$\begin{array}{rrrrrrr}21.0 & 23.0 & 11880 . & 4.0 & 0.02 & 0.50 & 0.8 \\ 77.7 & 82.0 & 11441 . & 6.4 & 0.01 & 0.46 & 0.8 \\ 94.5 & 95.9 & 11115 . & 9.0 & 0.01 & 0.45 & 0.8 \\ 100.0 & 100.0 & 10835 . & 11.0 & 0.01 & 0.44 & 0.8\end{array}$

$\begin{array}{rrrrrrr}0.3 & 0.4 & 11536 . & 4.6 & 0.02 & 0.39 & 0.7 \\ 36.3 & 4 . .1 & 11490 . & 4.9 & 0.02 & 0.49 & 0.9 \\ 85.6 & 90.0 & 10680 . & 9.9 & 0.02 & 0.50 & 0.9 \\ 100.0 & 100.0 & 10153 . & 14.2 & 0.02 & 0.48 & 0.9\end{array}$

$\begin{array}{rrrrrrr}11.0 & 11.4 & 10576 . & 11.8 & 0.02 & 0.33 & 0.6 \\ 23.0 & 23.9 & 10629 . & 11.4 & 0.02 & 0.32 & 0.6 \\ 53.3 & 55.5 & 10611 . & 11.4 & 0.02 & 0.33 & 0.6 \\ 69.6 & 72.3 & 10593 . & 11.6 & 0.02 & 0.33 & 0.6 \\ 100.0 & 106.0 & 10197 . & 14.7 & 0.02 & 0.31 & 0.6\end{array}$


TABLE XXVII

WASIIABHLITY ANALYSIS SIIOWIN(; THE EFFECTS OF CRUSHING ON TIIE LIBERATION

OF ASH FORMING IMPURITIES AND PYRITIC SULFUR FOR SAMPLE UA 119

STATE: ALASKA

COUNTY: KOYUKUK-MIDDLE YUKON

TOWN: HEALY

DIRECT

PROOUCI
WEIGIIT
SCREEN

ANALYSIS

$1-1 / 2 \times 3 / 8 \quad 37.7$

$3 / 8 \times 14$ MESH 49.1

$112 \times 0$

FLOAT 1.30

$1.30-1.40$
$1.40-1.60$

SINK 1.60

MINUS 100

$\begin{array}{rrrrrr}35.5 & 37.3 & 11441 . & 5.5 & 0.03 & 0.21 \\ 6.3 & 59.8 & 10644 . & 10.9 & 0.01 & 0.30 \\ 3.0 & 2.7 & 9978 . & 22.2 & 0.02 & 0.86 \\ 0.2 & 0.2 & 7771 . & 33.5 & 0.13 & 0.51 \\ 0.8 & 0.7 & 10102 . & 15.8 & 0.03 & 0.57\end{array}$

$\overrightarrow{\mathbb{C}}$

$3 / 8 \times 0$
$14 \mathrm{M} \times 100 \mathrm{M} \quad 12.4$

\section{MINE: \\ USIBELLII \\ COALBED: NO. FOUR \\ COMPANY: USIBELLI COAL CO.}

CUMULATIVE

$\begin{array}{ccccc}\text { RECOVERY } & & \text { ASH } & \text { SULFUR } & \text { I.IBS(I.:! } \\ \text { WEIGHT BIU } & \text { BTURB } & & \text { PYR TOTAL MIMIUIII }\end{array}$

37.7

86.8

100.0

$\begin{array}{rrrrrrr}35.5 & 37.3 & 11441 . & 5.5 & 0.03 & 0.21 & 0.4 \\ 96.8 & 97.1 & 10936 . & 8.9 & 0.02 & 0.27 & 0.5 \\ 99.8 & 99.8 & 10908 . & 9.3 & 0.02 & 0.28 & 0.5 \\ 100.0 & 100.0 & 10901 . & 9.4 & 0.02 & 0.29 & 0.5 \\ 100.0 & 100.0 & 10895 . & 9.4 & 0.02 & 0.29 & 0.5\end{array}$

$\begin{array}{rrrrrrr}\text { FLAT 1.30 } & 34.4 & 35.9 & 11245 . & 5.4 & 0.01 & 0.17 \\ 1.30-1.40 & 61.1 & 60.0 & 10575 . & 10.5 & 0.01 & 0.34 \\ 1.40-1.60 & 4.1 & 3.7 & 9739 . & 19.7 & 0.11 & 0.50 \\ \text { SINK 1.00 } & 0.4 & 0.4 & 9335 . & 21.1 & 0.05 & 0.38 \\ \text { MINUS 100 } & 3.1 & 3.1 & 10801 . & 8.3 & 0.03 & 0.23 \\ & & & & & & \\ \text { I4 M X } & & & & & & \\ & & & & & & \\ \text { FLOAT 1.30 } & 1.0 & 1.1 & 11502 . & 4.7 & 0.02 & 0.20 \\ 1.30-1.40 & 69.3 & 70.4 & 10886 . & 8.2 & 0.01 & 0.26 \\ 1.40-1.60 & 28.8 & 28.1 & 10456 . & 11.3 & 0.01 & 0.54 \\ \text { SINK 1.60 } & 0.9 & 0.4 & 4766 . & 55.6 & 0.06 & 0.18 \\ \text { 65 M X 0 } & & & & & & \\ & & & & & & \\ \text { FLOAT 1.30 } & 0.1 & 1.4 & 11446 . & 3.9 & 0.02 & 0.53 \\ 1.30-1.40 & 31.4 & 33.4 & 11310 . & 5.0 & 0.02 & 0.22 \\ 1.40-1.60 & 56.9 & 55.4 & 10362 . & 8.5 & 0.02 & 0.24 \\ \text { SINK 1.60 } & 11.6 & 9.8 & 8957 . & 20.8 & 0.02 & 0.23\end{array}$

SAMPLE MESH SIZE

$\begin{array}{rrrrrrr}\text { PLUS 65 } & 7.9 & 8.0 & 10788 . & 7.6 & 0.02 & 0.17 \\ 65-100 & 10.5 & 10.6 & 10750 . & 7.4 & 0.02 & 0.16 \\ 100-200 & 33.5 & 34.0 & 10763 . & 7.4 & 0.02 & 0.17 \\ 200-325 & 16.0 & 16.2 & 10740 . & 7.7 & 0.02 & 0.19 \\ \text { MINUS 325 } & 32.2 & 31.1 & 10211 . & 11.8 & 0.02 & 0.20\end{array}$

$\begin{array}{rrrrrrr}34.4 & 35.9 & 11245 . & 5.4 & 0.01 & 0.17 & 0.3 \\ 95.5 & 95.9 & 10816 . & 8.7 & 0.01 & 0.28 & 0.5 \\ 99.6 & 99.6 & 10772 . & 9.1 & 0.01 & 0.29 & 0.5 \\ 100.0 & 100.0 & 10766 . & 9.2 & 0.01 & 0.29 & 0.5 \\ 100.0 & 100.0 & 10767 . & 9.1 & 0.01 & 0.29 & 0.5\end{array}$

$\begin{array}{rrrrrrr}1.0 & 1.1 & 11502 . & 4.7 & 0.02 & 0.20 & 0.3 \\ 70.4 & 71.5 & 10895 . & 8.2 & 0.01 & 0.26 & 0.5 \\ 99.2 & 99.6 & 10768 . & 9.1 & 0.01 & 0.34 & 0.6 \\ 100.0 & 100.0 & 10717 . & 9.5 & 0.01 & 0.34 & 0.6\end{array}$

$\begin{array}{rrrrrrr}0.1 & 1.4 & 11446 . & 3.9 & 0.02 & 0.53 & 0.1 \\ 31.5 & 34.8 & 11735 . & 5.0 & 0.02 & 0.22 & 0.4\end{array}$

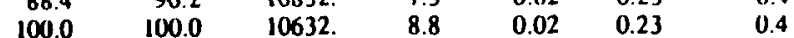

$\begin{array}{rrrrrrr}7.9 & 8.0 & 10788 . & 7.6 & 0.02 & 0.17 & 0.3 \\ 18.3 & 18.7 & 10766 . & 7.5 & 0.02 & 0.16 & 0.3 \\ 51.8 & 52.7 & 10764 . & 7.4 & 0.112 & 0.17 & 0.3 \\ 67.8 & 68.9 & 10758 . & 7.5 & 0.12 & 0.17 & 0.3 \\ 100.0 & 100.0 & 10582 . & 8.9 & 0.02 & 0.18 & 0.3\end{array}$

$\begin{array}{lrlllll}31.5 & 34.8 & 11735 . & 5.0 & 0.02 & 0.22 & 0.4 \\ 88.4 & 90.2 & 10852 . & 7.3 & 0.02 & 0.23 & 0.4 \\ 100.0 & 100.0 & 10632 & 8.8 & 0.02 & 0.23 & 0.4\end{array}$


TABLE XXVIII

WASHABILITY ANALYSIS SHOWING THE EFFECTS OF CRUSHING ON THE LIBERATION OF ASH FORMING IMPURITIES AND PYRITIC SULFUR FOR SAMPLE UA 120

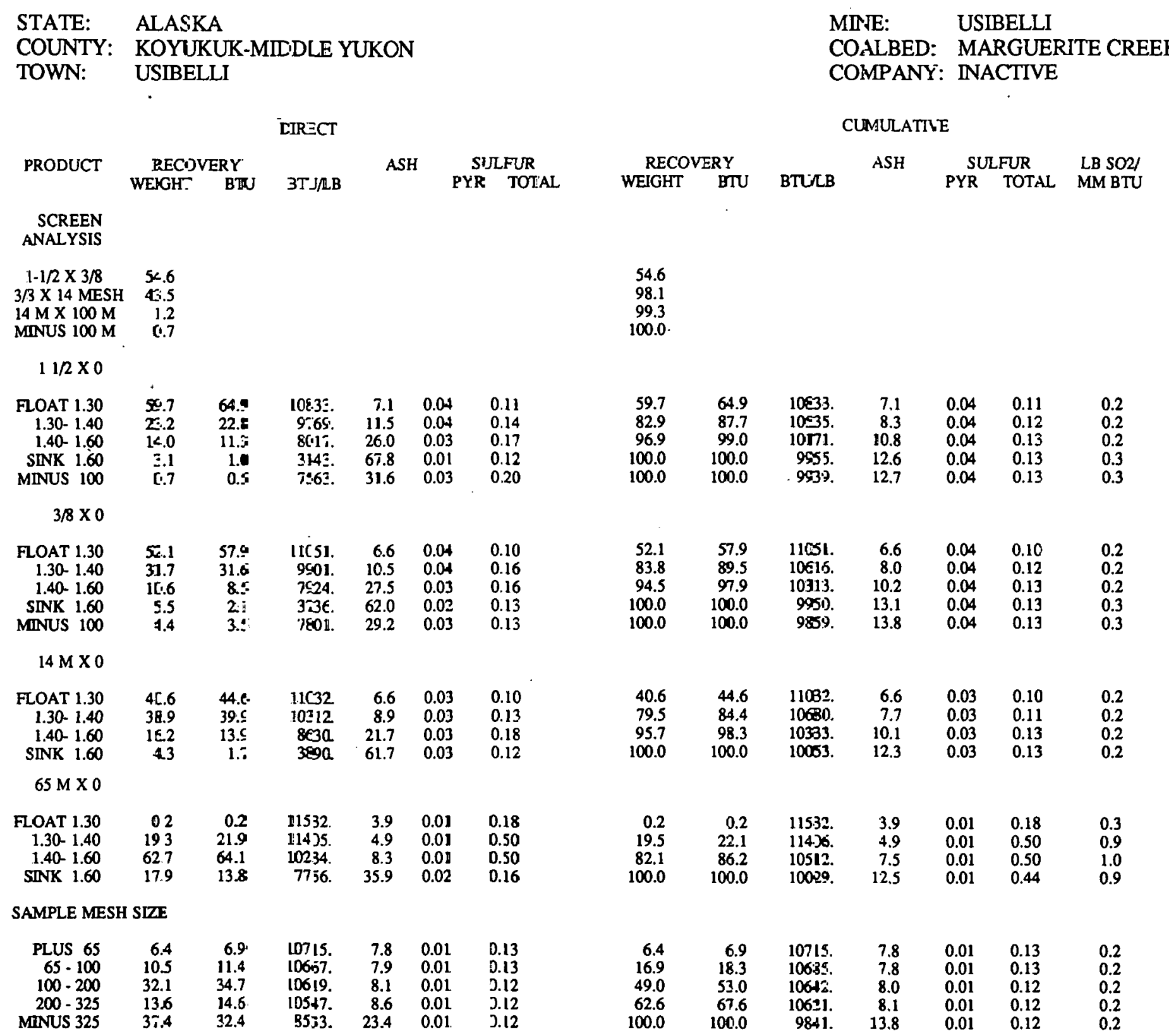




\section{TABLE XXIX}

WASHABILITY ANALYSIS SHOWING THE EFFECTS OF CRUSHING ON THE LIBERATION OF ASH FORMING IMPURITIES AND PYRITIC SULFUR FOR SAMPLE UA 121

STATE: $\quad$ ALASKA

COUNTY: YUKON FLATS

TOWN: COAL CREEK

DIRECT

PRODUCT

RECOVERY

WEIGHT

BTU

BTU/LB

ASH

SULFUR
PYR TOTAL

$11 / 2 \times 0$

\section{FLOAT 1.30}

1.30- 1.40

$1.40-1.60$

SINK 1.60

$\begin{array}{rr}0.0 & 0.1 \\ 21.9 & 26.5 \\ 60.7 & 68.8 \\ 17.3 & 4.7 \\ 0.9 & 0.8\end{array}$

$\begin{array}{rrrr}11141 . & 7.8 & 0.03 & 0.27 \\ 8949 . & 9.6 & 0.03 & 0.55 \\ 8392 . & 15.2 & 0.06 & 0.58 \\ 1989 . & 71.6 & 0.04 & 0.17 \\ 6445 . & 30.0 & 0.03 & 0.34\end{array}$

$3 / 8 \times 0$

$\begin{array}{rr}\vec{v} & \text { FLOAT } 1.30 \\ & 1.30-1.40\end{array}$

$1.40-1.60$

SINK 1.60

MINUS 100

$\begin{array}{rr}0.0 & 0.0 \\ 23.0 & 28.4 \\ 60.0 & 66.5 \\ 16.9 & 5.1 \\ 2.0 & 1.7\end{array}$

$\begin{array}{rrrr}11025 . & 3.8 & 0.03 & 0.24 \\ 9454 . & 10.3 & 0.04 & 0.64 \\ 8483 . & 16.0 & 0.06 & 0.62 \\ 2321 . & 69.5 & 0.04 & 0.20 \\ 6415 . & 32.5 & 0.03 & 0.39\end{array}$

$14 \mathrm{M} \mathrm{X} 0$

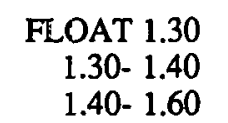

SINK 1.60

$\begin{array}{rr}0.2 & 0.2 \\ 10.0 & 12.5 \\ 73.9 & 83.0\end{array}$

$\begin{array}{rrr}11002 . & 2.9 & 0.03 \\ 9642 . & 10.6 & 0.03 \\ 8675 . & 13.9 & 0.06\end{array}$

2086.

71.6

$65 \mathrm{MX} 0$

\section{FLOAT 1.30}

$1.30-1.40$

$1.40-1.60$

SINK 1.60

$\begin{array}{rr}0.0 & 0.0 \\ 0.6 & 0.8 \\ 58.9 & 75.6 \\ 40.5 & 23.6\end{array}$

0.
9575
9118

0.0

9575. 6.6

9118. $10.6 \quad 0.03$

$\begin{array}{lll}\text { 4129. } & 46.9 & 0.04\end{array}$

0.29

0.60

0.17

SAMPLE MESH SIZE

$\begin{array}{rr}\text { PLUS 65 } & 2.0 \\ 65-100 & 5.5 \\ 100-200 & 23.9 \\ 200-325 & 16.2 \\ \text { MINUS 325 } & 52.4\end{array}$

$\begin{array}{rllll}2.4 & 8771 . & 16.1 & 0.04 & 0.53 \\ 6.5 & 8726 . & 15.6 & 0.03 & 0.49 \\ 27.3 & 8460 . & 16.9 & 0.04 & 0.58 \\ .17 .6 & 8025 . & 20.3 & 0.03 & 0.48 \\ 46.2 & 6523 . & 33.5 & 0.03 & 0.38\end{array}$

\section{MINE:}

COAL CREEK

COALBED: COAL CREEK

COMPANY: INACTIVE

\section{CUMULATIVE}

RECOVERY WEIGHT

BTU

ASH

SULFUR

LB SO2/

PYR TOTAL MMBTU

$\begin{array}{rrrrrrr}0.0 & 0.1 & 11141 . & 7.8 & 0.03 & 0.27 & 0.5 \\ 22.0 & 26.5 & 8953 . & 9.6 & 0.03 & 0.55 & 1.2 \\ 82.7 & 95.3 & 8541 . & 13.7 & 0.05 & 0.57 & 1.3 \\ 100.0 & 100.0 & 7406 . & 23.7 & 0.05 & 0.50 & 1.4 \\ 100.0 & 100.0 & 7398 . & 23.8 & 0.05 & 0.50 & 1.4\end{array}$

$100.0 \quad 100.0$

7398. $\quad 23.8$

$\begin{array}{rr}0.0 & 0.0 \\ 23.0 & 28.4 \\ 83.1 & 94.9 \\ 100.0 & 100.0 \\ 100.0 & 100.0\end{array}$

$\begin{array}{rr}11025 . & 3.8 \\ 9456 . & 10.3 \\ 8753 . & 14.4 \\ 7664 . & 23.8 \\ 7639 . & 23.9\end{array}$

0.03

$0.04 \quad 0.64$

$0.05 \quad 0.63$

$0.05 \quad 0.55$

$\begin{array}{ll}0.05 & 0.55\end{array}$

$\begin{array}{rr}0.2 & 0.2 \\ 10.1 & 12.7 \\ 84.0 & 95.7 \\ 100.0 & 100.0\end{array}$

$\begin{array}{rr}11002 . & 2.9 \\ 9663 . & 10.4 \\ 8794 . & 13.4 \\ 7722 . & 22.7\end{array}$

0.03
0.03

0.06

0.06

$\begin{array}{ll}0.29 & 0.5 \\ 0.60 & 1.3 \\ 0.60 & 1.4 \\ 0.53 & 1.4\end{array}$

$\begin{array}{rr}0.0 & 0.0 \\ 0.6 & 0.8 \\ 59.5 & 76.4 \\ 100.0 & 100.0\end{array}$

$\begin{array}{rr}0 . & 0.0 \\ 9575 . & 6.6 \\ 9123 . & 10.5 \\ 7100 . & 25.2\end{array}$

$\begin{array}{lll}0.00 & 0.00 & 0.0 \\ 0.03 & 0.64 & 1.3 \\ 0.03 & 0.71 & 1.6 \\ 0.03 & 0.60 & 1.7\end{array}$

$\begin{array}{rr}2.0 & 2.4 \\ 7.6 & 8.9 \\ 31.4 & 36.2 \\ 47.7 & 53.8 \\ 100.0 & 100.0\end{array}$

$\begin{array}{ll}\text { 8771. } & 16.1 \\ 8738 . & 15.7 \\ 8527 . & 16.6 \\ 8356 . & 17.9 \\ 7396 . & 26.0\end{array}$

$\begin{array}{ll}0.04 & 0.53 \\ 0.03 & 0.50 \\ 0.04 & 0.56 \\ 0.04 & 0.53 \\ 0.03 & 0.48\end{array}$


TABLE XXX

WASHABILITY ANALYSIS SHOWING THE EFFECTS OF CRUSHING ON THE LIBERATION

OF ASH FORMING IMPURITIES AND PYRITIC SULFUR FOF. SAMPLE UA 122

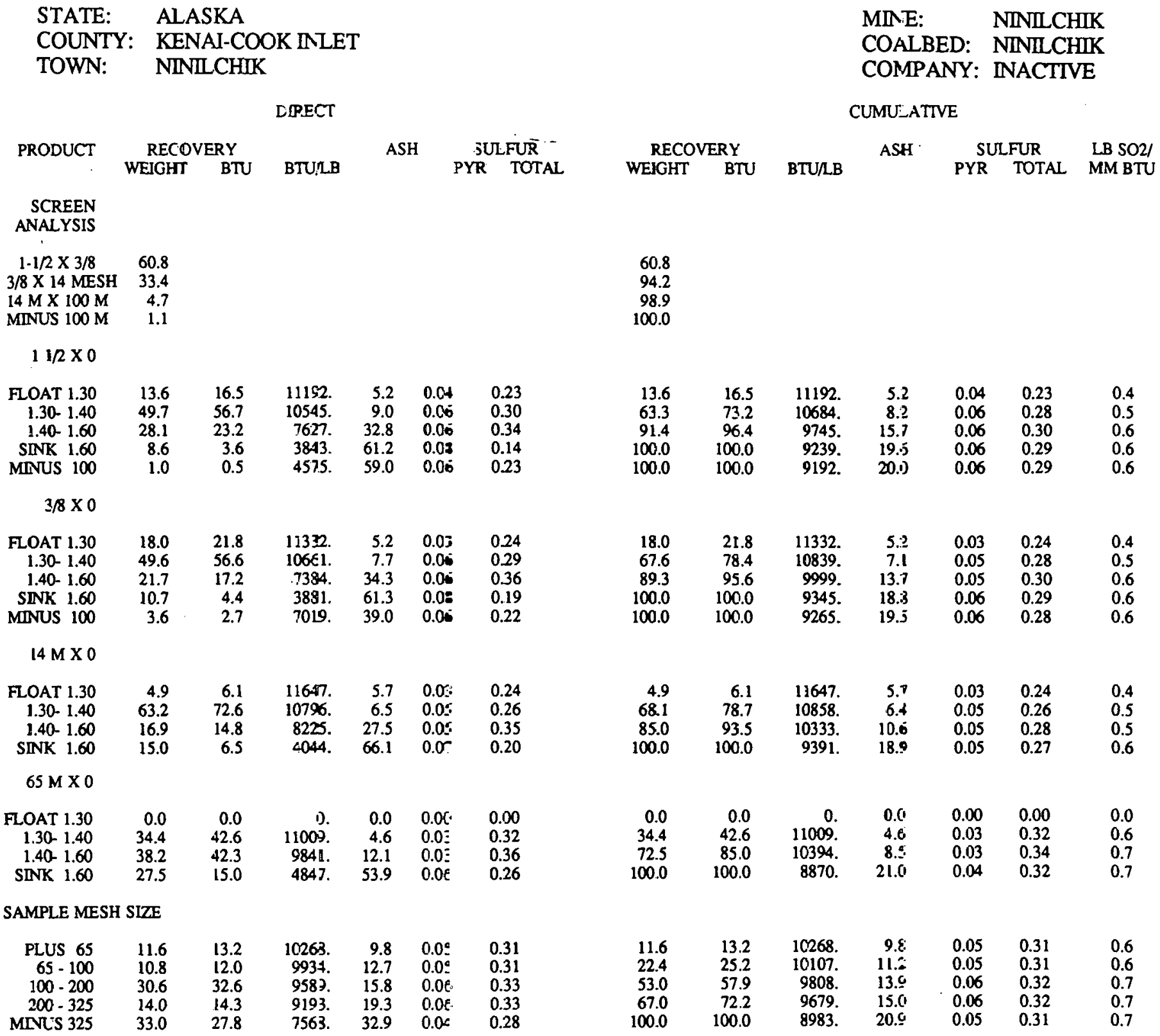


TABLE XXXI

WASHABILITY ANALYSIS SHOWING THE EFFECTS OF CRUSHING ON THE LIBERATION OF ASH FORMING IMPURITIES AND PYRITIC SULFUR FOR SAMPLE UA 123

STATE: ALASKA

COUNTY: MATANUSKA-SUSITNA

TOWN: BROAD PASS

\section{DIRECT}

PRODUCT RECOVERY

WEIGHT BTU BTU/LB

ASH SULFUR

$11 / 2 \times 0$

FLOAT 1.30 $1.30-1.40$

$1.40-1.60$ SINK 1.60 MINUS 100

$\begin{array}{rrrrrr}42.1 & 49.8 & 12823 . & 4.6 & 0.03 & 0.45 \\ 34.0 & 37.3 & 11921 . & 9.2 & 0.03 & 0.52 \\ 11.8 & 10.2 & 9406 . & 24.0 & 0.11 & 0.34 \\ 12.1 & 2.7 & 2381 . & 70.8 & 0.11 & 0.11 \\ 1.2 & 0.6 & 5286 . & 56.1 & 0.03 & 0.35\end{array}$

$3 / 8 \times 0$

FLOAT 1.30

$1.30-1.40$

$1.40-1.60$

SINK 1.60

MINUS 100

$\begin{array}{rr}46.9 & 54.8 \\ 31.5 & 34.0 \\ 9.6 & 8.3 \\ 12.1 & 2.8 \\ 6.2 & 5.3\end{array}$

$\begin{array}{rrrr}12832 . & 4.2 & 0.03 & 0.53 \\ 11874 . & 9.2 & 0.03 & 0.49 \\ 9573 . & 24.5 & 0.11 & 0.38 \\ 2578 . & 68.9 & 0.10 & 0.12 \\ 9421 . & 27.7 & 0.03 & 0.42\end{array}$

$14 \mathrm{M}$ X 0

FLOAT 1.30

1.30- 1.40

$1.40-1.60$

$\begin{array}{rr}30.7 & 36.0 \\ 46.5 & 52.2 \\ 9.9 & 8.8 \\ 129 & 3.0\end{array}$

12886.

12301 .

9746

$\begin{array}{lll}2563 . & 67.2 & 0.08\end{array}$

0.49

0.44

0.37

SINK 1.60

$12.9 \quad 3.0$

$65 \mathrm{M} \mathrm{X} 0$

FLOAT 1.30

1.30- 1.40

$1.40-1.60$

$\begin{array}{rr}1.4 & 1.6 \\ 67.4 & 78.3 \\ 13.4 & 12.9 \\ 17.8 & 7.2\end{array}$

12683.

12305 .

10217.

4288.

$\begin{array}{rrr}3.0 & 0.03 & 0.53 \\ 4.3 & 0.03 & 0.45 \\ 17.2 & 0.04 & 0.49 \\ 57.4 & 0.04 & 0.22\end{array}$

SAMPLE MESH SIZE

$\begin{array}{rrrrrrr}\text { PLUS 65 } & 7.6 & 8.2 & 11548 . & 11.4 & 0.03 & 0.52 \\ 65-100 & 11.0 & 11.8 & 11519 . & 11.6 & 0.03 & 0.50 \\ 100-200 & 33.7 & 35.6 & 11323 . & 12.2 & 0.03 & 0.53 \\ 200-325 & 18.5 & 19.2 & 11130 . & 13.9 & 0.03 & 0.57 \\ \text { MINUS 325 } & 29.4 & 25.1 & 9160 . & 24.9 & 0.03 & 0.42\end{array}$

MINE:

DUNKLE

COALBED: DUNKLE BED

COMPANY: INACTIVE

\section{CUMULATIVE}

RECOVERY

WEIGHT BTU BTU/LB

ASH

SULFUR

LB SO2/

PYR TOTAL MM BTU

$\begin{array}{rrrrrrr}42.1 & 49.8 & 12823 . & 4.6 & 0.03 & 0.45 & 0.7 \\ 76.1 & 87.1 & 12420 . & 6.7 & 0.03 & 0.48 & 0.8 \\ 87.9 & 97.3 & 12016 . & 9.0 & 0.04 & 0.46 & 0.8 \\ 100.0 & 100.0 & 10847 . & 16.5 & 0.05 & 0.42 & 0.8 \\ 100.0 & 100.0 & 10780 . & 17.0 & 0.05 & 0.42 & 0.8\end{array}$

100.

100.0

\section{9}

78.4

87.9

100.0

100.0

\section{8}

88.8

97.2

97.2
100.0

100.0

12832.

12447.

12135.

10980.

10890.

4.2
6.2
8.2
15.5
16.2

$\begin{array}{lll}0.03 & 0.53 & 0.8 \\ 0.03 & 0.51 & 0.8 \\ 0.04 & 0.50 & 0.8 \\ 0.05 & 0.45 & 0.8 \\ 0.05 & 0.45 & 0.8\end{array}$

30.7

30.7
77.2

36.0

36.0
88.2

88.2
97.0

12886

12533.

12218.

4.1
5.8
7.8
15.5

$\begin{array}{ll}0.03 & 0.49 \\ 0.03 & 0.46\end{array}$

$0.04 \quad 0.45$

100.0

100.0

10968.

0.04

0.41

0.8

0.7

1.4

\section{8}

1.6
79.9
92.8

12683

12312.

11970.

10606.

3.0
4.2
6.4
15.4

0.03
0.03

0.53

0.45

0.46

0.42

0.8

100.0

100.0
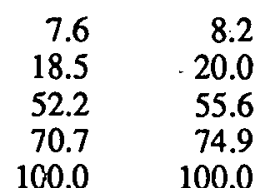

$\begin{array}{ll}11548 . & 11.4 \\ 11531 . & 11.5 \\ 11397 . & 11.9 \\ 11327 . & 12.4 \\ 10691 & 16.1\end{array}$

$\begin{array}{ll}0.03 & 0.52 \\ 0.03 & 0.51 \\ 0.03 & 0.52 \\ 0.03 & 0.53 \\ 0.03 & 0.51\end{array}$

0.9
0.9
0.9
0.9
0.9 
TABLE XXXII

WASHABILITY ANALYSIS SHOWING THE EFFECTS OF CRUSHING ON THE LIBERATION OF' ASH FORMING IMPURITIES AND PYRITIC SULFUR FOR S.MMPLE UA 124

\section{STATE: ALFSKA \\ COUNTY: YUKON FLATS \\ TOWN: CHIIKEN}

DLKECT

PRDDUCT RECOVERY
WEIGHT BTU BTU/LB

ASH SULFUR

SCREEN

NALYSIS

$\begin{array}{cc}1-1.2 \times 3 / 8 & 61 .(1 \\ 3 / B \times 14 \text { MESH } & 34.5\end{array}$

$14 \mathrm{M} \times 100 \mathrm{M}$

MINUS $100 \mathrm{M}$

$11 / 2 \times 0$

FLOAT 1.30

1.30- 1.40

$1.40-1.60$

SINK 1.60
MINUS 100

$\begin{array}{rrrrrr}12.6 & 17.3 & 10666 & 7.0 & 0.03 & 1.26 \\ 28.1 & 34.9 & 9250 & 1.1 .3 & 0.03 & 1.39 \\ 35.4 & 33.8 & 7703 & 27.5 & 0.04 & 1.29 \\ 23.9 & 13.9 & 4337 & 66.1 & 0.06 & 2.49 \\ 1.5 & 0.9 & 4775 & 49.2 & 0.04 & 1.29\end{array}$

$\overrightarrow{\mathrm{I}}$

FLOAT 1.30

$1.30-1.40$

$1.40-1.60$

SINZ 1.60
MINUS 100

$\begin{array}{rr}4.9 & 7.3 \\ 30.9 & 39.3 \\ 37.7 & 38.0 \\ 26.5 & 15.4 \\ 2.8 & 1.8\end{array}$

$\begin{array}{rrrr}\text { 10940. } & 6.4 & 0.03 & -.26 \\ 9338 . & 8.8 & 0.03 & i .28 \\ 7452 . & 24.9 & 0.03 & 1.20 \\ 4236 . & 66.3 & 0.06 & 2.45 \\ 4783 . & 48.6 & 0.04 & (1.84\end{array}$

$14 \mathrm{M} \mathrm{X} 0$

$\begin{array}{rrrrrrr}\text { FLOAT 1.30 } & 3.2 & 4.1 & 10520 . & 5.5 & 0.03 & \text { L.20 } \\ 1.30-1.40 & 28.6 & 34.3 & 9888 . & 6.7 & 0.03 & 1.26 \\ 1.40-1.60 & 44.2 & 38.3 & 7152 & 27.7 & 0.04 & 1.24 \\ \text { SINE 1.60 } & 24.0 & 23.3 & 75 \$ 7 . & 66.2 & 0.06 & 250\end{array}$

$65 \mathrm{M} \times 0$

$\begin{array}{lllllll}\text { FLOAT } 1.30 & 0.0 & 0.0 & \text { J. } & 0.0 & 0.00 & 0.00\end{array}$

$\begin{array}{rrrrrrr}1.36-1.40 & 5.2 & 8.1 & 114 * 4 . & 2.6 & 0.03 & 1.21\end{array}$

$\begin{array}{rrrrrrr}1.40-1.60 & 48.8 & 51.5 & 9285 . & 10.2 & 0.04 & 1.28\end{array}$

SAMPLE MESH SIZE

$\begin{array}{rrrrrrr}\text { PLLS 65 } & 6.6 & 7.7 & 8868 . & 17.3 & 0.06 & 1.11 \\ 65-100 & 11.9 & 13.7 & 86019 . & 18.3 & 0.06 & 1.17 \\ 100-200 & 14.2 & 15.7 & 83: ? . & 20.1 & 0.06 & 1.31 \\ 200-325 & 29.4 & 30.7 & 7343 . & 24.2 & 0.06 & 1 . .2 \\ \text { MINUS 325 } & 38.0 & 3.2 & 6376 . & 37.6 & 0.06 & 0.93\end{array}$

MINE: CHICKEN

COALBED: CHICKEN

CDMPANY: INACTIVE

CUMULATIVE

\begin{tabular}{clcccc}
\multicolumn{2}{c}{ RECOVERY } & & ASH & SULFUR & LB SO2 \\
WEIGHT BTU & BTU/LB & & PYR TOTAL & MM BTU
\end{tabular}

61.0

95.5
98.7

100.0

$\begin{array}{rrrrrrr}12.6 & 17.3 & 10266 . & 7.0 & 0.03 & 1.26 & 2.5 \\ 40.7 & 52.2 & 9564 . & 1 C .0 & 0.03 & 1.35 & 2.8 \\ 76.1 & 86.1 & 8418 . & 18.1 & 0.03 & 1.32 & 3.1 \\ 100.0 & 100.0 & 7442 . & 25.6 & 0.04 & 1.60 & 4.3 \\ 100.0 & 100.0 & 7399 . & 29.9 & 0.04 & 1.60 & 4.3\end{array}$

$\begin{array}{rrrrrrr}4.9 & 7.3 & 10940 . & 64 . & 0.03 & \cdot 1.26 & 2.3 \\ 35.8 & 46.6 & 9602 . & 8.5 & 0.93 & 1.28 & 2.7 \\ 73.5 & 84.6 & 8500 . & 16.9 & 0.73 & 1.24 & 2.9 \\ 100.0 & 100.0 & 7384 . & 3000 & 0.34 & 1.56 & 4.2 \\ 100.0 & 100.0 & 7312 . & 30.5 & 0.34 & 1.54 & 4.2\end{array}$

$\begin{array}{rrrrrrr}3.2 & 4.1 & 10520 . & 5.5 & 0.03, & 1.20 & 2.3 \\ 31.8 & 38.4 & 9951 & 6.5 & 0.03 & 1.25 & 2.5\end{array}$

$\begin{array}{rrrrrrr}76.0 & 38.4 & 9951 . & 6.5 & 0.03 & 1.25 & 2.5 \\ 16.7 & 8324 . & 18.3 & 0.04 & 1.25 & 3.0\end{array}$

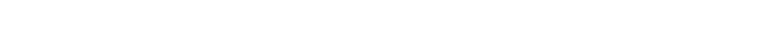

$\begin{array}{rrrrrrr}0.0 & 0.0 & 0 . & 0.0 & 0.60 & 0.00 & 0.0 \\ 5.2 & 8.1 & 11494 . & 2.6 & 0.03 & 1.21 & 2.1 \\ 54.0 & 69.6 & 9494 . & 9.5 & 0.04 & 1.27 & 2.7 \\ 100.0 & 100.0 & 7359 . & 27.8 & 0.06 & 1.64 & 4.4\end{array}$

$\begin{array}{rrlllll}6.6 & 7.7 & 8868 . & 17 . \Xi & 0.05 & 1.11 & 2.5 \\ 18.5 & 21.4 & 8701 . & 18 . \overline{5} & 0.05 & 1.15 & 2.6 \\ 32.7 & 37.1 & 8543 . & 18.5 & 0.05 & 1.22 & 2.9 \\ 62.0 & 67.8 & 8211 . & 21.4 & 0.05 & 1.17 & 2.9 \\ 100.0 & 100.0 & 7515 . & 27.5 & 0.05 & 1.11 & 2.9\end{array}$


TABLE XXXIII

WASHABILITY ANALYSIS SHOWING THE EFFECTS OF CRUSHING ON THE LIBERATION OF ASH FORMING IMPURITIES AND PYRITIC SULFUR FOR SAMPLE UA 125

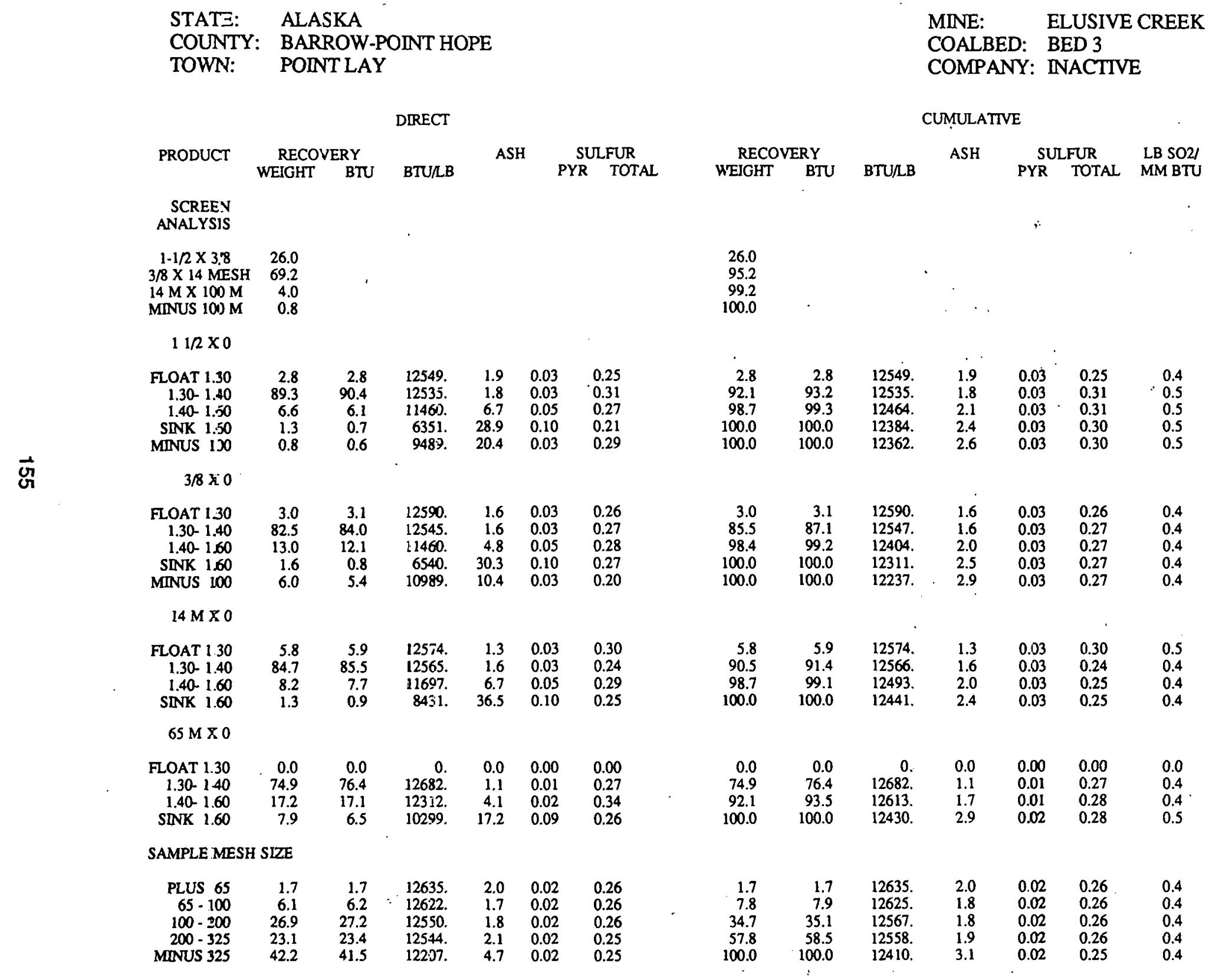


TABLE XXXIV

WASHABILITY ANALYSIS SHOWING THE EFFECTS OF CRUSHING ON THE LIBERATION OF ASH FORMING IMPURITIES AND PYRITIC SULFUR FOR SAMPLE UA 126

STATE: ALASKA

COUNTY: BARROW-POINT HOPE

TOWN:

POINT LAY

DIRECT

PRODUCT

RECOVERY WEIGHT BTU

BTULB

ASH

SULFUR

PYR TOTAL

$11 / 2 \times 0$

FLOAT 1.30

$1.30-1.40$

$1.40-1.60$

SINK 1.60

$\begin{array}{rr}1.9 & 2.1 \\ 79.3 & 83.2 \\ 13.5 & 12.5 \\ 5.3 & 2.3 \\ 1.8 & 1.4\end{array}$

13923

13923.

11876 .

5489 .

10063.

$3 / 8 \times 0$

FLOAT 1.30
$1.30-1.40$
$1.40-1.60$
SINK 1.60
MINUS 100

$\begin{array}{rr}11.9 & 12.8 \\ 72.2 & 75.5 \\ 10.2 & 9.4 \\ 5.7 & 2.3 \\ 2.5 & 2.2\end{array}$

14 M X 0

FLOAT 1.30

$1.40-1.60$

SINK 1.60

$\begin{array}{rr}1.6 & 1.8 \\ 80.6 & 84.5 \\ 12.5 & 11.6 \\ 5.3 & 2.1\end{array}$

14239

13765.

13451 .

11868

5325.

11307

14239.

11840

5087.

$65 \mathrm{M} X 0$

FLOAT 1.30

1.30- 1.40

1.40- 1.60

SINK 1.60

$\begin{array}{rr}5.6 & 6.3 \\ 68.5 & 72.7 \\ 14.5 & 14.1\end{array}$

14426

13588 .

12401.

7778 .

\begin{tabular}{ll}
1.0 & 0.02 \\
1.5 & 0.02 \\
8.1 & 0.02 \\
\hline
\end{tabular}

40.8

0.01

SAMPLE MESH SIZE

$$
\begin{array}{r}
\text { PLUS } 65 \\
65-100 \\
100-200 \\
200-325
\end{array}
$$

MINUS 325

2.2
6.9
27.8
21.3
41.8

2.2
7.0
28.5
21.9
40.5

12911.

12962.

13094.

13103.

12388 .
0.23
0.16
MINE:

KOKOLIK RIVER

COALBED: 11.5 FT BED

COMPANY: INACTTVE

\section{CUMULATIVE}

RECOVERY

WEIGHT BTU BTU/LB

ASH

SULFUR

LB SO2/

PYR TOTAL MMBTU

$\begin{array}{rrrrrrr}1.9 & 2.1 & 13923 . & 2.2 & 0.03 & 0.18 & 0.3 \\ 81.3 & 85.3 & 13446 . & 2.6 & 0.03 & 0.27 & 0.4 \\ 94.7 & 67.7 & 13223 . & 3.6 & 0.03 & 0.26 & 0.4 \\ 100.0 & 160.0 & 12814 . & 6.2 & 0.03 & 0.25 & 0.4 \\ 100.0 & 160.0 & 12766 . & 6.5 & 0.03 & 0.25 & 0.4\end{array}$

$\begin{array}{lllllll}100.0 & 160.0 & 12766 & 6.5 & 0.03 & 0.25 & 0.4\end{array}$

$\begin{array}{rrrrrrr}11.9 & 12.8 & 13765 . & 2.3 & 0.03 & 0.23 & 0.3 \\ 84.2 & \$ 8.3 & 13496 . & 3.2 & 0.03 & 0.29 & 0.4 \\ 94.4 & 97.7 & 13320 . . & 4.0 & 0.03 & 0.28 & 0.4 \\ 100.0 & 100.0 & 12868 . & 6.8 & 0.03 & 0.27 & 0.4 \\ 100.0 & 100.0 & 12830 . & 6.9 & 0.03 & 0.27 & 0.4\end{array}$

100.0

12830.

\section{6}

82.2
94.8

1.8
85.3

85.3
97.9

14239.

13420.

13211.

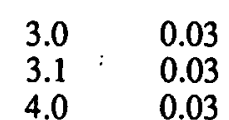

0.31

0.25

100.0

103.0

12785.

6.9

0.03

0.24

0.4

0.4

0.4
0.4

5.6
74.0
88.6
100.0

5.3
79.0
93.1

14426.

13651 .

13446.

12798.

1.0
1.5
2.6
7.0

0.02

0.02

$\begin{array}{ll}0.02 & 0.26\end{array}$

$0.02 \quad 0.24$

\section{4}

0.4

100.0

$\begin{array}{rr}2.2 & 2.2 \\ 9.1 & 0.2 \\ 36.9 & 3.7 \\ 58.2 & 50.5 \\ 100.0 & 100.0\end{array}$

$\begin{array}{ll}12911 . & 7.1 \\ 12950 . & 6.9 \\ 13059 . & 5.8 \\ 13075 . & 5.6 \\ 12788 . & 7.2\end{array}$

$\begin{array}{ll}0.02 & 0.27 \\ 0.02 & 0.28 \\ 0.02 & 0.28 \\ 0.02 & 0.28 \\ 0.02 & 0.27\end{array}$

0.4
0.4
0.4
0.4

0.4 


\section{TABLE XXXV}

WASHABILITY ANALYSIS SHOWING THE EFFECTS OF CRUSHING ON THE LIBERATION

OF ASH FORMING IMPURITIES AND PYRITIC SULFUR FOR SAMPLE UA 127

$\begin{array}{ll}\text { STATE: } & \text { ALASKA } \\ \text { COUNTY: } & \text { KENAI-COOK INLET } \\ \text { TOWN: } & \text { TYONEK }\end{array}$

DIRECT

PRODUCT

RECOV'ERY

WEISHT BTU BTU/LB

ASH

SULFUR

PYR TOTAL

$11 / 2 \times 0$

FLOAT 1.30

1.30- 1.40

$1.40-1.60$

SINK 1.60

$\begin{array}{rr}0.9 & 0.9 \\ 71.8 & 78.4 \\ 21.4 & 17.6 \\ 6.0 & 3.1 \\ 1.8 & 1.2\end{array}$

$\begin{array}{rrrr}\text { 10447. } & 5.9 & 0.03 & 0.24 \\ 10661 . & 8.0 & 0.03 & 0.19 \\ \text { 8069. } & 27.3 & 0.03 & 0.16 \\ \text { 5047. } & 56.5 & 0.03 & 0.13 \\ \text { 6194. } & 42.3 & 0.04 & 0.15\end{array}$

$3 / 8 \times 0$

FLOAT 130

$1.30-1.40$

$1.40-1.60$

SINK 1.60

MINUS 100

$\begin{array}{rr}26.6 & 30.6 \\ 47.0 & 49.3 \\ 10.6 & 16.8 \\ 6.7 & 3.3 \\ 1.9 & 1.4\end{array}$

$\begin{array}{lll}11115 . & 3.8 & 0.03 \\ 10125 & 9.6 & 0.03\end{array}$

$\begin{array}{lrr}10125 . & 9.6 & 0.03 \\ 8 & \end{array}$

8242. $25.4 \quad 0.03$

4699. $54.1 \quad 0.03$

$\begin{array}{lll}\text { 6956. } & 36.4 & 0.04\end{array}$

0.19

0.15

0.10

0.11
0.15

14 M X 0

100.0

26.6
73.6

93.3

100.0

100.

100.0

FLOAT 1.30
$1.30-1.40$
$1.40-1.60$
SINK 1.60

19.5

27.4

$51.9 \quad 47.2$

SINK 1.60

$\begin{array}{rrr}11782 . & 3.8 & 0.03 \\ 10860 . & 7.6 & 0.01 \\ 8937 . & 21.5 & 0.03 \\ 5072 . & 46.6 & 0.03\end{array}$

0.17

0.17

0.19

0.17

$65 \mathrm{M} \mathrm{X} 0$

FLOAT 1.30
$1.30-1.40$
$1.40-1.60$
SINK 1.60

0.7
39.3
50.3
9.8

0.9
45.6
47.8
5.7

12264.
11225.
9173.

5678.

$\begin{array}{rr}2.6 & 0.02 \\ 4.6 & 0.02 \\ 17.7 & 0.02 \\ 49.0 & 0.02\end{array}$

0.28

0.26

0.25

0.24

SAMPLE MESH SLZZE

$\begin{array}{rrrrrrr}\text { PLUS 65 } & 7.7 & 8.1 & 10073 . & 11.4 & 0.03 & 0.25 \\ 65-100 & 7.6 & 8.0 & 10174 . & 10.4 & 0.02 & 0.25 \\ 100-200 & 29.7 & 30.9 & 9971 . & 12.0 & 0.03 & 0.25 \\ 200-325 & 15.2 & 15.7 & 9909 . & 13.7 & 0.02 & 0.25 \\ \text { MINUS 325 } & 39.8 & 37.2 & 8969 . & 20.5 & 0.02 & 0.22\end{array}$

RECOVERY

MINE: BELUGA COAL

COALBED: CAPPS

COMPANY: BELUGA COAL CO

\section{CUMULATIVE}

RECOVERY
WEIGHT BTU

BTU/LB

ASH

SULFUR

LB SO2/

PYR TOTAL MMBTU

$\begin{array}{rr}0.9 & 0.9 \\ 72.7 & 79.3 \\ 94.0 & 96.9 \\ 100.0 & 100.0 \\ 100.0 & 100.0\end{array}$

$\begin{array}{rr}10447 . & 5.9 \\ 10658 . & 8.0 \\ 10070 . & 12.3 \\ 9770 . & 15.0 \\ 9706 . & 15.5\end{array}$

$\begin{array}{ll}0.03 & 0.24 \\ 0.03 & 0.19 \\ 0.03 & 0.18 \\ 0.03 & 0.18 \\ 0.03 & 0.18\end{array}$

0.5

0.4

100.0

30.6
80.0
96.7
100.0
100.0

$\begin{array}{rr}11115 . & 3.8 \\ 10483 . & 7.5 \\ 10011 . & 11.3 \\ 9654 . & 14.2 \\ 9605 . & 14.6\end{array}$

$0.03 \quad 0.19$

$0.03 \quad 0.16$

$0.03 \quad 0.15$

$0.03 \quad 0.15$

$0.03 \quad 0.15$

0.3

0.3
0.3

$\begin{array}{rrrrrrr}19.5 & 23.4 & 11782 . & 3.8 & 0.03 & 0.17 & 0.3 \\ 44.4 & 50.9 & 11266 . & 5.9 & 0.02 & 0.17 & 0.3 \\ 96.2 & 98.0 & 10011 . & 14.4 & 0.02 & 0.18 & 0.4 \\ 100.0 & 100.0 & 9824 . & 15.6 & 0.03 & 0.18 & 0.4\end{array}$

0.7

39.9

90.2

100.0

0.9
46.5
94.3
100.0

$\begin{array}{rr}12264 . & 2.6 \\ 11242 . & 4.6 \\ 10089 . & 11.9 \\ 9658 . & 15.5\end{array}$

$\begin{array}{ll}0.02 & 0.28 \\ 0.02 & 0.26 \\ 0.02 & 0.25 \\ 0.02 & 0.25\end{array}$

0.5

0.5

0.5

0.5

$\begin{array}{rrrrrrr}7.7 & 8.1 & 10073 . & 11.4 & 0.03 & 0.25 & 0.5 \\ 15.3 & 16.1 & 10123 . & 10.9 & 0.03 & 0.25 & 0.5 \\ 45.0 & 47.0 & 10023 . & 11.6 & 0.03 & 0.25 & 0.5 \\ 60.2 & 62.8 & 9994 . & 12.2 & 0.03 & 0.25 & 0.5 \\ 100.0 & 100.0 & 9586 . & 15.5 & 0.02 & 0.24 & 0.5\end{array}$


TABLE XXXVI

WASHABILITY ANALYSIS SHOWING THE EFFECTS OF CRUSHING ON THE LIBERATION OF ASH FORMING IMPURITIES AND PYRITIC SULFUR FOR SAMPLE UA 128

$\begin{array}{ll}\text { STATE: } & \text { AIASKA } \\ \text { COUNTY: } & \text { KOYUKUK-MIDDLE YUKON } \\ \text { IOWN: } & \text { KOYUKUK }\end{array}$

DIRECT

PRODUCT RECOVERY WEIGHT BTU BTLILB
ASH

SULFUR
PYR TOTAL
MINE:

COMPANY: INACTIVE

CUMLL:TIVE

$$
\begin{array}{r}
23.6 \\
94.1 \\
99.3 \\
100.0
\end{array}
$$$$
\begin{aligned}
& \text { RECOVERY } \\
& \text { WEIGHT }
\end{aligned}
$$

BTU/LB

ASH SULFUR PעR TOTAL MM BTU

ANALYYIS

$\begin{array}{lr}1.1 / 2 \times 3 / 8 & 23.6 \\ 38 \times 14 \text { MESH } & 70.5\end{array}$

$14 \mathrm{M} \mathrm{X} 100 \mathrm{M} \quad 5.2$

MINCS $100 \mathrm{M} \quad 0.7$

$11 / 2 \times 0$

FLOAT 1.30

1.31)- 1.40

SiNK 1.60

MINUIS 100

$\begin{array}{rrrrrr}5.9 & 14.3 & 14: 68 . & 5.7 & 0.05 & 0.94 \\ 10.4 & 24.7 & 141.8 . & 7.6 & 0.05 & 0.94 \\ 2.8 & 4.9 & 10493 . & 28.9 & 0.08 & 1.17 \\ 80.9 & 56.2 & 4 k 3 . & 72.8 & 0.05 & 0.51 \\ 0.7 & 1.0 & 8799 . & 37.3 & 0.05 & 1.26\end{array}$

ज़

$3 / 8 \times 0$

FLOAT 1.30

$1.30-1.40$
$1.40-1.60$

$1.40-1.60$
SINE 1.60

MINUS 100

$\begin{array}{rrrrrr}3.6 & 9.1 & 146016 . & 4.4 & 0.05 & 1.01 \\ 8.0 & 19.5 & 13958 . & 7.2 & 0.05 & 0.94 \\ 4.9 & 9.4 & 11050 . & 25.5 & 0.08 & 0.94 \\ 83.5 & 52.0 & 4259 . & 77.4 & 0.10 & 0.43 \\ 2.9 & 4.2 & 8378 . & 41.0 & 0.05 & 1.25\end{array}$

$14 \mathrm{M} \times 0$

FLOAT 1.30
$1.30-1.40$

$1.40-1.60$

$\begin{array}{rrrrrr}0.7 & 2.0 & 14734 . & 4.4 & 0.05 & 0.91 \\ 2.4 & 6.6 & 14472 . & 4.5 & 0.05 & 0.91 \\ 5.6 & 12.9 & 12033 . & 14.1 & 0.08 & 0.81 \\ 91.3 & 78.6 & 45.40 . & 69.8 & 0.10 & 0.58\end{array}$

$65 \mathrm{M} \mathrm{X} 0$

FLOAT 1.30

$1.30-1.40$

$1.40-1.60$

2.2
10.1
8.9

$1.40-1.60$
SINK 1.60

10.1
8.9
78.8

6.4
25.2
19.1
49.3

14784. $2.5 \quad 0.02$

$\begin{array}{lll}12903 . & 6.8 & 0.02\end{array}$

$\begin{array}{ccc}11107 . & 25.5 & 0.05 \\ 3220 & 74.7 & 0.25\end{array}$

0.84

SAMPLE MESH SIZE

$\begin{array}{rrrrrrr}\text { PLLS 65 } & 1.0 & 0.9 & 46 \pi 7 . & 65.6 & 0.16 & 0.67 \\ 65-100 & 5.0 & 4.8 & 4918 . & 64.2 & 0.16 & 0.64 \\ 100-200 & 16.7 & 19.8 & 6020 . & 58.1 & 0.17 & 0.69 \\ 200-325 & 12.4 & 11.1 & 457 . & 67.9 & 0.18 & 0.72 \\ \text { MINUS 325 } & 65.0 & 63.4 & 4978 . & 64.6 & 0.16 & 0.86\end{array}$

$\begin{array}{rrrrrrr}5.9 & 14.3 & 14368 . & 5.7 & 0.05 & 0.94 & 1.3 \\ 16.4 & 39.0 & 14209 . & 6.9 & 0.05 & 0.94 & 1.3 \\ 19.1 & 43.8 & 13672 . & 10.1 & 0.05 & 0.97 & 1.4 \\ 100.0 & 100.0 & 5965 . & 60.3 & 0.05 & 0.60 & 2.0 \\ 100.0 & 100.0 & 5984 . & 60.5 & 0.05 & 0.60 & 2.0\end{array}$

$\begin{array}{rrrrrrr}3.6 & 9.1 & 14606 . & 4.7 & 0.15 & 1.01 & 1.4 \\ 11.6 & 28.6 & 14186 . & 6.7 & 0.15 & 0.96 & 1.4 \\ 16.5 & 38.0 & 13243 . & 12.9 & 0.66 & 0.96 & 1.4 \\ 100.0 & 100.0 & 5738 . & 66.5 & 0.09 & 0.52 & 1.8 \\ 100.0 & 100.0 & 5812 . & 65.9 & 0.09 & 0.54 & 1.8\end{array}$

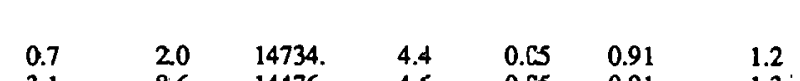

$\begin{array}{rrrrrrr}3.1 & 8.6 & 14476 . & 4.5 & 0.65 & 0.91 & 1.3 \\ 8.7 & 21.4 & 12940 . & 10.7 & 0.67 & 0.85 & 1.3\end{array}$

$\begin{array}{rrrrrrr}8.7 & 21.4 & 12940 . & 10.9 & 0.07 & 0.85 & 1.3 \\ 100.0 & 100.0 & 5274 . & 64.6 & 0.10 & 0.60 & 2.3\end{array}$

$\begin{array}{rrrrrrr}2.2 & 6.4 & 14784 . & 2.5 & 0.02 & 0.86 & 1.2 \\ 12.3 & 31.6 & 13244 . & 6 . C & 0.02 & 0.84 & 1.3 \\ 21.2 & 50.7 & 12348 . & 14.2 & 0.03 & 0.93 & 1.5 \\ 100.0 & 100.0 & 5162 . & 61.8 & 0.211 & 0.74 & 2.9\end{array}$

$\begin{array}{rrrllll}1.0 & 0.9 & 4677 . & 65.6 & 0.16 & 0.67 & 2.9 \\ 5.9 & 5.7 & 4879 . & 64.4 & 0.16 & 0.64 & 2.6 \\ 22.6 & 25.4 & 5727 . & 59.8 & 0.17 & 0.68 & 2.4 \\ 35.0 & 36.6 & 5319 . & 62.6 & 0.17 & 0.69 & 2.6 \\ 100.0 & 100.0 & 5098 . & 63.9 & 0.17 & 0.76 & 2.9\end{array}$


TABLE XXXVII

WASHABILITY ANALYSIS SHOWING THE EFFECTS OF CRUSHING ON THE LIBERATION

OF ASH FORMING IMPURITIES AND PYRITIC SULFUR FOR SAMPLE UA 129

STATE: ALASKA

COUNTY: KOYUKUK-MIDDLE YUKON

TOWN: HEALY

DIRECT

RECOVERY
MEIGHT BTU BTU/LB

ASH

SULFUR
PYR TOTAL

SCREEN
ANALYSIS

$1-1 / 2 \times 3 / 8 \quad 56.6$

$3 / 8 \times 14$ MESH 40.6

$14 \mathrm{M} \times 100 \mathrm{M} \quad 1.6$

$11 / 2 \times 0$

FLOAT 130

1.30- 1.40

$1.30-1.40$
$1.40-1.60$

SINK 160

MINUS 100

7.1
76.3
10.3
6.3
1.2

8.0
81.6
8.0
2.5
0.7

11405.

10807.
7875.

3956.

$3 / 8 \times 0$

FLOAT 1.30

$1.30-1.40$

$1.40-1.60$

SINK 1.60

$\begin{array}{rr}59.3 & 65.6 \\ 26.9 & 25.7 \\ 6.8 & 5.7 \\ 6.9 & 3.0 \\ 2.5 & 2.4\end{array}$

$\begin{array}{rrrr}11186 . & 9.9 & 0.01 & 0.19 \\ 9646 . & 14.9 & 0.01 & 0.21 \\ 8442 . & 26.3 & 0.03 & 0.26 \\ 4387 . & 66.4 & 0.03 & 0.19 \\ \text { 9544. } & 17.2 & 0.04 & 0.24\end{array}$

$14 \mathrm{M} \approx 0$

FLOAT 1.30
$1.30-1.40$
$1.40-1.60$
SINK 1.60

$\begin{array}{rrrrrr}10.8 & 12.8 & 11562 . & 6.9 & 0.01 & 0.17 \\ 64.4 & 68.5 & 10455 . & 9.4 & 0.01 & 0.19 \\ 15.9 & 14.7 & 9116 . & 19.8 & 0.03 & 0.23 \\ 8.9 & 4.0 & 4349 . & 70.1 & 0.03 & 0.12\end{array}$

$65 \mathrm{M}=0$

\section{FLOAT 1.30
$1.30-1.40$}

$1.40-1.60$
SINK 1.60

32.7
12.2
35.4
19.7$$
\begin{aligned}
& 38.1 \\
& 14.2 \\
& 36.9 \\
& 10.7
\end{aligned}
$$

\section{7}

SAMPLE MESH SIZE

$\begin{array}{rllllll}\text { PLUS 65 } & 12.3 & 12.9 & 10050 . & 13.1 & 0.01 & 0.28 \\ 65-100 & 10.4 & 10.8 & 9971 . & 12.4 & 0.01 & 0.27 \\ 100-200 & 28.2 & 29.5 & 9994 . & 13.7 & 0.01 & 0.26 \\ 200-325 & 16.4 & 16.8 & 9815 . & 14.7 & 0.01 & 0.26 \\ \text { MINUS 325 } & 32.8 & 29.9 & 8711 . & 23.8 & 0.01 & 0.27\end{array}$

$\begin{array}{lll}6.9 & 0.01 & 0.17\end{array}$

$\begin{array}{lll}.2 & 0.03 & 0.27\end{array}$

$\begin{array}{ll}.2 & 0.03 \\ 7.2 & 0.03\end{array}$

0.27
0.15

0.15

MINUS 325

$\begin{array}{llll}8711 . & 23.8 & 0.01 & 0.27\end{array}$
MINE:

USIBELLI

COALBED: NO. ONE

COMPANY: USIBELLI COAL CO.

CUMULATIVE

\begin{tabular}{cccccc}
\multicolumn{2}{c}{ RECOVERY } & & ASH & SULFUR & LB SO2/ \\
WEIGHT & BTU & BTU/LB & & PYR TOTAL & MM BTU
\end{tabular}

56.6

56.6
97.2
98.8

100.0

83.4
93.7

93.7
100.0

100.0

$8.0 \quad 11405$

89.5
97.5

97.5
100.0

100.0

10858

$10531 . \quad 10.0$

$\begin{array}{llll}10531 . & 12.3 & 0.01 & 0.17 \\ 10114 . & 16.2 & 0.01 & 0.17 \\ 10068 . & 16.6 & 0.01 & 0.17\end{array}$

0.3

0.3

$\begin{array}{rrrrrrr}59.3 & 65.6 & 11186 . & 9.9 & 0.01 & 0.19 & 0.3 \\ 86.2 & 91.3 & 10705 . & 11.5 & 0.01 & 0.20 & 0.4 \\ 93.1 & 97.0 & 10539 . & 12.6 & 0.01 & 0.20 & 0.4 \\ 100.0 & 100.0 & 10111 . & 16.3 & 0.01 & 0.20 & 0.4 \\ 100.0 & 100.0 & 10097 . & 16.4 & 0.01 & 0.20 & 0.4\end{array}$

$\begin{array}{lllllll}10.8 & 12.8 & 11562 . & 6.9 & 0.01 & 0.17 & 0.3\end{array}$

$\begin{array}{rrrrrrr}75.2 & 81.3 & 10614 . & 9.1 & 0.01 & 0.19 & 0.4 \\ 91.1 & 96.0 & 10353 . & 10.9 & 0.01 & 0.19 & 0.4 \\ 100.0 & 100.0 & 9817 . & 16.2 & 0.01 & 0.19 & 0.4\end{array}$


TABLE XXXVIII

WASHABILITY ANALYSIS SHOWING THE EFFECTS OF CRUSHING ON THE LIBERATION OF ASH FORMING IMPURITIES AND PYRITIC SULFUR FOR SAMPLE UA 130

STATE: ALASKA

COUNTY: KOYUKUF-MIDDLE YUKON'

TOWN: HEALY

[IRECT

?RODUCT RECOVERY WEGHT BTU BTU/LB
MINE:

CCIALBED: NO. THREE

COMFANY: USIBELLI COAL CO.

CUMU_ATIVE

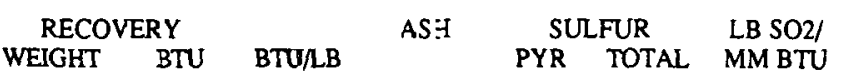

$\begin{array}{lrr}\text { SCREEN } & & \\ \text { ANALYSIS } & & \\ & & \\ -1 / 2 \times 3 / 8 & 82.9 & 82.9 \\ 3 / 8 \times 14 \text { MESH } & 14.0 & 96.9 \\ 14 \mathrm{M} \times 100 \mathrm{M} & 1.7 & 98.6 \\ \text { MNUS } 100 \mathrm{M} & 1.4 & 100.0\end{array}$

$11 / 2 \times 0$

FLOAT 1.30

$1.30-1.40$

$1.40-1.60$

SINK 1.60

$\begin{array}{rr}16.1 & 17.2 \\ 69.1 & 72 . \\ 6.6 & 5.2 \\ 8.2 & 4.5 \\ 1.4 & 0.5\end{array}$

17.7
72.5
5.1
4.5

$-1466$.

-0881.
7973.

$\begin{array}{ll}6.6 & 0.01\end{array}$

13.40 .010 .13

$\begin{array}{llll}6194 & 68.8 & 0.01 & 0.28\end{array}$

MEUS 100

$3 / 8 \times 0$

FLOAT 1.30
$0.30-1.40$
I.40- 1.60
SLNK 1.60

$\begin{array}{rrrrrr}12.6 & 14.3 & 11556 & 4.4 & 0.01 & 0.16 \\ 73.1 & 77.6 & 10852 . & 6.8 & 0.0 & 0.21 \\ 4.8 & 3.9 & 8259 . & 23.5 & 0.01 & 0.26 \\ 9.5 & 4.3 & 4634 . & 66.3 & 0.01 & 0.12 \\ 3.2 & 2.7 & 8557 . & 24.5 & 3.01 & 0.17\end{array}$

MINUS 100

$14 \mathrm{MXO}$

FLDAT 1.30
$-30-1.40$

$.30-1.40$
$: .40-1.60$

$\vdots .40-1.60$
SINK 1.60

$\begin{array}{rrrrrr}15.3 & 17.2 & 11659 . & 4.6 & 3.01 & 0.15 \\ 68.4 & 72.1 & 1.0924 . & 9.1 & 1.03 & 0.16 \\ 9.1 & 7.9 & 2023 . & 17.9 & 1.01 & 0.23 \\ 7.2 & 2.8 & 3988 . & 70.9 & 0.01 & 0.10\end{array}$

65 M X 0

FLOAT 1.30

L $30-1.40$

L $40-1.60$
SLVK 1.60

1.0
50.5
36.2

1.0
50.5
36.2
12.2

1.1
54.8

54.8
36.5
7.5

1.:559.

1.262.
10477.
6362

$\begin{array}{ll}2.1 & 0.02 \\ 4.3 & 0.04\end{array}$

$\begin{array}{ll}4.3 & 0.04 \\ 6.8 & 0.03\end{array}$

SAMPLE MESH SIZE

$\begin{array}{rrrllll}\text { FLUS 65 } & 6.9 & 7.7 & 15121 . & 12.6 & C .04 & 0.24 \\ 65-100 & 10.4 & 10.5 & 10721 . & 13.2 & C .02 & 0.11 \\ -00-200 & 32 . & 33.6 & 16871 . & 13.8 & C 02 & 0.14 \\ 200-325 & 15.3 & 15.2 & 1(606 . & 13.2 & C 02 & 0.12 \\ \text { MLNUS 325 } & 34.7 & 33.1 & 1 C 176 . & 13.6 & C 02 & 0.19\end{array}$

82.9
96.9

98.6
100.0

$\begin{array}{rrrrrrr}16.1 & 17.7 & 11466 . & 4.6 & 0.01 & 0.09 & 0.2 \\ 85.2 & 90.1 & 10991 . & 6.4 & 0.03 & 0.12 & 0.2 \\ 91.8 & 95.1 & 10774 . & 6.5 & 0.03 & 0.13 & 0.2 \\ 100.0 & 100.0 & 10400 . & 12.6 & 0.03 & 0.15 & 0.3 \\ 100.0 & 100.0 & 10354 . & 12.3 & 0.03 & 0.15 & 0.3\end{array}$

$\begin{array}{rrrrrrr}12.6 & 14.3 & 11556 . & 4.4 & 0.01 & 0.16 & 0.3 \\ 85.8 & 91.9 & 10956 . & 6.4 & 0.03 & 0.20 & 0.4 \\ 90.5 & 95.7 & 10814 . & 7.3 & 0.03 & 0.21 & 0.4 \\ 100.0 & 100.0 & 10229 . & 12.9 & 0.02 & 0.20 & 0.4 \\ 100.0 & 100.0 & 10177 . & 13.3 & 0.02 & 0.20 & 0.4\end{array}$

$\begin{array}{rrrrrrr}15.3 & 17.2 & 11659 . & 4.6 & 0.01 & 0.15 & 0.3 \\ 83.8 & 89.4 & 11058 & 8.3 & 0.03 & 0.16 & 0.3 \\ 92.8 & 97.2 & 10860 . & 9.2 & 0.02 & 0.17 & 0.3 \\ 100.0 & 100.0 & 10366 . & 13.7 & 0.02 & 0.16 & 0.3\end{array}$

$\begin{array}{rrrrrrr}1.0 & 1.1 & 11599 . & 2.1 & 0.02 & 0.14 & 0.2 \\ 51.6 & 56.0 & 11268 . & 4.3 & 0.04 & 0.14 & 0.2 \\ 87.8 & 92.5 & 1094 . & 5.3 & 0.04 & 0.14 & 0.3 \\ 100.0 & 100.0 & 10382 . & -3.0 & 0.03 & 0.15 & 0.3\end{array}$

$\begin{array}{rrrrrrr}6.8 & 7.7 & 12127 . & 12.6 & 0.04 & 0.24 & 0.4 \\ 17.2 & 18.2 & 11277 . & 129 & 0.03 & 0.16 & 0.3 \\ 50.1 & 51.8 & 11009 . & 13.5 & 0.02 & 0.15 & 0.3 \\ 65.4 & 66.9 & 10915 . & 13.4 & 0.02 & 0.14 & 0.3 \\ 100.0 & 100.0 & 10659 . & 13.5 & 0.02 & 0.15 & 0.3\end{array}$


TABLE XXXIX

WASHABILITY ANALYSIS SHOWING THE. EFFECTS OF CRUSHING ON THE LIBERATION OF ASH FORMING IMPURITIES AND PYRITIC SULFUR FOR SAMPLE UA 131

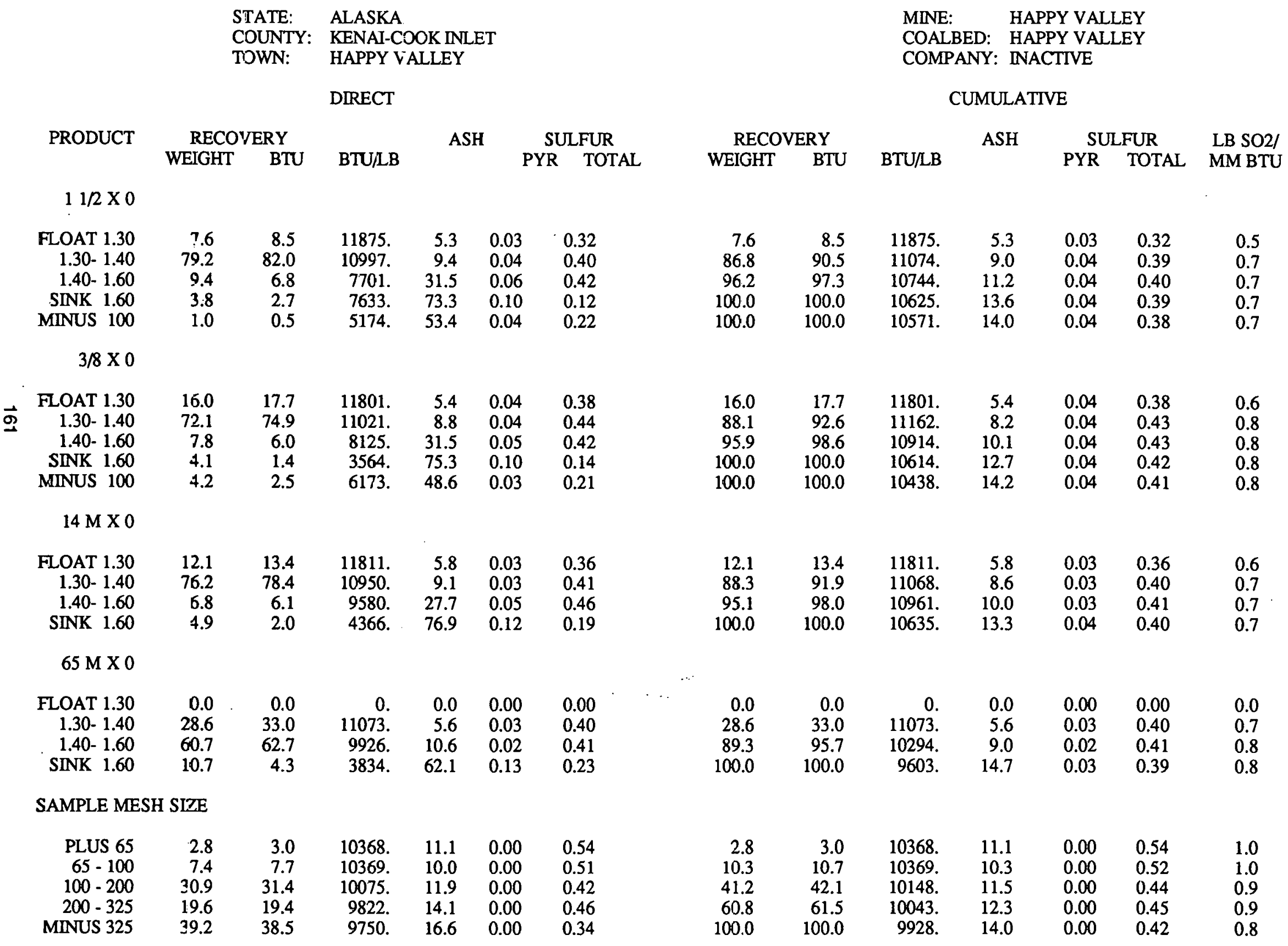


TABLE XL

WASHABILITY ANALYSIS SHOWING THE EFFECTS OF CRUSHING ON THE LIBERATION OF ASH FORMING IMFURITIES AND PYRITIC SULFUR FOR SAMPLE UA 132

\begin{abstract}
STATE: ALASKA
COUNTY: KOYUKUK MIDDLE YUKON

TOWV: MCKINLEY VILLAGE
\end{abstract}

DIRECT

PRODUCT

RECOVERY
WEIGHT BTU

BTU/LB

ASH SULFUR
PYR TOTAL

$11 / 2 \times 0$

\section{FLOAT 1.30}

1.30- 1.40

1.40- 1.60

SINK 1.60

MINUS 100

$\begin{array}{rr}0.1 & 0.1 \\ 10.8 & 20.8 \\ 24.5 & 37.5 \\ 64.7 & 41.2 \\ 1.4 & 1.5\end{array}$

$\begin{array}{rrrr}13004 . & 6.4 & 0.03 & 0.38 \\ 12895 . & 6.8 & 0.03 & 0.35 \\ 10298 . & 23.9 & 0.03 & 0.33 \\ 4234 . & 71.3 & 0.09 & 0.14 \\ 6940 . & 44.4 & 0.03 & 0.26\end{array}$

$3 / 8 \times 0$

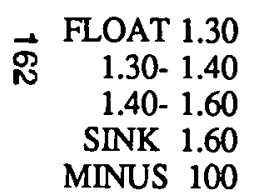

6.4
13.9
17.2
62.4
3.1

12.8
25.9
26.2
35.1
2.1

$\begin{array}{rrr}\text { 13609. } & 4.0 & 3.03 \\ 12765 . & 7.3 & 0.03 \\ 1037 . & 23.6 & 0.03 \\ 3837 . & 77.0 & 0.07 \\ 454 \mathrm{C} . & 53.8 & 0.03\end{array}$

0.41
0.45
0.35
0.12
0.48

$14 \mathrm{M} \mathrm{X} 0$

FLOAT 1.30
$1.30-1.40$
$1.40-1.60$
SINK 1.60

0.0
3.0
23.2
73.8

0.0
6.5
41.1
52.3

$\begin{array}{rrrr}0 . & 0.0 & 0.00 & 0.00 \\ \text { i.3529. } & 4.0 & 0.03 & 0.41 \\ 11099 . & 17.5 & 0.03 & 0.37 \\ 4445 & 67.7 & 0.06 & 0.12\end{array}$

$65 \mathrm{M} \mathrm{X0}$

FLOAT 1.30
$1.30-1.40$

$1.40-1.60$

$\begin{array}{rr}0.0 & 10.0 \\ 15.6 & 35.3 \\ 16.3 & 23.2 \\ 68.1 & 35.6\end{array}$

$\begin{array}{rrrr}0 . & 0.0 & (1.00 & 0.00 \\ 13263 . & 4.3 & C .05 & 0.44 \\ 10165 . & 24.5 & C .05 & 0.37 \\ 3154 . & 72.4 & C .07 & 0.13\end{array}$

SAMPLE MESH SIZE

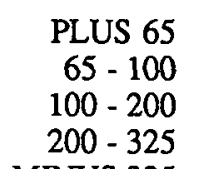

$200-325$
MINUS 325

17.3
7.1
21.1
13.0
41.6

$\begin{array}{rllll}17.3 & 5657 . & 53.2 & 0.06 & 0.22 \\ 6.7 & 5407 . & 53.5 & 0.06 & 0.22 \\ 24.5 & 5575 . & 47.2 & 0.06 & 0.24 \\ 16.7 & 7273 . & 44.4 & 0.06 & 0.26 \\ 34.8 & 7742 . & 60.2 & 0.104 & 0.19\end{array}$

MINE:

COMPANY: INACTIVE

\section{CUMULATIVE}

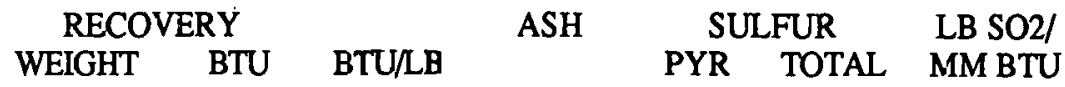

$\begin{array}{rrrrrrr}0.1 & 0.1 & 13004 . & 6.4 & 0.03 & 0.38 & 0.6 \\ 10.8 & 21.0 & \text { 12896. } & 6.8 & 0.03 & 0.35 & 0.5 \\ 35.3 & 58.8 & 11094 . & 18.6 & 0.03 & 0.34 & 0.6 \\ 100.0 & 100.0 & 6656 . & 52.7 & 0.07 & 0.21 & 0.6 \\ 100.0 & 100.0 & 6660 . & 52.6 & 0.07 & 0.21 & 0.6\end{array}$

$\begin{array}{rrrrrrr}6.4 & 12.8 & \text { 13609. } & 4.0 & 0.03 & 0.41 & 0.6 \\ 20.3 & 38.8 & 13031 . & 6.3 & 0.03 & 0.44 & 0.7 \\ 37.6 & 64.9 & 11812 . & 14.2 & 0.03 & 0.40 & 0.7 \\ 100.0 & 100.0 & 5832 . & 53.4 & 0.05 & 0.22 & 0.7 \\ 100.0 & 100.0 & 5764 . & 53.4 & 0.05 & 0.23 & 0.7\end{array}$

$\begin{array}{rrrrrrr}0.0 & 0.0 & 0 . & 0.0 & 0.00 & 0.00 & 0.0 \\ 3.0 & 6.5 & 13529 . & 4.0 & 0.03 & 0.41 & 0.6 \\ 26.3 & 47.7 & 1.379 . & 16.0 & 0.03 & 0.37 & 0.7 \\ 100.0 & 100.0 & 6265 . & 54.2 & 0.05 & 0.19 & 0.6\end{array}$

$\begin{array}{rrrrrrr}0.0 & 0.0 & 0 . & 0.0 & 0.00 & 0.00 & 0.0 \\ 15.6 & 35.3 & 1: 263 . & 4.3 & 0.05 & 0.44 & 0.7 \\ 31.9 & 63.4 & 11682 . & 14.6 & 0.05 & 0.40 & 0.7 \\ 100.0 & 100.0 & 5872 . & 54.0 & 0.06 & 0.22 & 0.7\end{array}$

$\begin{array}{rrrrrrr}17.3 & 17.3 & 5657 . & 53.2 & 0.06 & 0.22 & 0.8 \\ 24.3 & 24.0 & 5584 . & 53.3 & 0.06 & 0.22 & 0.8 \\ 45.4 & 48.5 & 5044 . & 50.5 & 0.06 & 0.23 & 0.8 \\ 58.4 & 65.1 & 5317 . & 49.1 & 0.06 & 0.24 & 0.7 \\ 100.0 & 100.0 & 5562 . & 53.7 & 0.05 & 0.22 & 0.8\end{array}$


TABLE XLI

WASHABILITY ANALYSIS SHOWING THE EFFECTS OF CRUSHING ON THE LIBERATION OF ASH FORMING IMPURITIES AND PYRITIC SULFUR FOR SAMPLE UA 136

STATE: ALASKA

COUNTY: DILLINGHAM

TOWN: CHIGNIK

DIRECT

PRODUCT RECOVERY
WEIGHT BTU BTU/LB ASH

SULFUR
PYR TOTAL

SCREEN

ANALYSIS

$1-1 / 2 \times 3 / 8 \quad 40.9$

$3 / 8 \times 14$ MESH 48.1

$14 \mathrm{M} \mathrm{X} 100 \mathrm{M} \quad 9.4$

MINUS $100 \mathrm{M} \quad 1.6$

$11 / 2 \times 0$

FLOAT 1.30

$1.30-1.40$

SINK 1.60

MINUS 100

5.8
29.8
14.7
49.8
1.6

$\begin{array}{rr}9.3 & 137 \\ 44.6 & 1273 \\ 18.9 & 1095 \\ 27.1 & 469 \\ 1.4 & \end{array}$

$\begin{array}{rrrr}\text { 13793. } & 4.1 & 0.29 & 1.54 \\ 12738 . & 7.7 & 0.54 & 1.92 \\ 10952 . & 20.5 & 1.01 & 2.02 \\ 4635 . & 59.5 & 1.22 & 1.51 \\ 7438 . & 41.2 & 0.93 & 1.97\end{array}$

$\vec{\Phi}$



FLOAT 1.30
$1.30-1.40$
$1.40-1.60$
SINK 1.60

SINK 1.60

MINUS 100

4.6
28.3
16.8
50.3
3.2

7.7
44.8
20.9
26.6
3.3

$\begin{array}{rrrr}\text { 13847. } & 3.3 & 0.22 & 1.48 \\ \text { 13243. } & 6.6 & 0.46 & 1.82 \\ 10405 . & 23.0 & 0.81 & 2.02 \\ 4425 . & 60.2 & 1.22 & 1.68 \\ 8564 & 35.2 & 0.82 & 1.92\end{array}$

$14 \mathrm{M} \mathrm{X0}$

FLOAT 1.30
$1.30-1.40$

$1.40-1.60$

$\begin{array}{rrrrrr}4.2 & 6.7 & 13711 . & 2.8 & 0.16 & 1.34 \\ 31.3 & 46.6 & 12856 & 8.0 & 0.36 & 1.67\end{array}$

$\begin{array}{rrrrrr}31.3 & 46.6 & 128.56 . & 8.0 & 0.36 & 1.67 \\ 16.0 & 20.3 & 10971 . & 20.7 & 0.81 & 1.82 \\ 48.5 & 26.4 & 4704 . & 59.3 & 1.32 & 1.68\end{array}$

SINK 1.60

$65 \mathrm{MXO}$

FLOAT 1.30

SINK 1.60

$\begin{array}{rrrrrr}7.3 & 11.8 & 13544 . & 2.3 & 0.06 & 1.27 \\ 30.6 & 48.0 & 13491 . & 4.6 & 0.16 & 1.31 \\ 12.4 & 15.6 & 10.56 . & 25.1 & 0.76 & 1.46 \\ 49.7 & 24.6 & 4253 . & 65.4 & 1.28 & 1.47\end{array}$

SAMPLE MESH SLZE

$\begin{array}{rrrrrrr}\text { PLUS 65 } & 3.0 & 2.8 & 7865 . & 40.9 & 0.97 & 1.55 \\ 65-100 & 9.0 & 8.7 & 8152 . & 36.0 & 0.89 & 1.00 \\ 100-200 & 27.2 & 29.0 & 9926 . & 30.7 & 0.06 & 1.40 \\ 200-325 & 17.6 & 19.5 & 9347 . & 30.1 & 0.06 & 1.18 \\ \text { MINUS 325 } & 43.2 & 40.0 & 7976 . & 40.1 & 0.05 & 1.19\end{array}$

MINE:

CHIGNIK RIVER

COALBED: CHIGNIK

COMPANY: INACTIVE

CUMULATIVE

$$
\begin{array}{r}
40.9 \\
89.0 \\
98.4 \\
100.0
\end{array}
$$$$
\text { RECOVERY }
$$$$
\text { WEIGHT BTU BTU/LB }
$$$$
\text { ASH }
$$$$
\begin{array}{cc}
\text { SULFUR } & \text { LB SO2/ } \\
\text { PYR TOTAL } & \text { MM BTU }
\end{array}
$$

$\begin{array}{rrrrrrr}5.8 & 9.3 & 13793 . & 4.1 & 0.29 & 1.54 & 2.2 \\ 35.6 & 54.0 & 12909 . & 7.1 & 0.50 & 1.86 & 2.9 \\ 50.3 & 72.9 & 12340 . & 11.0 & 0.65 & 1.91 & 3.1 \\ 100.0 & 100.0 & 8507 . & 35.1 & 0.93 & 1.71 & 4.0 \\ 100.0 & 100.0 & 8490 . & 35.2 & 0.93 & 1.71 & 4.0\end{array}$

$\begin{array}{rrrrrrr}4.6 & 7.7 & 13847 . & 3.3 & 0.22 & 1.48 & 2.1 \\ 32.9 & 52.4 & 13328 . & 6.1 & 0.43 & 1.77 & 2.7 \\ 49.7 & 73.4 & 12340 . & 11.8 & 0.56 & 1.86 & 3.0 \\ 100.0 & 100.0 & 8357 . & 36.1 & 0.89 & 1.77 & 4.2 \\ 100.0 & 100.0 & 8363 . & 36.1 & 0.89 & 1.77 & 4.2\end{array}$

$\begin{array}{rrrrrrr}4.2 & 6.7 & 13711 . & 2.8 & 0.16 & 1.34 & 2.0 \\ 35.5 & 53.3 & 12957 . & 7.4 & 0.34 & 1.63 & 2.5 \\ 51.5 & 73.6 & 12340 . & 11.5 & 0.48 & 1.69 & 2.7 \\ 100.0 & 100.0 & 8639 . & 34.7 & 0.89 & 1.69 & 3.9\end{array}$

$\begin{array}{rrrrrrr}7.3 & 11.8 & 13944 . & 2.3 & 0.06 & 1.27 & 1.8 \\ 37.9 & 59.8 & 13578 . & 4.1 & 0.14 & 1.30 & 1.9 \\ 50.3 & 75.4 & 12881 . & 9.3 & 0.29 & 1.34 & 2.1 \\ 100.0 & 100.0 & 8594 . & 37.2 & 0.78 & 1.41 & 3.3\end{array}$

$\begin{array}{rrrrrrr}3.0 & 2.8 & 7865 . & 40.9 & 0.97 & 1.55 & 3.9 \\ 12.0 & 11.5 & 8229 . & 37.3 & 0.91 & 1.14 & 2.8 \\ 39.2 & 40.5 & 8920 . & 32.7 & 0.32 & 1.32 & 3.0 \\ 56.8 & 60.0 & 9114 . & 31.9 & 0.24 & 1.28 & 2.8 \\ 100.0 & 100.0 & 8622 . & 35.5 & 0.18 & 1.25 & 2.9\end{array}$


TABLE XLII

WASHABILITY ANALYSIS SHOWING THE EFFECTS OF CRUSHING ON THE LIBERATION OF ASH FORMING IMPURITIES AND PYRITIC SULFUR FOR SAMPLE UA 137

\section{STATE: ALASKA \\ COUNTY: ALUETIAN ISLANDS \\ TOWN: FORT MOLLER}

DIRECT

PRODUCT$$
\text { FECOVERY }
$$
WEEGHT BTU BTULB
ASH

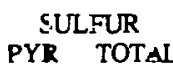

SCREEN

$1-1 / 2 \times 3 / 8$

$3 / 8 \times 14$ MESH 523

$14 \mathrm{MX100 \textrm {M }} 1 \mathrm{I}$

MINUS $100 \mathrm{M}$

$11 / 2 \times 0$

FLOAT 1.30

$1.30-1.40$
$1.40-1.60$

SINK 1.60

MNUS 100

$3 / 8 \times 0$

FLOAT 1.30

$1.30-1.40$

$1.40-1.60$
SINK 1.60

SINK 1.60
MINUS 100

2.3
29.5
20.7
47.3
3.7

3.9
47.7
27.2
21.2
2.4

13527.

10592.

3508 .

3508.
5158.

$\begin{array}{ll}10.3 & 0.62 \\ 23.9 & 1.81\end{array}$

$\begin{array}{ll}67.4 & 0.92\end{array}$

1.35

$\begin{array}{rrrrrr}5.8 & 10.1 & 13794 . & 3.6 & 0.12 & 0.75 \\ 29.6 & 48.4 & 13008 . & 8.9 & 0.56 & 1.22 \\ 17.3 & 23.3 & 10689 . & 23.5 & 1.91 & 2.37 \\ 47.3 & 18.2 & 3062 . & 69.9 & 0.88 & 1.19 \\ 6.8 & 3.5 & 4052 . & 62.8 & 0.48 & 0.95\end{array}$

MINE:

COAL POINT

CCALBED: HERENDEEN BAY

CCMPANY: INACTIVE

CULAULATIVE

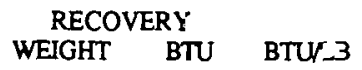

ASH $\begin{array}{cc}\text { SULFUR } & \text { LB SO2/ } \\ \text { PYR TOTAL } & \text { MM BTU }\end{array}$

42.9

95.2

96.3
100.0

$\begin{array}{rrrrrrr}2.3 & 3.9 & 13527 . & 4.6 & 0.18 & 0.76 & 1.1 \\ 31.8 & 51.6 & 12841 . & 9.9 & 0.59 & 1.31 & 2.0 \\ 52.2 & 78.8 & 1196.3 . & 15.4 & 1.07 & 1.69 & 2.8 \\ 100.0 & 100.0 & 7920 . & 40.3 & 1.00 & 1.44 & 3.6 \\ 100.0 & 100.0 & 7822 . & 41.2 & 0.98 & 1.42 & 3.6\end{array}$

$\begin{array}{rrr}5.8 & 10.1 & \text { 1379. } \\ 35.5 & 58.6 & 1313 .\end{array}$

$\begin{array}{rrr}52.8 & 81.8 & 12334 .\end{array}$

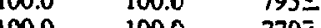

$\begin{array}{rlll}3.6 & 0.12 & 0.75 & 1.1 \\ 3.0 & 0.49 & 1.14 & 1.7 \\ 13.1 & 0.95 & 1.55 & 2.5 \\ 39.9 & 0.92 & 1.38 & 3.5 \\ 4 . .4 & 0.89 & 1.35 & 3.5\end{array}$

$14 \mathrm{M} \mathrm{X} 0$

FLOAT 1.30
$1.30-1.40$

$1.40-1.60$

SINK 1.60

$\begin{array}{rrrrrr}1.1 & 2.0 & 13963 . & 3.5 & 0.07 & 10.68 \\ 28.2 & 48.5 & 13215 . & 7.3 & 0.42 & 1.04 \\ 10.0 & 14.7 & 11274 & 19.9 & 1.58 & 3.03\end{array}$

$\begin{array}{lll}10.0 & 14.7 & 1127\end{array}$

$\begin{array}{rrr}1274 . & 19.9 & 1.58 \\ 4390 & 61.3 & 0.96\end{array}$

1.04
2.03

$65 \mathrm{M} \mathrm{X} 0$

FLOAT 1.30

1.30- 1.40

$1.40-1.60$
SINK 1.60

$\begin{array}{rrrrrr}12.9 & 22.5 & 13895 . & 2.2 & 0.06 & 6.71 \\ 25.2 & 41.6 & 13065 . & 7.6 & 0.20 & C .87 \\ 13.6 & 16.3 & 9550 . & 31.0 & 0.91 & 1.39 \\ 48.3 & 19.6 & 3209 . & 73.3 & 1.77 & 169\end{array}$

SAMPLE MESH SIZZE

$\begin{array}{rrr}\text { PLUS } 65 & 4.5 & 5.7 \\ 65-100 & 6.6 & 7.8 \\ 100-200 & 26.0 & 30.5 \\ 200-325 & 18.9 & 21.9\end{array}$

$\begin{array}{rrrrr}5.7 & 9860 . & 29.5 & 0.91 & 1.04 \\ 7.8 & 9395 . & 31.8 & 1.22 & 118 \\ 30.5 & 9278 . & 32.4 & 1.26 & 1.42 \\ 21.9 & 9089 . & 34.3 & 1.55 & 1.79 \\ 34.1 & 6119 . & 52.8 & 1.06 & 1.12\end{array}$

$\begin{array}{rrrrrrr}1.1 & 2.0 & 13963 . & 3.5 & 0.07 & 0.68 & 1.0 \\ 29.3 & 50.6 & 13244 . & -.1 & 0.41 & 1.03 & 1.5 \\ 39.3 & 65.2 & 12742 & 1 C .4 & 0.71 & 1.28 & 2.0 \\ 100.0 & 100.0 & 7671 . & 413 & 0.86 & 1.32 & 3.4\end{array}$

$\begin{array}{rrrrrrr}12.9 & 22.5 & 13895 . & 2.2 & 0.06 & 0.71 & 1.0 \\ 38.1 & 64.1 & 13345 . & 58 & 0.15 & 0.82 & 1.2 \\ 51.7 & 80.5 & 12349 . & 12.4 & 0.35 & 0.97 & 1.6 \\ 100.0 & 100.0 & 7932 . & 41.3 & 1.04 & 1.32 & 3.3\end{array}$

$\begin{array}{rrrrrrr}4.5 & 5.7 & 9860 . & 29.5 & 0.91 & 1.04 & 2.1 \\ 11.1 & 13.5 & 9585 . & 30.3 & 1.09 & 1.12 & 2.3 \\ 37.1 & 44.0 & 9370 . & 31.9 & 1.21 & 1.33 & 2.8 \\ 56.0 & 65.9 & 9275 . & 32.7 & 1.32 & 1.49 & 3.2 \\ 100.0 & 100.0 & 7887 . & 41.0 & 1.24 & 1.37 & 3.3\end{array}$


TABLE XLIII

WASHABILITY ANALYSIS SHOWING THE EFFECTS OF CRUSHING ON THE LIBERATION OF ASH FORMING IMPLRITIES AND PYRITIC SULFUR FOR SAMPLE UA 138

STATE: ALASKA

COUNTY: KOBUK

TOWN: CHICAGO CREEK

DIRECT

PRODUCT

RECOVERY
WEIGHT BTU BTU/LB

AS:I

SULFUR
PYR TOTAL

SCREEN

$1-1 / 2 \times 3 / 8 \quad 25.3$

3/8 X 14 MESH $\quad 70.7$

$\begin{array}{ll}14 \mathrm{M} X 100 \mathrm{M} & 3.0 \\ \text { MINUS } 100 \mathrm{M} & 1.0\end{array}$

$11 / 2 \times 0$

FLOAT 1.30

$1.30-1.40$

$1.40-1.60$
SINK 1.60

SINK 1.60
MINUS 100

$\begin{array}{lll}69.6 & 74.7 & 10412 .\end{array}$

$\begin{array}{rrr}69.6 & 74.7 & 10412 . \\ 17.1 & 17.2 & 9743 .\end{array}$

$\begin{array}{lll}4.0 & 1.8 & 4320 .\end{array}$

舀

1.0

0.9

8320.

$\begin{array}{rrr}8.3 & 0.04 & 0.84 \\ 11.0 & 0.04 & 0.88 \\ 34.9 & 0.15 & 0.72 \\ 52.4 & 0.16 & 0.47 \\ 25.4 & 0.06 & 0.67\end{array}$

FLOAT 1.30
$1.30-1.40$

$1.30-1.40$
$1.40-1.60$
SINK 1.60

MINUS 100

$14 \mathrm{M} \times 0$

FLOAT 1.30
$1.30-1.40$
$1.40-1.60$

$1.40-1.60$
SINK 1.60

$\begin{array}{ll}48.0 & 53.5 \\ 26.9 & 28.1\end{array}$

26.9
15.4
9.7

$53.5 \quad 10742$

10742.
10090.

$\begin{array}{rrrr}28.1 & 10090 . & 7.4 & 0.01 \\ 13.7 & 8620 . & 17.8 & 0.09 \\ 4.7 & 4639 & 50.4 & 0.18\end{array}$

$\begin{array}{rr}5.7 & 0.01 \\ 7.4 & 0.01 \\ 17.8 & 0.09\end{array}$

$\begin{array}{ll}9.7 & 4.7 \\ 3.7 & 3.2\end{array}$

8309.

\begin{tabular}{lll}
7.4 & 0.018 & 0.78 \\
\hline & 0.18 & 0.50
\end{tabular}

$$
42.300 .00
$$

$\begin{array}{rrrrrr}42.3 & 46.0 & 10402 . & 7.7 & 0.02 & 0.83 \\ 35.0 & 35.6 & 9736 & 9.7 & 0.05 & 0.79\end{array}$

$\begin{array}{rrrrrr}9.5 & 35.6 & 9736 . & 9.7 & 0.05 & 0.79\end{array}$

$65 \mathrm{M} \times 0$

$\begin{array}{rrrrrr}9.5 & 8.8 & 8845 . & 16.7 & 0.14 & 0.81 \\ 13.1 & 9.6 & 6962 . & 34.8 & 0.21 & 0.58\end{array}$

FLOAT 1.30

$1.30-1.40$

$\begin{array}{rrrrrr}0.0 & 0.0 & 0 . & 0.0 & 0.00 & 0.00 \\ 14.6 & 16.7 & 11070 . & 5.6 & 0.05 & 0.97 \\ 71.7 & 74.6 & 10118 . & 9.7 & 0.06 & 0.89\end{array}$

SINK 1.60

13.7

74.6
8.7

SAMPLE MESH SIZE

$\begin{array}{rrrrrrr}\text { PLUS 65 } & 8.1 & 8.7 & 10463 . & 8.1 & 0.06 & 0.96 \\ 65-100 & 9.9 & 10.4 & 10224 . & 9.8 & 0.07 & 0.92 \\ 100-200 & 25.5 & 26.3 & 10061 . & 14.5 & 0.08 & 0.92 \\ 200-325 & 12.5 & 12.4 & 9661 . & 12.9 & 0.14 & 0.91 \\ \text { MINUS 325 } & 43.9 & 42.2 & 9374 . & 15.1 & 0.14 & 0.75\end{array}$

MINE:

CHICAGO CREEK

COALBED: THREE FT SEAM

COMPANY: INACTIVE

CUMULATIVE

\begin{tabular}{cccccc}
\multicolumn{2}{c}{ RECOVERY } & ASH & SULFUR & LB SO2/ \\
WEIGHT & BTU & BTULB & & PYR TOTAL & MM BTU
\end{tabular}
25.3

96.0

100.0

$\begin{array}{rrrrrrr}69.6 & 74.7 & 10412 . & 8.3 & 0.04 & 0.84 & 1.6 \\ 86.7 & 91.9 & 10280 . & 8.8 & 0.04 & 0.85 & 1.6 \\ 96.0 & 98.2 & 9924 . & 11.3 & 0.05 & 0.84 & 1.7 \\ 100.0 & 100.0 & 9702 . & 13.0 & 0.06 & 0.82 & 1.7 \\ 100.0 & 100.0 & 9689 . & 13.1 & 0.06 & 0.82 & 1.7\end{array}$

$\begin{array}{llllll}48.0 & 53.5 & 10742 . & 5.7 & 0.01 & 0.80 \\ 75.0 & 81.6 & 10508 & 6.3 & 0.01 & 0.81\end{array}$

$\begin{array}{llllll}75.0 & 81.6 & 10508 . & 6.3 & 0.01 & 0.81 \\ 90.3 & 95.3 & 10187 & 8.3 & 0.02 & 0.81\end{array}$

$\begin{array}{rrrrrr}90.3 & 95.3 & 10187 . & 8.3 & 0.02 & 0.81\end{array}$

$\begin{array}{llllll}100.0 & 100.0 & 9650 . & 12.4 & 0.04 & 0.78 \\ 100.0 & 100.0 & 9602 . & 12.9 & 0.04 & 0.77\end{array}$

$\begin{array}{lllllll}42.3 & 46.0 & 10402 . & 7.7 & 0.02 & 0.83 & 1.6 \\ 77.4 & 81.7 & 10100 . & 8.6 & 0.03 & 0.81 & 1.6\end{array}$

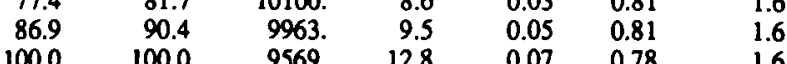

$\begin{array}{rrrrrrr}0.0 & 0.0 & 0 . & 0.0 & 0.00 & 0.00 & 0.0 \\ 14.6 & 16.7 & 11070 & 5.6 & 0.05 & 0.97 & 1.8\end{array}$

$\begin{array}{rrrrrrr}14.6 & 16.7 & 11070 . & 5.6 & 0.05 & 0.97 & 1.8 \\ 86.3 & 91.3 & 10279 . & 9.0 & 0.06 & 0.90 & 1.8 \\ 100.0 & 100.0 & 9720 . & 13.2 & 0.11 & 0.86 & 1.8\end{array}$

$\begin{array}{rrrrrrr}8.1 & 8.7 & 10463 . & 8.1 & 0.06 & 0.96 & 1.8 \\ 18.0 & 19.1 & 10332 . & 9.0 & 0.07 & 0.94 & 1.8 \\ 43.6 & 45.4 & 10173 . & 12.2 & 0.07 & 0.93 & 1.8 \\ 56.1 & 57.8 & 10059 . & 12.4 & 0.09 & 0.92 & 1.8 \\ 100.0 & 100.0 & 9758 . & 13.6 & 0.10 & 0.87 & 1.8\end{array}$


TABLE XLIV

WASHABILITY ANALYSIS SHOWING THE EFFECTS OF CRUSHING ON THE LIBERATION OF ASH FORMING IMPURITIES AND PYRITIC SULFUR FOR SAMPLE lia 139

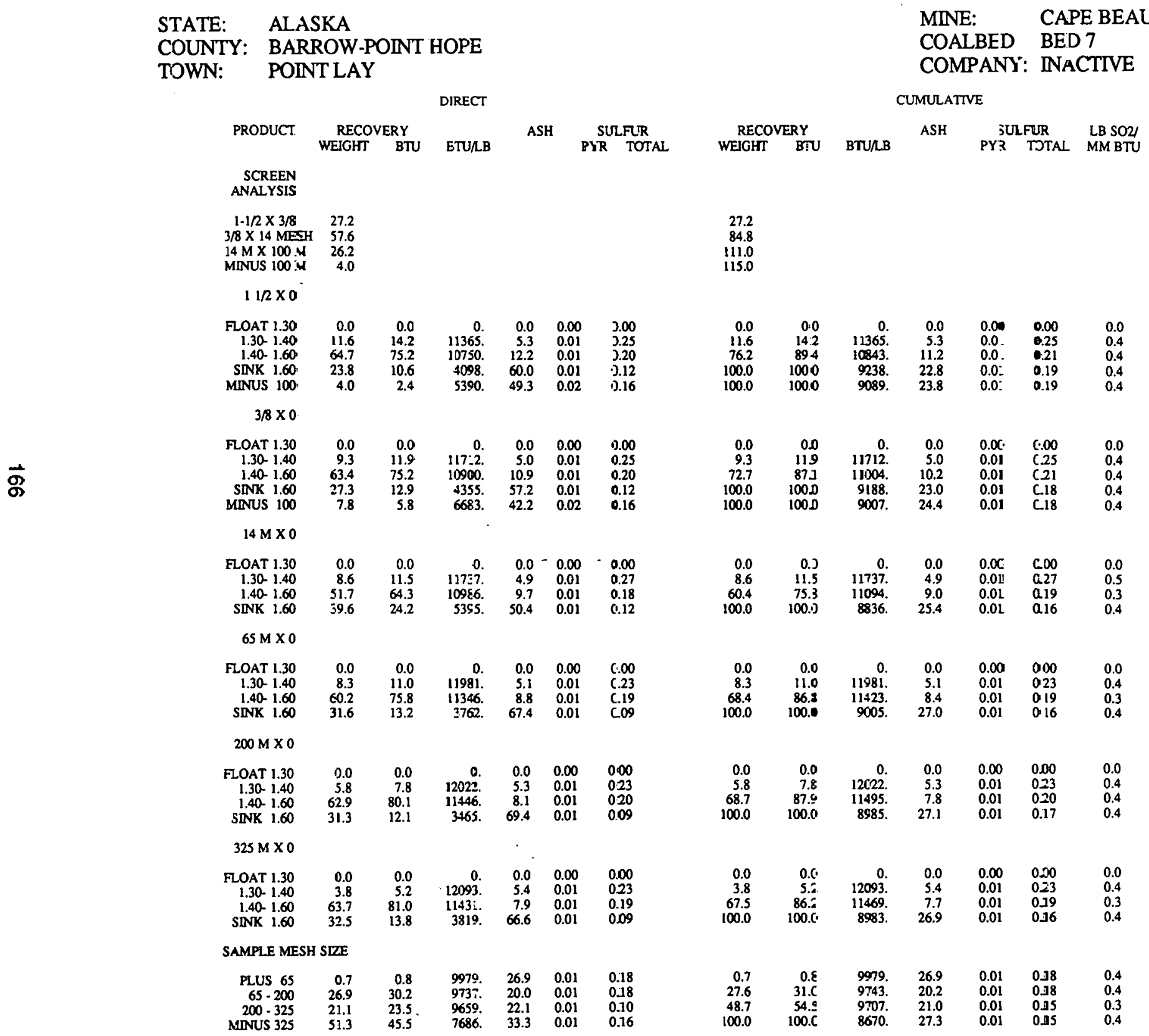


TABLE XLV

WASHABILITY ANALYSIS SHOWING THE EFFECTS OF CRUSHING ON THE LIBERATION OF ASH FORMING IMPURITIES AND PYRITIC SULFUR FOR SAMPLE UA 140

\section{STATE: ALASKA \\ COUNTY: KOYUKUK-MIDDLE YUKON \\ TOWN: \\ USIBELLI}

DIRECT

PRODUCT

RECOVERY
WEIGHT BTU BTU/LB

ASH

SULFUR
PYR TOTAL

SCREEN

$1-1 / 2 \times 3 / 8 \quad 48.2$

$3 / 8 \times 14$ MESH $\quad 49.4$

$\begin{array}{ll}14 \mathrm{M} X 100 \mathrm{M} & 0.9 \\ \text { MINUS } 100 \mathrm{M} & 1.5\end{array}$

$11 / 2 \times 0$

FLOAT 1.30

$1.30-1.40$
$1.40-1.60$

SINK 1.60

MINUS 100

$\begin{array}{rrr}31.1 & 36.5 & 11230 \\ 42.7 & 45.8 & 10264 \\ 16.7 & 14.0 & 8011 \\ 9.5 & 3.6 & 3674 . \\ 1.3 & 0.7 & 4860 .\end{array}$

$\begin{array}{rr}6.9 & 0.02 \\ 12.5 & 0.02 \\ 28.1 & 0.09 \\ 61.4 & 0.12 \\ 47.6 & 0.03\end{array}$

0.38

0.41
0.47

0.48
0.61

$\vec{g}$
$3 / 8 \times 0$

FLOAT 1.30

$1.30-1.40$
$1.40-1.60$

SINK 1.60

MINUS 100

$\begin{array}{rrrrr}21.5 & 25.2 & 11365 . & 6.6 & 0.01 \\ 54.1 & 56.8 & 10177 . & 13.4 & 0.02 \\ 14.8 & 12.5 & 8181 . & 29.1 & 0.03 \\ 9.6 & 5.5 & 5527 . & 55.7 & 0.10 \\ 5.8 & 4.9 & 8020 . & 25.3 & 0.02\end{array}$

0.38

0.41

0.44

0.54
0.51
0.41

$14 \mathrm{M} \mathrm{X} 0$

FLOAT 1.30
$1.30-1.40$

$1.40-1.60$
SINK 1.60

$\begin{array}{rrrrrr}12.6 & \cdot 14.7 & 11299 & 8.1 & 0.01 & 0.33\end{array}$

$\begin{array}{rrr}54.8 & 58.7 & 10386 .\end{array}$

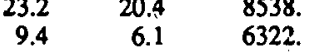

\begin{tabular}{ll}
11.9 & 0.02 \\
23.6 & 0.02 \\
\hline & 0.03
\end{tabular}

0.31
0.36
0.37

$65 \mathrm{MX0}$

FLOAT 1.30
$1.30-1.40$

$1.30-1.40$
$1.40-1.60$

0.1
28.8
50.5
20.6

0.1
33.6
52.0
14.3

11592.

11474.
10128.

10128.
6830.

$\begin{array}{rr}4.9 & 0.02 \\ 6.3 & 0.02 \\ 15.8 & 0.03 \\ 44.7 & 0.05\end{array}$

\subsection{1}

SINK 1.60

SIZE

PLUS 65 S

$\begin{array}{rrrrrrr}\text { PLUS 65 } & 9.8 & 10.4 & 10375 . & 13.5 & 0.02 & 0.41 \\ 65-100 & 14.1 & 14.9 & 10320 . & 13.8 & 0.03 & 0.44 \\ 100-200 & 25.8 & 27.2 & 10297 . & 14.1 & 0.03 & 0.44 \\ 200-325 & 14.7 & 15.3 & 10134 . & 15.4 & 0.03 & 0.44 \\ \text { MINUS 325 } & 35.7 & 32.2 & 8806 . & 26.3 & 0.03 & 0.42\end{array}$

MINE:

USIBELLI

COALBED: BASAL

COMPANY: USIBELLI COAL CO.

CUMULATIVE

\begin{tabular}{cccccc} 
RECOVERY & ASH & \multicolumn{2}{c}{ SULFUR } & LB SO2/ \\
WEIGHT BTU ETU/LB & & PYR TOTAL & MM BTU
\end{tabular}

48.2

97.6

98.5
100.0

$\begin{array}{rrrrrrr}31.1 & 36.5 & 11230 . & 6.9 & 0.02 & 0.38 & 0.7 \\ 73.8 & 82.3 & 10671 . & 10.2 & 0.02 & 0.40 & 0.7 \\ 90.5 & 96.4 & 10179 . & 13.5 & 0.03 & 0.41 & 0.8 \\ 100.0 & 100.0 & 9563 . & 18.0 & 0.04 & 0.42 & 0.9 \\ 100.0 & 100.0 & 9501 . & 18.4 & 0.04 & 0.42 & 0.9\end{array}$

100.0

$100.0 \quad 9501$.

$\begin{array}{rrrrrrr}21.5 & 25.2 & 11365 . & 6.6 & 0.01 & 0.38 & 0.7 \\ 75.6 & 82.0 & 10515 . & 11.5 & 0.02 & 0.40 & 0.8 \\ 90.4 & 94.5 & 10133 . & 14.4 & 0.02 & 0.41 & 0.8 \\ 100.0 & 100.0 & 9690 . & 18.4 & 0.03 & 0.42 & 0.9 \\ 100.0 & 100.0 & 9598 . & 18.7 & 0.03 & 0.42 & 0.9\end{array}$

$\begin{array}{rrrrrrr}12.6 & 14.7 & 11299 & 8.1 & 0.01 & 0.33 & 0.6\end{array}$

$\begin{array}{lllllll}90.6 & 93.9 & 10040 & 14.4 & 0.02 & 0.31 & 0.6\end{array}$

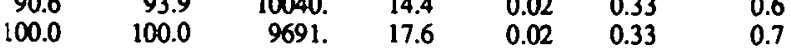

$\begin{array}{rrrrrrr}0.1 & 0.1 & 11592 . & 4.9 & 0.02 & 0.41 & 0.7 \\ 28.9 & 33.7 & 11474 . & 6.3 & 0.02 & 0.43 & 0.7 \\ 79.4 & 85.7 & 10618 & 12.3 & 0.03 & 0.44 & 0.8\end{array}$

$\begin{array}{rrrrrrr}79.4 & 85.7 & 10618 . & 12.3 & 0.03 & 0.44 & 0.8 \\ 100.0 & 100.0 & 9836 . & 19.0 & 0.03 & 0.43 & 0.9\end{array}$

$\begin{array}{rrrrrrr}9.8 & 10.4 & 10375 . & 13.5 & 0.02 & 0.41 & 0.8 \\ 23.8 & 25.3 & 10343 . & 13.7 & 0.03 & 0.43 & 0.8 \\ 49.6 & 52.5 & 10319 . & 13.9 & 0.03 & 0.43 & 0.8 \\ 64.3 & 67.7 & 10277 . & 14.2 & 0.03 & 0.44 & 0.8 \\ 100.0 & 100.0 & 9751 . & 18.5 & 0.03 & 0.43 & 0.9\end{array}$


TABLE XLVI

WASHABILITY ANALYSIS SHOWING THE EFFECTS OF CRUSHING ON THE LIBERATION OF ASH FORMING IMPURITIES AND PYRITIC SULFUR FOR SAMPLE UA 141

STATE: ALASKA

COUNTY: KOYUKUK-MIDDLE YUKON

TOWN: USIBELL]

DIRECT

PRODUCT

RECOVERY

WEIGHT BTU BTU/LB

ASH

SULFUR

PYR .TOTAL
MINE:

USIBELLI

COALBED: UPPER LIGNITE CREEK

COMPANY: INACTIVE

\section{CUMULATIVE}

RECOVERY

WEIGHT

BTU

BTU/LB
SULFUR PYR TOTAL
LB SO2/

MM BTU

\begin{tabular}{|c|c|c|c|c|c|c|c|c|c|c|c|c|c|}
\hline FLOAT 1.30 & 60.6 & 66.1 & 10681. & 6.3 & 0.01 & 0.32 & 60.6 & 66.1 & 10681. & 6.3 & 0.01 & 0.32 & 0.6 \\
\hline $1.30-1.40$ & 28.1 & 27.4 & 9533. & 16.0 & 0.01 & 0.42 & 88.6 & $93 . \angle$. & 10317. & 9.4 & 0.01 & 0.35 & 0.7 \\
\hline $1.40-1.60$ & 7.8 & 5.4 & 6764. & 38.6 & 0.01 & 0.42 & 96.5 & 98.5 & 10029. & 11.7 & 0.01 & 0.36 & 0.7 \\
\hline SINK 1.60 & 3.5 & 1.1 & 3169. & 69.4 & 0.09 & 0.23 & 100.0 & 100.6 & 9787. & 13.8 & 0.01 & 0.35 & 0.7 \\
\hline MINUS 100 & 1.1 & 0.6 & 5430. & 53.8 & 0.02 & 0.23 & 100.0 & 100. & 9740. & 14.2 & 0.01 & 0.35 & 0.7 \\
\hline \multicolumn{14}{|l|}{$3 / 8 \times 0$} \\
\hline FLOAT 1.30 & 49.8 & 54.6 & 10668. & 6.1 & 0.01 & 0.32 & 49.8 & $54 . \epsilon$ & 10668. & 6.1 & 0.01 & 0.32 & 0.6 \\
\hline$\quad 1.30-1.40$ & 38.1 & 37.7 & 9634. & 13.9 & 0.01 & 0.38 & 87.9 & 92.4 & 10220. & 9.5 & 0.01 & 0.35 & 0.7 \\
\hline $1.40-1.60$ & 7.8 & 5.9 & 7342. & 33.4 & 0.02 & 0.39 & 95.7 & 98.3 & 9984. & 11.4 & 0.01 & 0.35 & 0.7 \\
\hline SINK 1.60 & 4.3 & 1.7 & 3871. & 63.8 & 0.05 & 0.22 & 100.0 & 100.0 & 9721. & 13.7 & 0.01 & 0.34 & 0.7 \\
\hline MINUS 100 & 0.7 & 0.6 & 7585. & 25.8 & 0.05 & 0.30 & 100.0 & 100.0 & 9706. & 13.8 & 0.01 & 0.34 & 0.7 \\
\hline \multicolumn{14}{|l|}{$14 \mathrm{M} \times 0$} \\
\hline FLOAT 1.30 & 46.0 & 49.9 & 10820. & 6.3 & 0.01 & 0.34 & 46.0 & 49.9 & 10820 & 6.3 & 0.01 & 0.34 & 0.6 \\
\hline $1.30-1.40$ & 41.3 & 40.0 & 9658. & 14.4 & 0.01 & 0.34 & 87.2 & 89.9 & 10270 & 10.2 & 0.01 & 0.34 & 0.7 \\
\hline $1.40-1.60$ & 7.7 & 6.7 & 8665. & 24.5 & 0.01 & 0.37 & 94.9 & 96.6 & 10140. & 11.3 & 0.01 & 0.34 & 0.7 \\
\hline SINK 1.60 & 5.1 & 3.4 & 6715. & 39.0 & 0.06 & 0.26 & 100.0 & 100.0 & 9965. & 12.7 & 0.01 & 0.34 & 0.7 \\
\hline \multicolumn{14}{|l|}{$65 \mathrm{M} \times 0$} \\
\hline FLOAT 1.30 & 0.0 & 0.0 & 0. & 0.0 & 0.00 & 0.00 & 0.0 & 0.0 & 0. & 0.0 & 0.00 & 0.00 & 0.0 \\
\hline $1.30-1.40$ & 16.2 & 18.8 & 10966. & 3.6 & 0.02 & 0.45 & 16.2 & 18.8 & 10966. & 3.6 & 0.02 & 0.45 & 0.8 \\
\hline $1.40-1.60$ & 72.8 & 75.3 & 9780. & 11.3 & 0.02 & 0.40 & 89.0 & 94.1 & 9996. & 9.9 & 0.02 & 0.41 & 0.8 \\
\hline SINK 1.60 & 11.0 & 5.9 & 5051. & 41.8 & 0.03 & 0.30 & 100.0 & 100.0 & 9451. & 13.4 & 0.02 & 0.40 & 0.8 \\
\hline \multicolumn{14}{|c|}{ SAMPLE MESH SIZE } \\
\hline PLUS 65 & 13.4 & 14.1 & 10317. & 9.8 & 0.02 & 0.41 & 13.4 & 14]$. & 10317. & 9.8 & 0.02 & 0.41 & 0.8 \\
\hline $65-100$ & 8.8 & 9.4 & 10423. & 8.5 & 0.02 & 0.40 & 22.2 & 23.5 & 101359. & 9.2 & 0.02 & 0.41 & 0.8 \\
\hline $100-200$ & 26.7 & 28.0 & 10256. & 10.1 & 0.02 & 0.38 & 48.9 & 51.5 & 10303. & 9.7 & 0.02 & 0.39 & 0.8 \\
\hline $200-325$ & 13.9 & 14.1 & 9976. & 12.2 & 0.02 & 0.39 & 62.8 & 65.7 & 10231. & 10.3 & 0.02 & 0.39 & 0.8 \\
\hline MINUS 325 & 37.2 & 34.3 & 9014. & 20.9 & 0.02 & 0.33 & 100.0 & 100.0 & 9778. & 14.2 & 0.02 & 0.37 & 0.8 \\
\hline
\end{tabular}


TABLE XLVII

WASHABILITY ANALYSIS SHOWING THE EFFECTS OF CRUSHING ON THE LIBERATION OF ASH FORMING IMPURITIES AND PYRITIC SULFUR FOR SAMPLE UA 142

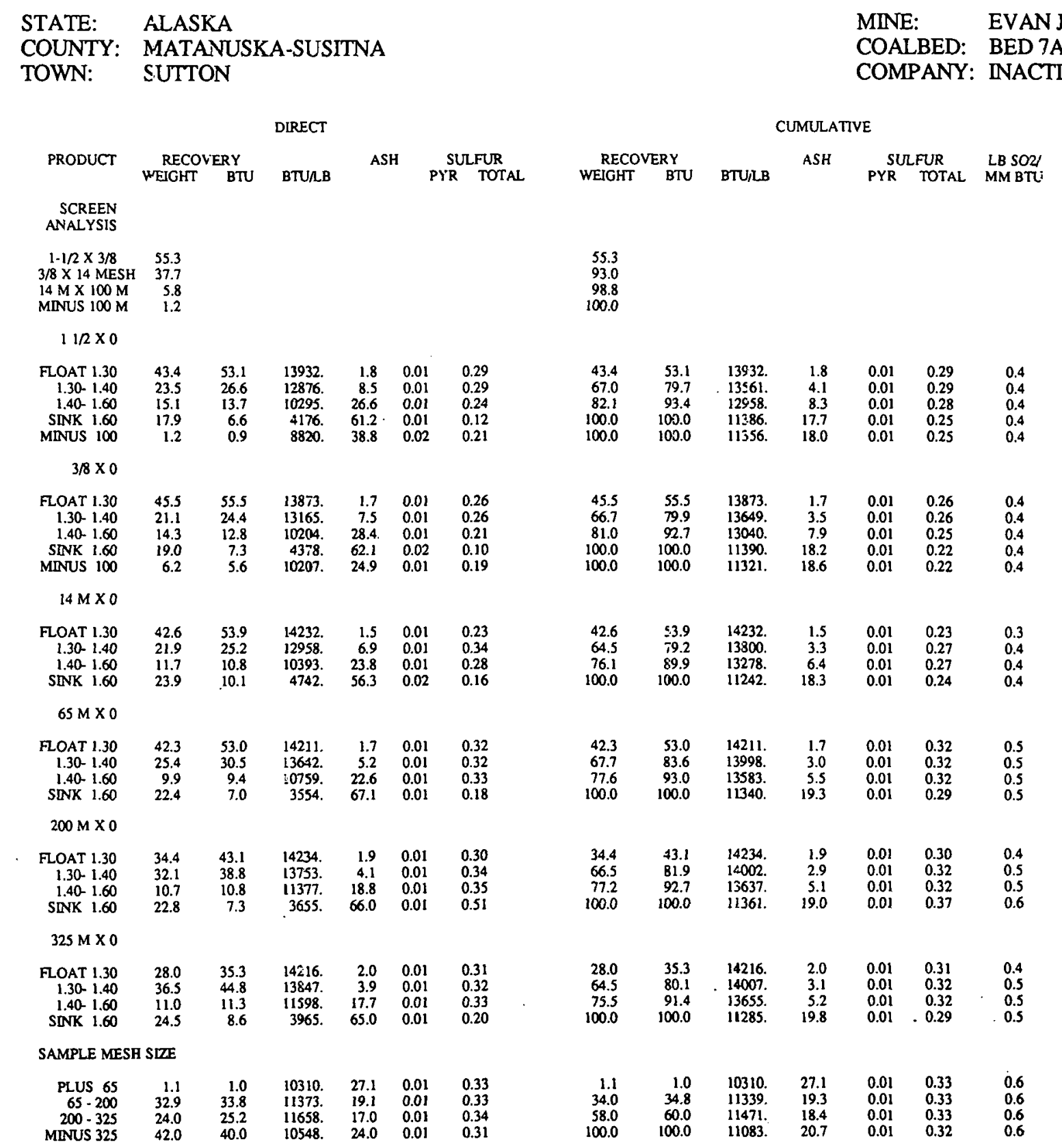


TABLE XLVIII

WASHABILITY ANALYSIS SHOWING THE EFFECTS OF CRUSHING ON THE LIBERATION OF ASH FORMING IMPURITIES AND PYRITIC SULFUR FOR SAMPLE UA 143

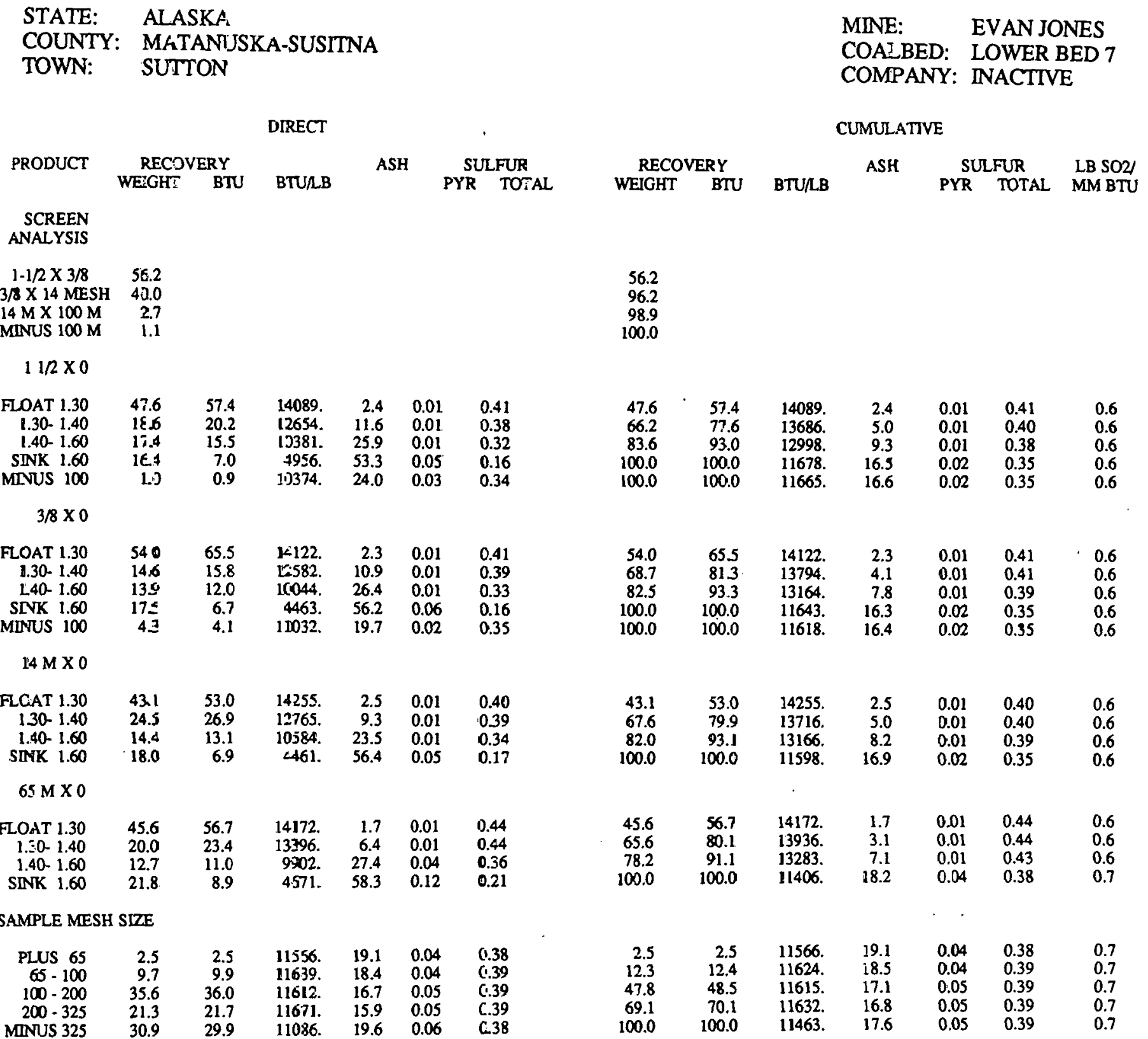


TABLE XLIX

WASHABILITY ANALYSIS SHOWING THE EFFECTS OF CRUSHING ON THE LIBERATION OF ASH FORMING IMPURITIES AND PYRITIC SULFUR FOR SAMPLE UA 144

$\vec{\Xi}$

\section{STATE: ALASKA \\ COUNTY: MATANUSKA-SUSITNA \\ TOWN: SUTTON}

DIRECT

PRODLCT

RECOVERY

NEIGHT BTU BTU/LB
SULFUR

SCREEN
ANALYSIS

$1-1 / 2 \times 3 / 8 \quad 44.7$

$38 \times 14$.MESH 52.0

$\begin{array}{ll}14 \mathrm{MX}: 00 \mathrm{M} & 1.9 \\ \text { MINUS } \mathrm{I} 00 \mathrm{M} & 1.4\end{array}$

$11 / 2 \times 0$

$\begin{array}{rr}\text { FLOAT } 1.30 & 40.3 \\ 1.30-1.40 & 23.4\end{array}$

$1.40=1.60$

SINK 1.60

MINUS 100

40.3
23.4
28.8
7.5

47.4
24.9

$\begin{array}{rrrr}\text { 13547. } & 2.5 & 0.01 & 0.36 \\ 12588 . & 10.9 & 0.02 & 0.35\end{array}$

$\begin{array}{llll}10116 . & 26.3 & 0.03 & 0.31\end{array}$

$3 / 8 \times 0$

FLOAT 1.30

$1.30-1.40$

$1.40-1.60$
SINK 1.60

SINK 1.60

45.2
18.7
26.3
9.9
7.2

54.2
19.8
22.0
4.0

$\begin{array}{llll}9891 . & 25.9 & 0.03 & 0.28\end{array}$

$14 \mathrm{M} \times 0$

FLOAT 1.30
$1.30-1.40$

$1.40-1.60$

$46.6 \quad 55.3$

SINK 1.60

$\begin{array}{rrrrrr}46.6 & 55.3 & 13981 . & 2.7 & 0.01 & 0.36 \\ 7.0 & 7.6 & 12342 . & 9.2 & 0.01 & 0.34 \\ 37.9 & 33.7 & 10479 & 23.9 & 0.02 & 0.30\end{array}$

$\begin{array}{rrrr}14: 19 . & 2.3 & 0.01 & 0.35 \\ 12522 . & 10.9 & 0.01 & 0.33 \\ 9867 . & 27.0 & 0.01 & 0.39 \\ \text { 4732. } & 53.6 & 0.06 & 0.15\end{array}$

$\begin{array}{rrrrr}4.0 & 4732 . & 53.6 & 0.06 & 0.15 \\ 6.9 & 11369 . & 17.6 & 0.01 & 0.30\end{array}$

$65 \mathrm{M} \mathrm{X0}$

FLOAT 1.30

$1.30-1.40$
$1.40-1.60$

8.5

33.7
3.5

$\begin{array}{rrrr}10479 . & 23.9 & 0.02 & 0.30\end{array}$

33.6

$\begin{array}{rrrrr}40.7 & 14050 . & 1.5 & 0.01 & 0.37 \\ 19.6 & 13174 . & 6.5 & 0.02 & 0.37 \\ 22.5 & 11404 . & 18.1 & 0.03 & 0.34 \\ 17.3 & 7518 . & 39.3 & 0.11 & 0.23\end{array}$

SAMPLE MESH SLZE

$\begin{array}{rrrrrrr}\text { PLU. 65 } & 11.1 & 11.0 & 11563 . & 8.9 & 0.03 & 0.32 \\ 65-100 & 7.2 & 7.0 & 11438 . & 17.5 & 0.03 & 0.28 \\ 100-200 & 29.1 & 29.5 & 11879 . & 16.7 & 0.03 & 0.30 \\ 200-325 & 18.5 & 19.1 & 12083 . & 13.5 & 0.03 & 0.32 \\ \text { MNNUS 325 } & 34.1 & 33.4 & 11495 . & 17.1 & 0.03 & 0.30\end{array}$

MINE:

EVAN JONES

COALBED: UPPER BED 7

COMPANY: INACTIVE

CUMULATIVE

\begin{tabular}{cccccc} 
RECOVERY & & ASH & \multicolumn{2}{c}{ SULFUR } & LB SO2/ \\
WEIGHT BTU & BTU/LB & & PYR TOTAL & MM BTU
\end{tabular}

44.7

96.7

98.6
100.0

$\begin{array}{rrrrrrr}40.3 & 47.4 & 13947 . & 2.5 & 0.01 & 0.36 & 0.5 \\ 63.8 & 72.3 & 13448 . & 5.6 & 0.01 & 0.36 & 0.5 \\ 92.5 & 96.9 & 12412 . & 12.0 & 0.02 & 0.34 & 0.6 \\ 100.0 & 100.0 & 11857 . & 15.0 & 0.02 & 0.33 & 0.6 \\ 100.0 & 100.0 & 11830 . & 15.2 & 0.02 & 0.33 & 0.6\end{array}$

100.0

100.0

$\begin{array}{rrrrrrr}45.2 & 54.2 & 14119 . & 2.3 & 0.01 & 0.35 & 0.5 \\ 63.8 & 74.0 & 13652 . & 4.8 & 0.01 & 0.34 & 0.5 \\ 90.1 & 96.0 & 12547 . & 11.3 & 0.01 & 0.36 & 0.6 \\ 100.0 & 100.0 & 11777 . & 15.4 & 0.01 & 0.34 & 0.6 \\ 100.0 & 100.0 & 11749 . & 15.6 & 0.01 & 0.33 & 0.6\end{array}$

$\begin{array}{lllllll}46.6 & 55.3 & 13981 . & 2.7 & 0.01 & 0.36 & 0.5 \\ 53.6 & 62.9 & 13833 . & 3.6 & 0.01 & 0.36 & 0.5\end{array}$

$\begin{array}{rrrrrrr}91.5 & 96.5 & 12444 . & 12.0 & 0.01 & 0.36 & 0.5 \\ 100.0 & 100.0 & 11791 . & 15.6 & 0.02 & 0.32 & 0.5\end{array}$

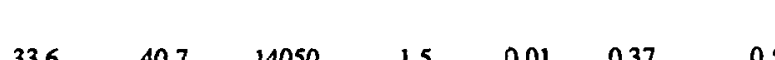

$\begin{array}{lllllll}33.6 & 40.7 & 14050 . & 1.5 & 0.01 & 0.37 & 0.5 \\ 50.8 & 60.2 & 13753 . & 3.2 & 0.01 & 0.37 & 0.5 \\ 73.7 & 82.7 & 13024 & 7.8 & 0.02 & 0.36 & 0.6\end{array}$

$\begin{array}{rrrrrrr}73.7 & 82.7 & 13024 . & 7.8 & 0.02 & 0.36 & 0.6 \\ 100.0 & 100.0 & 11603 . & 16.1 & 0.04 & 0.33 & 0.6\end{array}$

$\begin{array}{lllllll}\text { MINUS 325 } & 34.1 & 33.4 & 11495 . & 17.1 & 0.03 & 0.30\end{array}$

$\begin{array}{rrrrrr}11.1 & 11.0 & 11663 . & 8.9 & 0.03 & 0.32 \\ 18.3 & 18.0 & 11575 . & 12.3 & 0.03 & 0.30 \\ 47.4 & 47.5 & 11762 . & 15.0 & 0.03 & 0.30 \\ 65.9 & 66.6 & 11852 . & 14.6 & 0.03 & 0.31 \\ 100.0 & 100.0 & 11730 . & 15.4 & 0.03 & 0.31\end{array}$

0.5
0.5
0.6

0.6

0.6

0.6

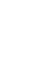

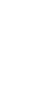

0.5 
TABLE $L$

WASHABILITY ANALYSIS SHOWING THE EFFECTS OF CRUSHING ON THE LIBERATION OF ASH FORMING IMPURITIES AND PYRITIC SULFUR FOR SAMPLE UA 145

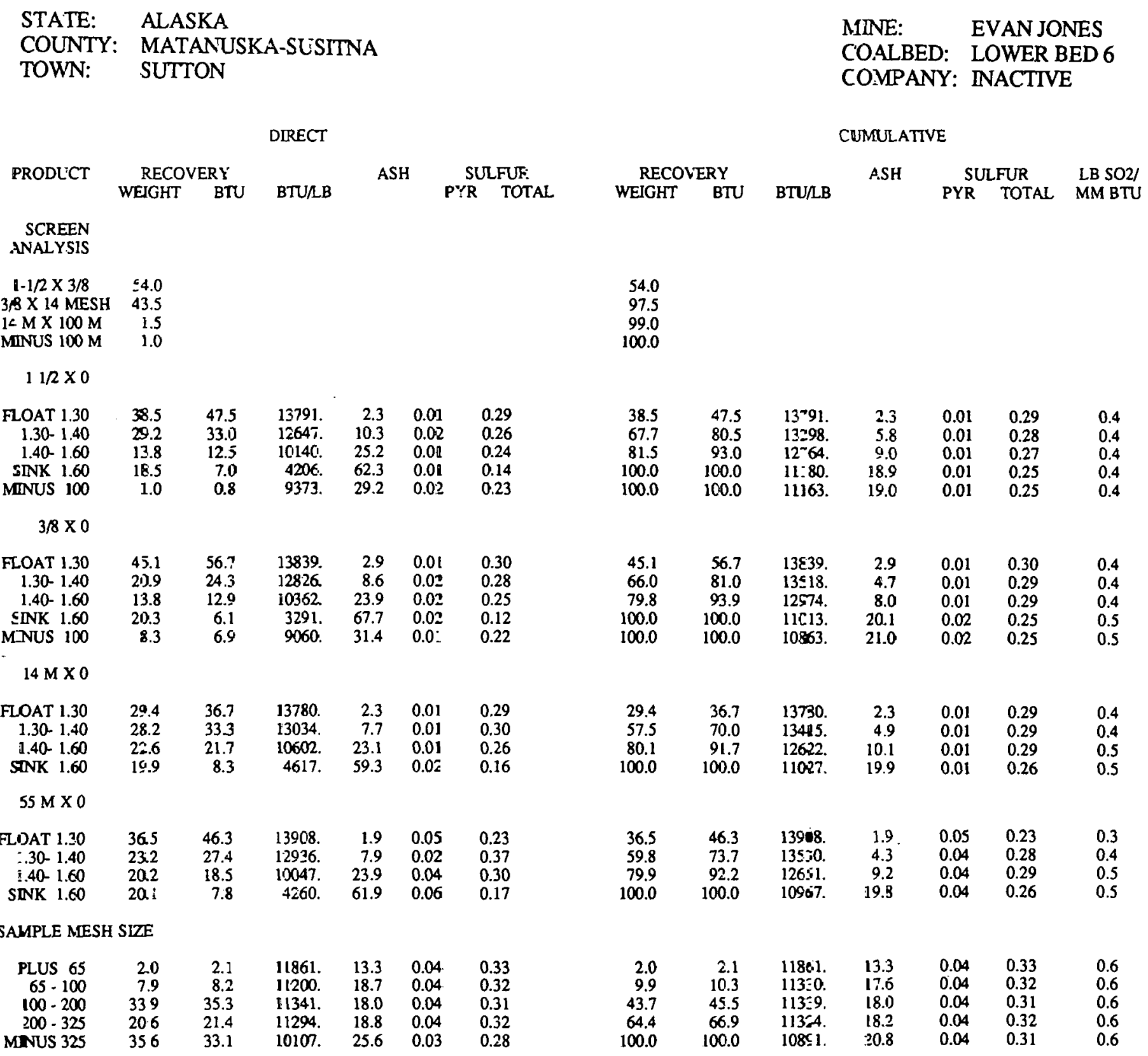


TABLE LI

WASHABILITY ANALYSIS SHOWING THE EFFECTS OF CRUSHING ON THE LIBERATION OF ASH FORMING IMPURITIES AND PYRITIC SULFUR FOR SAMPLE UA 146

STATE: ALASKA

COUNTY: MATANUSKA-SUSITNA

TOWN: SUTTON

DIRECT

PRODUCT

RECOVERY

WEIGHT BTU BTU/LB

ASH SULFUR PYR TOTAL
MINE:

EVAN JONES

COALBED: UPPER BED 6

COMPANY: INACTIVE

CUMULATIVE

FLOAT 1.30

$1.30-1.40$

$1.40-1.60$

SINK 1.60

MINUS 100

$\begin{array}{rrrrrr}14.2 & 19.7 & 13858 . & 3.8 & 0.01 & 0.40 \\ 30.6 & 38.0 & 12379 . & 10.7 & 0.01 & 0.38 \\ 31.4 & 31.8 & 10084 . & 27.4 & 0.02 & 0.34 \\ 23.8 & 10.6 & 4437 . & 61.9 & 0.03 & 0.17 \\ 1.0 & 0.8 & 8201 . & 38.1 & 0.05 & 0.32\end{array}$

$3 / 8 \times 0$

$\begin{array}{rr} & \text { FLOAT } 1.30 \\ \vec{\omega} \quad 1.30-1.40 \\ 1.40-1.60 \\ \text { SINK } 1.60 \\ \text { MINTUS } 100\end{array}$

$\begin{array}{rrrrrr}16.1 & 23.2 & 13970 . & 3.7 & 0.01 & 0.45 \\ 25.0 & 32.8 & 12712 . & 10.9 & 0.01 & 0.37 \\ 28.2 & 30.1 & 10321 . & 26.2 & 0.02 & 0.34 \\ 30.8 & 13.9 & 4372 . & 62.4 & 0.04 & 0.14 \\ 14.3 & 14.1 & 9470 . & 29.4 & 0.04 & 0.32\end{array}$

$14 \mathrm{M} \mathrm{X} 0$

$\begin{array}{rrrrrrr}\text { FLOAT } 1.30 & 11.4 & 16.5 & 13958 . & 2.5 & 0.01 & 0.41 \\ 1.30-1.40 & 18.8 & 25.0 & 1279 \mathrm{I} . & 9.1 & 0.01 & 0.38 \\ 1.40-1.60 & 30.5 & 34.2 & 10769 . & 21.3 & 0.01 & 0.32 \\ \text { SINK } 1.60 & 39.3 & 24.3 & 5930 . & 51.8 & 0.02 & 0.20\end{array}$

$65 \mathrm{M} \mathrm{X0}$

FLOAT 1.30

$12.8 \quad 18.8$

$\begin{array}{rrrr}13935 . & 2.1 & 0.01 & 0.42 \\ 13082 . & 7.0 & 0.01 & 0.39 \\ 10706 . & 22.9 & 0.02 & 0.33 \\ 5260 . & 57.7 & 0.09 & 0.19\end{array}$

RECOVERY WEIGHT BTU
ASH

BTU/LB
37.3

59.4

100.0

11.4

30.2

60.7

100.0

$$
\begin{array}{r}
16.5 \\
41.6 \\
75.7 \\
100.0
\end{array}
$$

41.6
75.7

18.8
52.6
77.5

100.0
13958.

13231.

9609.

13935.

13375.

12384.

$\begin{array}{rr}12384 . & 11.9 \\ 9491 . & 30.5\end{array}$

2.1
5.3
11.9
30.5

0.01

0.01

0.04
1.30- 1.40

$1.40-1.60$

SINK 1.60

24.5

220

40.6

33.8

22.5

SAMPLE MESH SIZE

$\begin{array}{rrrrrrr}\text { PLUS 65 } & 3.3 & 3.0 & 8589 . & 35.7 & 0.03 & 0.28 \\ 65-100 & 8.7 & 8.1 & 8681 . & 35.6 & 0.03 & 0.27 \\ 100-200 & 28.6 & 28.4 & 9287 . & 30.8 & 0.03 & 0.29 \\ 200-325 & 17.9 & 19.1 & 10031 . & 26.3 & 0.03 & 0.30 \\ \text { MINUS 325 } & 41.5 & 41.3 & 9313 . & 30.9 & 0.03 & 0.30\end{array}$

MINUS 325

41.5
SULFUR PYR TOTAL MMBTU

$\begin{array}{rrrrrrr}14.2 & 19.7 & 13858 . & 3.8 & 0.01 & 0.40 & 0.6 \\ 44.8 & 57.7 & 12847 . & 8.5 & 0.01 & 0.39 & 0.6 \\ 76.2 & 89.4 & 11708 . & 16.3 & 0.01 & 0.37 & 0.6 \\ 100.0 & 100.0 & 9979 . & 27.1 & 0.02 & 0.32 & 0.6 \\ 100.0 & 100.0 & 9962 . & 27.2 & 0.02 & 0.32 & 0.6\end{array}$

$\begin{array}{rrrrrrr}16.1 & 23.2 & 13970 . & 3.7 & 0.01 & 0.45 & 0.6 \\ 41.0 & 56.0 & 13205 . & 8.0 & 0.01 & 0.40 & 0.6 \\ 69.2 & 86.1 & 12031 . & 15.4 & 0.01 & 0.38 & 0.6 \\ 100.0 & 100.0 & 9670 . & 29.9 & 0.02 & 0.30 & 0.6 \\ 100.0 & 100.0 & 9645 . & 29.8 & 0.02 & 0.31 & 0.6\end{array}$

0.40

0.37

0.30

0.6

0.6

0.6

$\begin{array}{rr}3.3 & 3.0 \\ 12.0 & 11.1 \\ 40.6 & 39.5 \\ 58.5 & 58.7 \\ 100.0 & 100.0\end{array}$

$\begin{array}{ll}\text { 8589. } & 35.7 \\ 8656 . & 35.7 \\ 9101 . & 32.3 \\ 9384 . & 30.4 \\ 9355 . & 30.6\end{array}$

0.03
0.03
0.03
0.03
0.03


TABLE LII

WASHABILITY ANALYSIS SHOWING THE EFFECTS OF CRUSHING ON THE LIBERATION OF ASH FORMING IMPURITIES AND PYRITIC SULFUR FOR SAMPLE UA 147

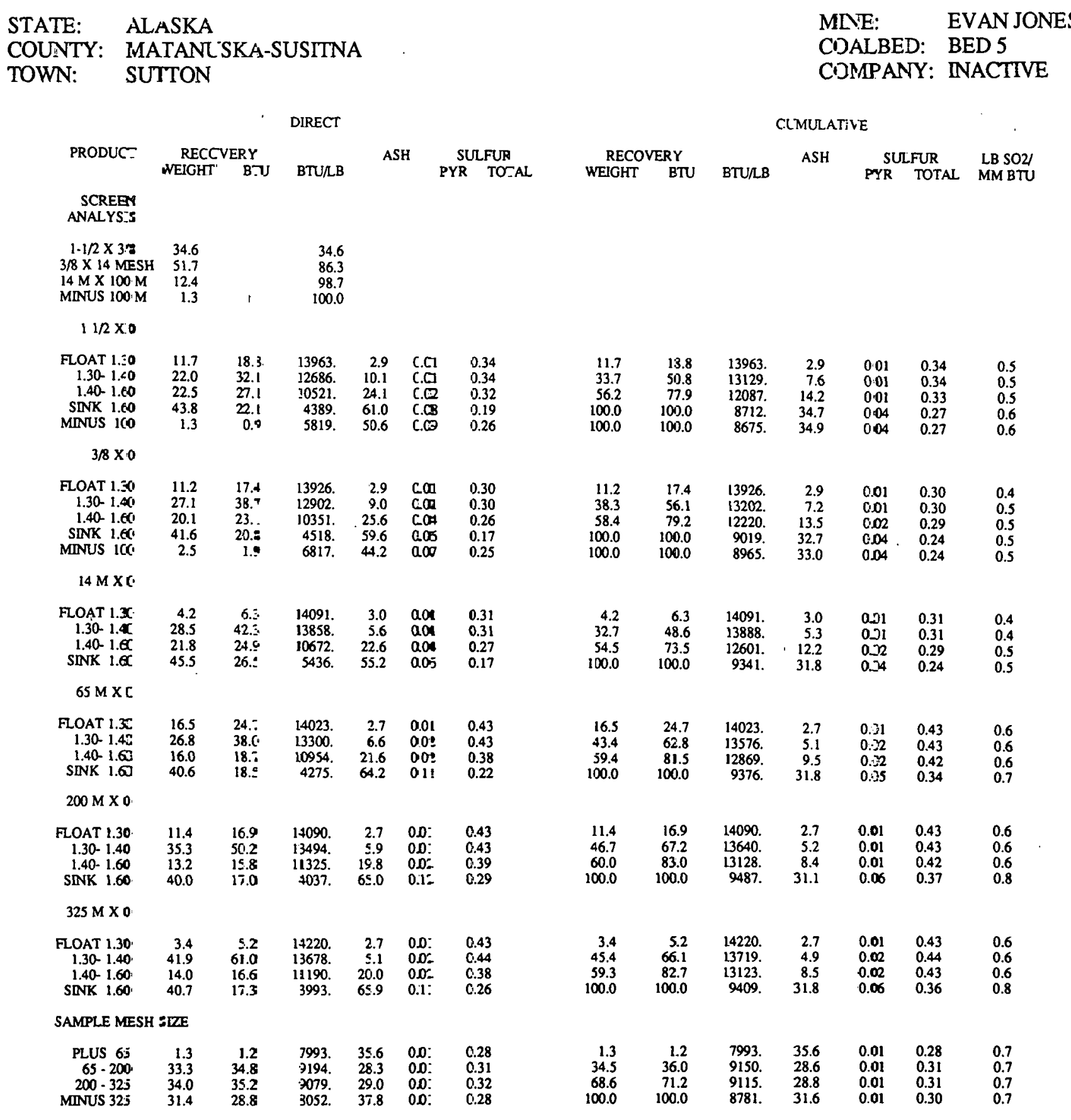


TABLE LIII

WASHABILITY ANALYSIS SHOWING THE EFFECTS OF CRUSHING ON THE LIBERATION OF ASH FORMING IMPURITIES AND PYRITIC SULFUR FOR SAMPLE UA 148

STATE: ALASKA

COUNTY: KENA:-COOK INLET

TOWN: TYONEK

DIRECT

PRODUCT RECOVERY WEIGHT BTU BTU/LB
ASH
SULFUR PYR TOTAL
MINE:

BELUGA COAL

COALBED: TON 6 FT WATERFALL

COMPANY: BELUGA COAL CO

\section{CUMULATIVE} WEIGHT BTU BTU/LB

ASH SULFUR LB SO2/ PYR TOTAL MMBTU

$11 / 2 \times 0$

FLOAT 1.30

$1.30-1.40$

$1.40-1.60$

SINK 1.60

MINUS 100

$\begin{array}{rrrrrr}13.9 & 22.8 & 11435 . & 4.1 & 0.01 & 0.23 \\ 28.4 & 41.2 & 10138 . & 12.3 & 0.04 & 0.30 \\ 20.8 & 22.3 & 7502 . & 31.3 & 0.07 & 0.33 \\ 38.0 & 14.7 & 2708 . & 72.3 & 0.05 & 0.13 \\ 1.1 & 0.7 & 4154 . & 58.0 & 0.04 & 0.20\end{array}$

$3 / 8 \times 0$

FL FOAT 1.30
$1.30-1.40$
$1.40-1.60$
SINK 1.60
MINUS 100

$\begin{array}{rrrrrr}11.6 & 18.8 & 11485 . & 3.6 & 0.01 & 0.24 \\ 29.3 & 43.3 & 10525 . & 11.3 & 0.02 & 0.29 \\ 18.3 & 20.2 & 7891 . & 22.3 & 0.08 & 0.31 \\ 40.8 & 17.7 & 3083 . & 68.2 & 0.02 & 0.14 \\ 2.5 & 1.4 & 3843 & 50.8 & 0.05 & 0.19\end{array}$

$14 \mathrm{M} \mathrm{X} 0$

FLOAT 1.30

$1.30-1.40$

$1.40-1.60$

0.0

10.4

SINK 1.60

38.2

0.0
16.8
60.0
23.2

$\begin{array}{rrrr}0 . & 0.0 & 0.00 & 0.00 \\ 1109 \cdot . & 5.1 & 0.02 & 0.25 \\ 8045 . & 25.1 & 0.05 & 0.36 \\ 418 \% . & 57.3 & 0.04 & 0.22\end{array}$

$65 \mathrm{M} \mathrm{X} 0$

FLOAT 1.30

$1.30-1.40$

$1.40-1.60$

0.2
30.4

SINK 1.60

13.1
56.3

0.3
46.7
13.9
39.2

$\begin{array}{rrrr}10911 . & 5.5 & 0.02 & 0.35 \\ 10752 . & 6.3 & 0.02 & 0.34 \\ 7400 . & 33.0 & 0.02 & 0.27 \\ 4869 . & 53.1 & 0.05 & 0.21\end{array}$

SAMPLE MESH SIZE

$\begin{array}{rrrrrrr}\text { PLUS 65 } & 4.0 & 6.2 & 10293 . & 10.8 & 0.00 & 0.42 \\ 65-100 & 9.5 & 14.6 & 10189 . & 11.0 & 0.00 & 0.40 \\ 100-200 & 19.2 & 28.2 & 9722 . & 14.5 & 0.00 & 0.40 \\ 200-325 & 10.7 & 14.5 & 9029 . & 20.2 & 0.00 & 0.40 \\ \text { MINUS 325 } & 56.6 & 36.5 & 4286 . & 57.0 & 0.00 & 0.23\end{array}$

13.9

42.3

63.0

101.0

100.0

22.8
64.0
86.3
101.0
100.0

11.6

41.0

41.0
59.2

100.0

100.0

18.8
62.1
82.3
100.0
100.0

$\begin{array}{rr}0.0 & 0.0 \\ 10.4 & 16.8 \\ 61.8 & 76.8 \\ 100.0 & 100.0\end{array}$

$\begin{array}{rr}0 . & 0.0 \\ 11099 . & 5.1 \\ 8561 . & 21.7 \\ 6893 . & 35.3\end{array}$

0.00

0.02

0.04

0.04

0.25

0.34

0.30

0.5

0.8

0.9

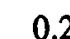

0.2
30.6

43.7

0.3
46.9
60.8
100.0

10911.

10753.

$9746 . \quad 14.3$

6999. $\quad 36.2$

$\begin{array}{ll}0.02 & 0.35 \\ 0.02 & 0.34 \\ 0.02 & 0.32 \\ 0.04 & 0.26\end{array}$

0.6

0.6

0.7
MINUS 325

56.6

$\begin{array}{lll}\text { 4286. } 57.0 & 0.00\end{array}$

0.23

$\begin{array}{rr}4.0 & 6.2 \\ 13.5 & 20.8 \\ 32.7 & 48.9 \\ 43.4 & 63.4 \\ 100.0 & 100.0\end{array}$

$\begin{array}{rr}10293 . & 10.8 \\ 10220 . & 10.9 \\ 9927 . & 13.1 \\ 9706 . & 14.8 \\ 6638 . & 38.7\end{array}$

$\begin{array}{ll}0.00 & 0.42 \\ 0.00 & 0.41 \\ 0.00 & 0.40 \\ 0.00 & 0.40 \\ 0.00 & 0.34\end{array}$

0.8

0.8

0.8

0.9

14.5
36.5 
TABLE LIV

WASHABILITY ANALYSIS SHOWING THE EFFECTS OF CRUSHING ON THE LIBERATION OF ASH FORMING IMPURITIES AND PYRITIC SULFUR FOR SAMPLE UA 149

\section{STATE: ALASKA \\ COUNTY: MATANUSKA-SUSITNA \\ TOWN: SKWENTNA}

\begin{tabular}{|c|c|c|c|c|c|c|}
\hline & & & DiRECT & & & \\
\hline PRODUCT & RECO & ERY & & AS & & SULFUR \\
\hline & & & BTU/LB & & & $\begin{array}{ll}\mathrm{R} & \mathrm{TO}\end{array}$ \\
\hline $\begin{array}{r}\text { SCREEN } \\
\text { ANALYSIS }\end{array}$ & & & & & & \\
\hline $1.1 / 2 \times 3 / 8$ & 63.9 & & & & & \\
\hline $3 / 8 \times 14$ MESH & 28.2 & & & & & \\
\hline $14 \mathrm{M} \times 100 \mathrm{M}$ & 1.2 & & & & & \\
\hline MNUS $100 \mathrm{M}$ & 6.7 & & & & & \\
\hline $11 / 2 \times 0$ & & & & & & \\
\hline FOAT 1.30 & 32.0 & 36.5 & 11283. & 5.2 & a.c1 & 0.25 \\
\hline $1.30-1.40$ & 47.3 & 49.9 & 10443. & 10.8 & 0.01 & 0.26 \\
\hline $1.40-1.60$ & 14.3 & 11.1 & 7673. & 28.8 & 0.01 & 0.24 \\
\hline SINK 1.60 & 6.5 & 2.5 & 3831. & 64.2 & 0.03 & 0.14 \\
\hline MINUS 100 & 1.0 & 0.6 & 5797. & 40.6 & 0.02 & 0.19 \\
\hline $3 / 8 \times 0$ & & & & & & \\
\hline FLOAT 1.30 & 30.4 & 34.3 & 11427. & 5.0 & $\mathrm{OCl}$ & 0.23 \\
\hline $1.30-1.40$ & 50.4 & 52.4 & 10546. & 9.3 & (i.C4 & 0.24 \\
\hline $1.40-1.60$ & 13.1 & 10.6 & 8167. & 25.9 & a.c1 & 0.22 \\
\hline SINK 1.60 & 6.1 & 2.7 & 4446. & 65.8 & 0.02 & 0.13 \\
\hline MINUS 100 & 4.2 & 3.1 & 7373. & 29.6 & 0.02 & 0.20 \\
\hline $14 \mathrm{M} \times 0$ & & & & & & \\
\hline FLAT 1.30 & 26.1 & 28.3 & 10750. & 4.9 & $a . c 1$ & 0.24 \\
\hline $1.30-1.40$ & 44.9 & 48.5 & 10749 & 9.0 & 0.68 & 0.25 \\
\hline $1.40-1.60$ & 16.9 & 14.6 & 8625. & 23.8 & a.c1 & 0.21 \\
\hline SINK 1.60 & 12.1 & 8.6 & 7094. & 39.7 & 0.07 & 0.17 \\
\hline $65 \mathrm{MXO}$ & & & & & & \\
\hline FLOAT 1.30 & 0.9 & 1.2 & 12321. & 3.9 & C.C1 & 0.27 \\
\hline $1.30 \cdot 1.40$ & 47.6 & 57.0 & 11446. & 7.2 & a.ci & 0.25 \\
\hline $1.40-1.60$ & 40.6 & 41.8 & 9854. & 16.2 & C.CI & 0.25 \\
\hline SINK 1.60 & 10.9 & 0.1 & 55. & 53.1 & 0.02 & 0.29 \\
\hline $200 \mathrm{M} \mathrm{X} 0$ & & & & & & \\
\hline FLOAT 1.30 & 0.3 & 0.3 & 11146. & 6.4 & $\mathrm{CO}$ & 0.22 \\
\hline $1.30-1.40$ & 43.3 & 49.2 & ii 1538. & 6.4 & $\mathrm{CQ}$ & 0.19 \\
\hline $1.40-1.60$ & 44.2 & 43.7 & 10034 & 14.4 & Ca & 0.17 \\
\hline SINK 1.60 & 12.3 & 5.7 & 5552. & 53.1 & $C B$ & D.24 \\
\hline $325 \mathrm{M} \mathrm{X} 0$ & & & & & & \\
\hline FLOAT 1.30 & 0.6 & 0.6 & 11309 & 5.9 & $\mathrm{CO}$ & D. 21 \\
\hline $1.30-1.40$ & 33.0 & 37.6 & 11568. & 5.7 & Cต & D. 20 \\
\hline $1.40-1.60$ & 54.2 & 55.6 & 10448. & 12.6 & Cต & D.11 \\
\hline SINK 1.60 & 12.2 & 6.2 & 5138. & 55.9 & $C D$ & D.18 \\
\hline SAMPLE MESH & SIZE & & & & & \\
\hline PLUS 65 & 2.1 & 2.2 & 10540. & 10.3 & $c \infty$ & D). 26 \\
\hline $65-200$ & 39.3 & 42.1 & 10447. & 12.1 & $\operatorname{con}$ & 0.24 \\
\hline $\begin{array}{r}200-325 \\
\text { MINUS } 325\end{array}$ & $\begin{array}{l}19.5 \\
39.1\end{array}$ & $\begin{array}{l}20.4 \\
35.2\end{array}$ & $\begin{array}{l}10183 . \\
8789\end{array}$ & 15.3 & $\cos$ & 0.23 \\
\hline MUNUS S2S & & & 8789. & 16.8 & & \\
\hline
\end{tabular}

MINE: MOBILE OIL CO COALBED: JOHNSON CREEK $20 \mathrm{FT}$ COMPANY: INACTIVE

oumulative

\begin{tabular}{clcccc}
\multicolumn{2}{c}{ RECOVERY } & ASH & \multicolumn{2}{c}{ SULFUR } & LB SO2/ \\
WEIGHT BTU BTU/LB & & PYR TOTAL. & MM BTU
\end{tabular}

63.9

92.1
93.3
100.0

$\begin{array}{rrrrrrr}32.0 & 36.5 & 11283 . & 5.2 & 0.01 & 0.25 & 0.4 \\ 79.2 & 85.4 & 10782 . & 8.5 & 0.01 & 0.26 & 0.5 \\ 93.5 & 97.5 & 10307 . & 11.6 & 0.01 & 0.25 & 0.5 \\ 100.0 & 100.0 & 9888 . & 15.0 & 0.01 & 0.25 & 0.5 \\ 100.0 & 100.0 & 9848 . & 15.3 & 0.01 & 0.25 & 0.5\end{array}$

สั

$\begin{array}{rrrrrrr}30.4 & 34.3 & 11427 . & 5.0 & 0.01 & 0.23 & 0.4 \\ 80.8 & 85.7 & 10878 . & 7.7 & 0.03 & 0.24 & 0.4 \\ 93.9 & 97.3 & 1049 . & 10.2 & 0.03 & 0.23 & 0.4 \\ 100.0 & 100.0 & 10130 . & 13.6 & 0.03 & 0.23 & 0.4 \\ 100.0 & 100.0 & 10020 . & 14.2 & 0.03 & 0.23 & 0.5\end{array}$

$\begin{array}{rrrrrrr}26.1 & 23.3 & 10750 . & 4.9 & 0.01 & 0.24 & 0.4 \\ 71.1 & 75.8 & 10749 . & 7.5 & 0.05 & 0.25 & 0.5 \\ 87.9 & 91.4 & 10342 . & 10.6 & 0.05 & 0.24 & 0.5 \\ 100.0 & 100.0 & 9950 . & 14.1 & 0.05 & 0.23 & 0.5\end{array}$

$\begin{array}{rrrrrrr}0.9 & 1.2 & 12321 . & 3.9 & 0.01 & 0.27 & 0.4 \\ 48.6 & 5.2 & 11463 & 7.2 & 0.01 & 0.25 & 0.4\end{array}$ $\begin{array}{rrrrrrr}89.2 & 99.9 & 10731 . & 11.3 & 0.01 & 0.25 & 0.5 \\ 100.0 & 100.0 & 9572 . & 15.8 & 0.01 & 0.25 & 0.5\end{array}$

$\begin{array}{rrrrrrr}0.3 & 0.3 & 11146 . & 6.4 & 0.01 & 0.22 & 0.4 \\ 43.6 & 49.6 & 11535 . & 6.4 & 0.01 & 0.19 & 0.3 \\ 87.7 & 93.3 & 10780 . & 10.4 & 0.01 & 0.18 & 0.3 \\ 100.0 & 101.0 & 10137 . & 15.7 & 0.01 & 0.19 & 0.4\end{array}$

$\begin{array}{rrrrrrr}0.6 & 0.6 & 11309 . & 5.9 & 0.01 & 0.21 & 0.4 \\ 33.6 & 38.2 & 11564 . & 5.7 & 0.01 & 0.20 & 0.3 \\ 87.8 & 93.8 & 10875 . & 9.9 & 0.01 & 0.14 & 0.3 \\ 100.0 & 100.0 & 10173 . & 15.5 & 0.01 & 0.15 & 0.3\end{array}$

$\begin{array}{rrrrrrr}2.1 & 2.2 & 10540 . & 10.3 & 0.01 & 0.26 & 0.5 \\ 41.4 & 44.4 & 10452 . & 12.0 & 0.01 & 0.24 & 0.5 \\ 60.9 & 64.8 & 1036 . & 13.0 & 0.01 & 0.24 & 0.5 \\ 100.0 & 100.0 & 9749 . & 14.5 & 0.01 & 0.23 & 0.5\end{array}$


TABLE LV

WASHABILITY ANALYSSIS SHOWING THE EFFECTS OF CRUSHING ON THE LIBERATION OF ASH FORMING IMPURITIES AND PYRITIC SULFUR FOR SAMPLE UA 150

STATE: ALASKA

COUNTY: MATANUSKA-SUSITNA

TOWN: SKWENTNA

DIRECT

PRODUCT RECOVERY WEIGHT BTU BTU/LB ASH

SULFUR

SCREEN
ANALYSIS

$\begin{array}{lr}1-1 / 2 \times 3 / 8 & 86.4 \\ 3 / 8 \times 14 \mathrm{MESH} & 12.2 \\ 14 \mathrm{M} \times 100 \mathrm{M} & 0.5\end{array}$

$\begin{array}{ll}14 \mathrm{M} X 100 \mathrm{M} & 0.5 \\ \text { MINUS } 100 \mathrm{M} & 0.9\end{array}$

$11 / 2 \times 0$

FLOAT 1.30

$1.30-1.40$

SINK 1.60

MINUS 100

$\begin{array}{rr}18.3 & 20.4 \\ 52.9 & 54.2 \\ 20.9 & 21.4 \\ 7.9 & 4.0 \\ 0.9 & 0.5\end{array}$

$\begin{array}{rrrr}11657 . & 4.9 & 0.01 & 0.19\end{array}$

$\begin{array}{llll}10707 . & 11.4 & 0.01 & 0.18\end{array}$

$\begin{array}{llll}10737 . & 27.3 & 0.01 & 0.14\end{array}$

$\vec{y}$

$3 / 8 \times 0$

FLOAT 1.30
$1.30-1.40$

$1.30-1.40$
$1.40-1.60$

SINK 1.60

SINK 1.60
MINUS 100

$\begin{array}{rrrrrr}21.8 & 25.5 & 11873 . & 4.4 & 0.01 & 0.18 \\ 51.2 & 55.0 & 10884 . & 9.0 & 0.01 & 0.17 \\ 18.4 & 15.2 & 8354 . & 26.0 & 0.02 & 0.14 \\ 8.6 & 4.3 & 5093 . & 55.8 & 0.01 & 0.08 \\ 4.5 & 3.3 & 7237 . & 32.4 & 0.01 & 0.13\end{array}$

$14 \mathrm{MXO}$

FLOAT 1.30

$1.30-1.40$

$1.40-1.60$

SINK 1.60

$\begin{array}{llllll}23.1 & 27.2 & 11640 . & 4.4 & 0.01 & 0.17 \\ 40.4 & 44.9 & 10971 . & 8.2 & 0.01 & 0.15\end{array}$

$\begin{array}{rrrrrr}40.4 & 44.9 & 10971 . & 8.2 & 0.01 & 0.15 \\ 21.0 & 18.5 & 8675 & 23.3 & 0.01 & 0.13\end{array}$

$65 \mathrm{M} \times 0$

$\begin{array}{rrrrrr}21.0 & 18.5 & 8675 . & 23.3 & 0.01 & 0.13 \\ 15.5 & 9.3 & 5940 . & 47.7 & 0.02 & 0.09\end{array}$

FLOAT 1.30

$1.30-1.40$

$1.40-1.60$
SINK 1.60

0.4
53.3
26.8
19.5

$\begin{array}{rr}0.5 & 119 \\ 61.7 & 1168\end{array}$

AMPLE MESH SIZE

$\begin{array}{rrrrrrr}\text { PLUS 65 } & 4.9 & 5.1 & 10319 . & 1.9 & 0.01 & 0.21 \\ 65-100 & 12.1 & 13.2 & 10856 . & 11.2 & 0.01 & 0.21 \\ 100-200 & 32.0 & 34.0 & 10602 . & 12.7 & 0.01 & 0.22 \\ 200-325 & 16.5 & 17.0 & 10306 . & 14.6 & 0.01 & 0.22 \\ \text { MINUS 325 } & 34.5 & 30.7 & 8840 . & 26.9 & 0.01 & 0.19\end{array}$

$\begin{array}{rrrr}11683 . & 5.7 & 0.01 & 0.24 \\ 9670 & 18.5 & 0.01 & 0.23\end{array}$

$\begin{array}{llll}9670 . & 18.5 & 0.01 & 0.23 \\ 6241 . & 51.8 & 0.01 & 0.16\end{array}$
11973. $\quad 2.2 \quad 0.01 \quad 0.24$
MINE:

MOBILE OIL CO

COALBED: CANYON CREEK 34 FT

COMPANY: INACTIVE

CUMULATIVE

\begin{tabular}{cccccc}
\multicolumn{2}{c}{ RECOVERY } & & ASH & SULFUR & LB SO2/ \\
WEIGHT BTU & BTU/LB & & PYR TOTAL & MM BTU
\end{tabular}

86.4

9.9 .1

100.0

$\begin{array}{rrrrrrr}18.3 & 20.4 & 11657 . & 4.9 & 0.01 & 0.19 & 0.3 \\ 71.2 & 74.6 & 10951 . & 9.8 & 0.01 & 0.18 & 0.3 \\ 92.1 & 96.0 & 10902 . & 13.7 & 0.01 & 0.17 & 0.3 \\ 100.0 & 100.0 & 10452 . & 17.0 & 0.01 & 0.17 & 0.3 \\ 100.0 & 100.0 & 10408 . & 17.3 & 0.01 & 0.17 & 0.3\end{array}$

100.0

100.0

21.8

73.0

91.4

100.0

25.5

95.7

95.7
100.0

10138.

$100.0 \quad 10013$

$\begin{array}{lllll}11873 . & 4.4 & 0.01 & 0.18 & 0.3\end{array}$

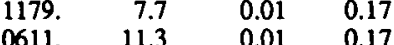

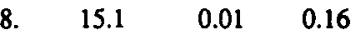

$\begin{array}{ll}0.01 & 0.16 \\ 0.01 & 0.16\end{array}$

0.3

0.3

$\begin{array}{lllllll}23.1 & 27.2 & 11640 . & 4.4 & 0.01 & 0.17 & 0.3 \\ 63.5 & 72.2 & 11214 . & 6.8 & 0.01 & 0.16 & 0.3\end{array}$

$\begin{array}{rrrrrrr}63.5 & 72.2 & 11214 . & 6.8 & 0.01 & 0.16 & 0.3 \\ 84.5 & 90.7 & 10583 . & 10.9 & 0.01 & 0.15 & 0.3\end{array}$

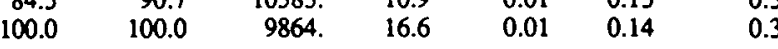
-.

$\begin{array}{rrrrrrr}0.4 & 0.5 & 11973 . & 2.2 & 0.01 & 0.24 & 0.4 \\ 53.7 & 62.3 & 11685 . & 5.7 & 0.01 & 0.24 & 0.4 \\ 80.5 & 88.0 & 11015 . & 10.0 & 0.01 & 0.24 & 0.4 \\ 100.0 & 100.0 & 10085 . & 18.1 & 0.01 & 0.22 & 0.4\end{array}$

100.010085 .

$\begin{array}{lll}18.1 & 0.01 & 0.22\end{array}$

0.4
0.4

0.4
0.4

$\begin{array}{rrrrrrr}4.9 & 5.1 & 10319 . & 1.9 & 0.01 & 0.21 & 0.4 \\ 17.0 & 18.3 & 10701 . & 8.5 & 0.01 & 0.21 & 0.4 \\ 49.0 & 52.3 & 10636 . & 11.2 & 0.01 & 0.22 & 0.4 \\ 65.5 & 69.3 & 10553 . & 12.1 & 0.01 & 0.22 & 0.4 \\ 100.0 & 100.0 & 9961 . & 17.2 & 0.01 & 0.21 & 0.4\end{array}$


TABLE LVI

WASHABILITY ANALYSIS SHOWING THE EFFECTS OF CRUSHING ON THE LIBERATION OF ASH FORMING IMPURITIES AND PYRITIC SULFUR FOR SAMPLE UA 151

STATE: ALASKA

COUNTY: NOME

TOWN: UNALAKLEET

DRECT

PRODUCT

FECOVERY
WEIGH] BTU BTU/LB

ASH

SULFUR

SCREEN

ANALYSIS

$\begin{array}{cr}1-1 / 2 \times 3 / 8 & 4 \leq .2 \\ 3 / 8 \times 14 \mathrm{MESH} & 4 \epsilon .6\end{array}$

$14 \mathrm{M} \mathrm{X} 100 \mathrm{M}$

$11 / 2 \times 0$

FLOAT 1.30

$1.30-1.40$

$1.40-1.60$

SINK 1.60

MINUS 100

$\begin{array}{rr}45.8 & 46 . \\ 45.2 & 48 . \\ 4.0 & 3 . \\ 4.0 & 1.4 \\ 5.3 & 2 .\end{array}$

1179

11128.

$\vec{\infty}$

$3 / 8 \times 0$

FLOAT 1.30

$1.30-1.40$

SINK 1.60

MINUS 100

$$
\begin{array}{r}
4: .5 \\
49.3 \\
5.6 \\
3.6 \\
5.6
\end{array}
$$

44.1

$\begin{array}{ll}5.3 & 49.1 \\ 5.6 & 4.0 \\ 5.6 & 2.1\end{array}$

$14 \mathrm{MX} 0$

FLOAT 1.30
$1.30-1.40$

$1.30-1.40$
$1.40-1.60$

SINK 1.60

$\begin{array}{rrrrrr}2^{7.8} & 30.5 & 12052 . & 6.5 & 0.01 & 0.64 \\ \mathbf{5 7 . 8} & 59.5 & 11265 . & 6.4 & 0.02 & 0.76 \\ 7.1 & 6.0 & 9670 . & 17.2 & 0.02 & 0.63\end{array}$

$65 \mathrm{M} \times 0$

FLOAT 1.30

SINK 1.60

$\begin{array}{rrrrrr}2.7 & 3.4 & 13605 . & 4.2 & 0.02 & 0.50 \\ 6.1 & 71 . & 11702 . & 6.3 & 0.02 & 0.73 \\ 16.3 & 18.3 & 10437 . & 11.4 & 0.02 & 0.73 \\ 10.9 & 6.6 & 6649 . & 44.4 & 0.15 & 0.55\end{array}$

SAMPLE MESH SLZTE

$\begin{array}{rrrrrrr}\text { PLUS 65 } & 7.1 & 7.5 & 11540 . & 7.1 & 0.02 & 0.68 \\ 65-100 & 13.9 & 14.6 & 1150 . & 7.2 & 0.03 & 0.82 \\ 100.200 & 32.1 & 33.7 & 1141 . & 8.3 & 0.03 & 0.73 \\ 200-325 & 16.9 & 17.4 & 11264 . & 9.8 & 0.02 & 0.69 \\ \text { MINUS 325 } & 30.0 & 26.5 & 9742 . & 21.1 & 0 . C 2 & 0.59\end{array}$

$\begin{array}{llll}11792 . & 6.7 & 0.03 & 0.58\end{array}$

11095. $\quad 6.4 \quad 0.01$

$\begin{array}{llll}905 . & 22.3 & 0.02 & 0.48\end{array}$

6421. $\quad 58.9 \quad 0.04 \quad 0.36$
MINE: UNALAKLEET'

CDALBED: BEACH BLUFF

COMPANY: INACTIVE

CUMULATTVE

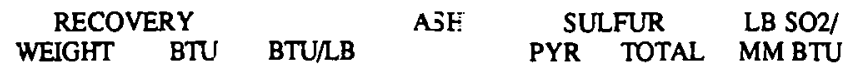

45.2

91.8

96.7

$\begin{array}{lllllll}43.8 & 46.8 & 11792 . & 5.9 & 0.01 & 0.52 & 0.9\end{array}$

$\begin{array}{llllll}92.0 & 95.5 & 11444 . & 6.1 & 0.02 & 0.60 \\ 96.0 & 98.6 & 11328 . & -.0 & 0.02 & 0.60\end{array}$

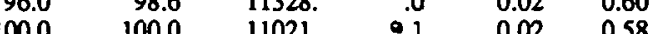

$\begin{array}{llllll}100.0 & 100.0 & 11021 . & 9.1 & 0.02 & 0.58 \\ 100.0 & 10929 . & 9.7 & 0.02 & 0.58\end{array}$

$\begin{array}{llll}3698 . & 59.1 & 0.03 & 0.29 \\ 8184 . & 28.5 & 0.07 & 0.63\end{array}$

41.5
90.8
96.4

100.0

100.0

$44.1 \quad 11792$.

$\begin{array}{ll}93.4 & 11413 \\ 97.9 & 11276\end{array}$

11103

100.010923

$\begin{array}{rlll}.7 & 0.03 & 0.58 & 1.0 \\ .5 & 0.02 & 0.61 & 1.1 \\ 7.5 & 0.02 & 0.60 & 1.1 \\ 9.3 & 0.02 & 0.59 & 1.1 \\ 10.5 & 0.02 & 0.59 & 1.1\end{array}$

27.8

$\begin{array}{llllll}30.6 & 12052 . & 6.5 & 0.01 & 0.64 & 1.1\end{array}$

$85.6 \quad 90.2 \quad 11520$.

92.6

$100.0 \quad 10927$

$\begin{array}{lll}0.4 & 0.02 & 0.72\end{array}$

$\begin{array}{lll}7.3 & 0.02 & 0.71\end{array}$

$\begin{array}{lll}0.02 & 0.71 & 1.3\end{array}$

$\begin{array}{rrrrrrr}2.7 & 3.4 & 13605 . & 4.2 & 0.02 & 0.50 & 0.7 \\ 69.9 & 75.1 & 11776 . & 6.2 & 0.02 & 0.72 & 1.2 \\ 89.1 & 93.4 & 11487 . & 7.3 & 0.02 & 0.72 & 1.3 \\ 100.0 & 100.0 & 10960 . & 1 . .4 & 0.03 & 0.70 & 1.3\end{array}$

89.1
100.0

$00.0 \quad 10960$

$\begin{array}{rrrrrrr}7.1 & 7.5 & 11540 . & 7.1 & 0.02 & 0.68 & 1.2 \\ 21.0 & 22.1 & 11514 . & 7.2 & 0.03 & 0.77 & 1.3 \\ 53.1 & 55.8 & 11452 . & 7.8 & 0.03 & 0.75 & 1.3 \\ 70.0 & 73.2 & 11407 . & .3 .3 & 0.03 & 0.73 & 1.3 \\ 100.0 & 100.0 & 10907 . & 12.1 & 0.03 & 0.70 & 1.3\end{array}$


TABLE LVII

WASHABILITY ANALYSIS SHOWING THE EFFECTS OF CRUSHING ON THE LIBERATION OF ASH FORMING IMPURITIES AND PYRITIC SULFUR FOR SAMPLE UA 152

\section{STATE: ALASKA \\ COUNTY: KENAI-COOK INLET \\ TOWN: TYONEK}

DIRECT

PRODUCT

RECOVERY
WEIGHT BTL
BTU/LB

ASH

SULFUR

SCREEN
ANALYSIS

$\begin{array}{lr}1-1 / 2 \times 3 / 8 & 53.2 \\ 3 / 8 \times 14 \mathrm{MESH} & 35.7 \\ 14 \mathrm{M} \times 100 \mathrm{M} & 9.6 \\ \text { MNUS } 100 \mathrm{M} & 1.5\end{array}$

$11 / 2 \times 0$

$\begin{array}{rr}\text { FLOAT } 1.30 & 64 \\ 1.30-1.40 & 31.4 \\ 1.40-1.60 & 3.0 \\ \text { SINK } 1.60 & 1.5 \\ \text { MINUS } 100 & 2.2\end{array}$

$\overrightarrow{0}$

$3 / 8 \times 0$

$\begin{array}{rr}64.1 & 66.5 \\ 31.4 & 30.8 \\ 3.0 & 2.2 \\ 1.5 & 0.4 \\ 2.2 & \end{array}$

$\begin{array}{rr}66.5 & 11633 \\ 30.8 & 11007 \\ 2.2 & 8464 \\ 0.4 & 2727 \\ 1.5 & 7459\end{array}$

$\begin{array}{lll}11633 . & 3.5 & 0.01 \\ 11007 & 7.2 & 0.01\end{array}$

$\begin{array}{llll}11007 . & 7.2 & 0.01 & 0.16 \\ 119 & 0.19\end{array}$

$\begin{array}{llll}2727 . & 64.7 & 0.03 & 0.08 \\ 7459 . & 29.0 & 0.04 & 0.17\end{array}$
MINE: LONE RIDGE MINE

COALBED: GREEN

COMPANY: BELUGA COAL CO

CUMULATIVE

\begin{tabular}{cccccc}
\multicolumn{2}{c}{ RECOVERY } & ASH & SULFUR & LB SO2/ \\
WEIGHT & BTU & BTU/LB & PYR TOTAL & MM BTU
\end{tabular}

53.2

88.9

98.5
100.0

$\begin{array}{llll}\text { 8464. } & 22.1 & 0.01 & 0.18\end{array}$

FLOAT 1.30
$1.30-1.40$
$1.40-1.60$
SINK 1.60

$\begin{array}{rr}50.6 & 52.7 \\ 44.2 & 44.3 \\ 3.2 & \\ 2.1 & \\ 4.2\end{array}$

$\begin{array}{rr}52.7 & 1158 \\ 44.3 & 1115 \\ 2.5 & \\ 0.6 & 304 \\ 3.5 & \end{array}$

11588. $\quad 3.7 \quad 0.01 \quad 0.13$

$\begin{array}{rrrr}11152 . & 5.2 & 0.01 & 0.18 \\ 8882 & 19.5 & 0.02 & 0.11\end{array}$

$\begin{array}{llll}\text { 8882. } & 19.5 & 0.02 & 0.11\end{array}$

MINUS 100

$\begin{array}{llll}3049 . & 64.5 & 0.02 & 0.07 \\ 9147 . & 18.6 & 0.02 & 0.15\end{array}$

$14 \mathrm{M} \times 0$

FLOAT 1.30
$1.30-1.40$

$1.30-1.40$
$1.40-1.60$

$\begin{array}{rr}51.7 & 54.3 \\ 39.2 & 39.0 \\ 6.4 & 5.7 \\ 2.7 & \end{array}$

54.3
39.0
5.7
1.0

$\begin{array}{llll}11626 . & 3.8 & 0.01 & 0.17\end{array}$

$\begin{array}{rrrr}11626 . & 3.8 & 0.01 & 0.17 \\ 10995 . & 7.4 & 0.01 & 0.15 \\ 9899 . & 15.1 & 0.01 & 0.16\end{array}$

SNK 1.60

$\begin{array}{llll}4197 & 56.9 & 0.03 & 0.10\end{array}$

$65 \mathrm{M} \mathrm{X} 0$

FLOAT 1.30

$1.30-1.40$

$1.40-1.60$

$\begin{array}{rrrrrr}0.8 & 0.8 & 11570 . & 2.8 & 0.02 & 0.20 \\ 83.5 & 86.7 & 11403 . & 4.8 & 0.03 & 0.22 \\ 10.4 & 9.2 & 9781 . & 15.1 & 0.02 & 0.24 \\ 5.3 & 3.3 & 6822 . & 44.2 & 0.04 & 0.16\end{array}$

SAMPLE MESH SIZE

$\begin{array}{rrrrrrr}\text { PLUS 65 } & 12.6 & 13.3 & 11540 . & 5.3 & 0.03 & 0.19 \\ 65-100 & 14.4 & 14.8 & 11315 . & 6.4 & 0.05 & 0.20 \\ 100-200 & 29.0 & 30.0 & 11352 . & 6.3 & 0.03 & 0.17 \\ 200-325 & 14.2 & 14.5 & 1117 . & 7.7 & 0.02 & 0.19 \\ \text { MINUS 325 } & 29.8 & 27.4 & 10092 . & 12.8 & 0.01 & 0.19\end{array}$

$\begin{array}{rrlllll}64.1 & 66.5 & 11633 . & 3.5 & 0.01 & 0.16 & 0.3 \\ 95.5 & 97.4 & 11427 . & 4.7 & 0.01 & 0.17 & 0.3 \\ 98.5 & 99.6 & 11338 . & 5.3 & 0.01 & 0.17 & 0.3 \\ 100.0 & 100.0 & 11205 . & 6.2 & 0.01 & 0.17 & 0.3 \\ 100.0 & 100.0 & 11124 . & 6.7 & 0.01 & 0.17 & 0.3\end{array}$

$\begin{array}{rrlllll}50.6 & 52.7 & 11588 . & 3.7 & 0.01 & 0.13 & 0.2 \\ 94.8 & 96.9 & 11385 . & 4.4 & 0.01 & 0.15 & 0.3 \\ 97.9 & 99.4 & 11304 . & 4.9 & 0.01 & 0.15 & 0.3 \\ 100.0 & 100.0 & 11132 . & 6.1 & 0.01 & 0.15 & 0.3 \\ 100.0 & 100.0 & 11052 . & 6.6 & 0.01 & 0.15 & 0.3\end{array}$

$\begin{array}{lllllll}51.7 & 54.3 & 11626 & 3.8 & 0.01 & 0.17 & 0.3\end{array}$

$\begin{array}{llllll}90.9 & 93.3 & 11354 . & 5.3 & 0.01 & 0.16\end{array}$

$\begin{array}{lllll}97.3 & 99.0 & 11258 & 6.0 & 0.01\end{array}$

$\begin{array}{llllll}100.0 & 100.0 & 11069 & 7.4 & 0.01 & 0.16\end{array}$

0.3
0.3

0.3
0.3

$\begin{array}{rrlllll}0.8 & 0.8 & 11570 . & 2.8 & 0.02 & 0.20 & 0.3 \\ 84.3 & 87.5 & 11405 . & 4.7 & 0.03 & 0.22 & 0.4 \\ 94.7 & 96.7 & 11227 . & 5.9 & 0.03 & 0.22 & 0.4 \\ 100.0 & 100.0 & 10992 . & 7.9 & 0.03 & 0.22 & 0.4\end{array}$

$\begin{array}{rrrrrrr}12.6 & 13.3 & 11540 . & 5.3 & 0.03 & 0.19 & 0.3 \\ 27.0 & 28.1 & 11420 . & 5.9 & 0.04 & 0.20 & 0.3 \\ 56.0 & 58.1 & 11385 . & 6.1 & 0.04 & 0.18 & 0.3 \\ 70.2 & 72.6 & 11331 . & 6.4 & 0.03 & 0.18 & 0.3 \\ 100.0 & 100.0 & 10962 . & 8.3 & 0.03 & 0.19 & 0.3\end{array}$




\section{- REFERENCES}

Adkinson, W.L., Kelley, J.S., and Newman, K.R., 1975, Lithology and palynology of Tertiary rocks exposed near Capps glacier and along Chuitna River, Tyonek quadrangle, southern Alaska: U.S. Geol. Survey Open-File Report 75-21, 58 p.

Barnes, F.A., Mining and Exploration in 1945 in the Wishbone Hill District, Matanuska Valley, Alaska, in Barnes, F.F. and others, Coal Investigations in Southcentral Alaska, 194446: U.S. Geol. Survey Bull. 963-E, 1951, p. 193-201.

Barnes, F.F. and Payne, Thomas G., The Wishbone Hill District, Matanuska Coal Field, Alaska: U.S. Geol. Survey Bull. 1016, 1956, 88 pp.

Barnes, F.F. and Cobb, E.H., 1959, Geology and coal resources, Homer district, Alaska: U.S. Geol. Survey Bull. 1058-F, 217-260 p.

Barnes, F.F., 1962, Geologic Máp of Lowèr Matanuska Valley, Alaska, Misc. Gieological Investigations Map I-359.

Barnes, F.F., 1966, Geology and coal resources of the Beluga-Yentna region, Alaska: U.S. Geol. Survey Bull. 1202-C, 54 p.

Barnes, F.F., 1967, Coal resources of Alaska: U.S. Geol. Survey Bull. 1232-B, 89 p.

Barnes, F.F., 1967, Coal resources of the Cape Lisburne - Colville River region, Alaska: U.S. Geol. Survey Bull. 1242-E, 37 p.

Blumer, J.W., 1980, Review of Mobil Coal Leases - Yentna Region, Alaska, Proceedings of Coal Conference, Focus on Alaska's Coal '80, Mineral Industry Research Laboratory, Report No. 50, University of Alaska, p. 122-126.

Brabb, E.E. and Churkin, Michael, Jr., 1964, Preliminary geologic map of the Charley River quadrangle, east-central Alaska, U.S. Geol. Survey Open-file map, Scale 1:250,000. $234 \mathrm{p}$.

Brooks, A.H., 1911, Mt McKinley region, Alaska: U.S. Geol. Survey Prof. Paper 70,

Calderwood, K.W. and Fackler, W.C., 1972, Proposed nomenclature for Kenai Group, Cook Inlet Basin, Alaska: American Association of Petroleum Geologists Bull. vol. 56, No. 4, p. 739-754.

Callahan, James E., 1975, Coal Investigation in Western Arctic Alaska, in Focus on Alaska's Coal '75, Proceedings of Coal Conference: Report No. 37, Mineral Industry Research Laboratory, University of Alaska, Fairbanks, p. 48-53:

Callahan, James E. and Sloan, E.G., 1978, Preliminary Report on Analyses of Cretaceous Coals from Northwestern Alaska, U.S. Geological Survey Open-file Report 78-319, 29 p.

Callahan, J.E. and Martin, G.C., 1980, Coal Occurrences of the Nanushuk Group, Western Arctic Alaska - an update, proceedings of the conference "Focus on Alaska's Coal '80": Report No. 50, Mineral Industry Research Lajoratory, University of Alaska, p.32-60. 
Capps, S.R., 1919, Kantishna region, Alaska: U.S. Geol. Survey Bull. 687, 118 p.

Cavallaro, J.A., M.T. Johnson and A.W. Deurbrouck, 1976, Sulfur Reduction Potential of the Coals of the United States: U.S. Bureau of Mines, RI 8118, $323 \mathrm{p}$.

Chapman, R.M. and Sable, E.G., 1960, Geology of the Utukok-Corwin region, northwestern Alaska, Part 3, Area Geology: U.S. Geol. Survey Prof. Paper 303-C, 167 p.

Chapman, R.M., 1963, Coal deposits along the Yukon River between Ruby and Anvik, Alaska, in Contributions to Economic Geology of Alaska, U.S. Geol. Survey Bull. 1155, p. 23.

Collier, Arthur, J., 1903, The coal resources of the Yukon, Alaska, U.S. Geological Survey Bulletin 218.

Conwell, C.N. and Triplehorn, D.M., 1978, Herendeen Bay - Chignik Coals, Southern Alaska Peninsula, Alaska Division of Geological and Geophysical Surveys Special Report $8,15 \mathrm{p}$.

Denton, Steve W., 1980, Geology and Coal Resources of the Lower Lignite Creek Area, Proceedings of Conference, "Focus on Alaska's Coal '80", Mineral Industry Research Laboratory, Report No. 50, University of Alaska, pp. 138-143.

Ferrians, O.J., 1971, Preliminary engineering geologic maps of the proposed TransAlaska Pipeline route, Beecy Point and Sagavanirktok quadrangles:U.S. Geol. Survey OpenFile Map.

Gates, G.O., 1944, Part of the Herendeen Bay Coal Field, Alaska, U.S. Geological Survey Open-file Report 2, 5 p.

Geer, M.R. and Yancey, H.F., 1946, Washability Characteristics and Washing of Coals from the matanuska field of Alaska, U.S. Bureau of Mines Report of Investigations 3840, $17 \mathrm{p}$.

Geer M.R. and Fennessy, F.D., 196s, Washability of Coals from the Matanuska Valley and Beluga River Fields, Alaska, U.S. Bureau of Mines Report of Investigations 6017, 33 p.

Henshaw, F.T., 1910, Mining in Seward Peninsula, in Brooks, A.H. and others, Mineral Resources of Alaska, Report on progress of investigations in 1909, U.S. Geol. Survey Bull. 442 , p. $368-369$.

Hopkins, D.M., 1951, Lignite deposits near Broad Pass Station, Alaska: in Barnes, F.F. and others, Coal investigations in south-central Alaska, 1944-46: U.S. Geol. Survey Bull. 963-E, pp. 187-191.

Jolley, T.R., Tonges, A.L. and Turnbull, L.A., 1952, Bituminous Coal Deposits in the Vicinity of Eska, Matanuska Valley Coal Field, Alaska, U.S. Bureau of Mines, Report of Investigation $4838,87 \mathrm{p}$.

Keller, S.A., Morris, R.M. and Detterman, R.L., 1961, Geology of the Shaviovik and 
Sagavanirktok Rivers region, Alaska: U.S. Geol. Survey Prof. Paper 303-D, pp. 169-222.

Laird, A.M., 1978 Development of the Beluga coal field, a status report: A paper presented at the annual convention, Alaska Miners Association, October, 1978, 7 p.

Magoon, L.B., Adkison, W.L. and Egbert, R.M., 1976, Map showing geology, wild cat wells, Tertiary plant fossil localities, $\mathrm{K}$-Ar age dates, and petroleum operations, Cook Inlet area, Alaska: U.S. Geol. Survey, Misc. Inv. Series. Map I-1019.

Manning, K.H. and Stevens, D.L., 1982, Chicago Creek and Norton Sound Area Coal Exploration programs, Report prepared for State of Alaska, Division of Geological and Geophysical Surveys.

Martin, G.C., 1926, The Mesozoic Stratigraphy of Alaska, U.S. Geological Survey Bulletin 776, pp. 403-407.

Martin, G.C. and Callahan, J.E., 1978, Preliminary report on the coal resources of the National Petroleum Reserve in Alaska: U.S. Geol. Survey Open File Report 78-1033, 23p.

McGee, D.L., 1976, Gasification prospects and application in Cook Inlet, Alaska: in Focus on Alaska's Coal '75: University of Alaska, Mineral Industry Research Laboratory, p. 219-226.

Mertie, J.B., Jr., 1930, Mining in the Forty mile District, Alaska, U.S. Geol. Survey Bull. 813-C, p. 141-142.

Patsch, Benno J.G., 1980, Remaining coal resources of the Matanuska field, proceedings of the Conference "Focus on Alaska's Coal '80", Mineral Industry Research Laboratory, Report No. 50, University of Alaska, p. 144-151.

Paige, Sidney, 1906, The Herendeen Bay Coal Field, Alaska, U.S. Geol. Survey Bull. $281, p .101108$.

Patton, W.W., Jr., 1973, Reconnaissance geology of the northern Yukon-Koyukuk Province, Alaska: U.S. Geol. Survey Prof. Paper 774-A, 17 p.

Player, A.F., 1976, The Little Tonzona coal bcd ncar Farewell, Alaska: An important extension of the coal field north of the Alaska Range; a report by Gary Player Ventures, Box 476-M, Star Route A, Anchorage, Alaska 99507, 10 p.

Ramsey, J.P., 1980, Geology - Coal Resources and Mining Plan for the Chuitna River Field, Alaska, Proceedings of Coal Conference "Focus on Alaska's Coal '80", Mineral Industry Research Laboratory, Report No. 50, University of Alaska, p. 111-121.

Rao, P.D., 1975, Characterization of Alaskan Coals, Proceedings of Coal Conference "Focus on Alaska's Coal '75", Mineral Industry Research Laboratory, Report No. 37, University of Alaska, p. 33-47.

Rao, P.Dharma and Wolff, E.N., 1978, Characterization and Evaluation of Washability of Alaskan Coals, Phase I. Selected seams from Nenana, Matanuska and Jarvis Creek Fields: Report No. 41, Mineral Industry Research Laboratory, University of Alaska, 35 p. (DOE/ 
ET/13350-T1).

Rao, P. Dharma and Wolff, E.N., 1980, Characterization and Evaluation of Washability of Alaskan Coals, Phase II. Selected seams from Northern Alaska, Broad Pass, Little Tonzona, Tramway Bar, Beluga, Yentna, Kenai and Nenana Coal Fields: Report No. 42, Mineral Industry Research Laboratory, University of Alaska, 47 p. (DOE/ET/13350-T2).

Rao, P. Dharma, 1980, Petrographic Mineralogical and Chemical Characterization of Certain Arctic Alaskan Coals from the Cape Beaufort Region, Report No. 44, Mineral Industry Research Laboratory, University of Alaska, 66 p., U.S. Dept. of Energy Contract No. DE-FG22-80PC30237, University of Alaska, Fairbanks.

Rao, P. Dharma and Wolff, E.N., 1980, Steam drying of Subbituminous coals from the Nenana and Beluga fields, a laboratory study, Proceedings of conference "Focus on Alaska's Coal '80": Report No. 50, Mineral Industry Research Laboratory, University of Alaska, p. 278-304.

Rao, P.D., 1981, Raw Coal Characterization and Washability Studies of Core Drill Coal from Little Tonzona Field, Near Farewell, Alaska, Mineral Industry Research Laboratory, Report submitted to McIntyre Mines Ltd, 115 p.

Rao, P. Dharma and Wolff, E.N., 1982, Characterization and Evaluation of Washability of Alaskan Coals, Phase III. Selected seams from Northern Alaska, Nulato, Eagle, Nenana, Broad Pass, Kenai, Beluga, and Chignik coal fields: Report No. 62, Mineral Industry Research Laboratory, University of Alaska, 62 p. (DOE/ET/13350-T6).

Rao, P. Dharma and Wolff, E.N., 1982, Characterization and Evaluation of Washability of Alaskan Coals, Phase IV. Selected seams from Northern Alaska, Chicago Creek, Unalakleet, Nenana, Matanuska, Beluga, Yentna and Herendeen Bay coal fields: Report No. 63, Mineral Industry Research Laboratory, University of Alaska, 60 p. (DOE/ET/13350T5).

Rao, P. Dharma and Smith, Jane S., 1983, Petrology of Cretaceous Coals from Northern Alaska, Mineral Industry Research Laboratory Report No. 64, U.S. Dept. of Energy Grant No. DE-FG22-80 PC30237, 141 p.

Retherford, R.M., Hinderman, T.K. and Hawley, C.C., 1986, Preliminary Feasibility Study of a Coal Mine at Chicago Creek, Report prepared for State of Alaska, Division of Geological and Geophysical Exploration, Contract No. CC10-DO71, 123 p. and appendices.

Sanford, R.S. and Pierce, H.C., 1946, Exploration of coal deposits of the Point Barrow and Wainwright areas, northern Alaska: U.S. Bureau of Mines, RI 3934, 17 p.

Schrader, F.C., 1900, Preliminary Report on reconnaissance along the Chandalar and Koyukuk Rivers, Alaska in 1899: U.S. Geol. Survey Twenty-First Annual Report part 2, $485 \mathrm{p}$.

Smith, P.S. and Eakin, H.M., 1910, Mineral resources of the Nulato-Council region in Brooks, A.H. and others, Mineral resources of Alaska report on progress of investigations in 1909: U.S. Geological Survey Bulletin 442, p. 350-52. 
Smith, P.S., Mertie, J.B., Jr., 1930, Geology and mineral resources of northwestern Alaska: U.S. Geol. Survey Bull. 815, 351 p.

Tailleur, I.L., Brosge, W.P., 1976, Coal Resources of Northern Alaska may be Nation's Largest, in Focus on Alaska's Coal '75: University of Alaska, Mineral Industry Research Laboratory, pp. 219-226.

Thorpe, Walter, 1982, Tonzona Project, Summary report for 1981, Report submitted to McIntyre Mines, 22 p.

Tonges, A.L. and Jolley, T.R., 1947, Investigation of coal deposits for local use in the Arctic regions of Alaska and proposed mine development: U.S. Bureau of Mines, RI 4150, $19 \mathrm{p}$.

Tonges, A.L. and Jolley, T.R., 1949, Investigations of coal deposits in southcentral Alaska and the Kenai Peninsula: U.S. Bureau of Mines, RI 4520, 37 p.

Tucker, R.L., 1968, Final Report, Evan Jones Coal Company, Jonesville, Alaska (unpublished), $47 \mathrm{p}$.

Wahrhaftig, Clyde, 1944, Coal deposits of the Costello Creek Basin, Alaska, U.S. Geol. Survey Open File Rept. 8, 7 p.

Wahrhaftig, Clyde, Hickcox, C.A. and Freedman, Jacob, 1951, Coal Deposits on Healy and Lignite Creeks, Nenana Coal Field, Alaska, in Barnes, F.F. and others, Coal Investigations in Southcentral Alaska, 1944-46: U.S. Geol. Survey Bull. 963-E, p. 141-165.

Wahrhaftig, Clyde, 1951, Geology and Coal Deposits of the Western Part of the Nenana Coal Field, Alaska, in Barnes, F.F. and others, Coal Investigations in Southcentral Alaska, 1944-46: U.S.' Geol. Survey Bull. 963-E, p. 169-186.

Wahrhaftig, Clyde and Birmon, Joseph H., 1954, Stripping Coal Deposits on Lower Lignite Creek, Nenana Coal Field, Alaska: U.S. Geol. Survey Circular 310, 11 p.

Wahrhaftig, Clyde and Hickcox, C.A., 1955, Geology and Coal Deposits, Jarvis Creek Coal Field, Alaska: U.S. Geol. Survey Bull. 989-G, p. 353-367.

Wahrhaftig, Clyde, Wolfe, Jack A., Leopold, Estella B., and Lanphere, Marvin A., 1969, The coal-biaring group in the Nenana coal field, Alaska: U.S. Geol. Survey Bull. 1274D, $30 \mathrm{p}$.

Warfield, R.S., and Boley, Charles C., 1969, Sampling and Coking Studies of Several Coal Beds in the Kokolik River, Kukpowrik River and Cape Beaufort Areas of the Arctic Northwestern Alaska, U.S. Bureau of Mines, Rl 7321, 58 p.

Warfield, R.S., 1973, Rotary Drilling for Strippable Coal in the Jarvis Creek Coal Field, Alaska: U.S. Bureau of Mines Open File Report 7-73, 8 pp.

Wolf, Jack A., Hopkins, D.M. and Leopold, Estella A., 1966, Tertiary stratigraphy and paleobotany of the Cook Inlet Region, Alaska: U.S. Geol. Survey Prof. Paper 398-A, 29p. 